UNIVERSIDADE DE SÃO PAULO

INSTITUTO DE GEOCIÊNCIAS

\title{
EVOLUÇÃO TECTÔNICA DO GRABEN DA GUANABARA
}

\section{ANDRÉ LUIZ FERRARI}

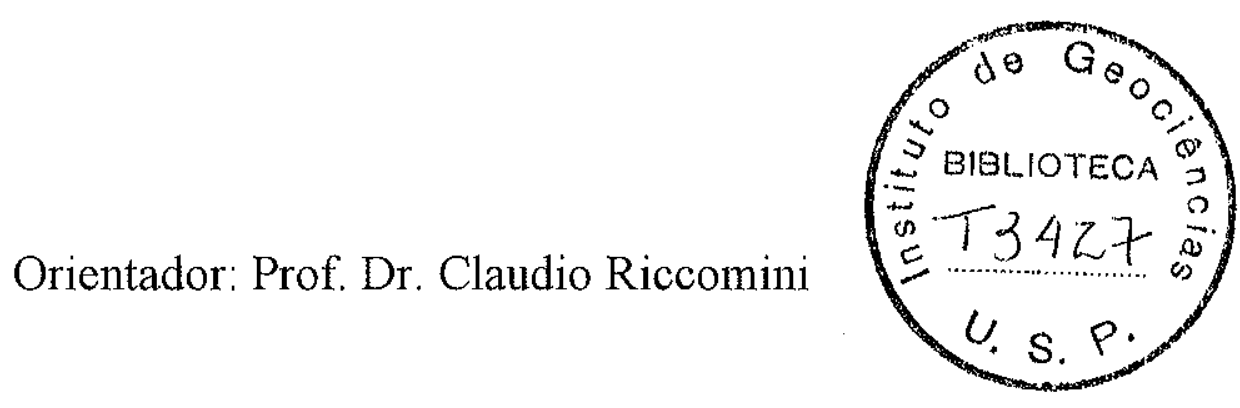

TESE DE DOUTORAMENTO

Programa de Pós-Graduação em Geologia Sedimentar

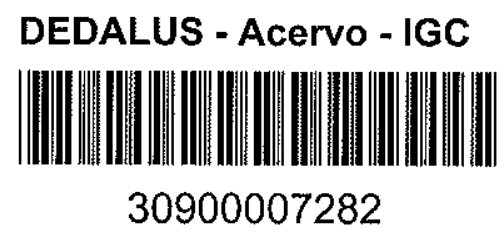

São Paulo

2001 


\title{
UNIVERSIDADE DE SÃO PAULO INSTITUTO DE GEOCIENNCIAS
}

\section{EVOLUÇÃO TECTÔNICA DO GRABEN DA GUANABARA}

\author{
ANDRÉ LUIZ FERRARI
}

Orientador: Prof. Dr. Claudio Riccomini

TESE DE DOUTORAMENTO

COMISSÃO JULGADORA

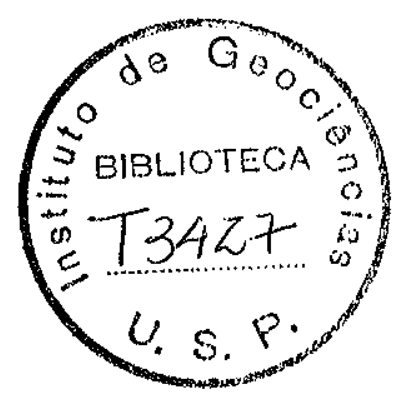

Nome

Presidente: Prof. Dr. Claudio Riccomini

Examinadores: Prof. Dr. Carlos José Archanjo

Prof. Dr. Claudio Limeira Mello

Dr. Peter Szatmari

Prof. Dr. Sidnei Pires Rostirolla

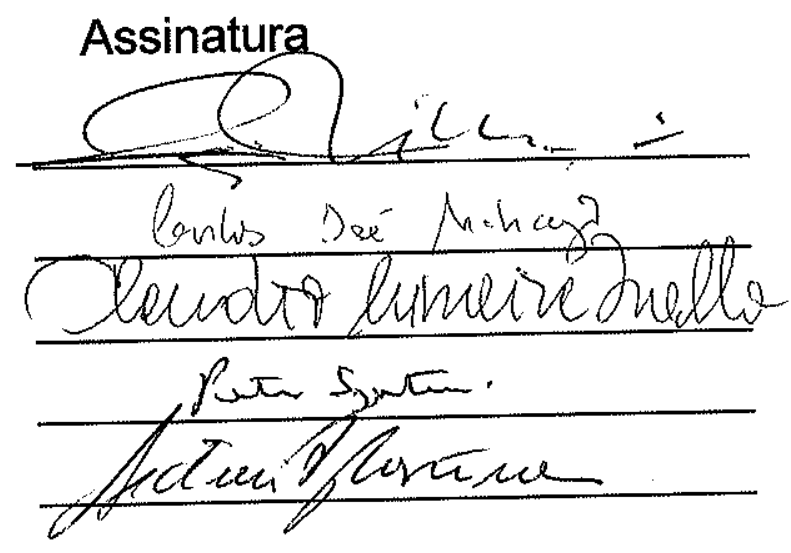

SÃO PAULO

2001 
Ficha catalográfica realizada pelo serviço de Biblioteca e Documentação do Instituto de Geociências da Universidade de São Paulo

Ferrari, André Luiz

Evolução tectônica do Graben da Guanabara / André Luiz Ferrari - São Paulo, 2001. 412p. : il. +anexos

Tese (Doutorado): Igc / USP - 2001

1.Graben da Guanabara 2. Tectônica rúptil 3. Análise cinemática 4. Paleotensões 5. Tectônica de bacias 6 . Neotectônica 


\section{ABSTRACT}

This thesis investigates the tectonic evolution of the Guanabara Graben (SE Brazil) from the analysis of paleostress fields that controls the deformation of the sedimentary sequences of the São José do Itaboraí and Macacu Basins as well as of the igneous alkaline bodies and dikes, which precede and, locally, follow the graben formation. This analysis is focused on the geometry and kinematics of the brittle structures. Furthermore, the paleogeography of the Guanabara Graben is characterized from a tectonic-sedimentary study of the Macacu Formation, with emphasis on the facies variation and depositional environments.

Four events of brittle deformation were characterized from the Late Cretaceous to the Holocene:

1) First Event - Sinistral transcurrence from the Campanian to the Early Eocene characterized by horizontal $\sigma 1$ striking NE-SW. This stress field controlled the graben formation with the development of the São José do Itaboraí Basin, the intrusion of the alkaline bodies and related dikes and the late hydrothermal activity as indicated by silicified tectonic breccias;

2) Second Event - Extension NW-SE from the Early Eocene to the Late Oligocene. This extension controlled the formation of the Macacu Basin;

3) Third Event - Extension NE-SW/dextral transcurrence, probably in the Pleistocene. This extension deformed the alkaline bodies and the sedimentary infill of the graben. The dextral transcurrence affects the alkaline bodies and related dikes with a $\sigma 1$ striking NW-SE. Apparently, this paleostress field is synchronous with the NE-SW extension of the Macacu Basin;

4) Fourth Event - Holocenic extension E-W that controlled the segmentation of the Macacu Basin deposits. This event isolates the Macacu Formation at Ilha do Governador and Duque de Caxias from the main deposit.

Compared to the other basins of the Continental Rift of the Southeastern Brazil, the Paleocenic São José do Itaboraí Basin shows the highest rate of stretching ( 10\% more). Calcareous veins with high and low angle cutting across the basement and filling the São 
José Fault, the strike-slip micro faults in the basin sediments and the synchronous NW-SE and NE-SW extension are all indicative of sinistral transcurrence of the São José Fault.

Three main facies associations were recognized in the Macacu Basin (EoceneOligocene): alluvial fans, braided plains and lacustrine. This facies distribution coupled with the structural analysis shows an asymmetric-type-graben with the main tectonic depression located first at the southeastern border and later migration to the northeastern border of the basin. The analysis of paleocurrents indicates a changing in the sediments flow from SW to NE, reflecting the importance of the tectonic control in the Macacu Formation. This is also shown by the episodic flooding of the braided alluvial plain, which seems to be of tectonic origin.

The presence of fonolithic hialoclastites $(65,7 \mathrm{Ma})$ aside of sienic bodies of the same age demonstrates local low rate of denudation in the Guanabara Graben and shows that the erosional processes in the region was heterogeneous.

The overall interpretation indicates that the Guanabara Graben was formed in the Paleocene under a strike-slip regime controlled by an E-W sinistral couple. The graben evolution from the Eocene to the Oligocene was dominated by a NW-SE extension. This indicates a persistent orientation of the SHmax and Shmin, NE-SW e NW-SE, respectively, from the Upper Cretaceous to the Oligocene. There is a change to orthogonal position of the stresses axis only in the Pleistocene. Apparently, the paleostress field that controls the formation of the Guanabara Graben was triggered by the local stresses related to the uplift that generated the Japi Erosion Surface. The initial strike-slip regime that controls the formation of the graben was probably influenced by a mechanical anisotropy in the mantle. The Neogenic paleostress fields is in agreement with the Cenozoic far field dictated by the ridge push. 


\section{RESUMO}

Esse trabalho investiga a evolução tectônica do Graben da Guanabara a partir dos campos de paleotensões geradores e deformadores das bacias de São José do Itaboraí e do Macacu, bem como dos corpos ígneos alcalinos e diques associados, que precedem e, localmente, acompanham a implantação do graben.

Foram analisadas a geometria e a cinemática das estruturas rúpteis que afetam os corpos alcalinos e o preenchimento sedimentar. Realizou-se, também, a caracterização tectono-sedimentar da Formação Macacu, a partir do estudo de sua faciologia e paleogeografia, buscando determinar a evolução paleogeográfica do Graben da Guanabara.

Caracterizou-se a atuação de quatro campos de paleotensões distintos, entre o Cretáceo Superior e o holoceno, correspondendo a quatro eventos deformacionais rúpteis:

1) Evento 1 - transcorrência sinistral, com atuação do Campaniano ao Eoceno Inferior, caracterizada por um $\sigma 1$ horizontal posicionado na direção NE-SW. Esse campo de esforços controlou a implantação do Graben da Guanabara a partir da geração da Bacia de São José do Itaboraí, a intrusão dos corpos alcalinos e dos diques a eles associados e o hidrotermalimo tardio representado pelas brechas tectônicas silicificadas;

2) Evento 2 - extensão NW-SE, que atuou do Eoceno Inferior ao Oligoceno Superior e controlou a impantação e evolução tectono-sedimetar da Bacia do Macacu;

3) Evento 3 - extensão NE-SW/transcorrência dextral, com provável atuação no Pleistoceno, deformou os corpos alcalinos e o preenchimento sedimentar do graben. A transcorrência dextral foi identificada nos corpos alcalinos, sendo posterior à sua intrusão e dos diques associados, sendo caracterizada por um $\sigma$ l de direção NW-SE. Esse campo de paleotensões foi considerado comtemporâneo com a extensão NE-SW identificada na Bacia do Macacu;

4) Evento 4 - extensão E-W, de idade holocênica, foi responsável pela segmentação dos depósitos da Bacia do Macacu, separando a bacia e as ocorrências isoladas da Formação Macacu da Ilha do Governador e de Duque de Caxias.

Determinou-se que a Bacia de São José do Itaboraí, de idade paleocênica, possui a maior taxa de estiramento entre todas as bacias do RCSB, de pouco mais de $10 \%$. A presença de veios de calcário travertino com alto e baixo ângulo de mergulho, cortando o 
embasamento e preenchendo a Falha de São José; as microfalhas direcionais que afetam o preenchimento da bacia e a contemporaneidade de extensões nas direções NW-SE e NESW indicam a complexidade da evolução tectônica da Bacia de São José do Itaboraí e foram interpretadas como geradas por uma transcorrência sinistral dessa falha.

$\mathrm{Na}$ Bacia do Macacu, de idade eocênica a oligocênica, foram caracterizadas três associações de fácies, de leques aluviais, fluvial entrelaçada e lacustre. A distribuição das associações de fácies, em conjugação com as estruturas, indicou que essa bacia é do tipo graben assimétrico, e que os depocentros se deslocaram da borda sudeste para a noroeste. As paleocorrentes mostram uma variação no sentido, passando de SW para NE, reforçando a importância do tectonismo na sedimentação da Formação Macacu. Essa relação foi evidenciada, também, pelos afogamentos episódicos da planície aluvial, interpretados como de origem tectônica.

A presença de hialoclastitos fonolíticos no Plug do Country Club, que constitui o embasamento da Bacia do Macacu, com idade de 65,7 Ma (obtida no presente trabalho), indicou que esse segmento do Graben da Guanabara não sofreu erosão desde o Paleoceno Inferior. A localização desse plug próxima aos maciços do Tanguá e Rio Bonito, de mesma idade, mostra que as taxas de erosão no interior do Graben da Guanabara foram heterogêneas.

Assim, a interpretação dos dados permite inferir que a implantação do Graben da Guanabara deu-se no Paleoceno, sob um regime de esforços direcional, tendo sido controlada por um binário sinistral E-W. Sua evolução ao longo do Eoceno e do Oligoceno foi controlada por um regime de esforços extensional, com o eixo de extensão posicionado na direção NW-SE. Dessa forma, registrou-se a persistência das direções de SHmax e Shmin, NE-SW e NW-SE respectivamente, entre o Cretáceo Superior e o Oligoceno e a sua variação, para posições ortogonais a essas, apenas no Pleistoceno. Admite-se que os campos de paleotensões responsáveis pela implantação e evolução do Graben da Guanabara foram desencadeados pelas tensões locais associadas ao soerguimento que gerou a Superficie Japi. O regime direcional que gerou sua implantação foi provavelmente controlado por anisotropias mecânicas do manto. Os campos de paleotensões neogênicos são compatíveis com as tensões regionais geradas pelo empurrão da cordilheira mesoceânica ao longo do Cenozóico. 


\section{AGRADECIMENTOS}

A realização dessa tese não teria sido possível sem o apoio e o incentivo de muitas pessoas e instituições.

Inicialmente agradeço o pronto apoio e o incentivo dado ao longo do curso pelo meu orientador, Professor Claudio Riccomini. Seja pelas questões fundamentais levantadas, seja pelos meios disponibilizados, devo a ele a concretização desse trabalho.

Quero agradecer aos colegas da minha instituição de origem, o Departamento de Geologia/LAGEMAR da UFF, pela liberação e incentivo para a realização do doutoramento. Particularmente agradeço a Maria Augusta Martins Silva, com quem iniciei o trabalho na Bacia do Macacu, a Sidney Luiz de Matos Mello, pelas sugestões na organização do texto e pela revisão do abstract e a Adalberto da Silva pelas discussões e pelo auxílio na elaboração dos arquivos "pdf" para impressão. Agradeço também ao IG/USP, que me recebeu, oferecendo todas as suas instalações, laboratórios e a excelente biblioteca. Agradecimentos são devidos a FAPESP, que apoiou o projeto "Evolução Tectônica do Graben da Guanabara", e a CAPES pela concessão de bolsa no âmbito do programa PICDT.

Diversos colegas tiveram participação ativa ao longo do trabalho, durante os levantamentos de campo, como o Alexandre Magno Sales, Hélio Monteiro Penha, Cleverson Guizan Silva e Claudio Limeira de Melo, a quem agradeço a ajuda e as sugestões. Também quero agradecer ao colega Victor Fernadez Velázquez, pelo apoio na petrografia das rochas alcalinas.

Uma menção especial é devida ao colega Afonso C. R. Nogueira, pelo acompanhamento nos trabalhos de campo, pelas discussões e sugestões sobre a geologia da Bacia do Macacu e, ainda, pela leitura crítica do texto.

Agradeço a Damien Delvaux por ter cedido prontamente o seu programa TENSOR, que foi de utilidade fundamental na inversão dos dados de falhas, e pelas sugestões quanto ao tratamento desses dados.

Em Itaúna o trabalho de campo seria impossível sem o apoio do líder comunitário Nílson Rodrigues Coelho. Nesse aspecto devo agradecer, também, à Cooperágua, por facilitar os trabalhos na Bacia de São José do Itaboraí, particularmente na pessoa do Sr. Arino Vieira de Souza, pelo acompanhamento na 
bacia; ao IEAPM/Marinha do Brasil pela autorização e apoio no acesso à Ilha de Cabo Frio; à GEOPLAN por ceder os perfis de poços artesianos utilizados, especialmente ao geólogo Fernando Zulian; ao pessoal das pedreiras Irmãos Vignê, Santo Antônio, Emasa, Simgra e Bangu. Nessa última, agradeço ao geólogo João A. P. Silva, pelo acompanhamento na pedreira e indicação de outros bons afloramentos. Sou muito grato ao colega Raul Rodrigues Valle, da Mineração Sartor, pelo apoio e pelas frutíferas discussões sobre a análise cinemática do fraturamento.

Também sou grato ao pessoal do Laboratório de Microscopia Eletrônica, em especial ao Isaac Jamil Sayeg e à estagiária Camila Miranda Michelin; bem como ao Flávio Machado Souza Carvalho, do Laboratório de Difratometria de Raios X, e a Arthur Onoe e ao Paulo Vasconcelos, do Laboratório de Datação Radiométrica Ar/Ar.

Esses anos de trabalho intenso foram mais prazerosos pela companhia dos diversos amigos da pós graduação e dos que trabalham no IG/USP particularmente o Afonso, Leandro, Alexei, Alexandre, Claudio, Lucy, Chicão, Sapo, Renata, João Matos, Candeias, Pinheiro, Sônia, Chico Bill, Paulo, Jefferson, Glória, Mancini, Victor, Hachiro, Ginaldo, Rômulo, Alethéa, Willian, Isaac, Gianini e Elaine.

$O$ interesse pelo tema aqui tratado teve origem na convivência com alguns geólogos por quem quero externar minha gratidão e admiração, como Hélio Monteiro Penha, um geólogo com formação geomorfológica e naturalista; Thomas Lafayette Brenner, com quem travei as primeiras discussões sobre o Graben da Guanabara; Haroldo Erwin Asmus, que me apresentou a tectônica da margem continental brasileira e Marcus Aguiar Gorini, que me apresentou a tectônica global. Quero registrar, também, que as disciplinas Análise de Fraturas e Análise de Bacias, ministradas por Georg Robert Sadowski e por Vicente José Fúlfaro, respectivamente, influenciaram os desdobramentos do trabalho, dando-lhe novas perspectivas.

Sobretudo sou grato à Ana Paula, minha mulher e antropóloga preferida, pela inspiração e apoio constantes e que, além de tudo, me deu a Beatriz e o Victor. A eles eu dedico a tese. 


\section{ÍNDICE}

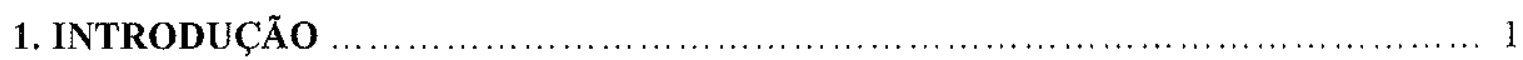

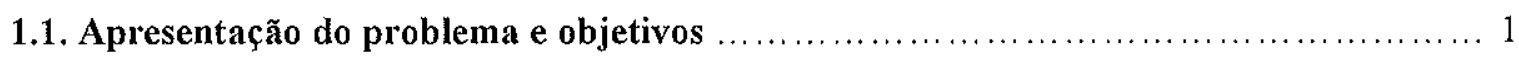

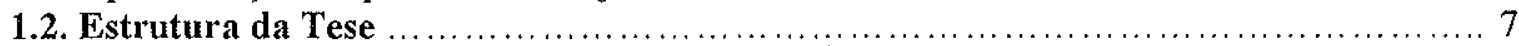

2. REVISÃO DOS ASPECTOS GEOLÓGICOS REGIONAIS SOBRE O GRABEN DA

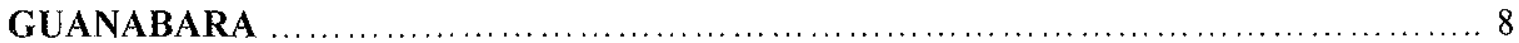

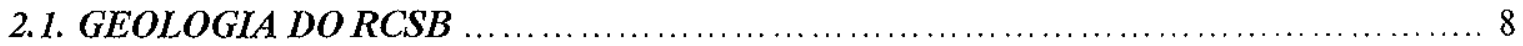

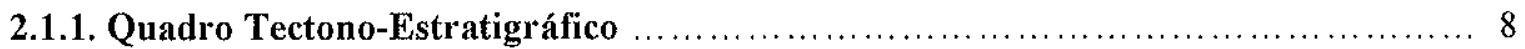

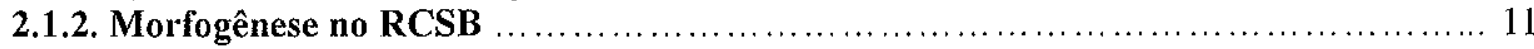

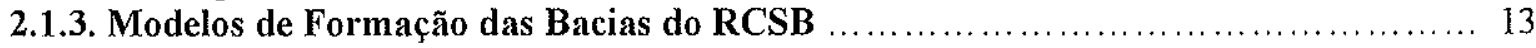

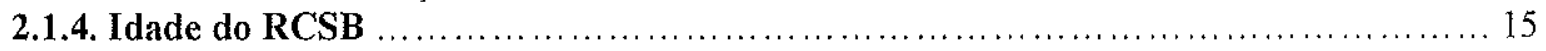

2.2. EMBASAMENTO DO GRABEN DA GUANABARA .............................. 15

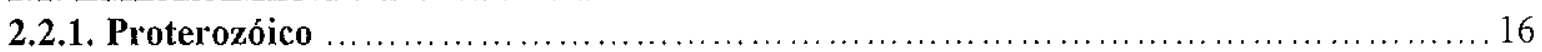

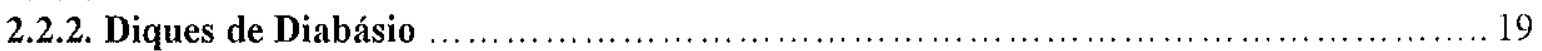

2.3 MEGAESTRUTURAS MESOZOICO-CENOZÓICAS' NA PORÇ̃̃O NE DO RCSB ....... 22

2.4. DISTRIBUIÇÃO DOS ESFORÇOS NA PLACA SULAMERICANA .................. 27

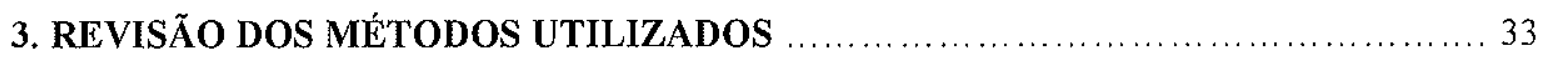

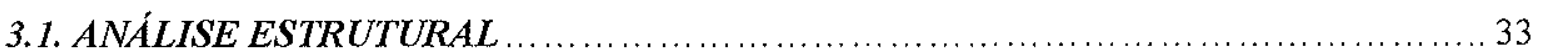

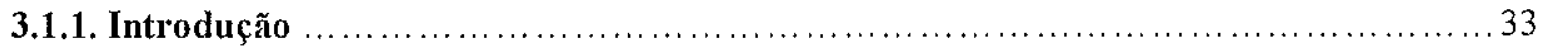

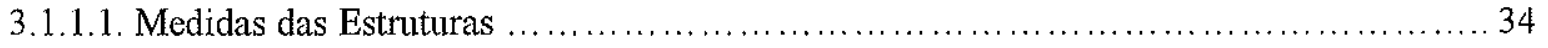

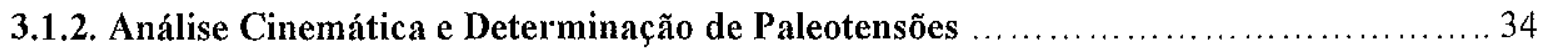

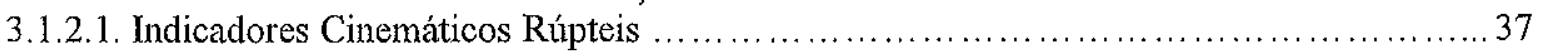

3.1.2.2. Ordem de Desenvolvimento de Estruturas Secundárias Relacionadas a Zonas de Cisa-

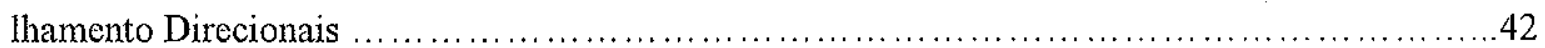

3.2. UTILIZAÇÃO DE DIQUES COMO INDICADORES TECTÔNICOS ................. 44

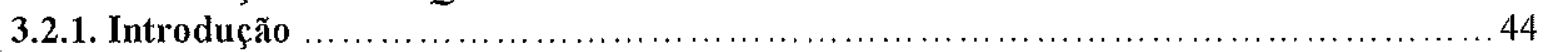

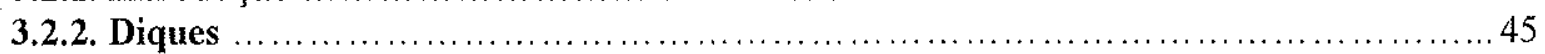

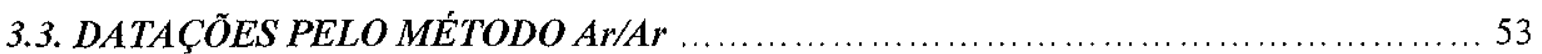

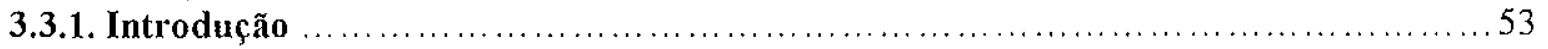

3.3. MICROSCOPIA ELETRÔNICA DE VARREDURA - MEV ........................ 54

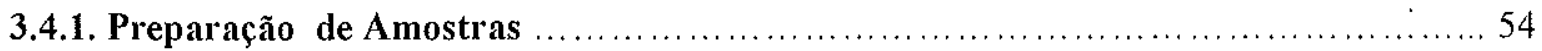

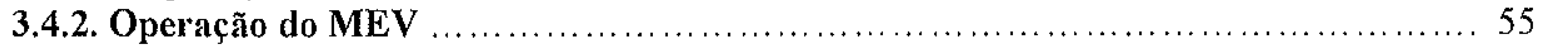


4. CONTROLE DE INTRUSÃO E TECTÔNICA DEFORMADORA DO MAGMATISMO ALCALINO PRÉVIO A CONTEMPORÂNEO COM A IMPLANTAÇÃO DO GRABEN DA GUANABARA

4.1. INTRODUÇÃO: APRESENTAÇÃO DO QUADRO REGIONAL ...................... 56

4.2. AREA OCIDENTAL DO GRABEN-MACIÇO DO MENDANHA ..................62

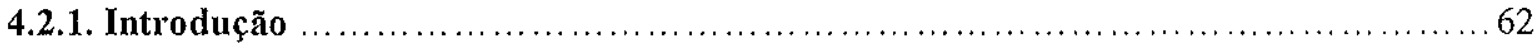

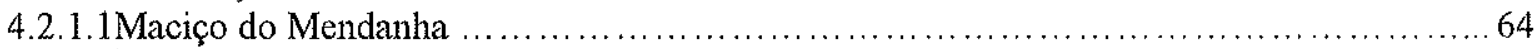

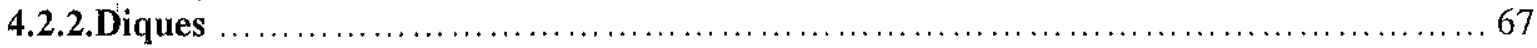

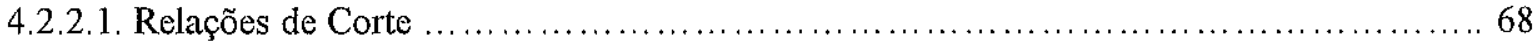

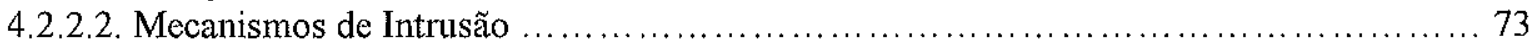

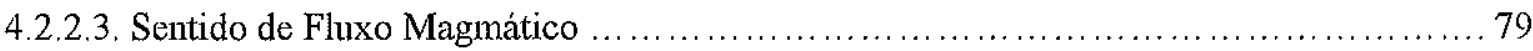

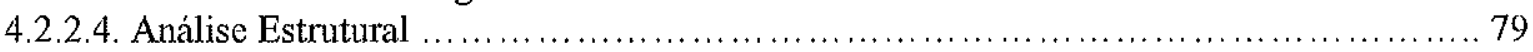

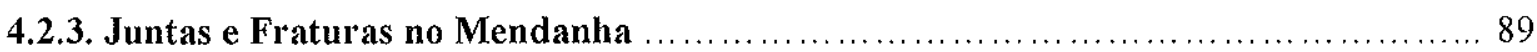

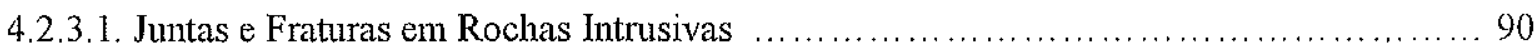

4.2.3.2. Juntas e Fraturas em Rochas Extrusivas ........................................... 98

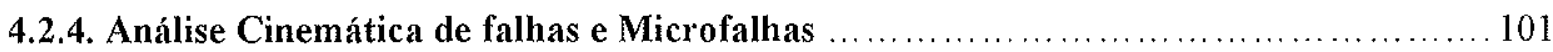

4.2.4.1. Falhas e Microfalhas no Mendanha ......................................... 102

4.2.4.2. Falhas e Microfalhas em Diques de Rochas Alcalinas que Cortam o Embasamento ..... 105

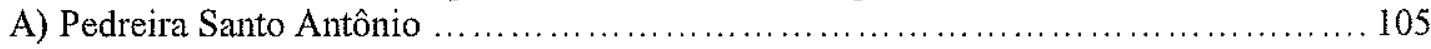

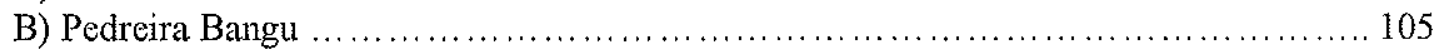

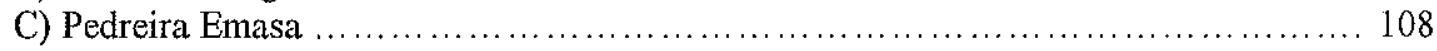

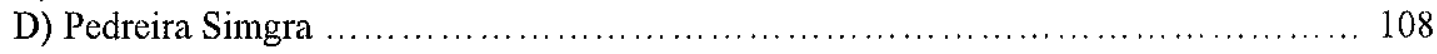

4.2.5. Síntese das Paleotensões na Porção Oeste do Graben da Guanabara ................ 111

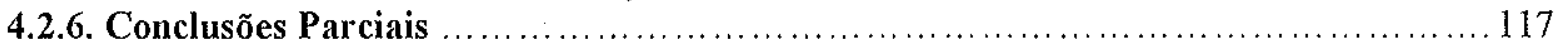

4.3. AREA CENTRAL DO GRABEN ........

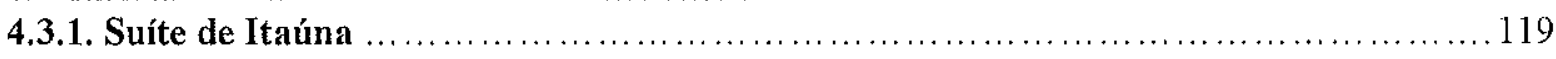

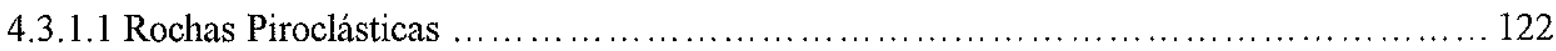

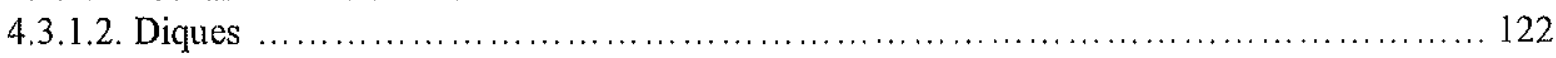

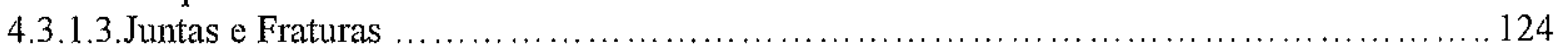

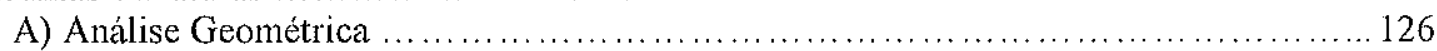

A. 1) Juntas e fraturas em Rochas Intrusivas ................................126

A.2) Juntas e Fraturas em Rochas Vulcânicas ................................ 142

B) Análise Cinemática de Falhas e Microfalhas ................................ 147

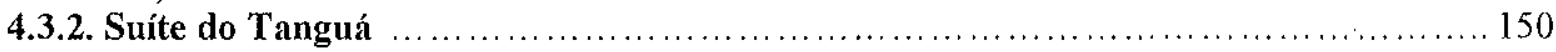

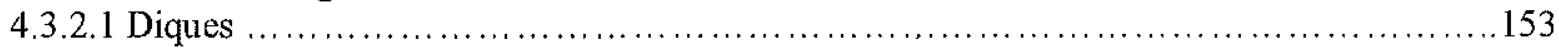

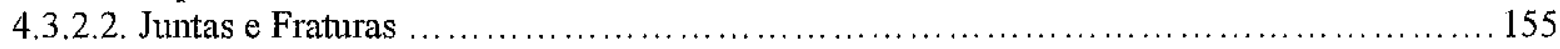

A) Análise Geométrica .................................................... 155

B) Análise cinemática de Falhas e Microfalhas ................................ 157

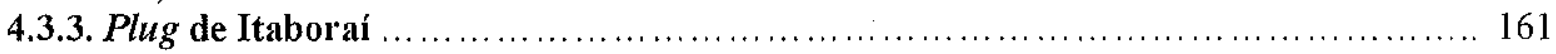

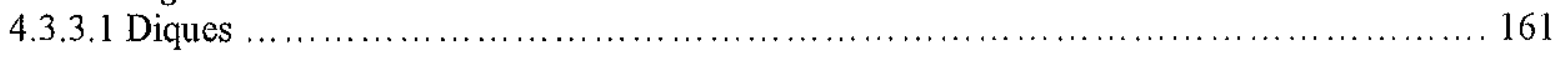

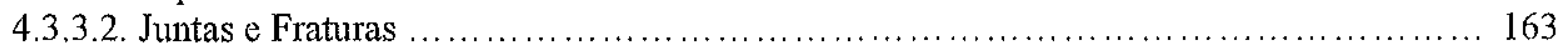

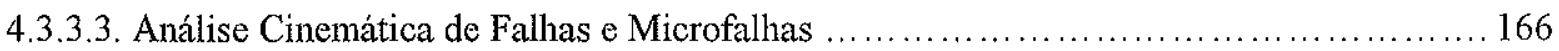

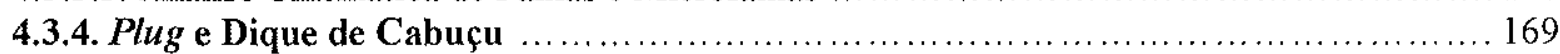

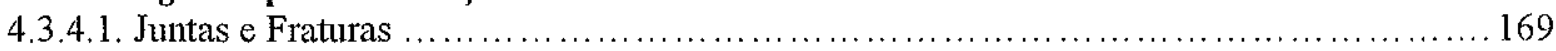

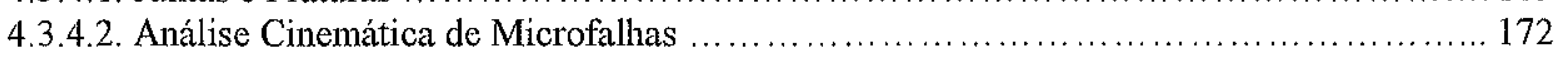

4.3.5. Plug de Jardim Cabuçu ......................................................... 174

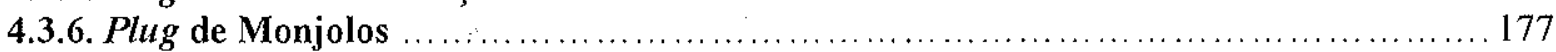

4.3.7. Plug do Country Club .................................................... 178 
4.3.8. Síntese das Paleotensões determinadas nos Corpos Alcalinos da Área Central ........ 184

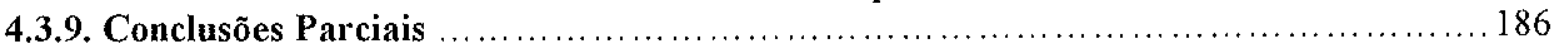

4.4 AREA ORIENTAL DO GRABEN-SUÍTE ALCALINA DA ILHA DE CABO FRIO _... 188

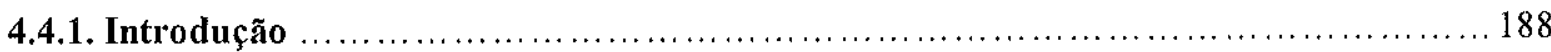

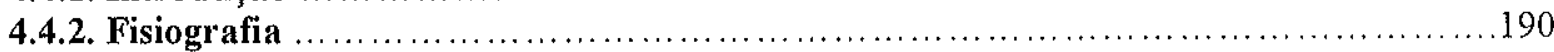

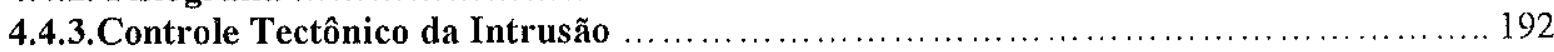

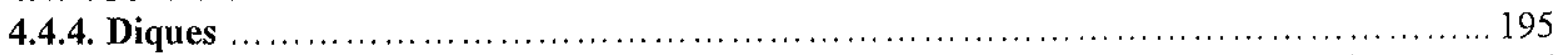

4.4.5. Juntas e Fraturas na Suíte Alcalina da Ilha de cabo Frio e nos Diques Associados ... 206

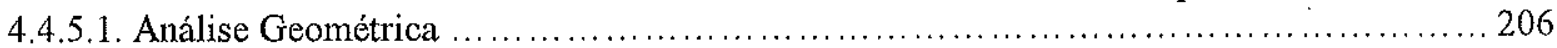

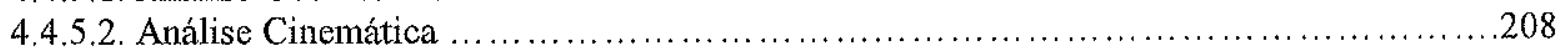

A) Juntas e Fraturas em Rochas Plutônicas ....................................... 208

B) Juntas e Fraturas em Rochas Hipabissais ...................................... 213

4.4.6. Falhas e Microfalhas que Afetam o Complexo da Ilha de Cabo Frio e os Diques

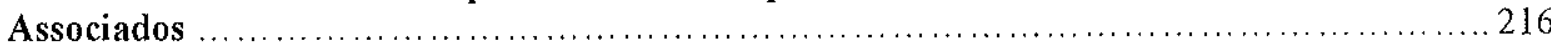

4.4.6.1. Falhas e Microfalhas em Rochas Hipabissais ................................. 216

4.4.7. Síntese das Paleotensões Determinadas na Porção Leste do Graben da Guanabara ... 220

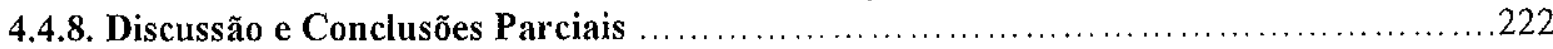

4.5. BRECHAS TECTÔNICAS SILICIFICADAS _...

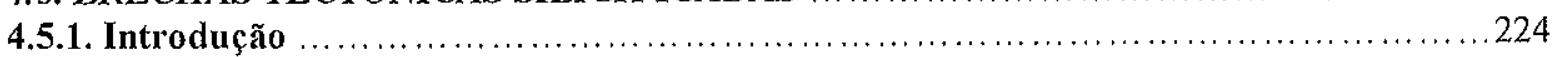

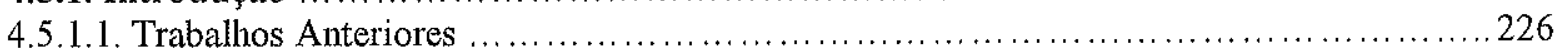

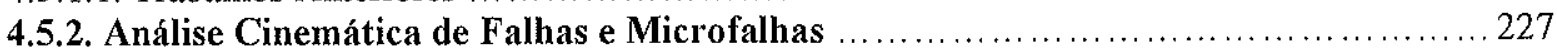

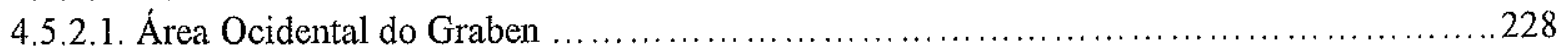

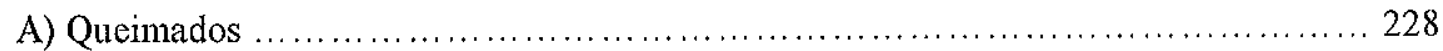

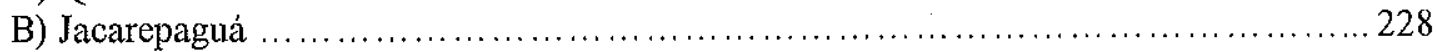

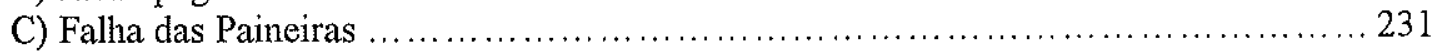

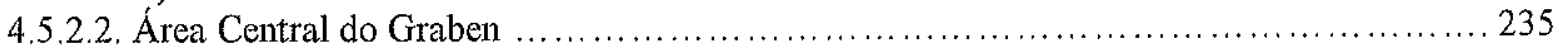

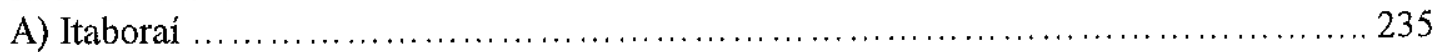

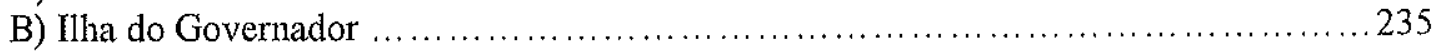

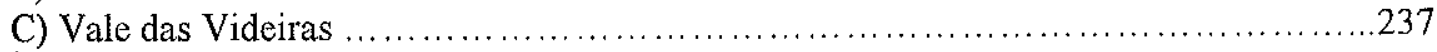

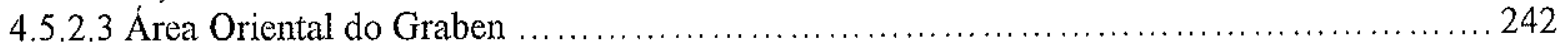

A) Falha de Barra de Sana ................................................ 242

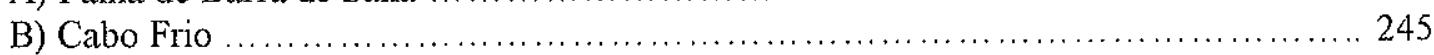

C) São Pedro da Aldeia .................................................... 245

4.5.4. Síntese das Paleotensões Determinadas para as Brechas Tectônicas Silicificadas ...... 247

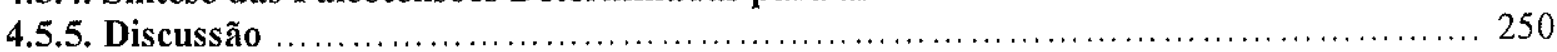

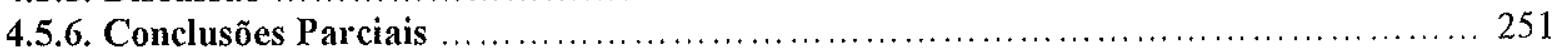

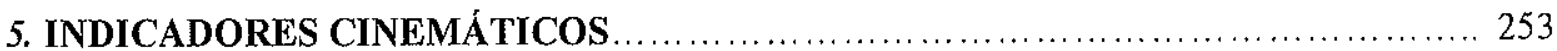

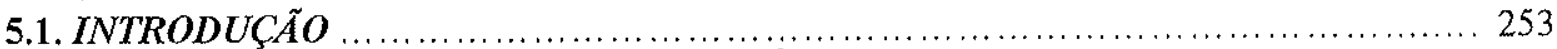

5.2. EXEMPLOS DE INDICADORES CINEMATTICOS DETERMINADOS NAS ROCHAS

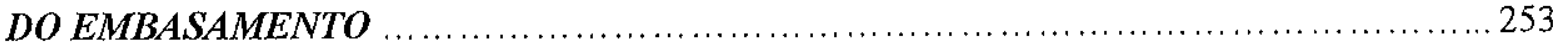

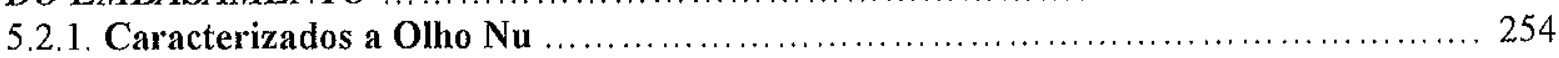

5.2.2. Caracterizadas no Microscópio Eletrônico de Varredura - MEV ................... 258

6. PREENCHIMENTO SEDIMENTAR DO GRABEN DA GUANABARA - TECTONISMO GERADOR E DEFORMADOR DOS DEPÓSITOS SEDIMENTARES . ............ 264 
6.1 BACIA DE SÃO JOSÉ DO ITABORAÍ . . . . .

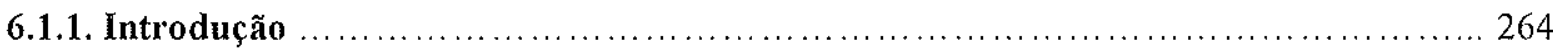

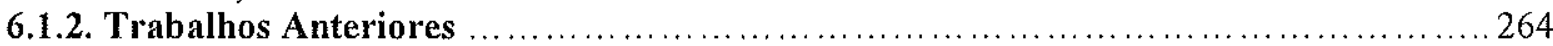

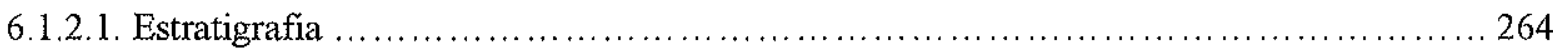

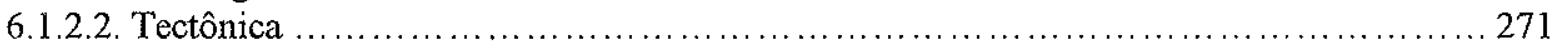

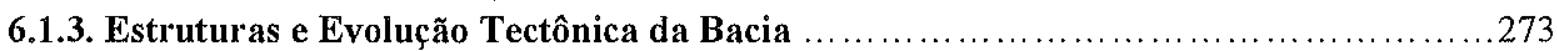

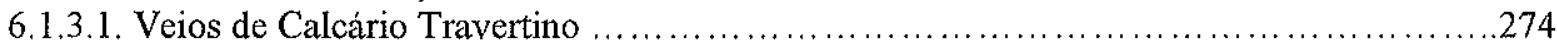

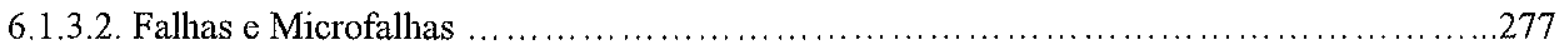

6.1.3.3. Arcabouço Estrutural da Bacia a Partir de Dados de Sondagens ........................ 279

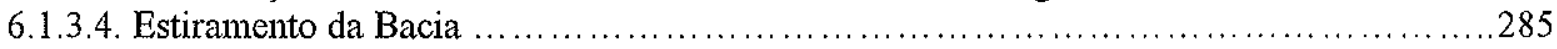

6.1.3.5. Adernamento das Camadas ..................................................... 286

6.1.3.5. Síntese dos Eventos Deformacionais ......................................... 289

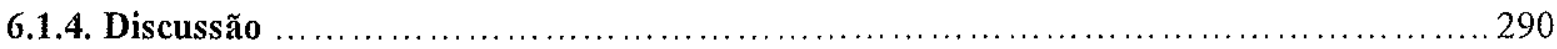

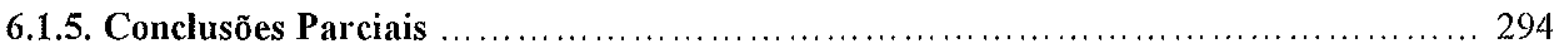

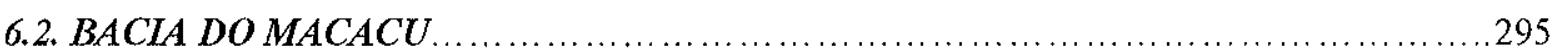

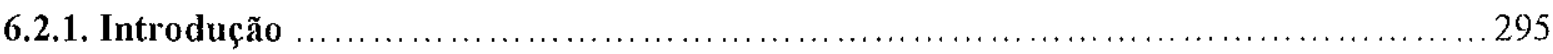

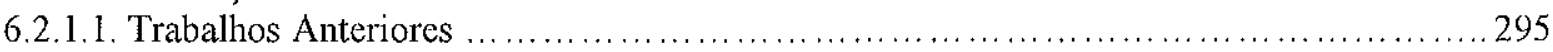

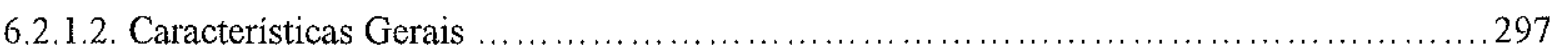

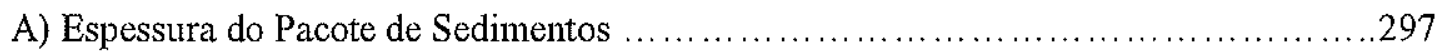

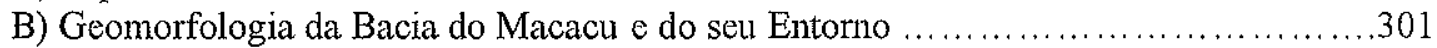

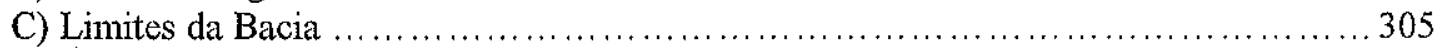

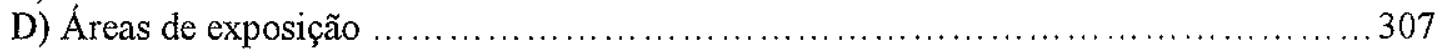

E) Características Litológicas ....................................................... 307

6.2.2. Fácies Sedimentares da Formação Macacu ....................................... 309

6.2.3. Associações de Fácies Sedimentares da Formação Macacu ............................ 319

6.2.3.1. Associação de Fácies A - Lacustre ............................................... 321

6.2.3.2. Associação de Fácies B - Leque Aluvial com Lobos de Fluxo de Detritos/Corridas de Lama e de Fluxo em Lençol ......................................................... 322

6.2.3.3. Associação de Fácies C - Canal Fluvial Entrelaçado com Afogamentos Episódicos ...... 324

6.2.3.4. Associação de Fácies D - Canal Fluvial Entrelaçado .................................. 327

6.2.4. Ocorrência do Icnofóssil Taenidium e Implicaçôes Paleoambientais ................... 328

6.2.5. Formação Macacu em Sub-superfície - Perfis de Sondagens de Poços Artesianos

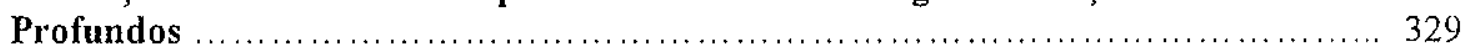

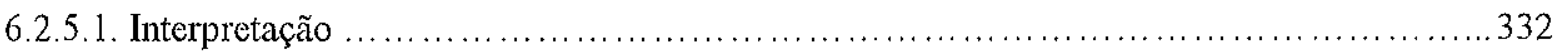

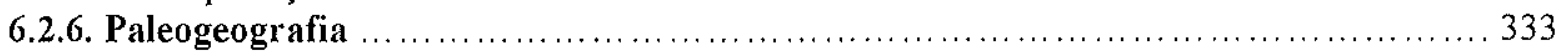

6.2.6.1. Distribuição Geográfica das Associações de Fácies ................................... 333

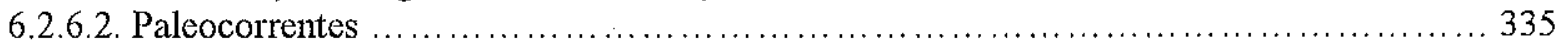

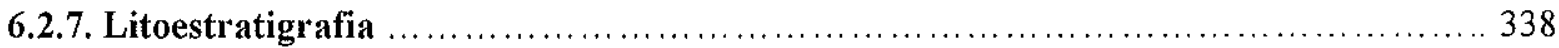

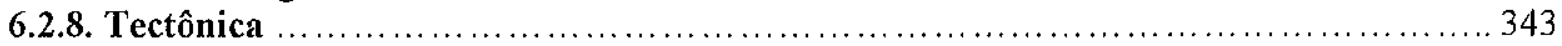

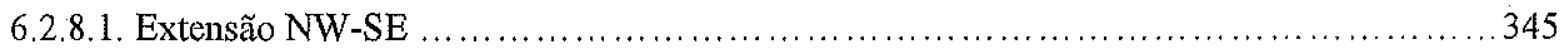

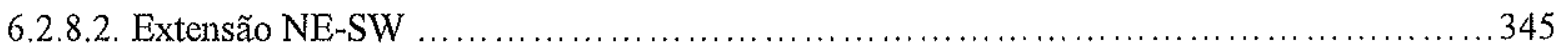

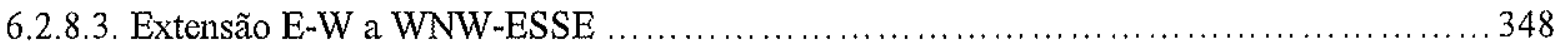

6.2.8.4. Síntese dos Eventos Geradores e Deformadores da Bacia do Macacu ................... 348

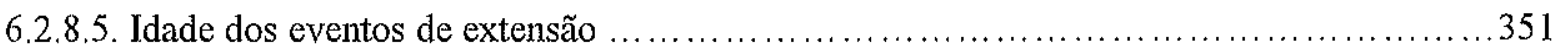

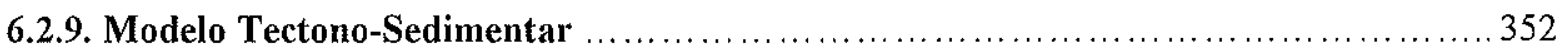

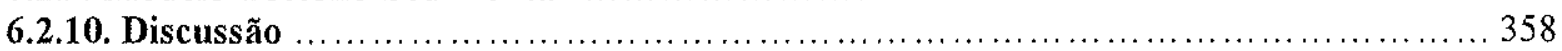

6.2.10.1. Planícies de Inundação em Sistemas Fluviais Entrelaçados ......................... 358

6.2.10.2. Controle Tectônico x Controle Climático da Sedimentação .............................. 359

6.2.10.3. Deformação da Bacia do Macacu ................................................. 362 


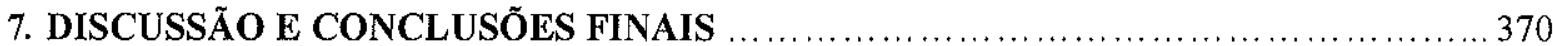

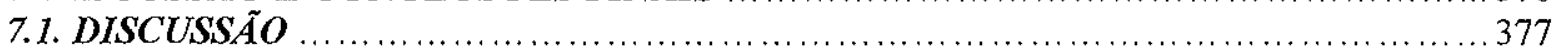

7.1.1. Origem dos Campos de Paleotensões no Graben da Guanabara - Tensões Locais X

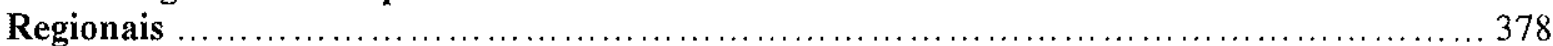

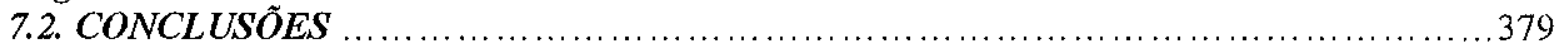

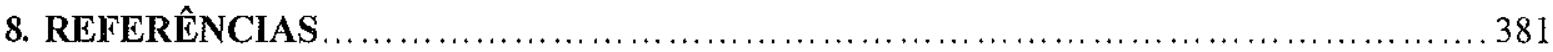




\section{LISTA DE FIGURAS}

\section{Capítulo 1}

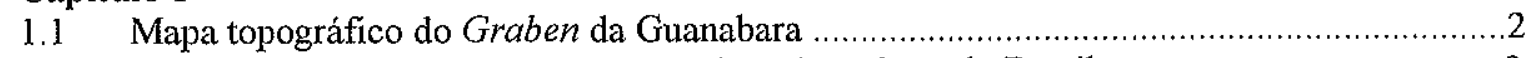

1.2 Principais feições estruturais fanerozóicas do sudeste do Brasil ........................................3

1.3 Mapa geológico do Graben da Guanabara e arredores ................................................. 4

\section{Capítulo 2}

2.1 Relações entre a estratigrafia e a tectônica no RCSB .................................................

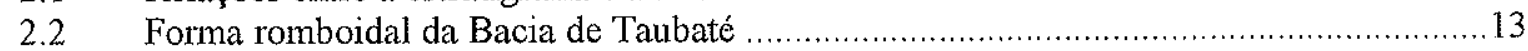

2.3 Mapa do arcabouço estrutural da Bacia de Taubaté ........................................................ 14

2.4 Mapa tectônico da região sudeste do Brasil .................................................................... 18

2.5 Mapa geológico do Graben da Guanabara e arredores, destacando os diques

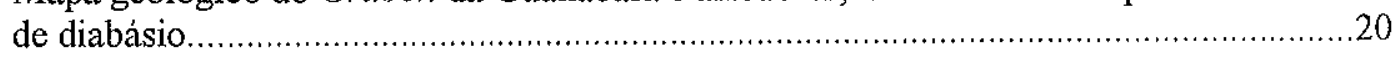

2.6 Diagrama de roseta com a direção de diques de diabásio do Estado do Rio de

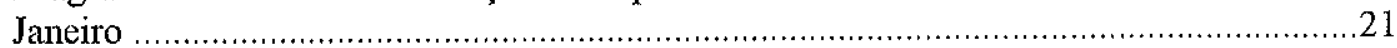

2.7 Projeções ciclográficas e diagrama de roseta de diques de diabásio ..............................22

2.8 Localização das principais megaestruturas da Região Sudeste e área

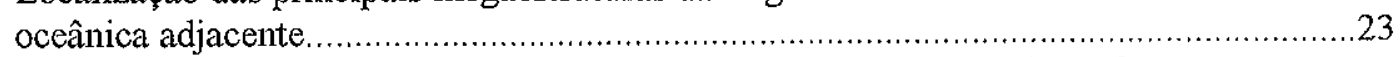

2.9 Mapa esquemático mostrando duas hipóteses acerca da natureza dos esforços tectônicos que teriam afetado a margem sul-sudeste do Brasil ......................................25

2.10 Distribuição das tensões regionais na Placa Sul-Americana .........................................28

2.11 Variações das tensões horizontais máximas e mínimas na América do Sul .....................29

2.12 Geometria para avaliação da rotação dos tensores devido a fontes locais .......................30

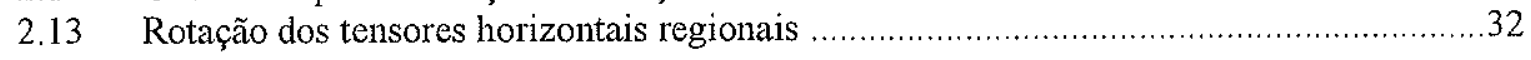

\section{Capítulo 3}

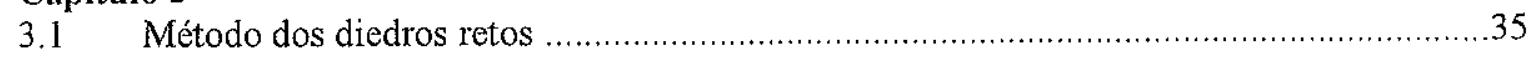

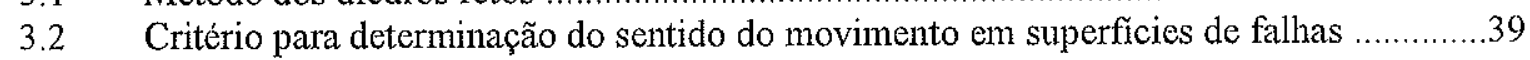

3.3 Terminologia para descrição de fraturas secundárias elementares em um contexto

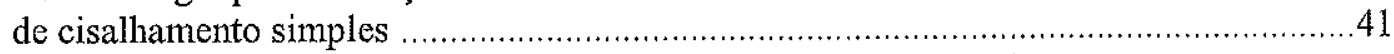

3.4 Principais tipos de critérios utilizados como indicadores cinemáticos em um contexto de cisalhamento simples ............................................... 42

3.5 Orientação de estruturas secundárias, com arranjo en echelon, associadas a uma zona

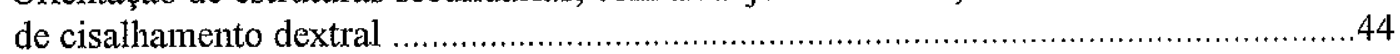

3.6 Terminologia para deslocamentos e separações entre diferentes segmentos de

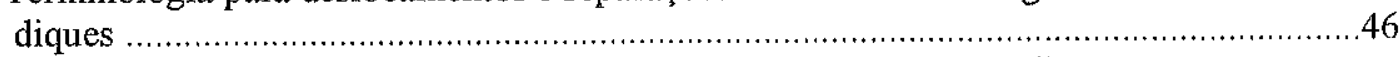

3.7 Terminologia para o deslocamento entre diferentes segmentos de diques, em

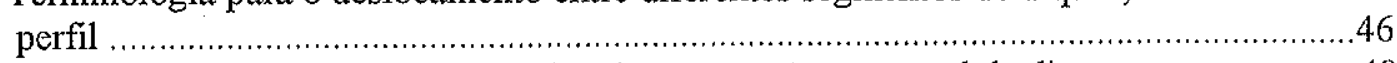

3.8 Três figuras esquemáticas ilustrando a interpretação estrutural de diques .......................48

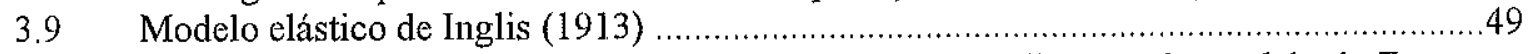

3.10 Ilustração esquemática do mecanismo de propagação de diques pelo modelo da Zona

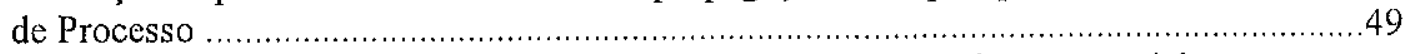

3.11 Trajetórias de propagação para diques relacionadas com a mudança espacial na oreintação do menor esforço compressivo .......................................................51

3.12 Figuras en echelon preenchidas, vistas em projeção horizontal e em

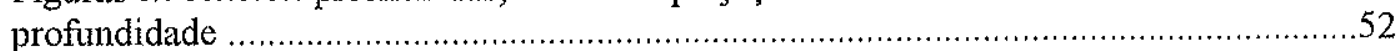

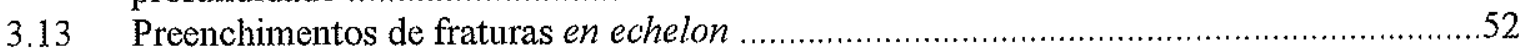




\section{Capítulo 4}

4.1 Distribuição do magmatismo alcalino no Graben da Guanabara ..................................57

4.2 Mapa geológico da porção ocidental do Graben da Guanabara ......................................63

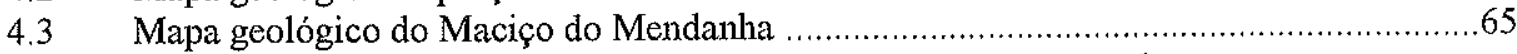

4.4 Prancha com fotos de diques de rochas alcalinas que cortam o embasamento na

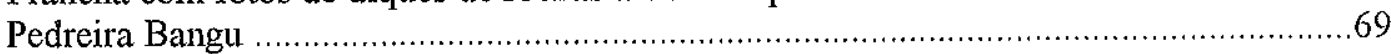

4.5 Prancha com fotos de diques de rochas alcalinas que cortam o embasamento na Pedreira Santo Antônio ............................................................................................. 70

4.6 Prancha com fotos de diques de rochas alcalinas que cortam o embasamento na

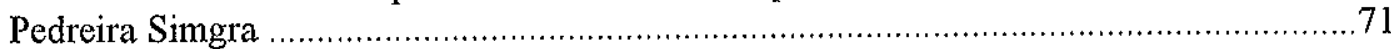

4.7 Prancha com fotos de diques de rochas alcalinas que cortam o embasamento na

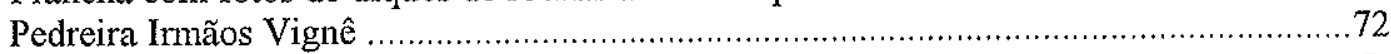

4.8 Dique de lamprófiro alcalino cortando sienito na Pedreira Vignê ................................74

4.8 Prancha com fotos de diques de rochas alcalinas que cortam o embasamento na

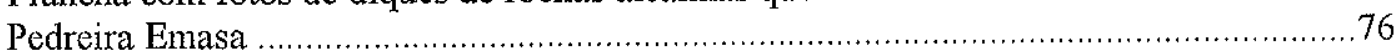

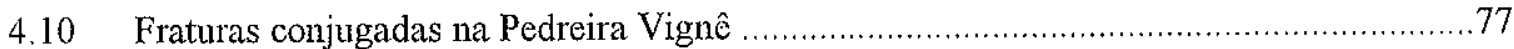

4.11 Dique de basanito cortando granito em Barra de Guaratiba ..........................................78

4.12 Fraturas paralelas e oblíquas a diques de basanito em Barra de Guaratiba ......................80

4.13 Projeções ciclográficas e polares, e diagramas de rosetas de diques de rochas alcalinas

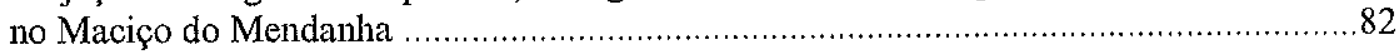

4.14 Projeções ciclográficas e polares, e diagramas de rosetas de diques de rochas alcalinas na Pedreira Santo Antônio ......................................................................................... 83

4.15 Projeções ciclográficas e polares, e diagramas de rosetas de diques de rochas alcalinas

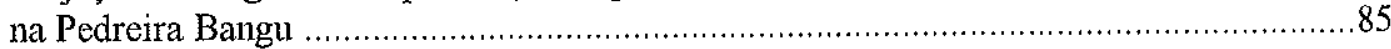

4.16 Projeções ciclográficas e polares, e diagramas de rosetas de diques de rochas alcalinas

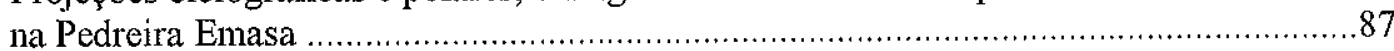

4.17 Projeções ciclográficas e polares, e diagramas de rosetas de diques de rochas alcalinas

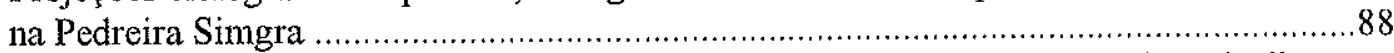

4.18 Projeções ciclográficas e polares, e diagramas de rosetas de diques de rochas alcalinas

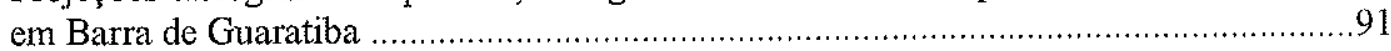

4.19 Projeções ciclográficas e polares de fraturas que afetam sienito na Pedreira

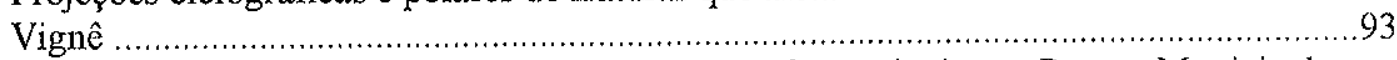

4.20 Projeções ciclográficas e polares de fraturas que afetam sienito no Parque Municipal do Mendanha .............................................................................................94

4.21 Projeções ciclográficas e polares de fraturas que afetam sienito no Maciço do Mendanha, Ponto Me6 .......................................................................................96

4.22 Projeções ciclográficas e polares de fraturas que afetam sienito no Maciço do Mendanha, Ponto Me8

4.23 Projeções ciclográficas, polares e diagrama de rosetas de fraturas que afetam brecha vulcânica no Maciço do Mendanha, Ponto Me7 ...................................................99

4.24 Mapa síntese das paleotensões determinadas no Maciço do Mendanha ........................100

4.25 Dados de falhas e respectivos eixos de tensões para a Pedreira Vignê ...........................103

4.26 Dados de falhas e respectivos eixos de tensões para os pontos Me3, 4 e 5 .....................104

4.27 Dados de microfalhas e respectivos eixos de tensões na Pedreira Santo Antônio ...........106

4.28 Dados de microfalhas e respectivos eixos de tensões na Pedreira Bangu .....................107

4.29 Dados de microfalhas e respectivos eixos de tensões na Pedreira Emasa ......................109

4.30 Dados de microfalhas e respectivos eixos de tensões na Pedreira Simgra ......................110

4.31 Mapa síntese dos diques de rochas alcalinas máficas associadas ao Maciço do

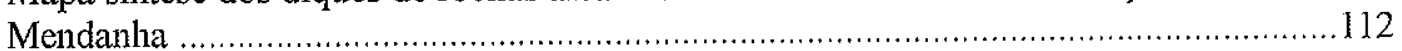

4.32 Mapa sintese dos diques de rochas alcalinas félsicas associadas ao Maciço do Mendanha 
4.33 Mapa síntese das paleotensões determinadas a partir de fallhas e microfalhas que afetam o Maciço do Mendanha

4.34 Mapa com distribuição de corpos alcalinos na porção central do Graben da

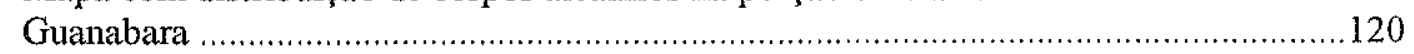

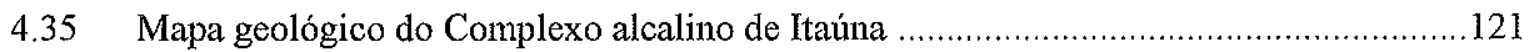

4.36 Fotos de tufos e brechas piroclásticas no Maciço de Itaúna ...........................................123

4.37 Projeções ciclográficas e polares, e diagramas de rosetas de diques de rochas alcalinas félsicas no Maciço de Itaúna ................................................................ 125

4.38 Projeções ciclográficas e polares de fraturas afetando microssienito e sienito no

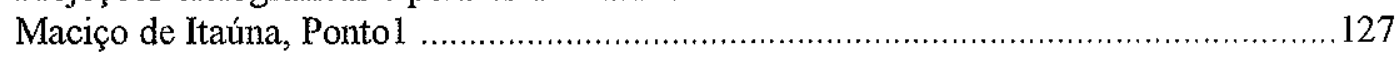

4.39 Projeções ciclográficas e polares de fraturas afetando microssienito e sienito no

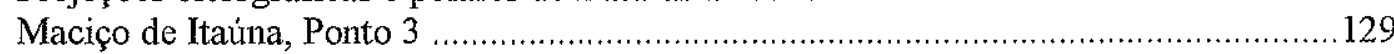

4.40 Familias de fraturas de cisalhamento conjugadas que afetam microssienito no Maciço de Itaúna, Ponto 3 .................................................................................. 130

4.41 Projeções ciclográficas e polares de fraturas afetando microssienito e sienito no

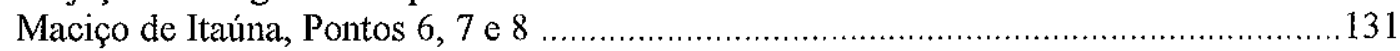

4.42 Projeções ciclográficas e polares de fraturas afetando fonolito no Maciço de Itaúna,

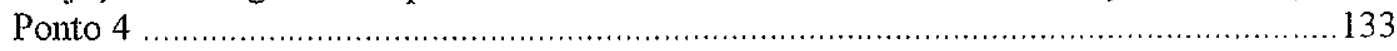

4.43 Famílias de fraturas de cisalhamento conjugadas que afetam traquito no Maciço

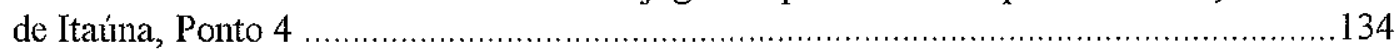

4.44 Projeções ciclográficas e polares de fraturas afetando fonolito e tufo no Maciço de

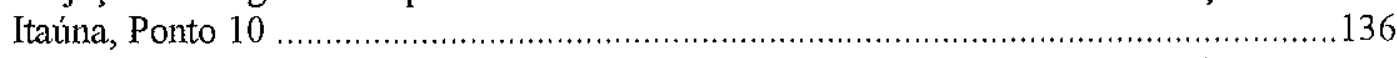

4.45 Famílias de fraturas de cisalhamento conjugadas que afetam fonolito no Maciço

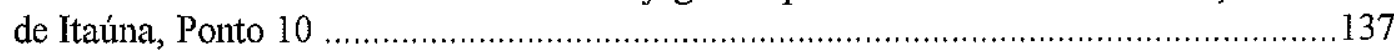

4.46 Projeções ciclográficas e polares de fraturas afetando fonolito pórfiro e microssienito no Maciço de Itaúna, Pontos 11 e 14 ........................................................................... 138

4.47 Projeções ciclográficas e polares de fraturas afetando fonolito pórfiro no Maciço de Itaúna, Ponto 12 .......................................................................................... 140

4.48 Projeções ciclográficas e polares de fraturas afetando tufo e fonolito pórfíro no Maciço de Itaúna, Pontos 16 e 17 .............................................................................. 141

4.49 Projeções ciclográficas e polares de fraturas afetando brecha vulcânica no Maciço

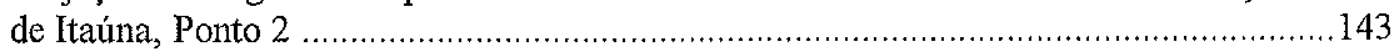

4.50 Famílias de fraturas de cisalhamento conjugadas que afetam brechas piroclásticas no Maciço de Itaúna, Ponto 5 ........................................................................... 144

4.51 Projeções ciclográficas e polares de fraturas afetando tufo e brecha vulcânica no Maciço de Itaúna, Pontos 5 e 9 ................................................................................. 145

4.52 Dados de falhas e respectivos eixos de tensões para o Maciço alcalino de Itaúna,

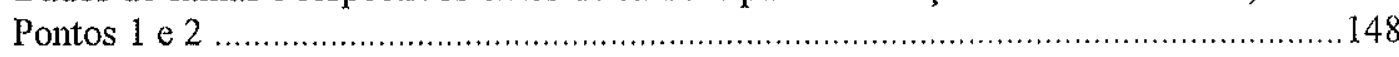

4.53 Dados de falhas e respectivos eixos de tensões para o Maciço alcalino de Itaúna, Pontos 3 e 4

4.54 Dados de falhas e respectivos eixos de tensões para o Maciço alcalino de Itaúna,

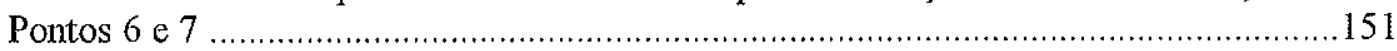

4.55 Mapa síntese das paleotensões determinadas no Maciço de Itaúna ................................. 152

4.56 Projeções ciclográficas e polares, e diagramas de rosetas de diques de rochas alcalinas félsicas no Maciço de Tanguá ........................................................................ 154

4.57 Projeções ciclográficas e polares de fraturas afetando sienito no Maciço do Tanguá, Ponto 1, Pedreira Santor .......................................................................... 156

4.58 Projeções ciclográficas e polares de fraturas afetando sienito no Maciço de Tanguá, Ponto 2, Pedreira Ermitang ................................................................................. 158

4.59 Dados de falhas e respectivos eixos de tensões para o Maciço de Tanguá, Ponto........ 160

4.60 Projeções ciclográficas e polares, e diagramas de rosetas de diques de rochas 
alcalinas félsicas do Plug de Itaboraí

4.61 Famílias de fraturas de cisalhamento conjugadas que afetam fonolito pórfiro no Plug de Itaboraí

4.62 Projeções ciclográficas e polares de fraturas afetando microssienito no Plug de

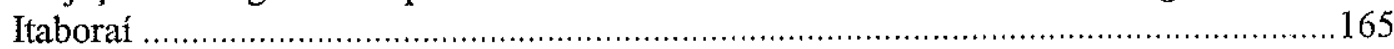

4.63 Dados de falhas e respectivos eixos de tensões para o Plug alcalino de Itaboraí......... 167

4.64 Projeções ciclográficas e polares de fraturas afetando fonolito pórfiro no Plug e Dique

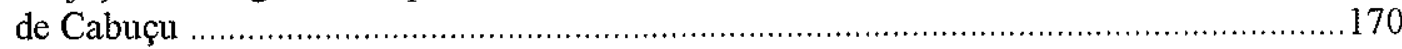

4.65 Famílias de fraturas de cisalhamento conjugadas que afetam fonolito pórfiro no Plug

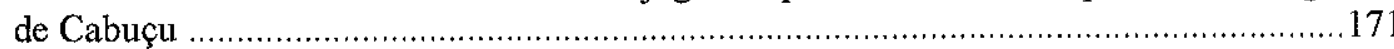

4.66 Dados de falhas e respectivos eixos de tensões para o Plug e o Dique de

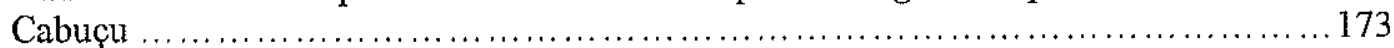

4.67 Pranchas de fotos do Plug do Jardim Cabuçu ............................................................. 175

4.68 Projeções ciclográficas e polares de fraturas afetando fonolito pórfiro no Plug de

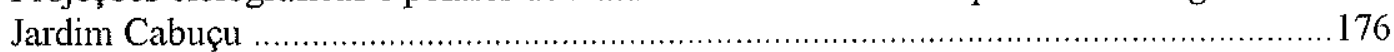

4.69 Projeções ciclográficas e polares de fraturas afetando fonolito pórfiro no Plug

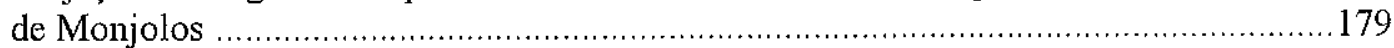

4.70 Pranchas de fotos do Plug do Country Club ............................................................. 180

4.71 Projeções ciclográficas e polares de fraturas que afetam fraturas no Plug do

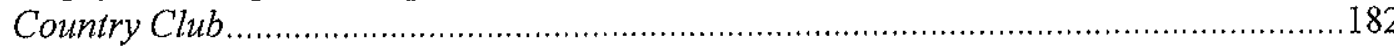

4.72 Mapa sintese das paleotensões determinadas para os corpos alcalinos da porção central

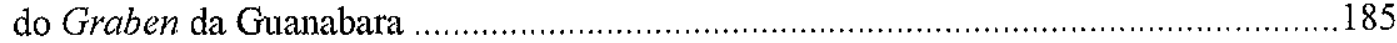

4.73 Mapa geológico da região de Arraial do Cabo, RJ, destcando o complexo alcalino da

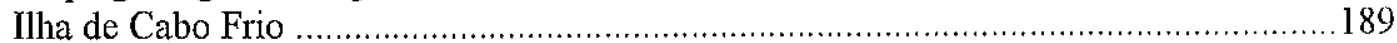

4.74 Pranchas de fotos da Ilha de Cabo de Frio .................................................................191

4.75 Mapa dos pontos com afloramentos descritos e amostrados do Complexo alcalino da Ilha de Cabo Frio e área adjacente ............................................................................ 193

4.76 Pranchas de fotos mostrando diques e famílias de fraturas na suite de Cabo

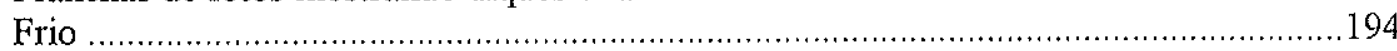

4.77 Pranchas de fotos mostrando diques alcalinoscortando o embasamento da suite de

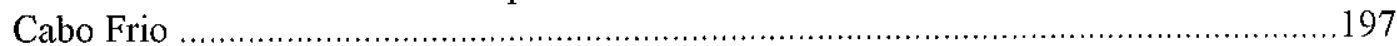

4.78 Relações angulares entre diques de traquito no Pontal do Atalaia .................................198

4.79 Relaçoes de corte entre diques alcalinos félsicos no Pontal do Atalaia, Município de Arraial do Cabo, ponto Arr 27 ............................................................................... 199

4.80 Projeções ciclográficas e polares, e diagramas de rosetas de diques de rochas alcalinas félsicas e máficas associadas à suíte da Ilha de Cabo Frio .............................200

4.81 Variação da espessura dos diques de rochas alcalinas associadas à suíte da Ilha de

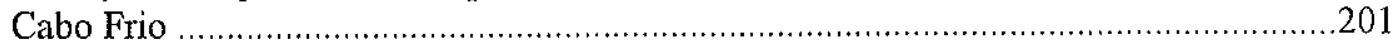

4.82 Aspectos do controle estrutural do embasamento sobre os diques terciários da região

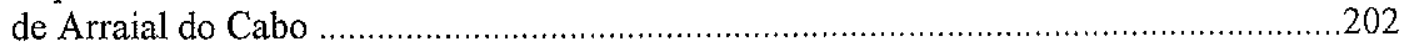

4.83 Mecanismo de intrusão de dique de lamprófiro …...................................................203

4.84 Análise cinemática dos diques associados à suíte da Ilha de Cabo Frio ........................205

4.85 Projeções ciclográficas e polares de famílias de fraturas que afetam rochas plutônicas hipabissais na suite da llha de Cabo Frio .....................................................207

4.86 Dados de fraturas e falhas, com os respectivos eixos de tensões, para o Município

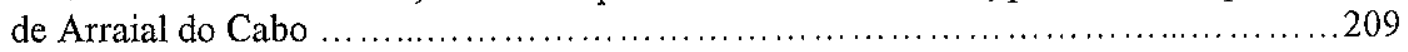

4.87 Fraturas de cisalhamento conjugadas em quartzo sienito na Ilha de Cabo Frio ............211

4.88 Mapa das paleotensões caracterizadas nas rochas plutônicas do Complexo alcalino da Ilha de Cabo Frio

4.89 Dados de fraturas e falhas, com os respectivos eixos de tensões, afetando traquito e preenchidas por veios pegmatóides para o Maciço da llha de 
Cabo Frio

4.90 Estruturas sigmóides em veios pegmatóides que cortam melassienito na liha de

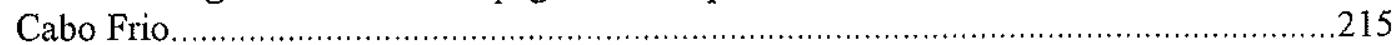

4.91 Juntas de tração escalonadas afetando diques de traquito ............................................216

4.92 Dados de falhas e respectivos eixos de tensões afetando traquito e basalto alcalino, Arraial do Cabo, Pontos Arr 45, 42-46, 39 e 29 .................................... 218

4.93 Faixas cataclásticas associadas à falha normal que afeta o embasamento e dique de basalto alcalino na Pedreira do Forno, Arraial do Cabo

4.94 Mapa das paleotensões caracterizadas nas rochas hipabissais do Maciço da Illha de

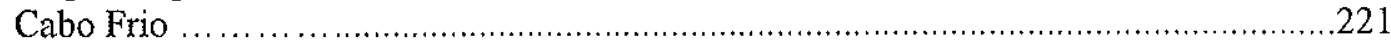

4.95 Mapa de pontos de coleta de dados estruturais, indicando a distribuição das falhas

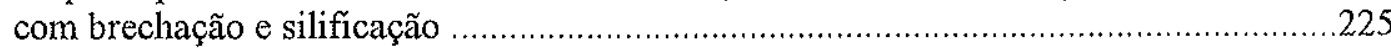

4.96 Diagrama de roseta com distribuição das direções das falhas com brechas

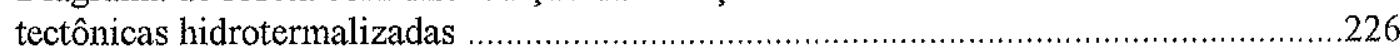

4.97 Dados de falhas e respectivos eixos de tensões para brechas tectônicas silicificadas, corte na Rodovia Presidente Dutra

4.98 Dados de falhas e respectivos eixos de tensões para brechas tectônicas silicificadas, bairro de Jacarepaguá

4.99 Veios de calcedônia injetados no Gnaisse Leptinítico, cataclasado e silicificado,

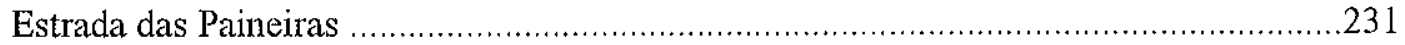

4.100 Dados de falhas e respectivos eixos de tensões para brechas tectônicas silicificadas, Estrada das Paineiras, Ponto Br-03

4.101 Dados de falhas e respectivos eixos de tensões para brechas tectônicas silicificadas, Estrada das Paineiras, Ponto Br-04

4.102 Dados de falhas e respectivos eixos de tensões para brechas tectônicas silicificadas,

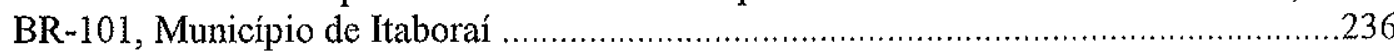

4.103 Dados de falhas e respectivos eixos de tensões para brechas tectônicas silicificadas,

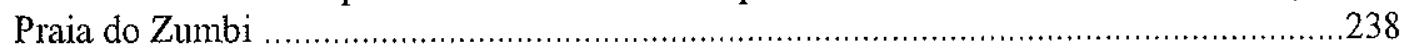

4.104 Prancha de fotos de brechas tectônicas silicificadas .....................................................239

4.105 Relação entre deformação e injeção de veios de calcedônia ...........................................240

4.106 Dados de falhas e respectivos eixos de tensões para brechas tectônicas silicificadas,

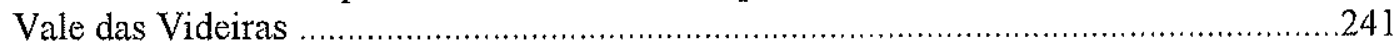

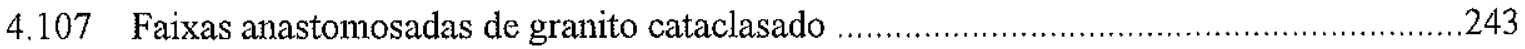

4.108 Dados de falhas e respectivos eixos de tensões para brechas tectônicas silicificadas, Município de Casemiro de Abreu .....................................................2. 244

4.109 Dados de falhas e respectivos eixos de tensões para brechas tectônicas silicificadas,

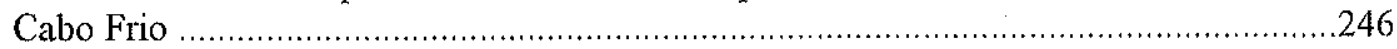

4.110 Dados de falhas e respectivos eixos de tensões para brechas tectônicas silicificadas,

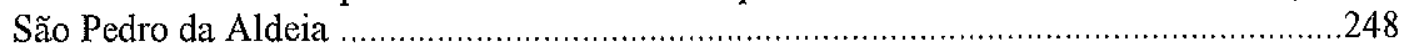

4.111 Mapa síntese das paleotensões determinadas nas brechas tectônicas silicificadas, a partir de falhas e microfalhas

\section{Capítulo 5}

5.1 Prancha de fotos de plano de falha no Maciço de Itaúna 255

5.2 Fotos de amostra evidenciando falha direcional sinistral em borda de dique de basalto alcalino

5.3 Fotos e imagem de MEV de amostras de plano de falha reversa que afeta fonolito no Maciço de Itaúna

5.4 Imagens de fraturas preenchidas obtidas por MEV

5.5 Imagens de plano de fallhas com indicadores cinemáticos obtidas por MEV.

5.6 Imagens de plano de falhas direcional em borda de dique de diabásio obtidas 
por MEV

5.7 Imagem de plano de falha em dique de diabásio mostrando fraturas de

extensão preenchidas

\section{Capítulo 6}

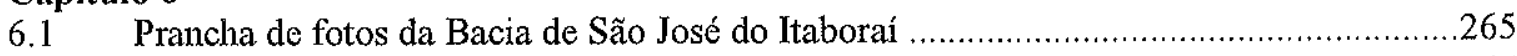

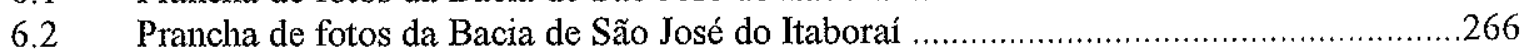

6.3 Perfil N-S na porção mais tectonizada da bacia de São José do Itaboraí ......................271

6.4 Prancha de fotos da Bacia de São José do Itaboraí ……............................................2.

6.5 Projeções ciclográficas, polares e diagramas de rosetas de veios de calcário travertino

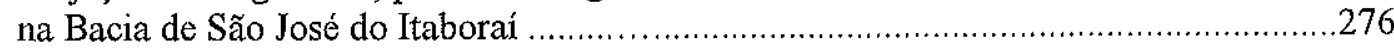

6.6 Dados de microfalhas e respectivos eixos de tensões, afetando calcário travertino e calcário maciço, na Bacia de São José do Itaboraí ...................................................278

6.7 Dados de microfalhas e respectivos eixos de tensões, afetando calcário maciço e calcário cinzento, na Bacia de São José do Itaboraí ....................................................28

6.8 Perfis de sondagens modificados a partir de Companhia Nacional de

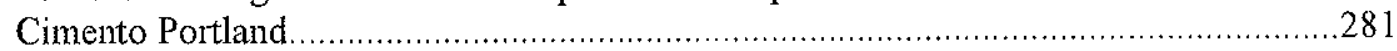

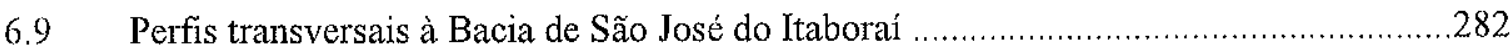

6.10 Perfis rebatidos indicando os novos limites da Bacia de São José do Itaboraí ...............284

6.11 Perfis geológicos esquemáticos da Bacia de São José do Itaboraí construídos a partir

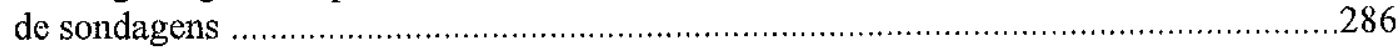

6.12 Mapa estrutural da Bacia de São José do Itaboraí ......................................................28

6.13 Geologia simplificada do Cretáceo e Paleógeno na porção central do Rift

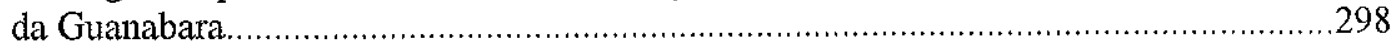

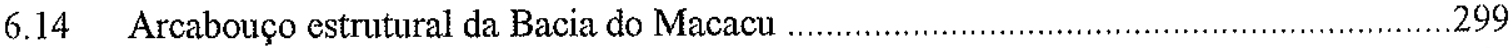

6.15 Prancha de fotos mostrando o relevo da Bacia de Macacu e de seu entorno ..................302

6.16 Prancha de fotos mostrando o relevo da borda norte da Bacia de Macacu e de seu

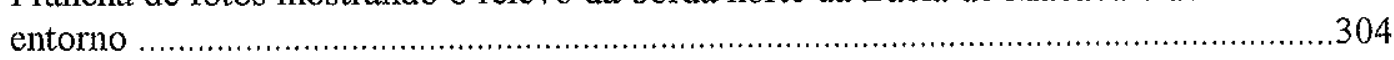

6.17 Mapa com os pontos descritos nas áreas de ocorrência da Formação Macacu ................306

6.18 Pranchas de fotos do Barreiro de São João Batista, em Itaboraí, e de fácies

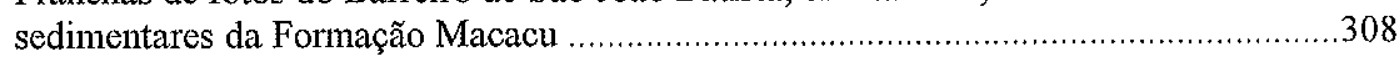

6.19 Perfis colunares das associações de fácies da Formação Macacu .................................310

6.20 Prancha de fotos panorâmicas da Formação Macacu, Ponto 12 ....................................313

6.21 Prancha de fotos panorâmicas da Formação Macacu, Ponto 25 ..................................... 314

6.22 Pranchas de fotos de fácies sedimentares da Formação Macacu e do

Conglomerado Itambi

6.23 Pranchas de fotos mostrando fácies sedimentares de leques aluviais da Formação

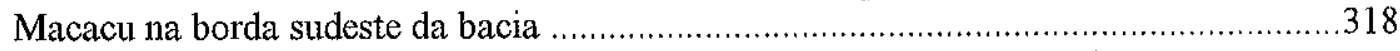

6.24 Poços artesianos profundos que não atingiram o embasamento na Bacia do

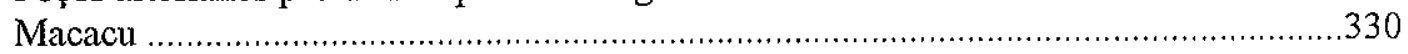

6.25 Rosetas com medidas de paleocorrentes nos depósitos da Formação Macacu ................336

6.26 Direções médias de paleocorrentes da Formação Macacu ...........................................337

6.27 Coluna geológica esquemática dos depósitos sedimentares da Formação Macacu,

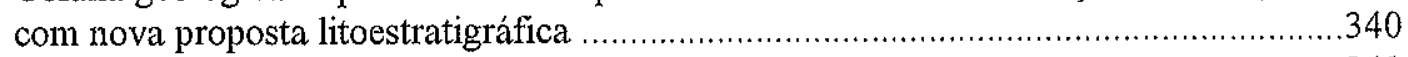

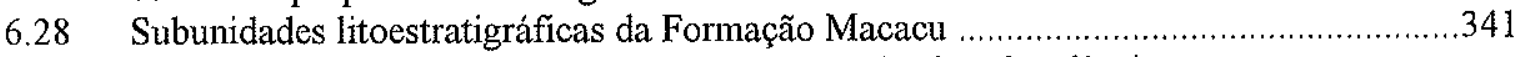

6.29 Prancha de fotos mostrando falhas normais, de alto ângulo e lístricas,

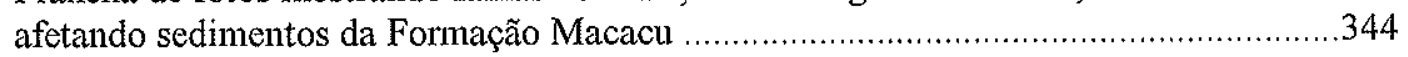

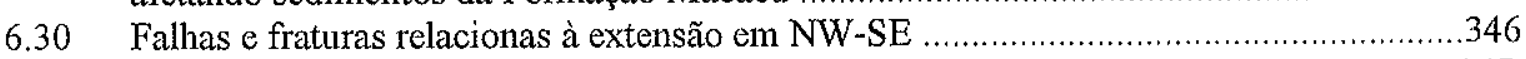

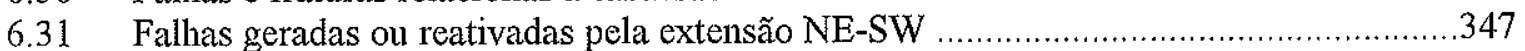

6.32 Falhas geradas ou reativadas pela extensão E-W a WNW-ESE ……............................349

6.33 Mapa das paleotensões caracterizadas nos sedimentos da Bacia de Macacu e 
nas ocorrências isoladas da Formação Macacu

Modelo tectono-sedimentar para a evolução da Bacia do Macacu

6.35 Assinatura tectônica da sedimentação da associação de fácies de canal entrelaçado, da Formação Macacu

\section{Capítulo 7}

7.1 Perfil geológico ns porção central do Graben da Guanabara

7.2 Síntese da paleotensões determinadas no Graben da Guanabara.

7.3 Coluna cronoestratigráfica do Graben da Guanabara

7.4 Quadro evolutivo proposto para o Graben da Guanabara. 


\section{LISTA DE ANEXOS}

ANEXO A - Datações radiométricas pelo Método AR ${ }^{40} / \mathrm{AR}^{39}$, realizadas no ACTLABS (Canadá)

ANEXO B - Datações radiométricas pelo Método $\mathrm{AR}^{40} / \mathrm{AR}^{39}$, realizadas no IG / USP ANEXO C - Difratogramas de Raios X 


\section{INTRODUÇÃO}

\subsection{APRESENTAÇAO DO PROBLEMA E OBJETIVOS}

O Graben da Guanabara foi definido por Almeida (1976) que o denominou Rift da Guanabara, englobando toda a área de relevo deprimido que se estende desde a Baía de Sepetiba, a oeste, até a localidade de Barra de São João, a leste. Essa área é bordejada ao norte pela Serra do Mar, que chega a alcançar 2200 metros de altitude e pelos maciços litorâneos, ao sul, com altitudes máximas em torno de 1000 metros (Figura 1.1). No interior do graben as altitudes raramente ultrapassam os 100 metros, com exceção para os maciços constituídos de rochas alcalinas, quando podem chegar a quase 1000 metros (Ferrari 1990).

A íntima relação entre um evento tectônico cenozóico e a formação das bacias continentais do sudeste brasileiro, como as de Taubaté, São Paulo, Resende e Volta Redonda, já apontada por diversos autores (Almeida 1967,1969,1976, Asmus \& Ferrari 1978, Hasui et al. 1978, Melo et al. 1985a), que as caracterizaram como bacias tafrogênicas, vem sendo corroborada por estudos mais recentes, de detalhe, que têm demonstrado uma complexa sucessão de eventos tectônicos rúpteis acompanhados de sedimentação, cujos registros se estendem até o Holoceno, indicando atividade neotectônica no sudeste brasileiro (Riccomini 1989, 1995a; Riccomini et al. 1989). Riccomini (1989) definiu o Rift Continental do Sudeste do Brasil (RCSB), se estendendo desde a Bacia de Curitiba (PR), até o Graben de São João da Barra (RJ), por cerca de $900 \mathrm{~km}$, englobando as diversas bacias tafrogênicas que ocorrem numa faixa de aproximadamente $100 \mathrm{~km}$ de largura, junto ao litoral e que foram anteriormente agrupadas por Almeida (1976) no Sistema de Rifts da Serra do Mar (Figura 1.2).

A atividade neotectônica é confirmada pela sismicidade registrada nesta área, inclusive no Graben da Guanabara (Assumpção et al. 1980, 1997, Assumpção 1992, Mioto 1990).

O modelo desenvolvido por Riccomini (1989, 1995a), para o segmento do RCSB entre São Paulo e Volta Redonda, foi parcialmente estendido para o Graben da Guanabara (Riccomini \& Rodrigues Francisco 1992). Diversas evidências de atividade tectônica, sedimentação e vulcanismo recorrentes tem sido apontadas neste 


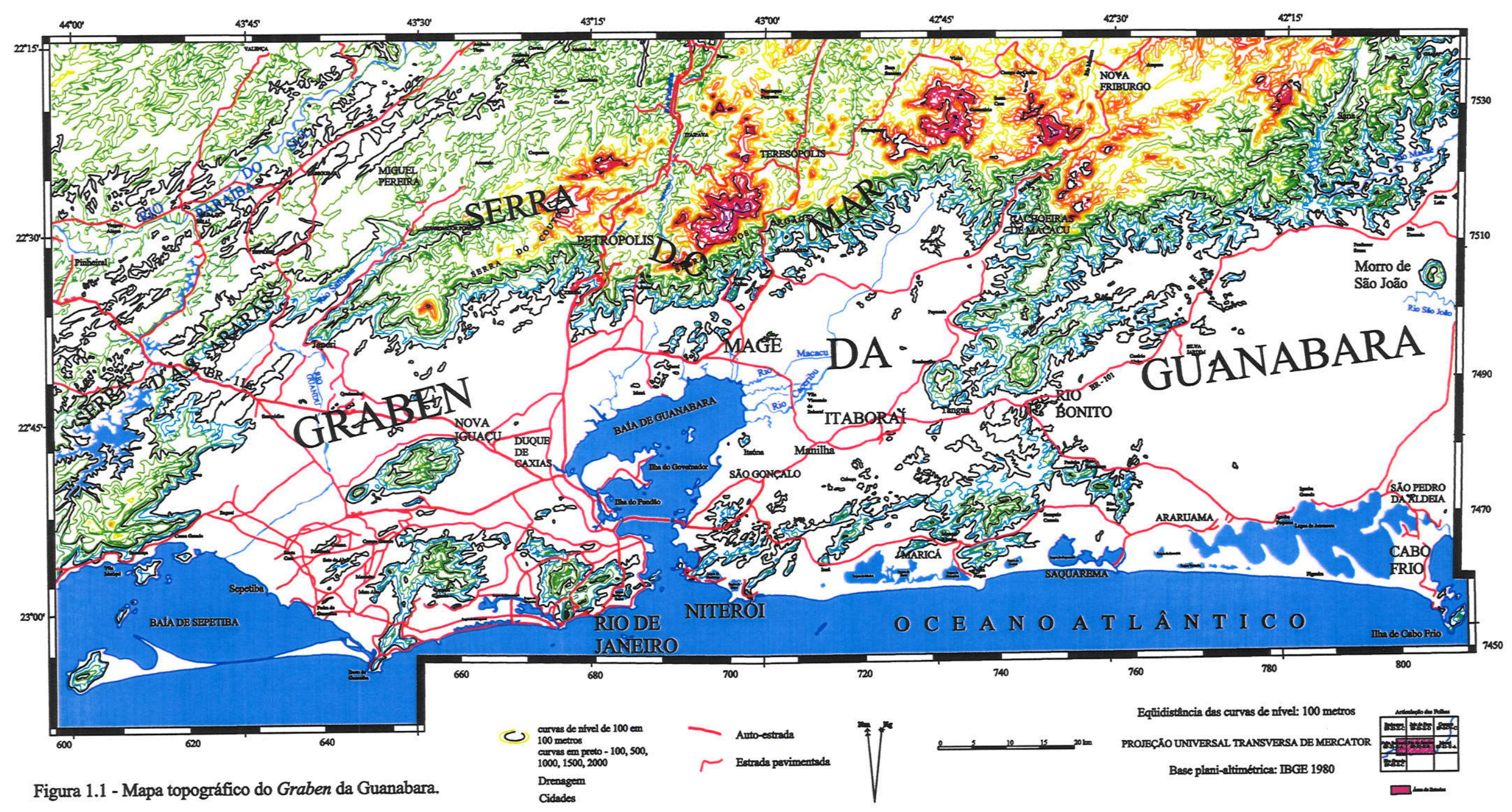




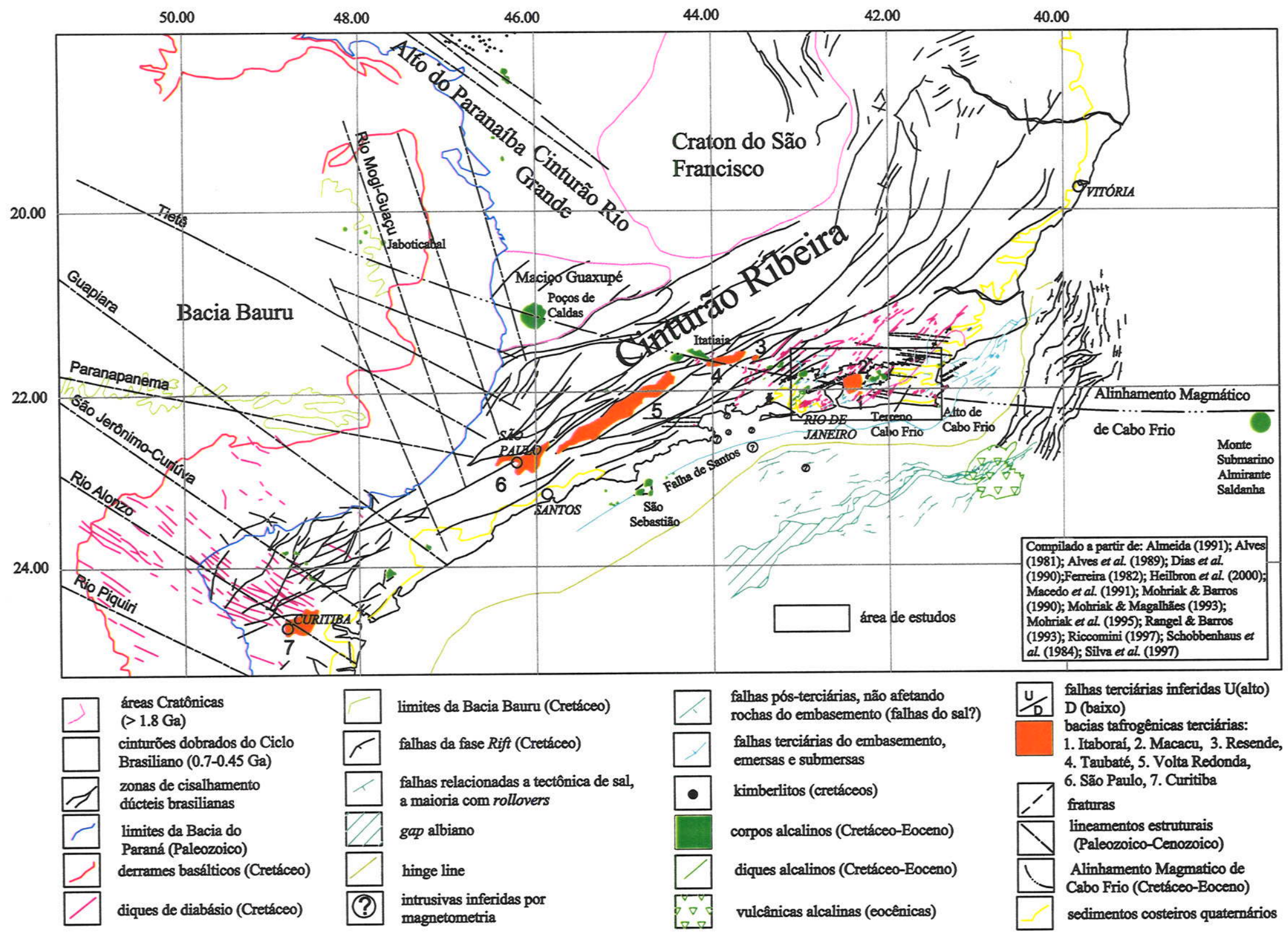

Figura 1.2 - Principais feições estruturais fanerozóicas do sudeste do Brasil, destacando o Sistema de Rifts do Sudeste (Almeida 1976) ou Rift Continental do Sudeste do Brasil (Riccomini 1989), constituídos pelas bacias tafrogênicas terciárias. Figura modificada a partir de Ferrari et al. (1999). 


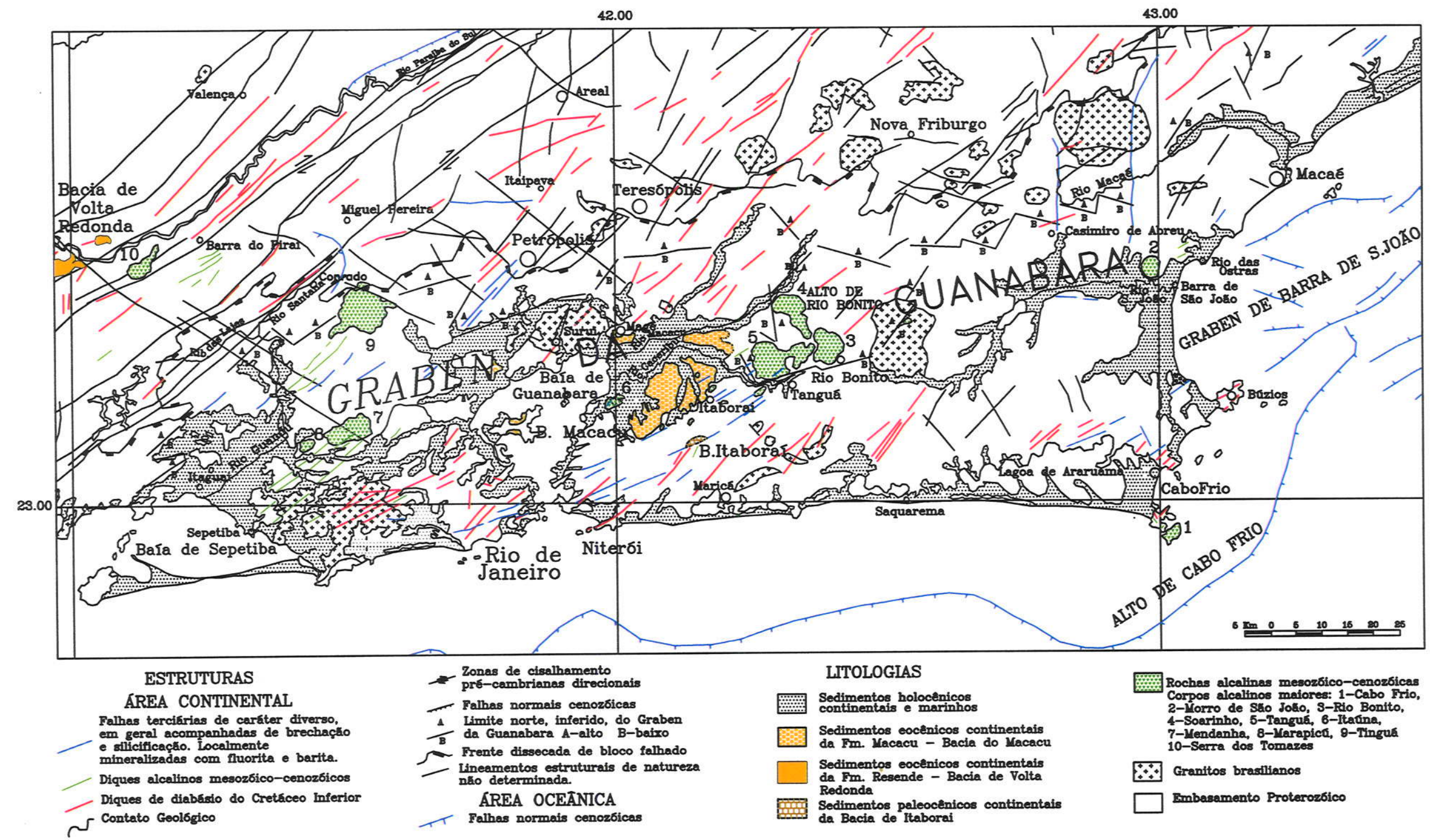

Figura 1.3 - Mapa geológico do Graben da Guanabara e arredores, integrado, modificado e atualizado por Silva et al. (1997), a partir de: Hembold et al. (1965); Penha et al. (1980, 1982); Barbosa et al. (1981, 1983); Dalcolmo et al. (1982); Machado Filho et al. (1983); Alves et al. (1989); Ferrari (1990); Mohriak et al. (1992) e Riccomini (1995a). 
graben (Almeida 1976, Ferrari, 1990, Ferrari et al. 1997a e b) (Figura 1.3). Os dados indicam que ele possui o registro sedimentar mais antigo, na Bacia de Itaboraí (Paula Couto 1952, Alvarenga 1983, Lima \& Cunha 1986, Bergqvist 1996), e a melhor preservação de rochas vulcânicas ao longo do RCSB (Dalcolmo et al. 1982, Klein et al. 1984, Klein \& Valença 1984 a e b, Andreis et al. 1999, Klein et al. 1999).

Diversos modelos têm sido propostos para a origem destas bacias tafrogênicas, em geral associando-as à importante morfogênese responsável pela formação das Serras do Mar e da Mantiqueira. Inicialmente, esses modelos tiveram enfoque essencialmente geomorfológico e dividiam-se entre uma origem tectônica (De Martonne 1943, Ruellan 1944, Freitas 1956, Birot 1959) ou puramente erosiva - borda erosiva de monoclinal (King 1956). Passaram, posteriormente, pelos modelos de deslizamento gravitacional (Almeida 1976) e de compensação isostática (Asmus \& Ferrari 1978), já associando sua origem à evolução da margem continental. Posteriormente, Azevedo Júnior (1991) retomou o modelo erosivo, considerando a Serra do Mar como um relevo residual, associado a migração continente adentro da frente erosiva do Planalto Atlântico.

Fernandes \& Chang (1992) e Fernandes (1993) propuseram uma variação do modelo anterior, em que as bacias tafrogênicas seriam geradas por colapso extensional da frente de dissecação do planalto do sudeste brasileiro em sua migração continente adentro, gerando bacias progressivamente mais jovens. Desta forma, segundo estes autores, a Bacia de São José do Itaboraí, de idade paleocênica, marcaria uma posição pretérita da Serra do Mar, mais próxima da falha de borda da Bacia de Santos. Como corolário, a Bacia do Macacu representaria uma posição mais nova dessa serra.

Evidências de taxas de erosão heterogêneas e de controle estrutural das formas de relevo, no interior do Graben da Guanabara, são apontadas por Ferrari (1990) e Silva \& Ferrari (1997a), respectivamente, reforçando a vinculação entre a evolução do graben e os eventos tectônicos cenozóicos.

Almeida \& Carneiro (1998) propuseram um modelo que conjuga tectonismo cenozóico e recuo erosivo de escarpa, no qual a proto Serra do Mar teria se originado no Paleoceno, junto à Falha de Santos (ver Figura 1.2). Esse evento teria sido contemporâneo à geração do Graben da Guanabara, posicionando-o, nessa época, longe do litoral e impedindo a sua invasão pelo mar. 
Dessa forma, algumas questões referentes à evolução do Graben da Guanabara permanecem em aberto:

1) as evidências de taxas de soerguimento heterogêneas, controladas por falhas, no interior do graben;

2) as características tectono-sedimentares do seu preenchimento, em especial na Bacia do Macacu, e a sua segmentação;

3) a recorrência e preservação do vulcanismo alcalino;

4) a recorrência e o padrão da atividade tectônica ao longo do Cenozóico;

5) o diacronismo entre a formação do rift precursor das bacias da margem continental e a formação do RCSB.

Tais questões indicam uma evolução mais complexa para o Graben da Guanabara do que o estabelecido até agora, estando possivelmente relacionada à interação de esforços de borda com esforços locais, a uma menor rigidez flexural que aquela assumida nos modelos de Azevedo Júnior (1991) e Fernandes (1993), como já sugerido por Gallager et al. (1994) e, possivelmente, à recorrência de anomalias térmicas geradoras de soerguimento, como, também, já sugerido por Valente (1997) e Thompson et al. (1998).

Neste sentido, com o objetivo de caracterizar a evolucão tectônica do Graben da Guanabara e responder algumas das questões levantadas propõe-se o seguinte:

1) determinar a deformação sin e pós-deposicional nas bacias de São José do Itaboraí e do Macacu e realizar a sua análise cinemática;

2) descrever e caracterizar a distribuição das fácies sedimentares e de suas associações, na Bacia do Macacu, visando determinar a sua evolução tectonosedimentar e paleogeográfica;

3) analisar a tectônica rúptil dos maciços alcalinos do Mendanha, Itaúna, Tanguá e Cabo Frio, buscando caracterizar as paleotensões vigentes do Cretáceo Superior ao Eoceno;

4) definir o controle tectônico dos diques de rochas alcalinas, e determinar os campos de paleotensões vigentes na sua intrusão;

5) determinar a idade, pelo método $\mathrm{Ar} / \mathrm{Ar}$, de alguns dos diques envolvidos na análise estrutural, buscando refinar o intervalo de atuação dos campos de paleotensões.

A discriminação das estruturas mesozóico-cenozóicas e a caracterização de seu processo de geração e/ou reativação, relacionado com os campos de paleotensões 
então vigentes, é de interesse para o melhor entendimento de diversos aspectos da geologia dessa área. Dentre esses destaca-se a neotectônica, sobretudo no seu caráter ressurgente, em uma área densamente habitada como a Região Metropolitana do Rio de Janeiro. Esta atividade neotectônica, evidenciada pela sismicidade existente na região (Assumpção et al. 1980), pode vir a caracterizar situações de risco geológico com resultados eventualmente nocivos à população, tendo em vista o relevo acidentado, com encostas íngremes e desordenadamente ocupadas e, ainda, as importantes instalações industriais, incluindo refinarias, e militares, ali existentes. Por outro lado, a determinação dos campos de paleotensões mais recentes pode ajudar na discriminação dos eventos de abertura e fechamento de famílias de fraturas e, como conseqüência, dos caminhos de migração de fluídos, como água subterrânea e, mesmo, de óleo nas bacias marginais adjacentes. Sob outro aspecto, essa caracterização pode auxiliar, também, no melhor entendimento de feições semelhantes existentes na área submersa adjacente, como o Graben de Barra de São João.

\subsection{ESTRUTURA DA TESE}

No Capítulo 1 é feita a apresentação do problema e os objetivos a serem perseguidos. Na segunda parte, capítulos 2 e 3, é apresenta-se uma revisão dos trabalhos anteriores acerca da evolução tectônica do Graben da Guanabara, no contexto do Rift Continental do Sudeste do Brasil (RCSB), e são revistos e apresentados os métodos que foram utilizados no desenvolvimento do trabalho de tese. Na terceira parte, capítulos 4 e 5 , são apresentados os dados de fraturamento nos corpos de rochas alcalinas (Mendanha, Itaúna, Tanguá, Cabo Frio e diversos plugs que ocorrem na porção central do graben) e nos diques a eles associados, além de exemplos de indicadores cinemáticos rúpteis caracterizados nas falhas que afetam as rochas alcalinas. Na quarta parte, Capítulo 6, é discutida a evolução tectonosedimentar do preenchimento do graben, representado pelas bacias de São José do Itaboraí e do Macacu. No Capítulo 7 são feitas as discussões de integração dos dados e apresentadas as conclusões finais. 


\section{REVISÃO DOS ASPECTOS GEOLÓGICOS REGIONAIS SOBRE O GRABEN DA GUANABARA}

\subsection{GEOLOGIA DO RCSB}

A evolução do RCSB tem sido relacionada à fase tardia do evento de ativação tectônica da Plataforma Sul Americana, associado à fragmentação do Gondwana e formação do Oceano Atlântico Sul. Este evento, denominado inicialmente de Reativação Wealdeniana, teria sido responsável pelos derrames basálticos juro-cretácicos da Formação Serra Geral, pela implantação das bacias marginais e, como efeito tardio, já no Cenozóico, pela "formação da antéclise do Rio Paraíba do Sul e de seu graben mediano" (Almeida 1967, 1969). Almeida (1976) englobou as bacias tafrogênicas associadas, de Curitiba, São Paulo, Taubaté, Resende, e o Graben da Guanabara no Sistema de Rifts da Serra do Mar. Schobbenhaus et al. (1984) denominaram de Evento Sul-Atlantiano as atividades tectonomagmáticas que acompanharam e se seguiram à separação dos continentes Africano e SulAmericano.

\subsubsection{Quadro Tectono-Estratigráfico}

Estudos de detalhe desenvolvidos ao longo dos anos oitenta, em especial no segmento central do RCSB (Riccomini et al. 1983, 1985, Melo et al. 1985a e b, Riccomini et al. 1996), levaram ao estabelecimento de um quadro tectono-estratigráfico regional (Riccomini 1989, 1995a), envolvendo a caracterização de cinco seqüências sedimentares, referidas a diferentes unidades litoestratigráficas, além de quatro fases de deformação rúptil (Figura 2.1):

a) Formação Resende, constituída por depósitos de leques aluviais e de rios entrelaçados;

b) Formação Tremembé, constituída por depósitos lacustres;

c) Formação São Paulo, constituída por depósitos de rios meandrantes; 
d) Formação Itaquaquecetuba, constituída por depósitos de rios entrelaçados;

e) Formação Pindamonhangaba, constituída por sedimentos de ambiente fluvial meandrante.

As três primeiras correspondem em seu conjunto ao Grupo Taubaté, depositado durante a fase extensional inicial, de direção NW-SE. Também faz parte dele, o Basanito Casa de Pedra, intercalado nos lamitos da Formação Resende. Este grupo mostra evidências de ter sido depositado dominantemente em clima semi-árido, com exceção da Formação São Paulo, de condições mais úmidas. De acordo com Riccomini (1989) a deposição da Formação Itaquaquecetuba teria sido controlada por uma transcorrência sinistral, associada a um binário $\mathrm{E}-\mathrm{W}$.

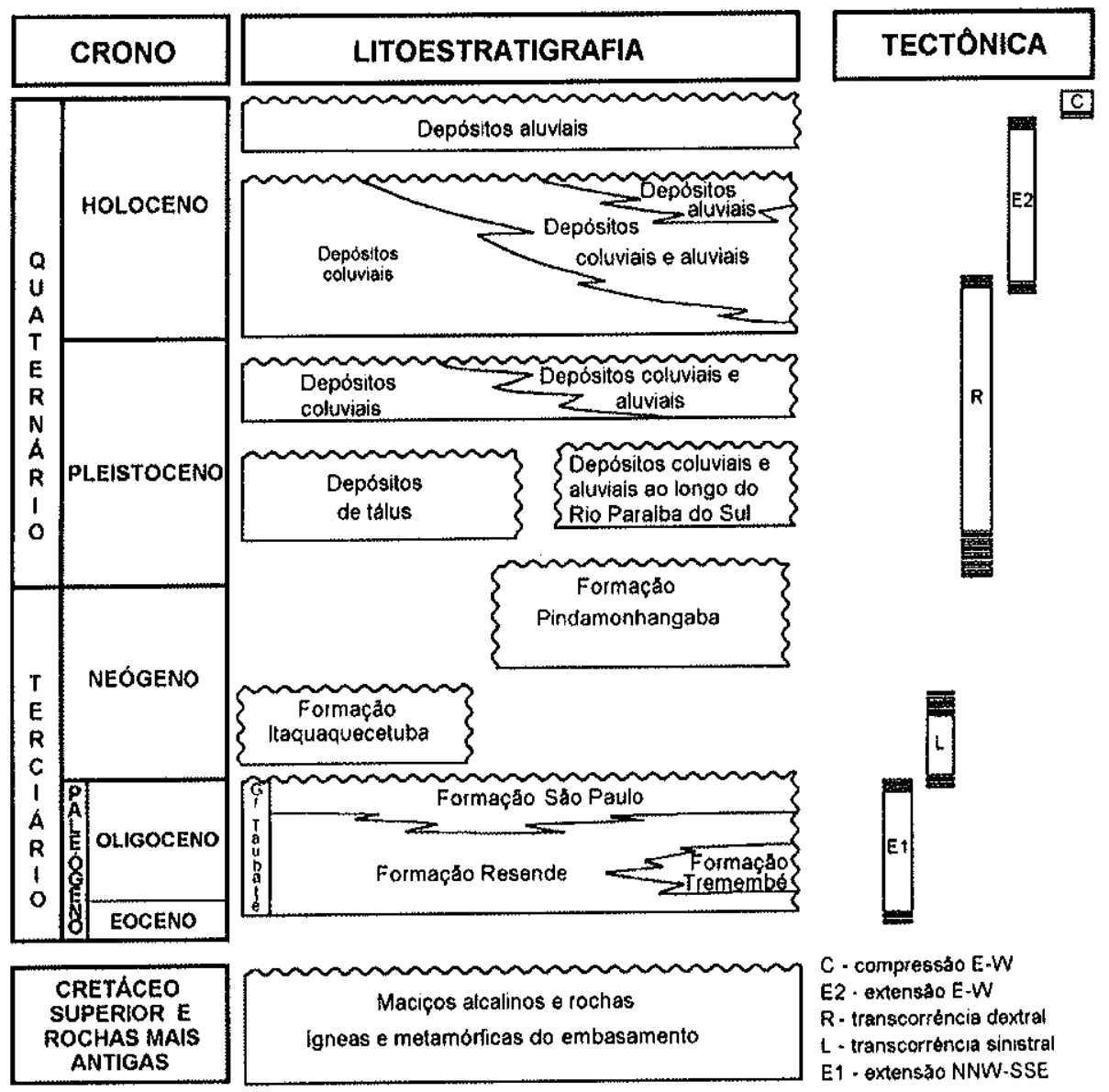

Figura 2.1 - Relações entre a estratigrafia e a tectônica no Rift Continental do Sudeste do Brasil (modificado de Riccomini 1989, Salvador 1994 e Mancini 1995, por Riccomini et al. 1996) 
Ainda de acordo com esses autor, no Quaternário se acumularam depósitos colúvioaluviais em duas fases distintas, inicialmente acompanhados por transcorrência dextral, passando a uma extensão WNW-ESE e, finalmente, por uma compressão E-W.

Nenhuma das bacias possui o pacote completo e a espessura máxima é observada na Bacia de Taubaté, onde chega a 850m (Riccomini 1989, Marques 1990), não passando de $300 \mathrm{~m}$ na de São Paulo, 200m na de Resende e 100m na de Volta Redonda (Riccomini 1989). Na Bacia de Curitiba a espessura máxima não ultrapassa 60m (Coimbra et al. 1996). No Graben de Barra de São João ela chega também a 800m (Mohriak \& Barros 1990). No Graben da Guanabara, a Bacia de Itaboraí tem $125 \mathrm{~m}$ de espessura (Rodrigues Francisco et al. 1986), e a Bacia do Macacu (Ferrari \& Silva 1997a) possui cerca de 120m de espessura conhecida (Meis \& Amador 1977) e, inferências discrepantes, a partir de dados gravimétricos, de uma espessura de $800 \mathrm{~m}$ (Haralyi et al. 1982) ou pouco mais de $200 \mathrm{~m}$ (Ferrari \& Ferraz 1988).

No modelo de Riccomini (1989) as fases de deformação neogênicas seriam essencialmente modificadoras do RCSB e responsáveis pela implantação e/ou inversão de altos e baixos, individualizando e dando a forma atual às bacias e, ainda, encaixando depósitos pouco extensos e pouco espessos nos altos interbasinais. Este autor relacionou as diversas fases de deformação que afetaram a área a dois fatores principais: a primeira delas, à subsidência térmica da Bacia de Santos e, as demais, a interações entre as taxas de espalhamento e subducção nos limites oriental e ocidental, respectivamente, da placa Sul Americana.

A inferência de uma nova variação no campo de esforços, no Holoceno, a partir de mecanismos focais de terremotos no RCSB (Riccomini et al. 1989, Assumpção 1992, Assumpção et al. 1997), indicando a atual vigência de esforços compressivos E-W, e que foram confirmados a partir de dados geológicos, por Salvador (1994) e Salvador \& Riccomini (1995), reforçam o modelo tectônico proposto para o Neógeno. 


\subsubsection{Morfogênese no RCSB}

A atuação de um evento de aplainamento no Sudeste do Brasil, no Cretáceo Superior e Paleógeno, é apontada por diversos autores. As superfícies de aplainamento geradas receberam diversas denominações de acordo com a altitude em que elas estão posicionadas, a saber:

- Superfície dos Campos ou dos Altos Campos (De Martonne 1944), ou ainda Superfície Sul Americana (King 1956), com 2000 a 2300 metros de altitude,

- Superfície das Cristas Médias (De Martonne 1944) ou Japi (Almeida 1964), com 1200 a 1400 metros de altitude.

Para De Martonne (1944) e Ab'Saber (1954), a Superfície Cristas Médias seria resultado da pediplanização da Superfície dos Campos. Para Freitas (1951) e Almeida $(1964,1976)$ a Superfície dos Campos é que seria o resultado do soerguimento de porções da Japi. Para esse último autor a Superfície Japi, "quando não deformada", teria 1200 metros de altitude, e segundo ele esse evento teria afetado os corpos alcalinos em São Paulo, aplainando-os e erodindo seus correspondentes vulcânicos. De acordo com Almeida (1976), esta superfície teria sido rebaixada tectonicamente para dar origem ao Sistema de Rifts da Serra do Mar (SRSM), posicionando a sua idade mínima no Eoceno. Os depósitos correlatos a ela na Bacia de Santos indicam seu desenvolvimento entre o Turoniano e o Paleoceno (Pereira et al. 1986, Almeida \& Carneiro 1998).

A partir dos anos 80 as datações por traços de fissão em apatitas têm apontado para uma taxa de erosão mais intensa junto ao litoral, em toda a região sudeste, entre 90 e $60 \mathrm{Ma}$ (Fonseca \& Poupeau 1984, Azevedo Júnior 1991, Gallagher et al. 1994). Segundo esses autores, tais resultados indicariam uma exumação de cerca de $3 \mathrm{~km}$ junto à costa. Para Gallagher et al. (1994) e Sperle et al. (1997) essa erosão intensa da borda continental estaria associada a um recuo erosivo das bordas do rift cretácico. Para Azevedo Júnior (1991) a Serra da Mantiqueira representaria a frente atual desse recuo erosivo e a Serra do 
Mar e os maciços litorâneos do Rio de Janeiro corresponderiam a um relevo residual, associado a litologias mais resistentes e/ou a áreas sem a atuação de drenagens importantes. Esse modelo retoma o conceito de pediplanização proposto por King (1956, 1957, 1967), segundo o qual áreas soerguidas posicionadas junto ao litoral sofreriam erosão remontante resultando, ao final do processo, em superfícies suavemente convexas com altitudes crescentes continente adentro. Esse conceito se contrapõe ao de peneplanização ou Ciclo de Davies (Davis 1902), que considera que o rebaixamento do relevo, por erosão, se efetua em todo o continente ao mesmo tempo. Na pediplanização, as superfícies de aplainamento geradas, terão idade mais nova do litoral para o interior do continente.

No Graben da Guanabara, apesar da presença de um relevo principal ao norte, aparentemente associado à falha de borda e responsável pelo basculamento da Superfície do Japi para NNW (Ruellan 1944, Asmus \& Ferrari 1978, Penha et al. 1980), os depósitos sedimentares no seu interior são controlados por falhas situadas ao sul (Rodrigues Francisco \& Cunha 1978, Ferrari 1990, Cabral Júnior 1993, Ferrari \& Silva 1997). A presença de sedimentos rudáceos junto a borda sul indica que este controle foi, pelo menos em parte, sinsedimentar (Cabral Júnior 1993, Lima et al. 1996, Ferrari \& Silva 1997). Este padrão é concordante com aquele descrito por Mohriak \& Barros (1990) para o Graben de Barra de São João, já na plataforma rasa da Bacia de Campos, junto ao Alto de Cabo Frio, onde, apesar da predominância de falhas sintéticas de pequeno rejeito, o seu depocentro é controlado por uma falha antitética, ao sul, com rejeito de 500 metros.

Considerando a preservação de diversas ocorrências de rochas extrusivas alcalinas no interior do graben (Dalcolmo et al. 1982, Klein 1992, Andreis et al. 1998, 1999), sobre a Superfície do Japi (Ferrari 1990), e considerando os novos dados geocronológicos disponíveis para as rochas alcalinas (Dehira et al. 1998), Capítulos 4.3.5, 4.3.7 e Anexo 1, nesse trabalho), que indicam que as vulcânicas são essencialmente coetâneas com os corpos intrusivos, conclui-se pela atuação de taxas de erosão heterogênas no interior do Graben da Guanabara desde o final do Cretáceo. Tal heterogeneidade pode ser explicada pelo tectonismo que afetou a borda continental da região sudeste nessa época, como será visto nos capítulos seguintes. 


\subsubsection{Modelos de Formação das Bacias do RCSB}

A Bacia de Taubaté é a maior do RCSB, com comprimento de pouco mais de 200 $\mathrm{km}$ e largura média de $20 \mathrm{~km}$, e também a que mais tem atraído a atenção dos pesquisadores e gerado interpretações divergentes sobre sua origem. $\mathrm{O}$ seu formato de romboedro alongado, a limitação por zonas de cisalhamento do embasamento e a existência de "fraturas en echelon" no embasamento adjacente, foram utilizados por Zalán (1986) para classificá-la como uma provável bacia transcorrente, resultante de movimentação sinistral ao logo das zonas de cisalhamento (Figura 2.2). Esta mesma origem foi defendida por Padilha et al. (1991), com base nas evidências geofísicas de uma crosta normal, com um pequeno afinamento em direção à região litorânea, de apenas $2 \mathrm{~km}$, sem heterogeneidades na sua porção média e inferior e com fluxo térmico compatível com o regional. Segundo eles, estas características, aliadas à ausência de vulcanismo e ao arranjo em semi-grabens, com depocentros deslocados por falhas transversais, sustentariam esta inferência.

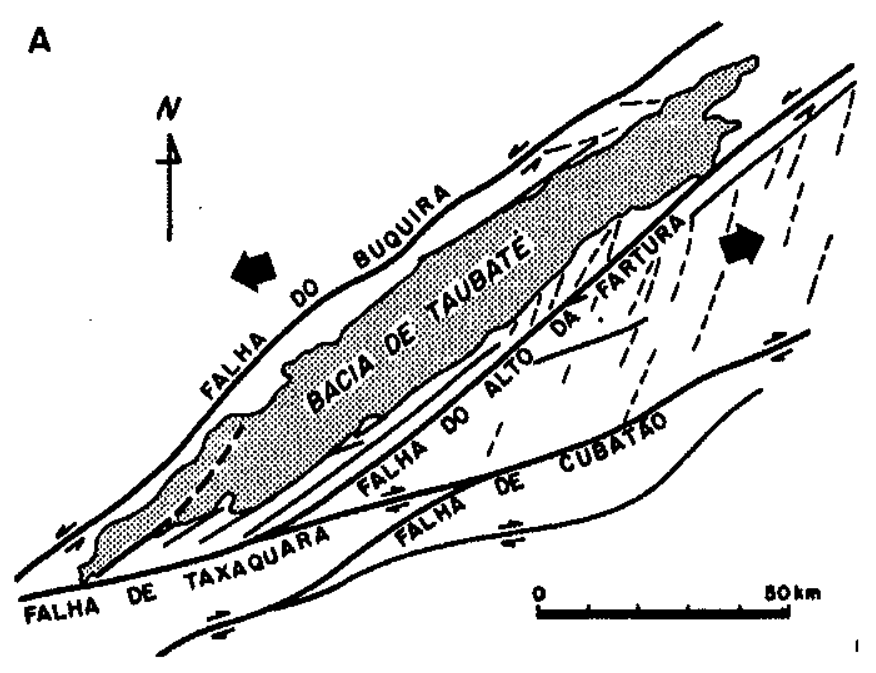

Figura 2.2 - Figura de Zalán (1986) inferindo que a forma grosseiramente romboidal da Bacia de Taubaté, e a presença de diversas fraturas (tracejadas) dispostas en echelon relativamente às grandes falhas, sugerem uma origem por cisalhamento sinistral divergente simples entre blocos crustais, ao longo de falhas transcorrentes antigas reativadas durante o Terciário.

Fernandes (1993), utilizando dados de sísmica multicanal e gravimétricos, interpretou os altos transversais que controlam inversões nos depocentros, como típicas 
zonas de transferência (Figura 2.3) e caracterizou a Bacia de Taubaté como uma bacia rift. Ainda, a partir da pequena espessura do seu preenchimento sedimentar e da limitada taxa de estiramento, interpretou-a como uma bacia gerada por um processo de colapso extensional.

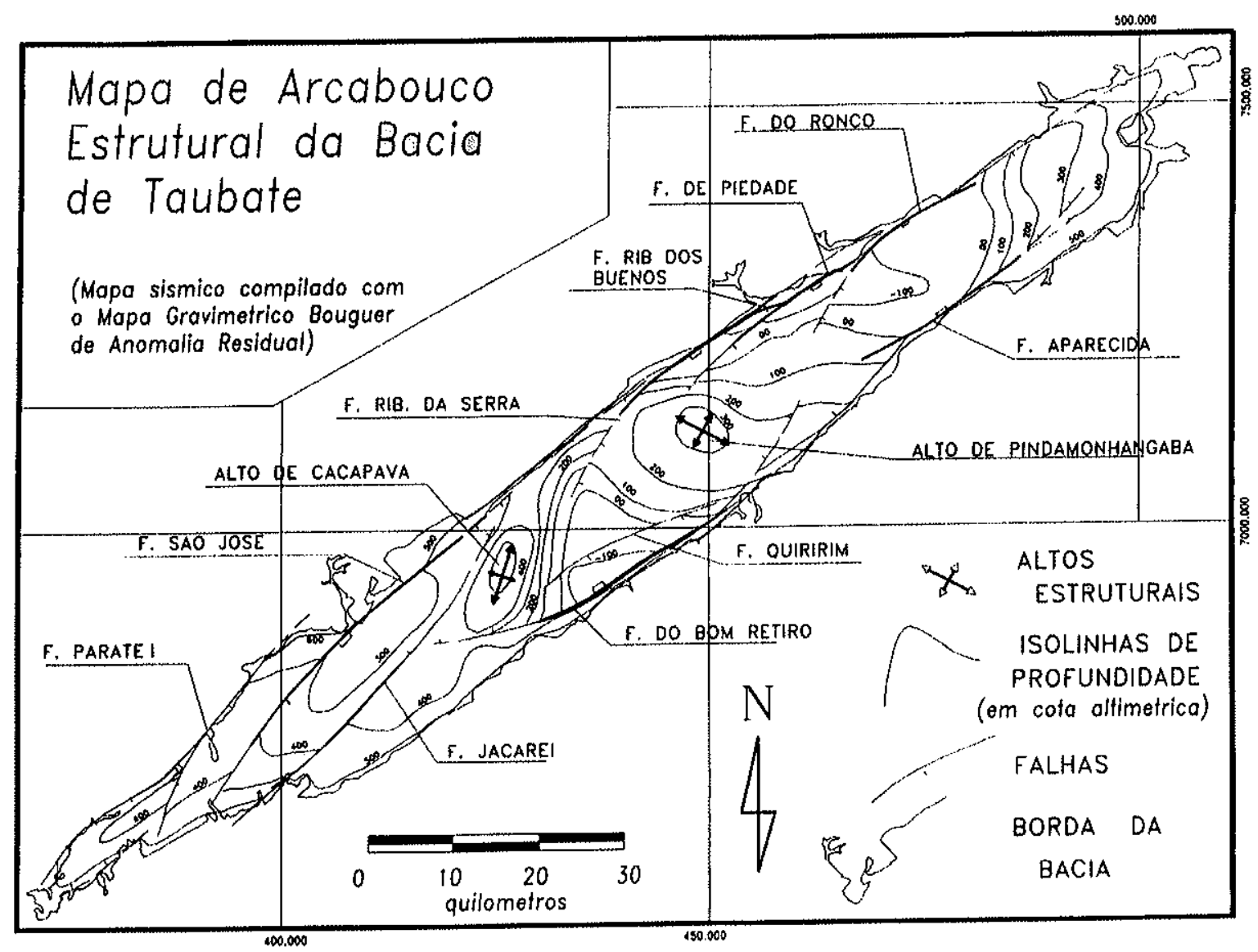

Figura 2.3 - Mapa de arcabouço estrutural da Bacia de Taubaté, com intervalo de contorno de $100 \mathrm{~m}$, compilado com o Mapa Gravimétrico Bouguer de Anomalia Residual (Segundo Fernandes 1993).

As bacias transcorrentes têm um preenchimento sedimentar bastante espesso em relação a sua área (Reading 1980, Mann et al. 1983, Christie-Blick \& Biddle 1985, Sylvester 1988, Nilsen \& Sylvester 1995). Além disso, elas se caracterizam pelos depósitos deslocados das suas áreas fontes e por uma migração das áreas de deposição com diminuição das idades no sentido contrário ao deslocamento das falhas (Christie-Blick \& Biddle 1985, Sylvester 1988, Nilsen \& Sylvester 1995), ambos ausentes da Bacia de Taubaté, ou mesmo das outras bacias do RCSB. Os depocentros nas bacias transcorrentes 
costumam estar associados à falha principal, de um dos lados da bacia, sendo raras as falhas de transferência que ocorrem nas bacias rift (Nilsen \& Sylvester, 1995).

Já o modelo de colapso extensional demanda uma elevação acima de $3 \mathrm{~km}$ e, principalmente, uma crosta espessa, em torno de $60 \mathrm{~km}$ (Dewey 1988). Dada a espessura atual da crosta sob a Bacia de Taubaté, de $35 \mathrm{~km}$ (Bassini 1986) e as diversas inferências de uma extensão limitada (menor do que 10\%) para o RCSB (Mohriak \& Barros 1990, Riccomini 1995b, Fernandes 1993), deve-se supor que este mecanismo seria pouco eficiente, sem que houvesse a atuação de esforços extensionais adicionais. Esta necessidade é reforçada pela localização do Graben de Barra de São João (Figura 1.1), na plataforma continental rasa, contígua a uma extensa planície costeira, com cerca de $30 \mathrm{~km}$ de largura.

Neste sentido, frente ao quadro tectono-estratigráfico conhecido, o modelo proposto por Riccomini (1989), onde sua geração se dá em caráter extensional e com posterior superposição de eventos transcorrentes modificadores, tem possibilitado uma melhor análise de suas características.

\subsubsection{Idade do RCSB}

A idade mínima do evento gerador do RCSB tem sido determinada pela idade da sedimentação sintectônica associada. O rift seria eocênico, com base na idade palinológica da Fm. Resende (Lima \& Amador 1985) e da Fm. Macacu (Lima et al. 1996), determinadas nas bacias homônimas, ou mesmo, paleocênico, a partir do preenchimento da Bacia de Itaboraí (Paula Couto 1952, Alvarenga 1983, Lima \& Cunha 1986, Bergqvist 1996). Tendo em vista o acesso limitado aos sedimentos da Bacia de Taubaté, dos quais se tem amostragem, por afloramentos e sondagens, apenas dos $200 \mathrm{~m}$ superiores, Melo et al. (1985a) aventaram a possibilidade do início da sedimentação ter se dado já no final do Cretáceo, com base na datação palinológica de sedimentos da Formação Tremembé, por Wickert (1974), provenientes de profundidades maiores do que as dos utilizados em estudos anteriores, e que forneceram idades do Terciário Inferior e Cretáceo Superior.

A esse respeito, Marques (1990) reconheceu duas unidades sísmicas sob o Grupo Taubaté. A primeira assentada em discordância sobre o embasamento e a segunda, em 
discordância erosiva e angular sobre ela. Sobreposta a esta última teria se depositado o Grupo Taubaté, também em discordância. Já Fernandes (1993) trabalhando nos mesmos dados sísmicos, reconheceu cinco unidades sísmicas, com "algumas podendo representar sismoseqüências", uma vez que, segundo ele, são separadas por discordâncias locais. A interdigitação da unidade sísmica por ele designada de $\mathrm{E}$, relacionada a leques aluviais associados a falhas de borda e caracterizada na coluna litoestratigráfica da bacia como Formação Resende, com as demais unidades sísmicas, indica ser toda a coluna sismoestratigráfica correlata ao Grupo Taubaté. Segundo este último autor, a ausência de discordâncias mais amplas na bacia sugere a continuidade da sedimentação.

Um início de formação no Cretáceo Superior foi aventado para a Bacia de Resende, com base em evidências tectono-sedimentares, como variações no sentido de paleodrenagens (Cabral Ramos 1997). A falta de evidências adicionais, palinológicas ou geocronológicas, mantém essa hipótese no terreno da especulação.

Desta forma, o processo de formação do RCSB, parece ter se superposto àquele do rift precursor das bacias de Santos e Campos, com um diacronismo de, no mínimo, $25 \mathrm{Ma}$ até, no máximo, 45 Ma. Essa última estimativa considera a idade mais antiga já confirmada para os seus sedimentos - paleocênica, na Bacia de São José do Itaboraí.

\subsection{EMBASAMENTO DO GRABEN DA GUANABARA}

\subsubsection{Proterozóico}

O Graben da Guanabara se estabeleceu sobre um embasamento proterozóico policíclico, parte do cinturão móvel que contorna o Craton do São Francisco a sudeste e leste, denominado Faixa de Dobramentos Sudeste (Schobbenhaus et al. 1984) e Faixa Ribeira (Hasui et al. 1975, Heilbron 1993). Este cinturão se consolidou no Ciclo Brasiliano, com a colagem de três terrenos: a) Ocidental, b) Serra do Mar ou Oriental e c) Cabo Frio (Heilbron et al. 2000). De acordo com esses autores, sobre o Terreno Ocidental se posicionam as supracrustais alóctones do Klippe Paraíba do Sul. Os terrenos se posicionam desde o Cráton do São Francisco, a NW, até o litoral, a SE, em faixas alongadas na direção 
NE-SW (Figura 2.4). Eles são limitados por zonas de cisalhamento dúctil de baixo a médio ângulo de mergulho, com vergência divergente a partir do Terreno Paraíba do Sul, o qual coincide com a zona de cisalhamento dúctil, de alto ângulo, homônima. Os terrenos são constituídos por substratos arqueanos e paleoproterozóicos, granulíticos e granitognáissicos, retrabalhados no Ciclo Transamazônico, cobertos por metassedimentos brasilianos (Heilbron et al. 2000).

O Graben da Guanabara está implantado sobre os terrenos Serra do Mar e Cabo Frio. O Terreno da Serra do Mar é constituído, localmente, pelos migmatitos, granitóides e granitos do Arco Magmático Rio Negro (Tupinambá et al. 1998), constituído pelo Batólito Serra dos Órgãos (Grossi Sad et al. 1980), além dos migmatitos da Unidade Rio Negro (Grossi Sad et al. 1980) e de paragnaisses do Grupo Italva (Machado Filho et al. 1983). O Terreno Cabo Frio, já discriminado como entidade tectônica distinta por Rosier (1965), com a Faixa Saquarema-Cabo Frio-Macaé, e por Fonseca (1994), com o Fragmento Tectônico de Cabo Frio, se caracteriza pelos ortognaisses e migmatitos, do embasamento proterozóico, denominados Unidade Região dos Lagos (Reis \& Licht 1980) ou Unidade Inferior (Heilbron et al. 1982) e pelos paragnaisses e metatexitos das Unidades Búzios (Heilbron et al. 1982) e Palmital (Reis \& Licht 1980). O limite entre esses dois domínios tectônicos, que tem direção NE-SW, é cortado pela estruturação do Graben da Guanabara, orientado segundo as direções ENE-WSW a E-W (Ferrari 1990) (Figura 2.4). A estruturação no interior do Terreno Cabo Frio é distoante das direções brasilianas, tipicamente NE-SW, tendo sido denominadas direções ante-assínticas por Rosier (1965). Essa discrepância foi também apontada por Fonseca (1998), que a relacionou com uma transposição incipiente das direções do embasamento pelo evento termo-tectônico Brasiliano.

Diversos autores têm apontado a reativação de estruturas do embasamento como um processo fundamental na formação das bacias do RCSB (Almeida 1976, Hasui et al. 1978, Riccomini et al. 1985, Melo et al. 1985a e b, Riccomini 1989), em especial as zonas de cisalhamento brasilianas de alto ângulo, com orientação ENE, geradas por um evento de deformação pós colisional (Heilbron et al. 2000). Segundo os autores acima essas estruturas se comportariam como "zonas de fraqueza" preferencial do embasamento. Riccomini (1989) aponta a direção das zonas de cisalhamento reativadas, nas diversas bacias do 


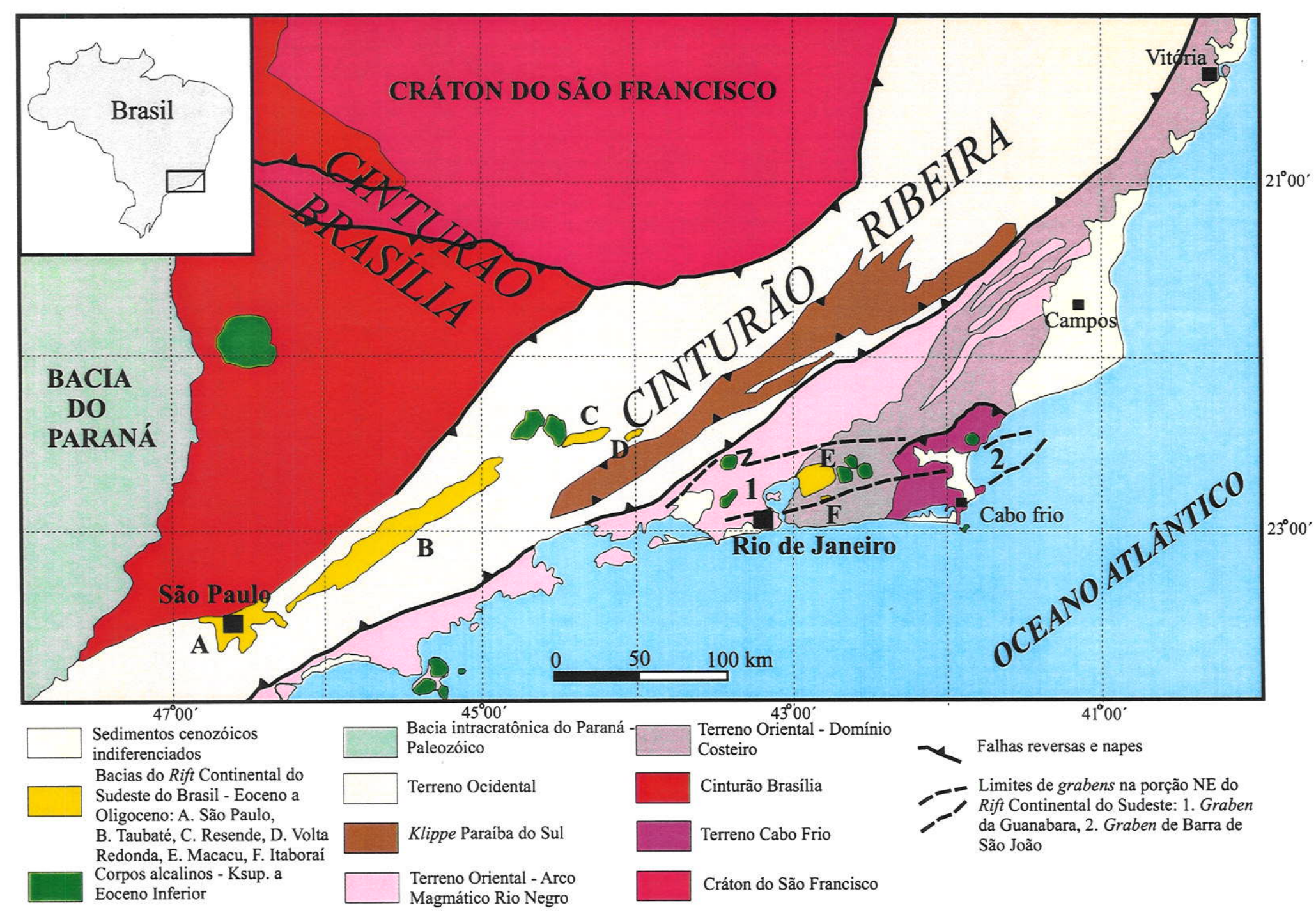

Figura 2.4 - Mapa tectônico da região sudeste do Brasil. Simplificado de Heilbron et al. (2000). Limites dos grabens da Guanabara e de Barra de São João a partir de Ferrari (1990) e Mohriak \& Barros (1990). 
RCSB: N70-80E, na Bacia de São Paulo; N55-60E, na Bacia de Taubaté; N80E, na Bacia de Resende e N60-70E, na Bacia de Volta Redonda. No Graben da Guanabara é marcante o controle de uma zona de cisalhamento na implantação da Falha de São José, que limita a borda sul da Bacia de Itaboraí, ambas com direção N65E (Klein \& Rodrigues Francisco 1981). Por outro lado, no caso da Zona de Falha de Rio Bonito (Almeida 1976), cuja reativação controla o limite sul da Bacia do Macacu (Capítulo 7, nesse trabalho), também de direção N65E, esta relação de paralelismo com estruturas do embasamento não foi identificada. Nesse sentido, este predomínio da geração de estruturas ENE a NE é verificada mesmo onde a estruturação do embasamento é distinta, como no Município do Rio de Janeiro (Ferrari 1990) e na região de Cabo Frio e Macaé (Heilbron et al. 1982, Nascimento et al. 1994, Araújo 1995), no domínio do Terreno Cabo Frio, evidenciando que estas reativações estão associadas, sobretudo, a campos de tensões propícios para tal e não apenas a estruturas preexistentes. Tal relação será discutida nesse trabalho, em especial nos Capítulo 4.2. e 4.3., quando se analisará a influência do embasamento proterozóico sobre o encaixamento dos diques de rochas alcalinas.

\subsubsection{Diques de Diabásio}

Um intenso magmatismo toleítico acompanhou a reativação da porção sul-sudeste da Plataforma Brasileira, que culminou na separação continental entre a América do Sul e África (Almeida 1967, 1969, 1986; Schobbenhaus et al. 1984). Esse magmatismo que teve sua expressão máxima nos derrames da Bacia do Paraná, com idades de 137-127 Ma (Turner et al. 1994), caracterizou-se, nesse segmento do Cinturão Ribeira, pela intrusão de um enxame de diques de diabásio denominado Santos-Rio de Janeiro (Renne et al. 1996), com idades de 134-129 Ma (Regelous 1990, Deckart et al. 1998).

No Graben da Guanabara os diques de diabásio se concentram principalmente na borda sul, nos maciços litorâneos, onde ocorrem em "enxames" de direção NE, separados um do outro por cerca de $15 \mathrm{~km}$, em média, nos municípios do Rio de Janeiro, Niterói, Maricá e Saquarema; subordinadamente ocorrem em diques com direção ENE e, mais raramente, com direção NW, E-W e N-S (Ferrari 1990; Figura 2.5). São diques com poucos 


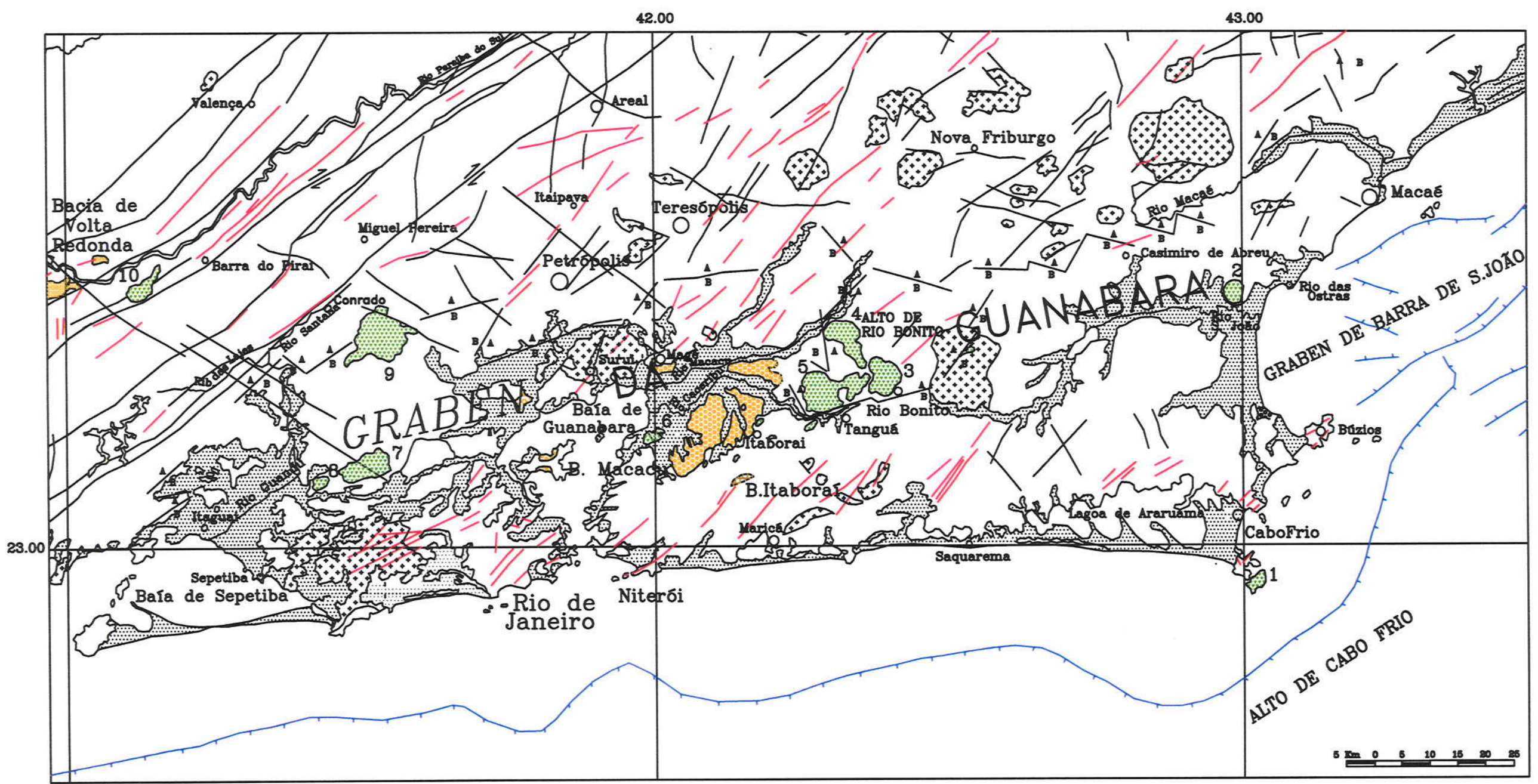

Figura 2.5 - Mapa geológico do Graben da Guanabara e arredores, destacando os diques de diabásio do Cretáceo Inferior. Integrado, modificado e atualizado, a partir de: Hembold et al. (1965); Penha et al. (1980, 1982); Barbosa et al. (1981, 1983); Dalcolmo et al. (1982); Alves et al. (1989); Ferrari (1990); Mohriak et al. (1992) e Riccomini (1995a). Legenda de acordo com a Figura 1.3. 
metros até quase uma centena de metros de espessura, que se prolongam desde algumas centenas de metros a poucas dezenas de quilômetros. No interior do graben estes diques são menos numerosos e podem ser seguidos, por magnetometria, sob a Formação Macacu e os sedimentos Pré-Macacu (Rodrigues \& Haralyi 1984). Na borda norte eles também são menos numerosos que na borda sul e mostram orientação NE predominante (Ferrari 1990).

As orientações dos diques de diabásio, medidas a partir dos mapas geológicos e abrangendo uma área entre Angra dos Reis, a oeste, Macaé, a leste, e a divisa entre os estados do Rio de Janeiro e Minas Gerais, ao norte, por Silva et al. (1996), forneceu a indicação de uma marcante concentração segundo a direção NE-SW (Figura 2.6). Esta direção preferencial indica a posição de $\mathrm{SH}_{\max }$ paralelo a ela e a posição do tensor mínimo de esforços, $\sigma 3$, ortogonal.

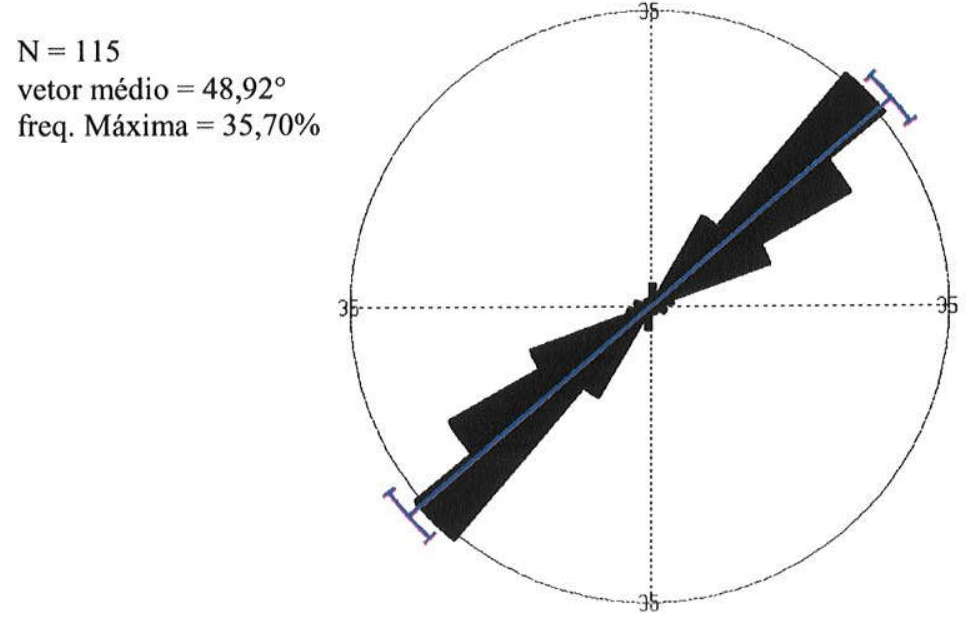

Figura 2.6 - Diagrama de roseta de mostrando a direção de diques de diabásio do Estado do Rio de Janeiro, medidos em mapa a partir de Mohriak et al. (1992).

As atitudes desses diques, medidas na borda sul do Graben da Guanabara junto ao litoral (Figura 2.7), apresentam dominantemente mergulhos altos, acima de $80^{\circ}$ (Ferrari \& Riccomini 2000). A presença de falhas e microfalhas de caráter direcional, nas bordas e no interior de alguns desses diques, além do arranjo escalonado apresentado localmente, levou Ferrari \& Riccomini (2000) a sugerirem que a sua intrusão deu-se sob um campo de paleotensões direcional, a partir de um binário sinistral de direção E-W. 

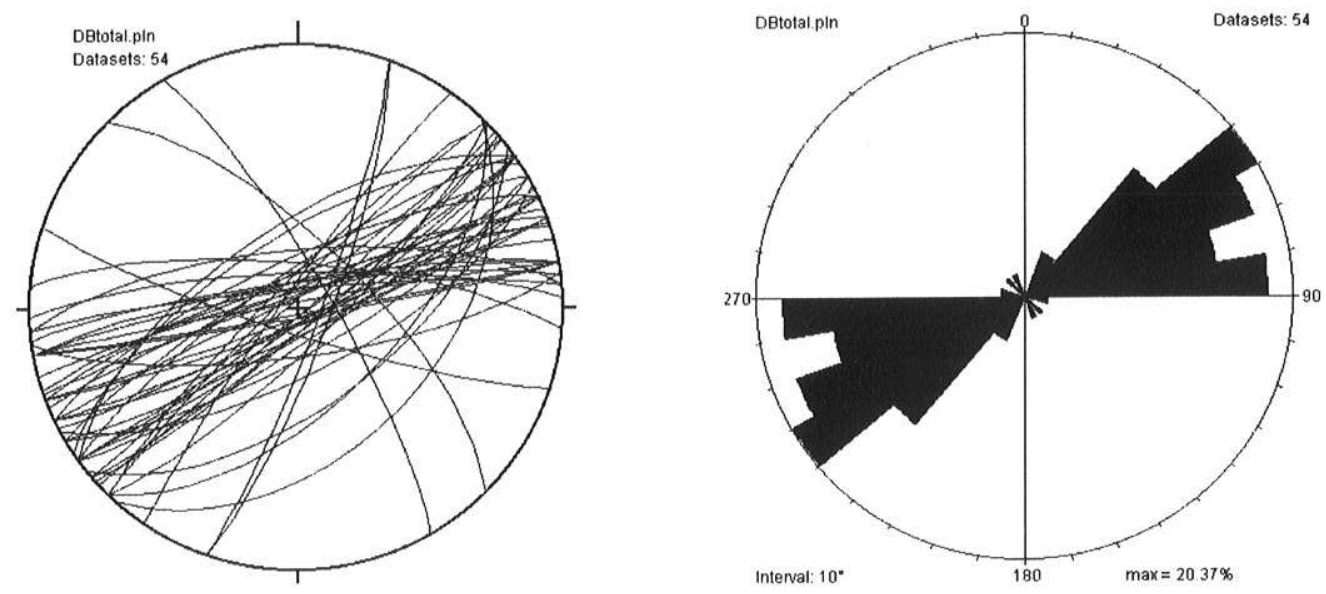

Figura 2.7 - Projeções ciclográficas e diagrama de roseta de diques de diabásio aflorantes na borda sul do Graben da Guanabara, na zona oeste da Cidade do Rio de Janeiro, em Niterói e na Região dos Lagos. Segundo Ferrari \& Riccomini (2000).

Ressalta-se que os diques de diabásio que ocorrem na área do Graben da Guanabara são, na média, mais contínuos e mais espessos do que os diques de rochas alcalinas do Cretáceo Superior e Paleógeno (Porto Jr. et al. 1989; Ferrari 1989, 1990; Valente et al. 1991, 1992; Valente 1997).

\subsection{MEGAESTRUTURAS MEZOSÓICO-CENOZÓICAS NO SEGMENTO} NORDESTE DO RCSB

Diversas megaestruturas mesozóico-cenozóicas, com atuação entre o Cretáceo e o Paleógeno, têm sido descritas nesta região, tanto na área emersa quanto submersa (Figura 2.8). A maior parte delas são tidas como tendo relação genética, direta ou indireta, com a formação da margem continental sudeste, dentro de uma visão dessa formação como um processo mais amplo, como admitido por Almeida $(1967,1969)$ e Schobbenhaus et al. (1994), a partir das respectivamente denominadas Reativação Wealdeniana e Evento SulAtlantiano. Entre elas estão: 
1) O Alinhamento Magmático de Cabo Frio, caracterizado pelo arranjo curvilinear dos corpos de rochas alcalinas entre o monte submarino Almirante Saldanha e as vulcânicas de Jaboticabal (SP), já na área geográfica da Bacia do Paraná, com direção WNW-ESE, e tido como produto da reativação de estruturas pré-deriva por variações na direção de movimentação da placa Sul Americana (Almeida 1991);

2) O Lineamento Sismo-Tectônico de Cabo Frio, com as mesmas características do anterior, mas restrito entre a Ilha de Cabo Frio e Poços de Caldas, e que caracterizaria uma trilha de hot spot (Sadowski \& Dias Neto 1981);

3) O Arco do Alto Paranaíba, de direção NW-SE, caracterizado no sudoeste de Minas Gerais, onde limita a Bacia do Paraná e aloja inúmeros corpos de rochas alcalinas, carbonatíticas e kimberlíticas (Ladeira et al. 1971);

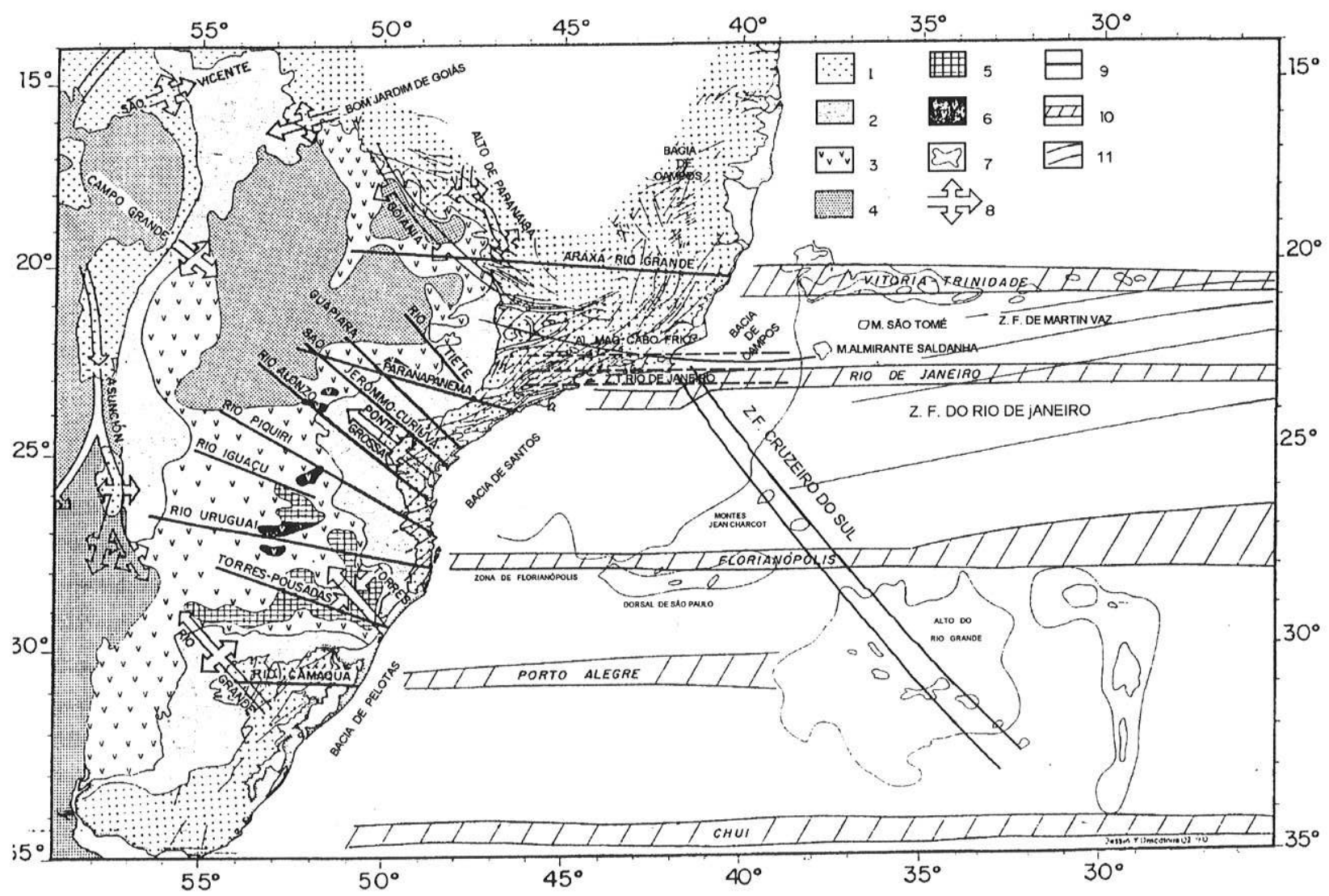

Figura 2.8 - Localização das principais megaestruturas da Região Sudeste do Brasil e área oceânica adjacente. Legenda: 1) embasamento Pré-Cambriano e principais falhas do cinturão Ribeira; 2) depósitos paleozóicos da Bacia do Paraná; 3) rochas basálticas da Bacia do Paraná; 4) depósitos mesozóicos da Bacia do Paraná; 5) rochas basálticas da Bacia do Paraná, com baixo teor de $\mathrm{TiO}_{2}$; 6) rochas basálticas da Bacia do Paraná, com alto teor de $\mathrm{TiO}_{2}$; 7) montes submarinos; 8) altos do embasamento; 9) principais lineamentos; 10) zonas de fraturas oceânicas, segundo Schobbenhaus et al. (1984); 11) zonas de fraturas oceânicas, segundo Cande et al. 
(1988) e Alves et al. (1997a e b). Traduzido e modificado de Souza (1991), com dados de Cande et al. (1988), Magalhães (1987), Almeida (1991) e Alves et al. (1997a e b).

4) A Zona de Fratura de Martin Vaz, de direção E-W a ENE, caracterizada em crosta oceânica pelo alinhamento de calhas e altos do embasamento submarino, e pelo deslocamento de anomalias magnéticas de espalhamento oceânico, até o meridiano $30^{\circ} \mathrm{W}$ (Alves et al. 1997b). Segundo estes autores seu prolongamento para oeste, em direção da margem continental, se faz pela ocorrência dos montes submarinos Almirante Saldanha e São Tomé. Esta zona de fratura se projetaria na plataforma continental, já em crosta continental, no Alto de Cabo Frio, coincidindo aí com a Zona de Transferência do Rio de Janeiro, sendo o limite sul de sua projeção coincidente com os corpos alcalinos de São Sebastião e Montão de Trigo. Ainda segundo estes autores, esta estrutura teria sua "continuidade no continente" representada pelo Alinhamento Magmático de Cabo Frio. A Zona de Fratura do Rio de Janeiro, tida como de direção E-W, caracterizada em crosta oceânica pelo alinhamento de calhas e altos do embasamento submarino e pelo deslocamento de anomalias magnéticas (Alves 1981), foi remapeada por Cande et al. (1988), os quais mostraram sua deflexão da direção E-W para ENE-WSW a oeste do meridiano $25^{\circ} \mathrm{W}$. Esta virgação faz com que ela se projete na margem continental na altura do limite norte do Arco de Ponta Grossa (Alves et al. 1997a), bem ao sul do que se inferia até então (Asmus 1978; Alves 1981);

5) A Zona de Transferência do Rio de Janeiro, de direção E-W, caracterizada na Bacia de Santos, onde deflete a linha de charneira e depocentros, coincide com o limite sul do Alto de Cabo Frio onde ela limitaria segmentos crustais com diferentes taxas de estiramento do embasamento das bacias de Campos e Santos (Magalhães 1987). Segundo esse autor essa estrutura controlaria a posição de altos interbasinais na Bacia de Taubaté;

6) A Zona de Deformação Cruzeiro do Sul, com direção NW-SE, caracterizada em crosta oceânica, com base no alinhamento de anomalias gravimétricas do SEASAT, tanto negativas quanto positivas, correspondendo respectivamente a montes submarinos e grabens (Souza 1991). Ela teria sido gerada por uma variação no pólo de espalhamento da porção meridional da Placa Sul Americana, ao sul do paralelo $35^{\circ} \mathrm{S}$, entre o Santoniano Superior e o Eoceno Médio (Souza 1991). Segundo ele a esta estrutura estariam 
relacionados o magmatismo alcalino da Serra do Mar e as bacias tafrogênicas, gerados por transcorrência dextral. Deve-se lembrar que os registros conhecidos de movimentação direcional dextral no RCSB são do Pleistoceno (Riccomini 1989, 1995a). A não verificação de espessamento crustal associado a esta zona de deformação levou Aguiar (1997) a descartar qualquer ligação desta feição com anomalias térmicas do tipo plumas do manto e a considerá-la, a exemplo de Souza (1991), uma zona de deformação intraplaca. A ocorrência de um amplo arqueamento do fundo oceânico, envolvendo o embasamento e todo o pacote sedimentar, com um desnível do embasamento de até $500 \mathrm{~m}$ junto à Dorsal de São Paulo, foi interpretada por Basseto \& Szatmari (1997) como uma falha reversa de direção NE-SW (Figura 2.9), que teria sido atuante desde o Oligoceno Superior ao Recente.

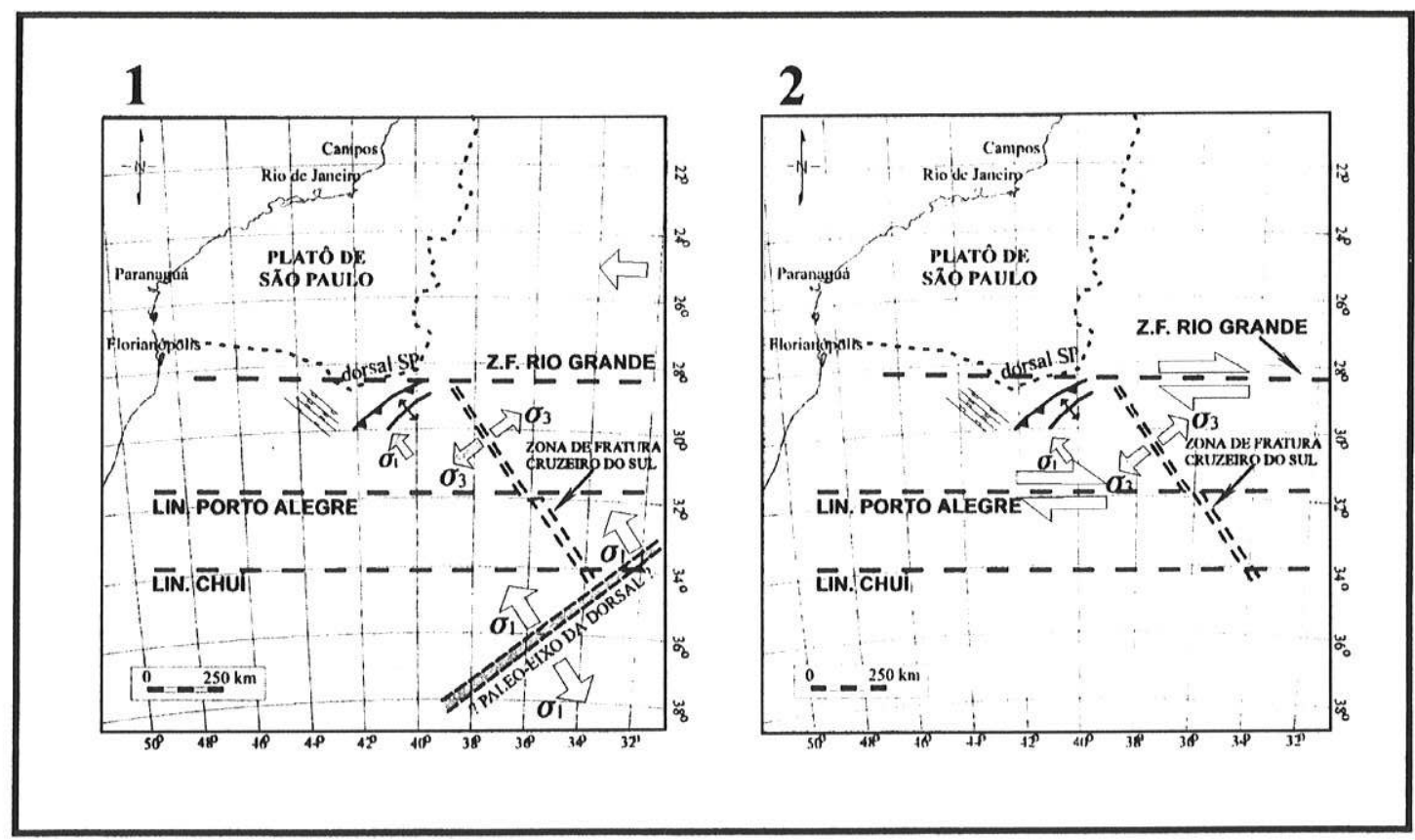

Figura 2.9 - Mapa esquemático, mostrando duas hipóteses acerca da natureza dos esforços tectônicos que teriam afetado a margem sul-sudeste do Brasil, durante o processo de espalhamento oceânico a partir da ruptura continental. Na hipótese 1, considera-se que o motor principal dos esforços seria o mecanismo de ridge-push junto a um paleo-eixo de espalhamento oceânico, posicionado a sudeste da elevação do Rio Grande; na hipótese 2, o motor principal dos esforços seria a movimentação dextral relativa entre os segmentos crustais envolvidos, basicamente ao longo do lineamento Porto alegre e da zona de fratura do Rio Grande (Segundo Basseto \& Szatmari 1997)

Segundo Basseto \& Szatmari (1997), o campo de esforços exigido para a geração desta estrutura seria compatível com aquele necessário para gerar a Zona de Deformação 
Cruzeiro do Sul, com $\sigma 1$ horizontal, orientado segundo a direção NW-SE, e $\sigma 3$ perpendicular orientado na direção NE-SW. Basseto \& Szatmari (1997) imaginaram dois modelos para explicar a geração deste campo de esforços (Figura 2.6): 1) um empurrão da cordilheira mesoceânica (ridge push) a partir de um paleo-eixo de direção NE-SW; 2) movimentação direcional dextral no segmento crustal entre a Zona de Fratura do Rio Grande e o Lineamento do Chuí.

Com relação a estes modelos deve-se tecer as seguintes considerações: 1) a Zona de Deformação Cruzeiro do Sul e a estrutura definida por Basseto \& Szatmari (1997) são diacrônicas, tendo a primeira sido ativa entre o Santoniano e o Eoceno Médio (Souza 1991, Aguiar 1997) e a segunda entre o Oligoceno Superior e o Recente (Basseto \& Szatmari 1997); 2) o paleo-eixo da dorsal com direção NE-SW, mapeado por Cande et al. (1988), se implantou no tempo da anomalia magnética 32 ( $71 \mathrm{Ma})$, no Maastrichtiano perdurando claramente até a anomalia magnética $30(\sim 66 \mathrm{Ma})$ no limite Cretáceo-Terciário. Após a anomalia magnética 30 não se tem qualquer referência a sua persistência. Deve-se salientar, no entanto, que segundo Cande et al. (1988), entre as anomalias magnéticas 30 ( $66 \mathrm{Ma})$ e 20 ( $45 \mathrm{Ma})$, esta última já no Eoceno Médio, o espalhamento oceânico se deu de forma lenta, levando a uma proliferação de zonas de fratura e que, especialmente na área em pauta, ao sul do Alto do Rio Grande, as zonas de fratura exibem traçado irregular, com alguns de seus segmentos com direção NW (Figura 2 de Cande et al. 1988), sugerindo que a orientação anômala do paleo-eixo da cordilheira pode ter persistido até o tempo da anomalia magnética 20, no Eoceno Médio; 3) o controle de idade da Zona de Deformação Cruzeiro do Sul é embasado, essencialmente, nas idades dos eventos vulcânicos que afetaram o Alto do Rio Grande no Santoniano e no Eoceno Médio (Souza 1991). Este mesmo autor utiliza a presença de grabens alinhados na direção NW-SE, na porção noroeste do Alto do Rio Grande, até às proximidades da anomalia magnética 21 ( $48 \mathrm{Ma}$ ), do Eoceno Médio, como um controle mínimo da idade de atuação da Zona de Deformação Cruzeiro do Sul. Porém, como não se conhece o processo de geração desta zona de deformação, este tipo de inferência tem pouca validade, uma vez que os referidos grabens não podem ser mais velhos do que crosta oceânica onde se instalaram. Outra feição listada por Souza (1991), o Graben de Barra de São João, de idade eocênica e localizado no Alto de Cabo Frio (Figura 2.5), caracterizado por Mohriak et al. (1990), parece estar totalmente 
atrelado ao processo de evolução do RCSB (Riccomini 1989, 1995a), além de ter sido posicionado em mapa cerca de $1^{\circ}$ ao sul de sua real localização (Souza 1991, Figura VI-4, pg. 192).

Dessa forma, não se tem conhecimento da relação destas feições com o quadro tectônico regional ou mesmo do seu real significado, como no caso da Zona Sismogênica de Cabo Frio/Alinhamento Magmático de Cabo Frio e da Zona de Deformação Cruzeiro do Sul, ou, ainda, de como se dão os processos de interação entre as feições caracterizadas em crosta oceânica e aquelas da crosta continental. Por outro lado, diversas evidências de reativação mesozóico-cenozóica de megaestruturas intraplaca vem sendo apontadas no sudeste brasileiro, na forma de deformações, pela implantação ou reativação de altos e/ou baixos e como condutos para manifestações magmáticas, principalmente de composição alcalina (Asmus 1978, Sadowski 1987, Zalán et al. 1987, Eyles \& Eyles 1993, Riccomini 1995a e b). Nesse sentido, o estudo da deformação neocretácica e paleogênica no Graben da Guanabara, e das paleotensões responsáveis pela sua geração, que serão apresentados nos próximos capítulos, permitiu que se caracterizasse a importância relativa das tensões regionais e locais. A persistência de um campo de paleotensões com direção de extensão variando entre NW-SE e N-S, com o SHmax variando entre NE-SW e E-W, além de indicar que as estruturas geradas ou reativadas no Graben da Guanabara responderam a esse campo, aponta ainda a importãncia das tensões regionais.

\subsection{DISTRIBUIÇÃO DOS ESFORÇOS NA PLACA SUL-AMERICANA}

O campo de esforços no interior da Placa Sul-Americana é função, essencialmente, da interação de dois processos tectônicos:

1 - forças de flutuação ou topográficas, representadas principalmente pelo empurrão exercido pela Cordilheira Meso-Atlântica (ridge push);

2 - esforços compressionais transmitidos a partir do limite oeste da placa, na fossa Peru Chile (Coblentz \& Richardson 1996).

As forças de flutuação resultam da variação lateral de densidade na litosfera, incluindo, a nível regional, além do empurrão da cordilheira, o puxão da placa (slab pull) e, 
a nível local, as forças associadas às margens continentais e às áreas elevadas (Coblentz \& Richardson 1996). Nas margens continentais passivas, como a brasileira, dois fatores geram esforços locais que interagem com os regionais, o contraste de densidade entre as crostas continental e oceânica, acarretando o espalhamento da borda continental, e a flexura da litosfera devido à carga de sedimentos das bacias marginais; estes dois fatores gerariam extensão na área emersa e compressão na submersa (Assumpção 1997). Estas tensões locais interagem com os regionais produzindo rotação e/ou variação de intensidade no campo regional. No interior da Placa Sul-Americana sabe-se que a tensão horizontal máxima regional $\left(\mathrm{SH}_{\max }\right)$ exibe uma boa concordância com a direção de movimentação da placa e com o empurrão exercido pela Cordilheira Meso-Atlântica, mormente na sua porção oceânica (Zoback et al. 1989, Assumpção 1992, Richardson 1992, Stefanick \& Jurdy 1992, Coblentz \& Richardson 1996) (Figura 2.10).

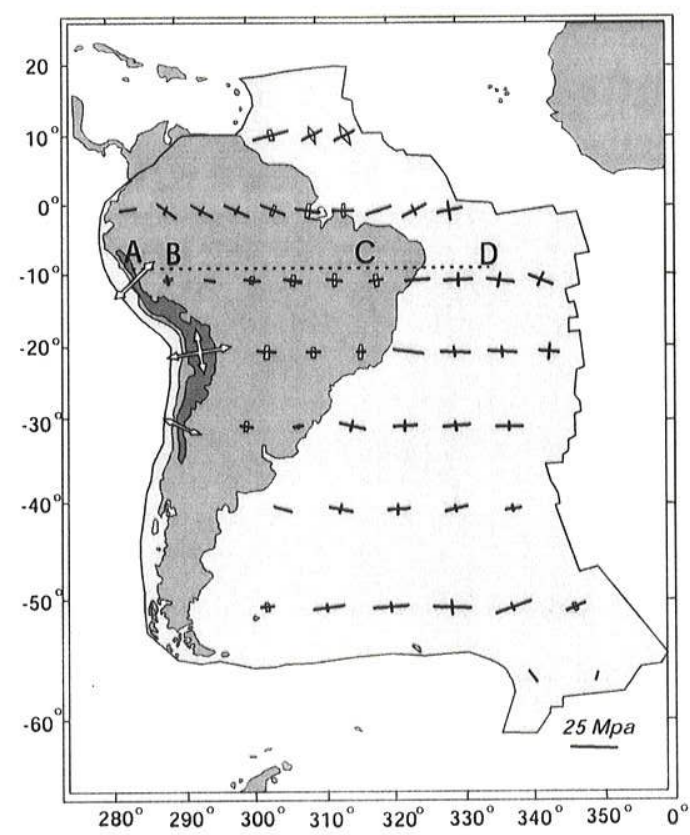

Figura 2.10 - Distribuição das tensões regionais na Placa Sul-Americana, segundo o modelo 3 de Coblentz \& Richardson (1996), considerando a força de empurrão da Cordilheira Meso-Atlântica, a força de contato entre diferentes porções litosféricas, a força topográfica e a força de arrasto da placa com a astenosfera. A linha pontilhada indica o perfil discutido na Figura 2.8. As letras indicam a posição da Cordilheira Blanca (A), Escudo Brasileiro Ocidental (B), Escudo Brasileiro Oriental (C) e bacia oceânica (D). As forças colisionais aplicadas neste modelo produziram grandes áreas de compressão nas porções setentrional e meridional da placa, mas não afetaram significativamente as tensões previstas no interior das regiões continentais (Segundo Coblentz \& Richardson 1996). 
O campo de esforços é extensional na Cordilheira dos Andes (acima de $3000 \mathrm{~m}$ de altitude), com extensão N-S e $\mathrm{SH}_{\max } \mathrm{E}-\mathrm{W}$, e compressional no resto da placa, com $\mathrm{SH}_{\max } \mathrm{E}$ $\mathrm{W}$, evidenciando, neste caso, que este $\mathrm{SH}_{\max }$ é o tensor principal de esforços $\sigma_{1}$ (Figura 2.11).
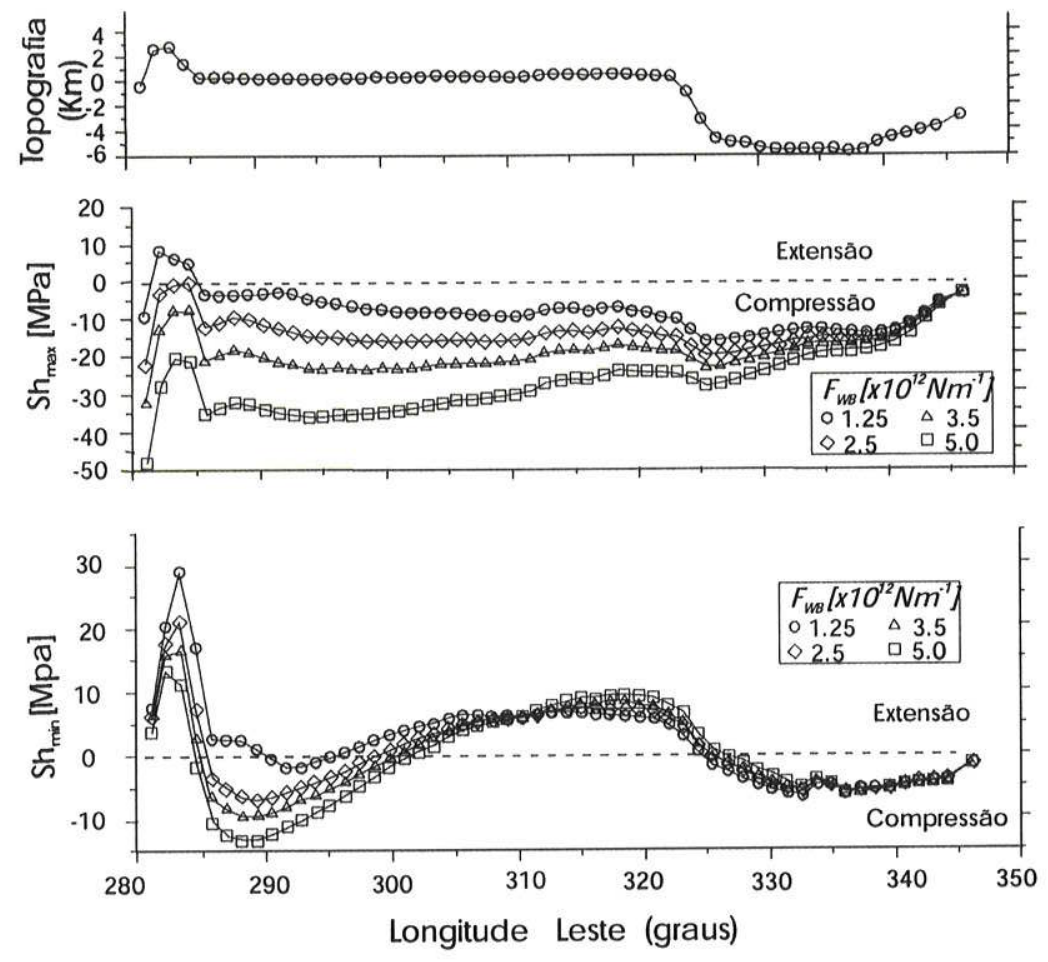

Figura 2.11 - (topo) Elevação média dos 56 elementos que cortam a América do Sul em um perfil ao longo de $9.5^{\circ} \mathrm{S}$, correspondendo à linha tracejada na Figura 2.7. (meio) Magnitudes do tensor horizontal máximo $\left(\sigma_{\mathrm{H}}\right)$ prognosticadas ao longo do perfil. (base) Magnitudes do tensor horizontal mínimo $\left(\sigma_{\mathrm{h}}\right)$ previstas ao longo do perfil. As magnitudes previstas para os tensores máximo e mínimo são mostradas para quatro magnitudes distintas de forças colisionais atuando ao longo da fossa Peru-Chile $\left(F_{\mathrm{wb}}\right): 1.25,2.5,3.5$, e $5.0 \times 10^{12} \mathrm{Nm}^{-1}$. Letras ao longo do perfil correspondem a Cordilheira Branca (A), Escudo Brasileiro Ocidental (B), Escudo Brasileiro Oriental (C), e bacia oceânica (D). Uma força colisional de $2.5 \times 10^{12} \mathrm{Nm}^{-1}$ produz um esforço consistente com as magnitudes dos esforços previstos por modelos anteriores. (Segundo Coblentz \& Richardson, 1996).

$\mathrm{O} \mathrm{Sh}_{\min }$ varia, sendo extensional na área emersa, onde origina um regime de esforços direcional, e compressional na área oceânica, gerando um regime de esforços inverso. A persistência da direção E-W para o $\mathrm{SH}_{\max }$ em toda a Cordilheira dos Andes, apesar da mudança na orientação da cadeia ao norte da Deflexão de Arica e das variações no ângulo de mergulho da Placa de Nazca, indica a predominância do empurrão da 
Cordilheira Meso-Atlântica no campo de esforços regional (Assumpção 1992, Coblentz \& Richardson 1996). A este respeito, Stefanick \& Jurdy (1992), calcularam que o empurrão da cordilheira é responsável por cerca de $80 \%$ do esforço compressivo observado na placa. As interferências locais no campo de esforços regional possibilitam que se aproxime a intensidade dos esforços regionais, como na Cordilheira dos Andes (Coblentz \& Richardson 1996), no Rift do Amazonas (Zoback \& Richardson 1996) e na margem continental brasileira (Assumpção 1997), indicando valores de $\mathrm{SH}_{\max }$ entre 13 e $20 \mathrm{MPa}$ na área emersa e entre 15 e $20 \mathrm{MPa}$ na submersa.

A rotação local das tensões regionais foi utilizada por Zoback (1992) para inferir a magnitude das tensões locais, a partir de discussão anterior de Sonder (1990). Segundo Zoback (1992) a avaliação quantitativa da interferência produzida por um esforço uniaxial local, no campo de esforços regional deve considerar, além do ângulo entre o $\mathrm{SH}_{\max }$ e a direção da estrutura responsável pelo esforço local, as magnitudes relativas dos esforços regionais e locais (Figura 2.12).
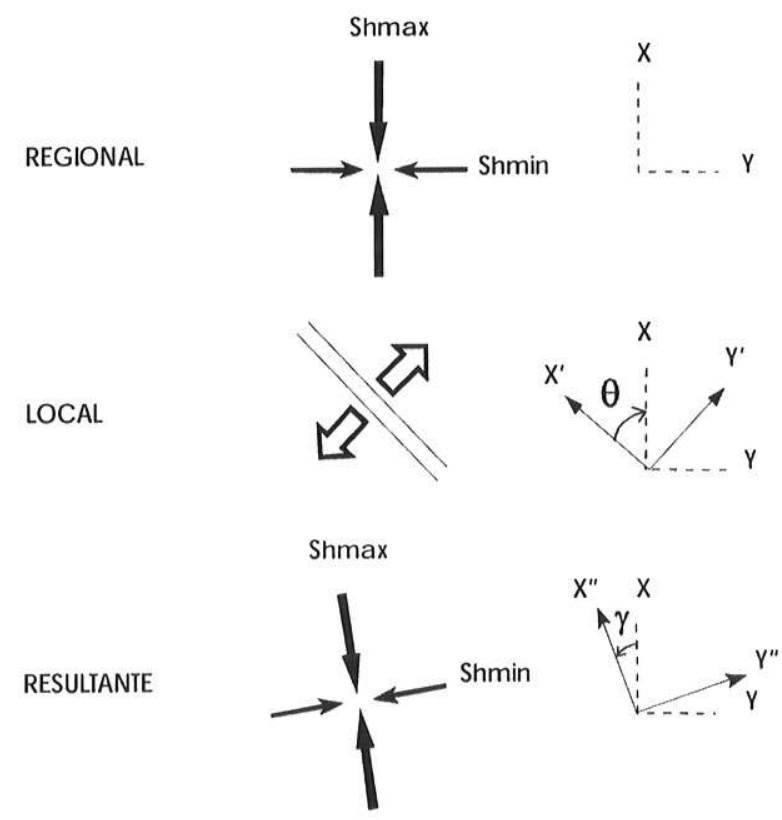

Figura 2.12 - Geometria para avaliação da rotação dos tensores devido a fontes locais (modificado de Sonder, 1990). $\mathrm{SH}_{\max }, \mathrm{SH}^{\prime}{ }_{\max } \mathrm{e} \mathrm{Sh}_{\min }, \mathrm{Sh}^{\prime}{ }_{\min }$ correspondem aos tensores horizontais máximo e mínimo, respectivamente (Segundo Zoback, 1992). 
Zoback (1992) assume que o campo de esforços regional orienta-se segundo os planos horizontal e vertical e que o $\mathrm{SH}_{\max }$ é paralelo ao eixo $\mathrm{x}, \mathrm{Sh}_{\min }$ ao eixo y e que o eixo $z$ é vertical, positivo para baixo. Já o campo de esforços local é, para ela, orientado segundo os planos x', y' e z', sendo a estrutura responsável por ele paralela a x' e o esforço uniaxial normal paralelo a y'. A magnitude da tensão horizontal desviatória é $\sigma_{\mathrm{L}}=\sigma_{\mathrm{y}}$, assumindose que a estrutura seja longa o suficiente para que a variação do esforço ao longo do seu comprimento seja desprezível. No caso de forças locais de flutuação será gerado uma tensão desviatória vertical, com magnitude equivalente à horizontal, mas com sinal oposto, $\sigma_{\mathrm{z}}=-\sigma_{\mathrm{L}}$. Neste caso, a tensão desviatória local será extensional.

Segundo Zoback (1992) as tensões normal e cisalhante, resultantes de uma compressão ou extensão horizontal desviatória local são dados por:

$$
\begin{gathered}
\tau_{x y}=1 / 2 \sigma_{L} \operatorname{sen} 2 \theta \\
\sigma_{x}=1 / 2 \sigma_{L}(1-\cos 2 \theta) \\
\sigma_{y}=1 / 2 \sigma_{L}(1+\cos 2 \theta)
\end{gathered}
$$

onde $\theta$ é o ângulo entre a direção da estrutura e do $\mathrm{SH}_{\max }$ regional, ou seja, o ângulo entre $\mathrm{x}$ e x', e é positivo no sentido horário (Figura 11).

Com a superposição dos dois esforços, regional e local, resulta um novo campo de esforços onde:

$$
\begin{gathered}
\tau_{x y}=1 / 2 \sigma_{L} \operatorname{sen} 2 \theta \\
\sigma_{x}=\mathrm{SH}_{\max }+1 / 2 \sigma_{\mathrm{L}}(1-\cos 2 \theta) \\
\sigma_{\mathrm{y}}=\mathrm{Sh}_{\min }+1 / 2 \sigma_{\mathrm{L}}(1+\cos 2 \theta)
\end{gathered}
$$

A rotação do $\mathrm{SH}_{\max }$ regional é dada por:

$$
\gamma=1 / 2 \tan ^{-1} \operatorname{sen} 2 \theta /\left[\left(\mathrm{SH}_{\max }-\mathrm{Sh}_{\min }\right) / \sigma_{\mathrm{L}}\right]-\cos 2 \theta \text {. }
$$

A nova orientação de $\mathrm{Sh}_{\min }$ será $\gamma+\pi / 2$. Os valores positivos de $\gamma$ representam uma rotação anti-horária. Uma simulação das variações nas magnitudes relativas das tensões 
regionais e locais, bem como as rotações impingidas nas primeiras, permitiram a elaboração do gráfico da Figura 2.13.

A importância relativa das paleotensões regionais e locais será discutida no Capítulo 7, com base nas relações sintetizadas na Figura 2.13 .

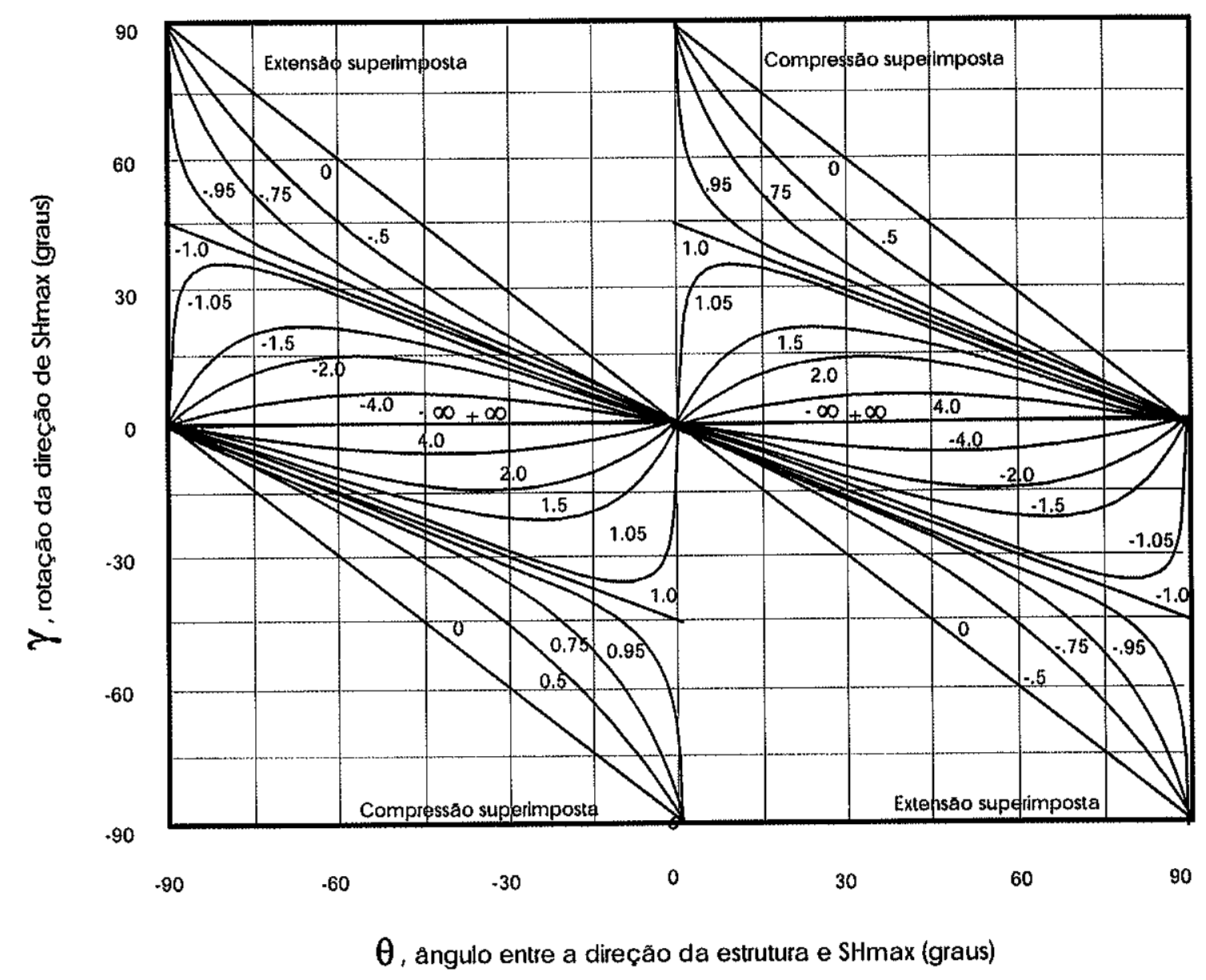

Figura 2.13 - Rotação dos tensores horizontais regionais $(\gamma)$ como função do ângulo entre a direção da feição local produzindo uma compressão ou extensão uniaxial local e a direção do $\mathrm{SH}_{\max }$ regional $(\theta)$. Os números nas curvas se referem a valores da razão entre a diferença dos tensores horizontais regionais pelo tensor uniaxial local $\left(\mathrm{SH}_{\max }-\mathrm{Sh}_{\min } / \sigma_{\mathrm{L}}\right)$; valores positivos indicam uma compressão uniaxial superposta $\mathrm{e}$ valores negativos indicam uma extensão uniaxial superposta (Segundo Zoback, 1992). 


\section{MÉTODOS - REVISÃO}

\subsection{ANALISE ESTRUTURAL}

\subsubsection{Introdução}

A análise estrutural foi o principal método utilizado no intuito de discriminar, qualificar e quantificar os eventos deformacionais rúpteis que atuaram na área. Ela envolveu principalmente a caracterização das feições geológico-estruturais rúpteis, associadas ao tectonismo mesozóico-cenozóico, tais como diques de rochas alcalinas, falhas, falhas acompanhadas de cataclase e silicificação, estruturas tectônicas sin a pós-deposicionais às bacias de São José do Itaboraí e do Macacu, além de juntas em áreas escolhidas.

A caracterização estrutural foi feita através de estudos em mesoescala, com a descrição de afloramentos e de amostras de mão. Em alguns casos, visando uma melhor caracterização dos indicadores cinemáticos nos planos de falha, foi utilizado o microscópio eletrônico de varredura (MEV). Estes estudos propiciaram a análise qualitativa e quantitativa da deformação, incluindo a determinação dos tensores, pelo método gráfico dos diedros retos de Angelier \& Mechler (1977), com modificações feitas por Delvaux (1993). Foram utilizados como base para determinação dos tensores os trabalhos de Tchalenko (1970), Angelier \& Mechler (1977) e Angelier (1979, 1984, 1989, 1994). Para caracterização dos indicadores cinemáticos nos planos de falhas, visando a determinação do sentido do movimento relativo dos blocos, foram utilizados os trabalhos de Petit (1987), Angelier (1994), Stewart \& Hancock (1994), Doblas et al. (1997). A análise estrutural de fraturas sem estrias visíveis e de juntas, teve como base os trabalhos de Hancock (1985), Hancock \& Engelder (1989), Olson \& Pollard (1989), Cruikshank et al. (1991), Cruikshank \& Aydin (1994), Dunne \& Hancock (1994), Ameen (1995), Caputo (1995) e Younes \& Engelder (1999).

Para o tratamento estatístico dos dados estruturais, foram utilizados programas de computação específicos, como o FpTectonics (Reiter \& Acs 1995) e o TENSOR (Delvaux 
1993). O primeiro foi usado para plotagem e análise geométrica de juntas e diques e o segundo para tratamento, plotagem e análise cinemática de dados pareados (falhas/estrias).

\subsubsection{Medidas das Estruturas}

a) estruturas planares (juntas e diques) - foram caracterizadas pelo rumo do mergulho e o mergulho;

b) dados pareados falhas/estrias - foram caracterizados pelo rumo do mergulho/mergulho dos planos de falha, pelo azimute/caimento das estrias e pelo sentido de movimento dos blocos.

\subsubsection{Análise Cinemática e Determinação de Paleotensões}

Nas falhas o sentido de movimento dos blocos foi determinado tanto por parâmetros estratigráficos como pelos indicadores cinemáticos rúpteis caracterizados nos planos de falhas.

Esses dados foram invertidos para obtenção das paleotensões responsáveis pela sua geração, com base no princípio de que as estrias são paralelas ao esforço cisalhante máximo exercido sobre o plano de falha e que a direção e o sentido de movimento é independente em cada falha (Carey \& Brunier 1974, Angelier \& Mechler 1977, Angelier 1984, 1990, 1994).

A inversão dos dados pareados de falhas e estrias foi efetuada computacionalmente, com a utilização do programa TENSOR (Delvaux 1993, modificado de Angelier 1984, 1990), que se baseia em uma versão modificada do Método dos Diedros Retos de Angelier \& Mechler (1997). O método dos diedros retos pressupõe que, para um determinado campo de tensões, as estruturas extensionais estarão posicionadas no diedro em que se situa o eixo de tensões mínimo, $\sigma 3$, e que as compressionais se posicionam no diedro em que se situa o eixo de tensões máximo, $\sigma 1$ (Figura 3.1A e B). Os diedros são delimitados pelo posicionamento de um plano imaginário, denominado auxiliar, ortogonalmente ao plano de falha e à direção das estrias situadas nesse plano. A superposição das áreas de tensão máxima e mínima, em 
projeção estereográfica, para diversas falhas irá indicar a posição dos eixos de tensões principais (Figura $3.1 \mathrm{C}$ ).

A)
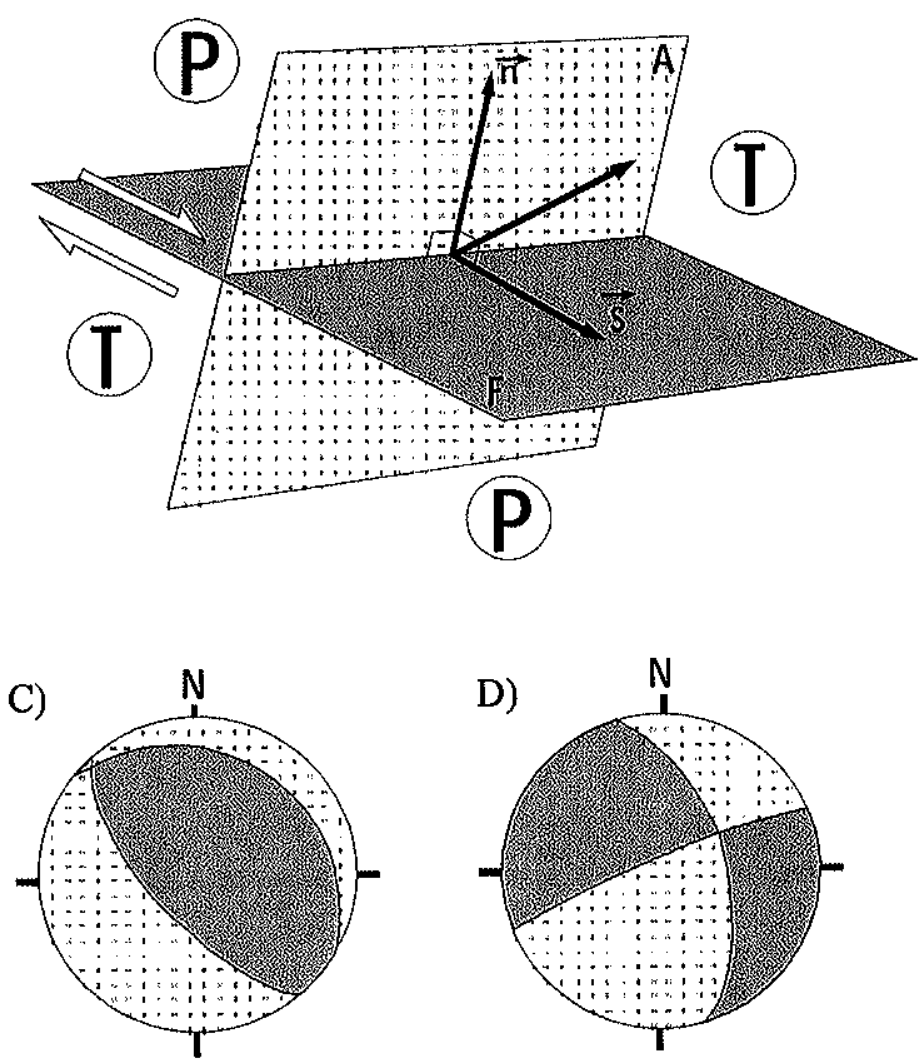

B)
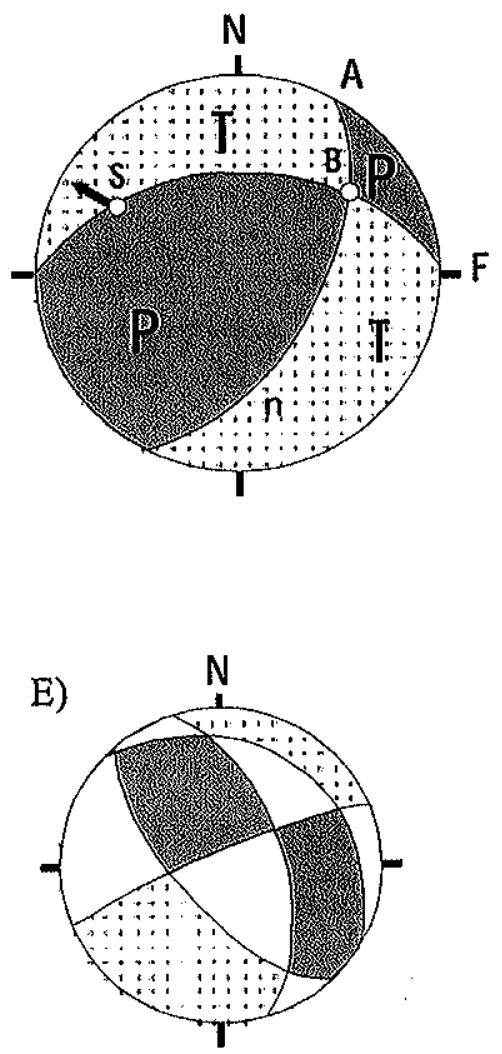

Figura 3.1 - Método dos diedros retos. A) Falha (F) e plano auxiliar (A) delimitando diedros compressivos (P) e distensivos $(\mathrm{T})$. A direção e o sentido de movimento da falha estão representados pelo vetor unitário de movimento (s) e (n) representa o vetor unitário ortogonal à falha; B) Projeções estereográficas dos planos $\mathrm{F}$ e A, onde $\mathrm{B}$ é a interseç̧ão dos dois, $\mathrm{P}$ é o diedro compressivo e $\mathrm{T}$ o distensivo. C) Projeção estereográfica de falha normal e seu plano auxiliar, delimitando os campos compressivo e distensivo; D) Idem à anterior, para uma falha direcional; E) Superposição das projeções estereográficas das falhas representadas em C e D, mostrando áreas $100 \%$ compressivas, em cinza, $100 \%$ distensivas, pontilhadas, resultantes da coerência desses domínios em $\mathrm{C}$ e $\mathrm{D}$, e áreas com $50 \%$ de cada, em branco, resultantes da superposição de domínios compressivos e distensivos.

Dessa forma, a utilização do programa TENSOR permitiu a obtenção dos eixos de tensões principais, incluindo a orientação dos principais eixos de tensões $\sigma 1, \sigma 2$, e $\sigma 3$, onde $\sigma 1 \geq \sigma 2 \geq \sigma 3$ (compressão considerada positiva). Adicionalmente foi calculada a razão de esforço $\mathrm{R}=\sigma 2-\sigma 3 / \sigma 1-\sigma 2,0 \leq \mathrm{R} \leq 1$, visando qualificar o regime de esforço responsável pela 
deformação. Esse parâmetro foi definido por Angelier (1989), que o denominou razão $\Phi$. Os regimes de esforços podem ser caracterizados com base em:

a) Classificação dos regimes de esforços de acordo com a natureza do eixo de tensão principal vertical:

1) extensional $\rightarrow \sigma 1$ vertical

2) direcional $\rightarrow \sigma 2$ vertical

3) compressional $\rightarrow \sigma 3$ vertical

b) Pela conjugação da posição do eixo de tensão principal com o parâmetro $R(R=\sigma 2-\sigma 3 /$ $\sigma 1-\sigma 3)$, com subdivisão dos campos de tensões:

1) EXTENSÃO Radial (Radial EXTENSIVE) $\rightarrow \sigma 1$ vertical, $0<\mathrm{R}<0.25$

2) EXTENSÃO Pura (Pure EXTENSIVE) $\rightarrow \sigma 1$ vertical, $0.25<\mathrm{R}<0.75$

3) EXTENSÃO Direcional (Strike-slip EXTENSIVE) $\rightarrow \sigma 1$ vertical, $0.75<\mathrm{R}<1.0$

4) DIRECIONAL Extensional (Extensive STRIKE-SLIP) $\rightarrow \sigma 2$ vertical, 1.0>R $>0.75$

5) DIRECIONAL Puro (Pure STRIKE-SLIP) $\rightarrow \sigma 2$ vertical, $0.75>\mathrm{R}>0.25$

6) DIRECIONAL Compressivo (Compressive STRIKE-SLIP) $\rightarrow \sigma 2$ vertical, $0.25>\mathrm{R}>0$

7) COMPRESSÃO Direcional (Strike-slip COMPRESSIVE) $\rightarrow \sigma 3$ vertical, $0<\mathrm{R}<0.25$

8) COMPRESSÃO Pura (Pure COMPRESSIVE) $\rightarrow \sigma 3$ vertical, $0.25<\mathrm{R}<0.75$

9) COMPRESSÃO Radial (Radial COMPRESSIVE) $\rightarrow \sigma 3$ vertical, $0.75<\mathrm{R}<1.0$

Outro parâmetro determinado com auxílio do programa TENSOR foi o ângulo $\alpha$, que representa o desvio médio entre as estrias medidas sobre o plano de falha e as calculadas teoricamente para um determinado campo de tensões. Para Angelier (1989) o valor médio máximo de $\alpha$, para uma determinada população de falhas, deve ser de $22^{\circ}$. No programa TENSOR são aceitos valores individuais de $\alpha$ de até $30^{\circ}$, mesmo que Choi et al. (1996) admitam um valor máximo de $45^{\circ}$. Porém os valores médios foram mantidos dentro do recomendado por Angelier (1989). O programa TENSOR dispõe de um procedimento de otimização rotacional dos eixos de tensões principais, que minimiza os desvios médios entre as estrias medidas e o cisalhamento teórico computado $(\alpha)$.

O programa TENSOR permite, também, a inversão de fraturas de cisalhamento conjugadas e de fraturas de extensão. No caso das fraturas de cisalhamento conjugadas, são 
consideradas como tal, no programa, as que possuem ângulos entre si variando de $45^{\circ}$ a $85^{\circ}$. Nesse caso, a direção de movimento em cada um dos conjugados será ortogonal à linha de interseç̧ão entre os dois planos e o sentido de movimento será o da porção interna da bissetriz aguda entre os dois planos (Ragan 1973). Dessa forma o eixo de tensões principal, $\sigma 1$, será posicionado na bissetriz aguda, o eixo intermediário, $\sigma 2$, irá coincidir com a linha de intersecção entre os dois planos e o eixo de tensões mínimo, $\sigma 3$, será ortogonal a $\sigma 1$. No caso dos planos de fraturas de extensão, preenchidas (p. ex. por veios ou diques) ou não, a direção de movimento é ortogonal à linha de interseç̧ão entre a fratura e o plano de movimento (Ragan 1973). Nesse caso pode-se determinar a direção de $\sigma 3$, o eixo de tensões mínimo, que é, também, ortogonal ao plano de fratura extensional.

\subsubsection{Indicadores Cinemáticos Rúpteis}

A indicação do sentido de movimento das falhas se baseia, tradicionalmente, na separação estratigráfica, indicada pelo deslocamento relativo de marcadores anteriores à movimentação da falha, e/ou nas dobras de arrasto, representadas pela assimetria das camadas junto ao plano de falha, devido ao arrasto exercido sobre elas pelo bloco oposto. Nas últimas duas décadas a caracterização da cinemática das falhas tem se baseado também nas feições geradas sobre os planos de falhas, denominadas indicadores cinemáticos rúpteis. Nesse sentido, será apresentada, a seguir, uma revisão dos conceitos referentes aos indicadores cinemáticos rúpteis, com base em Petit (1987) e Angelier (1994).

Feições Assimétricas Observáveis no Plano de Falha:

As feições assimétricas geradas pelo movimentos dos blocos de falhas podem ser separadas em duas grandes categorias:

a) Feições assimétricas positivas - apresentam menor fricção ao tato, sobre o plano de falha, no sentido de movimento do bloco perdido,

b) Feições assimétricas negativas - apresentam maior fricção ao tato, sobre o plano de falha, no sentido de movimento do bloco perdido.

Destaca-se abaixo as mais comuns, em ambas as categorias (Figura 3.2): 


\section{1) Degraus minerais acrescionários}

- função do crescimento de cristais fibrosos ou de outros cristais durante o movimento da falha

- $100 \%$ confiável

- positivo

\section{2) Marcas de objetos tectônicos}

- ocorrem tanto como um relevo positivo ou como cavidades assimétricas na superfície de falha, função do lado em que se observa. Ex. de objetos: grãos de quartzo, feldspato, seixos.

- $85 \%$ confiável

- negativo

3) Riedel shears - Planos $R$ de Ridel

- cruzam o plano de falha

- ângulos entre $5-25^{\circ}$

- mesmo sentido de movimento da falha

- perpendicular às lineações no plano de falha

- $75 \%$ confiável - pode ser ambíguo se lentes de cisalhamento se desenvolvem ao longo da superfície de falha

- negativo

4) Planos antitéticos - Planos $R^{\prime}$ de Riedel

- cruzam o plano de falha

- ângulos em torno de $75^{\circ}$

- sentido de movimento oposto ao da falha

- perpendicular às lineações no plano de falha

- $75 \%$ confiável

- negativo 

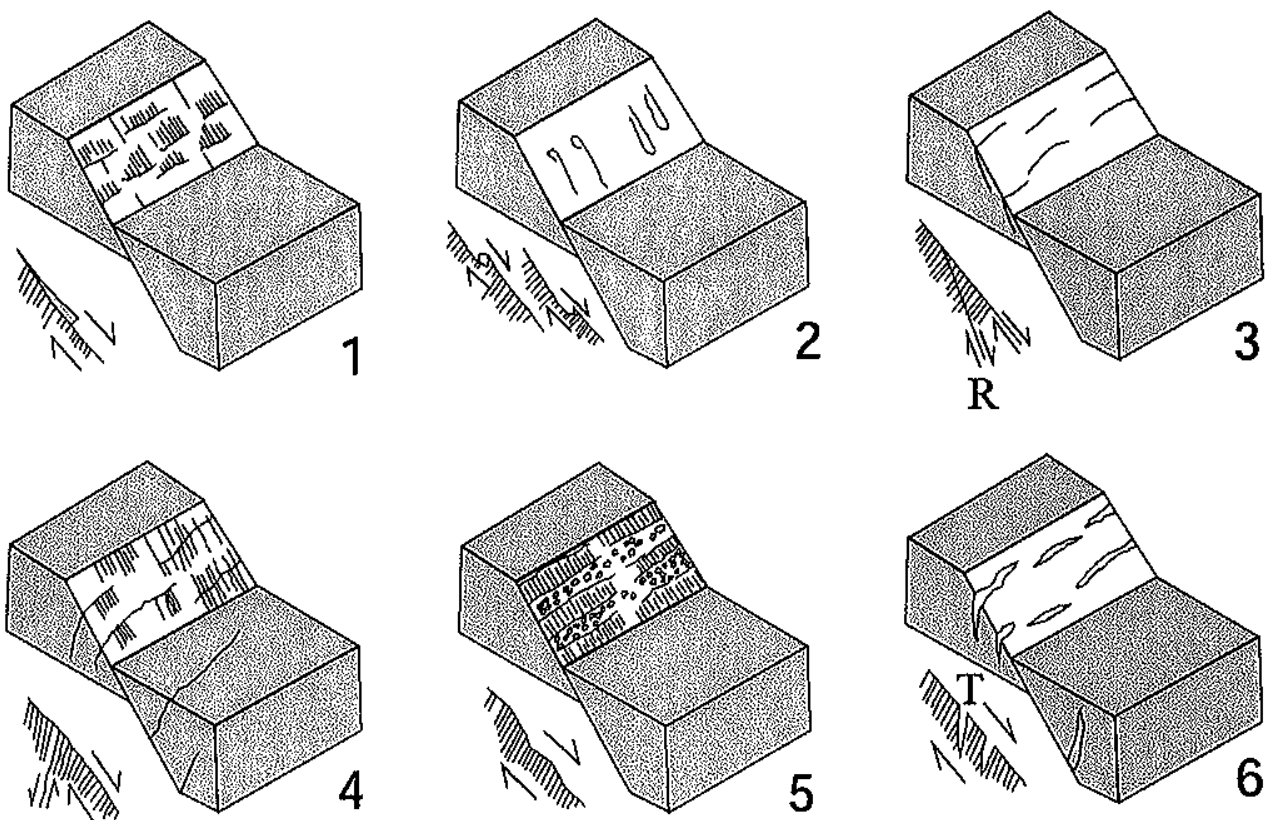

$\mathrm{R}^{\prime}$
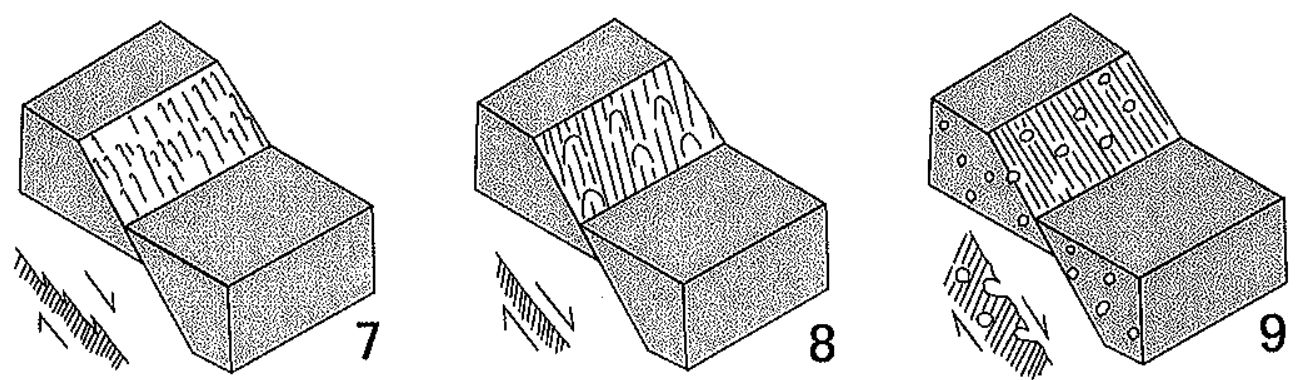

Figura 3.2 - Critérios para determinação do sentido do movimento em superficies de falhas. Os exemplos mostrados são de falhas normais, mas os critérios são válidos independente do tipo de movimento ocorrido. 1) Degraus de minerais neoformados, 2) marcas de objetos, 3) fraturas de cisalhamento sintéticas (R), 4) fraturas de cisalhamento antitéticas $\left(\mathrm{R}^{\prime}\right), 5$ ) facetas polidas e rugosas alternadas, 6) tension gashes, 7) picos estilolíticos, 8) marcas parabólicas e 9) vesículas deformadas em lavas (segundo Angelier 1994).

\section{5) Facetas polidas e rugosas}

- podem ocorrer em todos os tipos de rochas

- mais comuns nas rochas não carbonáticas

- em geral perpendiculares à direção de movimento 
- tipos de facetas: com friç̧ão - polidas e estriadas, ou moídas e esbranquiçadas (essas últimas podem ser confundidas com fibras); com abertura - rugosas, localmente com fragmentos de rochas, óxido de ferro, calcita e quartzo

- $80 \%$ confiável

- positivo

6) Tension Gashes - Planos T de Riedel

- aproximadamente perpendicular às lineações do plano de falha

- ângulo de $30-50^{\circ}$ com plano de falha

- $70 \%$ confiável

- negativo

7) Picos ou lineações estilolíticas

- produzidos por solução em facetas friccionais

- $100 \%$ confiáveis em calcário

- negativo

- em calcários pode-se observar, no mesmo plano, degraus de minerais acrescionários e lineações estilolíticas, que indicam feições de abertura e encurtamento, respectivamente. Os picos ou lineações estilolíticas implicam em creep, devido ao tempo necessário para o fenômeno ocorrer

8) Marcas Parabólicas

- comumente desenvolvidas em superfícies de falhas polidas, mostram formas em meia lua com concavidade voltada no sentido do movimento do bloco perdido. Representam lascas arrancadas pelo movimento, aproveitando fraturas antitéticas que fazem um ângulo alto com o plano de falha, normalmente fraturas $\mathrm{T}$

- positivas

9) Vesículas Deformadas em Lavas 
- formação de cornijas, a favor do movimento, e de concavidades, contra o movimento, na borda de orifícios vesiculares, por cataclase na superficie de falha

- positivas

As relações geométricas e a nomenclatura das fraturas secundárias associadas às superfícies de falha, geradas em ambiente rúptil, por cisalhamento simples, como aplicadas por Petit (1987) e Angelier (1994), são aquelas definidas pelo modelo de Riedel (Figura 3.3).

Petit (1987) propôs uma sistematização dos indicadores cinemáticos presentes nos planos de falhas, geradas por cisalhamento simples, em ambiente rúptil, com base na repetição e associação de famílias de fraturas secundárias. Ele separa três "critérios", T, R e P, com base nas fraturas secundárias predominantes nas superfícies de falhas (Figura 3.4). Adicionalmente, ele lista dois indicadores não relacionados com as fraturas secundárias, que são as estrias geradas por "elementos de aragem" (objetos mais duros que os materiais da superfície de falha) - denominados "marcas de objetos tectônicos" por Angelier (1994), e a "cristalização de minerais associada a irregularidades da superfície de falha" - denominados "degraus minerais acrescionários" por Angelier (1994).

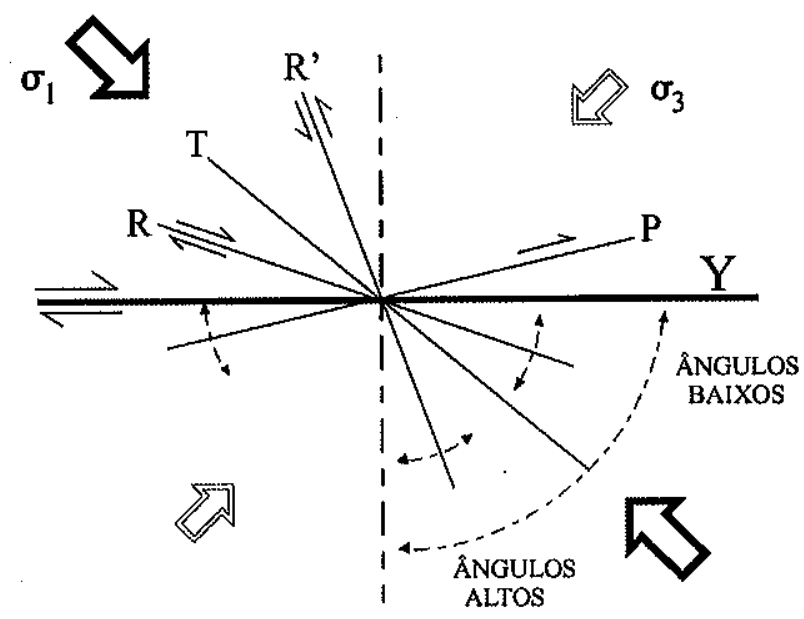

Figura 3.3 - Terminologia para descrição de fraturas secundárias elementares em um contexto de cisalhamento simples, segundo Petit (1987). 

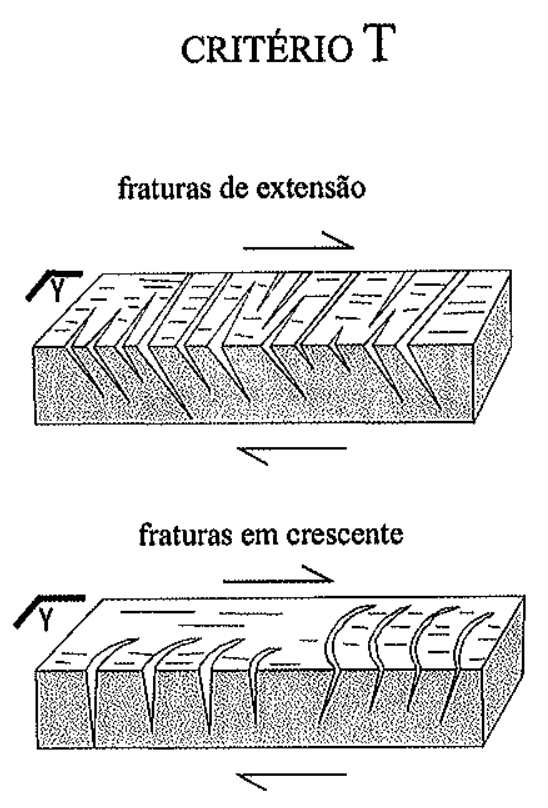

CRITÉRIO R

AR (apenas R)
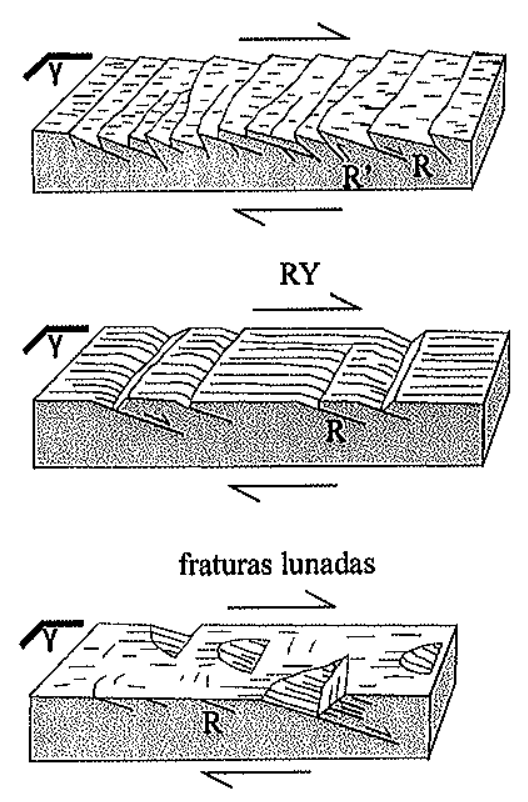

\section{CRITÉRIO P}
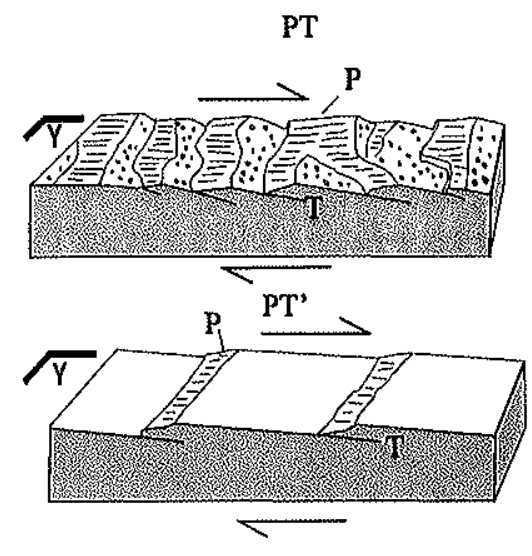

AP (apenas P)

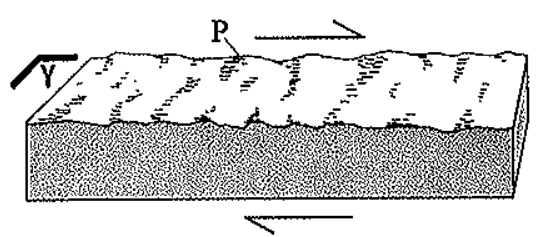

Figura 3.4 - Principais tipos de critérios utilizados como indicadores cinemáticos, em um contexto de cisalhamento simples, a partir da repetição das fraturas secundárias, segundo Petit (1987).

As indicações do sentido de movimento, a partir dos diversos critérios, é coincidente quando comparamos os dois autores.

3.1.2.2. Ordem de Desenvolvimento de Estruturas Secundárias Relacionadas a Zonas de Cisalhamento Direcionais

As estruturas secundárias relacionadas a zonas verticais submetidas a cisalhamento simples, em ambiente rúptil (Figura 3.3), foram estabelecidas inicialmente a partir do experimento clássico de Riedel (1929), com o denominado Modelo de Riedel. Esse experimento, desenvolvido originalmente em calcário, foi reproduzido por Tchalenko (1970) 
em uma caixa de cisalhamento em argila caulínica. Esse último autor preconizou o desenvolvimento de estruturas sintéticas ao movimento da falha principal (estruturas $R$ ), fazendo um ângulo inicial de $12^{\circ}$ a $16^{\circ}$ com a falha principal, no sentido do movimento, 0 qual, com a progressão da deformação, tornou-se cada vez menor, até cerca de $4^{\circ}$. O mesmo experimento com um conteúdo de água pouco menor na argila, propiciou o desenvolvimento de estruturas antitéticas, com um ângulo de $78^{\circ} \mathrm{com}$ a falha principal (estruturas R'). Tchalenko (1970) realizou o mesmo tipo de experimento, em uma caixa com paredes rígidas, reproduzindo, segundo ele, condições crustais mais profundas. Nesse caso foram geradas inicialmente as estruturas R', com um ângulo de $80-85^{\circ}$ com a falha principal e, logo após a essas, foram geradas as estruturas $\mathrm{R}$, a um ângulo de $12^{\circ} \mathrm{com}$ a falha principal. Com a continuidade da deformação foram geradas as estruturas $\mathbf{P}$, com um ângulo semelhante às $\mathrm{R}$, porém no sentido oposto ao do movimento. Wilcox et al. (1973) mostraram que as estruturas R' sofrem rotação no sentido de movimentação do binário, com a progressão da deformação. Já as $\mathrm{R}$ não sofreriam rotação porque as "rotações interna e externa de $\mathrm{R}$ teriam sentido contrário, se anulando". Segundo esses autores o desenvolvimento das estruturas T se dá logo no início da deformação, mas elas tendem a ser destruídas com a progressão da deformação. Já as estruturas $Y$, paralelas à zona de cisalhamento, só se desenvolvem com altas taxas de deformação.

De acordo com Woodcock \& Schubert (1994) nas zonas de cisalhamento com uma componente extensional forte (zonas transtrativas), ocorre uma rotação das estruturas secundárias, com R, R' e T diminuindo seus ângulos com a falha principal, e com as estruturas compressivas, falhas reversas e dobras, se tornando quase perpendiculares a ela. Ainda de acordo com esses autores, nas zonas de cisalhamento transpressivas ocorre o inverso.

Uma síntese dos tipos de fraturas secundárias geradas pelo movimento ao longo de zonas de cisalhamento rúpteis é apresentada por Sylvester (1988) (Figura 3.5). 


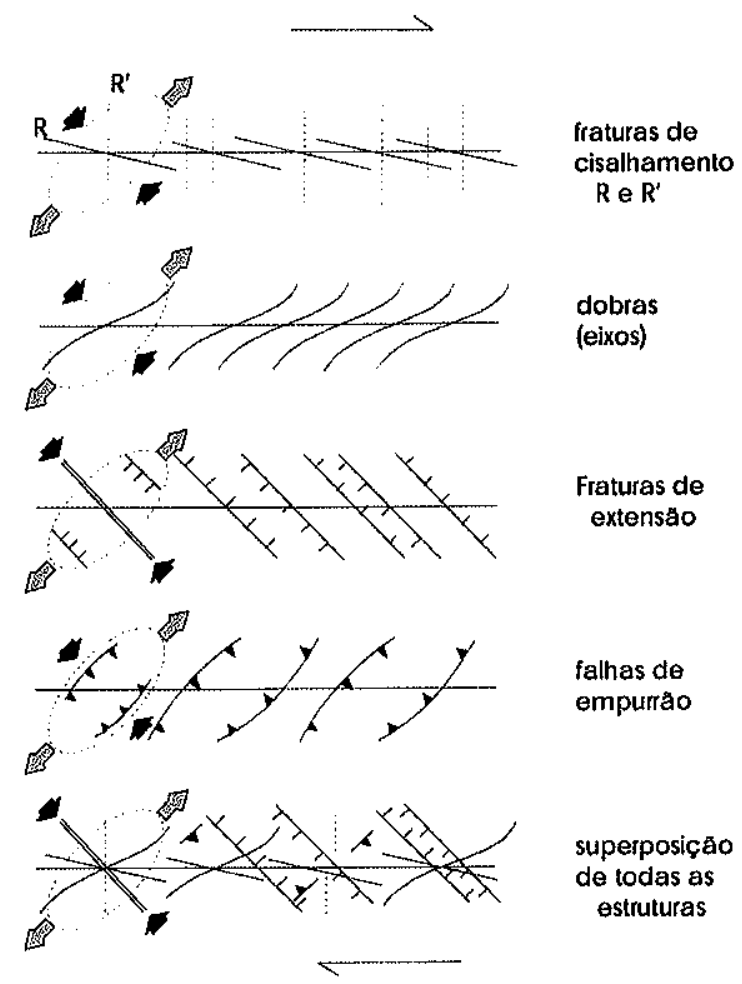

Figura 3.5 - Orientação de estruturas secundárias, com arranjo en echelon, associadas a uma zona de cisalhamento dextral (segundo Sylvester 1988).

\subsection{UTILIZAÇÃO DE DIQUES COMO INDICADORES TECTÓNICOS}

\subsubsection{Introdução}

Diques e silos são bons indicadores tectônicos uma vez que se posicionam a $90^{\circ}$ do tensor de menor esforço - $\sigma_{3}$ (Stevens 1911, Anderson 1951, Zoback et al. 1989, Zoback 1992). Geoffroy et al. (1993) encontraram uma boa concordância entre $\sigma_{1}$ e $\sigma_{2}$ calculados tanto através da orientação de diques, como do movimento das falhas, para um mesmo campo de esforços. Bons resultados tem sido obtidos com este método, em especial quando associado à datação geocronológica de diques utilizados como indicadores da deformação (Feraud \& Compredon 1983, Etchebehere et al. 1992, Hasui et al. 1992, Riccomini 1995a e b). 


\subsubsection{Diques}

Diques são corpos ígneos tabulares, de espessura variável e com uma relação comprimento/espessura, média, de aproximadamente 1000:1, e de no mínimo 1:200, no caso dos corpos menores (Rickwood 1990). Eles apresentam, em geral, mergulhos altos e são discordantes das estruturas das encaixantes. Um conjunto de diques coetâneos e geograficamente correlacionados, constituem um enxame de diques. Rickwood (1990) indica uma terminologia recomendada para a descrição de diques, tendo como parâmetro as suas dimensões no plano horizontal:

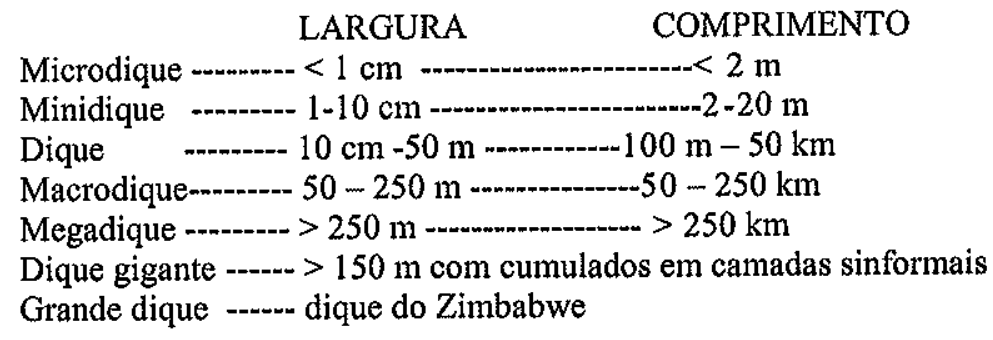

A terminologia para descrição da morfologia dos diques, para seções em planta ou verticais, é sintetizada por Rickwood (1990) e Nicholson \& Pollard (1985) (Figuras 3.6 e 3.7).
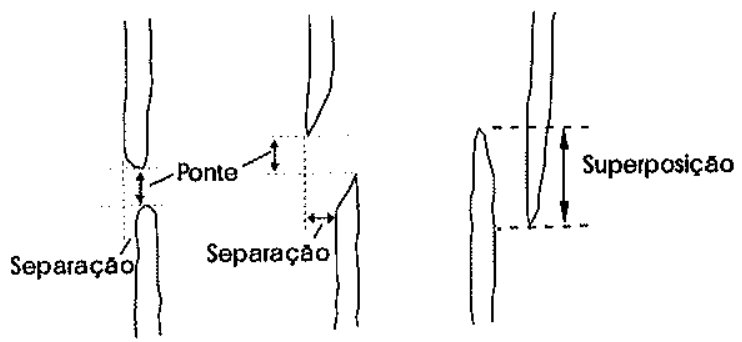

A)

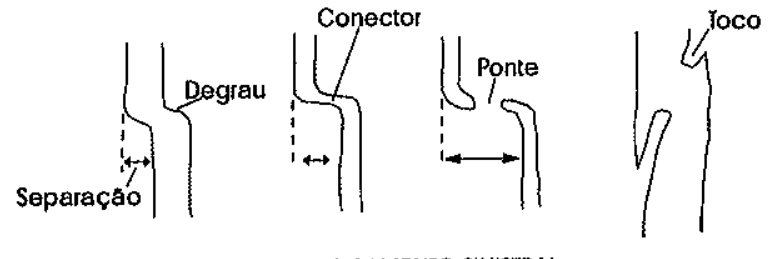

DESLOCAMENIO SINISTRAL 
B)

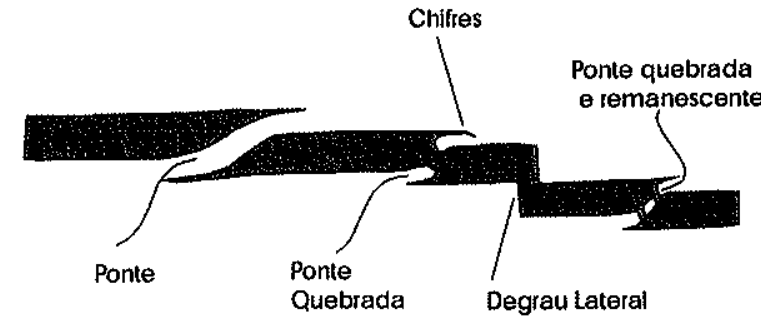

Figura 3.6 - Terminologia para deslocamentos e separações entre diferentes segmentos de diques, vistos em planta. Segundo A) Rickwood (1990) e B) Nicholson \& Pollard (1985).
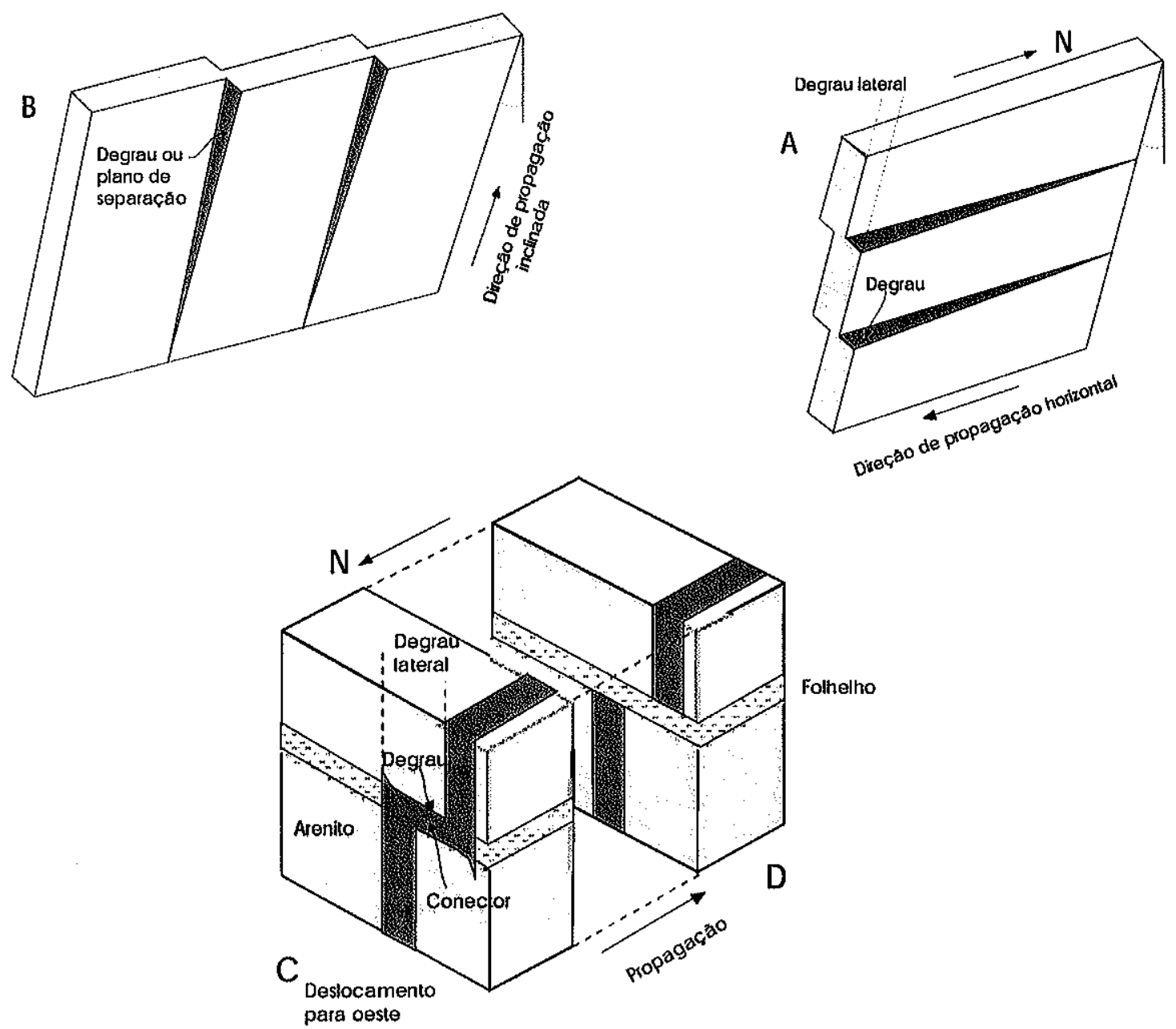

Figura 3.7 - Terminologia para o deslocamento entre diferentes segmentos de diques, em perfil. A e B mostram duas seções possiveis para um mesmo dique com deslocamento lateral. $\mathrm{C}$ mostra um dique com degraus horizontais, paralelos a direção de propagação. D mostra um dique de mergulho alto, próximo da vertical, com degraus de mesma orientação, também paralelos a direção de propagação do dique (segundo Rickwood 1990). 
Deve-se ressaltar a concordância entre a direção de alongamento dos degraus com a de propagação do dique, como mostrado na Figura 3.7.

Como antes referido, os diques são considerados bons indicadores tectônicos por se posicionarem perpendicularmente ao menor tensor de esforços $\sigma 3$ (Stevens 1911, Anderson 1951, Zoback et al. 1989, Zoback 1992). Esta relação é verdadeira, também, para alinhamentos vulcânicos ou de fendas para o extravasamento de magma e não apenas para estruturas puramente tracionais, mas também para as transtracionais (Zoback et al. 1989, Zoback 1992, Geoffroy et al. 1993, Basset \& Kleinspein 1996). Um dos problemas encontrados na utilização dessas feições como indicadores de esforços está em que, quanto mais superficiais, maior a tendência dos diques serem controlados por estruturas preexistentes (Zoback 1992). Porém, mesmo neste caso, as descontinuidades deverão estar aproximadamente perpendiculares ao $\sigma 3$ para serem aproveitadas (Delaney et al. 1986, Baer et al. 1994). Uma exceção, segundo estes autores, poderá ocorrer quando um, ou os dois outros tensores principais, tiverem magnitude próxima a $\sigma 3$, deixando o controle da propagação do dique ao cargo das estruturas da encaixante.

Pollard (1987) sintetiza alguns dos parâmetros básicos para interpretação estrutural de diques (Figura 3.8). Estes parâmetros incluem, além da atitude do dique, sua largura e comprimento, e o mapeamento de estruturas de pequena escala próximas ao contato, que "podem ajudar a identificar mecanismos de deformação inelástica atuantes na extremidade dos diques".

A solução dos esforços em uma placa elástica com um buraco elíptico é apresentada por Inglis (1913, apud Pollard 1987) (Figura 3.9). Segundo esse autor "a tração nas extremidades do eixo maior "a" (ponto A) é de longe o maior esforço", e a rapidez com que esse esforço decresce com o distanciamento de A é marcante. Este efeito aumenta com a ampliação da razão $a / b$ e, ainda, quando $a / b=1000$, a tração em A é 2001 vezes a tração média. A elipse, neste caso se parecerá com uma fina fratura, e um puxão muito pequeno aplicado a placa através da fratura gerará uma tração nas extremidades suficiente para iniciar um rasgo no material. Segundo Pollard (1987), a solução de Inglis racionaliza a proposição da $1^{a}$ Lei de Stevens, partindo-se da premissa de que há grande similaridade entre uma fenda numa placa e um dique na crosta, "pois ambos podem ser aproximados de buracos estreitos em 
sólidos elásticos carregados por tensões atuando perpendicularmente ao eixo maior do buraco". Segundo este autor, no caso da Figura 3.9 este carregamento é dado por um esforço tracional $\left(\sigma_{1}{ }^{\mathrm{r}}\right)$ aplicado nos limites da placa e, para o dique, o carregamento será a diferença entre a pressão interna do magma e o esforço compressivo regional (P-S) (Figura 3.8A).
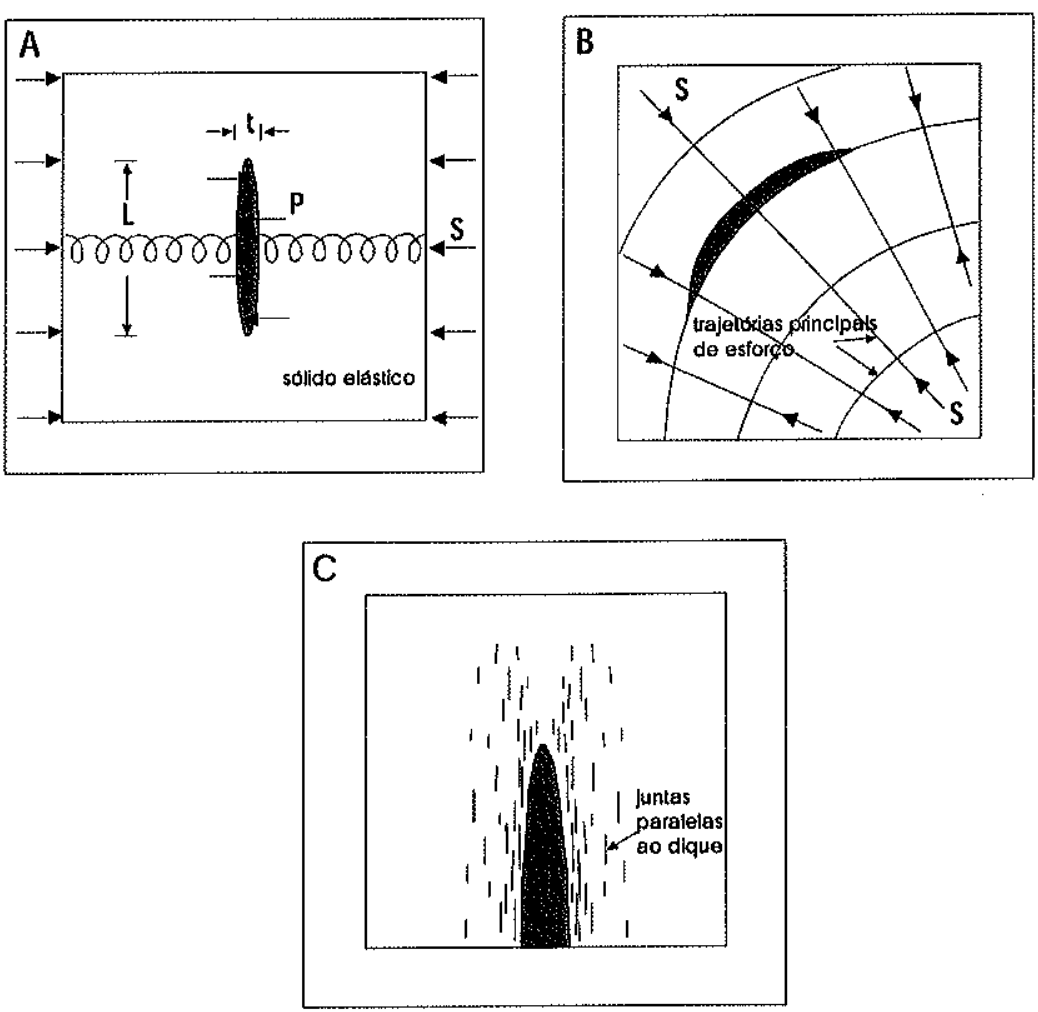

Figura 3.8 - Três figuras esquemáticas ilustrando a interpretação estrutural de diques. A: Pressão motriz do magma (diferença entre a pressão do magma $P$ e o esforço compressivo regional $S$ ) é estimada a partir da medida da espessura do dique ( $t$ ), do comprimento (l), e da dureza elástica da rocha encaixante (representada pela mola). B: A orientação da trajetória dos tensores principais é inferida a partir da rota que o dique segue. C: O mecanismo de propagação é identificado a partir da observação de estruturas, como juntas próximas ao contato e na extremidade do dique (segundo Pollard 1987). 


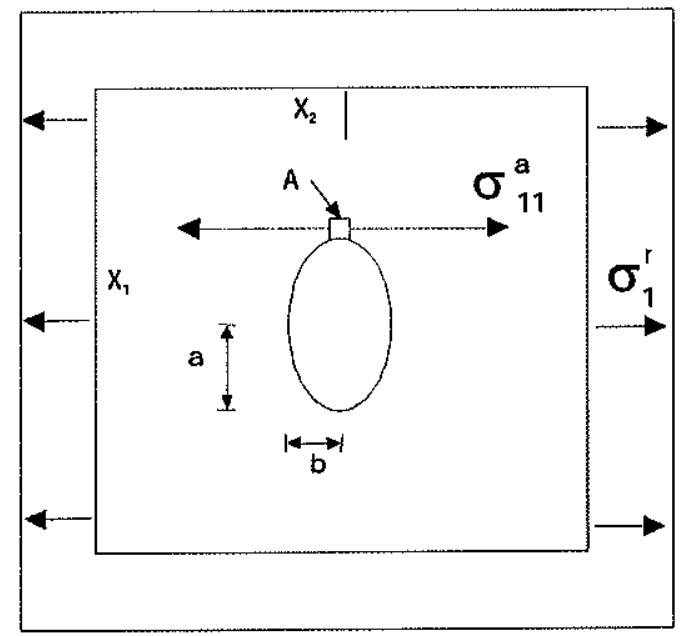

Figura 3.9 - Modelo elástico de Inglis (1913). A: Geometria e condições de carregamento de uma placa elástica contendo um buraco elíptico com semi-eixo maior (a) e semi-eixo menor (b). O esforço de tração $\sigma_{1}{ }^{r}$ regional é concentrado no ponto $(\mathrm{A})$, no final do eixo maior, onde a tração é designada $\sigma_{11}{ }^{\mathrm{a}}$.

Este princípio básico da mecânica de fraturas, de que o esforço de tração é concentrado nas extremidades da fratura, implica em que a sua propagação acontece essencialmente aí. Esta extremidade, caracterizada por verificação de deformação inelástica (Figura 3.10), é denominada "zona de processo" (Pollard 1987).

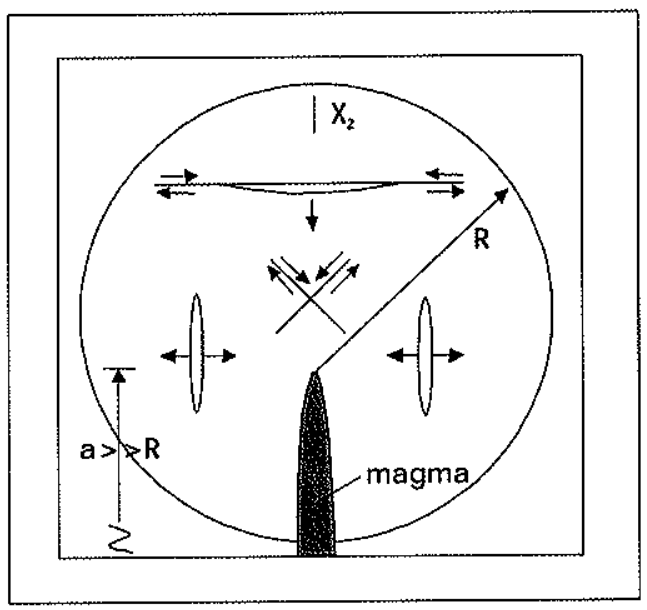

Figura 3.10 - Ilustração esquemática do mecanismo de propagação de diques pelo modelo da Zona de Processo. A distância radial $(R)$ indica o limite externo dessa zona. Os mecanismos aí operantes incluem a formação de juntas paralelas ao dique, de falhas conjugadas, e a abertura e o escorregamento de superficies de fraqueza, tais como planos de acamamento e contato de grãos. $O$ parâmetro (a) é a metade do comprimento do dique (segundo Pollard 1987) 
Segundo Pollard (1987), a amplitude da Zona de Processo pode ser estimada a partir da relação abaixo:

$$
\mathrm{R} \approx \mathrm{a} / 2[\mathrm{P}-\mathrm{S} / \mathrm{Tu}+\mathrm{S}]^{2}, \text { onde }
$$

$\mathrm{a}=$ comprimento do dique, $\mathrm{P}=$ pressão do magma, $\mathrm{S}=$ esforço compressivo regional, $\mathrm{Tu}=$ força tracional na extremidade do dique

Tomando valores de diques mapeados por Delaney et al. (1986, apud Pollard 1987):

$1 \leq(\mathrm{P}-\mathrm{S}) \leq 10 \mathrm{MPa}$

$1 \leq \mathrm{Tu} \leq 10 \mathrm{MPa}$

$25 \leq \mathrm{S} \leq 125 \mathrm{MPa}$ (1 a $5 \mathrm{~km}$ profundidade)

$1 \leq \mathrm{a} \leq 5 \mathrm{~km}$

Tem-se que o intervalo do raio $(R)$ para a zona de processo é estimada como tendo suas dimensões variando entre 0,03 e $370 \mathrm{~m}$

Segundo Pollard (1987) a geometria dos diques está relacionada, em parte, com a trajetória que ele segue enquanto se propaga. Esta, por sua vez, é função do campo de esforços atuante na sua extremidade. Segundo ele, dentro do contexto da mecânica de fraturas, as possíveis variações na distribuição do esforço compressivo mínimo se fazem segundo os três possíveis modos de fraturas: Modo Puro I, Modo Misto I-II e Modo Misto I-III (Figura 3.11).

No caso do Modo de Propagação I-II, se a mudança na orientação do eixo de menor esforço for gradual e contínua, o dique irá descrever uma curva suave, e se a mudança for brusca, o dique sofrerá uma dobra aguda na sua trajetória (Pollard 1987). Sommer (1966, apud Pollard 1987), demonstra que no Modo I-III as fraturas vão se fragmentar em múltiplos segmentos, que vão sofrer uma torção para atingir uma orientação perpendicular ao eixo de menor esforço compressivo local. Neste último caso, os diques vão apresentar um arranjo en echelon, perpendicular ao sentido de propagação (Anderson 1951). A limitada amplitude do tempo de intrusão dos diques, entre poucas horas e alguns dias, sugerem a manutenção de um campo de esforços constante durante a intrusão (Pollard 1987). Porém as variações no Modo 
de Intrusão indicam que este campo sofreu variações ao longo da trajetória de intrusão. $O$ arranjo en echelon de estruturas está comumente associado a falhas direcionais geradas em um mecanismo de cisalhamento simples (Tchalenko 1970, Wilcox et al. 1973, Sylvester 1988). Este arranjo en echelon está associado a uma rotação dos eixos de esforços, $\sigma 1$ e $\sigma 3$, em direção à superfície, a partir de uma falha principal, em profundidade (Figura 3.12).

\section{A. Fratura do Modo Puro I}

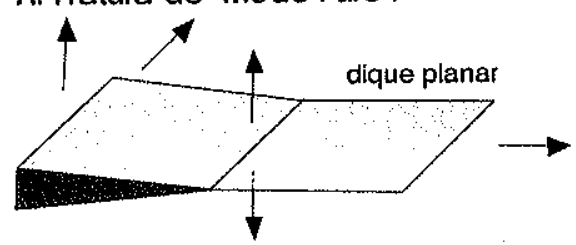

B. Fratura do Modo Misto I-ll
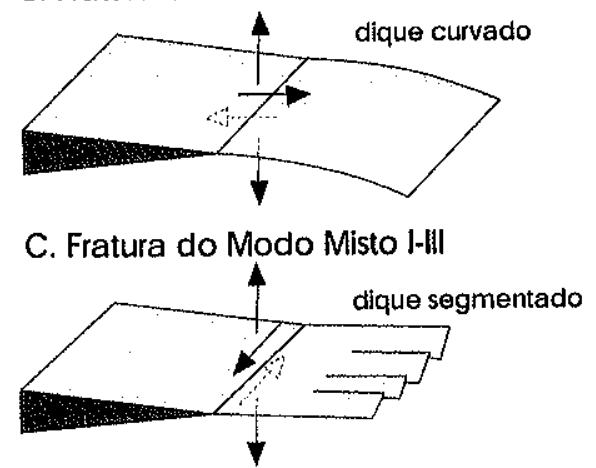

Figura 3.11 - Trajetorias de propagação para diques relacionadas com a mudança espacial na orientação do menor esforço compressivo. A: O Modo de Fratura Puro I é induzido pelo menor esforço compressivo atuando perpendicularmente ao plano do dique e produz um dique planar. B: O Modo de Fratura Misto I-II é induzido por uma rotação do menor esforço compressivo, segundo um eixo paralelo a periferia do dique, é perpendicular à direção de propagação, produzindo um dique curvado. C: o Modo de Fratura Misto I-III é induzido por uma rotação do menor esforço compressivo, segundo um eixo paralelo a direção de propagação, produzindo um dique segmentado (segundo Pollard 1987).

(A)

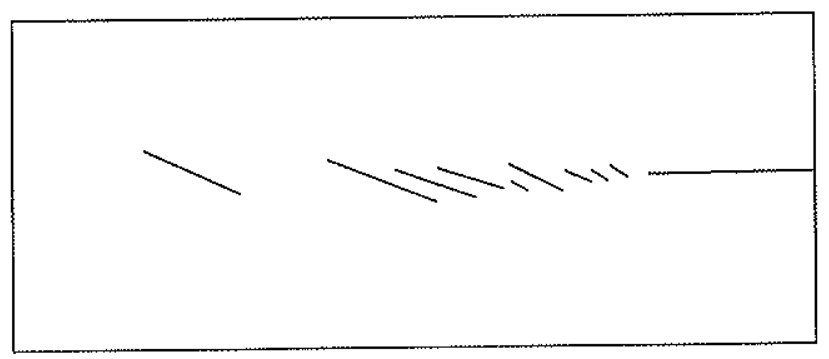




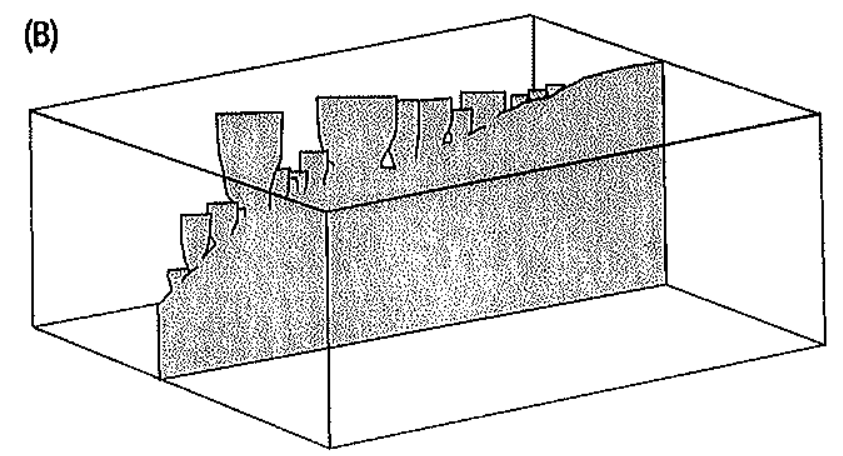

Figura 3.12 - Fraturas en echelon preenchidas, vistas em projeção horizontal e em profundidade (segundo Cruikshank et al. 1991).

De acordo com Wilcox et al. (1973) as estruturas T desenvolvem-se no início do processo de deformação pelo regime de cisalhamento simples, podendo, inclusive serem obliteradas na continuidade do processo por estruturas $\mathrm{R}$ e R'.

Deve-se ressaltar que fraturas en echelon preenchidas podem estar relacionadas a um regime extensional, desde que as fraturas sejam preexistentes (Figuras 3.13A, B e C) (Nicholson \& Pollard 1985).

A)
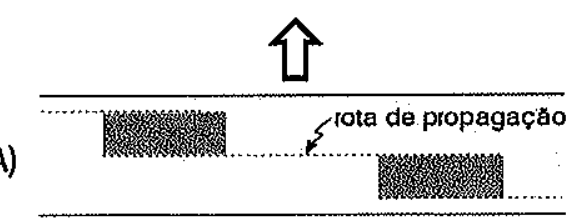

B)
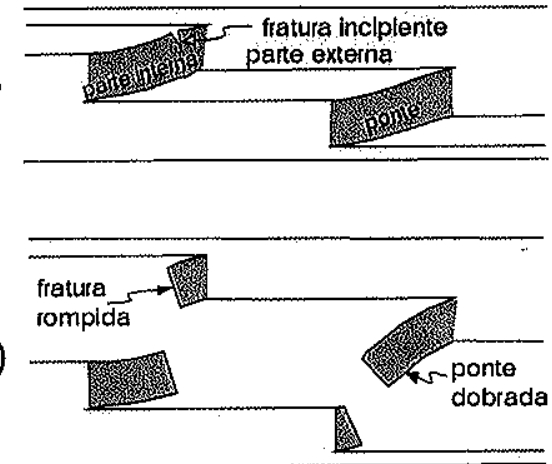

\section{$\sqrt{1}$}

Figura 3.13 - No lado esquerdo, ilustração esquemática de fraturas en echelon retilíneas. Parte da dilatação é acomodada pelo dobramento das pontes(B) podendo levar ao seu rompimento e ao aumento considerável da dilatação (Segundo Nicholson \& Pollard 1985). A direita, estágios de deslocamento das paredes do dique: (D) dilatação e (E) cisalhamento. A direção de propagação do dique é vertical (segundo Baer \& Beyth 1990). 
Em outros casos, a movimentação se deu em mais de uma fase (Figura 13D e E), onde uma extensão é seguida de movimentação direcional (Baer \& Beyth 1990).

É preciso ressaltar, no entanto, que admitindo-se que o arranjo en echelon está associado a uma rotação dos tensores principais horizontais, $\sigma 1$ e $\sigma 3$, no caso de um regime de esforços direcional, e que se esta rotação é progressiva, ter-se-á arranjos geométricos dos eixos intermediárias entre aquela inicial, anterior a rotação, e a posição final.

Neste sentido, Woodcock \& Schubert (1994) assinalam que a geometria das estruturas relacionadas com zonas de cisalhamento, podem tanto apresentar a característica orientação obliqua à zona na qual elas se incluem, como, também, um arranjo linear, paralelo a elas, escalonado ou não.

Uma dispersão na orientação dos diques com relação aos tensores principais pode estar também vinculada à relação das magnitudes relativas destes tensores com a pressão do magma. Jolly \& Sanderson (1995) encontraram uma relação direta entre o aumento da pressão do magma e da dispersão na orientação dos diques máficos do enxame de Mull na Escócia. De acordo com esses autores com o distanciamento da fonte do magma e conseqüente diminuição da sua pressão, o número de diques diminui, aumenta a sua espessura, sua retilinearidade, e eles se tornam normais ao esforço mínimo principal. A relação entre o distanciamento da fonte e a espessura dos diques pode ser distinta desta encontrada por Jolly \& Sanderson (1995). Para Smith (1987) a espessura diminui com o distanciamento da fonte. Para Halls (1982) há um afinamento para baixo, e para Geikie (1988) há um afinamento para cima. Dessa forma, as relações entre espessura dos diques e distanciamento da fonte devem ser analisadas para cada enxame.

\subsection{DATAÇÕES PELO MÉTODO $A r^{40} / A r^{39}$}

\subsubsection{Introdựão}


$\mathrm{O}$ método $\mathrm{Ar}^{40} / \mathrm{Ar}^{39}$ é uma variação do método $\mathrm{K}-\mathrm{Ar}$, sendo utilizado também para rochas com potássio. Sua importância reside na sua baixa margem de erro, menor que $1 \%$, e na possibilidade de sua obtenção a partir de amostras com baixa concentração de potássio. Neste sentido as datações $\mathrm{Ar}^{40} / \mathrm{Ar}^{39}$ têm sido bastante utilizadas em rochas vulcânicas máficas, permitindo uma baixa margem de erro, mesmo para aquelas do Quaternário.

$\mathrm{O}$ método consiste, basicamente, na obtenção do $\mathrm{Ar}^{39}$, por bombardeamento em um reator de neutrons. Este bombardeamento se dá em conjunto com o de uma amostra com idade K-Ar conhecida, para uma melhor determinação dos parâmetros de irradiação. A idade da amostra é definida pela razão $\mathrm{Ar}^{40} / \mathrm{Ar}^{39}$.

Para este método a bibliografia básica inclui Geyh \& Schleicher (1990), McDougall \& Harrison (1988) e Turner et al. (1994).

\subsection{MICROSCOPIA ELETONICA DE VARREDURA - MEV}

Utilizou-se o Microscópio Eletrônico de Varredura (MEV) da marca LEO, modelo 440i, que possui EDS com detetor de silício/lítio acoplado, instalado no Laboratório DE Microscopia Eletrônica do Departamento de Geologia Sedimentar e Ambiental - DGSA do IG-USP.

\subsubsection{Preparação de Amostras:}

a) Limpeza - retirada de pó da amostra, realizado com sopros de ar, e do stub (porta amostra) com algodão hidrófilo e acetona;

b) Fixação no stub - com cola de carbono condutor para auxiliar na condutibilidade da amostra;

c) Secagem - a amostra permaneceu em estufa, á temperatura de $35^{\circ} \mathrm{C}$ por três dias;

d) Conservação - em recipientes de vidro, dentro de secadores; 
e) Recobrimento com ouro ou carbono - para que a amostra se torne eletricamente condutora e possibilite o escoamento dos elétrons do feixe produzido pelo microscópio. $\mathrm{O}$ recobrimento de ouro visa possibilitar a caracterização morfológica das amostras e a de carbono visa a realização de análises semi-quantitativa e qualitativa.

\subsubsection{Operação do $\mathrm{MEV}$}

A operação do MEV, para obtenção das imagens de planos de falhas foi realizada com as seguintes calibrações:

a) Detectores - SE (detector de elétrons secundários) e QBSD (detector de elétrons retroespalhados)

b) $\mathrm{EHT}-15 \mathrm{KV}$

c) WD -50 a $70 \mathrm{~mm}$

d) Tilt-utilizado em algumas amostras, com ângulo de até $60^{\circ}$

Para a maioria das imagens foi usado o detector SE e para algumas foi utilizado o QBSD, que mostra a diferença de número atômico médio.

O resultado final obtido difere da microscopia óptica, principalmente na perda das cores originais, porém com duas vantagens: maior aumento com boa resolução (na ordem de $\mathrm{nm}$ ) e maior profundidade de campo. Adicionalmente o equipamento permite a realização de análises qualitativas e semiquantitativas com o EDS a ele acoplado. 


\section{CONTROLE DE INTRUSÃO E TECTÔNICA}

DEFORMADORA DO MAGMATISMO ALCALINO PRÉVIO A CONTEMPORÂNEO COM A IMPLANTAÇÃO DO GRABEN DA GUANABARA

\subsection{INTRODUÇAO: APRESENTAÇAO DO QUADRO REGIONAL}

O magmatismo alcalino está representado na área nordeste do RCSB por seis stocks, os corpos do Tinguá, Mendanha, Tanguá, Soarinho, Rio Bonito e Morro de São João, treze plugs como Serra dos Tomazes, Marapicu, Itaúna, Monjolos, Itaboraí, Country Club e Cabo Frio, entre outros, além de inúmeros diques (Figura 4.1). Datações geocronológicas indicam idades entre $80 \mathrm{Ma}$, para o Mendanha e $52 \mathrm{Ma}$ para Cabo Frio (Ulbrich \& Gomes 1981, Sonoki \& Garda 1988, Sichel et al.1997, Thompson et al. 1998, Deckart et al. 1998). A localização geográfica dos corpos de Morro de São João e de da Iha de Cabo Frio (Figura 4.1) coloca-os junto ao limite com o Graben de Barra de São João, no primeiro caso, e à sudoeste da projeção do Graben de Barra de São João para o continente. Dessa forma o corpo da Iha de Cabo Frio posiciona-se fora do Graben da Guanabara.

Os corpos maiores são caracterizados petrograficamente por uma associação félsica, constituída por sienitos, nefelina sienitos e, mais restritamente, foiaitos, por vezes com a presença de pseudoleucita (Valença 1975). Em Itaúna, estes tipos litológicos apresentam-se com textura microgranular. O stock de Morro de São João distingue-se pela ocorrência de tipos máficos (Lima 1976). Ainda de acordo com Valença (1975), diques de brechas magmáticas, associadas a traquitos, configurando uma estrutura semi-anelar, ocorrem nos maciços de Tanguá, Itaúna e Mendanha. Uma última geração de diques de fonolito, tinguaíto e traquito, teria intrudido contemporaneamente às brechas magmáticas, acompanhada por hidrotermalismo, gerando diques e brechas com matriz de calcedônia, aos quais, localmente, estão associadas mineralizações de fluorita e barita (Menezes \& Klein 1973, Valença 1975).

A ocorrência de rochas vulcânicas alcalinas constitui uma característica particular deste segmento do RCSB. Elas foram inicialmente reportadas por Derby 


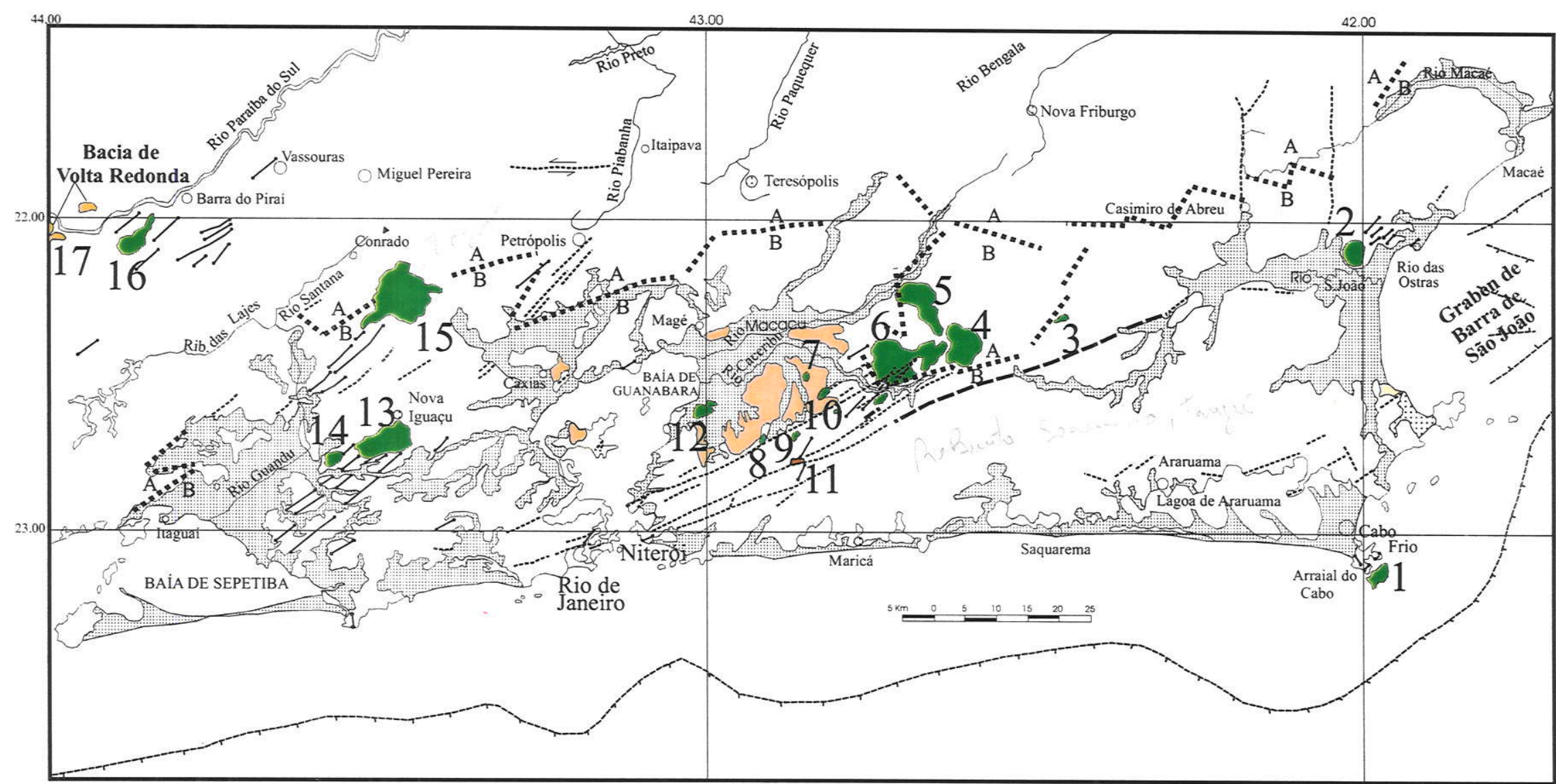

ESTRUTURAS

Sedimentos quarternários $\quad \square$ Corpos intrusivos e derrames de rochas alcalinas mesozóico-cenozóicas continentais e marinhos

Sedimentos eocênicos 1. Cabo Frio 2. Morro de São João 3. Morro dos Gatos 4. Rio Bonito 5.Soarinho 6.Tanguá

LITOLOGIAS Sedimentos Itaúna 13. Mendanha 14.Marapicu 15.Tinguá 16. Tomazes 17.AnkaramitodeVoltaRedonda

Figura 4.1-DistribuiçãodomagmatismoalcalinonoGrabendaGuanabara.Geologia a partirdeHemboldetal.,1965;Ferrarietal.,1977; Penhaetal. 1980;Barbosaet al., 1981,1983;Dalcolmo etal.,1982;Ferrari,1990;Mohriak et al.,1992;Riccomini,1995a). Idadesdoscorpos intrusivosederramesderochasalcalinas:1.54Ma2.77Ma 4. 70Ma 5.65 Ma 6.68Ma 7.66 Ma 11.52Ma12.69Ma 13.71Ma15.68Ma17.42Ma(idades a partirdeRiccominietal.,1983;Sonoki\&Garda,1988;Riccomini\&Rodrigues Francisco,1992;Sicheletal.,1997;Thompsonetal.,1998;Dehiraetal.,1998eFerrari,nessetrabalho). 
(1891), no Maciço do Tinguá, na forma de tufos associados a fonolitos e, posteriormente, por Lamego (1954), com a descoberta de tufos e bombas, por ele relacionadas a uma chaminé vulcânica, hoje conhecida como "Chaminé do Lamego". Estudos mais recentes no Mendanha (Klein \& Vieira 1980, Klein \& Valença 1984a e b, Klein 1993) identificaram mais dois depósitos vulcânicos, um caracterizado pela presença de brecha piroclástica e ignimbritos e outra, denominada Vulcão de Nova Iguaçu, com tufos, brechas fluidizadas e ignimbritos. Em ambos os casos as rochas vulcânicas estão associadas a traquito e microssienito. Tufos foram descritos também por Dalcolmo et al. (1982), associados ao plug fonolítico de Jardim Cabuçu. Mais recentemente foi descoberta uma nova ocorrência de tufos e ignimbritos no Maciço de Itaúna (Andreis et al. 1999, Klein et al. 1999). Uma ocorrência de ankaramito, similar àquele da Bacia de Volta Redonda (Riccomini et al. 1983), corta os sedimentos paleocênicos da Bacia de São José do Itaboraí, na forma de um dique alimentador de lavas almofadadas (Klein \& Valença 1984a). Para estes autores as lavas ankaramíticas representariam a extrusão de diferenciados máficos, a partir de câmaras magmáticas, causada pela rápida movimentação de blocos. Esta ocorrência foi datada, pelo método K-Ar e, a exemplo da de Volta Redonda (Riccomini et al. 1983), foi obtida uma idade eocênica, de 52 Ma., por Riccomini \& Rodrigues Francisco (1992). A direção NE-SW do seu dique alimentador foi utilizada por estes autores para a caracterização do seu controle estrutural a partir de um binário sinistral E-W. As diversas ocorrências de tufos e de ignimbritos não tem idade conhecida. Nesse trabalho são apresentadas duas novas datações para os plugs fonolíticos que ocorrem na área central do graben, aos quais se associam as vulcânicas (ver Capítulo 4.3 e Anexo A). Essas datações indicam que os tufos e brechas fonolíticos são essencialmente coetâneos aos corpos intrusivos, naquele segmento do graben.

Um controle tectônico sobre a intrusão, a partir de grandes estruturas, tem sido apontado para alguns dos corpos alcalinos do Graben da Guanabara. Os stocks de Tanguá, Rio Bonito e nove pequenos corpos intrusivos teriam, segundo Almeida (1976), sua intrusão controlada pela Zona de Falha de Rio Bonito, de direção ENE. Essa zona de falha é evidenciada pelo alinhamento de falhas preenchidas por brechas tectônicas silicificadas (Dalcolmo et al. 1982, Ferrari 1990), tardias ao magmatismo alcalino (Valença 1975, Santos 1994), indicando sua idade cenozóica. Já o Mendanha teria tido encaixado em um faixa de intensa transposição da foliação do embasamento, denominada Lineamento Surui-Sepetiba (Ferrari 1990), também orientado segundo a 
direção NE-SW. Por outro lado, alguns autores procuraram investigar os campos de paleotensões que controlaram essas intrusões. Klein (1993) propôs que o Mendanha teria tido sua intrusão controlada por uma zona de transtração dextral de direção ENE, com base na existência de brechas deformadas na porção NE do corpo. Entretanto, este campo de esforços geraria um corpo alongado na direção NW-SE, ortogonal à do Mendanha. Ferrari et al. (1997a e b), utilizando diques de rochas alcalinas como indicadores tectônicos, consideraram que o magmatismo alcalino no $\mathrm{GG}$ foi controlado tectonicamente por um binário sinistral E-W, com base, essencialmente, no arranjo en echelon dos diques com relação ao alinhamento descrito pelos stocks alcalinos (Figura 4.1).

Outros autores visualizaram um controle tectônico regional sobre 0 magmatismo alcalino do Graben da Guanabara. O marcante alinhamento descrito pelo conjunto de corpos alcalinos, entre a ocorrência de Jaboticabal e o Monte Submarino Almirante Saldanha, com direção WNW, foi denominado "Alinhamento Magmático de Cabo Frio" por Almeida (1991). Este alinhamento tem sido responsável pela proposição de diversos modelos geotectônicos causadores, envolvendo tanto a existência de estruturas continentais profundas que controlariam a implantação de zonas de fratura oceânicas, que posteriormente seriam reativadas (Marsh 1973, Sadowski 1976, Asmus 1978, Almeida 1991), como trilhas de deslocamento da placa sobre um hot spot (Herz 1977, Sadowski \& Dias Neto 1981). De acordo com Riccomini (1989) as marcantes estruturas de direção WNW-ESE que ocorrem na região da Bacia de Resende têm movimentação essencialmente direcional, sinistral e dextral, e deslocam o dique anelar do Maciço de Itatiaia, depósitos de leques aluviais a ele associados e, ainda, depósitos coluviais pleistocênicos, sendo relacionadas às fases de movimentação direcional do Mioceno e Pleistoceno, como estruturas sintéticas P e R. Desta forma, sua utilização como evidência para o controle estrutural do Alinhamento Magmático de Cabo Frio (Almeida 1991) depende, inicialmente, de eventuais indicações de uma atuação anterior.

É importante notar a distribuição heterogênea do magmatismo alcalino no RCSB. Enquanto ele é abundante no Graben da Guanabara, no seu segmento central, que inclui as Bacias de Taubaté, Resende e Volta Redonda, ele restringe às duas últimas, não ocorrendo na de Taubaté e na de São Paulo, o que leva a suspeitar da independência destes dois processos. Neste sentido, alguns modelos consideram que esses focos de rochas alcalinos não têm uma causa tectônica clara e relacionam este 
magmatismo à anomalia térmica residual associada à Pluma de Tristão da Cunha (Karner et al. 1994, VanDecar et al. 1995, Sichel et al. 1997). Já Thompson et al. (1998) consideram que o magmatismo alcalino da Serra do Mar está relacionado geneticamente com a Pluma de Trindade, tendo sido gerado pelo "vazamento" do material da pluma para áreas de litosfera mais afinada, por ocasião da passagem dessa pluma sob o Craton do São Francisco, entre 80 e $55 \mathrm{Ma}$. Estes modelos não tratam da relação entre o processo gerador e o deformador destes corpos alcalinos. No entanto, no caso do vulcanismo ankaramítico, que fecha o magmatismo alcalino no RCSB, é controlado pelo binário sinistral E-W, e ocorre em bacias associadas à falhas recorrentes, a vinculação entre tectonismo e magmatismo é evidente.

No presente capítulo serão descritas e analisadas as estruturas rúpteis que afetam os corpos alcalinos no Graben da Guanabara, bem como os diques a eles associados, visando a caracterização dos campos de tensões vigentes durante a intrusão desses corpos e as suas eventuais variações ao longo do tempo. Para a realização desse objetivo foram escolhidos alguns corpos, tendo em vista as suas condições de acesso e exposição, sua distribuição geográfica e as variações nas idades apresentadas pelos corpos alcalinos. Os corpos selecionados foram os seguintes:

1) Área oeste do graben: Maciço do Mendanha;

2) Área central do graben: Maciço de Itaúna, Maciço do Tanguá e plugs de Itaboraí, Country Club, Monjolos, Cubas e Jardim Cabuçu;

3) Área leste do graben: Maciço de Cabo Frio.

O Maciço da llha de Cabo Frio foi incluído nos corpos alcalinos a serem investigados quanto ao seu fraturamento, apesar de se localizar fora da área do Graben da Guanabara, considerando que:

a) é o único corpo alcalino que tem sua intrusão de fato contemporânea à implantação do Graben da Guanabara, tendo em vista sua idade paleocênica a eocênica; 
b) é o que se situa mais próximo do Alto de Cabo Frio, palco de importante magmatismo eocênico (Mohriak \& Barros 1990);

c) apresenta excelentes exposições nos costões rochosos da ilha e da área continental adjacente;

d) é tido como o limite oriental do denominado Alinhamento Magmático de Cabo Frio (Almeida 1991);

e) a sua idade é cerca de $25 \mathrm{Ma}$ mais nova do que os corpos alcalinos da área ocidental do graben e 15 Ma mais nova do que os corpos da área central, permitem que se investigue as paleotensões que atuaram num intervalo de idade mais amplo. Nesse sentido, o intervalo de idade dos corpos alcalinos nessas três diferentes porções do graben, 80-70 Ma na área ocidental, 68-65 Ma na central e 55-52 Ma na oriental, permite que se investigue as variações do campo de paleotensões entre o Cretáceo Superior (Campaniano) e o Eoceno Inferior (Ypresiano). 


\subsection{AREA OCIDENTAL DO GRABEN-MACIÇO DO MENDANHA}

\subsubsection{Introdução}

$\mathrm{Na}$ porção ocidental do Graben da Guanabara foi realizada a análise do fraturamento que afeta o Maciço do Mendanha, envolvendo juntas e fraturas sem estrias claramente identificadas, falhas e microfalhas nas quais pode-se determinar a direção e o sentido do movimento, além dos diques que cortam o Mendanha e os que cortam ao embasamento proterozóico. Nesse último caso foram analisados diques num raio de até 25 $\mathrm{km}$, especialmente em direção a sudoeste onde um conjunto de pedreiras possibilita boas exposições (Figura 4.2). Cerca de $90 \%$ dos diques identificados foram amostrados e, desses, $50 \%$ foram laminados visando determinar, ou não, sua filiação ao magmatismo alcalino e selecioná-los para a datação radiométrica pelo método Ar/Ar. Como critério de campo pode-se inferir, com pequena margem de erro, que os lamprófiros são biotíticos e que os basaltos alcalinos e basanitos apresentam a olivina substituída por carbonatos e serpentina. Por outro lado, os diques de diabásio, apesar de também apresentarem localmente amígdalas preenchidas por carbonatos, possuem as típicas texturas ofítica e subofítica, discerníveis nos mais alterados. Outra característica de campo importante na distinção entre os diques de diabásio e os de rochas alcalinas máficas é que esses últimos raramente apresentam espessura maior do que 2 metros, enquanto que nos primeiros são comuns as espessuras maiores do que 3 metros, podendo chegar a 50 metros. Nas pedreiras localizadas no embasamento não foram medidas juntas e fraturas, tendo em vista a dificuldade de se determinar a sua idade mínima, mesmo que no caso das fraturas associadas aos diques de diabásio essa distinção seja até possível, tendo em vista o hidrotermalismo acentuado que em geral os acompanha e que tem papel importante na propagação das fraturas "periféricas", diminuindo a tensão resultante mínima ortogonal à direção de propagação do dique (Pollard 1987). Esse hidrotermalismo é responsável, entre outras reações, pela cloritização das biotitas, conferindo uma cor verde a essas fraturas, além de levar ao seu preenchimento por sulfetos e carbonatos. Detalhes sobre o hidrotermalismo associado aos diques de rochas alcalinas e de diabásio são apresentados por Porto Jr. et al. (1989) e Valente et al. (1991, 1992). 

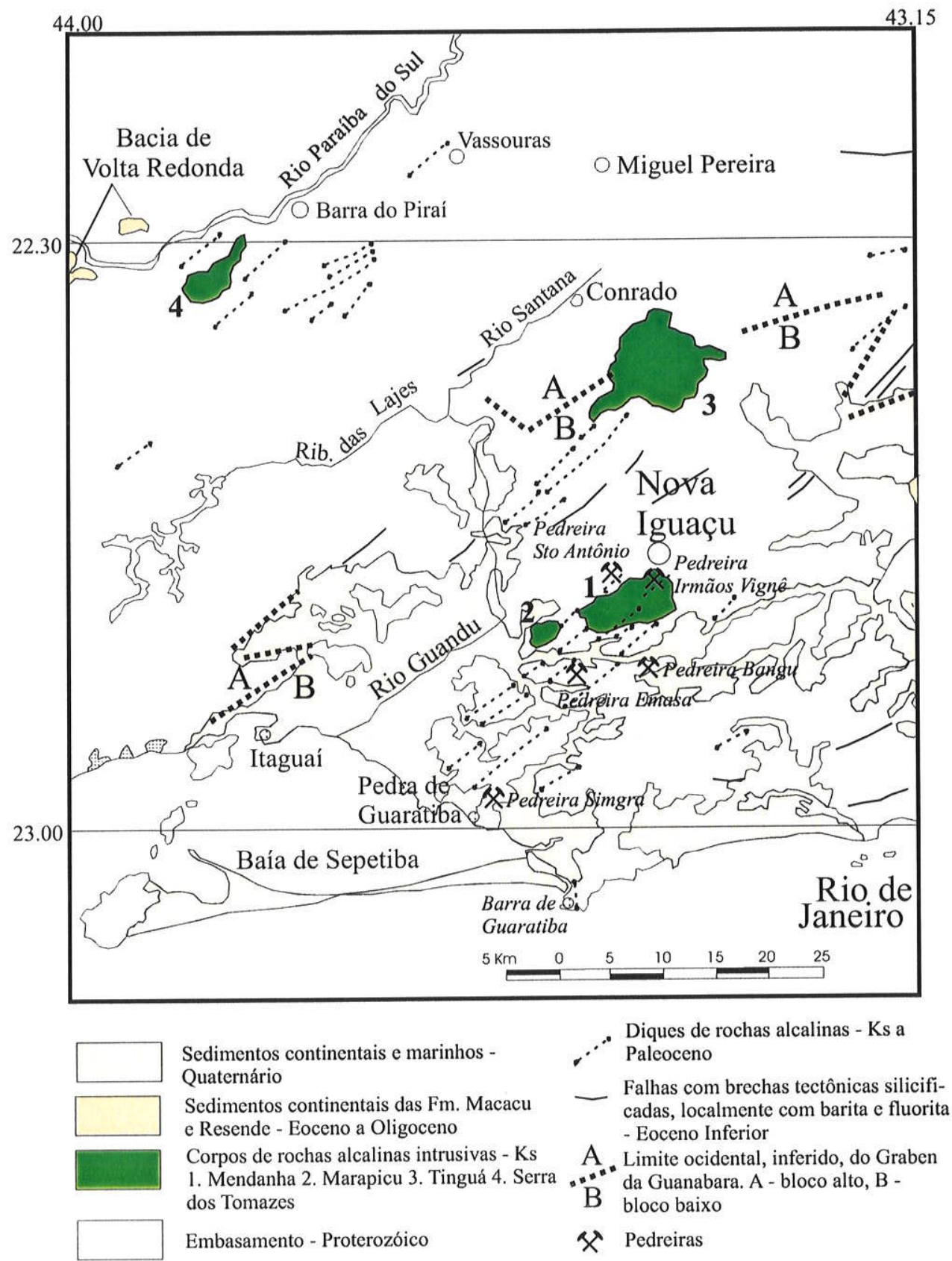

Figura 4.2 - Mapa geológico da porção ocidental do Graben da Guanabara, destacando os locais de coleta de dados estruturais. Ver detalhe para o Maciço do Mendanha na Figura 4.3. Geologia de acordo com Hemboldt et al. (1965), Barbosa et al. (1981, 1983), Dalcolmo et al. (1982), Ferrari (1990), Mohriak et al. (1992) e Riccomini 


\subsubsection{Maciço do Mendanha}

O Maciço do Mendanha tem um comprimento de cerca de $18 \mathrm{~km}$, na direção ENEWSW, e uma largura média de $5 \mathrm{~km}$, constituindo a serra homônima com altitude máxima de 974 metros. Esse maciço é constituído, principalmente, por um stock de rochas alcalinas félsicas intrusivas, sienitos e microssienitos e, subordinadamente, por rochas alcalinas piroclásticas, brechas e aglomerados, associadas a dois centros vulcânicos distintos denominados Chaminé do Lamego e Vulcão de Nova Iguaçu (Klein 1993, Figura 4.3). De acordo com Klein (1993) a forma semicircular dos microssienitos e sua associação geográfica com os depósitos piroclásticos, indica que eles são cronocorrelatos a esses. A sudoeste, alinhado com o Maciço do Mendanha, ocorre o Plug de Marapicu, constituído inteiramente de sienito (Klein 1993).

As datações radiométricas disponíveis para os corpos do Mendanha e Marapicu indicam idades entre 75 e $65 \mathrm{Ma}$ para os sienitos, entre 65 e $72 \mathrm{Ma}$ para os microssienitos e variando entre 82 e $72 \mathrm{Ma}$ para os diques de rochas alcalinas máficas que cortam o embasamento. Os resultados de Ar/Ar publicados por Smith et al. (2001) referem-se à Pedreira Vignê. Segundo esses autores as idades obtidas para o anfibólio e a pirita referemse à idade da rocha e a da flogopita estaria refletindo alteração secundária. As idades encontradas por Smith et al (2001) são bastante discrepantes das obtidas anteriormente para os sienitos, pelo método K/Ar em anfibólio. Ressalta-se que essa pedreira é localizada junto ao denominado Vulcão de Nova Iguaçu (Figura 4.3), e caracterizada por um intenso hidrotermalismo, responsável pela precipitação de fluorita, pirita e calcita em fraturas. Tais características sugerem que essas idades podem estar refletindo o evento vulcânico do mais novo e não a idade de intrusão do corpo sienítico principal.

Nesse trabalho foram realizadas duas análises radiométricas pelo método Ar-Ar, uma em flogopita de um dique de lamprófiro, que corta o embasamento e um dique composto de basalto alcalino e traquito na Pedreira Emasa, que forneceu idade de $77 \mathrm{Ma}$. Outra análise, em um dique de fonolito peralcalino que também corta o embasamento, na Pedreira Santo Antônio, e que teve como resultado a idade de $54 \mathrm{Ma}$. Essa última análise não forneceu um platô, referindo-se esse resultado à idade média ponderada (ver dados completos no Anexo A). Todos os dados de análise radiométrica acima referidos estão sintetizados na Tabela 4.1. 


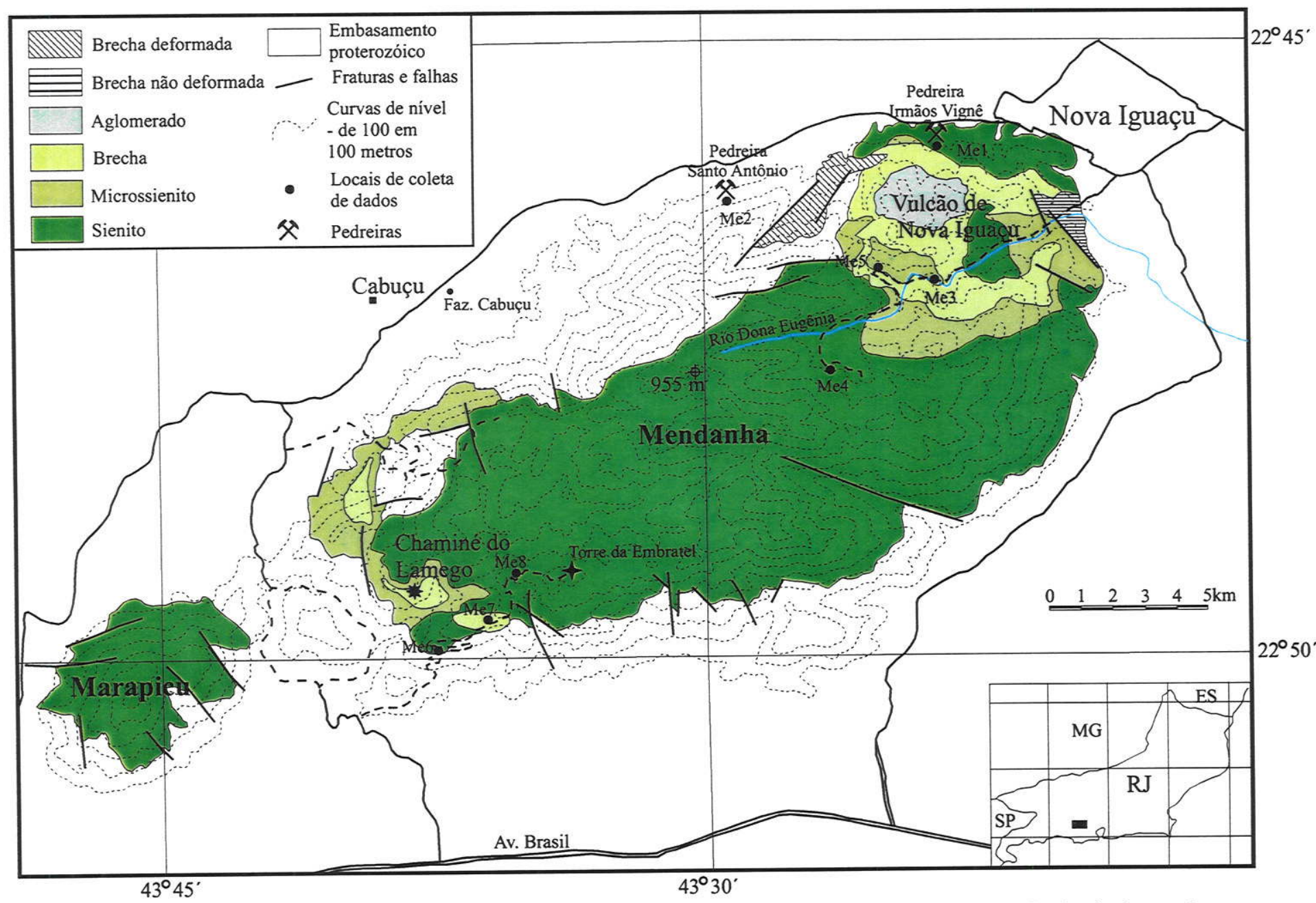

Figura 4.3 - Mapa geológico do Maciço do Mendanha, destacando os locais de coleta de dados estruturais. Geologia de acordo com Klein (1992). 
Apesar de ser constituído exclusivamente por rochas alcalinas evoluídas, o Mendanha apresenta no seu entorno uma grande quantidade de diques com tipos litológicos menos evoluídos, como lamprófiros, basaltos alcalinos, basanitos, tefritos e nefelinitos, além dos de fonolito e traquito (Hemboldt et al. 1965, Menezes et al. 1977, Porto Jr. \& Valente 1989, Valente et al. 1994 e 1995, Valente 1997, Deckart et al. 1998).

No presente trabalho caracterizou-se que no domínio do corpo intrusivo predominam amplamente os diques de traquito e de fonolito, tendo os tipos menos evoluídos sido identificados apenas na Pedreira Irmãos Vignê (Ponto ME1), na forma de dois basaltos alcalinos e um lamprófiro alcalino (Minette). Enclaves de basalto alcalino podem ser vistos também nos sienitos da Pedreira Vignê (Ponto ME1). Enclaves semelhantes foram descritos por Klein \& Valença (1989), no micro nefelina sienito associado ao centro vulcânico do Cabuçu, e interpretados como evidência de mistura de magmas.

\begin{tabular}{|c|c|c|c|c|}
\hline 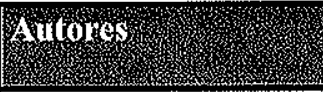 & $\begin{array}{l}\text { Wirogolinineral } \\
\text { Dindo }\end{array}$ & Drientiofoto & Método & Resultados \\
\hline Sonoki \& Garda 1988 & $\begin{array}{l}\text { Nefelina sienito/anfibólio } \\
\text { Nefelina sienito/anfibólio } \\
\text { Nefelina sienito/anfibólio } \\
\text { Microssienito/feld. K } \\
\text { Microssienito/matriz }\end{array}$ & & $\begin{array}{l}\mathrm{K} / \mathrm{Ar} \\
\mathrm{K} / \mathrm{Ar} \\
\mathrm{K} / \mathrm{Ar} \\
\mathrm{K} / \mathrm{Ar} \\
\mathrm{K} / \mathrm{Ar}\end{array}$ & $\begin{array}{l}73.7 \pm 3.5 \mathrm{Ma} \\
74.9 \pm 3.3 \mathrm{Ma} \\
73.3 \pm 1.7 \mathrm{Ma} \\
64.9 \pm 1.6 \mathrm{Ma} \\
71.7 \pm 2.1 \mathrm{Ma} \\
\end{array}$ \\
\hline Deckart et al. 1998 & $\begin{array}{l}\text { Dique de basalto alcalino/biotita-P } \\
\text { Dique de basalto alcalino/biotita-P } \\
\text { Dique de basalto alcalino/biotita-P }\end{array}$ & $\begin{array}{l}\mathrm{N} 65^{\circ} \mathrm{E} \text { (direção) } \\
\mathrm{N} 60^{\circ} \mathrm{E} \text { (direção) } \\
\mathrm{N} 60^{\circ} \mathrm{W} \text { (direção) }\end{array}$ & $\begin{array}{l}\mathrm{Ar} / \mathrm{Ar} \\
\mathrm{Ar} / \mathrm{Ar} \\
\mathrm{Ar} / \mathrm{Ar}\end{array}$ & $\begin{array}{l}81.8 \pm 1.8 \mathrm{Ma} \\
78.8 \pm 2.8 \mathrm{Ma} \\
72.5 \pm 0.5 \mathrm{Ma}\end{array}$ \\
\hline $\begin{array}{l}\text { Thompsom et al. } \\
1998\end{array}$ & $\begin{array}{l}\text { Dique alcalino félsico/biotita } \\
\text { Dique alcalino félsico/biotita }\end{array}$ & $\begin{array}{l}? \\
? \\
\end{array}$ & $\begin{array}{l}\mathrm{K} / \mathrm{Ar} \\
\mathrm{K} / \mathrm{Ar} \\
\end{array}$ & $\begin{array}{l}71.2 \pm 1.8 \mathrm{Ma} \\
73.3 \pm 1.4 \mathrm{Ma} \\
\end{array}$ \\
\hline Smith et al. 2001 & $\begin{array}{l}\text { Sienito/anfibólio - P } \\
\text { Sienito/pirita - Id } \\
\text { Sienito/flogopita - P }\end{array}$ & & $\begin{array}{l}\mathrm{Ar} / \mathrm{Ar} \\
\mathrm{Ar} / \mathrm{Ar} \\
\mathrm{Ar} / \mathrm{Ar}\end{array}$ & $\begin{array}{l}67.6 \pm 1.5 \mathrm{Ma} \\
65.2 \pm 0.8 \mathrm{Ma} \\
61.6 \pm 0.2 \mathrm{Ma}\end{array}$ \\
\hline Esse trabalho & $\begin{array}{l}\text { Dique de lamprófiro/biotita - P, I } \\
\text { Dique de fonolito/rocha total* }\end{array}$ & $\begin{array}{l}052 / 84 \text { (clar) } \\
110 / 89 \text { (clar) }\end{array}$ & $\begin{array}{l}\mathrm{Ar} / \mathrm{Ar} \\
\mathrm{Ar} / \mathrm{Ar}\end{array}$ & $\begin{array}{l}77.1 \pm 1.0 \mathrm{Ma} \\
54.2 \pm 2.8 \mathrm{Ma}\end{array}$ \\
\hline
\end{tabular}

Tabela 4.1 - Datações radiométricas disponíveis para os corpos alcalinos do Mendanha e Marapicu e diques associados.

P - platôs

I - isácrona

Id - ideograma

* esse resultado refere-se à idade média ponderada 
As melhores exposições são as das pedreiras Irmãos Vignê e Santo Antônio, e os cortes de estradas vicinais que dão acesso ao Parque Municipal do Mendanha e à Torre da Embratel (Figura 4.3). No parque pode-se coletar dados em alguns lajedos associados ao Rio Dona Eugênia. Os oito pontos em que foram levantados dados estruturais no Maciço do Mendanha permitiram a caracterização de seis estações, sendo cinco dentro do domínio do stock alcalino e uma no embasamento, essa última referente à Pedreira Santo Antônio (Ponto ME2, Figura 4.3). Na área em torno do maciço foram levantadas mais quatro estações, todas no domínio do Maciço da Pedra Branca, constituído pelo granito tarditectônico homônimo (Wiedemann et al. 1987). Os locais estudados referem-se às pedreiras Bangu e Emasa, localizadas no Bairro de Bangu, à Pedreira Simgra, localizada em Pedra de Guaratiba e aos costões rochosos de Barra de Guaratiba. Nessas estações enfocou-se as características estruturais dos diques de rochas alcalinas e das feições estruturais eventualmente associadas, como microfalhas internas aos diques e nas suas bordas e, ainda, a sua relação com as rochas encaixantes.

\subsubsection{Diques}

Foram identificados e caracterizados 88 diques de rochas alcalinas associados ao Mendanha, 35 cortando o próprio corpo intrusivo e 53 intrudidos no embasamento proterozóico em torno dele. Desse total, 50 referem-se a diques de rochas alcalinas félsicas e 38 a diques de rochas alcalinas máficas e ultramáficas. A espessura desses diques varia desde alguns centímetros até pouco mais de três metros, sendo essas últimas encontradas nos diques félsicos, especialmente nos de fonolito.

Não se observou qualquer relação nítida entre a espessura dos diques e a distância do corpo intrusivo principal, podendo ocorrer diques de fonolito com espessura de mais de 3 metros a mais de $20 \mathrm{~km}$ da borda do corpo, como no caso da Pedreira Simgra. 


\subsubsection{Relações de Corte}

As relações de corte indicam, no geral, que os diques félsicos cortam os máficos, representando um evento final do magmatismo associado ao Maciço do Mendanha. Porém, localmente, essa relação pode ser mais complexa, evidenciando pulsos alternados, com intrusão de diques máficos e félsicos, ressalvando-se que os pulsos finais são de caráter félsico. O primeiro caso pode ser observado na Pedreira Bangu, onde um dique de traquito orbicular, com espessura média de pouco mais de 1 metro, orientado na direção NNW-SSE e com mergulho intermediário a alto, atravessa toda a pedreira cortando os diques de rochas alcalinas máficas, orientados na direção ENE-WSW e com mergulho alto, maior do que $80^{\circ}$ (Figura 4.4B). Uma relação mais complexa é vista na Pedreira Santo Antônio, onde um dique de fonolito com direção NE-SW, com baixo ângulo de mergulho e escalonado, é cortado por um dique de lamprófiro com pouco mais de 1 metro de espessura, também de direção NE-SW, porém com mergulho alto, e ambos são cortados por um dique de traquito de direção NNW-SSE e mergulho alto, com cerca de 2 metros de espessura (Figuras 4.5B e B'). A alternância de pulsos com intrusão de diques de rochas alcalinas máficas e félsicas está bem representada na Pedreira Simgra (Figuras 4.6A, B, B' e C), onde um dique de traquito de direção NE-SW, com mergulho intermediário (dique 2), corta um dique de fonolito pórfiro, com direção em torno de E-W e mergulho alto (dique 4), e um dique composto, de fonolito e basalto alcalino, com direção WNW-ESE e mergulho alto (diques 3 e $3 a$ ). Por sua vez, o dique de fonolito pórfiro é cortado por um dique de basalto alcalino (dique 8). Essa recorrência na intrusão dos diques de rochas alcalinas máficas é evidenciada, também, no interior do corpo intrusivo principal, na Pedreira Irmãos Vignê, onde 2 diques de basaltos alcalinos e 1 de minette, com direção em torno de E-W e mergulho alto, cortam o sienito e diques de traquito com direção NE-SW e mergulho intermediário (Figuras 4.7B, B', C e Figura 4.8). Situação semelhante é encontrada na Pedreira Emasa, onde um dique de lamprófiro alcalino (minettte), de direção NW-SE e mergulho alto, corta um dique composto de traquito e basalto alcalino, de direção ENE-WSW e mergulho alto (Figuras 4.9B, B' e C). Pode-se observar, ainda, um dique de traquito orbicular, muito alterado, com direção NNW-SSE e mergulho alto, cuja relação com os demais não fica evidenciada, porém sua orientação paralela à do dique de 


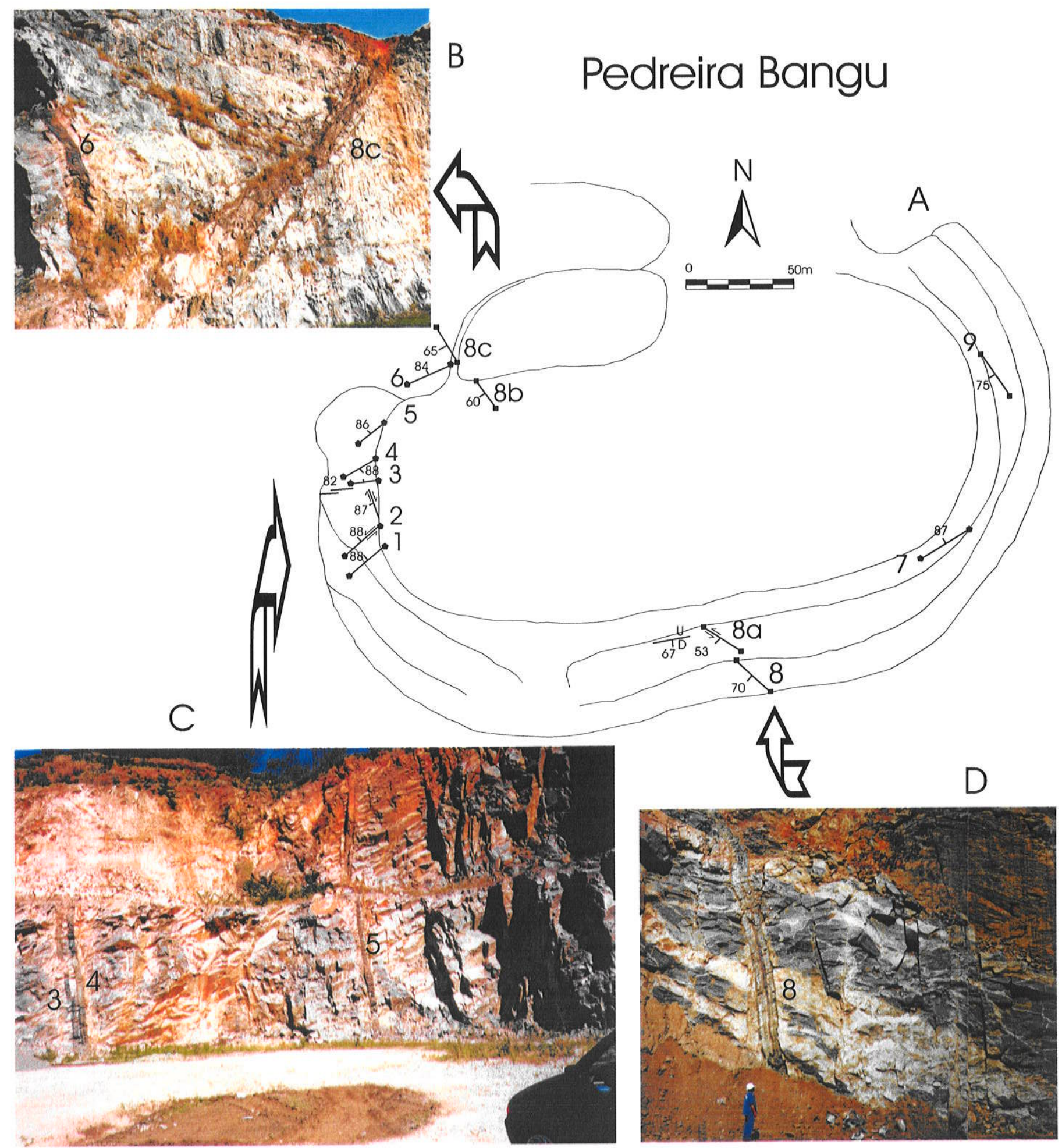

Figura 4.4 - Pedreira Bangu, Bairro de Bangu, Rio de Janeiro. Planta aproximada do contorno e das bancadas da pedreira, destacando a distribuição dos diques de rochas alcalinas máficas (lamprófiros e basaltos alcalinos- pentágonos), e de rochas alcalinas félsicas (traquito e fonolito - quadrados). A orientação principal dos diques se dá segundo a direção NE-SW. Diques de rocha alcalina félsica, traquito orbicular (8) e fonolito pórfiro (9), orientam-se segundo a direção NW-SE (cf. planta e foto A). Relações de corte indicam que os diques félsicos de direção NW cortam os máficos de direção NE (cf. foto c). O dique $8 \mathrm{a}$ apresenta cisalhamento sinistral nos contatos, acompanhado de cataclase e silicificação. Os diques estão intrudidos em biotita gnaisse injetado por material granítico, grosso, hololeucocrático. Esse conjunto mostra foliação com caimento suave para SW (240/35) (cf. foto A). Próximo ao dique 2 o gnaisse é cortado por plano estriado de direção NNW, com sentido de deslocamento sinistral indicado por ressaltos, no plano estriado, com e sem estrias (P e T?). Cortando o gnaisse, próximo ao dique 8a, ocorre plano estriado, de direção WNW, com sentido de deslocamento normal indicado por fibras de calcita. 


\section{Pedreira Santo Antônio}
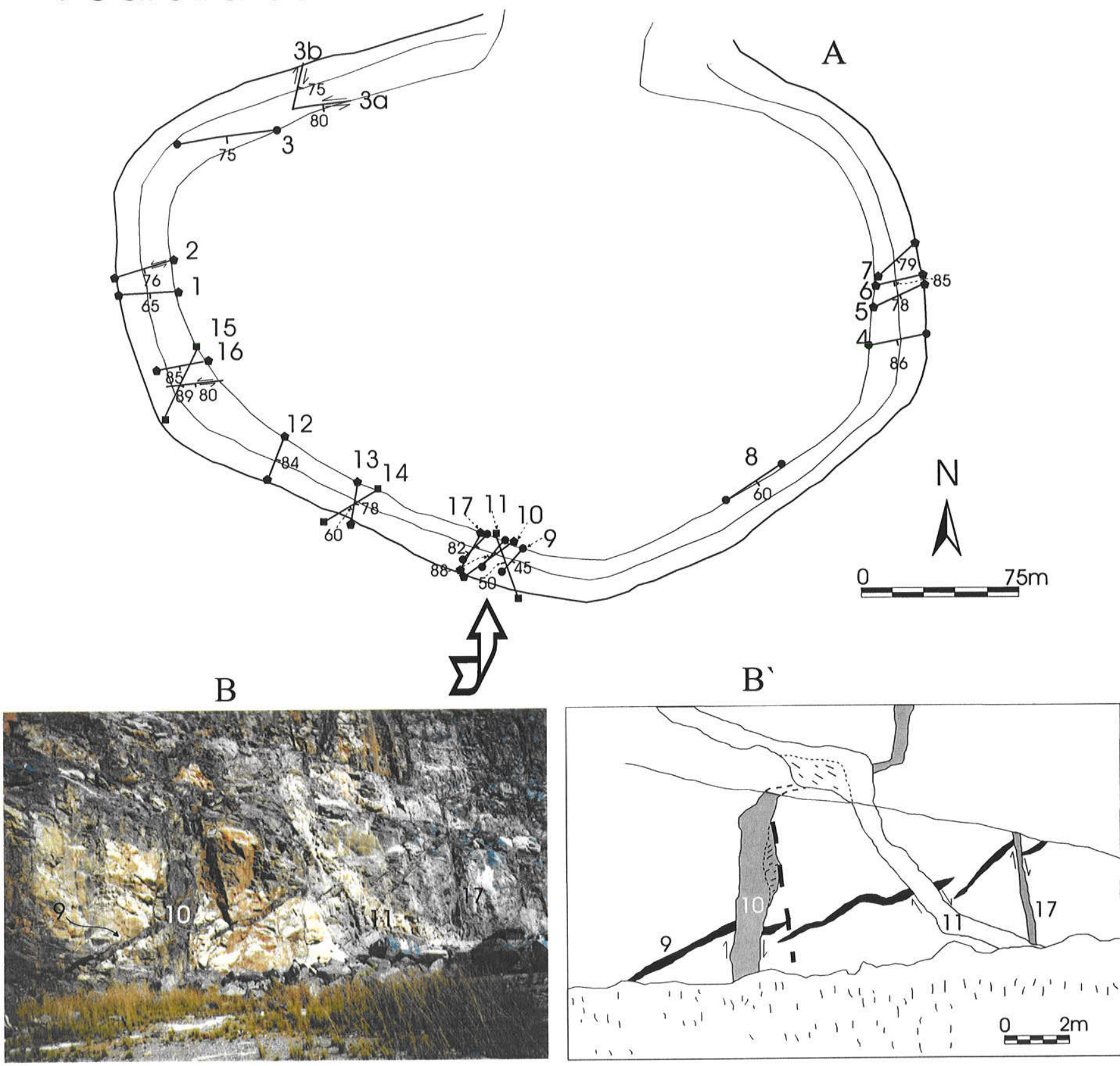

Figura 4.5 - Pedreira Santo Antônio, Município de Nova Iguaçu. Planta aproximada do contorno e das bancadas da pedreira, evidenciando a ocorrência de diques de diabásio (círculos), de lamprófíros (pentágonos) e de alcalinas félsicas (quadrados). A direção geral predominante é NE-SW a ENE-WSW. As relações de corte indicam que os mais novos são os de rochas félsicas alcalinas, fonolito $(15)$ e traquito $(11,14)$, e que os mais antigos são os de diabásio $(4,8,9)$. A figura em destaque sintetiza essas relações, mostrando um dique de diabásio, com arranjo en echelon, de baixo ângulo (9), cortado por lamprófiro (10), ambos de direção NE-SW, cortados por traquito (11), de direção NW-SE. Pode-se observar uma componente de deslocamento normal, associada a intrusão do lamprófiro e do traquito. O dique de lamprófiro (2) apresenta cisalhamento sinistral na borda. Fratura com cataclase e sulfetos, com cisalhamento sinistral, corta fonolito (15). Os planos 3a e 3b representam conjuntos de fraturas conjugadas de cisalhamento, com cloritização e sulfetos. A encaixante é um gd-bi-q-fd gnaisse bandado, injetado por um granitóide leucocrático, com anfibólio e biotita, semelhante ao Batólito Serra dos Órgãos. A foliação do conjunto pode ser vista na foto, caindo, com baixo ângulo, para NW (130/45), no sentido oposto ao do dique en echelon de baixo ângulo (9), e sub-paralela ao dique de traquito (15). 


\section{Pedreira Simgra}
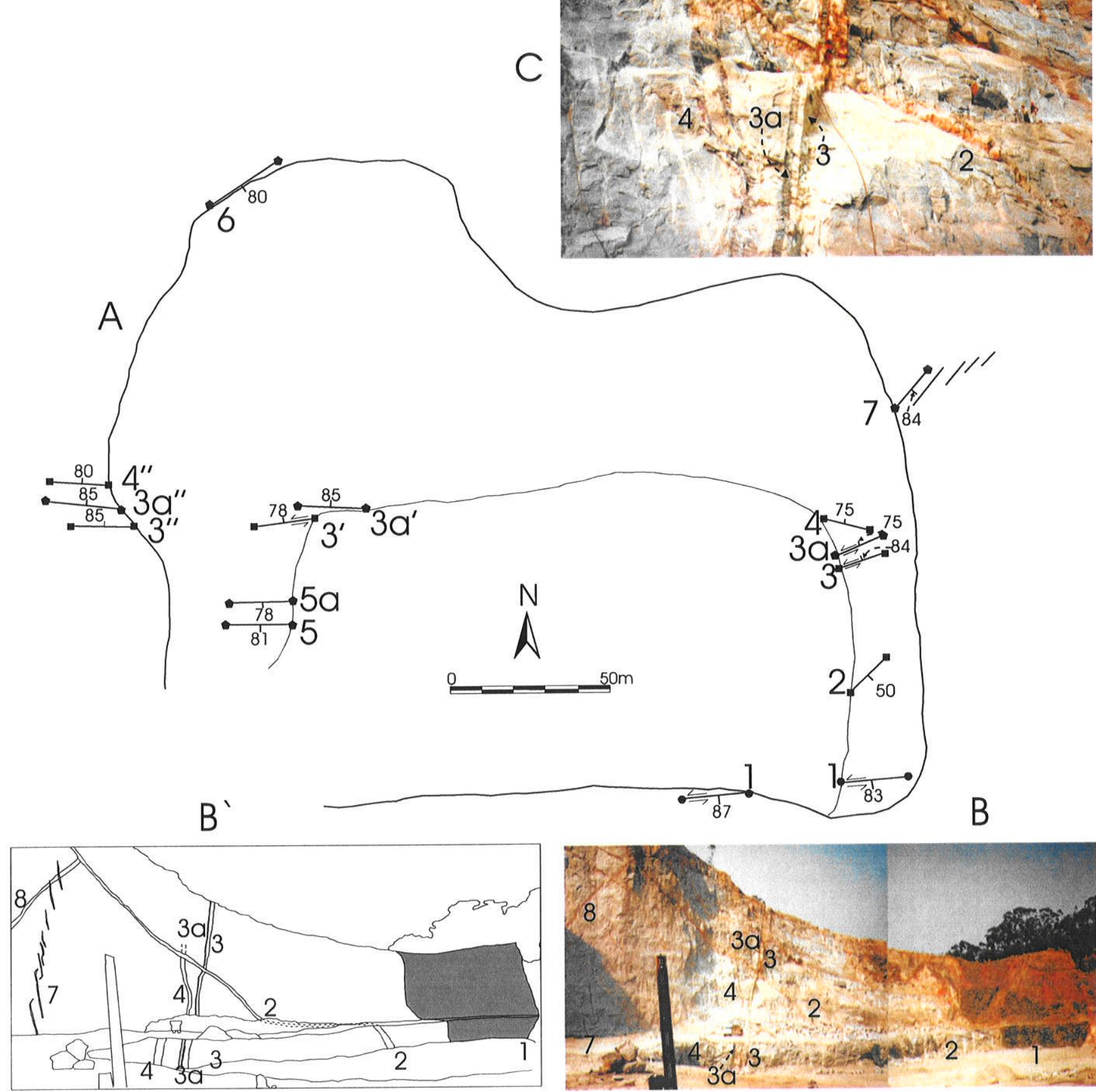

Figura 4.6 - Pedrerira Simgra, distrito de Pedra de Guaratiba, zona oeste da Cidade do Rio de Janeiro. Planta aproximada do contorno e das bancadas da pedreira, destacando os diques de diabásio (círculos), de lamprófiros e de basalto alcalino (pentágonos), e de rochas alcalinas félsicas (traquito e fonolito - quadrados). Esses diques cortam o granito porfirítico Pedra Branca, cuja foliação (de fluxo?) tem mergulho de valor intermediário para sudeste (120/60). Destaca-se no conjunto o dique de diabásio (1), por sua espessura de aproximadamente $30 \mathrm{~m}$. Os diques se orientam, na sua maioria, para WNW-ESE e ENE-WSW, e, mais restritamente, para NE-SW e NNE-SSW. As relações de corte mostram que o dique composto 3 (fonolito) - 3a (basalto alcalino), é cortado por dique traquito (2), com baixo ângulo de mergulho, o qual corta também um de fonolito pórfiro (4) e um de fonolito (8) (cf. B, B e detalhe em C). O dique (7), de basalto alcalino, mostra escalonamento à direita e também corta 0 dique (8) (cf. B e B'). Alguns dos diques apresentam cisalhamento sinistral nas suas bordas ( $3,3 \mathrm{a})$, evidenciado por estrias em bordas silicificadas (3, 3a e 3'). 

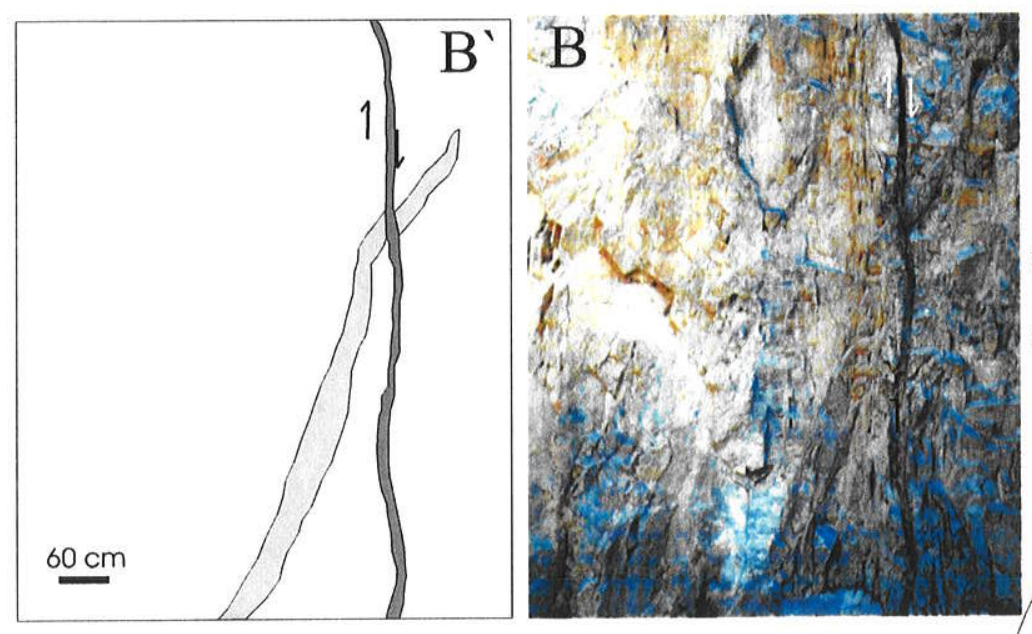

\section{Pedreira Irmãos Vignê}
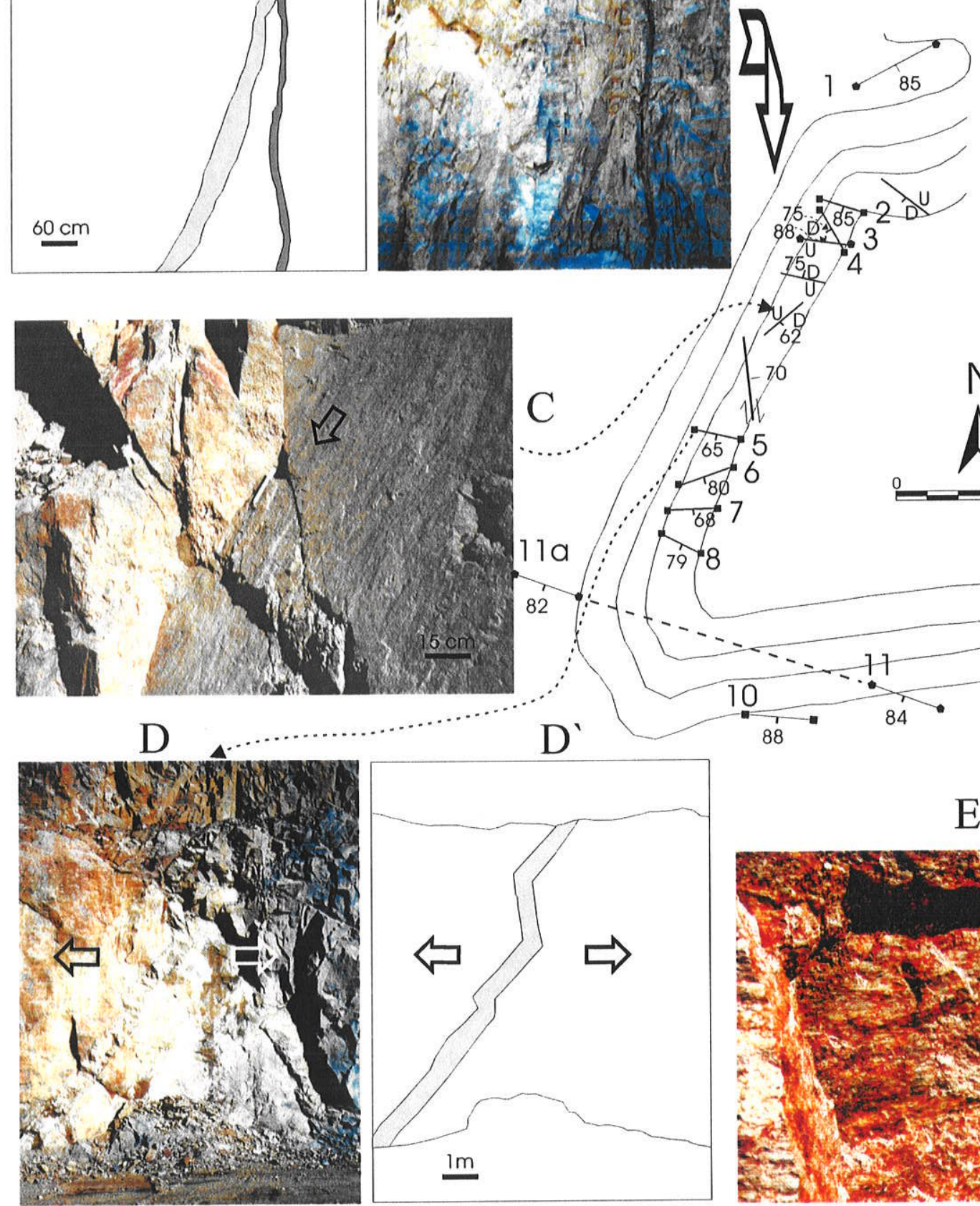
traquito orbicular que ocorre na Pedreira Bangu, sugere que ele possa representar o último pulso magmático também nesse local.

No caso dos diques compostos, algumas características indicam que a intrusão se deu em pulsos distintos. Nos dois casos onde eles foram observados, na Pedreira Emasa e na Pedreira Simgra, tanto os diques félsicos como os máficos, que fazem parte dos diques compostos, apresentam as duas bordas com granulometria mais fina, indicando resfriamento mais rápido do que as porções centrais, devido ao contato com encaixantes frias. Essa evidência é reforçada pela separação dos diques ao longo de sua trajetória. $\mathrm{Na}$ Pedreira Emasa os dois diques de basalto alcalino que bordejam o dique de traquito na frente oeste (Figura 4.9, diques 2 e 4), estão separados dele na frente leste (Figura 4.9, diques 10 e 11), mantendo-se como dois diques individualizados separados por uma faixa do granito de aproximadamente 0,5 metro. Na Pedreira Simgra, o dique composto de basalto alcalino e de fonolito, que ocorre na frente leste (Figura 4.6A, diques 3 e 3a), passa a ser um dique triplo na frente oeste, a partir da convergência do dique de fonolito pórfiro (Figura 4.6, diques 3", $3 \mathrm{a}^{\text {" }}$ e 4 "). Não há relações de corte inequívocas em ambos os diques compostos. Na Pedreira Simgra, localmente, o dique de basalto alcalino mostra-se hidrotermalizado na borda de contato com o dique de fonolito, o que se evidencia por intensa desferrificação do basalto alcalino. Essa relação sugere que o dique de fonolito é mais novo que o de basalto alcalino.

\subsubsection{Mecanismos de Intrusão}

Os contatos entre os diques alcalinos as encaixantes, sejam elas o corpo intrusivo principal ou o embasamento proterozóico, é quase sempre brusco, seja para os diques máficos seja para os félsicos. Esses contatos são, de maneira dominante, retilíneos, podendo apresentar chifres em uma ou nas duas bordas. São comuns também os tocos e as pontes rompidas com a progressão da extensão ortogonal ao dique. Por vezes eles apresentam uma das bordas irregular, com variações na sua espessura. Mais raramente os diques apresentam as duas bordas com contatos irregulares, chegando a envolver quase totalmente pedaços da encaixante, os quais podem chegar a ficar totalmente imersos no 

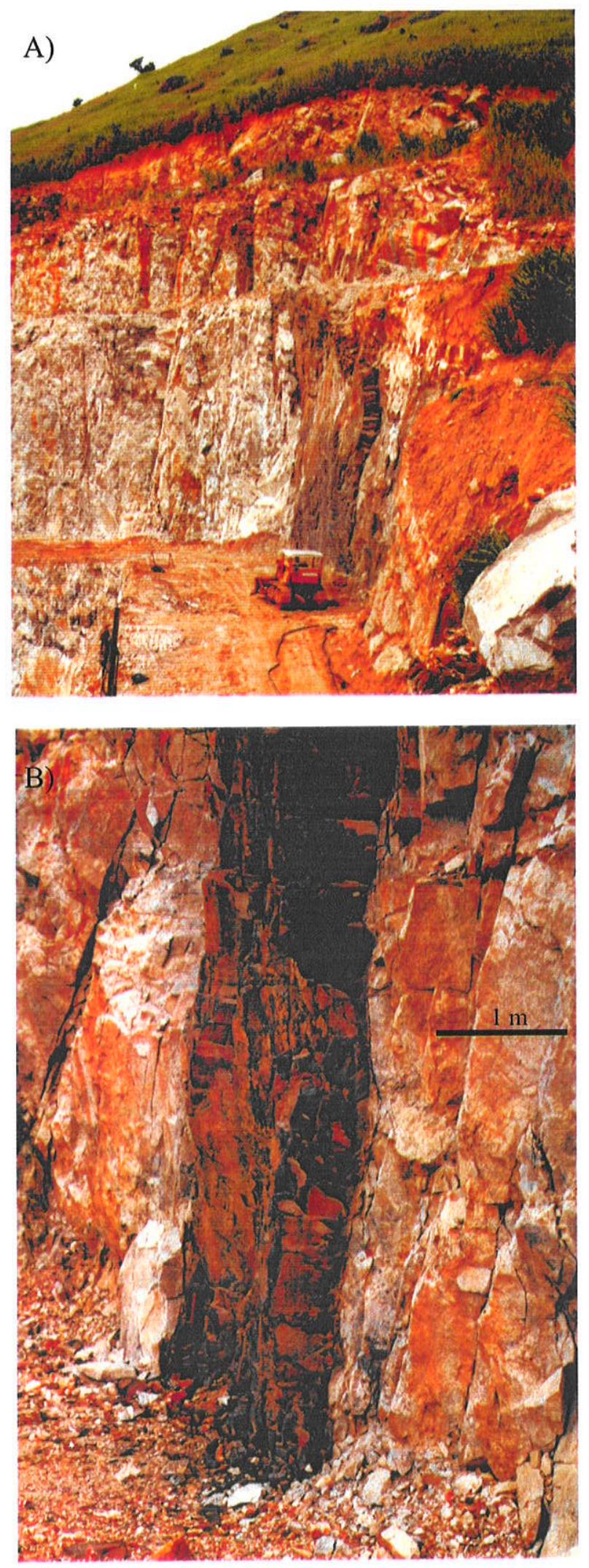

Figura 4.8 - Dique de lamprófiro alcalino (minette), de direção WNW-ESE, cortando sienito e diques de traquito no Maciço do Mendanha, Ponto Me1, Pedreira Irmãos Vignê; B) Detalhe da foto A. 
interior do dique, constituindo xenólitos. Essa característica é mais comum nos diques de traquito, mas pode estar presente também nos máficos, como por exemplo, no lamprófiro alcalino de direção NNW-SSE da Pedreira Emasa (Figura 4.9, dique 6). Uma característica particular dos traquitos é que os xenólitos no seu interior mostram-se sempre mais ou menos digeridos, o que não se percebe no caso dos diques máficos.

Alguns diques são nitidamente resultado de extensão ortogonal pura, como é o caso do dique de traquito da Pedreira Irmãos Vignê (Figura 4.7D), o qual tem direção WNWESE e mergulho intermediário. Em outros casos, os diques mostram evidências de terem sofrido cisalhamento nas suas bordas, como se pode observar na própria Pedreira Irmãos Vignê, a partir das fraturas secundárias de extensão (T) e das fibras de calcita associadas a um dique de traquito, de direção WNW-ESE e mergulho intermediário (Figura 4.10). As adaptações do dique às fraturas conjugadas indicam que elas são anteriores ao dique (Figura 4.10B). As fibras de calcita, evidenciando cinemática normal na borda do dique, corroboram as evidências de cisalhamento tardio à intrusão (Figura 4.10A).

Alguns diques exibem um arranjo escalonado nos cortes verticais, como pode ser visto na Pedreira Emasa (Figura 4.9A e B', diques 7, 8, 11 e 13), indicando que sua intrusão se deu, também nesse caso, sob cisalhamento (Ramsay \& Hubbert 1987, Dunne \& Hancock 1994, Srivastava 2000). A orientação vertical dos diques dentro dos segmentos conjugados indica que a intrusão se deu em um regime normal, com o eixo de tensões máximo, $\sigma 1$, vertical e paralelo aos diques e o eixo de tensões mínimo, $\sigma 3$, horizontal e ortogonal a eles. Essa característica pode estar presente tanto nos diques máficos como nos félsicos.

Por outro lado, em diversos casos têm-se evidências de movimentação direcional após a intrusão desses diques. Um desses casos pode ser visto em Barra de Guaratiba onde diques de basanito e de basalto alcalino, com direção em torno de N-S e ângulo de mergulho alto (Figura 4.11A), apresentam fraturas secundárias oblíquas a eles, com forma helicoidal (Figuras 4.12A e B), indicando movimentação dextral após a sua intrusão. A presença de cataclase na borda de alguns deles (Figura 4.11B), com hidrotermalismo associado, e também com indicação de movimentação direcional dextral, indica que essa movimentação ocorreu logo após a intrusão dos diques. 


\section{Pedreira Emasa}
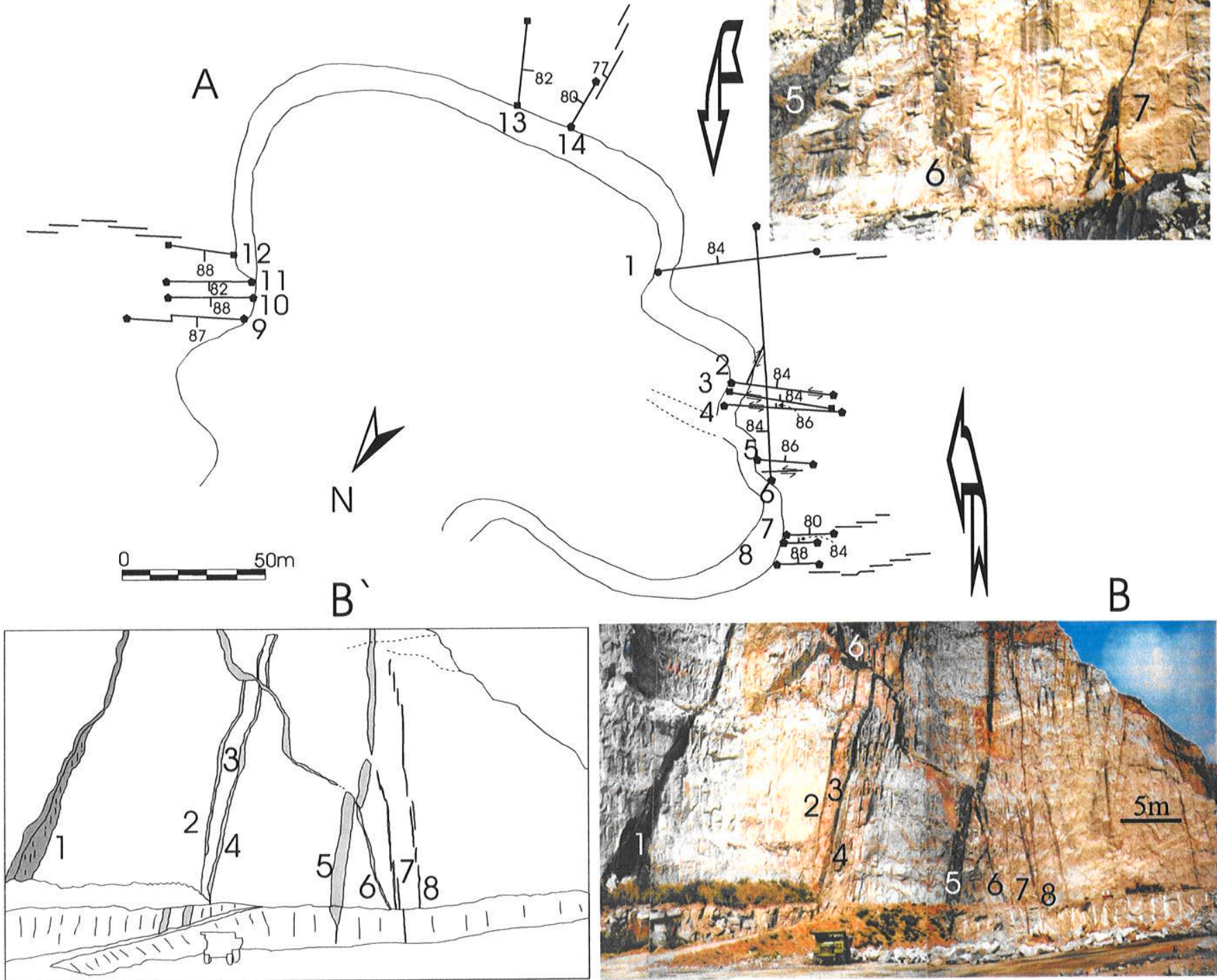

Figura 4.9 - Pedreira Emasa, bairro de Bangu, Rio de Janeiro. Planta aproximada do contorno e das bancadas da pedreira, onde predominam diques de lamprófiros (pentágonos) e de rochas alcalinas félsicas (quadrados), ocorrendo apenas um dique de diabásio (círculos,1). Os diques tem direção predominante para ENE-WSW, porém ocorrem dois lamprófiros (6 e 14) e um traquito orbicular (13) com direção NNW a NW. As idades relativas, inferidas a partir das relações de corte, tem observação direta apenas no dique composto (2-3-4), onde um traquito, com 1,5 m de espessura, é bordejado por lamprófiros, com pouco mais de $50 \mathrm{~cm}$ de largura. Neste caso o contato se dá numa faixa de aproximadamente $5 \mathrm{~cm}$, irregular, onde o traquito se torna mais escuro e, ainda, onde o traquito, mais claro, é injetado, sugerindo ser este o mais novo. Por outro lado, o lamprófiro (6), de direção NW, corta o lamprófiro de direção ENE (5), e o dique composto (2-3-4), interrompendo inclusive o traquito (B, B`e C). O lamprófiro (6) é cortado por fraturas de cisalhamento sinistral. O deslocamento dextral dos diques (2-3-4) e (5), observado na foto B é aparente. Diques dos três tipos litológicos mostram escalonamento visível no plano vertical, com os segmentos escalonados separados por degraus horizontais. No canto direito da foto B, pode-se observar o caimento suave da foliação de fluxo do granito encaixante, para SW (215/25). 
B)

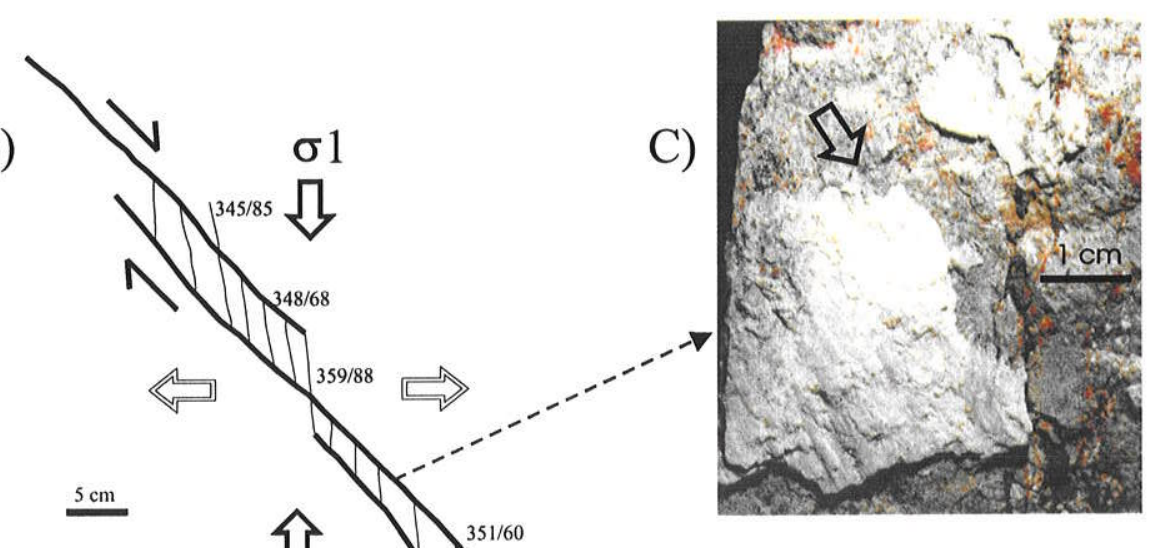

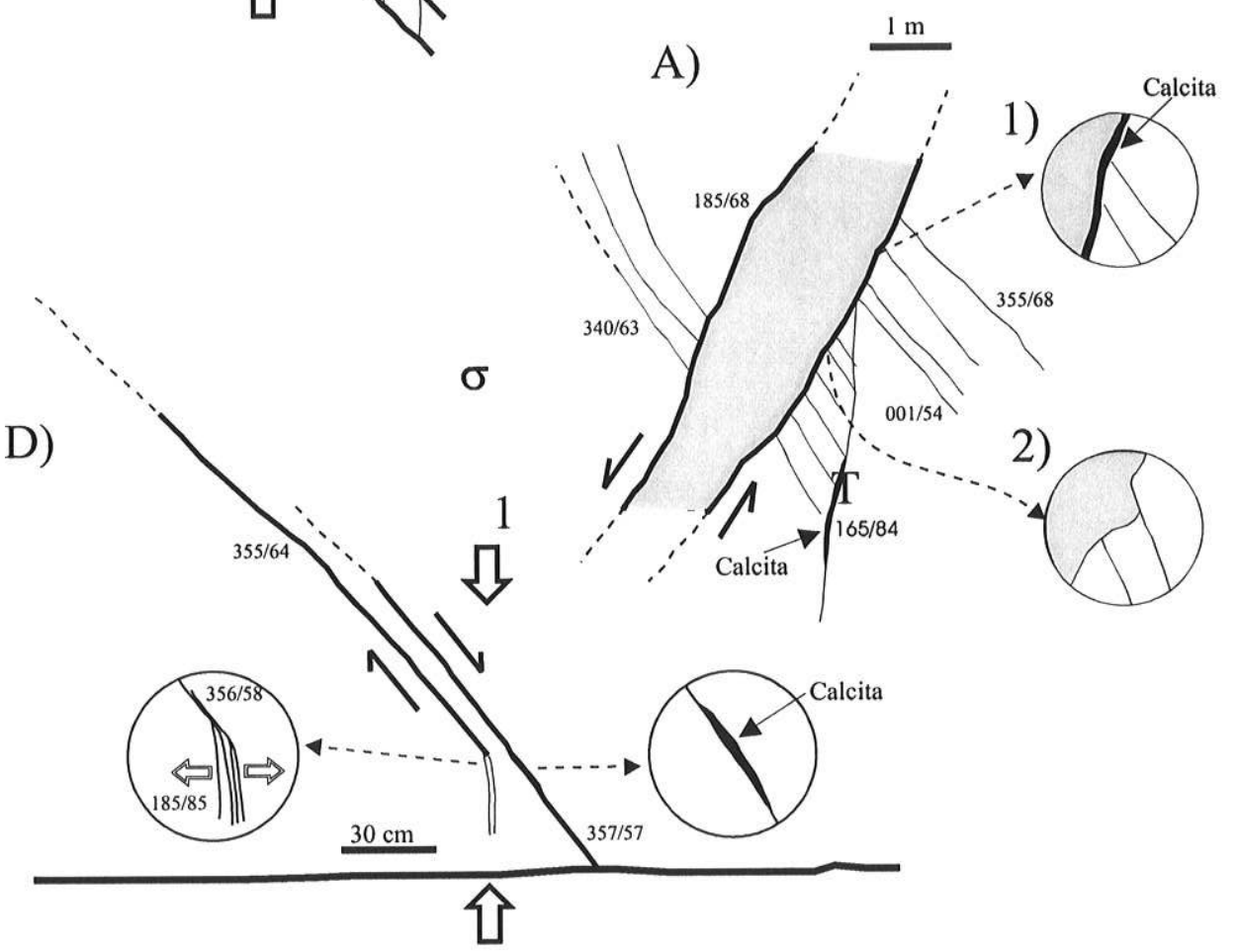

Figura 4.10 - A) Famílias de fraturas conjugadas, geradas em regime de esforço normal, onde uma fratura da família com mergulho para sul é preenchida por dique de traquito. A reativação dessa fratura, em caráter normal, é indicada por fibras de calcita presentes na borda do dique e por fraturas de tração, $\mathrm{T}$, geradas pela movimentação ao longo do dique. A deformação do dique (detalhe B2) evidencia a sua adaptação à fratura preexistente, durante a intrusão; B) Juntas de tração (traço fino) geradas por movimentação normal ao longo das fraturas maiores, C) Fibras de calcita contemporâneas a falhamento normal, D) Fraturas em microssienito, com preenchimento por calcita. A terminação em rabo de cavalo (Cruikshank et al. 1991), com variação brusca do seu mergulho (kink) indica tratarem-se de planos de tração, paralelos à direção do eixo de tensões máximo, $\sigma_{1}$, gerados pela movimentação dos planos das fraturas principais, em caráter normal, após sua formação. Os rumos dos mergulhos dos planos que constituem o rabo de cavalo indicam a posição do eixo principal de menor esforço, $\sigma 3$. Pedreira Vignê, Ponto ME1, Maciço do Mendanha, município de Nova Iguaçu. 

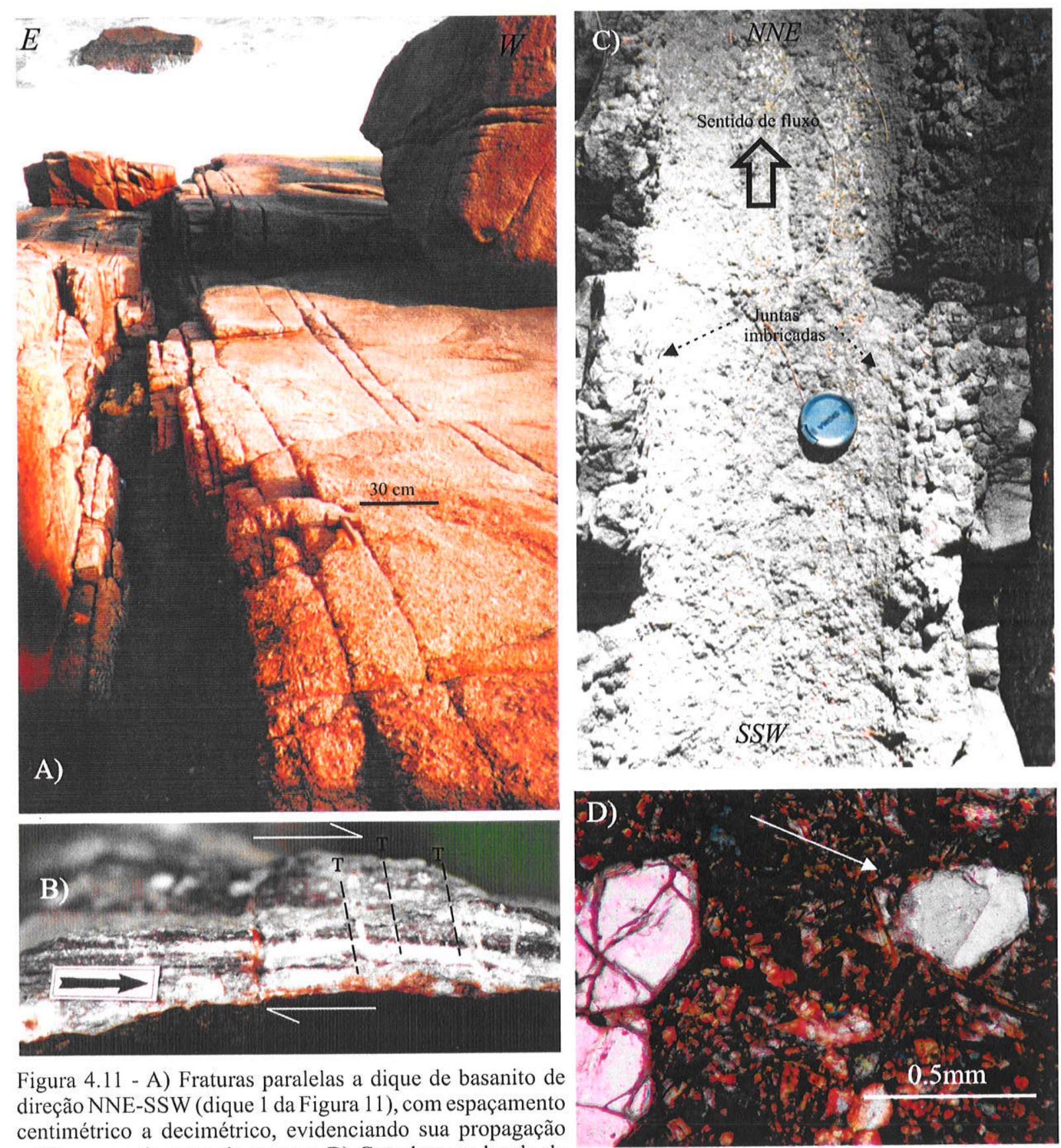

Figura 4.11 - A) Fraturas paralelas a dique de basanito de direção NNE-SSW (dique 1 da Figura 11), com espaçamento centimétrico a decimétrico, evidenciando sua propagação retilínea por dezenas de metros; B) Cataclase na borda de

dique de basalto alcalino, acompanhada por percolação de veios de calcita em fraturas de extensão (T), indicando movimentação direcional dextral. Seta com $1,0 \mathrm{~cm} ; \mathrm{C}$ ) Detalhe de dique de basanito, onde destacam-se grandes cristais de olivina (ressaltados em alto relevo) pseudomorfizadas por calcita e serpentina, evidenciando famílias de juntas imbricadas oblíquas às suas bordas, indicando a direção de fluxo do magma, de sul para norte; D) Fotomicrografia do basanito mostrando pórfiro de olivina em meio a uma matriz constituída por piroxênio e olivina. Observa-se também pórfiro de olivina pseudo morfizado por calcita (indicado pela seta) . Costões rochosos, em granito do Maciço da Pedra Branca, localizados no distrito de Barra de Guaratiba, no caminho entre a Ponta do Picão e a Praia do Perigoso. 


\subsubsection{Sentido de Fluxo Magmático}

Apesar de não se ter como objetivo a caracterização do sentido de fluxo magmático para os diques registra-se, pela clareza das evidências, o fluxo horizontal, de SSW para $\mathrm{NNE}$, em um dos diques de basanito, indicado pelas famílias de juntas imbricadas internas ao dique (Figura 4.11C), não presentes no corte vertical, de acordo com o proposto por (Knight \& Walker 1988) para diques do Havaí. Essas estruturas representariam juntas de resfriamento, inicialmente ortogonais às paredes do dique, posteriormente rotacionadas pelo fluxo magmático (Corrêa Gomes 1992). Tais indicações são reforçadas pelos degraus horizontais presentes nos diques (Rickwood 1990). Essas evidências apontam, nesse caso, para uma alimentação a partir de uma câmara magmática situada na plataforma continental e não a partir do Mendanha. Ressalta-se que esses diques não têm idade conhecida.

\subsubsection{Análise Estrutural}

Para a realização da análise estrutural com base na atitude dos diques, visando a determinação do eixo de tensões mínimo, $\sigma 3$, e do eixo de tensões horizontal máximo, SHmax, eles foram tratados por estação, considerando-se, nesse caso, o Mendanha como uma única estação. Foram, ainda, tratados em separado os diques de rochas alcalinas máficas e félsicas. Em cada um desses dois grupos foram separados diques com mergulho alto $\left(>65^{\circ}\right)$, intermediário $\left(<65^{\circ}\right.$ e $\left.>40^{\circ}\right)$ e baixo $\left(<40^{\circ}\right)$.

$\mathrm{Na}$ Figura 4.13A estão representadas as projeções ciclográficas, polares e os diagramas de rosetas dos diques de rochas alcalinas félsicas, de traquito e de fonolito, que cortam o corpo do Mendanha. Esses diques, dominantemente, orientam-se na direção ENE-WSW e possuem mergulho alto, indicando que sua intrusão foi controlada por uma extensão NNW-SSE, ortogonal aos diques, e por um SHmax de direção ENE-WSW, paralelo a eles. Uma concentração secundária, representada por diques de direção NNWSSE, também essencialmente com mergulho alto, indica que a direção de extensão variou local/temporalmente para ENE-WSW. A ocorrência de diques com ângulo de mergulho intermediário, predominantemente orientados também na direção ENE-WSW, indicam que 

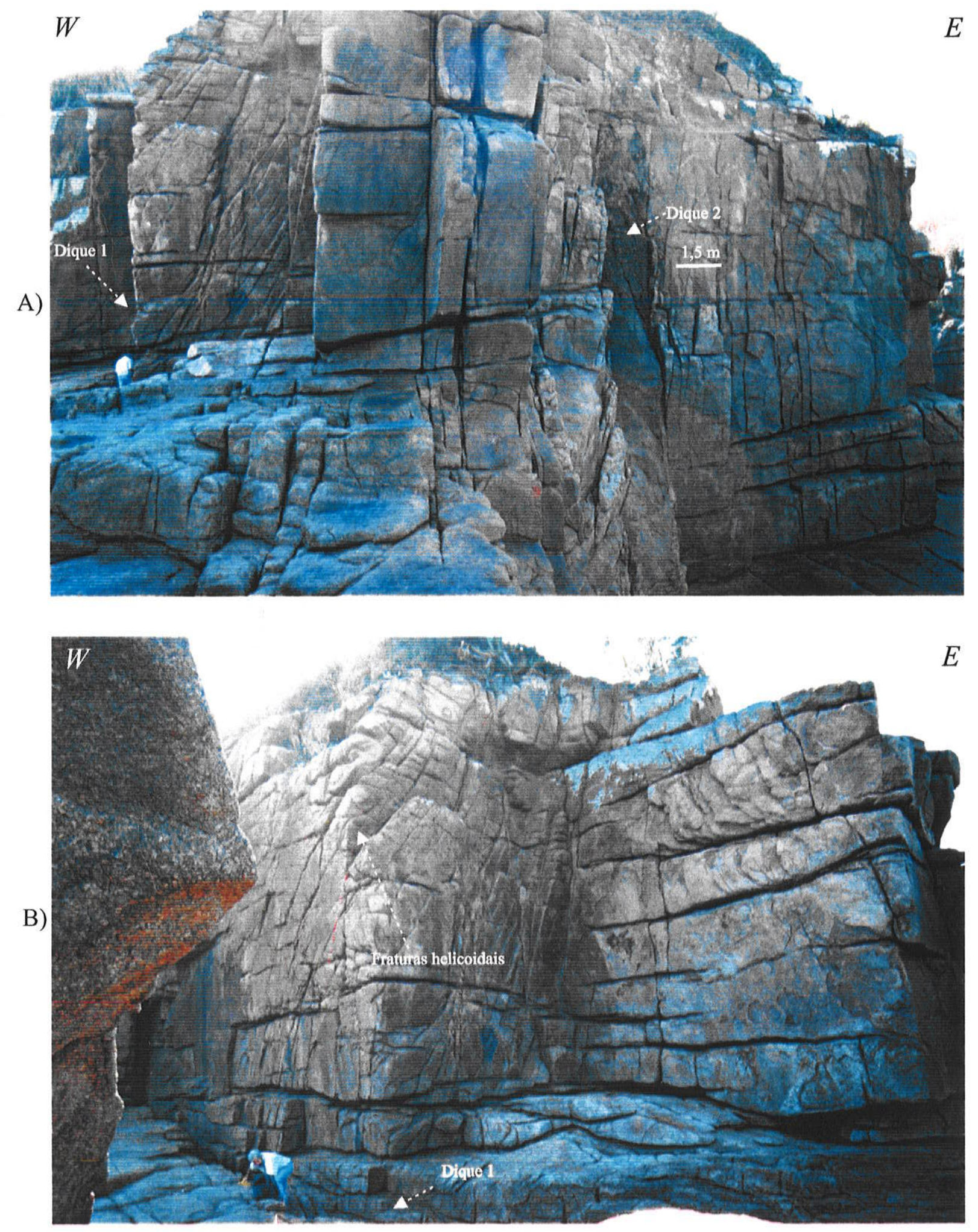

Figura 4.12 - A) Fraturas paralelas e oblíquas a diques de basanito com direção NNE-SSW; B) Detalhe das fratura obíquas ao dique 1 , com vista em 3 dimensões, evidenciando o seu arranjo helicoidal. Ver explanação no texto. Costões rochosos, em granito do Maciço da Pedra Branca, localizados no distrito de Barra de Guaratiba, no caminho entre a Ponta do Picão e a Praia do Perigoso. 
o eixo de tensões principal vertical foi em parte representado pelo eixo de tensões principal, $\sigma 1$, correspondendo a um campo de paleotensões normal.

$\mathrm{Na}$ Figura 4.13B estão representadas as projeções ciclográficas, polares e os diagramas de rosetas dos diques de rochas alcalinas máficas que cortam o Mendanha. Esses diques mostram orientação em torno de E-W e mergulho alto, indicando que a sua intrusão foi controlada por uma extensão N-S, com o SHmax orientando-se na direção EW.

Na Figura 4.14A estão representadas as projeções ciclográficas, polares e os diagramas de rosetas dos diques alcalinos félsicos identificados na Pedreira Santo Antônio, localizada junto ao corpo intrusivo do Mendanha (Figuras 4.2, 4.3 e 4.5). A orientação dos diques, variando entre NNW-SSE e NE-SW, é compatível com uma extensão WNW-ESE, posicionando-se o eixo de tensões horizontal máximo, SHmax, ortogonalmente à direção de extensão, segundo a direção NNE-SSW. O ângulo de mergulho de valor intermediário de dois dos três diques félsicos identificados indica que o eixo de tensões vertical, $\sigma \mathrm{z}$, corresponde ao eixo de tensões máximo, $\sigma 1$. Dessa forma, a intrusão dos diques félsicos foi controlada por um campo de paleotensões puramente extensional.

Na Figura 4.14B estão representadas as projeções ciclográficas, polares e os diagramas de rosetas dos diques alcalinos máficos identificados na Pedreira Santo Antônio (Figuras 4.2, 4.3 e 4.5). Os diques possuem direção variando entre NNE-SSW e ENEWSW, com maior concentração na direção ENE-WSW, indicando que a sua intrusão foi controlada por uma extensão NNW-SSE, com o eixo de tensões horizontal máximo, SHmax, ortogonal a ela, orientando-se na direção ENE-WSW. As relações geométricas entre a foliação dos gnaisses proterozóicos encaixantes, representada por suas projeções polares, e os diques evidencia que, apesar de ambos terem uma orientação sub-paralela, o ângulo de mergulho dos diques é, na grande maioria das vezes, maior do que o da foliação dos gnaisses.

Na Figura 4.15A estão representadas as projeções ciclográficas, polares e os diagramas de rosetas dos diques de rochas alcalinas félsicas identificados na Pedreira Bangu, que se localiza aproximadamente $5 \mathrm{~km}$ ao sul do Mendanha (Figura 4.2). Foram identificados quatro diques félsicos, com direção NW-SE e mergulhos variando entre 60 e $75^{\circ}$ (Figuras 4.4BB e D). Essa orientação indica que a intrusão deles foi controlada por 


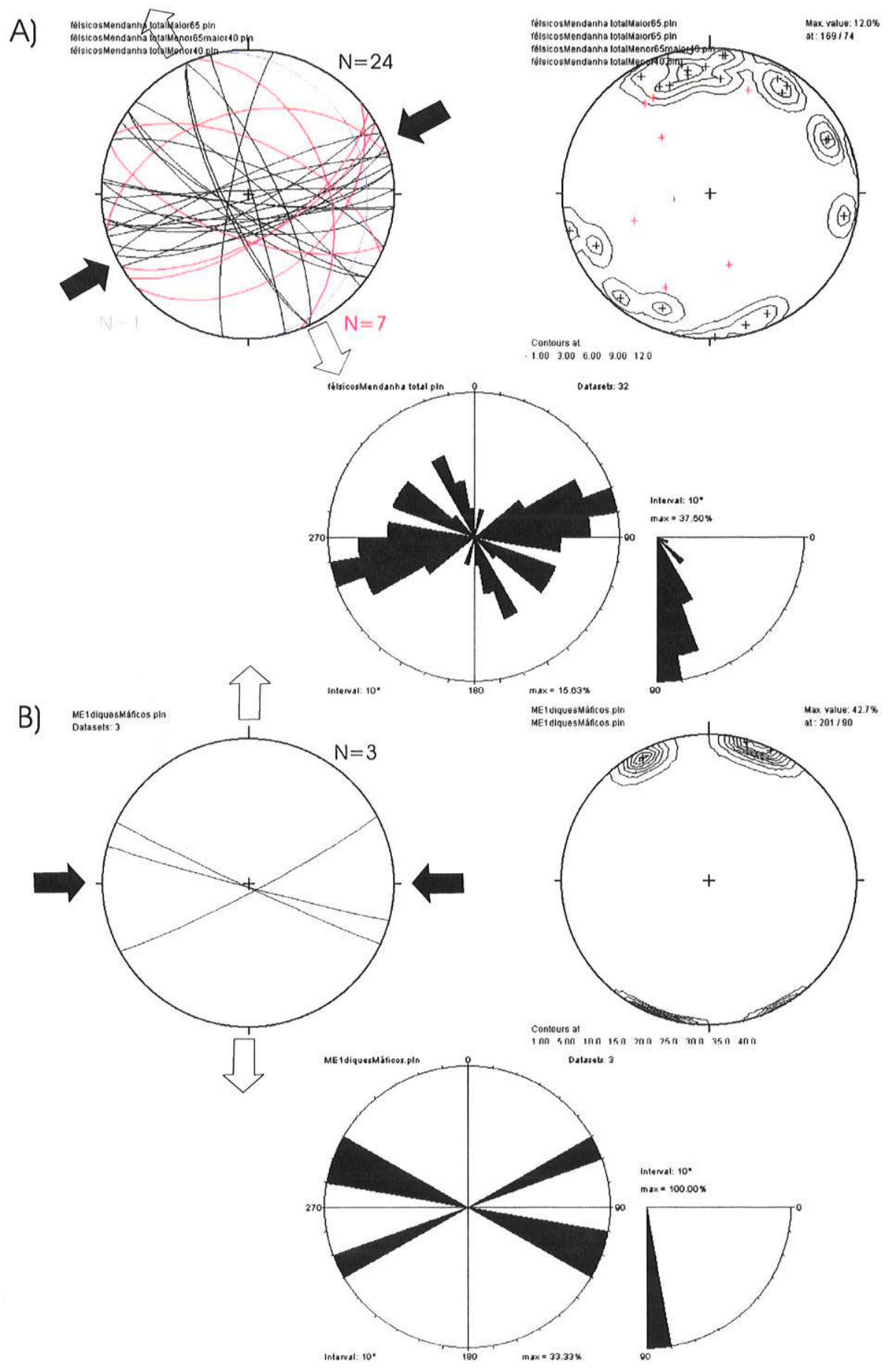

Figura 4.13 - Projeções ciclográficas e polares, e diagramas de rosetas, mostrando as direções e os mergulhos de diques de rochas alcalinas félsicas, traquito e fonolito (A), e máficas, basalto alcalino e lamprófiro (B), do Maciço do Mendanha. Em A e B estão separados os diques com ângulo de mergulho maior que 65 graus (preto), entre 65 e 40 graus (vermelho) e menor que 40 graus (azul). Setas grandes vazias indicam a posicão do eixo de tensões mínimo, $\sigma 3$, e setas grandes cheias indicam a posição do eixo de tensões horizontal máximo, SHmax. Ver explanação no texto. Diagramas de Schmidt-Lambert, hemisfério inferior. 


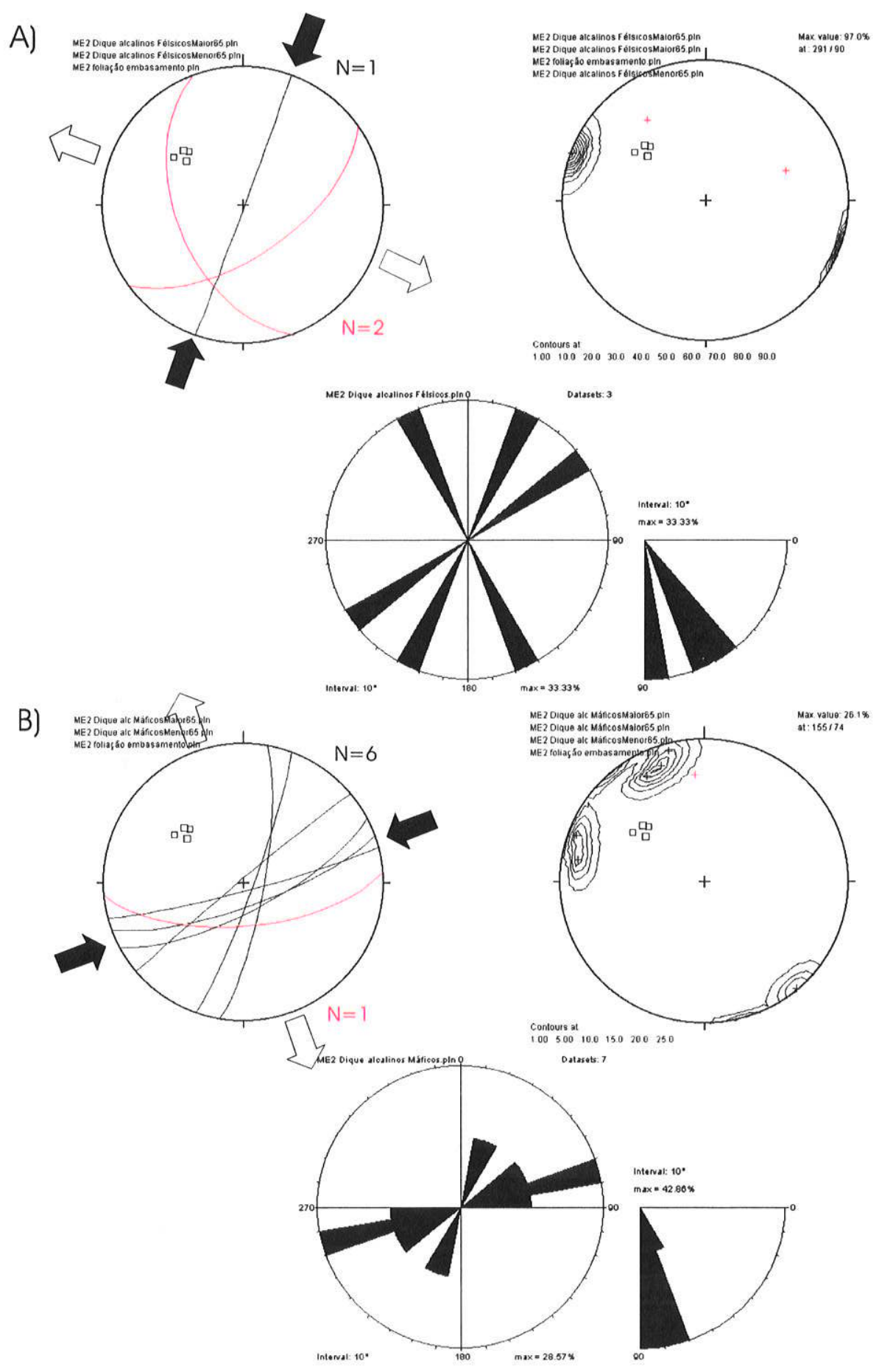

Figura 4.14 - Projeções ciclográficas, polares e diagramas de rosetas, mostrando as direções e os mergulhos de diques de rochas alcalinas félsicas, traquito e fonolito (A), e máficas, basalto alcalino e lamprófiro (B), da Pedreira Santo Antônio. Estão separados os diques com ângulo de mergulho maior que 65 graus (preto) e entre 65 e 40 graus (vermelho). Quadrados vazios representam polos da foliação dos gnaisses encaixantes. Setas grandes vazias indicam a posicão do eixo de tensões mínimo, $\sigma 3$, e setas grandes cheias indicam a posição do eixo de tensões horizontal máximo, SHmax. Ver explanação no texto. Diagramas de Schmidt-Lambert, hemisfério inferior. 
uma extensão NE-SW, posicionando-se o eixo de tensões máximo horizontal, SHmax, na direção NW-SE.

Na Figura 4.15B estão representadas as projeções ciclográficas, polares e os diagramas de rosetas dos diques de rochas alcalinas máficas identificados na Pedreira Bangu. Foram identificados sete diques, com direção ENE-WSW e ângulo de mergulho alto (Figura 4.4C), indicando que a sua intrusão foi controlada por uma extensão NNWSSE, posicionando-se o SHmax na direção ENE-WSW, paralelamente aos diques. Nessa pedreira os diques félsicos são claramente posteriores aos máficos, evidenciando uma variação no campo de paleotensões, passando de uma extensão inicialmente na direção NW-SE para uma extensão na direção NE-SW. As relações geométricas entre a foliação dos gnaisses encaixantes, representados por suas projeções polares, indicam que os diques félsicos são sub-paralelos a ela, tendo, em geral, um ângulo de mergulho um pouco mais alto (Figura 4.4D). Já os diques máficos mostram uma atitude totalmente diversa da apresentada pelos gnaisses do embasamento.

$\mathrm{Na}$ Figura 4.16A estão representadas as projeções ciclográficas, polares e os diagramas de rosetas dos diques de rochas alcalinas félsicas identificadas na Pedreira Emasa, localizada cerca de $7 \mathrm{~km}$ ao sudoeste do Mendanha (Figura 4.2). Nessa pedreira foram identificados apenas 3 diques félsicos, todos de traquito e com ângulo de mergulho alto, sendo 2 orientados na direção ENE-WSW, um deles caracterizando um dique composto com outro de basalto alcalino, e 1 na direção NNW-SSE, constituído de traquito orbicular (Figuras 4.9A e B). Não foi possível caracterizar as relações de corte entre os dois grupos, mas, com base na Pedreira Bangu, pode-se inferir que o traquito orbicular representa o último pulso magmático. Dessa forma, os dois diques orientados na direção ENE-WSW indicam que tiveram sua intrusão controlada por uma extensão NNW-SSE, com o SHmax posicionado na direção ENE-WSW. Por outro lado, o dique de traquito orbicular teve sua intrusão controlada por uma extensão NE-SW, ortogonal à anterior.

$\mathrm{Na}$ Figura 4.16B estão representadas as projeções ciclográficas, polares e de diagramas de rosetas dos diques de rochas alcalinas máficas. Dos 6 diques máficos identificados, 3 se orientam segundo a direção ENE-WSW e 3 na direção NNW-SSE, todos com altos ângulos de mergulho. Nesse caso, os diques de direção NNW-SSE são claramente posteriores (Figuras 4.9A, B, B` e C), indicando uma variação na direção de 
A)

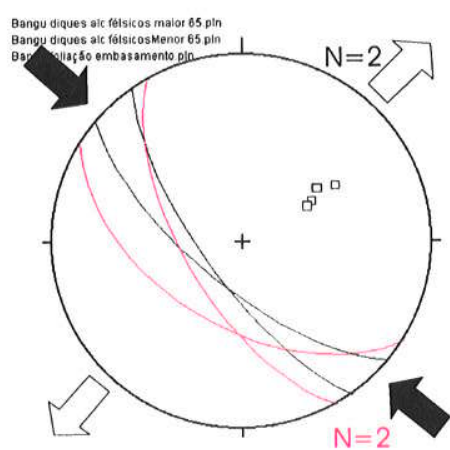

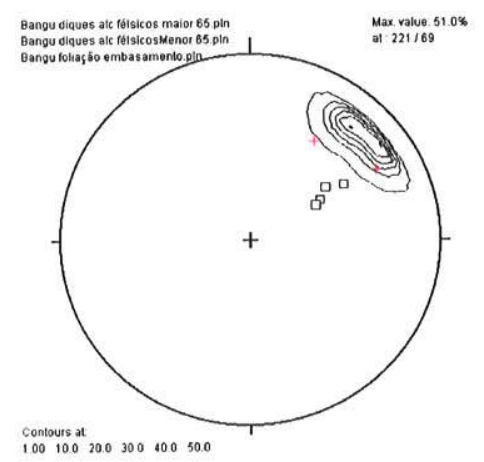

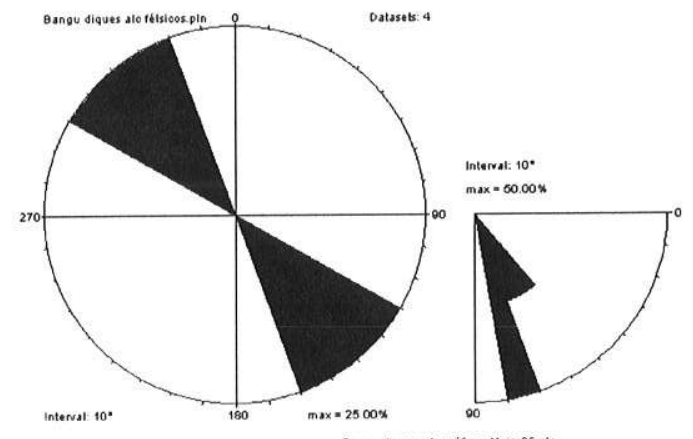

B)

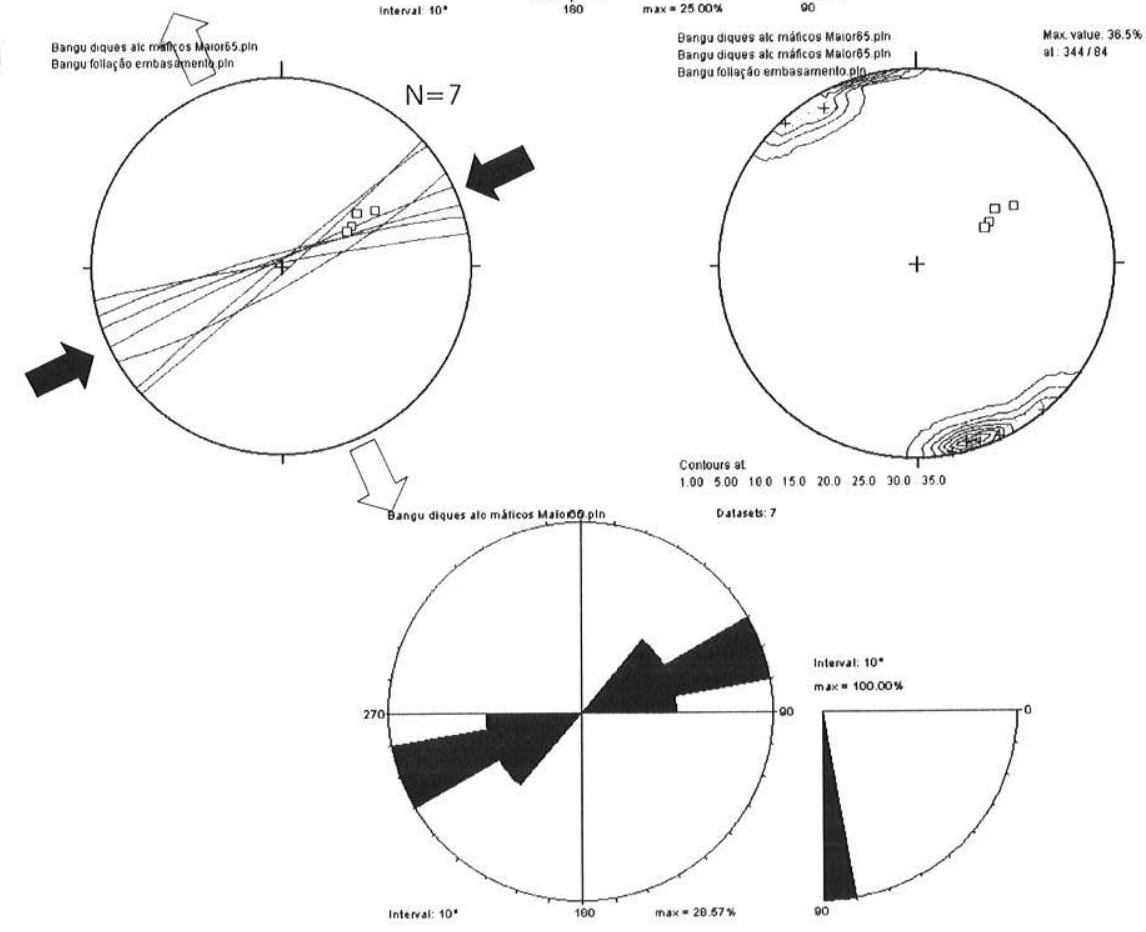

Figura 4.15 - Projeções ciclográficas, polares e diagramas de rosetas, mostrando as direções e os mergulhos de diques de rochas alcalinas félsicas, traquito e fonolito (A), e máficas, basalto alcalino e lamprófiro (B), da Pedreira Bangu. Quadrados vazios representam polos da foliação dos gnaisses encaixantes. Setas grandes vazias indicam a posicão do eixo de tensões mínimo, $\sigma 3$, e setas grandes cheias indicam a posição do eixo de tensões horizontal máximo, SHmax. Ver explanação no texto. Diagramas de Schmidt-Lambert, hemisfério inferior. 
extensão, inicialmente segundo NNW-SSE e posteriormente na direção NNW-SSE. Essa variação, semelhante à inferida para os diques máficos, sugere que as duas direções de extensão controlaram tanto pulsos de magmatismo máfico quanto félsico. As relações geométricas entre a foliação dos gnaisses encaixantes, representados por suas projeções polares, e os diques, evidencia que os diques de direção ENE-WSW são totalmente discrepantes, tanto na direção como no mergulho, enquanto que os de direção NNW-SSE, apesar de sub-paralelos, apresentam ângulos de mergulho bem mais altos.

$\mathrm{Na}$ Figura 4.17A estão representadas as projeções ciclográficas, polares e os diagramas de rosetas dos diques de rochas alcalinas félsicas identificados na Pedreira Simgra, localizada em Pedra de Guaratiba, cerca de $20 \mathrm{~km}$ ao sudoeste do Mendanha (Figura 1). Os 6 diques félsicos, de traquito e fonolito, identificados mostram direção variando entre ENE-WSW e WNW-ESE, com concentração na direção ENE-WSW, próxima a E-W, e ângulos de mergulho altos, com uma única exceção (Figuras 4.4A, B` e C). Essa distribuição indica que eles tiveram sua intrusão controlada por uma extensão NNW-SSE, posicionando-se o eixo de tensões horizontal máximo, Shmax, na direção ENE-WSW.

$\mathrm{Na}$ Figura 4.17B estão representadas as projeções ciclográficas, polares e os diagramas de rosetas dos diques de rochas alcalinas máficas identificados na Pedreira Simgra. A direção dos diques variando entre NE-SW e ESE-WNW, com concentração em torno de E-W, indica que eles tiveram sua intrusão controlada por uma extensão de direção ENE-WSW, próximo a E-W, posicionando-se o eixo de tensões principal máximo, SHmax, na direção NNW-SSE. As relações geométricas entre a foliação do Granito Pedra Branca (de fluxo?), no qual os diques estão encaixados, representada por suas projeções polares, e os diques, mostra uma discrepância total entre eles. Uma exceção é determinada pelo dique de traquito com baixo ângulo de mergulho, o qual é sub-paralelo à foliação.

Na Figura 4.18A estão representadas as projeções ciclográficas, polares e os diagramas de rosetas dos diques de rochas alcalinas félsicas, traquito e fonolito, identificados nos costões rochosos da localidade de Barra de Guaratiba, situada à cerca de $25 \mathrm{~km}$ ao sul-sudoeste do Mendanha (Figura 1). A direção NNE-SSW dos diques indica que eles tiveram sua intrusão controlada por uma extensão de direção WNW-ESE, posicionando-se o eixo de tensões horizontal máximo, SHmax, na direção NNE-SSW. 
A)

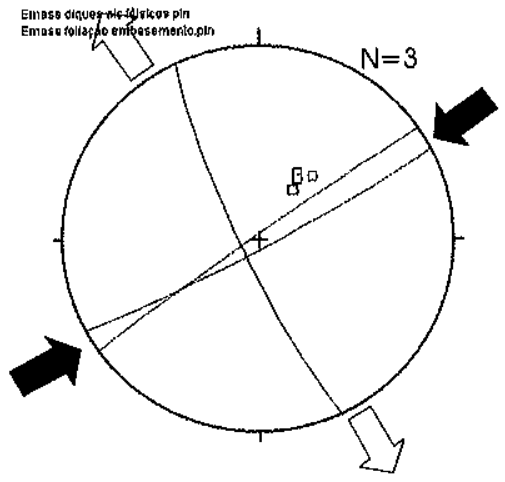

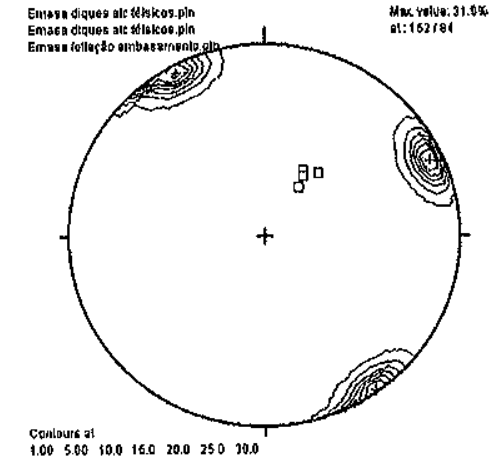

$\begin{array}{llll}\text { Copllours at } \\ 1.00 & 5.00 \quad 50.0 \quad 16.0 \quad 20.0 \quad 250 \quad 50.0\end{array}$

B)

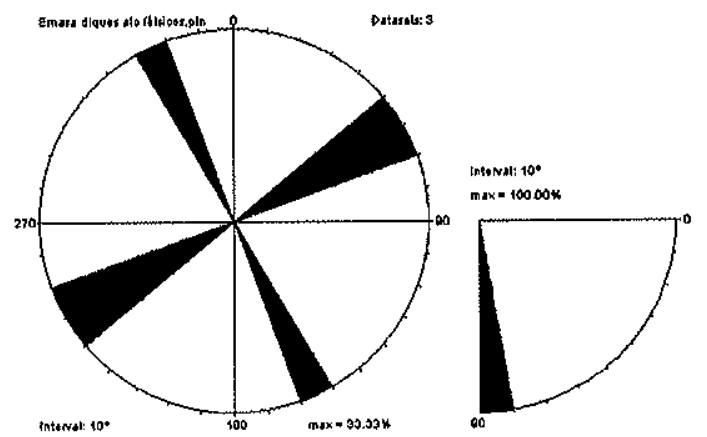

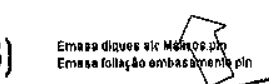
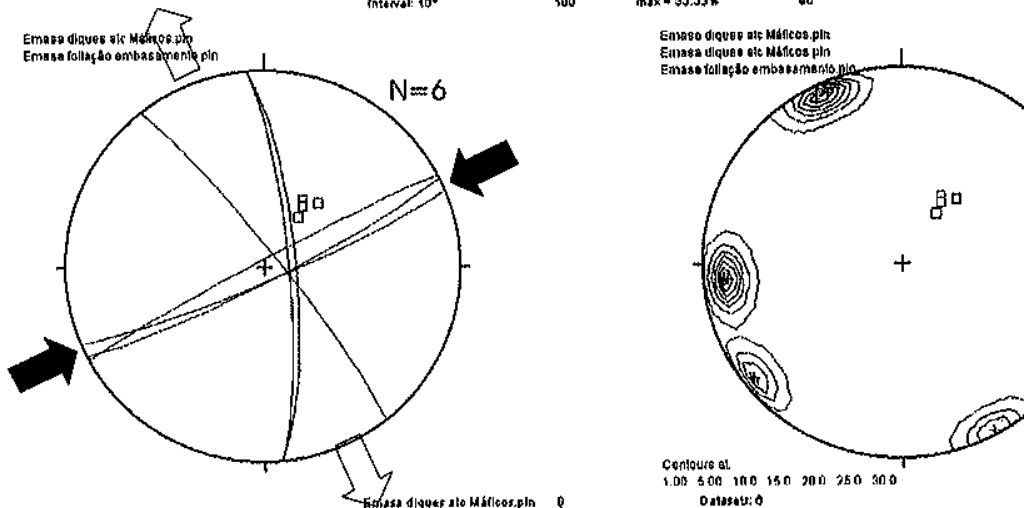

Hocralus: $31.2 \%$

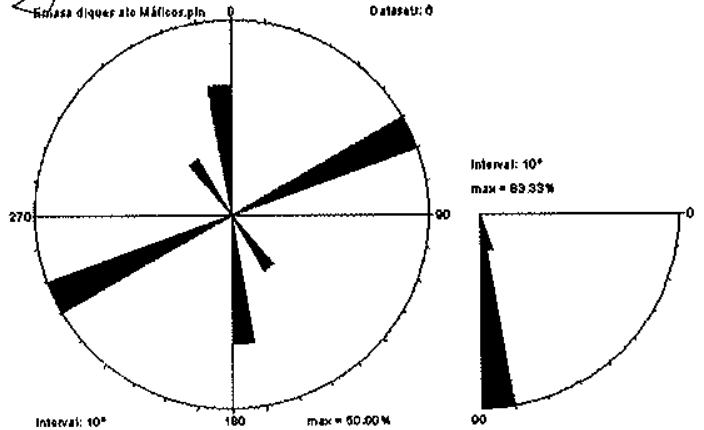

Figura 4.16 - Projeções ciclográficas, polares e diagramas de rosetas, mostrando as direções e os mergulhos de diques de rochas alcalinas félsicas, traquito e fonolito $(A)$, e máficas, basalto alcalino e lamprófiro (B), da Pedreira Emasa. Quadrados vazios representam polos da foliação de fluxo do granito encaixante. Setas grandes vazias indicam a posicão do eixo de tensões mínimo, $\sigma 3$, e setas grandes cheias indicam a posição do eixo de tensões horizontal máximo, SHmax. Ver explanação no texto. Diagramas de Schmidt-Lambert, hemisfério inferior. 


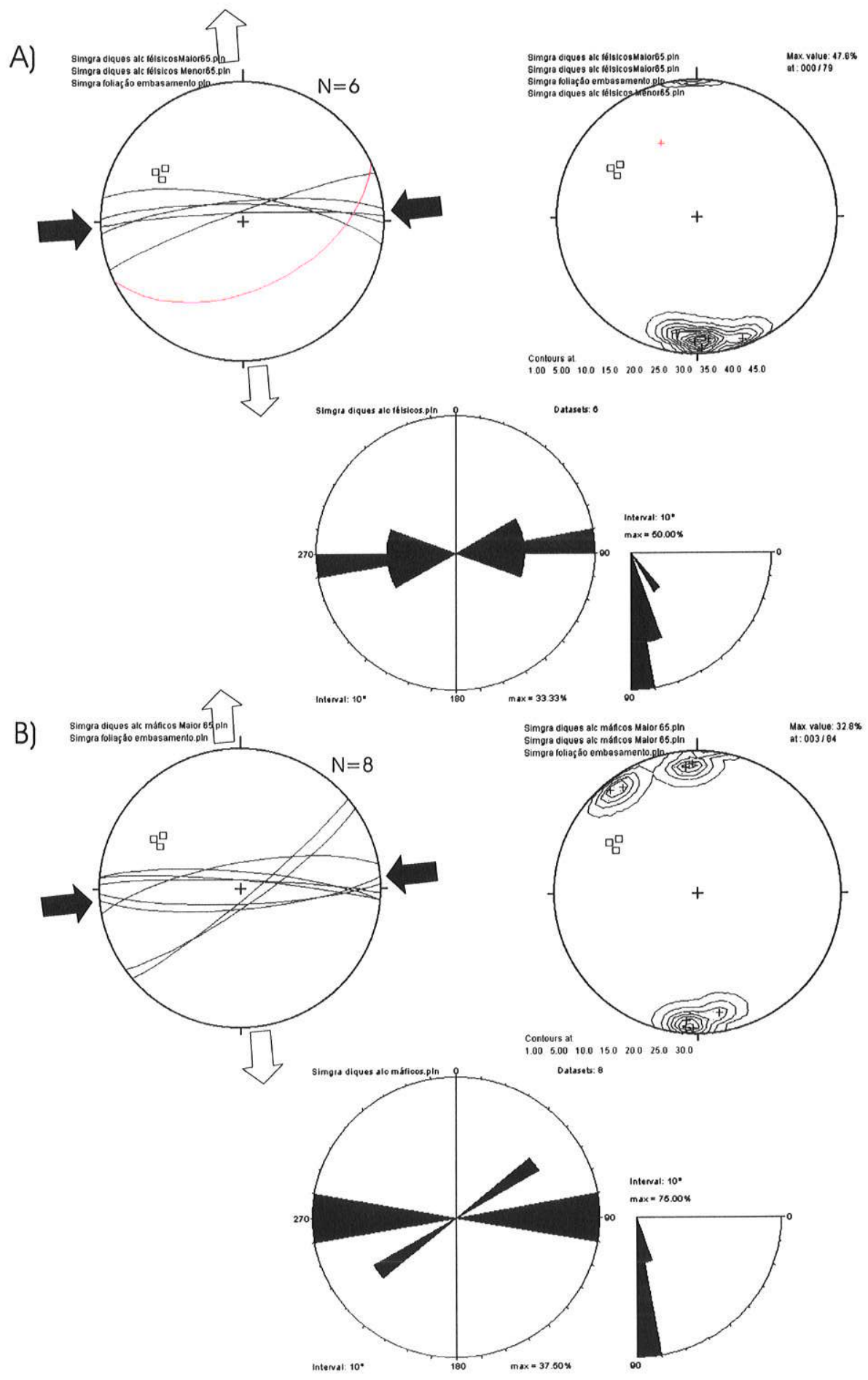

Figura 4.17- Projeções ciclográficas, polares e diagramas de rosetas, mostrando as direções e os mergulhos de diques de rochas alcalinas félsicas, traquito e fonolito (A), e máficas, basalto alcalino e lamprófiro (B), da Pedreira Simgra, Pedra de Guaratiba. Quadrados vazios representam polos da foliação de fluxo do Granito Pedra Branca encaixante. Setas grandes vazias indicam a posicão do eixo de tensões mínimo, $\sigma 3$, e setas grandes cheias indicam a posição do eixo de tensões horizontal máximo, SHmax. Ver explanação no texto. Diagramas de Schmidt-Lambert, hemisfério inferior. 
Na Figura 4.18B estão representadas as projeções ciclográficas, polares e os diagramas de rosetas dos diques de rochas alcalinas máficas, basalto alcalino e basanito, identificados nos costões de Barra de Guaratiba. A orientação desses diques segundo a direção NNE-SSW, invariavelmente com mergulhos altos, indica que a sua intrusão foi controlada por uma extensão de direção WNW-ESE, posicionando-se o eixo de tensões horizontal máximo, SHmax, na direção NNE-SSW. Ressalta-se que em Barra de Guaratiba os diques estão intrudidos em granito porfirítico sem anisotropias, pertencente ao corpo tardi-tectônico da Pedra Branca (Hemboldt et al. 1965, Wiedmann et al. 1987).

\subsubsection{Juntas e Fraturas no Corpo do Mendanha}

Esses dados referem-se tanto a juntas como a fraturas, incluindo-se as fraturas conjugadas, nas quais não se conseguiu determinar claramente as estrias, para obtenção dos dados pareados compreendendo planos de falhas ou microfalhas/estrias. Foram coletados dados em cinco estações distintas, a saber: Pedreira Irmãos Vignê (Ponto ME1), Parque Municipal do Mendanha (Pontos ME3, 4 e 5) e nos Pontos ME6, 7 e 8, localizados na estrada para a Torre da Embratel. Os dados foram tratados separadamente para rochas intrusivas e vulcânicas com o intuito de se caracterizar possíveis variações temporais no campo de paleotensões. Por outro lado, buscando melhor discriminar as relações geométricas e genéticas entre as diversas famílias de fraturas identificadas, as fraturas com alto ângulo de mergulho $\left(>65^{\circ}\right)$, com ângulo de mergulho intermediário $\left(<65^{\circ}\right.$ e $\left.>40^{\circ}\right)$ e as com ângulo de mergulho baixo $\left(<40^{\circ}\right)$, foram representadas de maneira distinta, porém plotadas em conjunto. Essa prática partiu da premissa que as fraturas com ângulo de mergulho intermediário podem ter sido geradas em um regime distensivo e que as de baixo ângulo podem ter sido geradas em um regime compressivo. No caso das famílias de fraturas de alto ângulo sua filiação genética depende do ângulo que essas famílias descrevem entre si (Hancock 1985), podendo caracterizar juntas de extensão (paralelas entre si), fraturas híbridas (ângulo de até $45^{\circ}$ ) e fraturas conjugadas de cisalhamento (ângulos maiores do que $45^{\circ}$ e menores do que $80^{\circ}$ ). Foram adotados os mesmos ângulos limites definidos pelo Programa TENSOR (Delvaux 1993). 


\subsubsection{Juntas e Fraturas em Rochas Intrusivas}

Na Figura 4.19 estão representadas as projeções ciclográficas e polares das juntas e fraturas caracterizadas na Pedreira Irmãos Vignê (Ponto ME1), afetando sienito. Nas Figuras 4.19A e B estão representadas a família de fraturas paralelas, com alto ângulo de mergulho e direção em torno de E-W. Essa família corresponde a um conjunto de fraturas de extensão, indicando que o eixo de tensões mínimo, $\sigma 3$, orienta-se na direção N-S, posicionando-se o eixo de tensões horizontal máximo, SHmax, na direção E-W. As relações geométricas entre essas fraturas e as famílias de fraturas conjugadas com ângulo de mergulho intermediário, também de direção $\mathrm{E}-\mathrm{W}$, indica que ambos os grupos foram gerados pelo mesmo campo de paleotensões, em um regime extensional, tendo havido variações na magnitude do eixo principal de tensões vertical, $\sigma \mathrm{z}, \mathrm{o}$ qual corresponde a $\sigma 1$ no caso das fraturas de ângulo de mergulho intermediário. Em algumas delas foi possível caracterizar uma componente de cisalhamento normal (Figuras 4.10B e C). Ambos os grupos de fraturas apresentam-se preenchidas por sulfetos e calcita, e são sub-paralelos a diques de traquito. A presença de quebras bruscas na direção dessas fraturas (kinks), constituindo localmente terminações em rabo de cavalo (Figura 4.10C) ou fraturas secundárias, indica que o cisalhamento foi posterior à sua formação (Cruikshank et al. 1991). Porém, o preenchimento por calcita indica que a movimentação ao longo dessas fraturas se deu logo após a intrusão dos diques. Nas Figuras 4.19C e D estão representadas as projeções ciclográficas e polares de famílias de fraturas de cisalhamento conjugadas, onde os pares conjugados apresentam direção NW-SE e N-S, posicionando-se o eixo de tensões máximo, $\sigma 1$, na horizontal, segundo a direção NNW-SSE. O eixo de tensões mínimo, $\sigma 3$, é também horizontal e ortogonal a ele e o eixo intermediário, $\sigma 2$, posiciona-se na vertical, caracterizando um campo de paleotensões direcional. Essas famílias de fraturas são mais novas que as de direção E-W, apresentando, raramente, cataclase ao longo dos planos. As relações geométricas entre as famílias de alto e médio ângulos de mergulho, sugerem variações locais no campo de paleotensões com eventual aumento na componente extensional, ou mesmo permutação entre os eixos de tensões máximo e intermediário, $\sigma 1 \mathrm{e}$ $\sigma 2$. 


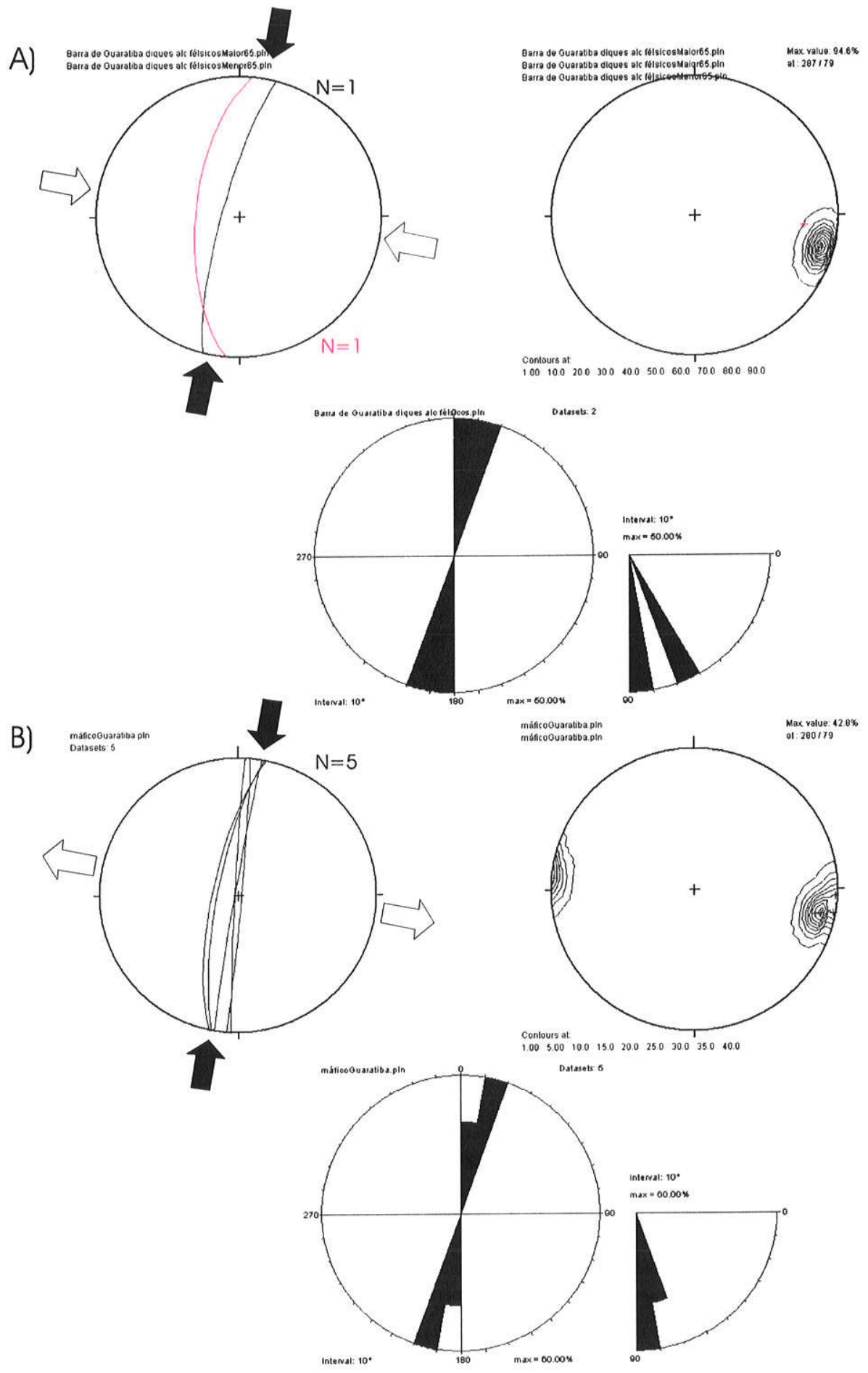

Figura 4.18 - Projeções ciclográficas, polares e diagramas de rosetas, mostrando as direções e os mergulhos de diques de rochas alcalinas félsicas, traquito e fonolito (A), e máficas, basalto alcalino e basanito (B), de distrito de Barra de Guaratiba. Setas grandes vazias indicam a posicão do eixo de tensões mínimo, $\sigma 3$, e setas grandes cheias indicam a posição do eixo de tensões horizontal máximo, SHmax. Ver explanação no texto. Diagramas de Schmidt-Lambert, hemisfério inferior. 
Na Figura 4.20 estão representadas as fraturas identificadas no Parque Municipal do Mendanha, Pontos ME3, 4 e 5, afetando sienito e microssienito. Foram caracterizados dois grupos de fraturas com alto ângulo de mergulho, um com direção variando entre NESW e WNW-ESE e outro com direção variando entre N-S e WNW-ESE. No primeiro caso (Figuras 4.20A e B) elas constituem uma família de juntas de extensão, de direção ENEWSW, e famílias de fraturas conjugadas de cisalhamento, com os pares conjugados orientados nas direções NE-SW e WNW-ESE, indicando que o eixo de tensões máximo, $\sigma 1$, é horizontal e orienta-se na direção ENE-WSW, o eixo de tensões mínimo, $\sigma 3$, é também horizontal e ortogonal a ele e o eixo intermediário, $\sigma 2$, é vertical. Essa distribuição dos eixos de paleotensões principais indica um paleocampo direcional. As relações geométricas entre as famílias de fraturas de ângulo de mergulho alto e intermediário, indicam que devem ter ocorrido variações no campo de paleotensões, provavelmente associadas a uma maior magnitude local da componente extensional. A relação das fraturas com ângulo de mergulho abaixo de $40^{\circ}$ não é clara. No segundo caso, as famílias de fraturas também caracterizam estruturas de cisalhamento conjugadas, associadas a um eixo de paleotensões máximo, $\sigma 1$, horizontal e orientado na direção NNW-SSE, o eixo mínimo, $\sigma 3$, também horizontal e ortogonal a ele e o eixo intermediário, $\sigma 2$, vertical, correspondendo a um campo de paleotensões direcional. As relações geométricas entre as famílias de fraturas com ângulo de mergulho alto e intermediário, indicam que ocorreram variações no campo de paleotensões, associadas provavelmente a variações locais/temporais na magnitude da componente extensional, ou a uma permutação entre os eixos de palotensões máximo e intermediário, $\sigma 1$ e $\sigma 2$, levando a uma mudança no regime de esforços de direcional para normal. As fraturas com baixo ângulo de mergulho são paralelas a um único dique com ângulo de mergulho abaixo de $40^{\circ}$, de composição fonolítica, identificado no maciço, no Ponto ME8, sugerindo uma variação local para um regime compressivo, no qual o eixo de paleotensões principal posicionava-se na horizontal, na direção ENE-WSW.

Na Figura 4.21 estão representadas as projeções ciclográficas e polares de juntas e fraturas identificadas no Ponto ME6, afetando sienito. Nesse local foram caracterizados dois grupos de famílias de fraturas, um com famílias de direção NE-SW e WNW-ESE e, outro, com famílias de direção NW-SE e NNE-SSW. No primeiro caso (Figuras 4.21A e B), as fraturas correspondem a famílias de cisalhamento conjugadas geradas campo de 

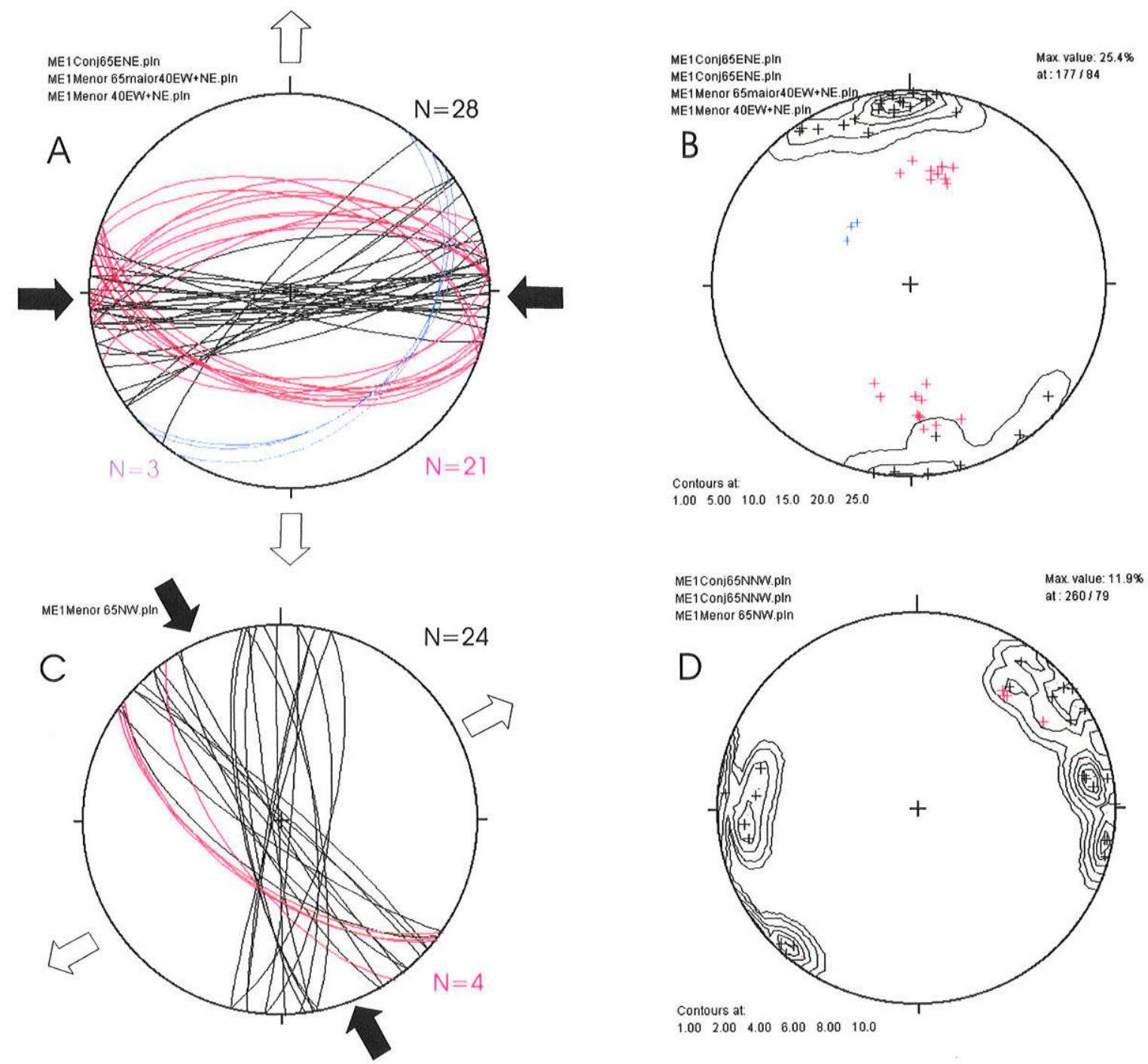

Figura 4.19 - Projeções ciclográficas e polares mostrando as relações geométricas entre fraturas conjugadas de cisalhamento com ângulo de mergulho maior que 65 graus (preto) e juntas com ângulo de mergulho menor que 65 graus e maior que 40 graus (vermelho) e juntas com ângulo de mergulho abaixo de 40 graus (azul), para famílias de direção NE-SW a E-W (A e B) e N-S a NW-SE (C e D). As juntas afetam sienito. Setas grandes vazias indicam a posição de Shmin e setas grandes cheias indicam a posição de SHmax. Ver explanação no texto. Diagramas de Schimidt-Lambert, hemisfério inferior. Maciço do Mendanha, Ponto ME1, Pedreira Irmãos Vignê. 

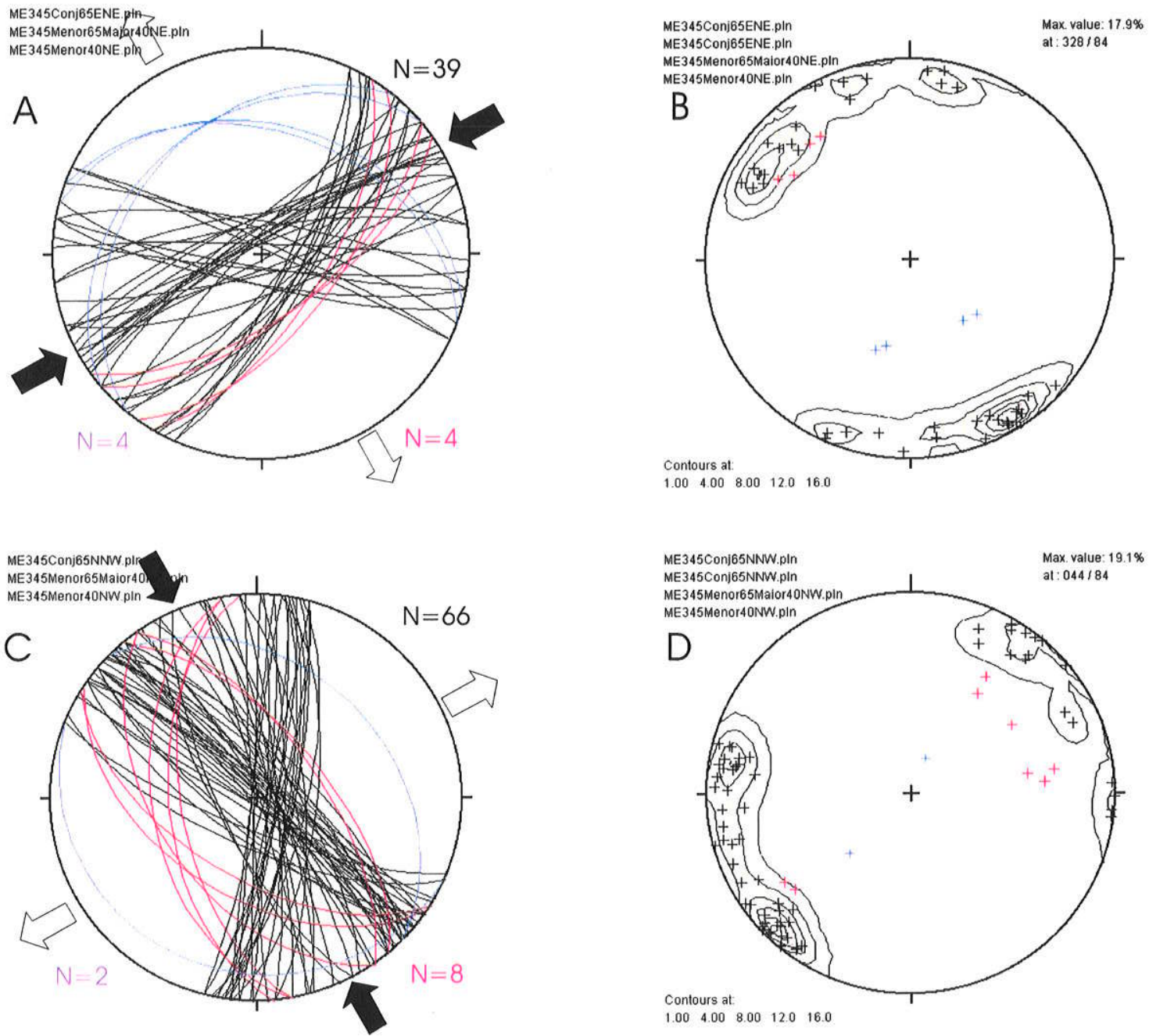

Figura 4.20 - Projeções ciclográficas e polares mostrando as relações geométricas entre fraturas conjugadas de cisalhamento com ângulo de mergulho maior que 65 graus (preto) e juntas com ângulo de mergulho menor que 65 graus e maior que 40 graus (vermelho) e juntas com ângulo de mergulho abaixo de 40 graus (azul), para famílias de direção NE-SW a E-W (A e B) e N-S a NW-SE (C e D). As juntas afetam sienito. Setas grandes vazias indicam a posição de Shmin e setas grandes cheias indicam a posição de SHmax. Ver explanação no texto. Diagramas de Schimidt-Lambert, hemisfério inferior. Maciço do Mendanha, Pontos Me3, 4 e 5, Parque Municipal do Mendanha. 
paleotensões onde o eixo de paleotensões máximo, $\sigma 1$, era horizontal e de direção ENEWSW, com o eixo de paleotensões mínimo, $\sigma 3$, também horizontal e ortogonal a ele e o eixo intermediário, $\sigma 2$, vertical, caracterizando um regime direcional. No segundo caso (Figuras $4.21 \mathrm{C}$ e D) estão muito bem caracterizadas as famílias conjugadas de cisalhamento, onde os pares conjugados de direção NW-SE e NNE-SSW indicam que o eixo de paleotensões máximo, $\sigma 1$, é horizontal e posiciona-se na direção NNW-SSE, com o eixo de paleotensões mínimo, $\sigma 3$, também horizontal e ortogonal a ele e o eixo intermediário, $\sigma 2$, vertical, correspondendo a um campo de paleotensões também direcional.

Na Figura 4.22 estão representadas as projeções ciclográficas e polares de fraturas que afetam sienito no Ponto ME8. Nas Figuras 4.22A e B estão representadas famílias de fraturas com direção variando entre NE-SW e ESE-WNW, onde as fraturas com alto ângulo de mergulho constituem um espectro de fraturas, incluindo fraturas de cisalhamento conjugadas, fraturas híbridas e juntas de extensão, de acordo com o conceito de Hancock (1985). A orientação dessas fraturas permite que se posicione o eixo de tensões máximo horizontal, SHmax, na direção ENE-WSW, com o eixo de tensões mínimo, $\sigma 3$, também posicionado na horizontal e ortogonal a ele, na direção NNW-SSE. As relações geométricas com as famílias de fraturas com ângulo de mergulho intermediário indicam variações locai/temporais no campo de paleotensões, com provável alternância dos eixos de tensões máximo e intermediário, $\sigma 1$ e $\sigma 2$, na posição de SHmax. Dessa forma, parecem ter atuado regimes de esforços normais e direcionais. Nas Figuras 4.22C e D estão representadas as projeções ciclográficas e polares das fraturas com direção variando entre NW-SE e NNE-SSW. Também nesse caso as fraturas com alto ângulo de mergulho constituem um espectro de fraturas, indicando que o eixo de tensões horizontal máximo, SHmax, orienta-se na direção NNW-SSE, posicionando se o eixo de tensões mínimo, $\sigma 3$, também na horizontal e ortogonal a ele, na direção ENE-WSW. As relações geométricas com as famílias de fraturas com ângulo de mergulho intermediário indicam também uma variação local/temporal no campo de paleotensões, com a alternância dos eixos de tensões máximo e intermediário na posição de $\mathrm{SHmax}$. Tal variação corresponderia à atuação de regimes de esforços normais e direcionais. A presença de diques de fonolito com direção ENE-WSW nessa estação indica que as famílias de fraturas com essa direção são as mais antigas. 

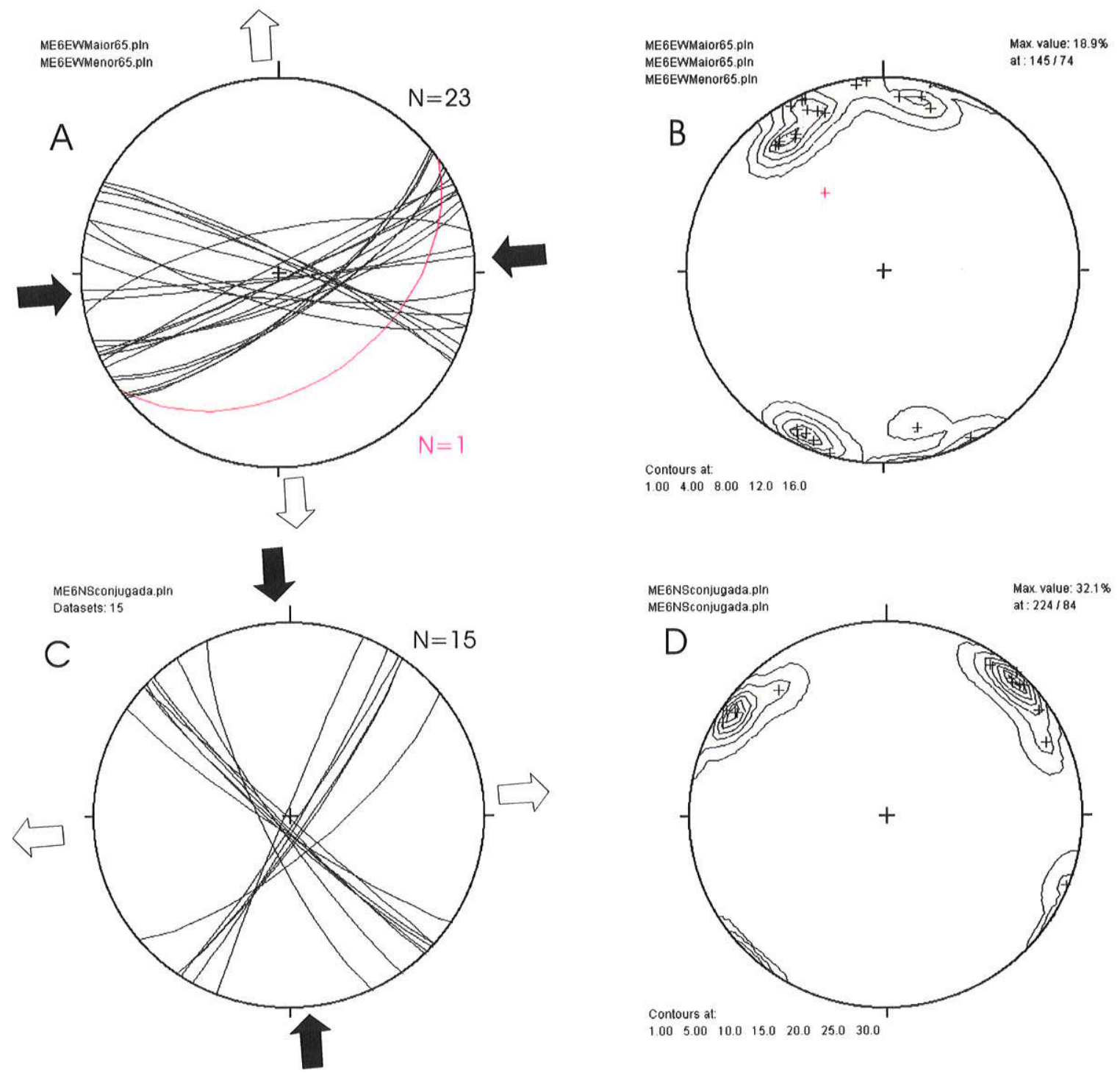

Figura 4.21 - Projeções ciclográficas e polares mostrando as relações geométricas entre fraturas conjugadas de cisalhamento com ângulo de mergulho maior que 65 graus (preto) e juntas com ângulo de mergulho menor que 65 graus e maior que 40 graus (vermelho), para famílias de direção NE-SW a NW-SE (A e B) e NNW-SSE a NNE-SSW (C e D). As juntas afetam sienito. Setas grandes vazias indicam a posição de Shmin e setas grandes cheias indicam a posição de SHmax. Ver explanação no texto. Diagramas de Schimidt-Lambert, hemisfério inferior. Maciço do Mendanha, Ponto Me6. 

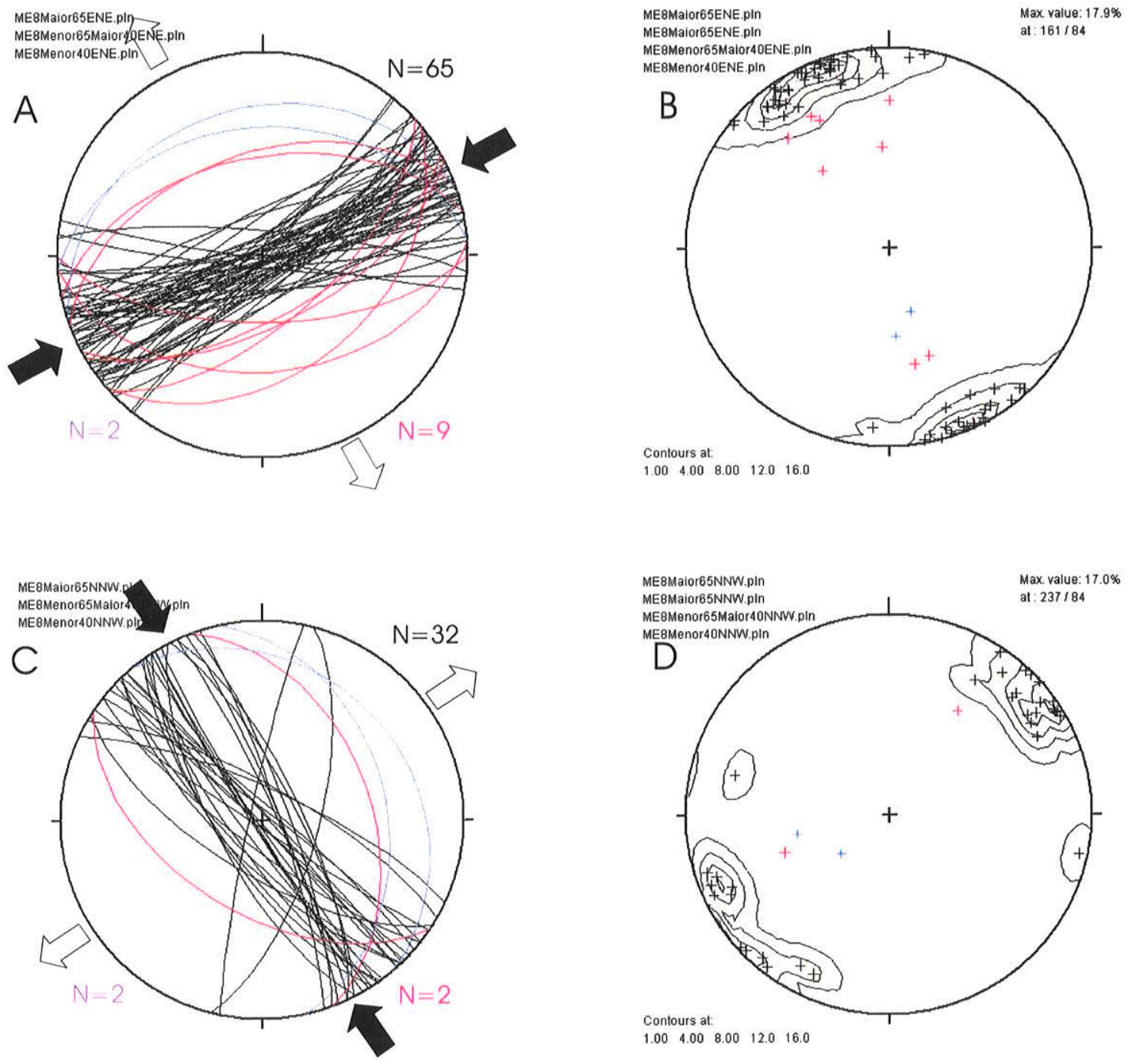

Figura 4.22 - Projeções ciclográficas e polares mostrando as relações geométricas entre fraturas conjugadas de cisalhamento com ângulo de mergulho maior que 65 graus (preto), juntas com ângulo de mergulho menor que 65 graus e maior que 40 graus (vermelho) e com ângulo de mergulho menor que 40 graus (azul), para famílias de direção NE-SW a ESE-WNW (A e B) e NW-SE a NNESSW (C e D). As juntas afetam sienito. Setas grandes vazias indicam a posição de Shmin e setas grandes cheias indicam a posição de SHmax. Ver explanação no texto. Diagramas de SchimidtLambert, hemisfério inferior. Maciço do Mendanha, Ponto Me8. 


\subsubsection{Juntas e Fraturas em Rochas Extrusivas}

Na Figura 22 estão representadas as projeções ciclográficas e polares das famílias de fraturas que afetam brecha vulcânica no Ponto ME7. Destacam-se duas famílias de fraturas com direção NE-SW, bem evidenciadas no diagrama de rosetas da Figura 4.23C, uma com mergulhos das fraturas alto, com caimento para SE e, outra, com valores de mergulho intermediários e caimento para NW. Essas duas famílias podem ser interpretadas como conjugadas, geradas em um campo de paleotensões normal, com o eixo de tensões máximo, $\sigma 1$, vertical, o eixo de tensões mínimo, $\sigma 3$, horizontal e com direção NW-SE e, o eixo intermediário, $\sigma 2$, também horizontal e ortogonal a $\sigma 3$. O deslocamento da bissetriz aguda entre as duas famílias de fraturas com relação à vertical estaria, de acordo com essa interpretação, relacionado com um adernamento dessas brechas vulcânicas para NW, após a geração das famílias de fraturas de direção NE-SW. As famílias de fraturas com direção variando em torno de NW-SE, parecem representar conjugadas de cisalhamento associadas a um eixo de tensões máximo, $\sigma 1$, horizontal e orientado na direção NW-SE, com o eixo de tensões mínimo, $\sigma 3$, também horizontal e orientado na direção NE-SW e o eixo intermediário, $\sigma 2$, vertical, correspondendo a um campo de paleotensões direcional. A presença de fraturas de direção NW-SE com ângulos de mergulho intermediários, indica variações locais/temporais no campo de paleotensões, com provável permutação de $\sigma 1 \mathrm{e}$ $\sigma 2$, entre um regime de paleotensões direcional e outro normal.

Uma síntese das paleotensões determinadas para o Maciço do Mendanha, a partir de juntas e fraturas, é apresentada na Tabela 4.2 e na Figura 4.24.

A análise dos dados apresentados permite caracterizar uma variação no campo de paleotensões que afetou o Maciço do Mendanha, na qual a direção de SHmax mudou do quadrante NE para o NW. No primeiro caso a direção de SHmax variou entre E-W e NESW, representando tanto o eixo de tensões máximo como o eixo intermediário, ligadas a um regime direcional ou extensional, respectivamente. Em ambos os casos essas fraturas são acompanhadas por hidrotermalismo mostrando sua contemporaneidade aos diques. $\mathrm{O}$ campo de paleotensões mais novo possui um SHmax de direção NW-SE, que corresponde principalmente ao eixo de tensões máximo associado a um regime direcional, apesar de também haver indicações de um aumento na magnitude da componente extensional e de permutações locais/temporais do eixo de tensões máximo para a posição vertical, gerando 

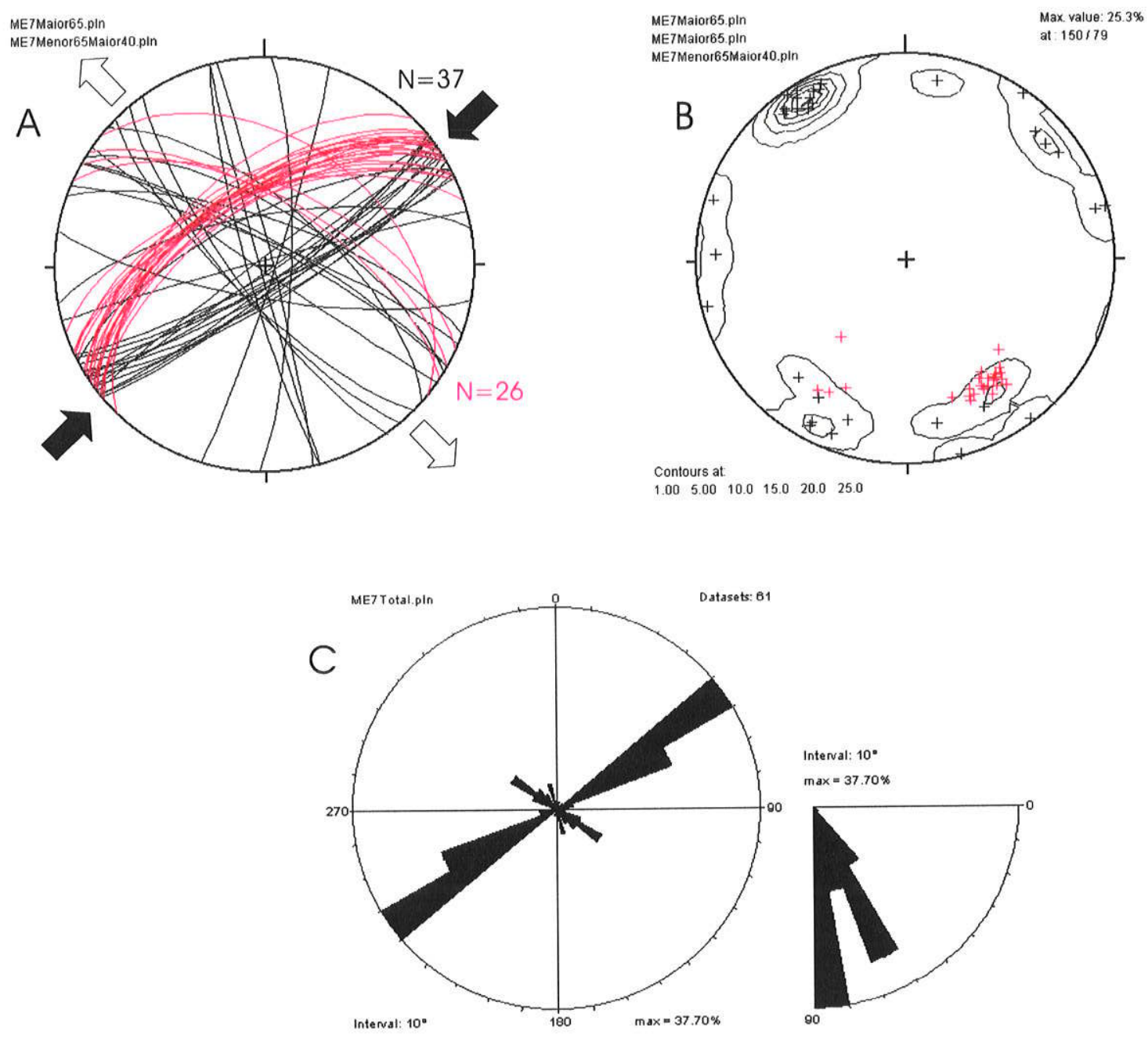

Figura 4.23 - Projeções ciclográficas, polares e diagrama de rosetas, mostrando as relações geométricas entre fraturas conjugadas de cisalhamento com ângulo de mergulho maior que 65 graus (preto) e juntas com ângulo de mergulho menor que 65 graus e maior que 40 graus (vermelho), para famílias que afetam brecha vulcânica. Setas grandes vazias indicam a posição de Shmin e setas grandes cheias indicam a posição de SHmax. Ver explanação no texto. Diagramas de Schimidt-Lambert, hemisfério inferior. Maciço do Mendanha, Ponto ME7. 


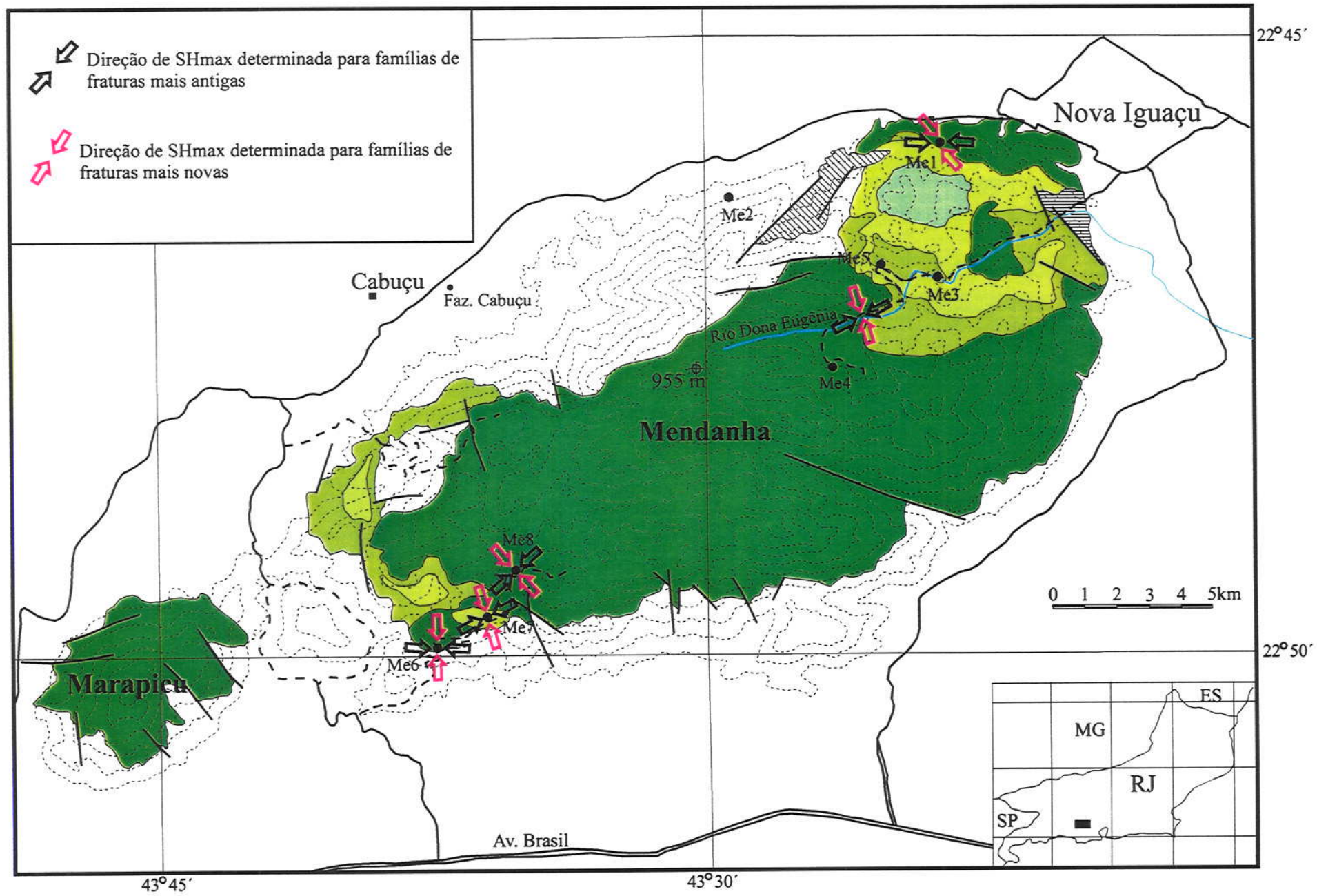

Figura 4.24 - Mapa síntese das paleotensões determinadas no Maciço do Mendanha, a partir de juntas e de fraturas sem estrias. Geologia de acordo com Klein (1992), com mesma legenda que a Figura 4.3. 
espectros de fraturas (Estação do Ponto ME8). As brechas vulcânicas são afetadas pelos dois campos de paleotensões, indicando que não houve um diacronismo acentuado entre a geração dos diques e o evento piroclástico.

\begin{tabular}{|c|c|c|c|c|c|}
\hline \multirow[t]{2}{*}{ Estações } & \multicolumn{2}{|c|}{$\begin{array}{l}\text { Pamílias de Fraturas } \\
\text { (direção de SHmax) }\end{array}$} & \multicolumn{2}{|c|}{ Tipos de Fraturas } & \multirow[t]{2}{*}{$\begin{array}{l}\text { Litologias } \\
\text { Afetadas }\end{array}$} \\
\hline & + antiga & tnova & + antiga & + nova & \\
\hline $\begin{array}{l}\text { Estação do Ponto } \\
\text { ME1 (Figura 18) }\end{array}$ & E-W & NW-SE & Extensão & Conj. Cis. & sienito \\
\hline $\begin{array}{l}\text { Estação dos } \\
\text { Pontos ME3, } 4 \text { e } 5 \\
\text { (Figura 19) }\end{array}$ & ENE-WSW & NNW-SSE & Conj.Cis. & Conj. Cis. & $\begin{array}{l}\text { sienito e } \\
\text { microssienito }\end{array}$ \\
\hline $\begin{array}{l}\text { Estação do Ponto } \\
\text { ME6 (Figura 20) }\end{array}$ & E-W & $\mathrm{N}-\mathrm{S}$ & Conj. Cis. & Conj. Cis. & sienito \\
\hline $\begin{array}{l}\text { Estação do Ponto } \\
\text { ME8 (Figura 21) }\end{array}$ & ENE-WSW & NNW-SSE & Espectro & Espectro & sienito \\
\hline $\begin{array}{l}\text { Estação do Ponto } \\
\text { ME7 (Figura 22) }\end{array}$ & NE-SW & NW-SE & Extensão & Conj. Cis. & brecha vulcânica \\
\hline
\end{tabular}

Tabela 4.2 - Síntese das paleotensões determinadas no Maciço do Mendanha, a partir de juntas e fraturas sem estrias.

\subsubsection{Análise Cinemática de Falhas e Microfalhas}

Os dados de falhas e microfalhas utilizados na análise cinemática foram coletados tanto no Maciço do Mendanha como nos diques associados a ele, que cortam o embasamento.

No caso do Mendanha os melhores dados foram obtidos na Pedreira Irmãos Vignê, onde pode ser muito bem caracterizado uma variação no campo de paleotensões, de normal para direcional. $O$ intenso hidrotermalismo identificado em ambas as famílias de falhas indica que elas são tardias à intrusão dos diques de traquito (cf. Figura 4.9). Por relações de corte pode-se inferir que as falhas direcionais são mais novas que as normais. As falhas direcionais, na Pedreira Irmãos Vignê, têm como característica particular a presença de degraus de fluorita, indicando o caráter sintectônico do hidrotermalismo.

No caso dos diques que cortam o embasamento, os dados referem-se a microfalhas identificadas tanto na sua borda como no interior. Em alguns casos essas microfalhas também são acompanhadas por hidrotermalismo, com presença de fibras de calcita ou de veios de calcedônia, indicando que elas foram geradas tardiamente à intrusão dos diques. 
Em ambos os casos, além das fibras e degraus acrescionários de minerais sintectônicos, os principais indicadores cinemáticos são as marcas de objetos, as facetas polidas e rugosas alternadas e as fraturas de cisalhamento sintéticas e antitéticas.

\subsubsection{Falhas e Microfalhas no Corpo do Mendanha}

Nas Figuras 4.25A e B estão representadas falhas e microfalhas normais e oblíquas que afetam sienito e traquito na Pedreira Irmãos Vignê, Ponto ME1. A inversão desses dados indicou que essas estruturas foram geradas em um campo de paleotensões EXTENSIVO Puro (Pure EXTENSIVE), onde o eixo de tensões principal, $\sigma 1$, é vertical, o eixo de tensões mínimo, $\sigma 3$, é horizontal e orientado na direção NNW-SSE, e o eixo intermediário, $\sigma 2$, é também horizontal e ortogonal a ele.

Nas Figuras $4.25 \mathrm{C}$ e D estão representadas falhas e microfalhas conjugadas de cisalhamento, onde as falhas de direção ENE-WSW e WNW-ESE representam as conjugadas sintéticas $\mathrm{R}$ e $\mathrm{P}$, respectivamente, e as de direção aproximadamente N-S representam as conjugadas antitéticas, $R^{\prime}$. A inversão desses dados indicou que essas falhas foram geradas em um campo de paleotensões DIRECIONAL Puro (Pure STRIKE$S L I P$ ), com o eixo de tensões máximo, $\sigma 1$, horizontal e orientado na direção NE-SW, o eixo de tensões mínimo, $\sigma 3$, também horizontal e orientado na direção NW-SE e o eixo de tensões intermediário, $\sigma 2$, vertical.

Nas Figuras 4.26A e B estão representadas microfalhas direcionais que afetam sienito e microssienito na estação constituída pelos Pontos ME3, 4 e 5. As microfalhas de direção ENE-WSW e NW-SE representam estruturas sintéticas R e P, respectivamente, e a de dirȩ̧ão NNW-SSE representa uma estrutura antitética, $R^{\prime}$. A inversão desse conjunto de dados indicou que as microfalhas foram geradas por um campo de paleotensões DIRECIONAL Puro (Pure STRIKE-SLIP), onde o eixo de tensões máximo, $\sigma 1$, é horizontal e orienta-se na direção ENE-WSW, o eixo de tensões mínimo, $\sigma 3$, é também horizontal e ortogonal a $\sigma 1$ e o eixo de tensões intermediário, $\sigma 2$, é vertical. 
A)

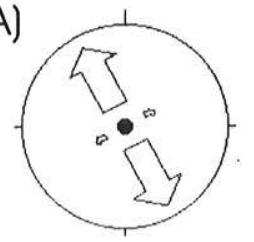

( ) $1: 77 / 295$

o2: $98 / 861$

б3: 18/152 Pure EXTENSIUE
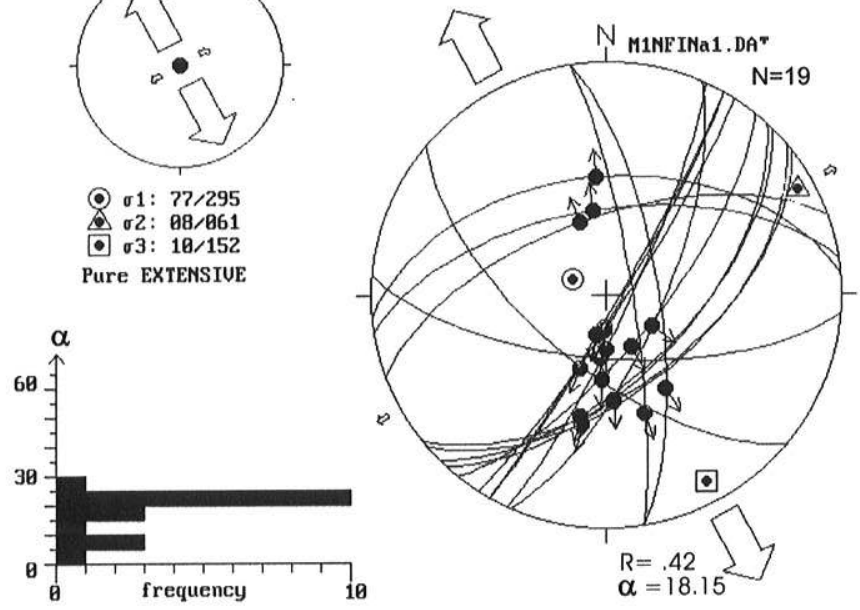

C)

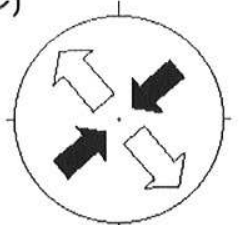

() 0ี1: $05 / 049$

0ิ2: $84 / 261$

ด อิ $3: 03 / 139$

Pure STRIKE-SL IP
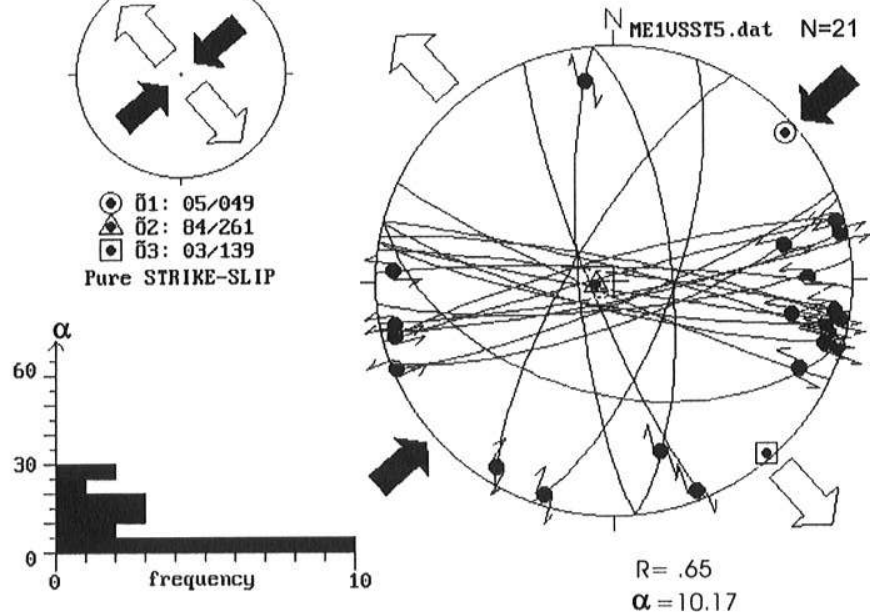

B)
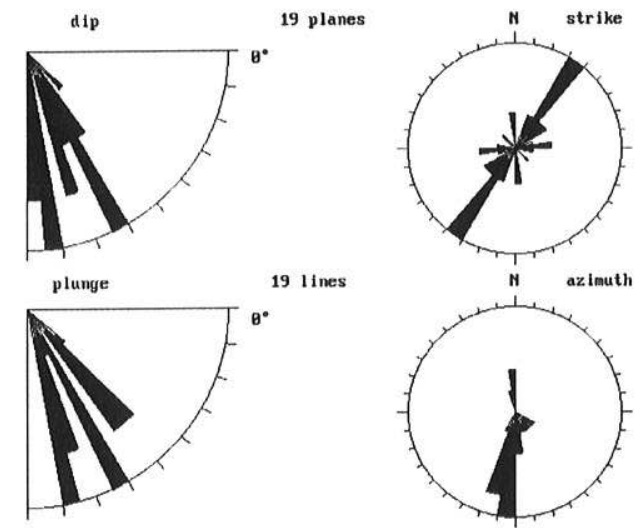

D)
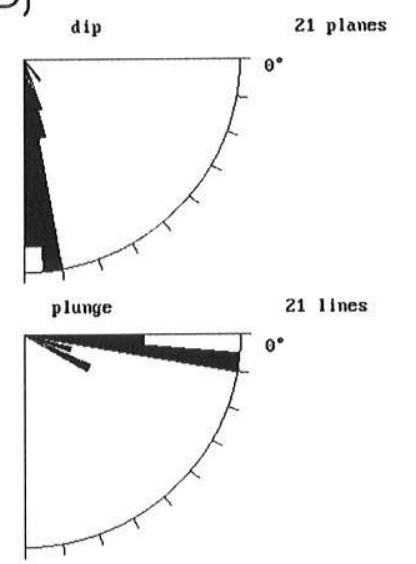

21 lines
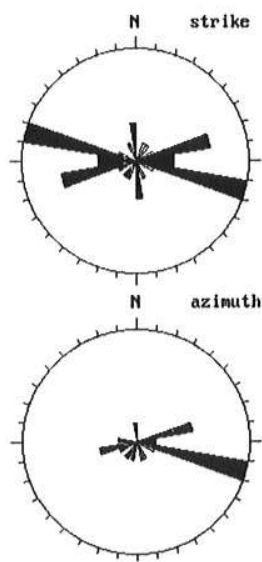

Figura 4.25 - Dados de falhas e respectivos eixos de tensões para o Maciço alcalino do Mendanha, Ponto Me1, Pedreira Vignê.Símbolos: círculos - $\sigma_{1}$ (eixo de maior esforço), triângulos - $\sigma 2$ (eixo de esforço intermediário), quadrados - $\sigma 3$ (eixo de menor esforço); $\mathrm{R}$ - razão de esforço ( $\sigma 2-\sigma 3 / \sigma 1-\sigma 3$ ); $\alpha$ - desvio médio entre as estrias medidas e e o cisalhamento computado sobre o plano de falha. Setas grandes cheias - eixos compressivos horizontais, setas grandes vazias - eixos distensivos horizontais. Projeções de Schmidt-Lambert, hemisfério inferior. 
A)

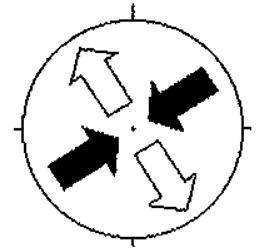

O o1: $89 / 237$

¿ $02: 81 / 069$

o3: $B 2 / 327$

Pure STRIKE-SLIP
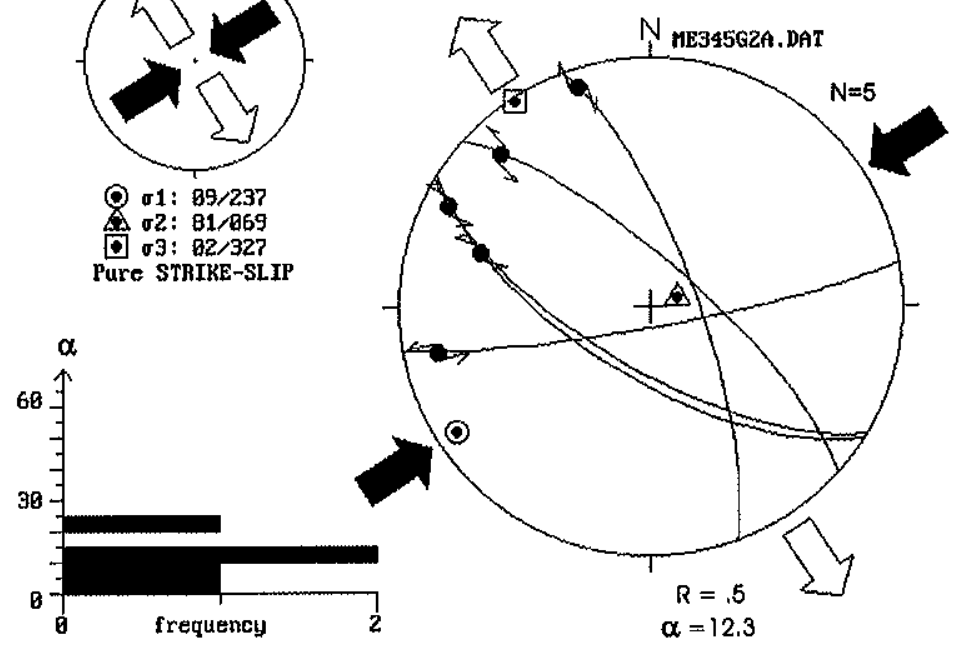

B)

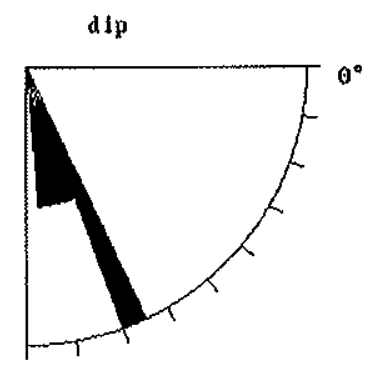

5 planes

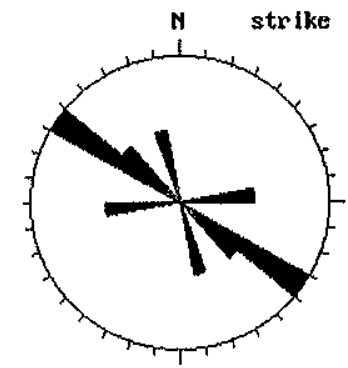

plunge

51 lnes

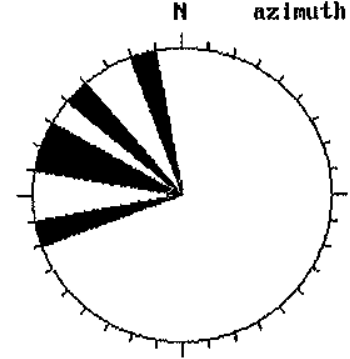

Figura 4.26 - Dados de microfalhas e respectivos eixos de tensões para o maciço do Mendanha, Pontos ME3, 4 e 5. Símbolos:círculos - $\sigma_{1}$ (eixo de maior esforço), triângulos - $\sigma_{2}$ (eixo de esforço intermediário), quadrados - $\sigma 3$ (eixo de menor esforço); $\mathrm{R}$ - razão de esforço $(\sigma 2-\sigma 3 / \sigma 1-\sigma 3) ; \alpha$ desvio médio entre as estrias medidas e o cisalhamento computado sobre o plano de falha. Setas grandescheias - eixos compressivos horizontais, setas grandes vazias - eixos distensivos horizontais. Projeções de Schmidt-Lambert, hemisfério inferior. 
4.2.4.2. Falhas e Microfalhas em Diques de Rochas Alcalinas que Cortam o Embasamento

A) Pedreira Santo Antônio

Na Figura 4.27 estão representadas microfalhas direcionais que afetam diques de rochas alcalinas máficas e félsicas na Pedreira Santo Antônio (Figura 4.5), Ponto ME2. As microfalhas de direção ENE-WSW e WNW-ESE representam estruturas sintéticas R e P, respectivamente. Apesar de não terem sido identificadas as estruturas conjugadas antitéticas, a inversão desses dados indicou que as microfalhas foram ativadas por um campo de paleotensões DIRECIONAL Puro (Pure STRIKE-SLIP), com o eixo de tensões principal, $\sigma 1$, posicionado na horizontal, segundo a direção NE-SW, o eixo de tensões mínimo, $\sigma 3$, posicionando-se também na horizontal e ortogonal a ele e o eixo de tensões médio, $\sigma 2$, posicionado na vertical.

B) Pedreira Bangu

As microfalhas que afetam diques de rochas alcalinas na Pedreira Bangu estão representados na Figura 4.28. Nas Figuras 4.28A e B estão representadas microfalhas direcionais, onde as de direção ENE-WSW e WNW-ESE representam estruturas sintéticas $\mathrm{R}$ e $\mathrm{P}$, respectivamente, e as de direção NNW-SSE representam estruturas antitéticas. A inversão desses dados evidenciou que esse conjunto de microfalhas foi ativado por um campo de paleotensões DIRECIONAL Puro (Pure STRIKE-SLIP), no qual o eixo de tensões máximo, $\sigma 1$, posiciona-se na horizontal e tem direção NE-SW, o eixo de tensões mínimo, $\sigma 3$, posiciona-se também na horizontal e tem direção NW-SE e o eixo de tensões intermediário, $\sigma 2$, é vertical. Nessa pedreira as falhas direcionais estão presentes nas bordas e internamente tanto dos diques de rochas alcalinas máficas e no traquito orbicular. 
A)

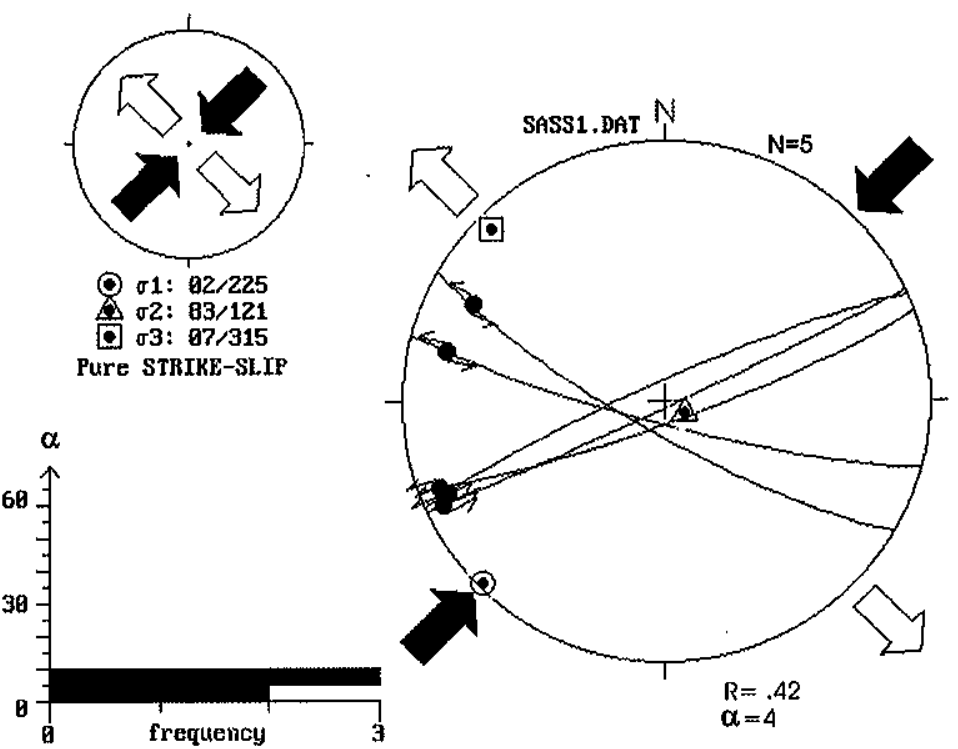

B)
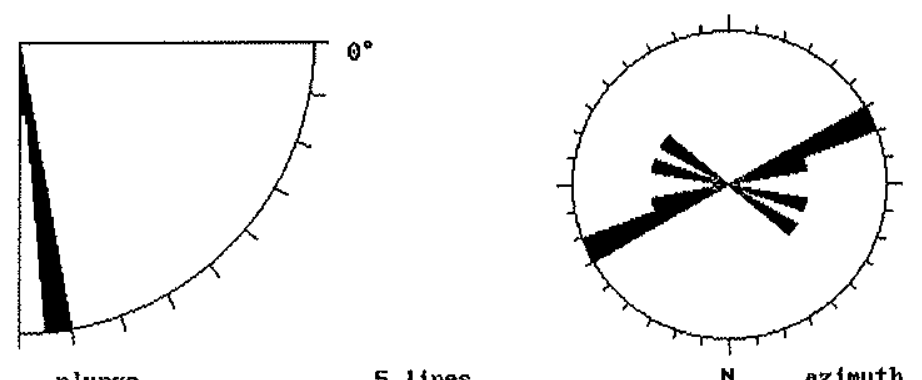

plunge

5 lines

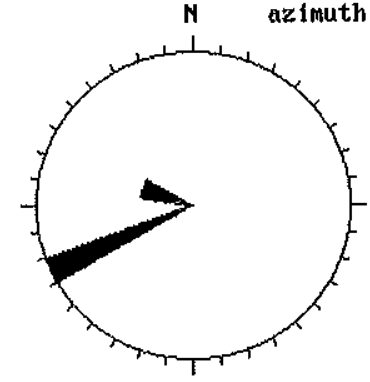

Figura 4.27 - Dados de microfalhas e respectivos eixos de tensões, afetando diques de rochas alcalinas, Pedreira SantoAntônio, Nova Iguaçu. Símbolos:círculos - $\sigma 1$ (eixo de maior esforço), triângulos $-\sigma 2$ (eixo de esforço intermediário), quadrados - $\sigma 3$ (eixo de menor esforço); R - razão de esforço $\left(\sigma_{2}-\sigma 3 / \sigma 1-\sigma 3\right) ; \alpha$ - desvio médio entre as estrias medidas e o cisalhamento computado sobre o plano de falha. Setas grandescheias - eixos compressivos horizontais, setas grandes vazias eixos distensivos horizontais. Projeções de Schmidt-Lambert, hemisfério inferior. 
A)

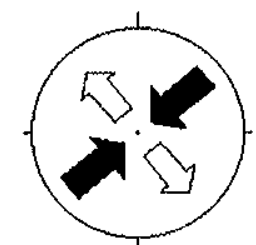

Q $01: 06 / 231$

o 02 : 81,005

03: $07 / 140$

Pure STRIKE-SLIP
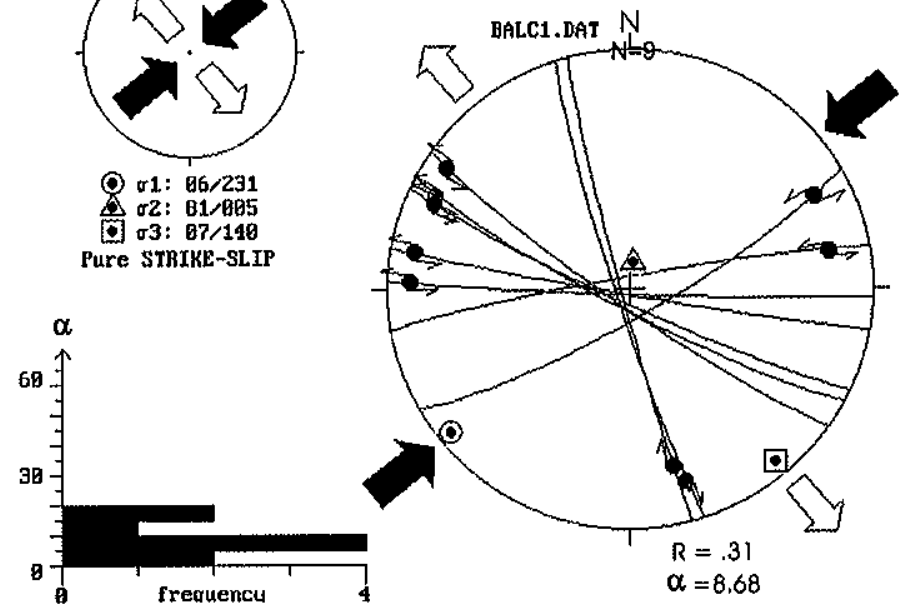

B)

dip

9 planes
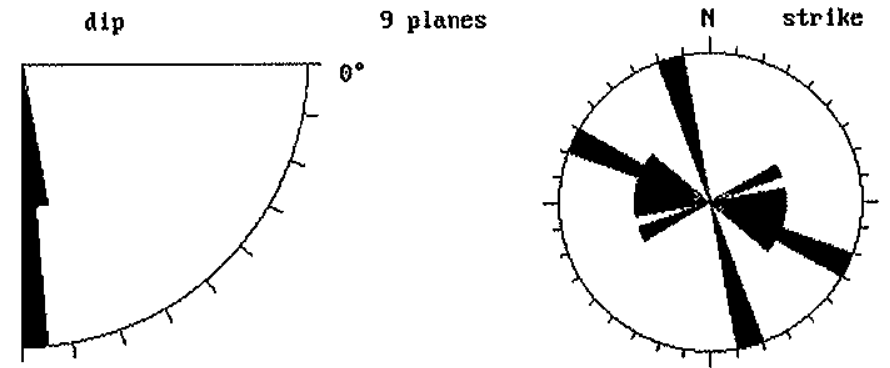

plunge

9 IInes
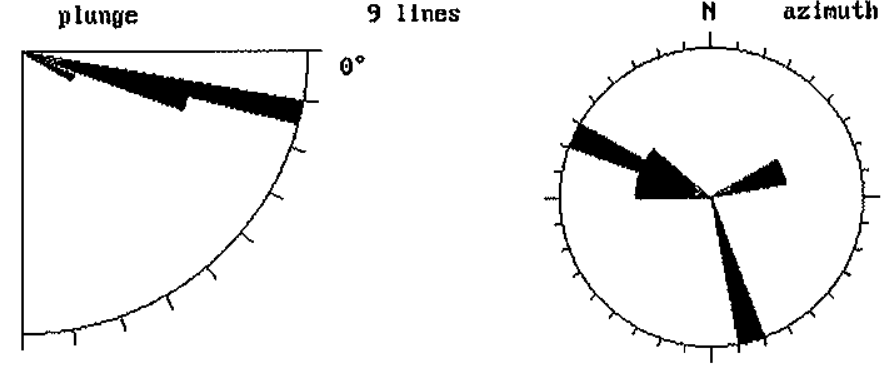

Figura 4.28 - Dados de microfalhas e respectivos eixos de tensões, afetando dique de traquito orbicular,Pedreira Bangu, bairro de Bangu, Ponto. Símbolos:círculos - $\sigma 1$ (eixo de maior esforço), triângulos $-\sigma_{2}$ (eixo de esforço intermediário), quadrados - $\sigma 3$ (eixo de menor esforço); R - razão de esforço $\left(\sigma_{2}-\sigma 3 / \sigma 1-\sigma 3\right) ; \alpha$ - desvio médio entre as estrias medidas e o cisalhamento computado sobre o plano de falha. Setas grandescheias - eixos compressivos horizontais, setas grandes vazias eixos distensivos horizontais. Projeções de Schmidt-Lambert, hemisfério inferior. 


\section{C) Pedreira Emasa}

As microfalhas que afetam diques de rochas alcalinas na Pedreira Emasa estão representadas nas Figuras 4.29A e B, na forma de estruturas de cisalhamento conjugadas de direção ENE-WSW, sinistrais, e NNE-SSW, dextrais. A inversão dessas estruturas indicou que elas foram ativadas em um campo de paleotensões DIRECIONAL Puro (Pure STRIKE-SLIP), onde o eixo de tensões máximo, $\sigma 1$, posiciona-se na horizontal e tem direção NNE-SSW, o eixo de tensões mínimo, $\sigma 3$, posiciona-se também na horizontal e tem direção WNW-ESE e o eixo de tensões intermediário, $\sigma 2$, é vertical. Nessa pedreira essas estruturas afetam tanto diques de rochas alcalinas máficas como félsicas. Salienta-se que mesmo o dique de lamprófiro de direção NW-SE apresenta microfalhas de direção ENE-WSW, com rejeito sinistral (cf. Figura 4.9), indicando que a atuação desse campo de paleotensões é posterior à sua intrusão, ou seja, é mais nova do que $77 \mathrm{Ma}$ (cf. Tabela 1).

\section{D) Pedreira Simgra}

As microfalhas que afetam diques de rochas alcalinas na Pedreira Simgra estão representadas nas Figuras $4.30 \mathrm{~A}$ e $\mathrm{B}$, constituindo estruturas de rejeito direcional de direção ENE-WSW, E-W e NNE-SSW, onde as duas primeiras representam estruturas sintéticas, $\mathrm{R}$ e $\mathrm{P}$, respectivamente, e as últimas representam estruturas antitéticas. A inversão desses dados indicou que elas foram ativadas por um campo de paleotensões DIRECIONAL Puro (Pure STRIKE-SLIP), onde o eixo de tensões máximo, $\sigma 1$, posicionase na horizontal, orientando-se segundo a direção NE-SW, o eixo de tensões mínimo, $\sigma 3$, posiciona-se também na horizontal, na direção WNW-ESE e o eixo de tensões médio, $\sigma 2$, é vertical. Essas microfalhas afetam tanto diques de rochas alcalinas máficas como félsicas, com alto ângulo de mergulho (cf. Figura 4.6), estando presentes tanto na sua borda como no seu interior. Não foram identificadas microfalhas na borda do dique de traquito com baixo ângulo de mergulho (Figura 4.6, dique 2). 
A)

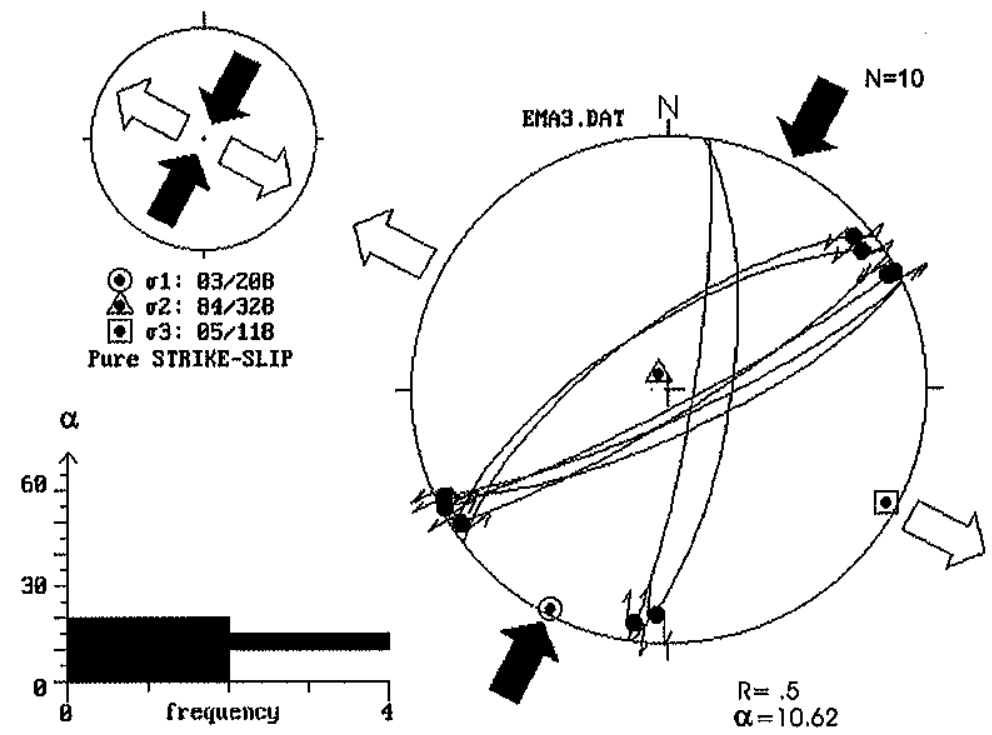

B)
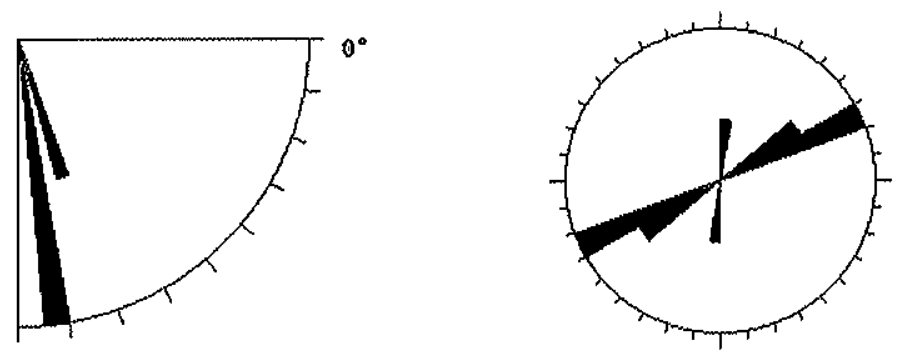

plunge

10 lines

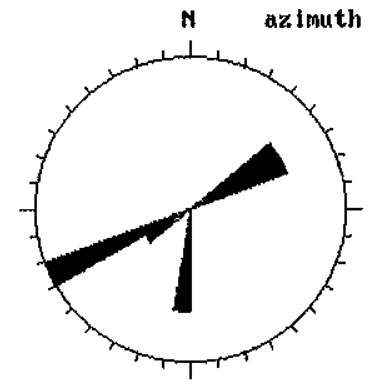

Figura 4.29 - Dados de microfalhas e respectivos eixos de tensões, afetando diques de rochas alcalinas, Pedreira Emasa, bairro de Bangu. Símbolos:círculos - $\sigma 1$ (eixo de maior esforço), triângulos $-\sigma 2$ (eixo de esforç̧o intermediário), quadrados $-\sigma 3$ (eixo de menor esforço); $R$ - razão

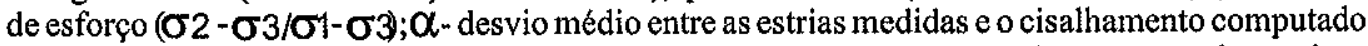
sobre o plano de falha. Setas grandescheias - eixos compressivos horizontais, setas grandes vazias eixos distensivos horizontais. Projeções de Schmidt-Lambert, hemisfério inferior. 
A)

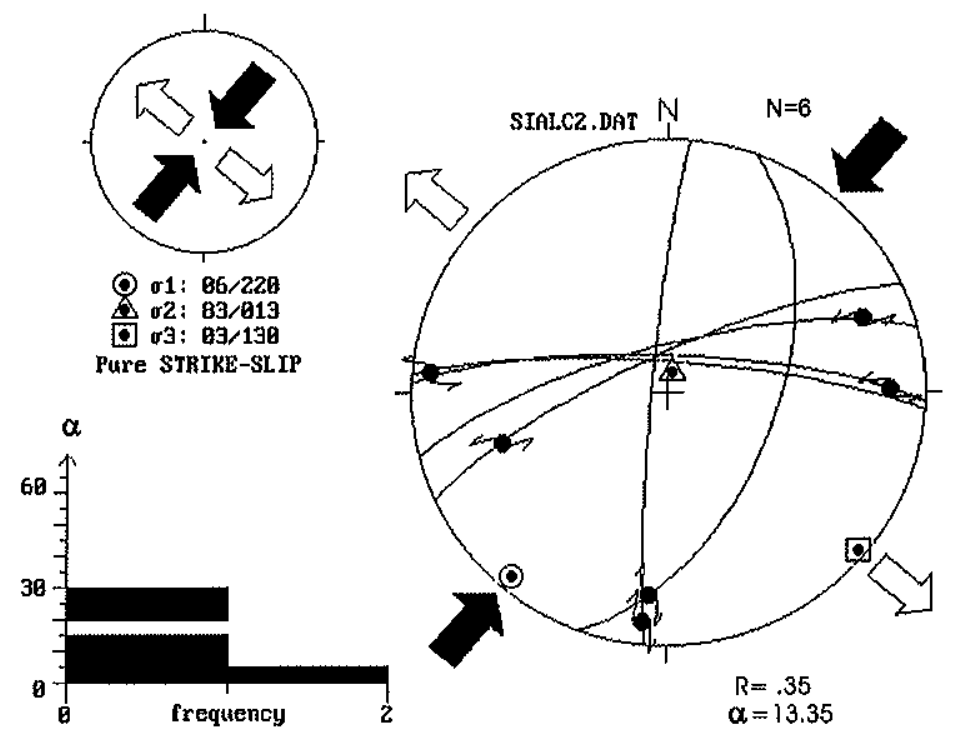

B)
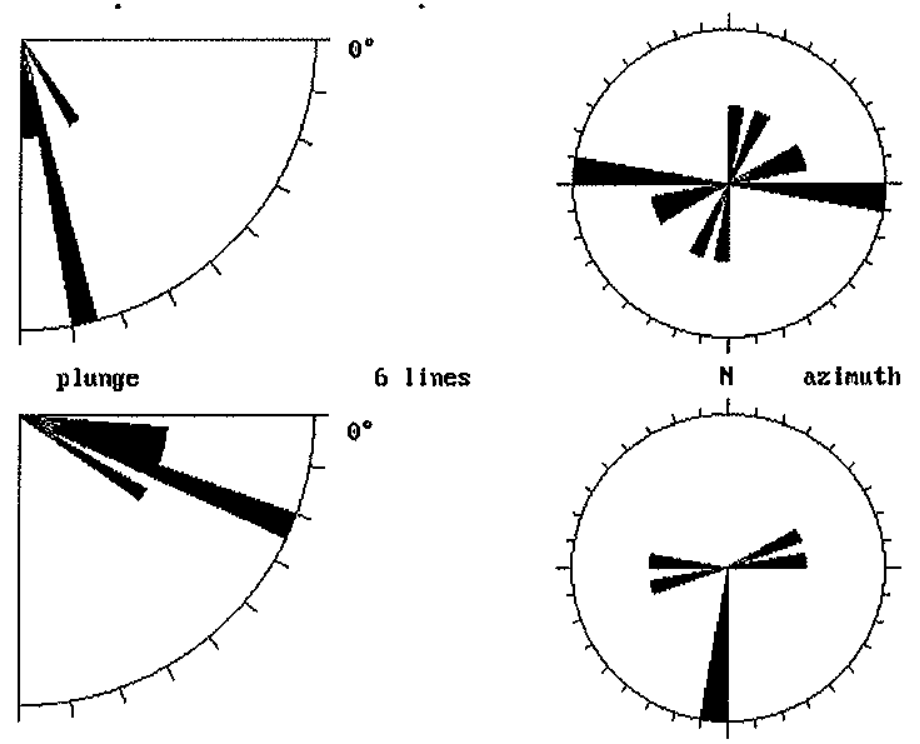

Figura 4.30 - Dados de microfalhas e respectivos eixos de tensões, afetando diques de rochas alcalinas, Pedreira Simgra, distrito de Pedra de Guaratiba. Símbolos:círculos - $\sigma 1$ (eixo de maior esforço), triângulos $-\sigma 2$ (eixo de esforço intermediário), quadrados $-\sigma 3$ (eixo de menor esforço); $\mathrm{R}$ - razão de esforço $\left(\sigma_{2}-\sigma_{3} / \sigma 1-\sigma 3\right) ; \alpha$ - desvio médio entre as estrias medidas e o cisalhamento computado sobre o plano de falha. Setas grandescheias - eixos compressivos horizontais, setas grandes vazias - eixos distensivos horizontais. Projeções de Schmidt-Lambert, hemisfério inferior. 


\subsubsection{Síntese das Paleotensões Determinadas na Porção Oeste do Graben da Guanabara}

Uma síntese das paleotensões determinadas para a área oeste do Graben da Guanabara, a partir dos diques de rochas alcalinas e de falhas e microfalhas, é apresentada a seguir.

Na Figura 4.31 estão representadas as direções de SHmax e de Shmin determinadas a partir dos diques de rochas alcalinas máficas, os quais apresentam orientação variando, predominantemente, entre NE-SW e E-W e mergulho alto, indicando que sua intrusão foi controlada por uma extensão de direção NW-SE a N-S. Os diques identificados em Barra de Guaratiba (Figura 4.31F) mostram uma orientação distinta dessa, na direção NNW-SSE, quase N-S, implicando numa extensão aproximadamente E-W. Em alguns casos esses diques apresentam escalonamento na vertical, indicando que essa era a posição do eixo de tensões máximo, $\sigma 1$, e que SHmax representa o eixo de tensões intermediário, $\sigma 2$, em um regime de esforços normal. Em alguns diques máficos tem-se a indicação de cinemática direcional acompanhada de hidrotermalimo, com geração de fibras de calcita, evidenciando uma variação no campo de paleotensões logo após a sua intrusão. Em Barra de Guaratiba essa evidência é reforçada pelo fraturamento helicoidal oblíquo aos diques. Nesse caso o eixo de tensões horizontal máximo, SHmax, passaria a representar o eixo de tensões máximo, $\sigma 1$, mantendo-se a sua direção NE-SW.

Na Figura 4.32 estão representadas as direções de SHmax e Shmin determinadas a partir dos diques de rochas alcalinas félsicas. Os diques félsicos mostram, também, uma orientação dominante voltada para o quadrante $\mathrm{NE}$, com direção variando entre $\mathrm{E}-\mathrm{W}$ e NNE-SSW, indicando que eles tiveram sua intrusão controlada por uma extensão WNWESE a N-S. A maior quantidade de diques apresentando mergulho intermediário, em torno de $65^{\circ}$, quando comparada com os máficos, indica que eles intrudiram sob um regime de tensões normal, provavelmente aproveitando fraturas preexistentes (cf. Figura 4.10). Nesse caso, também, o SHmax representa a direção do eixo de tensões intermediário, $\sigma 2$, e o eixo de tensões máximo, $\sigma 1$, posiciona-se na vertical. Essa relação foi muito bem caracterizada na Pedreira Irmãos Vignê (Figura 4.32E), onde a intrusão dos diques de traquito foi acompanhada por falhamentos normais (cf. Figura 4.10). Ainda nesse sentido, uma orientação distinta entre os diques félsicos e máficos foi identificada nas pedreiras Bangu e 
Bangu

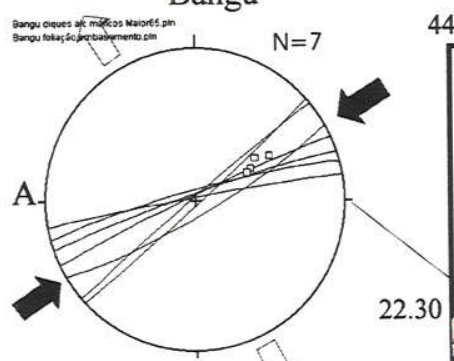

Emasa

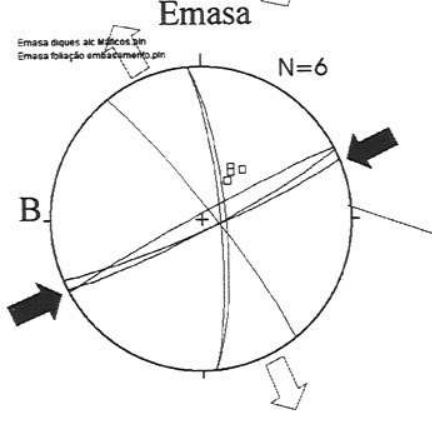

Sy

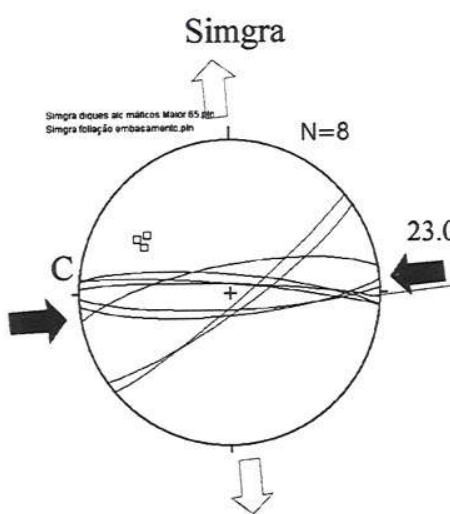

44.00

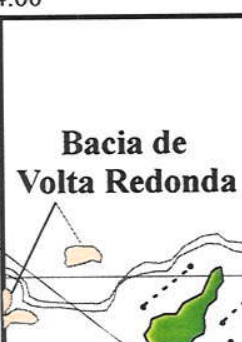

$0 \div$
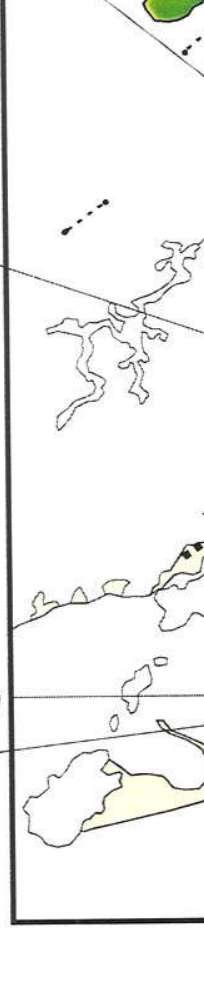

43.15

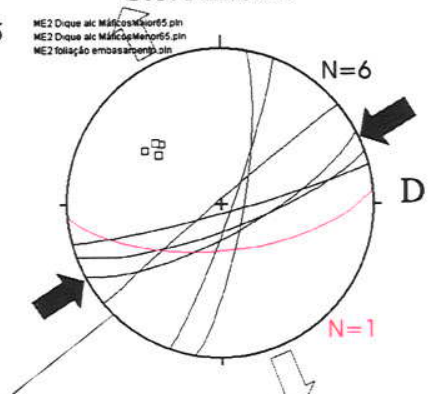

$\therefore \mathrm{B}$

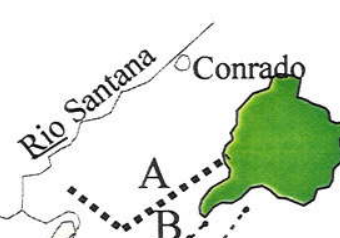<smiles>[13CH3][13CH3]</smiles><smiles>C1[C+]2CC12</smiles>

Miguel Pereira

...

$$
\text { - }
$$

Mendanha

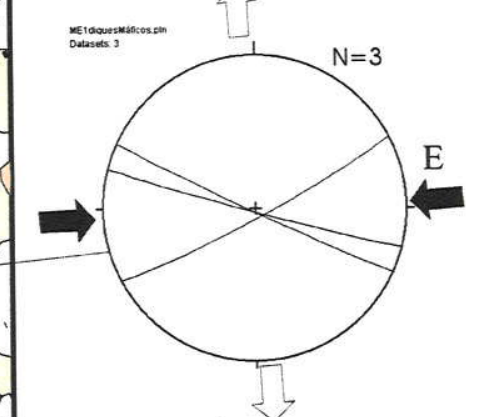

A.

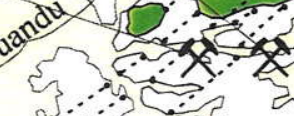

Nova

Itaguaí

Pedta de

Guaratiba

BAIA DE SEPETIBA

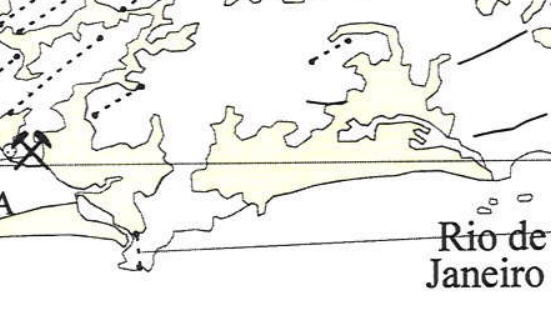

$5 \mathrm{~km} \quad 0 \quad 5 \quad 10 \quad 15 \quad 20 \quad 25$

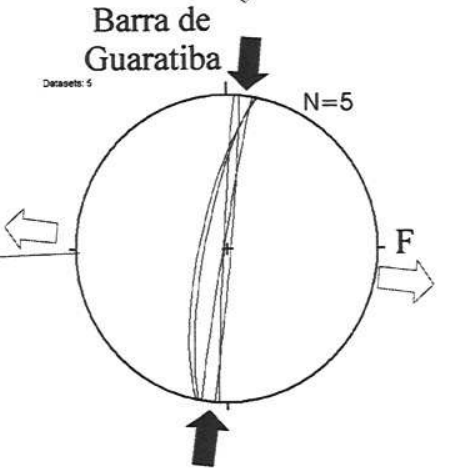

Figura 4.31 - Diques de rochas alcalinas máficas associadas ao Maciço do Mendanha, incluindo tanto os que cortam o maciço como os que atravessam o embasamento. As projeções ciclográficas em preto representam diques com ângulo de mergulho maior que 65 graus e, as em vermelho, diques com ângulo de mergulho entre 65 e 40 graus. Setas grandes vazias indicam a posicão do eixo de tensões mínimo, $\sigma 3$, e setas grandes cheias diques com ângulo de merção do eixo de tensões horizontal máximo, SHmax. Geologia de acordo com a Figura 1. Ver explanação no texto. 
Bangu

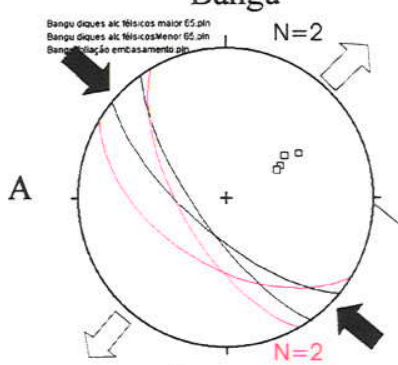

Emasa
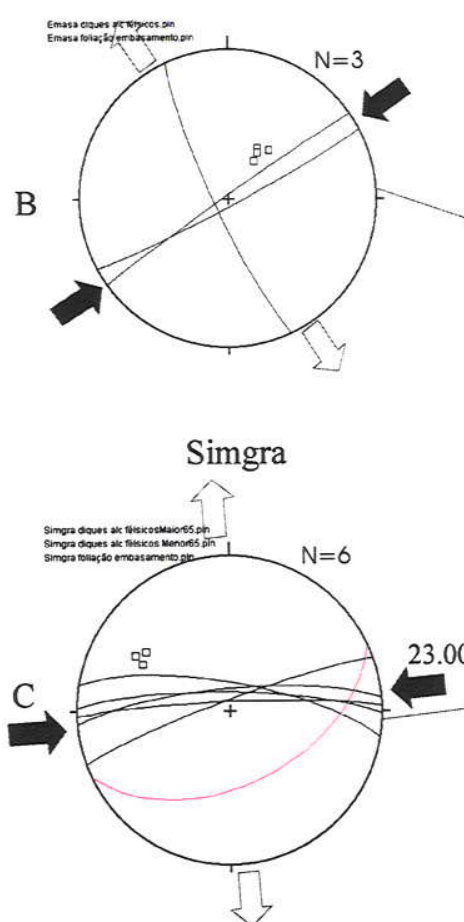

44.00

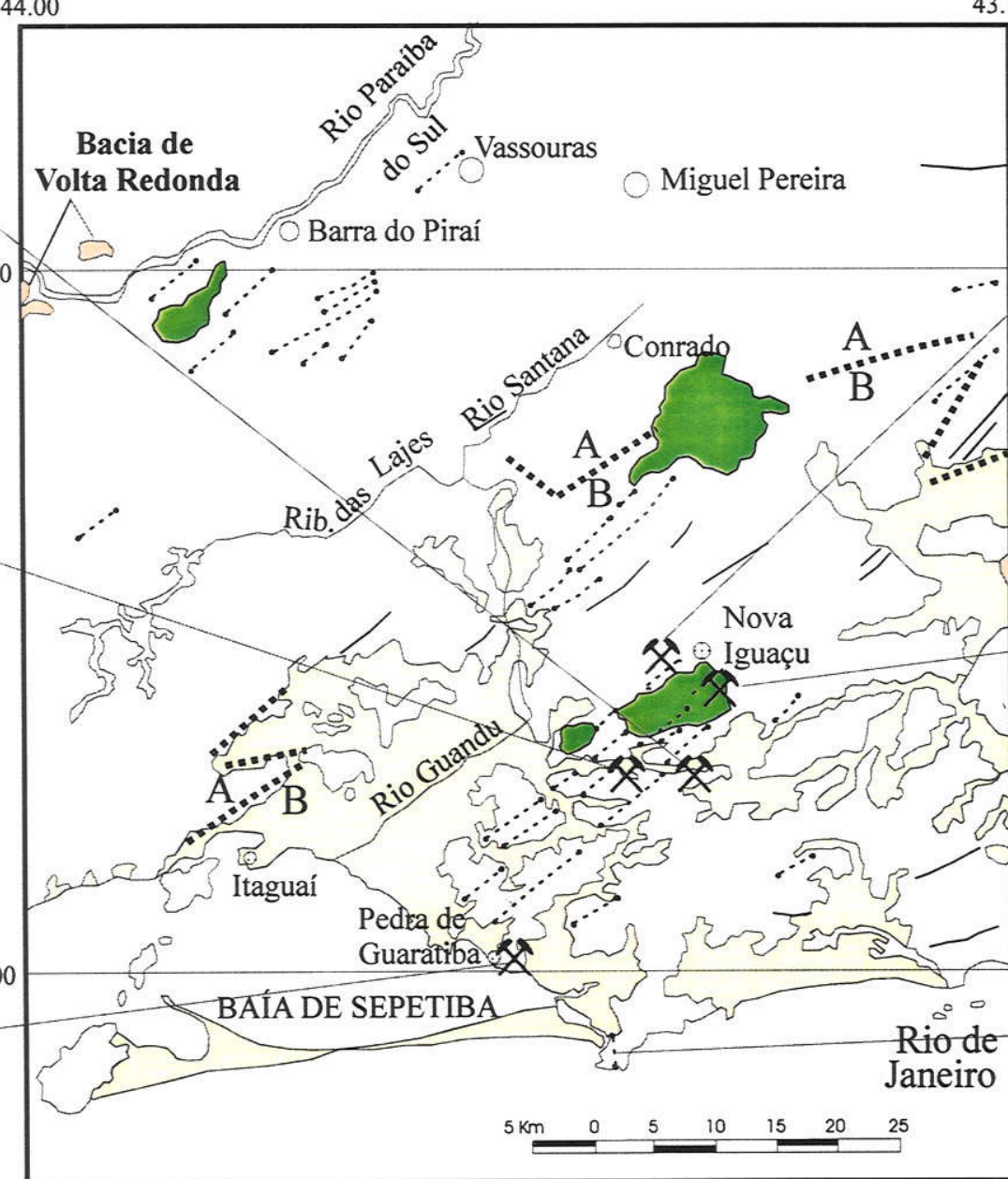

Sto. Antôni

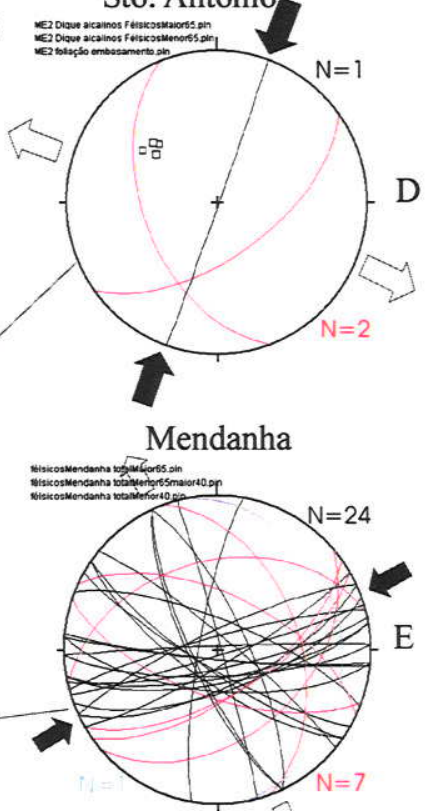

Barra de 4

Guaratiba

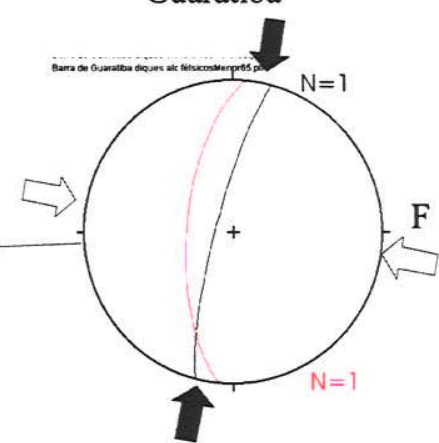

Figura 4.32 - Diques de rochas alcalinas félsicas associados ao Maciço do Mendanha, incluindo tanto os que cortam o maciço como os que atravessam o embasamento. As projeções ciclográficas em preto representam diques com ângulo de mergulho maior que 65 graus, as em vermelho representam diques com ângulo de mergulho entre $65 \mathrm{e} 40$ graus e, as em azul, os diques com ângulo de mergulho menor que 40 graus. Setas grandes vazias indicam a posicão do eixo de tensões mínimo, $\sigma 3$, e setas grandes cheias indicam a posição do eixo de tensões horizontal máximo, SHmax. Geologia de acordo com a Figura 4.2.Ver explanação no texto. 
Santo Antônio (Figuras 4.32A e D). Na primeira os félsicos têm direção NW-SE, subparalela à foliação das rochas encaixantes. Para os máficos essa relação não existe, uma vez que eles apresentam direção ENE-WSW e mergulhos altos, totalmente discrepantes da foliação das rochas do embasamento (Figura 4.31A). Na segunda essa relação é menos evidente, mas há um maior paralelismo entre os diques félsicos e a foliação das encaixantes. Nesses dois casos os diques félsicos representam o pulso magmático mais novo, o que pode indicar dois mecanismos distintos: 1) houve uma variação temporal no campo de tensões regional entre a intrusão dos diques máficos e dos félsicos, implicando na diminuição da tensão diferencial $(\sigma 1-\sigma 3)$. Essa variação implicaria em uma diminuição no controle efetivo das paleotensões remotas sobre a intrusão dos diques (Rickwood 1990), 2) os diques félsicos que ocorrem nas pedreiras Bangu e Santo Antônio, além da própria Pedreira Irmãos Vignê, intrudiram sob uma maior pressão de fluídos do que nas outras pedreiras, tendo em vista a maior proximidade dessas pedreiras com relação ao corpo intrusivo principal, levando a uma dispersão maior na atitude dos diques e adaptação às descontinuidades preexistentes (Jolly \& Sanderson 1995).

As estruturas "explosivas" associadas aos diques de traquito, reconhecidas por Valente (1997) e creditadas por ele a uma maior pressão de fluídos, podem respaldar a segunda hipótese. Por outro lado deve-se considerar que também os diques de rochas alcalinas máficas intrudiram sob uma alta pressão de fluidos, como evidencia o hidrotermalismo presente nas suas bordas e nas fraturas a eles associadas. Nesse sentido ainda, esse comportamento diferenciado dos diques félsicos, apesar de mais evidente nas porções mais próximas e internas ao corpo intrusivo principal, está presente num raio ainda maior. Dessa forma tal comportamento estaria relacionado não só às características do magma, mas, também, à menor profundidade da(s) câmara(s) magmática(s) que gerou ou geraram os diques mais evoluídos e que seria representada pela ascensão do corpo intrusivo do Mendanha. Essa câmara rasa causaria interferência no campo de paleotensões regional, tendo em vista o aumento "brutal" da pressão magmática em torno dela (Geoffroy et al. 1993). Assim, os diques félsicos estariam refletindo a interferência do campo de paleotensões local sobre o regional.

Na Figura 4.33 estão representadas as falhas e microfalhas que afetam o corpo intrusivo principal e os diques a ele associados. Os campos de paleotensões determinados 


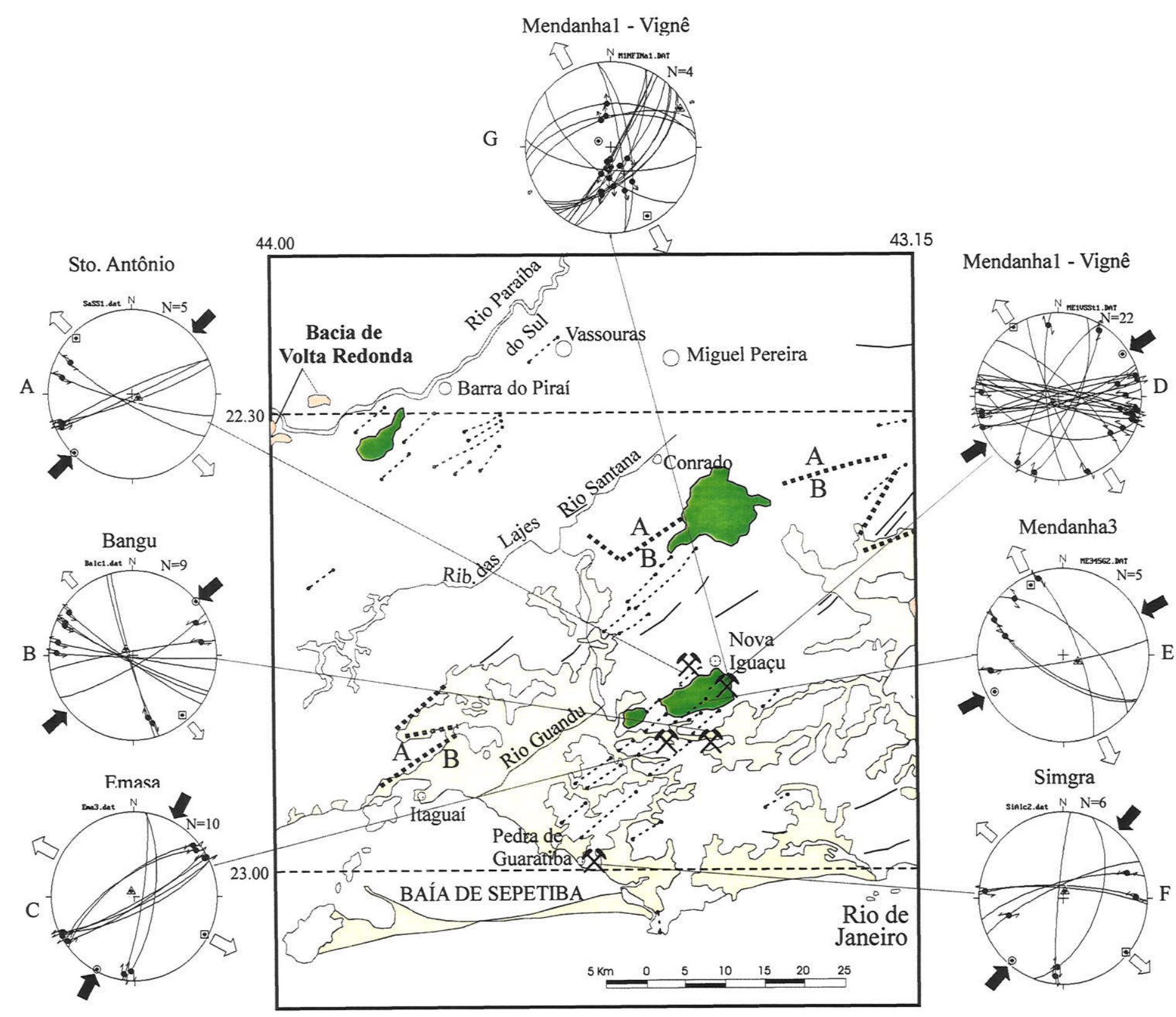

Figura 4.33 - Mapa síntese das paleotensões determinadas a partir de falhas e microfalhas que afetam o Maciço do Mendanha e os diques a ele associados. Nos estereogramas indica-se a posição dos três principais eixos de tensões, $\sigma 1$ (círculo), $\sigma 2$ (triângulo) e $\sigma 3$ (quadrado). Geologia de acordo com a Figura 1. 
mostram uma orientação de SHmax persistente, segundo a direção NE-SW. Nesse caso, esse SHmax representa principalmente o eixo de tensões máximo, $\sigma 1$, associado a um regime de paleotensões direcional puro. Na Pedreira Irmãos Vignê, pode-se caracterizar um campo de paleotensões extensional puro, responsável pela geração de falhas normais e oblíquas, onde esse SHmax representa o eixo de tensões intermediário, $\sigma 2$ (Figura 4.33H). Esse campo de paleotensões, que foi responsável pelo controle da intrusão dos diques de traquito, é anterior ao de regime direcional também registrado nesse local (Figura 4.33D). Nesse caso pode-se inferir uma diminuição temporal na magnitude do eixo de tensões vertical, $\sigma z$, passando de $\sigma 1$ para $\sigma 2$. A presença de microfalhas direcionais nas bordas e no interior dos diques de rochas alcalinas, máficas e félsicas, que cortam o embasamento proterozóico (Figuras 4.33A, B, C e F), estão associadas a esse campo de paleotensões mais novo, reforçando as evidências da diminuição da magnitude do eixo de tensões vertical. A presença de hidrotermalismo, com geração de degraus acrescionários de fluorita e fibras de calcita, nesse evento mais novo, indica que essa variação no campo de paleotensões deu-se logo após a intrusão dos diques. A presença constante de estruturas sintéticas $\mathrm{P}$ e o preenchimento dos planos de falhas e microfalhas por veios hidrotermais indica que esse campo de tensões direcional teve uma componente de extensão importante, tendo em vista que o desenvolvimento dessas estruturas demanda um alargamento da zona de falha (Gamond 1983, Wilcox et al. 1973). Essa característica foi indicada também, no caso da Pedreira Vignê, pela inversão dos dados de falhas e microfalhas (Figuras 4.25 e 4.33D), onde o valor de $\alpha$ ficou próximo do intervalo de um regime direcional extensivo $(0.75<\alpha<1.0)$.

As paleotensões determinadas a partir de juntas e fraturas sem estrias, obtidas apenas para o Mendanha, evidenciam também uma permutação dos eixos de tensões principal e intermediário, $\sigma 1$ e $\sigma 2$, ao longo do tempo, levando a uma mudança no regime de esforços de extensivo para direcional, mantendo-se a orientação de SHmax em torno da direção NE-SW (Figura 4.24). Esses dados indicam também que, após isso, houve uma variação de maior magnitude nas orientações de SHmax e Shmin, para NW-SE e NE-SW, respectivamente. Nesse caso, o SHmax representou principalmente o eixo de tensões máximo, $\sigma 1$, associado a um campo de paleotensões direcional. Esse evento não foi acompanhado pelo hidrotermalismo que caracterizou os dois primeiros, indicando uma atuação em um nível crustal mais superficial. 
Da mesma forma que para os diques, as paleotensões determinadas a partir de falhas e microfalhas estariam refletindo a interferência de um campo local sobre o regional. Esse campo local, representado pela intrusão do Mendanha, foi causado pelo aumento na pressão de fluídos, bem como do de $\sigma z$ em resposta ao soerguimento que acompanhou a intrusão. Com o resfriamento do corpo intrusivo, além da diminuição da pressão de fluidos, houve subsidência, acentuada pela erosão sofrida durante o soerguimento, levando a uma diminuição de $\sigma z$ e a implantação de uma campo de paleotensões direcional em âmbito regional.

\subsubsection{Conclusões Parciais}

As paleotensões determinadas a partir dos diques, de falhas e microfalhas e de juntas e fraturas sem estrias são coerentes em indicar que:

1) A intrusão dos diques e a geração de falhas e microfalhas foi controlada por uma extensão NW-SE, com o SHmax orientado na direção NE-SW. A maior dispersão apresentada pelos diques de rochas alcalinas félsicas, com adaptação local às estruturas preexistentes, está associada à atuação de um campo de paleotensões local gerado pela intrusão do Mendanha. Esse campo local implicou no aumento na pressão de fluídos e na magnitude do eixo de tensões vertical, $\sigma z$. As datações radiométricas disponíveis para esses diques $(82-72 \mathrm{Ma})$ posicionam a atuação desse campo de paleotensões no Campaniano;

2) Uma diminuição na magnitude do eixo de tensões vertical, $\sigma z$, em resposta à subsidência que acompanhou o resfriamento do corpo intrusivo principal, levou a uma permutação entre os eixos máximo e intermediário, $\sigma 1$ e $\sigma 2$, causando uma mudança no regime do campo de paleotensões, de extensivo para direcional. A contemporaneidade desse evento com intensa atividade hidrotermal indica que a sua atuação se deu logo após a intrusão dos diques, provavelmente no Maastrichitiano a Paleoceno;

3) Uma rotação nos eixos de paleotensões, com o eixo de tensões máximo, $\sigma 1$, orientando-se na direção NW-SE, foi identificado a partir da análise das juntas e 
fraturas sem estrias que afetam o Mendanha. A não caracterização de hidrotermalismo acompanhando esse evento indica que ele atuou em um nível crustal mais superficial. 


\subsection{AREA CENTRAL DO GRABEN}

Os corpos alcalinos da porção central do Graben da Guanabara nos quais foi realizada a análise do fraturamento (Figura 4.34), incluem um stock, o Corpo do Tanguá e seis plugs, sendo o maior deles a Suíte de Itaúna.

\subsubsection{Suíte de Itaúna}

A Suíte de Itaúna é um plug de rochas alcalinas que ocorre junto à borda NE da Baía da Guanabara, possui cerca de $9 \mathrm{~km}^{2}$ de área e é alongado na direção NE-SW (Figura 4.35). Ela constitui um maciço com altitude máxima de 280 metros, que se destaca em meio à planície flúvio-marinha holocênica, em grande parte ocupada por manguezais. As melhores exposições podem ser vistas no lado sudeste do maciço, onde, localmente, o solo foi retirado para aterro das áreas de mangue adjacentes, expondo a rocha já bastante alterada. O local do Ponto 1 foi o de onde mais se retirou material, constituindo uma pequena pedreira abandonada. A Suíte de Itaúna é constituída unicamente por rochas félsicas, como pseudoleucita microssienito e sienito, analcita-nefelina microssienito e sienito, fonolito, fonolito pórfiro e brecha fonolítica (Valença 1980, Dalcolmo et al. 1982). As brechas fonolíticas originalmente mapeadas por esses autores como brechas magmáticas, foram mais recentemente caracterizadas, em alguns locais, como brechas e tufos piroclásticos, com níveis de ignimbritos (Andreis et al. 1999, Klein et al. 1999), que estão presentes tanto no topo como nas encostas do maciço.

O embasamento da Suíte de Itaúna é constituído de gd-bi gnaisses migmáticos, da Unidade Santo Eduardo, e seus contatos são inferidos pela ocorrência de blocos de gnaisse (Dalcolmo et al. 1982).

As datações radiométricas disponíveis para a Suíte de Itaúna indicam idades entre 69 e $51 \mathrm{Ma}$. Uma análise radiométrica pelo método Ar-Ar, em dique de fonolito, obtida no presente trabalho, forneceu idade de $65,7 \mathrm{Ma}$, configurando um excelente platô (ver resultados das datações radiométricas no Anexo A). Todos os resultados disponíveis estão sintetizados na Tabela 4.3. 


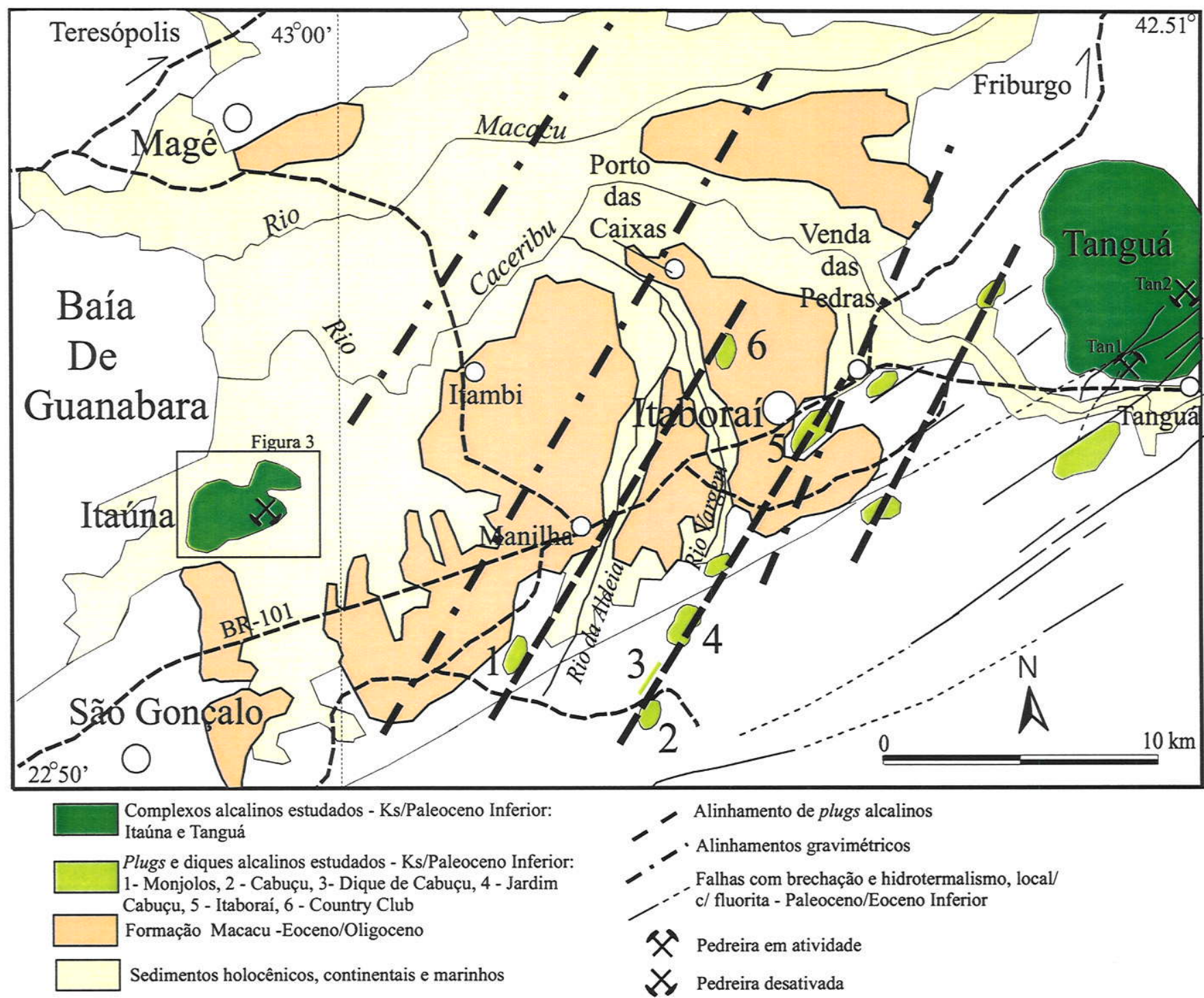

Figura 4.34 - Distribuição de corpos alcalinos na porcão central do Graben da Guanabara. Geologia modificada de Meis \& Amador (1977), Penha et al. (1979), Dalcolmo et al. (1982), Valença \& Klein (1984), Coelho et al. (1986), Ferrari (1990) e Dehira et al. (1998). Retângulo em torno do Maciço de Itaúna discrimina a localização da Figura 3. 


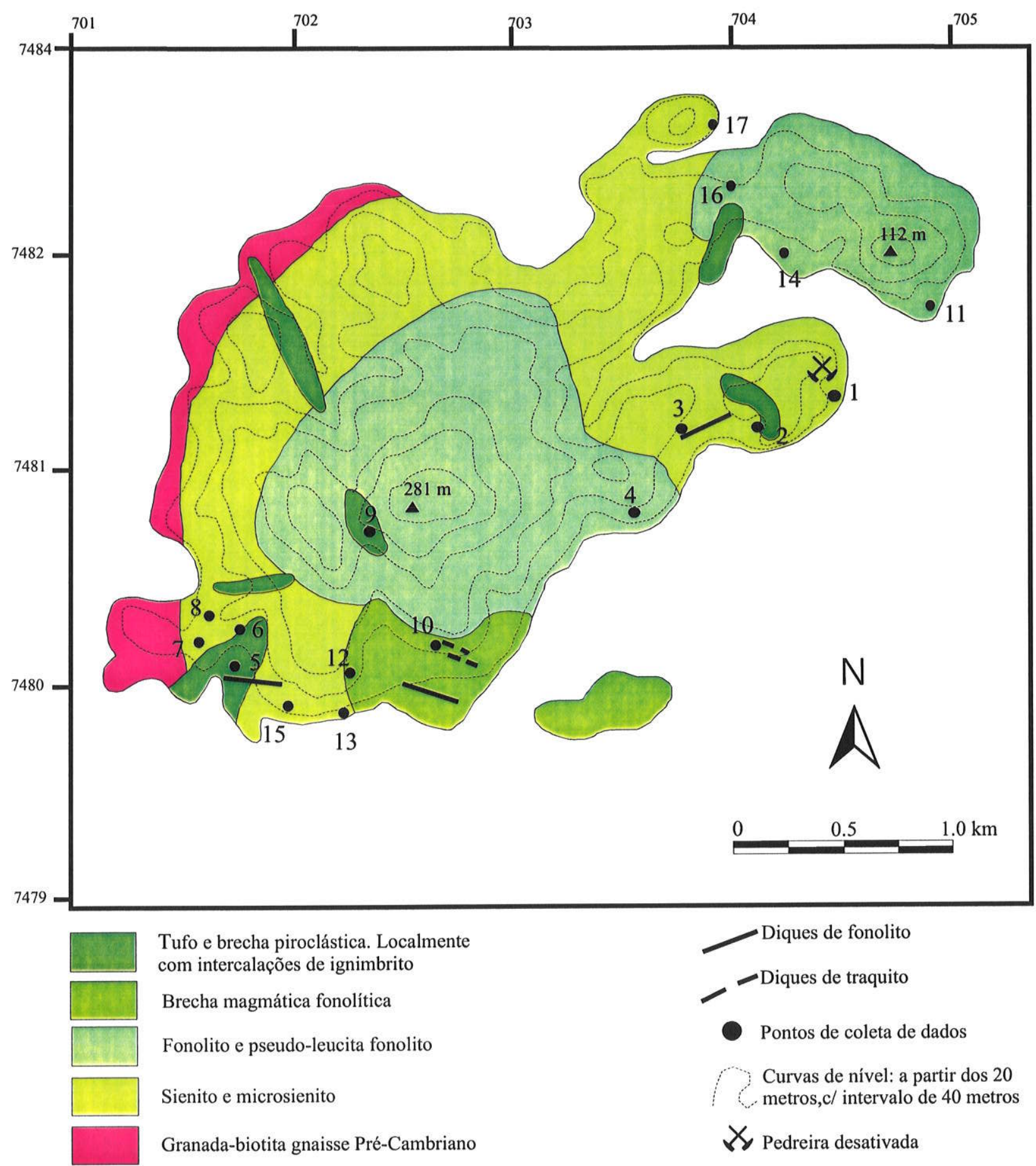

Figura 4.35 - Mapa geológico do Maciço de Itaúna, com os pontos de coleta de dados estruturais. Mapa simplificado e modificado de Valença (1980) e Dalcolmo et al. (1982). 


\begin{tabular}{|c|c|c|c|}
\hline Ainow & 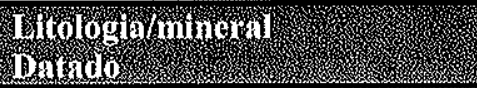 & Noworos & Resultados \\
\hline Sonoki \& Garda 1988 & $\begin{array}{l}\text { Microssienito/feld. K } \\
\text { Fonolito/rocha total } \\
\text { Sienito/feld. K }\end{array}$ & $\begin{array}{l}\mathrm{K} / \mathrm{Ar} \\
\mathrm{K} / \mathrm{Ar} \\
\mathrm{K} / \mathrm{Ar}\end{array}$ & $\begin{array}{l}50.9 \pm 1.6 \mathrm{Ma} \\
62.4 \pm 1.7 \mathrm{Ma} \\
69.4 \pm 2.2 \mathrm{Ma}\end{array}$ \\
\hline Esse trabalho & Dique de Fonolito/rocha total - $\mathbf{P}$ & $\mathrm{Ar} / \mathrm{Ar}$ & $65.7 \pm 0.7 \mathrm{Ma}$ \\
\hline
\end{tabular}

Tabela 4.3 - Datações radiométricas disponíveis para a Suíte de Itaúna. P - platôs

\subsubsection{Rochas Piroclásticas}

As rochas vulcânicas expostas no Maciço de Itaúna têm suas melhores exposições no Ponto Ita9, posicionado a uma cota de 200 metros, onde se assentam sobre fonolito (Figura 4.35). Nesse local, as brechas e tufos piroclásticos evidenciam diversos pulsos vulcânicos que configuram camadas horizontais distintas (Figura 4.36A). Em outros locais, as rochas piroclásticas assentam sobre sienito e microssienito, como nos pontos Ita2 e Ita5. Em algumas das camadas que afloram no Ponto Ita9 registra-se a presença de deformações do acamamento por blocos de fonolito balisticamente lançados (bomb sags), denotando uma deformação de caráter plástico (Figura 4.36B). Tais deformações plásticas são indicadoras de que elas se tratam de rochas vulcânicas hidroclásticas (Fisher \& Schmincke 1994) constituindo, nesse caso, depósitos piroclásticos basais (base surge deposits). Esses depósitos exigem a presença de água intersticial, apontando para explosões sob pequena lâmina d'água ou ao nível do lençol freático. Diques de fonolito cortam as rochas piroclásticas, como pode ser visto no Ponto 5 (Figura 4.35), indicando que o pacote de rochas extrusivas foi parcialmente erodido.

\subsubsection{Diques}

Quase todos os diques caracterizados referem-se àqueles que cortam o maciço (Figura 4.34). Foram identificados 7 diques cortando o maciço, 4 de fonolito e 3 de traquito e um dique de fonolito cortando o embasamento. Esses diques possuem direção entre WNW-ESE e ENE-WSW, mergulho alto e espessura decimétrica a métrica. Os mais 
A)

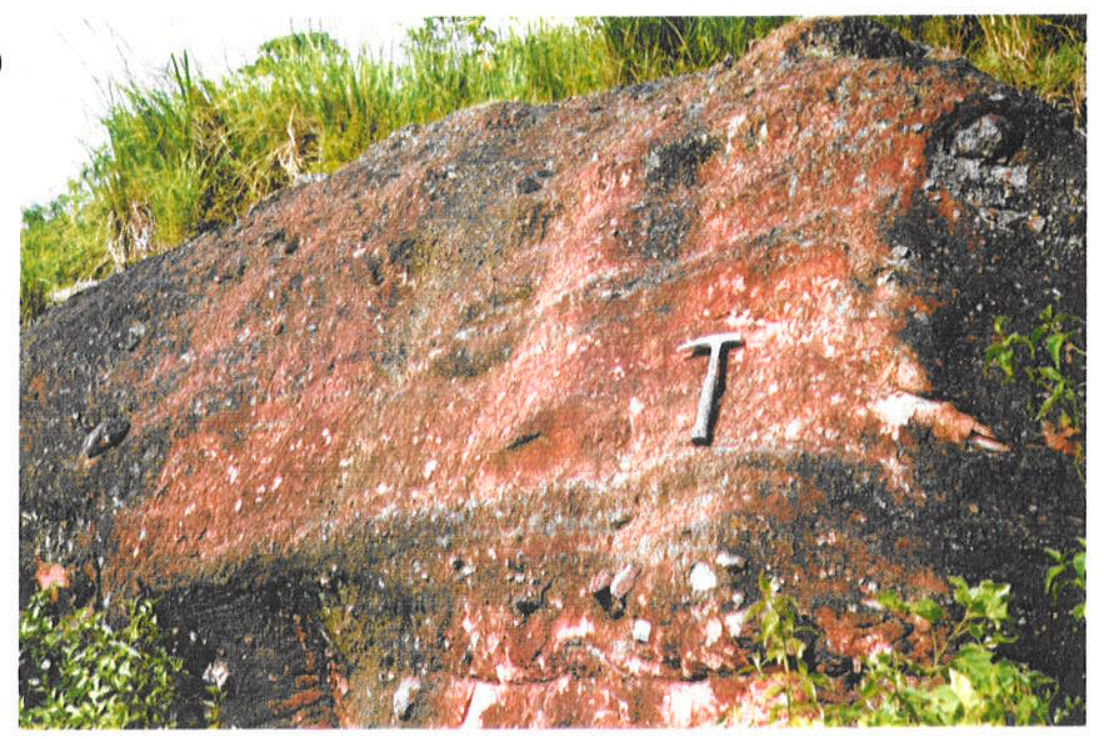

B)

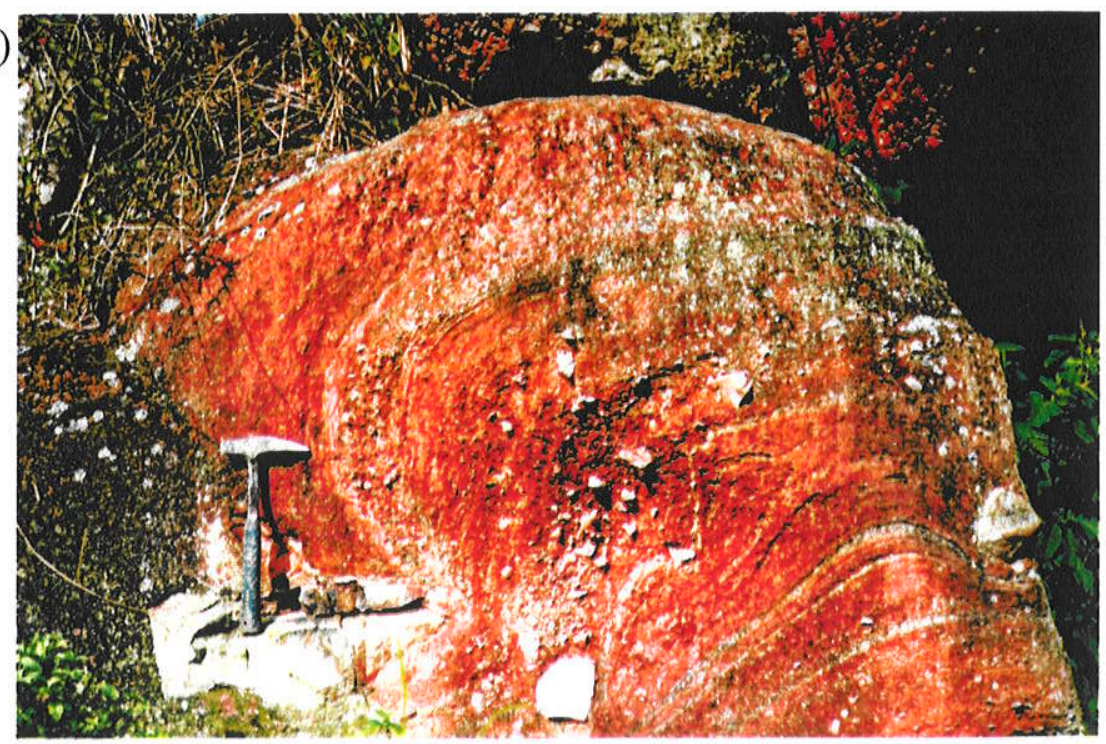

Figura 4.36 - Tufos e brechas piroclásticas intercaladas. Em A vê-se pacote de cerca de 3 metros de espessura, com blocos decimétricos de fonolito e um bloco métrico de brecha piroclástica, no canto esquerdo inferior. Em B tem-se detalhe do afloramento evidenciando deformações do acamamento (bedding sag) por blocos de fonolito balisticamente lançados. A deformação causada pelo bloco sobre o qual está apoiado o martelo, indica que o seu lançamento se deu da esquerda para a direita na foto (de oeste para leste no afloramento). Maciço de Itaúna, Ponto Ita 9. 
espessos são os de fonolito que ocorrem nos Pontos 3 e 5, que alcançam cerca de 3 metros de espessura. Não foram vistas relações de corte entre os fonolíticos e os traquíticos. $\mathrm{O}$ dique de fonolito do Ponto 5, que tem atitude 80/005 e textura afanítica, quase vítrea, corta tufos e brechas vulcânicas. Ele foi datado pelo método Ar-Ar, em rocha total, e forneceu um excelente resultado, constituindo um platô muito bem caracterizado (Tabela 4.3).

Os diques identificados estão representados na Figura 4.37. Eles mostram uma variação na orientação entre ENE-WSW e WNW-ESE, com uma pequena concentração na direção WNW-ESE. Considerando-se a orientação média dos diques pode-se posicionar o eixo de tensões mínimo, $\sigma 3$, ortogonalmente a ela, na direção N-S, e o eixo de tensões horizontal máximo, SHmax, paralela a ela, na direção E-W.

\subsubsection{Juntas e Fraturas}

Os dados tratados como fraturas referem-se tanto a fraturas de extensão, como a fraturas híbridas e fraturas conjugadas de cisalhamento. Nesse último caso elas constituem microfalhas, porém sem estrias claramente evidenciadas. Elas foram separadas, no campo em famílias de fraturas, tendo como base suas relações geométricas. Deu-se atenção às relações de "corte", com base na maior ou menor continuidade das famílias de fraturas (Hancock 1985), buscando-se caracterizar a sua cronologia relativa. Os dados coletados foram reunidos em dez estações, procurando compatibilizar domínios homogêneos pelas suas características estruturais, a proximidade geográfica e as litologias afetadas.

As diversas famílias de fraturas identificadas puderam ser separadas em dois grandes grupos, um mais antigo, com famílias orientadas segundo o quadrante NE-SW, variando entre E-W e NNE-SSW, e outro, mais novo orientado segundo o quadrante NWSW, variando entre N-S e WNW-ESE. Esses dois grupos, por sua vez, foram separados em sub-grupos, um com fraturas com ângulo de mergulho maior que $65^{\circ}$, constituído por famílias conjugadas de cisalhamento e por espectros de fraturas, no sentido de Hancock (1994), e outro com fraturas com ângulo de mergulho menor ou igual a $65^{\circ}$. 


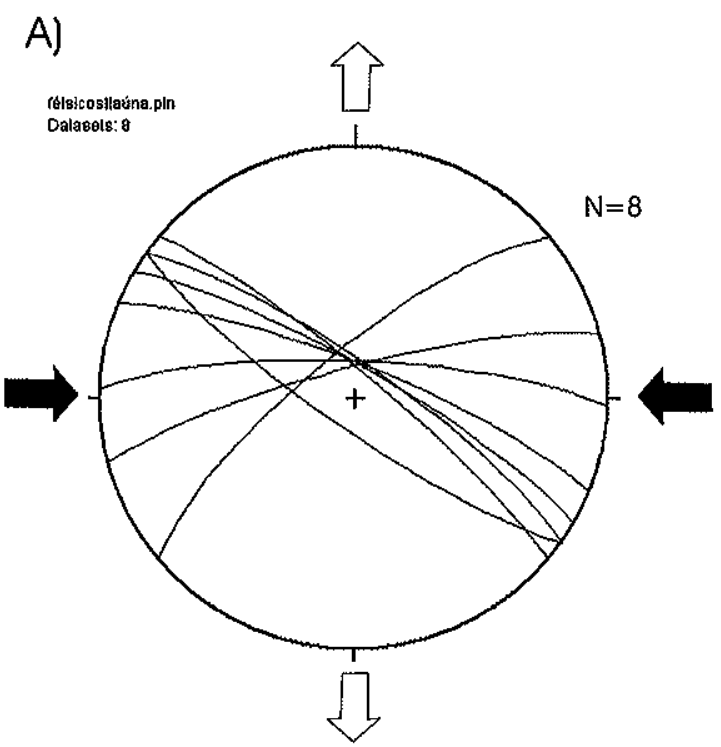

B)

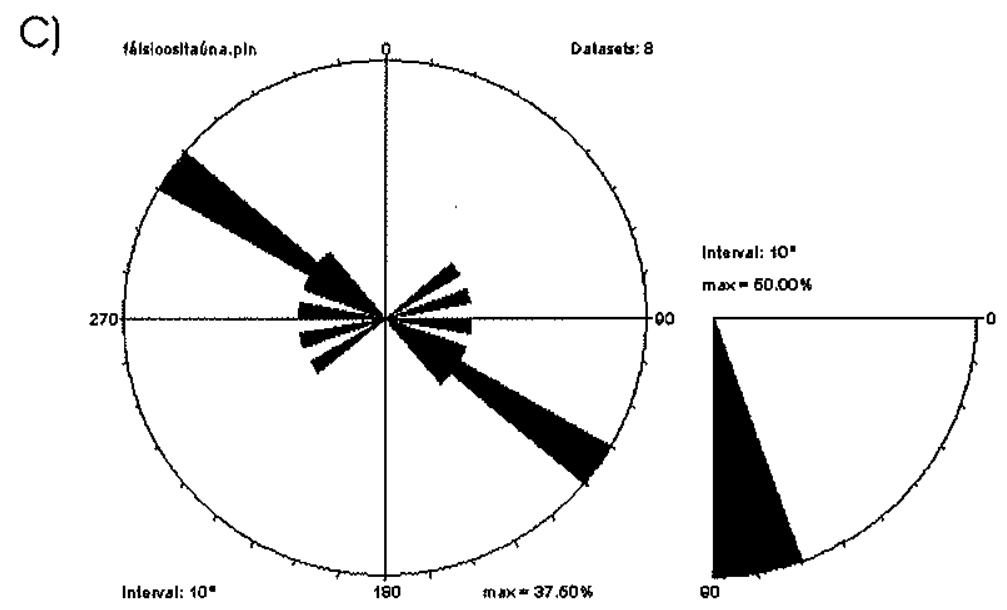

Figura 4.37 - Projeções ciclográficas e polares, e diagramas de rosetas, mostrando as direções e os mergulhos de diques de rochas alcalinas félsicas, traquitos e fonolitos, do Plug de Itaúna. A concentração dos diques WNW-ESE, permite posicionar o eixo de tensões horizontal mínimo, $\sigma 3$ (setas vazias), na direção WNW-ESE, e o eixo horzontal máximo, SHmax (setas cheias), na direção NNE-SSW. Diagramas de Schmidt-Lambert, hemisfério inferior. 
Nas falhas e microfalhas em que foi possível visualizar as estrias e caracterizar seu sentido de movimento, determinou-se os eixos de paleotensões principais, $\sigma 1 \geq \sigma 2 \geq \sigma 3$, a razão de esforço, $R$, e o valor de $\alpha$.

\section{A) Análise Geométrica}

As fraturas foram analisadas separadamente para rochas intrusivas e vulcânicas, com o intuito de caracterizar eventuais variações temporais no campo de tensões. Por outro lado, procurou-se melhor caracterizar as relações geométricas entre as fraturas com alto ângulo de mergulho $\left(>65^{\circ}\right)$, com ângulo de mergulho intermediário $\left(\leq 65^{\circ}\right.$ e $\left.>40^{\circ}\right)$ e as com baixo ângulo de mergulho $\left(\leq 40^{\circ}\right)$, plotando-as em conjunto, considerando que as fraturas de baixo ângulo poderiam ter sido geradas tanto em um regime compressivo, como em um regime distensivo.

\section{A.1) Juntas e Fraturas em Rochas Intrusivas}

Nas Figuras 4.38, 4.39 e 4.41, estão representadas fraturas que afetam rochas intrusivas de granulação média a grossa, microssienitos e sienitos, respectivamente.

A Figura 4.38 mostra fraturas caracterizadas no Ponto 1, em uma pequena pedreira abandonada. As famílias de fraturas de alto ângulo orientadas segundo a direção NE-SW a E-W, as mais antigas, têm suas projeções ciclográficas representadas nas Figuras 4.38A e C, e suas projeções polares, nas Figuras 4.38B e D. Da mesma forma, as fraturas de alto ângulo orientadas na direção NW-SE a N-S, mais novas, estão representadas ciclograficamente nas Figuras 4.38E e G, e suas representações polares são vistas nas Figuras $4.38 \mathrm{~F}$ e H. As famílias de fraturas de baixo ângulo, que se orientam nas direções E-W e N-S, foram plotadas, alternadamente, com os dois conjuntos de famílias de alto ângulo. As famílias de alto ângulo com direção NE-SW a E-W apresentam concentrações nas direções NNE-SSW, E-W e NE-SW. As duas primeiras parecem representar fraturas conjugadas de cisalhamento, $\mathrm{R}$ e $\mathrm{R}^{\prime}$, e as de direção NE-SW, mais numerosas, representariam fraturas extensionais, T. Nesse caso, a direção das fraturas T representa não apenas a direção do eixo horizontal de tensões máximo, SHmax, mas também a do eixo de 

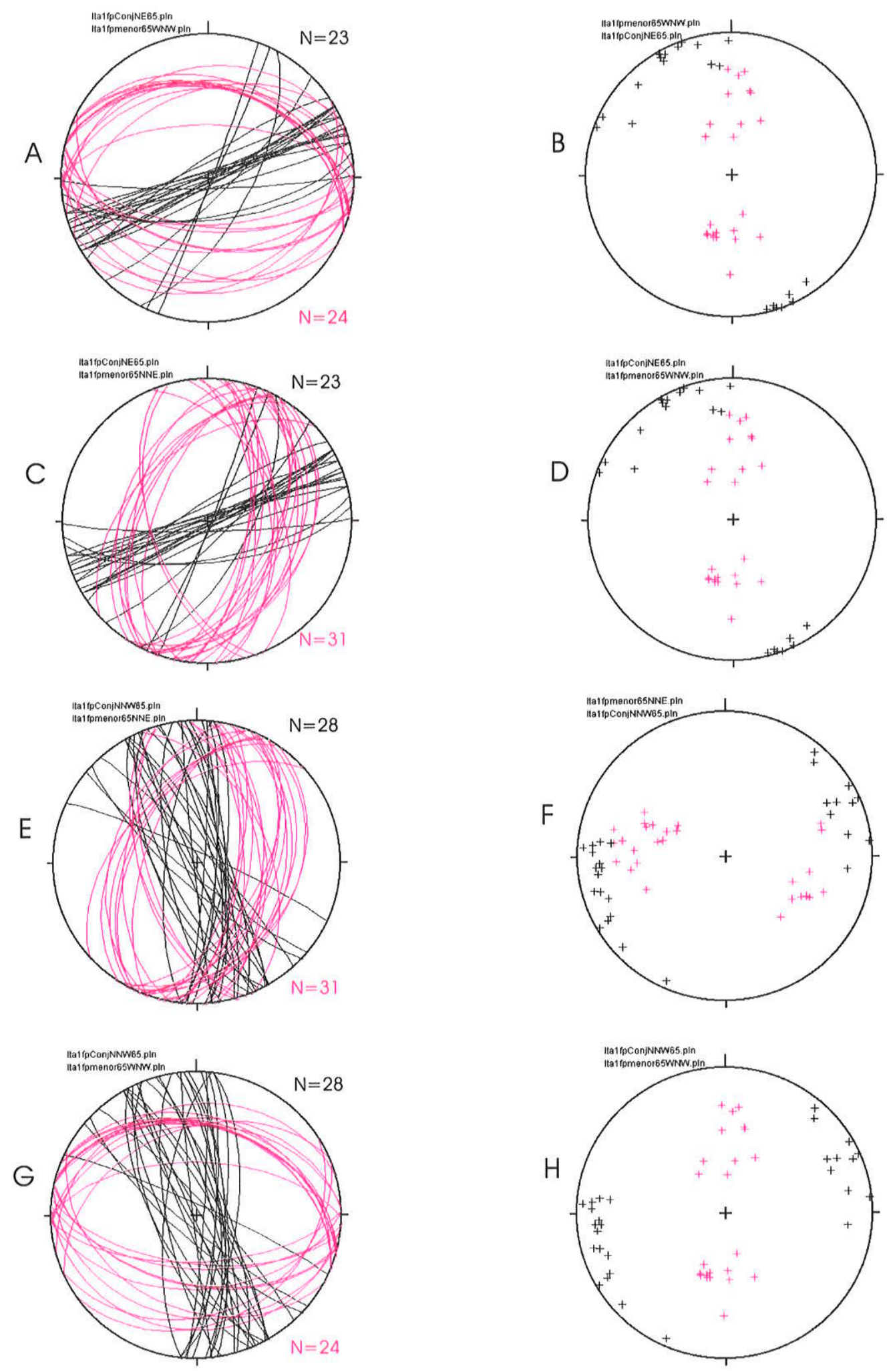

Figura 4.38 - Projeções ciclográficas e polares mostrando as relações geométricas entre juntas conjugadas de cisalhamento com ângulo de mergulho maior que 65 graus (famílias de direção NE-SW e NW-SE ) e juntas conjugadas com ângulo de mergulho menor que 65 graus (famílias de direção NNE-WSW e WNW-ESE). Nos estereogramas A, B, E e F, as juntas de baixo ângulo de mergulho são representadas como tendo sido geradas em um regime normal de esforços, e nos estereogramas $\mathrm{C}, \mathrm{D}, \mathrm{G}$ e H, elas são representadas como tendo sido geradas em um regime de esforços reverso. Ver explanação no texto. Diagramas de Schimidt-Lambert, hemisfério inferior. Itaúna, Ponto 1 , microssienito e sienito. 
tensões principal, $\sigma 1$. As fraturas de alto ângulo de direção NW-SE a N-S representam um espectro de fraturas, no sentido de Hancock (1994), tendo em vista a distribuição contínua de fraturas conjugadas de cisalhamento, fraturas híbridas e fraturas de extensão. Nesse caso, a posição mediana do espectro, de direção NNW-SSE, representa a direção de SHmax, podendo corresponder a $\sigma 2$ ou $\sigma 1$. A relação entre as famílias de fraturas de alto e de baixo ângulo não é clara, já que não se tem uma relação de paralelismo ou ortogonalidade entre eles, que pudessem sugerir tratar-se de fraturas geradas em regime extensional (Figuras 4.38A, B e E, F) ou reverso (Figuras $4.38 \mathrm{C}, \mathrm{D}$ e G, H), respectivamente.

Na Figura 4.39 estão representadas ciclograficamente e em projeção polar dois grupos distintos de famílias de fraturas de alto ângulo, relativos à estação levantada no Ponto 3. O mais antigo, de direção E-W, representa características famílias de fraturas conjugadas de cisalhamento, com $\sigma 1$ posicionado na direção $\mathrm{E}-\mathrm{W}$, coincidindo com a bissetriz do ângulo agudo entre as famílias de direção ENE-WSW e WNW-ESE (Figuras 4.39A, B, C, D e Figura 4.40). O grupo de famílias de fraturas de alto ângulo de direção N$\mathrm{S}$, mais novo, representa um espectro de fraturas (Figuras 4.39E, F, G, H), onde o eixo de tensões horizontais máximo, SHmax, estaria posicionado na direção N-S. As relações geométricas entre os grupos de famílias de fraturas de alto e de baixo ângulo sugerem que as de baixo ângulo podem tratar-se de fraturas de extensão geradas nos mesmos campos de tensões que geraram o grupos de fraturas de alto ângulo, como pode ser visto nas Figuras 4.39A, B, para as famílias de direção E-W, e Figuras 4.39E, F, para as famílias de direção N-S. No caso das fraturas mais antigas, de direção E-W, essa relação exige uma troca de posições entre $\sigma 1$ e $\sigma 2$, com a progressão da deformação. No segundo caso, essa alternância de posições entre os eixos de tensões principal e intermediário é ainda mais evidente, tendo em vista que as fraturas de alto ângulo constituem um espectro, sugerindo uma proximidade das magnitudes de $\sigma 1$ e $\sigma 2$.

Na Figura 4.41 estão representadas as famílias de fraturas levantadas na estação dos Pontos 4.38, 4.39 e 4.40. Nesse caso, têm-se dois grupos de famílias de alto ângulo, um de direção NE-SW, mais antigo, e outro de direção NE-SW, mais novo (Figuras 4.41A, $\mathrm{B}, \mathrm{C}$ e D). No primeiro caso, as famílias de fraturas constituem um espectro, tendo em vista a continuidade das fraturas conjugadas de cisalhamento, híbridas e de extensão. Dessa 

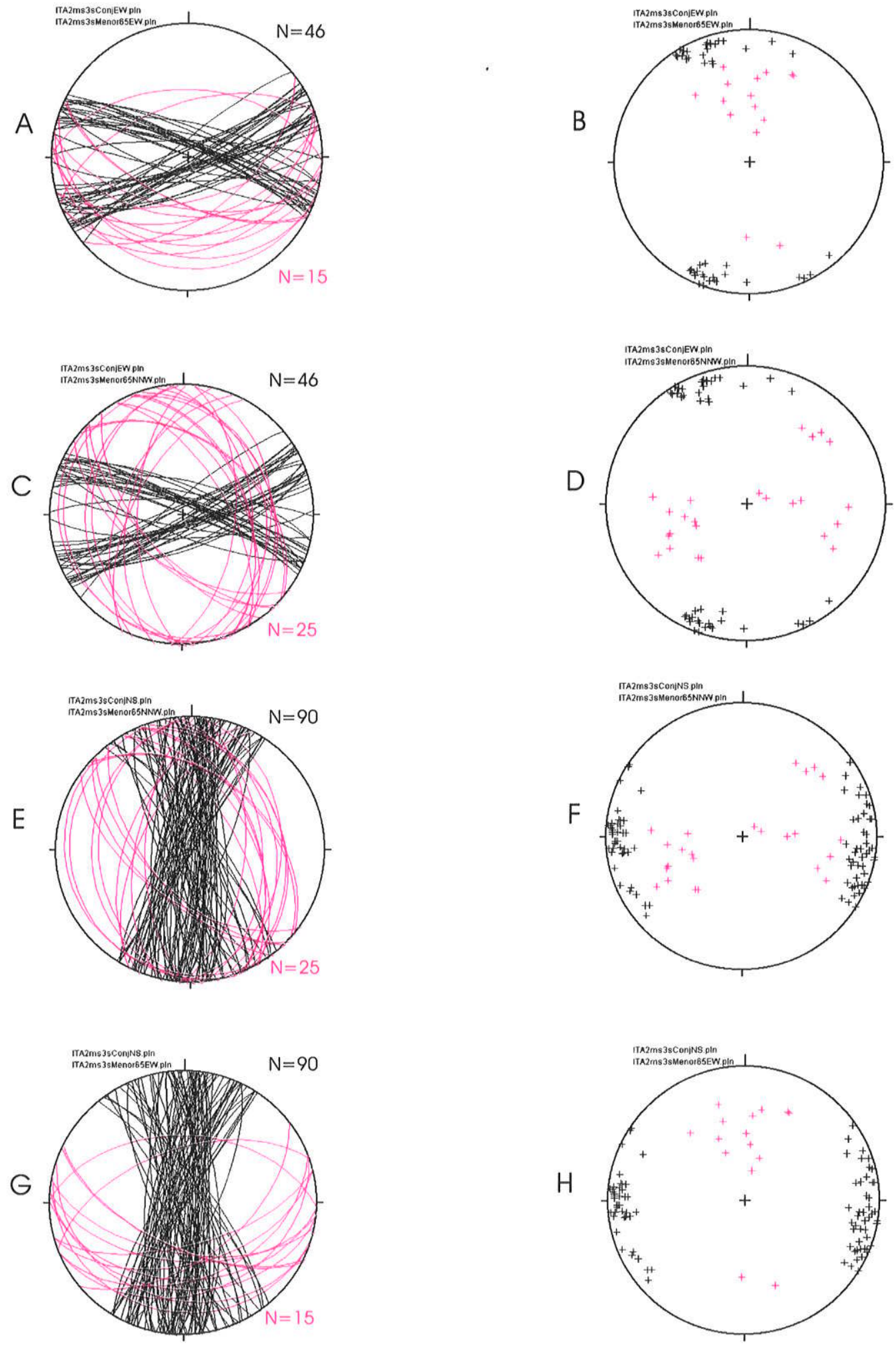

Figura 4.39 - Projeções ciclográficas e polares mostrando as relações geométricas entre juntas conjugadas de cisalhamento com ângulo de mergulho maior que 65 graus e juntas conjugadas com ângulo de mergulho menor que 65 graus, para famílias de direção E-W e N-S. Nos estereogramas A, B, E e F, as juntas de baixo ângulo de mergulho são representadas como tendo sido geradas em um regime normal de esforços, e nos estereogramas $\mathrm{C}$, $\mathrm{D}, \mathrm{G}$ e H, elas são representadas como tendo sido geradas em um regime de esforços reverso. Ver explanação no texto. Diagramas de Schimidt-Lambert,hemisfério inferior. Itaúna, Ponto 3, microssienito e sienito. 

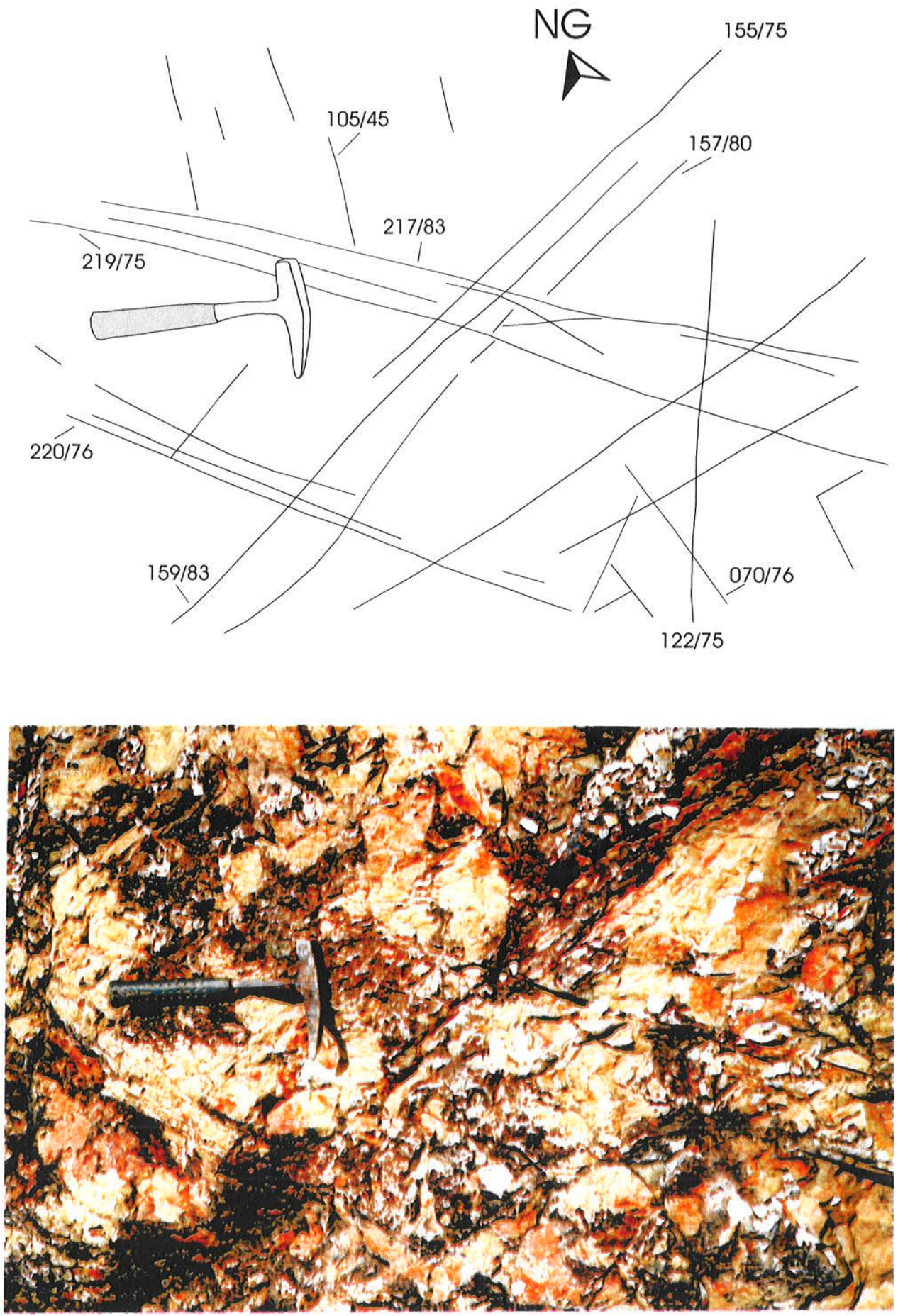

Figura 4.40 - Famílias de fraturas de cisalhamento conjugadas, com direção ENE-WSW e WNW-ESE e com alto ângulo de mergulho. Essas fraturas, que afetam microssienito, apresentam o típico padrão em X de Hancock (1985). O martelo indica a posição do eixo de tensões máximo, $\sigma 1$, na bissetriz do ângulo agudo entre as famílias conjugadas, orientado na direção E-W. Vista em planta, Maciço de Itaúna, Ponto Ita 3, Bairro do Salgueiro, Município de São Gonçalo. 
A

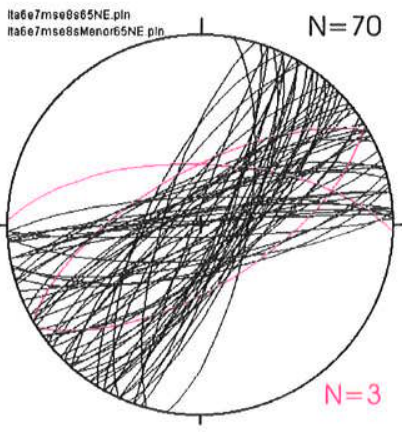

C

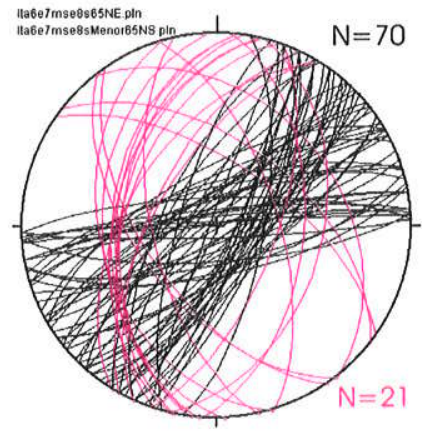

$\mathrm{E}$

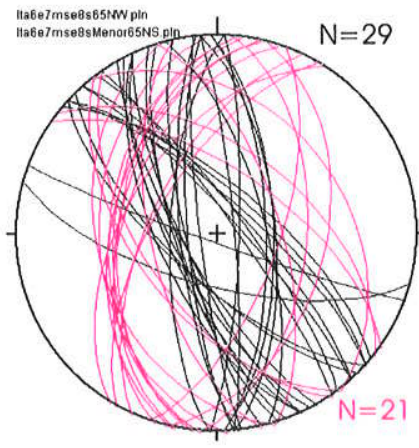

G

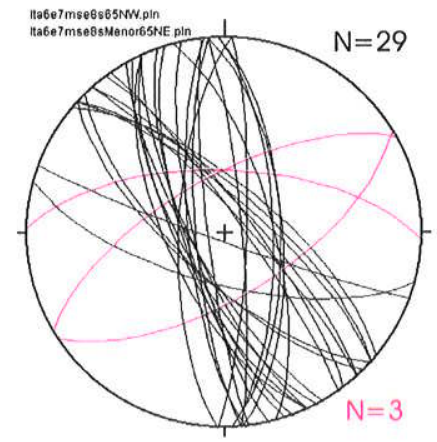

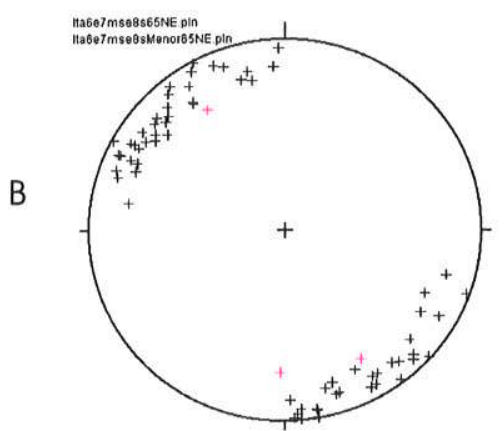
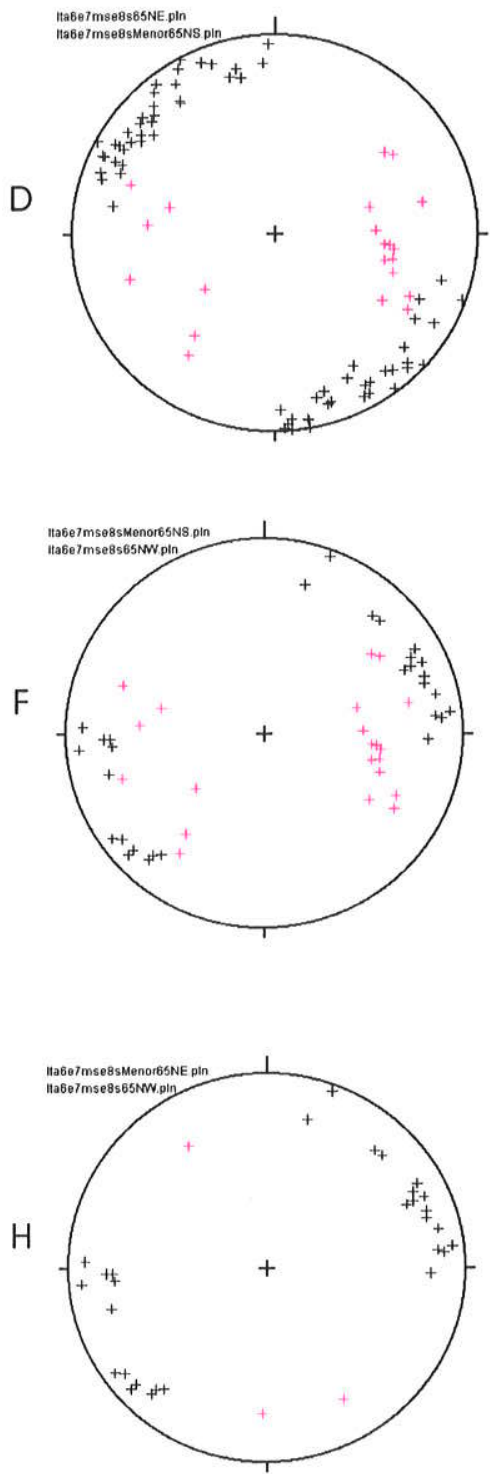

Figura 4.41 - Projeções ciclográficas e polares mostrando as relações geométricas entre juntas conjugadas decisalhamento com ângulo de mergulho maior que 65 graus e juntas conjugadas com ângulo de mergulho menor que 65 graus, para famílias de direção NE-SW e NNW. Nos estereogramas A, B, E e F as juntas de baixo ângulo de mergulho são representadas como tendo sido geradas em um regime normal de esforços, e nos estereogramas $\mathrm{C}, \mathrm{D}, \mathrm{G}$ e H, elas são representadas como tendo sido geradas em um regime de esforços reverso. Ver explanação no texto. Diagramas de Schimidt-Lambert, hemisfério inferior. Itaúna, Pontos 6, 7 e 8, microssienito e sienito. 
forma, o eixo de tensões horizontais máximo, SHmax, se orienta na direção NE-SW. O grupo de famílias de fraturas de alto ângulo de direção NW-SE, também constitui um espectro de fraturas, na qual a direção de SHmax se posiciona na direção NW-SE (Figuras 4.41E, $\mathrm{F}, \mathrm{G} \mathrm{e} \mathrm{H}$ ). As relações geométricas entre os grupos de famílias de fraturas de alto $\mathrm{e}$ de baixo ângulos, indicam que os grupos de famílias de fraturas de baixo ângulo representam fraturas de extensão (Figuras 4.41A, B e E, F) geradas provavelmente nos mesmos campos de tensões responsáveis pela formação dos espectros de fraturas de alto ângulo. Também aqui fica evidenciada uma alternância na posição dos eixos de tensões principal e intermediário, $\sigma 1$ e $\sigma 2$.

Nas Figuras 4.42, 4.44, 4.46, 4.47 e 4.48 estão representadas fraturas que afetam rochas intrusivas hipabissais, afaníticas ou porfiríticas. Estão incluídas aqui as brechas fonolíticas, tidas como brechas magmáticas (Valença 1980).

Na Figura 4.42 estão representadas as famílias de fraturas que afetam fonolito, na estação do Ponto 4. Nessa estação foram identificados dois grupos de famílias de fraturas, um com familias de direção NE-SW, mais antigo, e outro de direção NW-SE, mais novo. As famílias de fraturas de direção NE-SW constituem famílias de fraturas de cisalhamento, onde as fraturas sintéticas, $R$, têm direção ENE-WSW, e as antitéticas, R', possuem direção NNE-SSW (Figura 4.43), posicionando-se o eixo de tensões principal, $\sigma 1$, na bissetriz aguda entre as duas famílias, segundo a direção NE-SW (Figuras 4.42A, B e C, D). No caso das fraturas de direção NW-SE, há uma continuidade entre fraturas conjugadas de cisalhamento, híbridas e de extensão, caracterizando um espectro de fraturas. Dessa forma, pode-se inferir a orientação do eixo de tensões horizontal máximo, SHmax, na direção NW-SE. As relações geométricas entre os grupos de famílias de fraturas de alto e de baixo ângulo indicam, que as famílias de fraturas de direção NE-SW de baixo ângulo podem ter sido geradas no mesmo campo de tensões que gerou as de alto ângulo (Figuras 4.42A e B), exigindo, porém, uma alternância entre as posições de $\sigma 1 \mathrm{e}$ $\sigma 2$. No caso das famílias de fraturas de baixo ângulo, de direção NW-SE, essa relação não é tão clara, parecendo, entretanto, que elas também representam fraturas de extensão (Figuras 4.42E e F), uma vez que as de alto ângulo já indicam uma proximidade nas magnitudes de $\sigma 1$ e $\sigma 2$. 

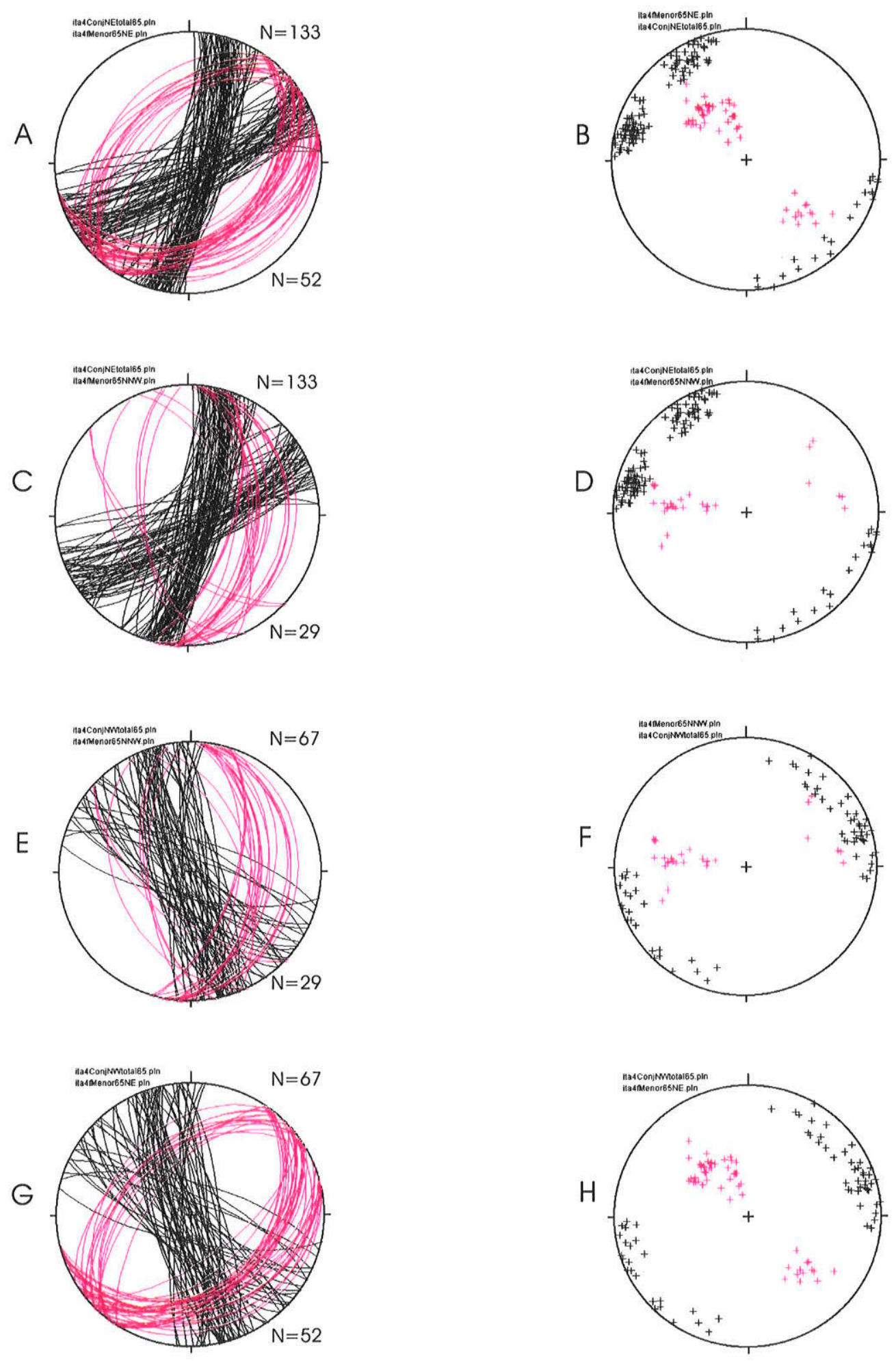

Figura 4.42 - Projeções ciclográficas e polares mostrando as relações geométricas entre juntas conjugadas de cisalhamento com ângulo de mergulho maior que 65 graus e juntas conjugadas com ângulo de mergulho menor que 65 graus, para famílias de direção NE-SW e NW-SE. Nos estereogramas A, B, E e F, as juntas de baixo ângulo de mergulho são representadas como tendo sido geradas em um regime normal de esforços, e nos estereogramas $\mathrm{C}, \mathrm{D}, \mathrm{G}$ e H , elas são representadas comotendo sido geradas em um regime de esforços reverso. Ver explanação no texto. Diagramas de SchimidtLambert, hemisfério inferior. Itaúna, Ponto 4 , fonolito. 

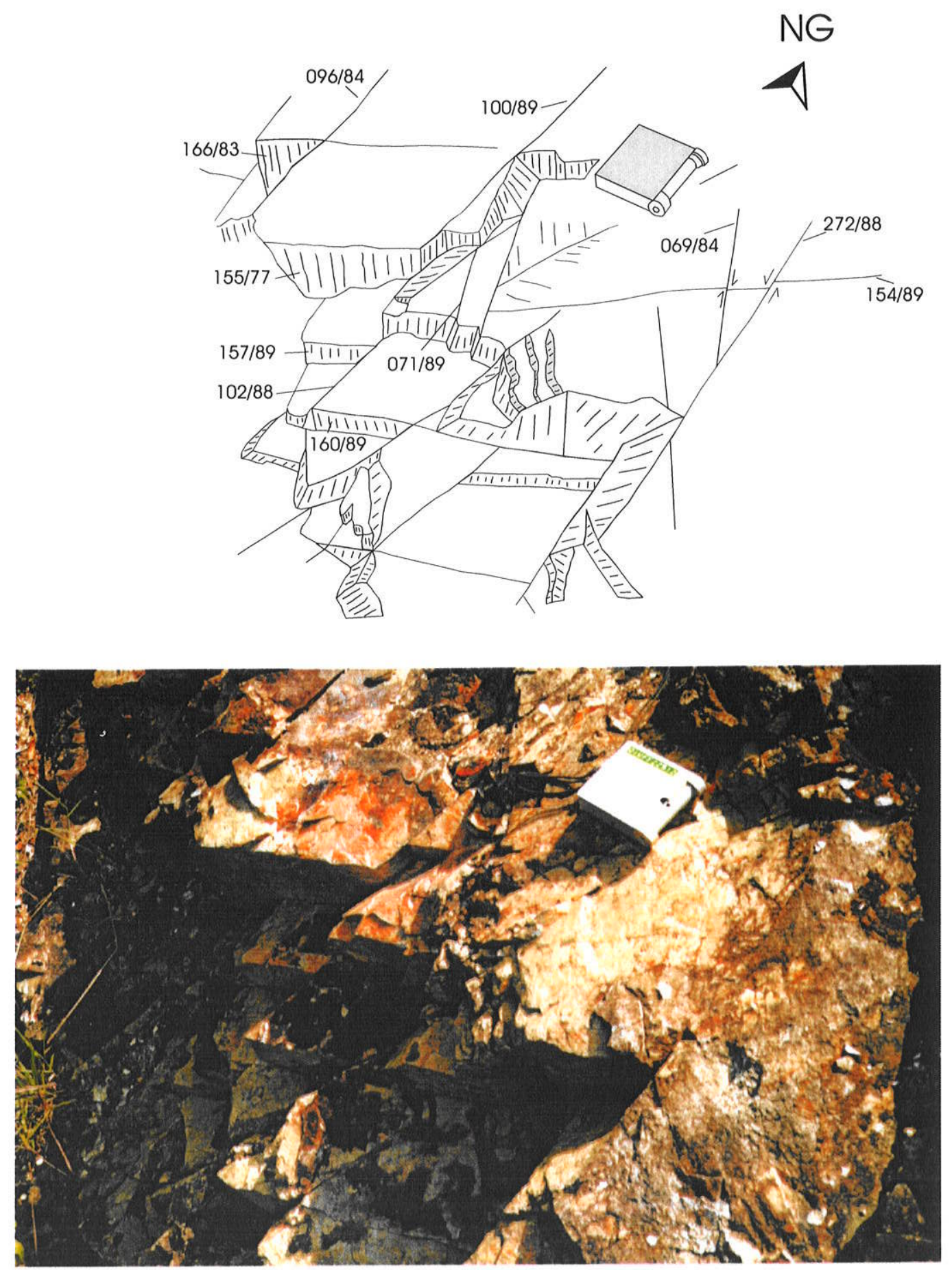

Figura 4.43 - Famílias de fraturas de cisalhamento conjugadas, com direção ENE-WSW e NNESSW, afetando traquito. Maciço de Itaúna, Ponto Ita 4, Bairro do Salgueiro, São Gonçalo. 
Na Figura 4.44 estão representadas as fraturas que afetam fonolito e brecha fonolítica, na estação do Ponto 4.42. As fraturas de alto ângulo foram separadas em dois grupos de famílias de fraturas, uma de direção NE-SW, mais antiga, e outra de direção NW-SE, mais nova. As fraturas de direção NE-SW constituem famílias de fraturas de cisalhamento conjugadas, onde as fraturas sintéticas, R, têm direção ENE-WSW, e as antitéticas, R', têm direção NNE-SSW (Figura 4.45), posicionando-se o eixo de tensões principal, $\sigma 1$, na direção NE-SW (Figuras 4.44A, B, C e D). As fraturas de alto ângulo de direção NW-SE também constituem famílias de fraturas de cisalhamento conjugadas, onde os estruturas sintéticas, R, orientam-se na direção WNW-ESE, e as antitéticas, R', orientam-se na direção NNW-SSE, posicionando-se o eixo de tensões máximo, $\sigma 1$, na direção NW-SE (Figuras 4.44E, F, G e H). As relações angulares entre os grupos de famílias de fraturas de alto e baixo ângulo sugerem, nos dois casos, que as famílias de fraturas de baixo ângulo podem ter ser formado sob o mesmo campo de tensões que as de alto ângulo (Figuras 4.44A, B e E, F), exigindo para isso uma permutação dos eixos de tensões principal e intermediário, $\sigma 1$ e $\sigma 2$.

$\mathrm{Na}$ Figura 4.46 estão representadas as projeções ciclográficas e polares das fraturas que afetam fonolito pórfiro, na estação que reúne os dados levantados nos Pontos $4.43 \mathrm{e}$ 4.46. Nessa estação foram separados dois grupos de famílias de fraturas de alto ângulo, um com famílias de fraturas com direção E-W, mais antiga, e outra com famílias de fraturas com direção NNW, mais nova. As primeiras constituem famílias de fraturas conjugadas de cisalhamento, onde as fraturas sintéticas, R, possuem direção WSW, e as antitéticas, R', têm direção ENE, posicionando-se o eixo principal de tensões, $\sigma 1$, na direção E-W (Figuras 4.46A, B, C e D). As fraturas de alto ângulo com direção NNW-SSE parecem constituir um espectro de fraturas, tendo em vista que não estão claramente caracterizadas duas famílias conjugadas (Figuras 4.46E, F, G e H). Nesse caso, pode-se inferir que o eixo de tensões máximo horizontal, SHmax, orienta-se na direção NNW-SSE. As relações geométricas entre os grupos de famílias de fraturas de alto ângulo e de baixo ângulo, permitem inferir que as fraturas de baixo ângulo foram geradas sob os mesmos campos de tensões que as de baixo ângulo, porém em um regime extensional (Figuras 4.46A, B e E, F), o que demandaria uma permutação entre as posições de $\sigma 1$ e $\sigma 2$, em especial no caso das famílias de fraturas de direção E-W. 
A

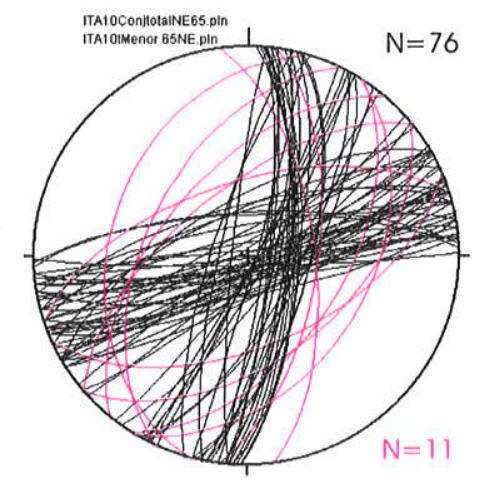

C

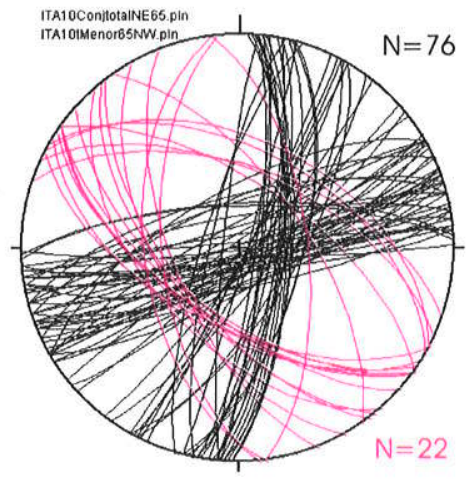

E

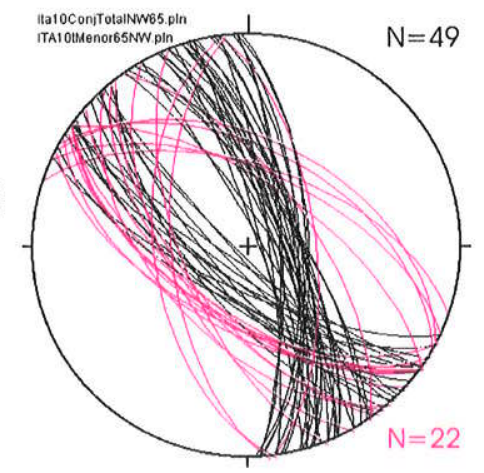

G

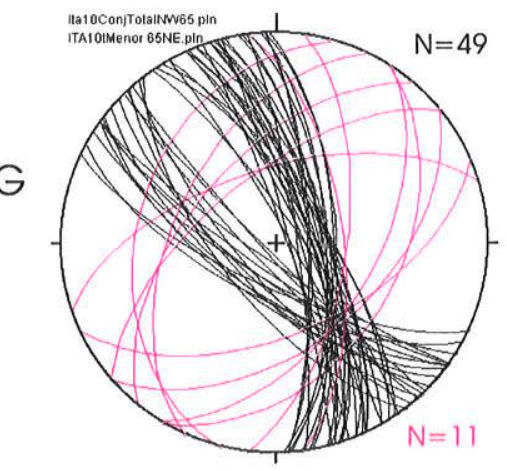

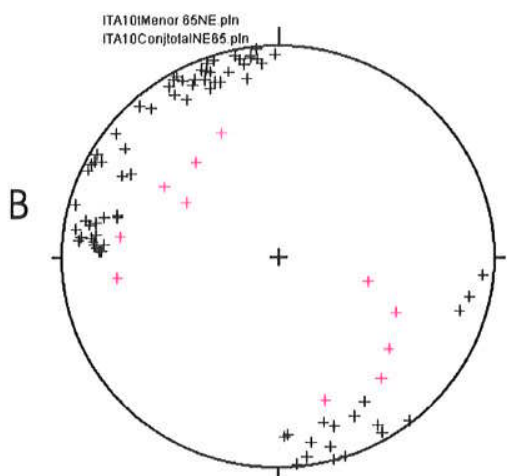
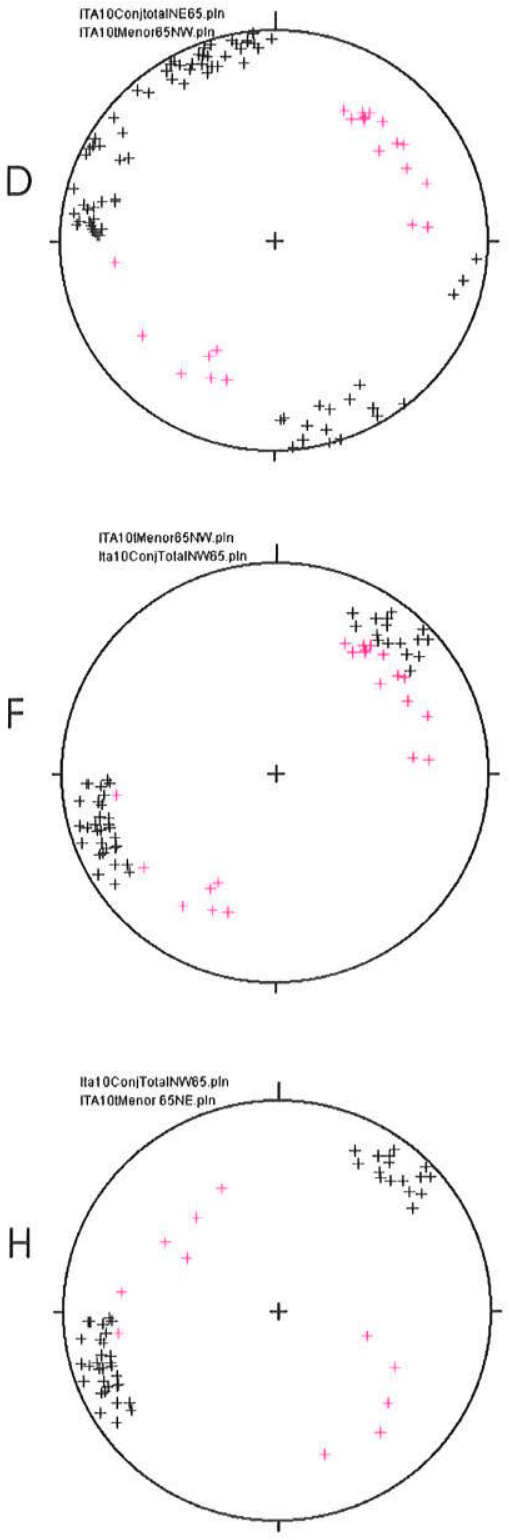

Figura 4.44 - Projeções ciclográficas e polares mostrando as relações geométricas entre juntas conjugadas de cisalhamento com ângulo de mergulho maior que 65 graus e juntas conjugadas com ângulo de mergulho menor que 65 graus, para famílias de direção NE-SW e NW-SE. Nos estereogramas A, B, E e F, as juntas de baixo ângulo de mergulho são representadas como tendo sido geradas em um regime normal de esforços, e nos estereogramas $\mathrm{C}, \mathrm{D}, \mathrm{G} \mathrm{e} \mathrm{H}$, elas são representadas como tendo sido geradas em um regime de esforços reverso. Ver explanação no texto. Diagramas de Schimidt-Lambert, hemisfério inferior. Itaúna, Ponto 10, fonolito e tufo. 

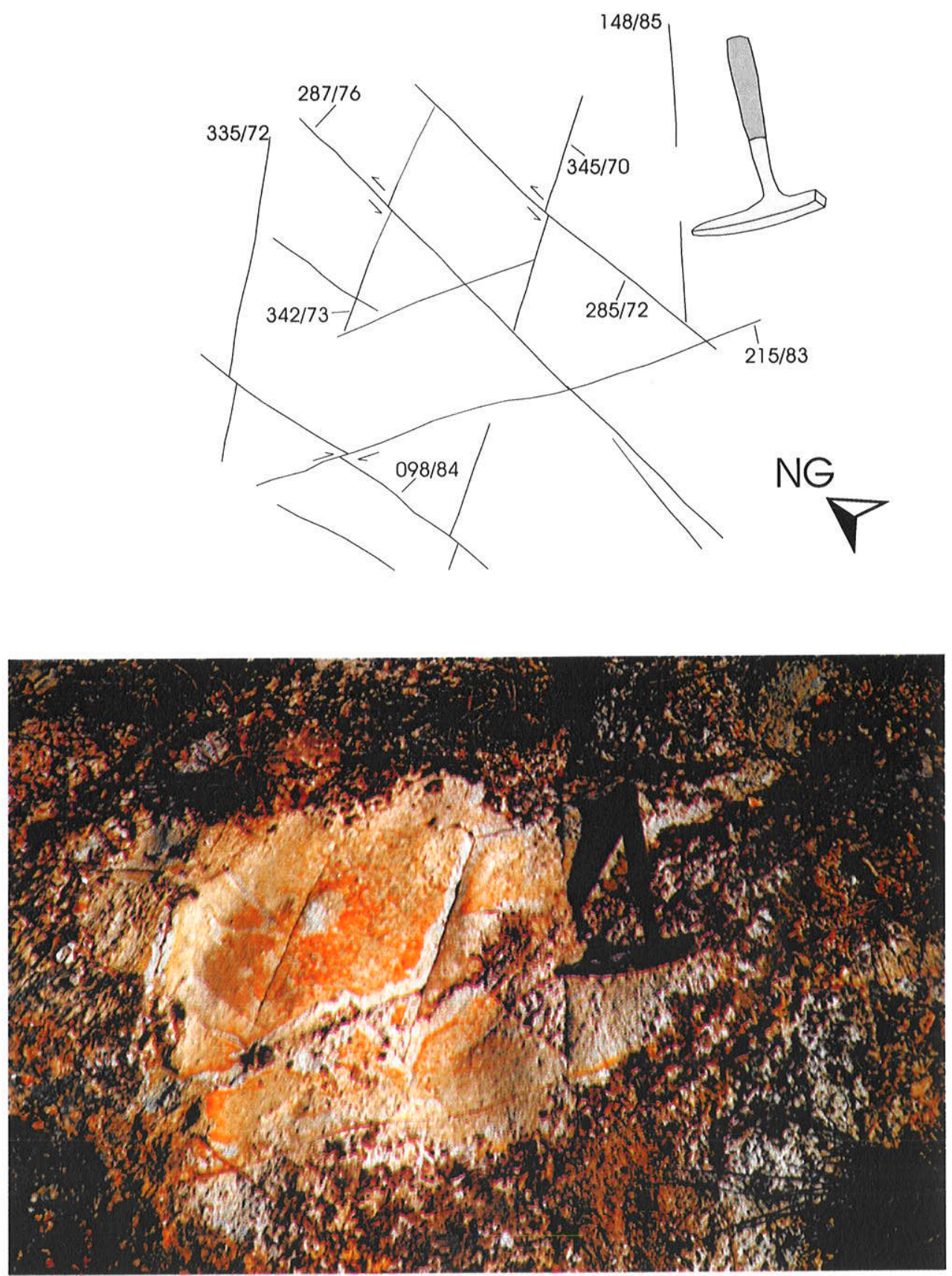

Figurra 4.45 - Famílias de fraturas de cisalhamento conjugadas com direção ENE-WSW e NNE-WSW e mergulho de alto ângulo. O típico arranjo em X apresentado por elas permite que se posicione o eixo de tensões máximo, $\sigma$ 1, na bissetriz aguda entre elas na direção NESW, paralelamente ao martelo. A microfalha de direção NW-SE, que exibe rejeito dextral, pertence às famílias ativadas sob um $\sigma 1$ de direção NW-SE. Essas fraturas afetam fonolito no Maciço de Itaúna, Ponto Ita 10, Bairro do Salgueiro, São Gonçalo.Vista em planta. 

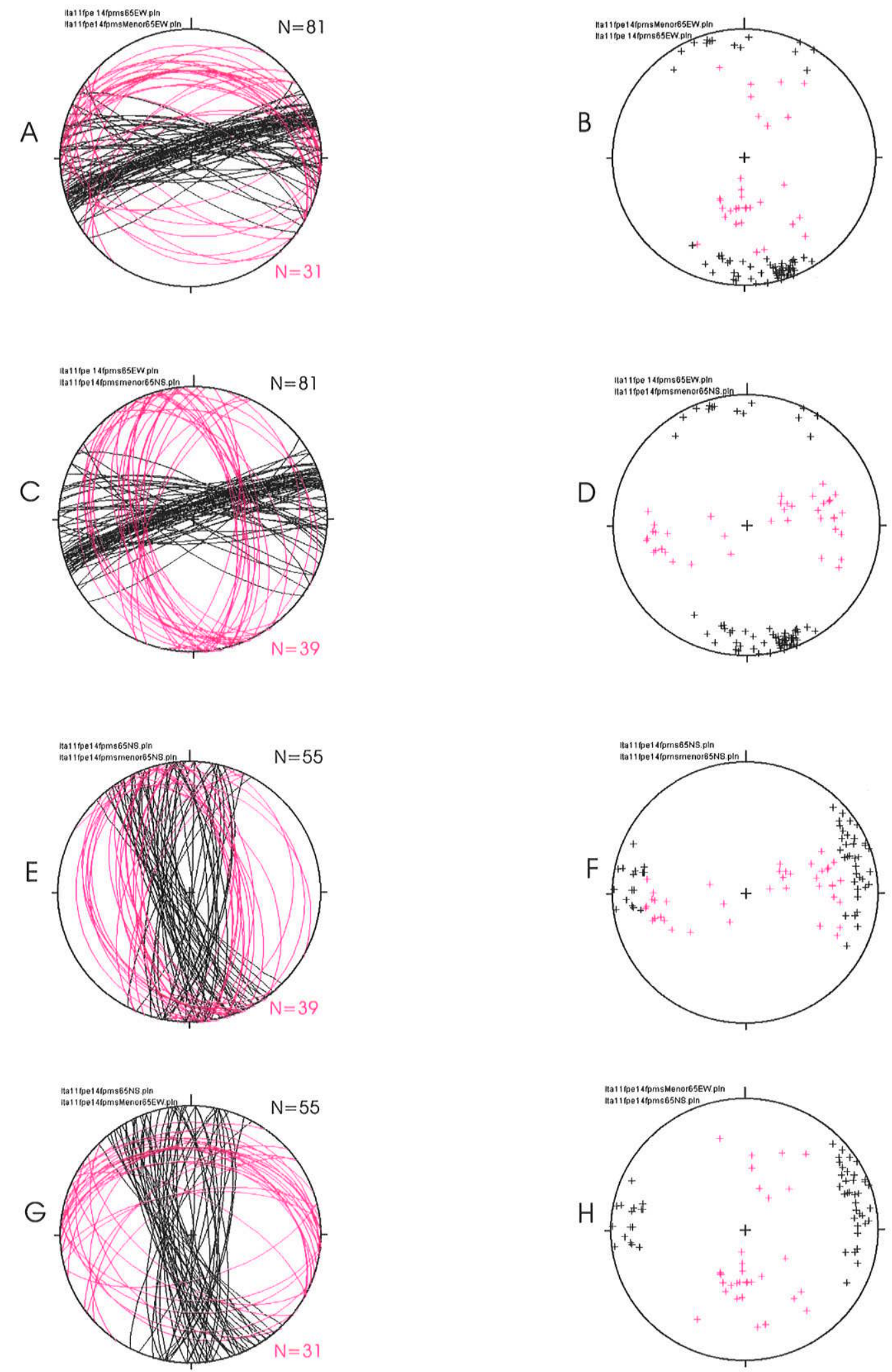

Figura 4.46 - Projeções ciclográficas e polares mostrando as relações geométricas entre juntas conjugadas de cisalhamento com ângulo de mergulho maior que 65 graus e juntas conjugadas com ângulo de mergulho menor que 65 graus, para famílias de direção E-W e N-S. Nos estereogramas A, B, E e F, as juntas de baixo ângulo de mergulho são representadas como tendo sido geradas em um regime normal de esforços, e nos estereogramas $\mathrm{C}, \mathrm{D}, \mathrm{G} \mathrm{e} \mathrm{H}$, elas são representadas como tendo sido geradas em um regime de esforços reverso. Ver explanação no texto. Diagramas de Schimidt-Lambert,hemisfério inferior. Itaúna, Pontos 11 e 14, fonolito pórfiro e microssienito. 
Na Figura 4.47 estão representadas as projeções ciclográficas e polares das fraturas que afetam fonolito pórfiro na estação do Ponto 12. Puderam ser separados dois grupos de famílias de fraturas de alto ângulo, um com direção NE-SW, mais antiga, e outro de direção NW-SE, mais nova. As fraturas de direção NE-SW constituem famílias conjugadas de cisalhamento, nas quais as fraturas sintéticas, R, possuem direção ENE-WSW, e as antitéticas, R', possuem direção NNE-SSW, posicionando-se o eixo principal de tensões, $\sigma 1$, na direção NE-SW, coincidente com a bissetriz do ângulo agudo entre as estruturas $\mathrm{R} e$ $\mathrm{R}^{\prime}$ (Figuras 4.47A, B, C e D). As fraturas de alto ângulo de direção NW-SE constituem, também, famílias conjugadas de cisalhamento, onde as estruturas sintéticas, $R$, apresentam direção WNW-ESE, e as antitéticas, R', possuem orientação NNW-SSE, posicionando-se o eixo de tensões principal, $\sigma 1$, na direção NW-SE (Figuras 4.47E, F, G e H). As relações geométricas entre os grupos de famílias de fraturas de alto e de baixo ângulo indicam que as fraturas de baixo ângulo foram formadas em regimes extensionais (Figuras 4.47A, B e E, F). Tais famílias de fraturas podem ter sido formadas sob os mesmos campos de tensões que geraram as fraturas de alto ângulo com orientação similar, demandando, no entanto, uma permutação, de $\sigma 1$ por $\sigma 2$, tanto para as fraturas mais antigas, de direção NE-SW, quanto para as mais novas, de direção NW-SE.

$\mathrm{Na}$ Figura 4.48 estão representadas as projeções ciclográficas e polares das fraturas que afetam fonolito pórfiro, relativas aos dados levantados nos Pontos 16 e 17. Foram distinguidos dois grupos de famílias de fraturas de alto ângulo, uma com direção ENEWSW, mais antiga, e outra com direção NNW-SSE, mais nova. As fraturas com direção ENE-WSW constituem famílias conjugadas de cisalhamento, onde as estruturas sintéticas, $\mathrm{R}$, têm direção E-W, e as antitéticas, $\mathrm{R}^{\prime}$, possuem direção NE-SW, posicionando-se o eixo de tensões principal, $\sigma 1$, na direção ENE-WSW (Figuras 4.48A, B, C e D). As fraturas de direção NNW-SSE parecem, também, representar famílias de fraturas de cisalhamento, apesar de não tão claramente definidas, onde as estruturas sintéticas, $R$, orientam-se na direção WNW, e as estruturas antitéticas, R', apresentam direção NNE-SSW. As fraturas de direção NNW-SSE, as mais numerosas, representam fraturas de tração, T, coincidentes com a direção do eixo de tensões principal, $\sigma 1$ (Figuras 4.48E, F, G e H). As relações geométricas entre os grupos de famílias de fraturas de alto e de baixo ângulo, tanto os de direção ENE-WSW, como os NNW-SSE, sugere que as fraturas de baixo ângulo foram 

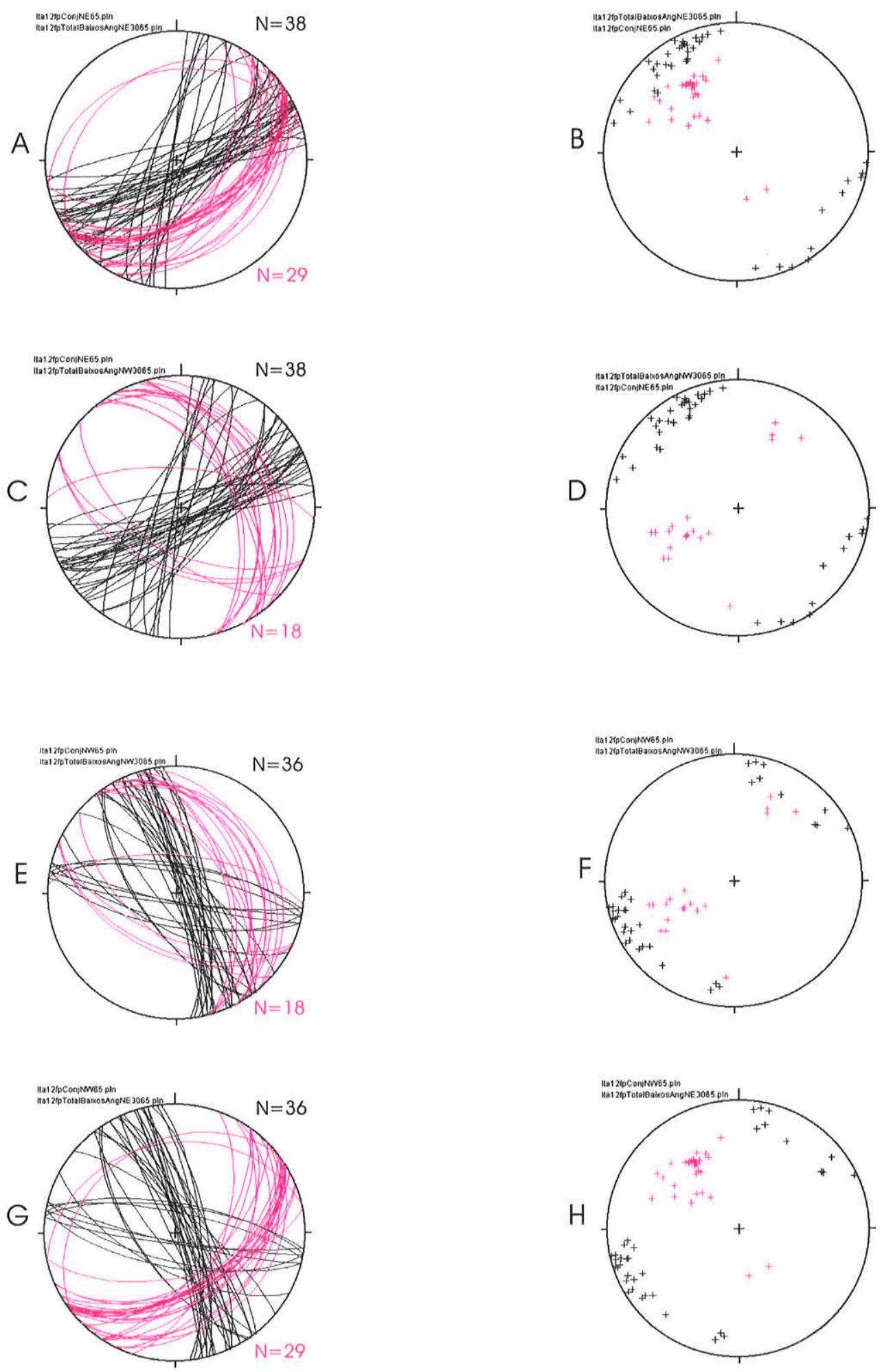

Figura 4.47 - Projeções ciclográficas e polares mostrando as relações geométricas entre juntas conjugadas de cisalhamento com ângulo de mergulho maior que 65 graus e juntas conjugadas com ângulo de mergulho menor que 65 graus, para famílias de direção NE-SW e NW-SE.. Nos estereogramas A, B, E e F, as juntas de baixo ângulo de mergulho são representadas como tendo sido geradas em um regime normal de esforços, e nos estereogramas $\mathrm{C}, \mathrm{D}, \mathrm{G}$ e H, elas são representadas como tendo sido geradas em um regime de esforços reverso. Ver explanação no texto . Diagramas de Schimidt-Lambert, hemisfério inferior. Itaúna, Ponto 12 , fonolito pórfiro. 

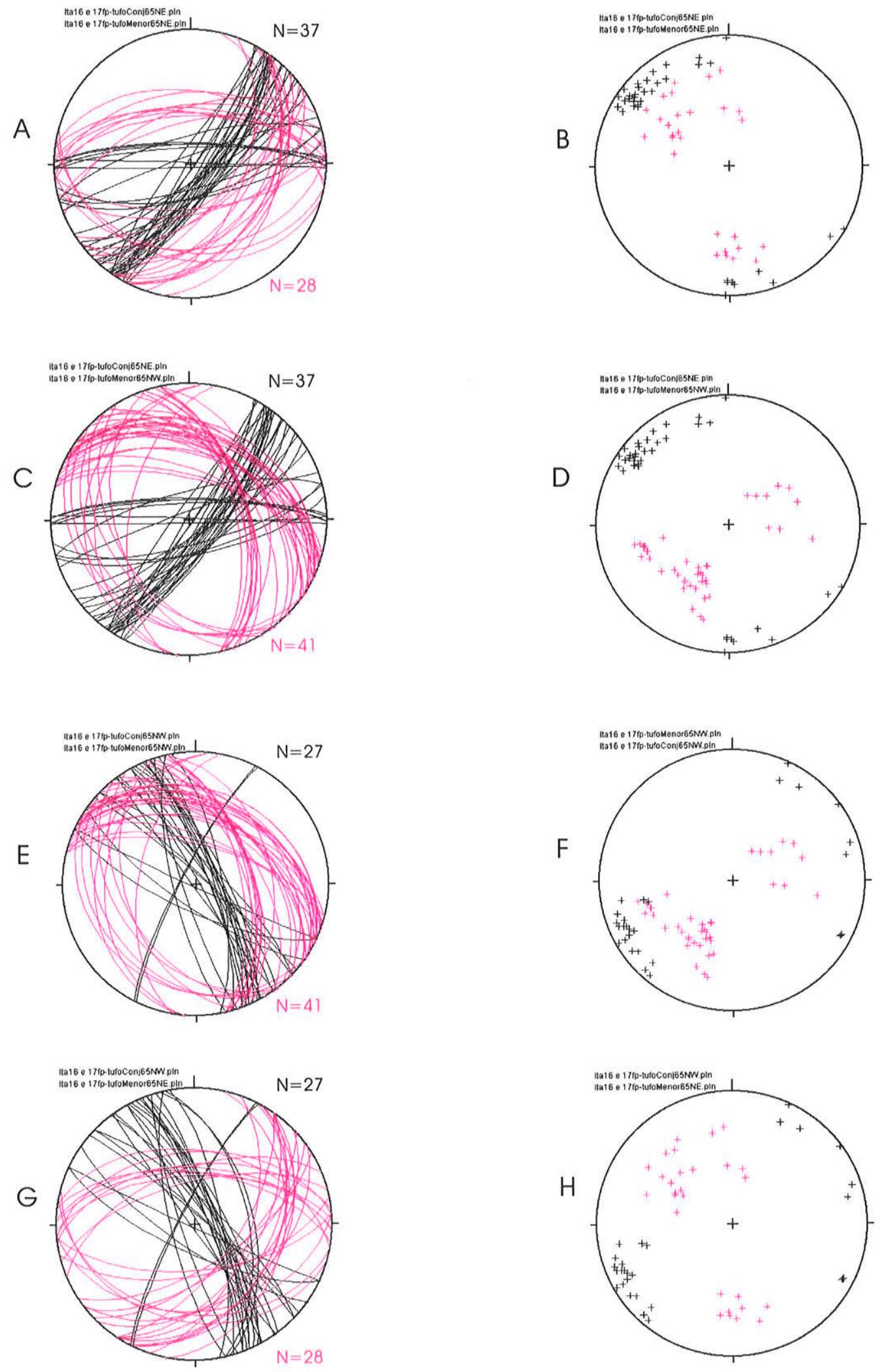

Figura 4.48 - Projeções ciclográficas e polares mostrando as relações geométricas entre juntas conjugadas de cisalhamento com ângulo de mergulho maior que 65 graus e juntas conjugadas com ângulo de mergulho menor que 65 graus, para famílias de direção N E-SW e NW-SE. Nos estereogramas A, B, E e F, as juntas de baixo ângulo de mergulho são representadas como tendo sido geradas em um regime normal de esforços, e nos estereogramas C, D, G e H, elas são representadas como tendo sido geradas em um regime de esforços reverso. Ver explanação no texto. Diagramas de Schimidt-Lambert,hemisfério inferior. Itaúna, Pontos 16 e 17, tufo e fonolito pórfiro. 
geradas em um regime extensional (Figuras 4.48A, B e E, F) e que a sua geração pode estar associada a uma permutação dos eixos de tensões principal e intermediário, $\sigma 1$ e $\sigma 2$.

\section{A.2) Juntas e Fraturas em Rochas Vulcânicas}

Na Figura 4.49 estão representadas as projeções ciclográficas e polares das fraturas que afetam brecha e tufo vulcânicos, na estação do Ponto 2. Puderam ser separados dois grupos de famílias de fraturas, um com direção NE-SW, mais antigo, e outro de direção NNW-SSE, mais novo. As fraturas de direção NE-SW constituem um espectro de fraturas, onde as fraturas de cisalhamento, as híbridas e as de extensão estão em continuidade (Figura 4.50). Nesse caso pode-se inferir que o eixo de tensões horizontal máximo, SHmax, orienta-se na direção ENE-WSW (Figuras 4.49A, B, C e D). As fraturas de direção NNW-SSE representam fraturas de extensão e fraturas híbridas, tendo em vista o ângulo entre elas abaixo de $60^{\circ}$ (Hancock 1985), posicionando-se o eixo de tensões máximo horizontal, SHmax, na direção NNW-SSE (Figuras 4.49E, F, G e H). As relações geométricas entre os grupos de fraturas de alto e de baixo ângulo, permite inferir que as de baixo ângulo foram formadas em um regime extensional, e que a sua geração pode ter se dado em campos de tensões semelhantes, com as mesmas orientações dos tensores principais horizontais, Shmin e SHmax, demandando, no entanto a permuta entre os eixos de tensões principal e intermediário, $\sigma 1$ e $\sigma 2$.

Na Figura 4.51 estão representadas as projeções ciclográficas e polares das fraturas que afetam brecha e tufo vulcânicos, levantadas na estação referente aos Pontos 5 e 9 . Foram separados dois grupos de famílias de fraturas, uma com direção ENE-WSW, e outra com direção NNW-SSE. As fraturas de direção ENE-WSW representam um espectro de fraturas, onde o eixo de tensões horizontal máximo, SHmax, orienta-se segundo a direção ENE-WSW (Figuras 4.51A, B, C e D). As fraturas com direção variando entre NW-SE e NNE-SSW representam, também, um espectro de fraturas, no qual o eixo de tensões horizontal máximo, SHmax, orienta-se na direção NNW-SSE. As relações geométricas entre os grupos de fraturas de alto e baixo ângulo, indicam que elas podem ter sido geradas em campos de tensões semelhantes (Figuras 4.51A, B e E, F). 

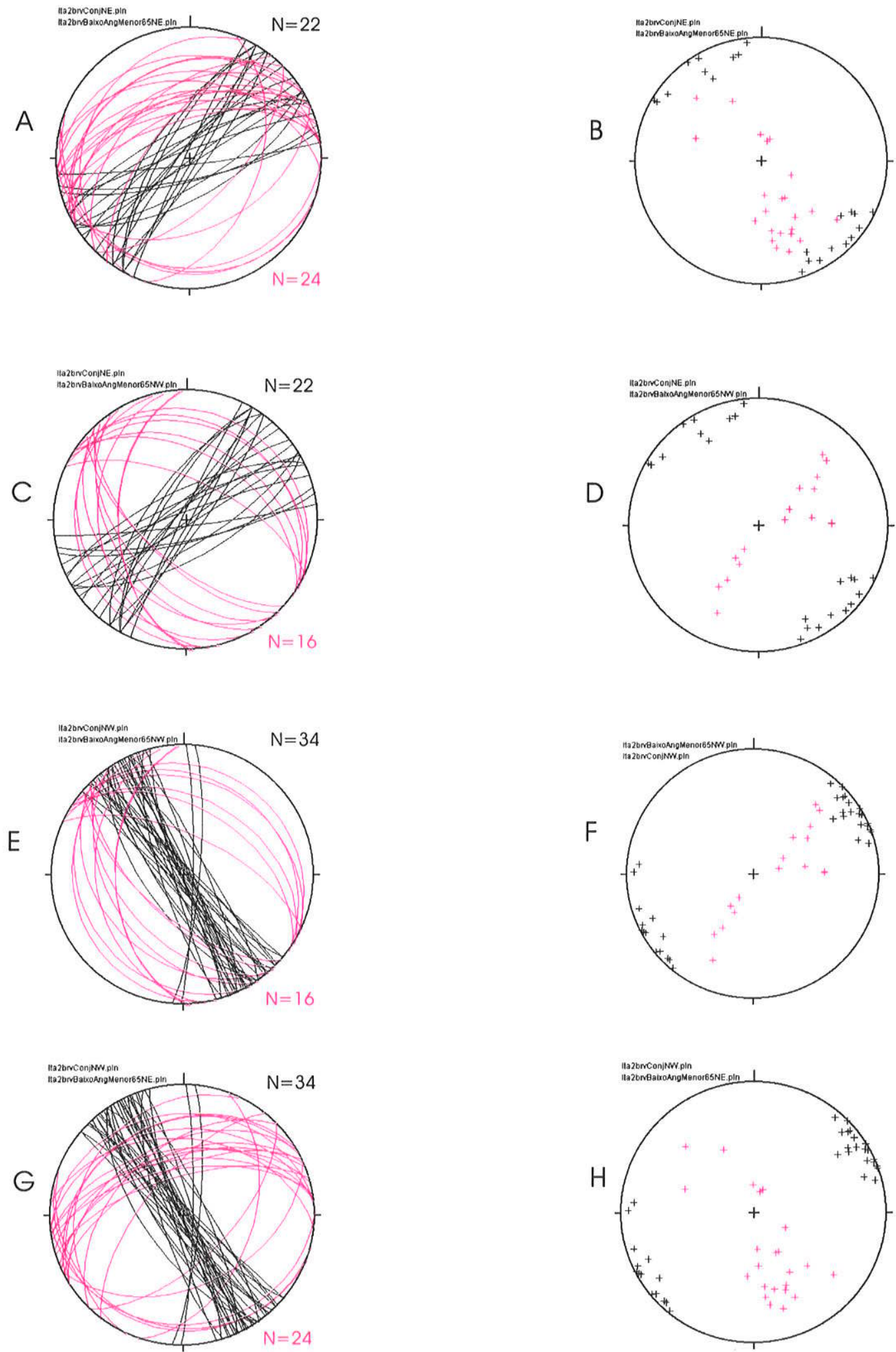

Figura 4.49 - Projeções ciclográficas e polares mostrando as relações geométricas entre juntas conjugadas decisalhamento com ângulo de mergulho maior que 65 graus e juntas conjugadas com ângulo de mergulho menor que 65 graus, para famílias de direção NE-SW e NW-SE. Nos estereogramas A, B, E e F, as juntas de baixo ângulo de mergulho são representadas como tendo sido geradas em um regime normal de esforços, e nos estereogramas $\mathrm{C}, \mathrm{D}, \mathrm{G}$ e H, elas são representadas como tendo sido geradas em um regime de esforços reverso. Ver explanação no texto. Diagramas de Schimidt-Lambert,hemisfério inferior. Itaúna, Ponto 2, brecha vulcânica. 

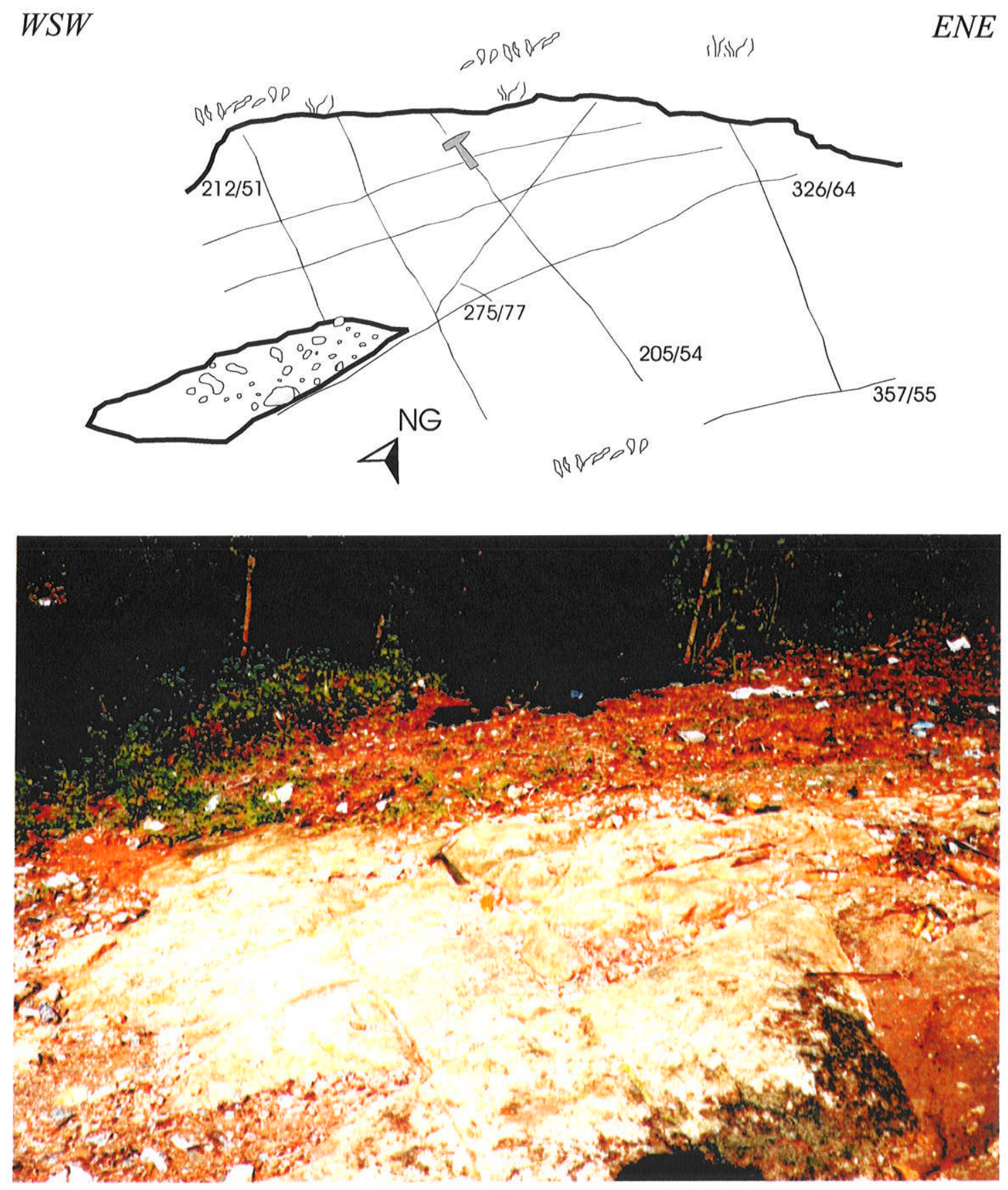

Figura 4.50 - Famílias de fraturas de extensão com direção ENE-WSW e NW-SE, afetando brechas piroclásticas. As de direção ENE mostram maior continuidade evidenciando serem as mais antigas. O conjunto constitui um padrão de tipo $\mathrm{H}$ de Hancock (1985). Maciço de Itaúna, Ponto Ita 5, Bairro do Salgueiro, São Gonçalo. 
A

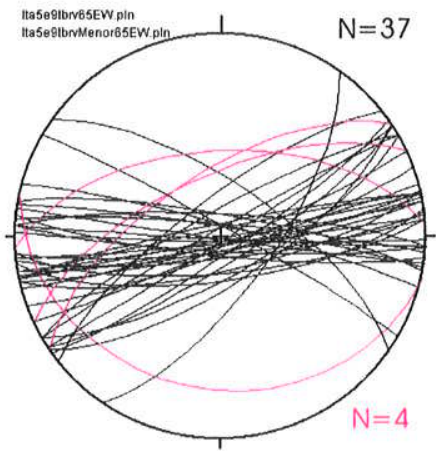

C

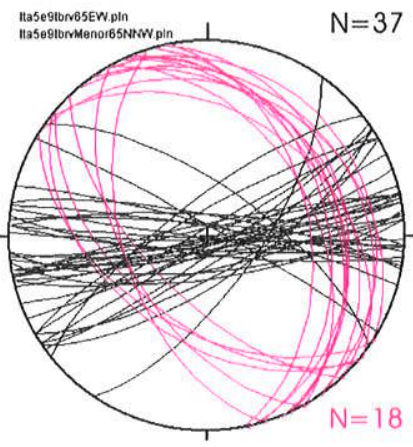

E

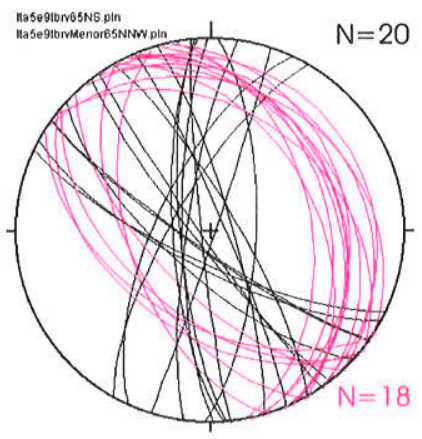

G

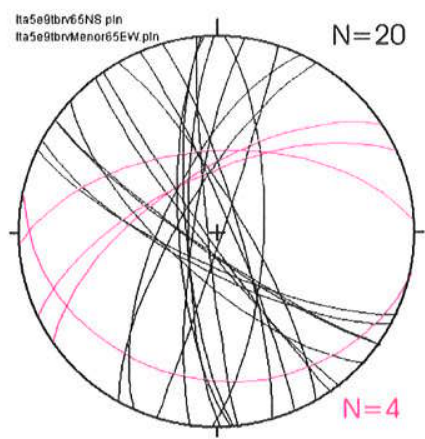

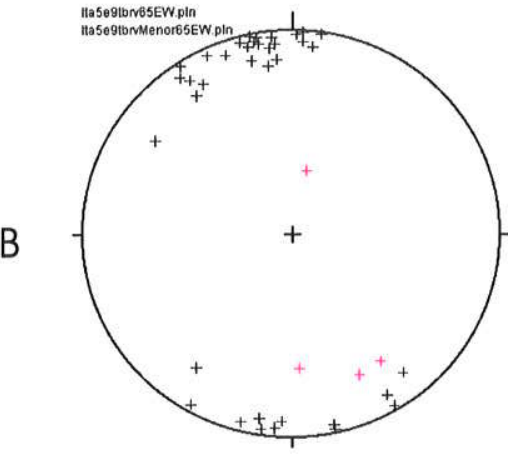
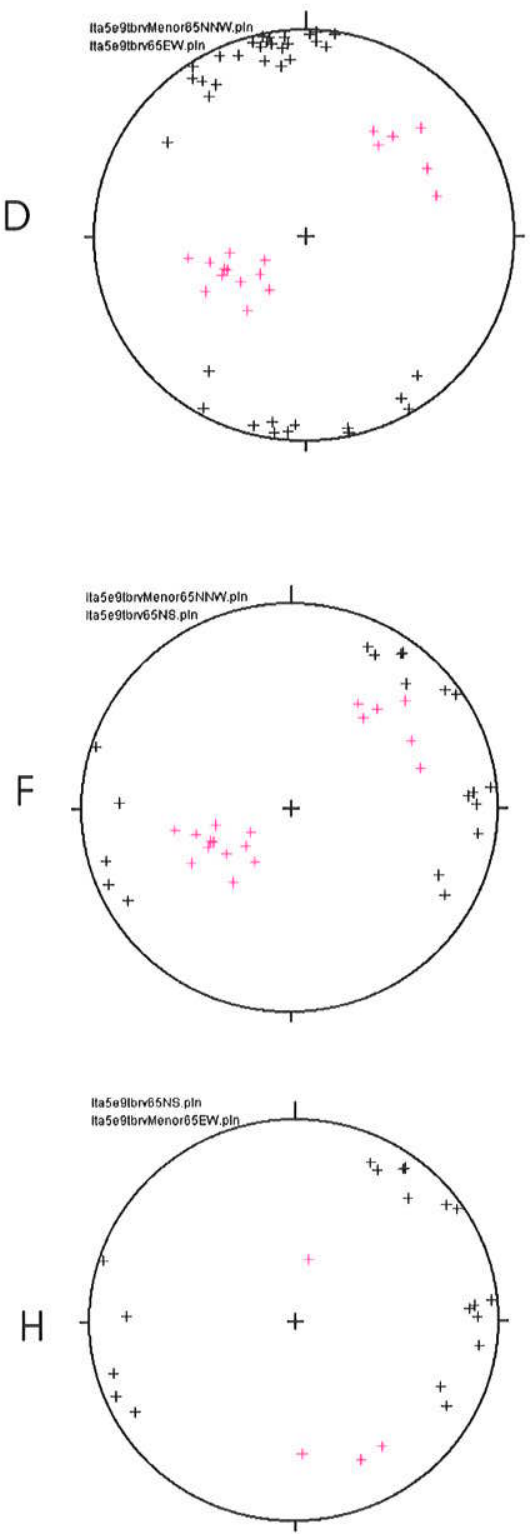

Figura 4.51 -Projeções ciclográficas e polares mostrando as relações geométricas entre juntas conjugadas decisalhamento com ângulo de mergulho maior que 65 graus e juntas conjugadas com ângulo de mergulho menor que 65 graus, para famílias de direção E-W e NNW-SSE. Nos estereogramas A, B, E e F as juntas de baixo ângulo de mergulho são representadas como tendo sido geradas em um regime normal de esforços, $\mathrm{e}$ nos estereogramas $\mathrm{C}, \mathrm{D}, \mathrm{G}$ e H, elas são representadas como tendo sido geradas em um regime de esforços reverso. Ver explanação no texto. Diagramas de Schimidt-Lambert, hemisfério inferior. Itaúna, pontos 5 e 9 , tufo e brecha vulcânica. 
Uma síntese das paleotensões determinadas a partir dos dados de juntas e fraturas sem estrias é apresentada na Tabela 4.4. Essas paleotensões evidenciam que o campo de tensões variou ao longo do tempo, inicialmente com uma direção de SHmax orientada segundo o quadrante nordeste, com a direção variando entre NE-SW e E-W e, posteriormente, com uma orientação de SHmax segundo o quadrante noroeste, variando entre N-S e NW-SE. Fica evidenciado, também, que esses campos de tensões afetam todas as litologias da suíte e que há coerência nas determinações em todo o maciço. Ficou caracterizado, ainda, que os SHmax determinados representam tanto $\sigma 1$, como $\sigma 2$, correspondendo, no primeiro caso, a um regime de esforços direcional e, no segundo, a um regime extensional. A presença de espectros de fraturas, bem como de fraturas extensionais de baixo ângulo com mesma orientação que as de alto ângulo, indica que devem ter havido permutações dos eixos de tensões principal e intermediário, $\sigma 1$ e $\sigma 2$, ao longo do tempo.

\begin{tabular}{|c|c|c|c|c|c|}
\hline \multirow[t]{2}{*}{ Estações } & \multicolumn{2}{|c|}{$\begin{array}{l}\text { Familias de Fraturas } \\
\text { (direção de Shmax) }\end{array}$} & \multicolumn{2}{|c|}{ Tipos de Fraturas } & \multirow[t]{2}{*}{$\begin{array}{l}\text { Litologias } \\
\text { Afetadas }\end{array}$} \\
\hline & + antiga & +nova & + antiga & +nova & \\
\hline $\begin{array}{l}\text { Estação do Ponto } \\
1 \text { (Figura 6) }\end{array}$ & $\begin{array}{c}\text { NE-SW } \\
\sigma 1\end{array}$ & $\begin{array}{c}\text { NNW-SSE } \\
\text { Shmax }\end{array}$ & Conj. Cis. & Espectro & microssienito \\
\hline $\begin{array}{l}\text { Estação do Ponto } \\
3 \text { (Figura 7) }\end{array}$ & $\begin{array}{l}\text { E-W } \\
\sigma 1 \\
\end{array}$ & $\begin{array}{c}\text { N-S } \\
\text { Shmax } \\
\end{array}$ & Conj.Cis. & Espectro & microssienito \\
\hline $\begin{array}{l}\text { Estação dos } \\
\text { Pontos } 6,7 \text { e } 8 \\
\text { (Figura 9) }\end{array}$ & $\begin{array}{l}\text { NE-SW } \\
\text { SHmax }\end{array}$ & $\begin{array}{r}\text { NW-SE } \\
\text { Shmax }\end{array}$ & Espectro & Espectro & sienito \\
\hline $\begin{array}{l}\text { Estação do Pontos } \\
4 \text { (Figura 10) }\end{array}$ & $\begin{array}{l}\text { NE-SW } \\
\sigma 1 \\
\end{array}$ & $\begin{array}{l}\text { NW-SE } \\
\text { Shmax }\end{array}$ & Conj. Cis. & Espectro & fonolito \\
\hline $\begin{array}{l}\text { Estação do Ponto } \\
10 \text { (Figura 12) }\end{array}$ & $\begin{array}{l}\text { NE-SW } \\
\sigma 1 \\
\end{array}$ & $\begin{array}{c}\text { NW-SE } \\
\sigma 1 \\
\end{array}$ & Conj. Cis. & Conj. Cis. & $\begin{array}{l}\text { fonolito e } \\
\text { brecha fonolítica }\end{array}$ \\
\hline $\begin{array}{l}\text { Estação dos } \\
\text { Pontos } 11 \text { e } 14 \\
\text { (Figura 14) }\end{array}$ & $\begin{array}{c}\mathrm{E}-\mathrm{W} \\
\sigma 1\end{array}$ & $\begin{array}{l}\text { NNW-SSE } \\
\text { Shmax }\end{array}$ & Conj. Cis. & Espectro & fonolito pórfiro \\
\hline $\begin{array}{l}\text { Estação do Ponto } \\
12 \text { (Figura } 15 \text { ) }\end{array}$ & $\begin{array}{l}\text { NE-SW } \\
\sigma 1\end{array}$ & $\begin{array}{c}\mathrm{NW}-\mathrm{SE} \\
\sigma \mathrm{l} \\
\end{array}$ & Conj. Cis. & Conj. Cis. & fonolito pórfiro \\
\hline $\begin{array}{l}\text { Estação dos } \\
\text { Pontos } 16 \text { e } 17 \\
\text { (Figura 16) }\end{array}$ & $\begin{array}{l}\text { ENE-WSW } \\
\sigma 1\end{array}$ & $\begin{array}{c}\text { NNW-SSE } \\
\sigma 1\end{array}$ & Conj. Cis. & Conj. Cis. & fonolito pórfiro \\
\hline $\begin{array}{l}\text { Estação do Ponto } \\
2 \text { (Figura 17) }\end{array}$ & $\begin{array}{l}\text { ENE-WSW } \\
\text { SHmax }\end{array}$ & $\begin{array}{c}\text { NNW-SSE } \\
\text { Shmax } \\
\end{array}$ & Espectro & Espectro & $\begin{array}{l}\text { brecha e tufo } \\
\text { vulcânicos }\end{array}$ \\
\hline $\begin{array}{l}\text { Estação dos } \\
\text { Pontos } 5 \text { e } 9 \\
\text { (Figura 19) }\end{array}$ & $\begin{array}{l}\text { ENE-WSW } \\
\text { SHmax }\end{array}$ & $\begin{array}{c}\text { NNW-SSE } \\
\text { Shmax }\end{array}$ & Espectro & Espectro & $\begin{array}{l}\text { brecha e tufo } \\
\text { vulcânicos }\end{array}$ \\
\hline
\end{tabular}

Tabela 4.4 - Síntese das paleotensões determinadas a partir da análise geométrica de juntas e fraturas sem estrias aparentes, na Suíte de Itaúna. 
B) Análise Cinemática de Falhas e Microfalhas

Os dados utilizados para análise cinemática referem-se essencialmente a microfalhas, nas quais as estrias geradas tratam-se, principalmente, de marcas de objetos, acompanhadas de facetas polidas e rugosas alternadas e de fraturas de cisalhamento sintéticas, $\mathrm{R}$, e antitéticas, $\mathrm{R}^{\prime}$. Os dados coletados foram reunidos em três estações distintas, cuja separação teve como critério a distribuição em área no maciço e, secundariamente, as litologias afetadas.

Na Figura 4.52 estão representados os dados de microfalhas que afetam microssienito e brecha e tufo vulcânico, na estação 1 , relativa aos Pontos 1 e 2, respectivamente.

Nas Figuras 4.52A e B estão representadas microfalhas conjugadas de cisalhamento, de direção NE-SW e NNW-SSE, além de microfalhas normais conjugadas de direção NE-SW. A inversão desses dados mostrou que eles foram gerados em um campo de tensões puramente DIRECIONAL (Pure STRIKE-SLIP), com o eixo de tensões máximo, $\sigma 1$, horizontal e orientado na direção NE-SW, o eixo de tensões mínimo, $\sigma 3$, também horizontal e ortogonal a ele, e o eixo de tensões intermediário, $\sigma 2$, vertical.

Nas Figuras $4.52 \mathrm{C}$ e $\mathrm{D}$ estão representadas microfalhas conjugadas de cisalhamento, de direção ENE-WSW e N-S a NNW-SSE, além de falhas normais conjugadas de direção em torno de E-W. A inversão desses dados indicou que eles foram gerados em um campo de esforços EXTENSIVO direcional (Strike-slip EXTENSIVE), com o eixo de tensões principal, $\sigma 1$, vertical, o eixo de tensões mínimo, $\sigma 3$, horizontal e orientado na direção NNE-SSW, e o eixo intermediário, $\sigma 2$, também horizontal e orientado na direção WNW-ESE. $\mathrm{O}$ alto valor de $\mathrm{R}$ indica uma proximidade na magnitude dos tensores principal e intermediário, $\sigma 1$ e $\sigma 2$.

$\mathrm{Na}$ Figura 4.53 estão representados dados de microfalhas que afetam fonolito e sienito, na estação 2, Pontos 3 e 4 . O conjunto de microfalhas envolve falhas direcionais e oblíquas, de alto ângulo de mergulho, bem como falhas normais. A inversão desses dados indicou que tais microfalhas desenvolveram-se em um único campo de tensões, de caráter Puramente DIRECIONAL (Pure STRIKE-SLIP), com o eixo de tensões principal, $\sigma$, posicionado na horizontal, segundo a direção NE-SW, o eixo mínimo, $\sigma 3$, também 
A)

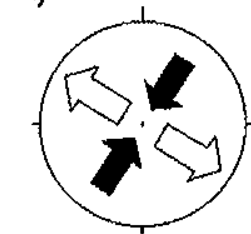

() ช1: $17 / 213$

\& ช2: $72 / 013$

बิ3: $06 / 12$

Pure STRIKE-SLIP
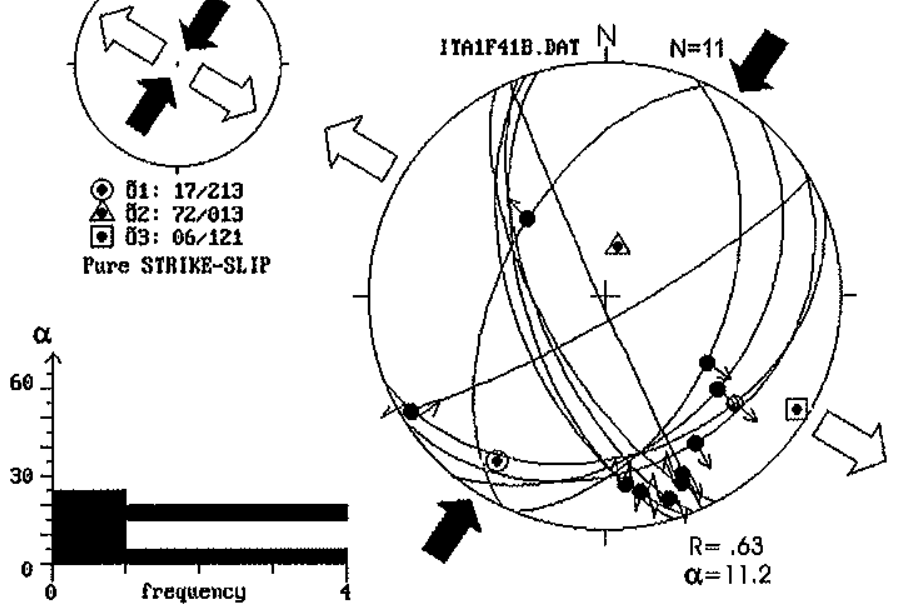

C)

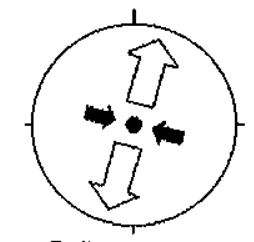

Q ธ1: 84/338 ช3: $05 / 196$ Strike-s! ip EXTENSIUE

$\alpha$

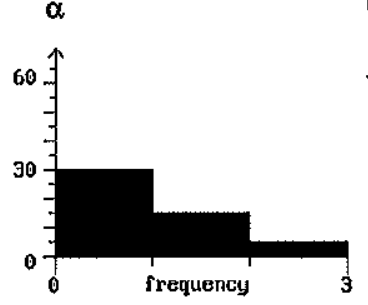

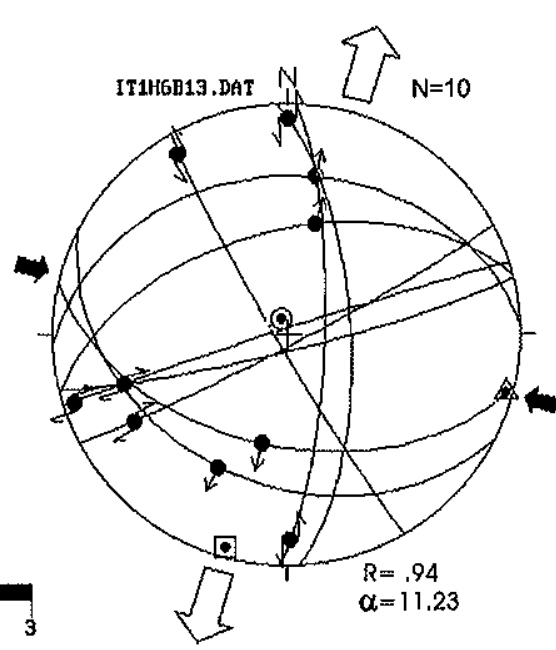

B)
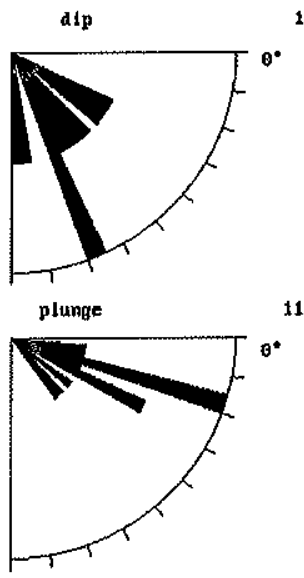

11 planes

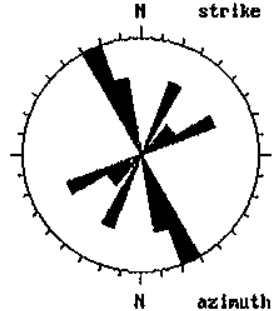

11 Itnes

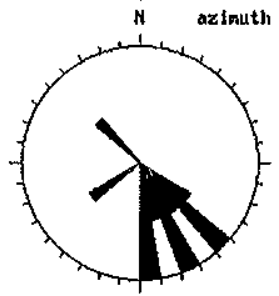

Figura 4.52-Dados de falhas e respectivos eixos de tensões para o Maciço Alcalino de ltaúna, Pontos Ita1 e 2. Símbolos:círculos - $\sigma 1$ (eixo de maior esforço), triângulos - $\sigma_{2}$ (eixo de esforço intermediário), quadrados - $\sigma 3$ (eixo de menor esforço); R - razão de esforço ( $\left.\sigma_{2}-\sigma_{3} / \sigma 1-\sigma 3\right) ; \alpha$ - desvio médio entre as estrias medidase o cisalhamento computado sobre o plano de falha. Setas grandes cheias - eixos compressivos horizontais, setas grandes vazias - eixos distensivos horizontais. Projeções de SchmidtLambert, hemisfério inferior. 

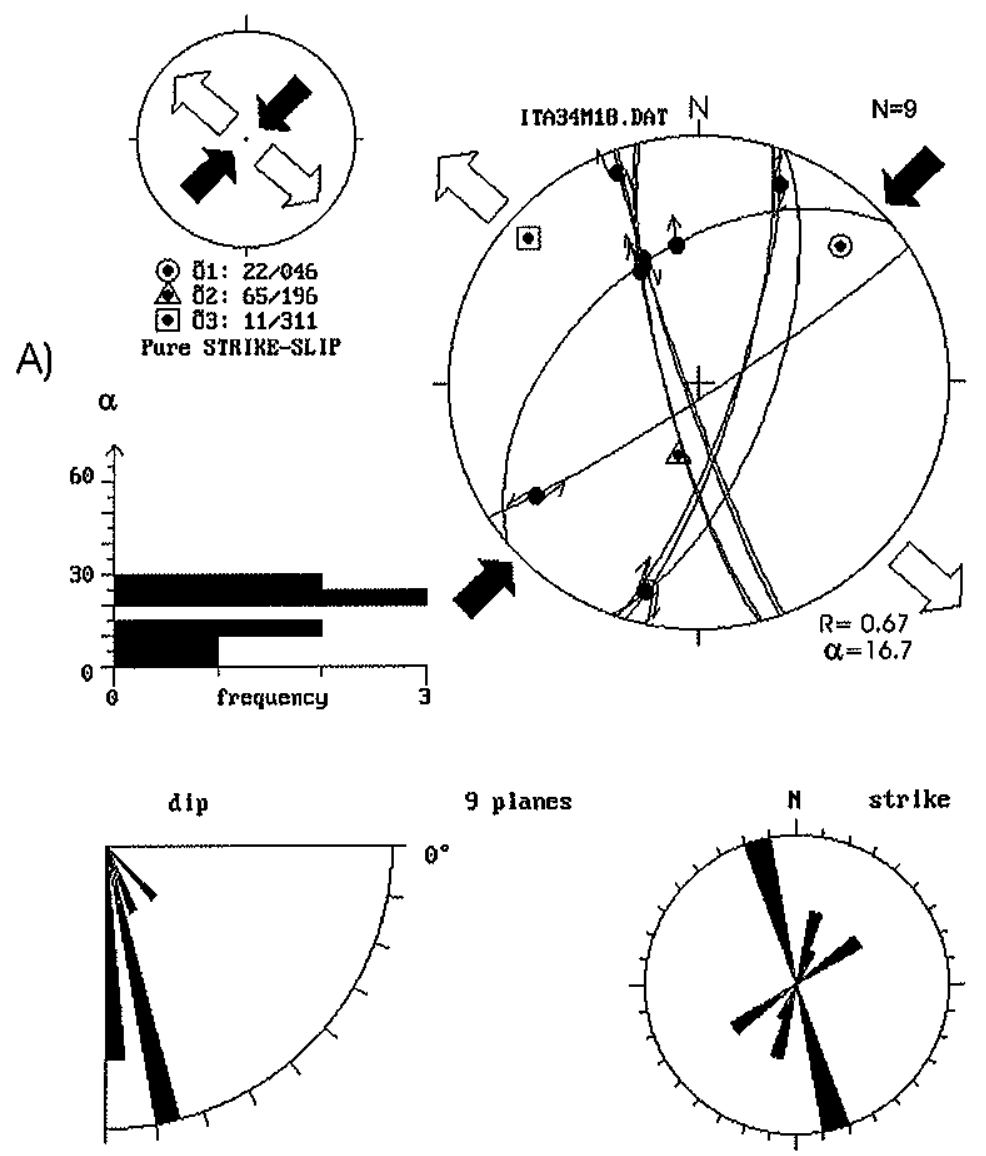

9 planes

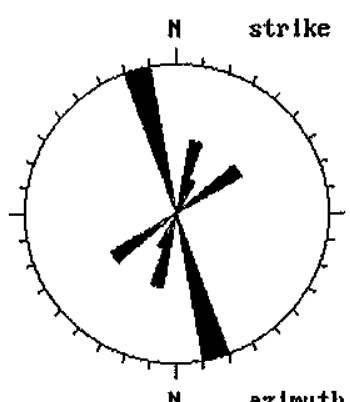

B)

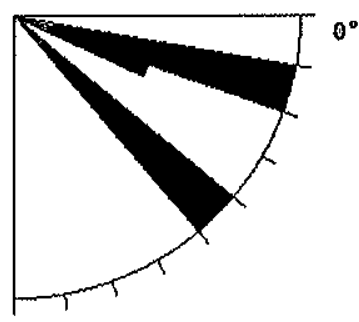

9 lines

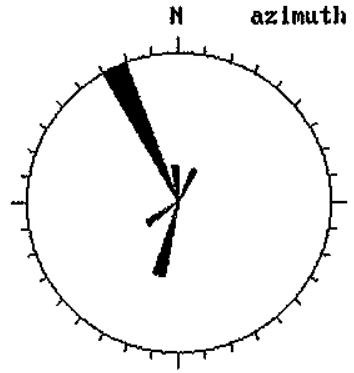

Figura 4.53 - Dados de falhas e respectivos eixos de tensões no Maciço de Itaúna, Pontos Ita3 e 4 . Símbolos: círculos - $\sigma 1$ (eixo de maior esforço), triângulos - $\sigma 2$ (eixo de esforço intermediário), quadrados - $\sigma 3$ (eixo de menor esforço); $R$ - razão de esforço ( $\left.\sigma 2^{n} \sigma 3 / \sigma 1-\sigma 3\right) ; \alpha$-desvio médio entre as estrias medidas e o cisalhamento computado sobre o plano de falha. Setas grandes cheias - eixos compressivos horizontais, setas grandes vazias - eixos distensivos horizontais. Projeções de Schmidt-Lambert, hemisfério inferior. 
horizontal, na direção NW-SE, e o eixo intermediário, $\sigma 2$, vertical. O histograma com os valores de $\alpha$ mostra dois grupos de falhas, onde as oblíquas exibem os maiores valores, evidenciando tratarem-se de estruturas reativadas.

A Figura 4.54 refere-se a microfalhas e falhas que afetam sienito na estação 3 , Pontos 6 e 7. Esse conjunto de estruturas se caracteriza pela presença de planos com mergulho alto a intermediário, com rejeito oblíquo, de caráter normal, indicando que se tratam de planos preexistentes reativados. A inversão dos dados mostrou que eles foram reativados por um campo de tensões Direcional EXTENSIVO (Strike-slip EXTENSIVE), com o eixo principal de tensões, $\sigma 1$, vertical, o eixo intermediário, $\sigma 2$, horizontal e orientado segundo a direção NNE-SSW, e o eixo mínimo, $\sigma 3$, também horizontal e ortogonal a $\sigma 2$. $\mathrm{O}$ alto valor de $\mathrm{R}$ indica, também nesse caso, que os tensores principal $\mathrm{e}$ intermediário, $\sigma 1$ e $\sigma 2$, têm magnitudes próximas.

As paleotensões determinadas para o Maciço de Itaúna, tanto a partir das famílias de juntas e fraturas sem estrias evidenciadas, como a partir de falhas e microfalhas, estão sintetizadas na Figura 4.55. Conclui-se pela atuação de dois campos de paleotensões, um mais antigo, com a direção do eixo de tensões principal horizontal, SHmax, variando entre E-W e NNE-SSW, e outro, mais novo, no qual a direção de SHmax variou entre N-S e WNW-ESE. Em ambos os campos de paleotensões o SHmax, determinado a partir de juntas e fraturas ou a partir de falhas e microfalhas, pode corresponder tanto a $\sigma 1$ como a $\sigma 2$. Tal característica indica que esses dois eixos tiveram magnitudes próximas, em ambos os campos de paleotensões. As paleotensões que controlaram a intrusão dos diques de fonolito e traquito que cortam o maciço, compativeis com uma extensão $\mathrm{N}-\mathrm{S}$, parecem estar relacionadas à primeira fase de deformação identificada, na qual SHmax variou entre E-W e NNE-SSW.

\subsubsection{Suíte do Tanguá}

A Suíte do Tanguá é um stock de rochas alcalinas intrusivas, com cerca de $40 \mathrm{~km}^{2}$, que constitui o denominado Maciço do Tanguá, localizado junto ao limite NE da Bacia do Macacu (Figura 4.34). Ele é formado por sienitos e nefelina sienitos, localmente com 

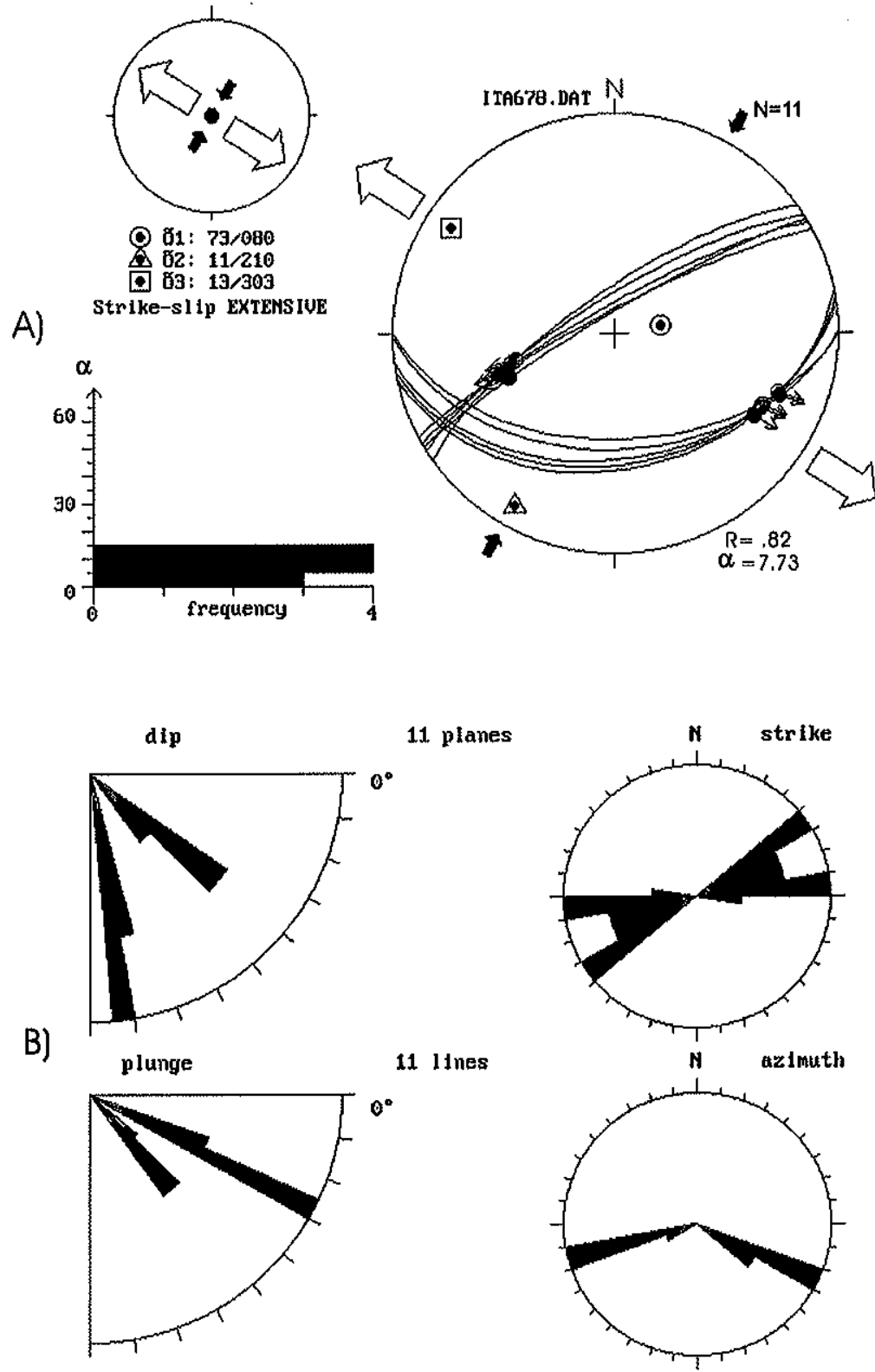

igura 4.54 - Dados de falhas e respectivos eixos de tensões no Maciço de Itaúna, Pontos Ita6 e 7. Símbolos: círculos - $\sigma 1$ (eixo de maior esforço), triângulos $-\sigma 2$ (eixo de esforço intermediário), quadrados - $\sigma 3$ (eixo de menor esforço); $R$ - razão de esforço ( $\sigma 2 \cdot \sigma 3 / \sigma 1-\sigma 3$ ); $\alpha$ - desvio médio entre as estrias medidas e e o cisalhamento computado sobre o plano de falha. Setas grandes cheias - eixos compressivos horizontais, setas grandes vazias - eixos distensivos horizontais. Projeções de SchmidtLambert, hemisfério inferior. 


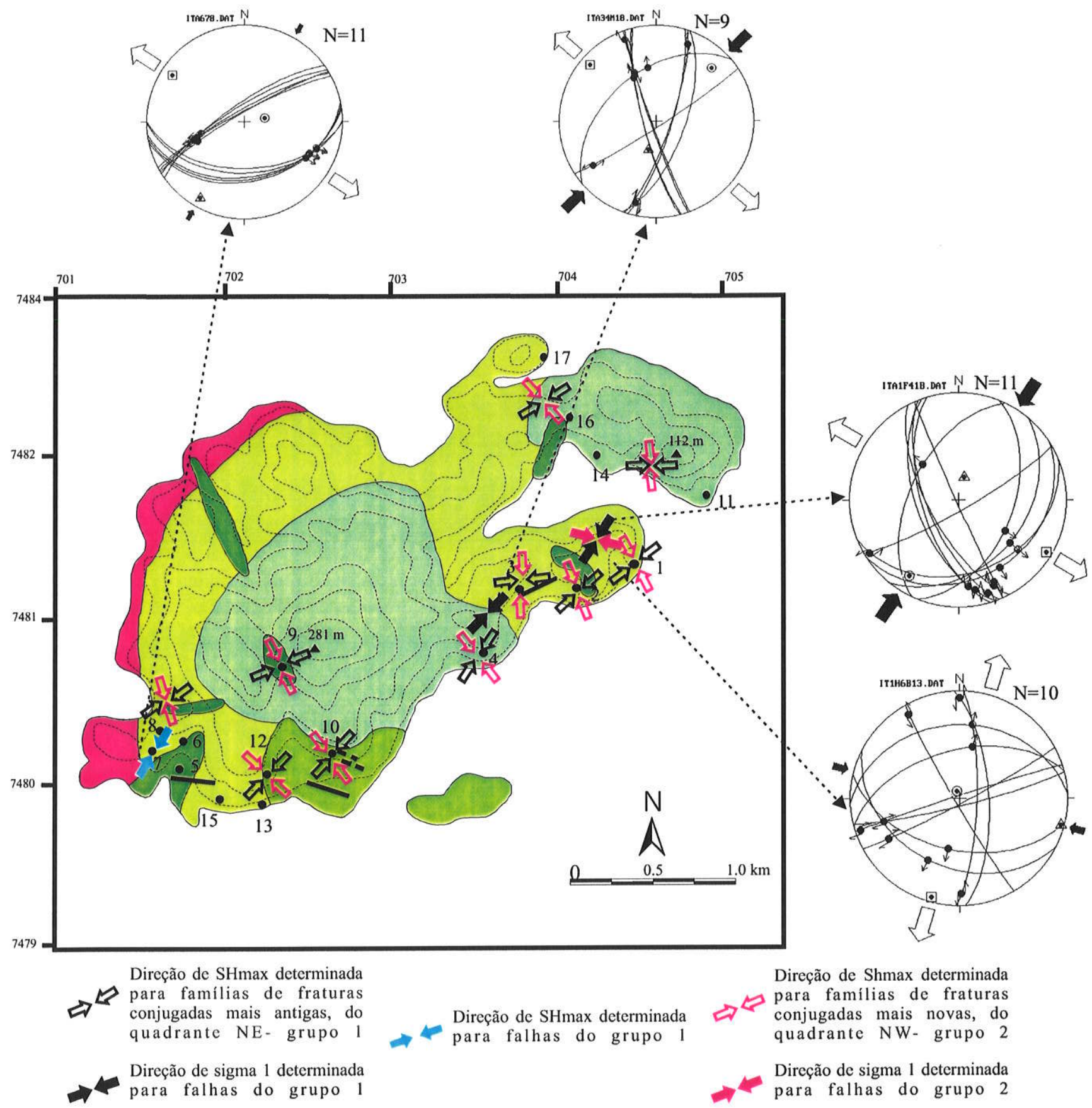

Figura 4.55 - Mapa síntese das paleotensões determinadas no Maciço de Itaúna. Mapa geológico simplificado e modificado de Valença (1980) e Dalcolmo et al. (1982), com mesma legenda que a Figura 4.35. 
pseudoleucita, e por brechas magmáticas fonolíticas, sendo esse conjunto cortado por diques fonolíticos e traquíticos (Valença 1980, Dalcolmo et al. 1982, Valença \& Klein 1984). Os diques traquíticos representam o encerramento da atividade magmática e mostram-se silicificados, podendo associar-se a brechas tectônicas silicificadas, localmente mineralizadas por fluorita (Coelho et al. 1986). Os levantamentos de dados estruturais, nesse maciço, restringiram-se a duas pedreiras, a pedreira Sartor, no Ponto Tan1, em atividade, e a pedreira Emitang, no Ponto Tan2, já desativada (Figura 2).

\subsubsection{Diques}

Foram caracterizado apenas diques que cortam o maciço, nas pedreiras Sartor e Emitang, Pontos Tan1 e 2. Os diques identificados são de fonolitos e traquitos, sendo que os primeiros apresentam alto ângulo de mergulho e os segundos mostram-se, também, com baixo ângulo de mergulho. Os diques de traquito de alto e baixo ângulo mostram relações de corte mútuas e, por vezes, os de alto ângulo mostram-se alimentadores dos de baixo ângulo. Essa relação pode ser vista apenas no Ponto Ita1, já que os diques os diques estão praticamente ausentes do Ponto Ita2, restringindo-se a um dique de traquito de alto ângulo. Todos os diques caracterizados, num total de 17, estão representado na Figura 4.56, sendo 11 de alto ângulo e 6 de baixo ângulo. Os diques de alto ângulo apresentam uma distribuição bastante homogênea, com direção ENE-WSW, indicando que o eixo de paleotensões mínimo responsável pelo controle da sua intrusão, $\sigma 3$, é horizontal e orientase na direção NNW-SSE. A direção do eixo de paleotensões horizontal máximo, SHmax, posiciona-se ortogonalmente a $\sigma 3$, orientando-se na direção ENE-WSW, sub-paralelo aos diques. Os diques de baixo ângulo, de direção NNW-SSE, todos traquíticos e com ângulo de mergulho abaixo de $40^{\circ}$, são compatíveis com um campo de paleotensões compressivo, onde o eixo de tensões mínimo, $\sigma 3$, é vertical. $O$ arranjo conjugado desses diques indica que o eixo de tensões intermediário, $\sigma 2$, é horizontal e orienta-se na direção da intersecção dos mesmos, NNW-SSE, com o eixo principal, $\sigma 1$, ortogonal a ele e aos diques, de direção ENE-WSW. Deve-se ressaltar que as direções de SHmax e de Shmin permanecem inalteradas. 

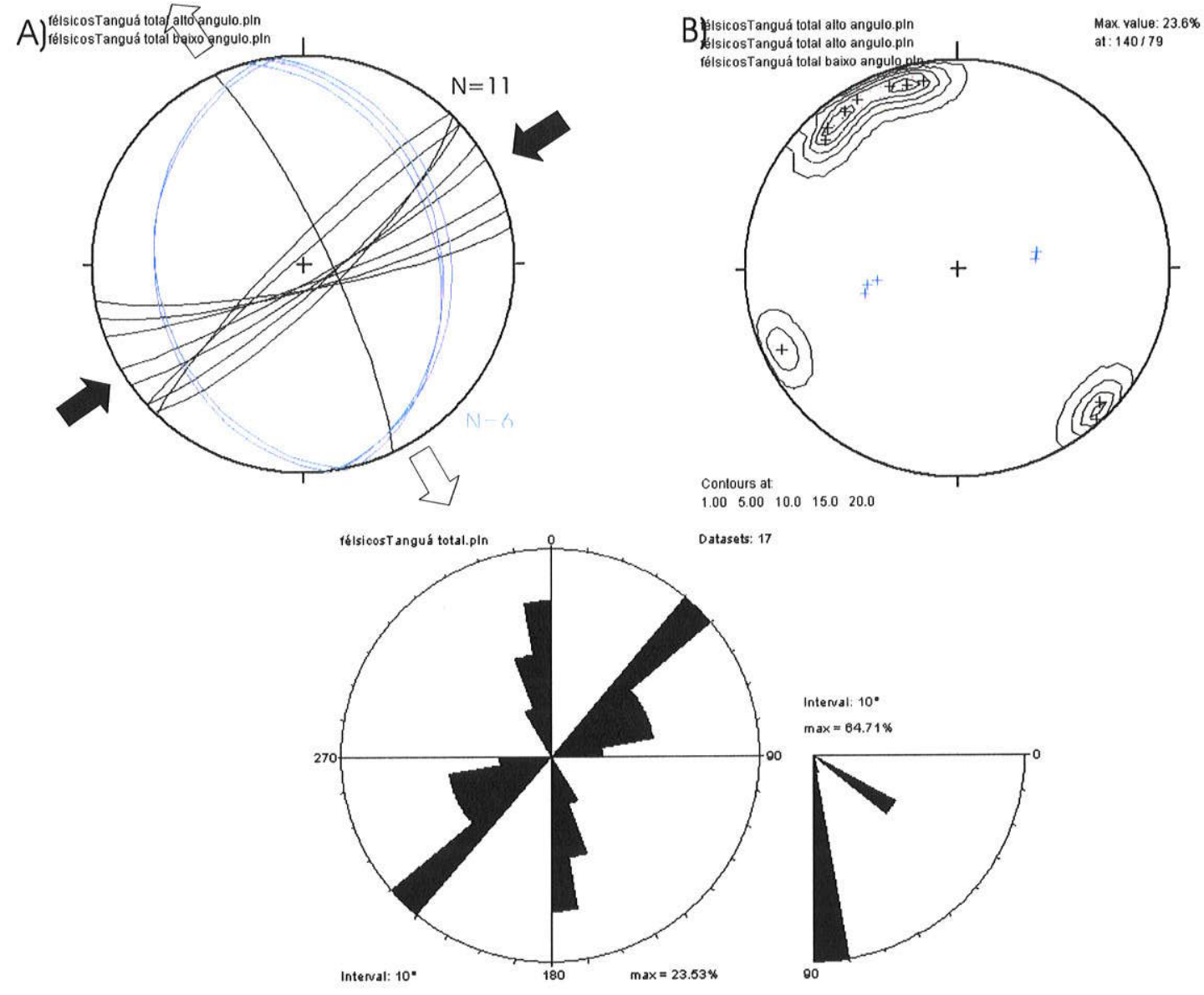

Figura 4.56 - Projeções ciclográficas e polares, e diagramas de rosetas, mostrando as direções e os mergulhos de diques de rochas alcalinas félsicas, traquitos e fonolitos, do Maciço do Tanguá. Em A e B estão separados os diques com ângulo de mergulho maior que 65 graus (preto) e com ângulo de mergulho menor que 40 graus (azul). A orientação principal dos diques com mergulho maior que 65 graus com direção variando entre NE-SW e ENE-WSW, permite posicionar o eixo de tensões horizontal máximo, SHmax (setas cheias), na direção ENE-WSW, e o eixo de tensões mínimo, $\sigma 3$ (setas vazias), na horizontal, segundo a direção NNW-SSE.Ver explanação no texto. Diagramas de Schmidt-Lambert, hemisfério inferior. 


\subsubsection{Juntas e Fraturas}

Os dados de juntas e fraturas foram coletados nas pedreiras dos Pontos Tan1 e 2 (Figura 4.34) e, em ambos os casos, referem-se a estruturas que afetam sienito.

\section{A) Análise Geométrica}

As juntas e fraturas puderam ser separadas, tanto no Ponto Tan1 como no Tan2, em dois grande grupos de famílias, um com famílias de fraturas conjugadas de cisalhamento e fraturas de extensão, de direção ENE-WSW, mais antigo, e outro, de direção NNW-SSE, mais novo, também com famílias de fraturas conjugadas de cisalhamento e fraturas de extensão. As fraturas do primeiro grupo encontram-se muitas vezes preenchidas por diques, veios de calcedonia, sulfetos e, mais raramente, fluorita

Foram tratadas como famílias de fraturas de cisalhamento as com ângulo de mergulho acima de $65^{\circ}$. Por outro lado, foram identificadas ainda famílias de fraturas com ângulo de mergulho abaixo de $65^{\circ}$, as quais foram separadas em dois subgrupos, o das fraturas com ângulo de mergulho entre $65^{\circ}$ e $40^{\circ}$ e o das fraturas com ângulo de mergulho abaixo de $40^{\circ}$. As famílias de fraturas de alto ângulo foram plotadas alternadamente com os dois subgrupos de fraturas de baixo ângulo, buscando caracterizar as relações geométricas entre eles.

Na Figura 4.57 estão representadas as projeções ciclográficas e polares das famílias de fraturas caracterizadas na Pedreira Sartor, Ponto Tan1. O grupo de fraturas de direção ENE-WSW, mais antigo, é caracterizado por duas famílias de fraturas conjugadas de cisalhamento, onde as estruturas sintéticas, R, têm direção ESE-WNW, as antitéticas, R', têm direção NE-SW e as estruturas de extensão, T, estão orientadas segundo a direção ENE-WSW, paralelas ao eixo de tensões principal, o1 (Figuras 4.57A, B, C e D). As fraturas de direção NNW-SSE, mais novas, constituem, também, famílias de fraturas conjugadas de cisalhamento, onde as estruturas sintéticas têm direção NW-SE, as antitéticas se orientam na direção N-S e as fraturas de extensão estão orientadas na direção NNW-SSE, paralelas ao eixo de tensões principal, $\sigma$ l (Figuras $4.57 \mathrm{E}, \mathrm{F}, \mathrm{G}$ e $\mathrm{H}$ ). As relações geométricas entre as famílias de alto ângulo e de baixo ângulo, indicam que as 


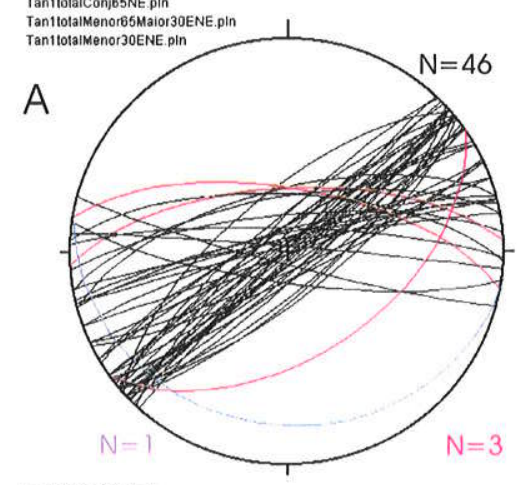

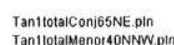

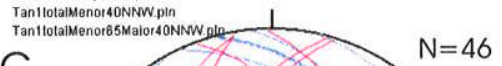

$\mathrm{C}^{\mathrm{Tan}}$

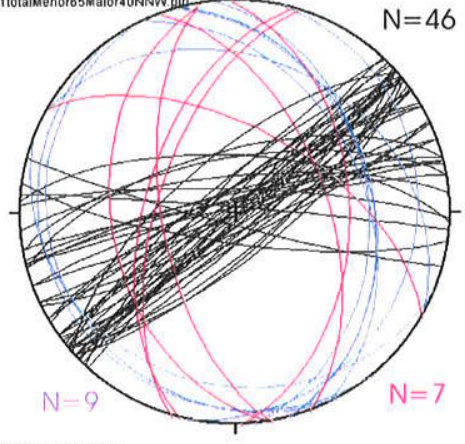

Tan 1totalc oni65NW plin

Tan1 totalMenor65MalortonNW. oln

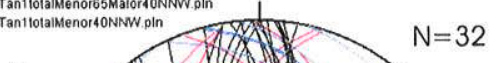

E

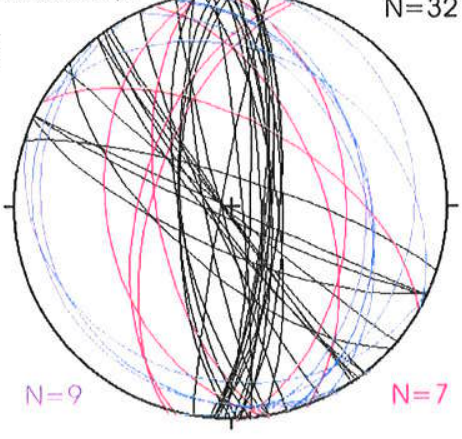

TantlotalMenor65Malor30ENE PD
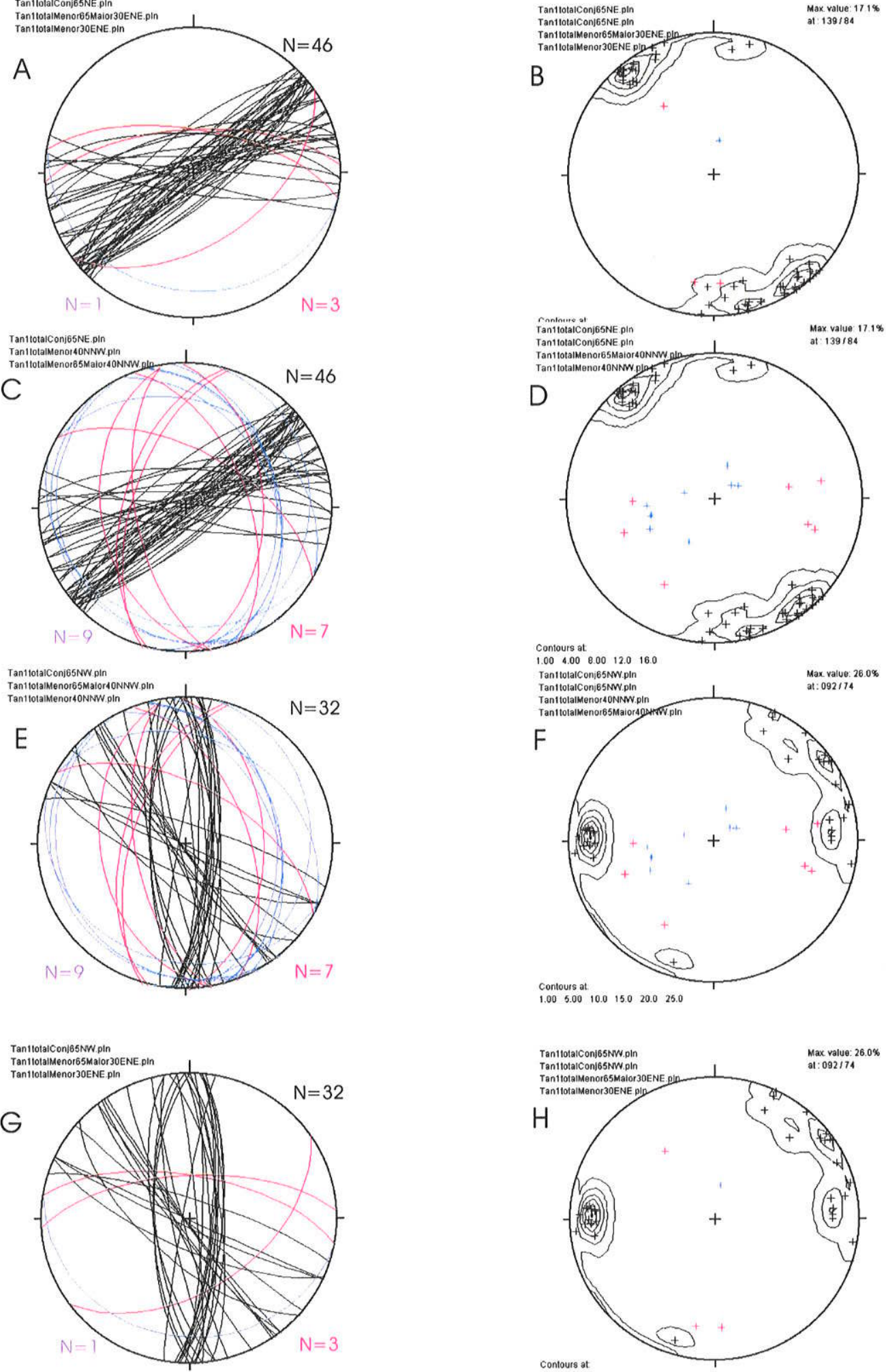

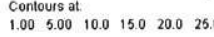

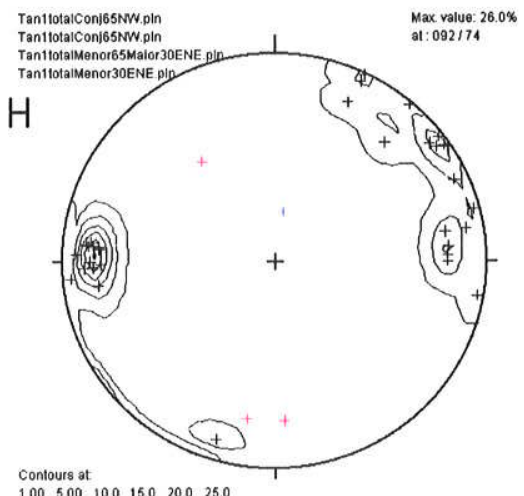

Figura 4.57 - Projeções ciclográficas e polares mostrando as relações geométricas entre juntas conjugadas de cisalhamento com ângulo de mergulho maior que 65 graus (preto) e juntas com ângulo de mergulho menor que 65 e maior que 40 graus (vermelho) e juntas com ângulo de mergulho me-nor do que 40 graus, para famílias de direção ENE-WSW e NW-SE. As juntas afetam sienito. Nos estereogramas A, B, E e F, as juntas de baixo ângulo de mergulho são representadas como tendo sido geradas em um regime normal de esforços, e nos estereogramas C, D, G e H, elas são re-presentadas como tendo sido geradas em um regime de esforços reverso. Ver explanação no texto. Diagramas de Schimidt-Lambert, hemisfério inferior. Maciço do Tanguá, Ponto 1, Pedreira Sartor. 
famílias de fraturas de baixo ângulo com direção ENE-WSW, nas quais predominam as fraturas com ângulo entre $65^{\circ}$ e $40^{\circ}$, foram geradas em um regime extensional (Figuras 4.57A e B). Por outro lado, as famílias de fraturas de baixo ângulo de direção NNW-SSE, nas quais ocorrem tanto as com ângulo de mergulho abaixo de $40^{\circ}$ como entre $65^{\circ}$ e $40^{\circ}$, podem ter sido geradas em um regime extensional ou compressivo, de acordo com as Figuras 4.57E, F e C, D, respectivamente. A predominância das fraturas com ângulo de mergulho menor do que $40^{\circ}$ indicam que essas fraturas devem ter sido geradas, pelo menos em parte, em um regime compressivo. Nesse caso, teria havido uma permutação entre os eixos de tensões intermediário e mínimo, $\sigma 2$ e $\sigma 3$, permanecendo o eixo de tensões principal, $\sigma 1$, orientado na direção ENE-WSW. Essa relação sugere que a direção de SHmax que controlou a intrusão dos diques de traquito, de alto e baixo ângulos, trata-se, também, do eixo de tensões principal, $\sigma 1$.

Na Figura 4.58 estão representadas as projeções ciclográficas e polares das fraturas que ocorrem no Ponto Tan2, Pedreira Emitang. O grupo de famílias de fraturas de alto ângulo com direção ENE-WSW, mais antigo, é constituído por um espectro de fraturas famílias de fraturas, onde as fraturas de cisalhamento conjugadas, as híbridas e as de extensão apresentam-se em continuidade. Nesse caso posiciona-se SHmax na direção ENE-WSW e Shmin ortogonal a ele, na direção NNW-SSE (Figuras 4.58A e B). As fraturas de alto ângulo de direção NNW-SSE constituem famílias de fraturas de cisalhamento conjugas, onde as estruturas sintéticas, R, têm direção WNW-ESE a NW-SE e as antitéticas têm direção N-S, posicionando-se o eixo de tensões principal, $\sigma 1$, na direção NNW-SSE e o eixo de tensões mínimo, $\sigma 3$, na direção ENE-WSW (Figura 4.58C e D). Dentre as fraturas de baixo ângulo, foram caracterizadas apenas fraturas com direção NE-SW, predominando as com ângulo de mergulho abaixo de $40^{\circ}$. Tais fraturas foram geradas em um regime de esforços compressivo, o qual pode estar relacionado a uma permutação dos eixos de tensões intermediário e mínimo, mantendo-se o eixo de tensões principal na direção NNW-SSE.

B) Análise Cinemática de Falhas e Microfalhas 

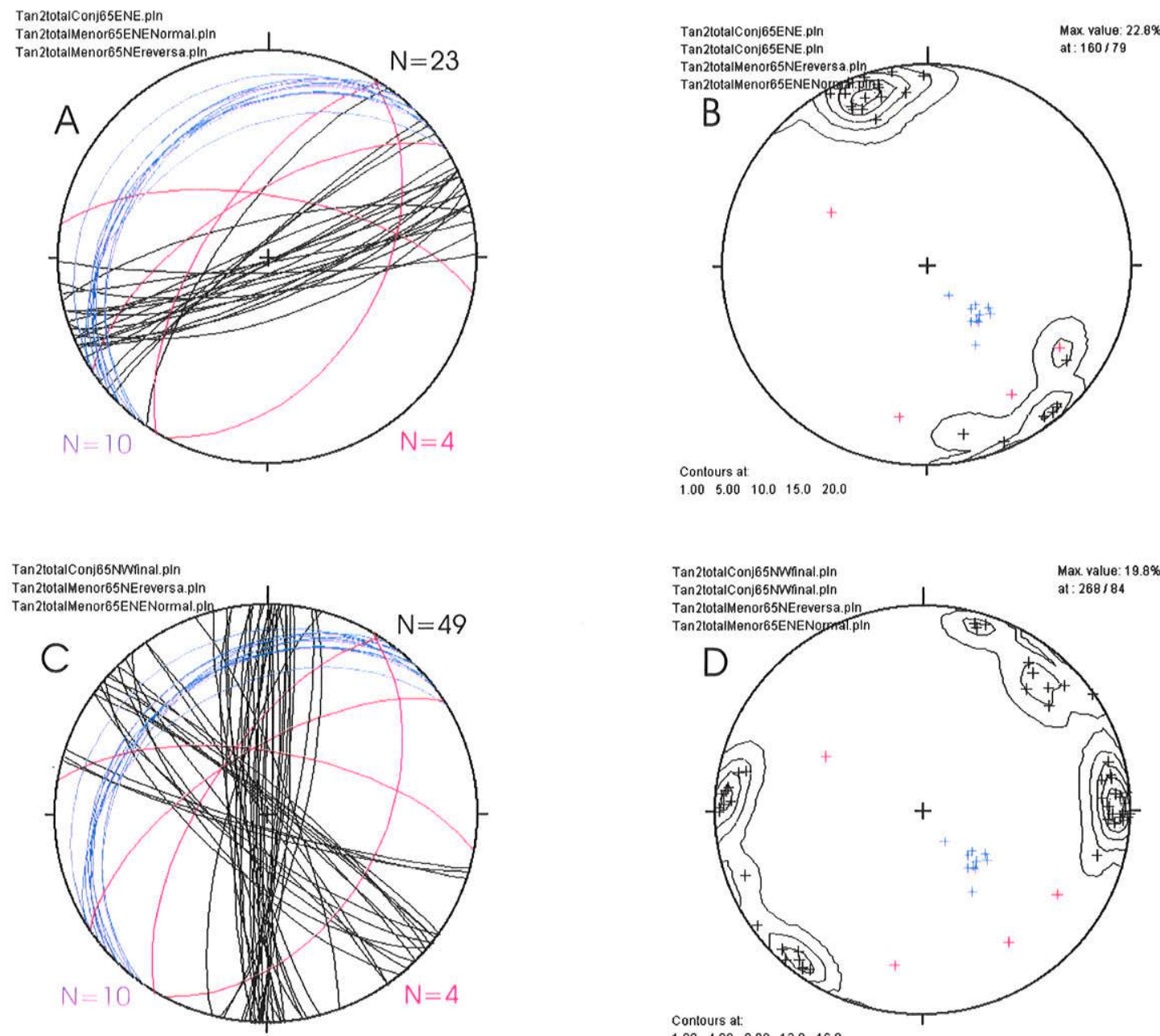

Figura 4.58 - Projeções ciclográficas e polares mostrando as relações geométricas entre fraturas conjugadas de cisalhamento com ângulo de mergulho maior que 65 graus (preto) e juntas com ângulo de mergulho menor que 65 graus e maior que 40 graus (vermelho) e juntas com ângulo de mergulho abaixo de 40 graus (azul), para famílias de direção ENE-WSW e NW-SE. As juntas afetam sienito. Nos estereogramas A e B, as juntas com baixo ângulo de mergulho são representadas como tendo sido geradas em um regime normal de esforços, e nos estereogramas $\mathrm{C}$ e $\mathrm{D}$, elas são representadas como tendo sido geradas em um regime de esforços reverso. Ver explanação no texto. Diagramas de Schimidt-Lambert, hemisfério inferior. Maciço do Tanguá, Ponto 2, Pedreira Emitang (desativada). 
Os dados de falhas e microfalhas utilizados na análise cinemática foram coletados principalmente na Pedreira Sartor, Ponto Tan1, e referem-se tanto a falhas como a microfalhas. Nessa pedreira foram identificadas três falhas principais, com rejeito direcional, duas de direção ENE e uma de direção NE-SW, todas hidrotermalizadas, com calcedônia e sulfetos. O sienito também se apresenta bastante hidrotermalizado mostrandose praticamente sem minerais máficos. Nos planos de falhas e microfalhas as estrias referem-se principalmente a marcas de objetos, facetas polidas e rugosas alternadas, fraturas de cisalhamento sintéticas e antitéticas e, mais raramente, degraus de minerais acrescionários com fluorita.

Nas Figuras 4.59A e B estão representadas falhas e microfalhas conjugadas de cisalhamento. As com direção ESE-WNW representam estruturas sintéticas, R, e as de direção NE-SW representam estruturas antitéticas. A inversão desses dados mostrou que eles foram gerados em um regime DIRECIONAL Puro (Pure STRIKE-SLIP), onde o eixo de tensões máximo, $\sigma 1$, é horizontal e orienta-se na direção ENE-WSW, o eixo de tensões mínimo, $\sigma 3$, é também horizontal e ortogonal a ele, e o eixo intermediário, $\sigma 3$, está posicionado na vertical.

Nas Figuras 4.59C e D estão representadas falhas e microfalhas conjugadas de cisalhamento, onde as de direção direção NW-SE e WNW-ESE a WSW-ENE representam estruturas sintéticas, $R$ e $P$, respectivamente, e as de direção NNE-SSW representam estruturas antitéticas, R'. A inversão desses dados indicou que essas estruturas foram geradas em um campo de paleotensões DIRECIONAL Puro (Pure STRIKE-SLIP), onde o eixo de tensões principal, $\sigma 1$, é horizontal e orientado na direção NW-SE, o eixo de tensões mínimo, $\sigma 3$, é também horizontal e ortogonal a ele e o eixo intermediário, $\sigma 2$, é vertical.

A análise de paleotensões no Maciço do Tanguá, a partir dos dados coletados nas pedreiras Sartor e Emitang, Pontos Tan 1 e 2, referentes a diques, fraturas e falhas, mostrou coerência na posição dos eixos de paleotensões, evidenciando que o maciço foi afetado por dois campos puramente direcional distintos, com $\sigma 1$, inicialmente, de direção ENE-WSW e, posteriormente, de direção NNW-SSE. Em ambos os casos houve mudanças temporais/locais nos regimes de esforços, com permutações tanto de $\sigma 2$ e $\sigma 3$, gerando um regime compressivo, como de $\sigma 1$ e $\sigma 2$, gerando um regime puramente extensional. 
A)

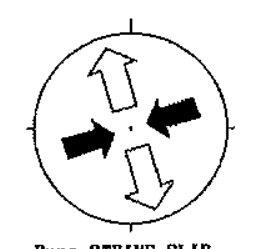

Pure STHIKE-SI, IP

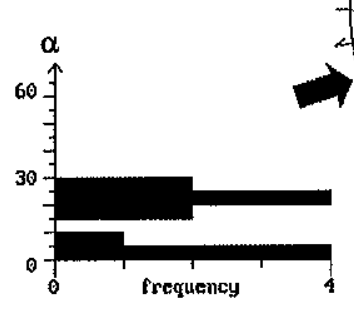

C)

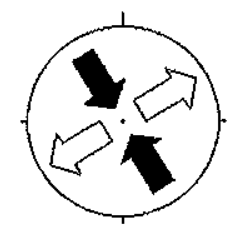

Pure STRIKE-SLIP
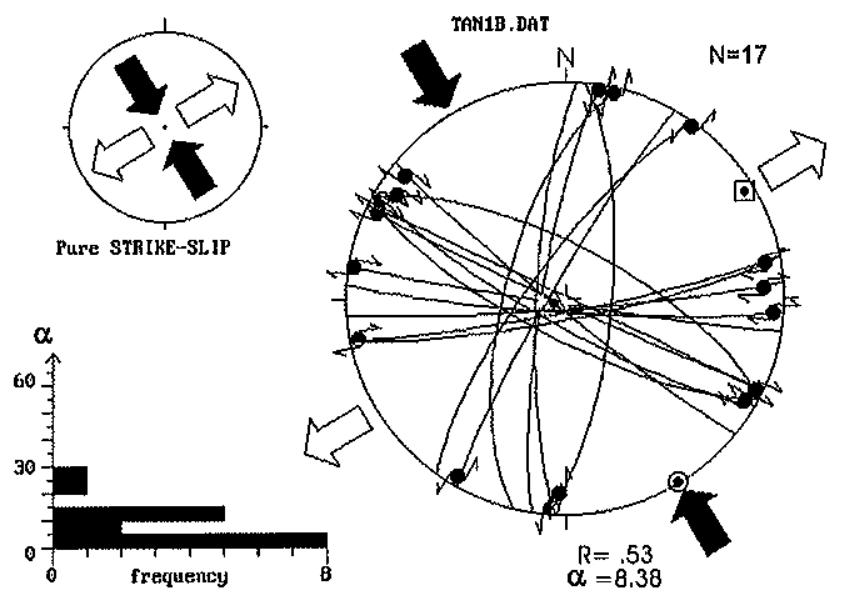

B)

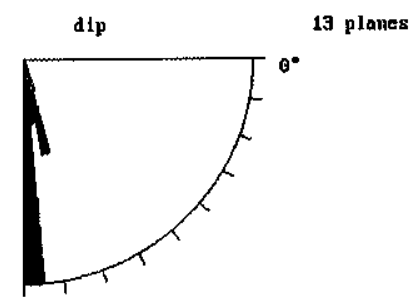

13 lines
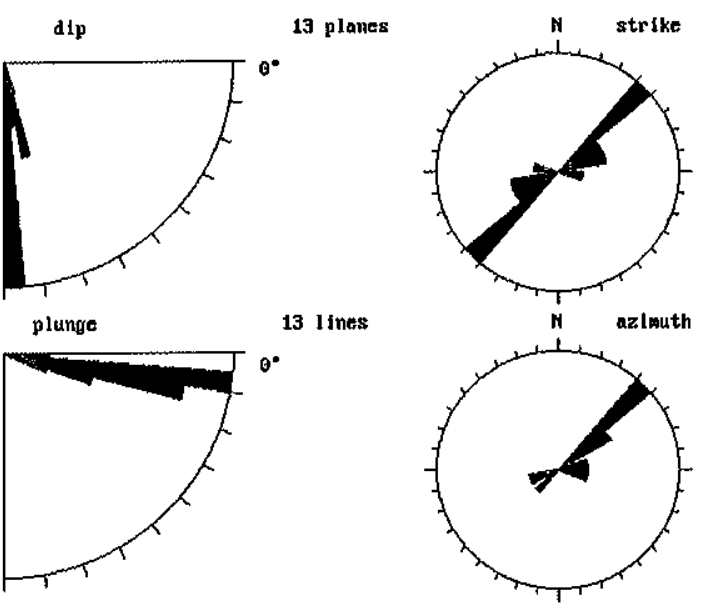

D)
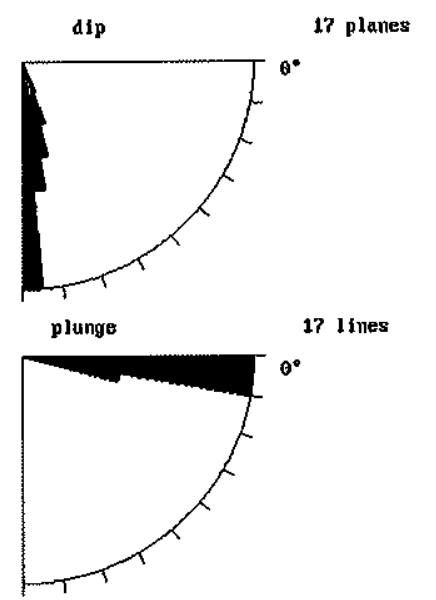
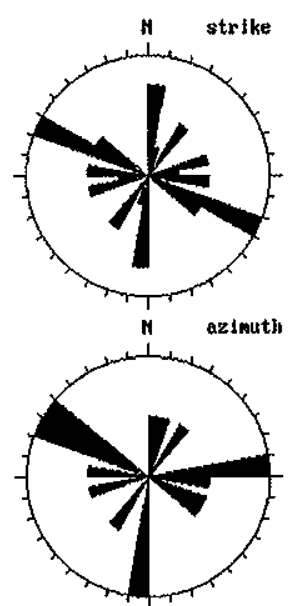

Figura 4.59 - Dados de falhas e respectivos eixos de tensões para o Maciço do Tanguá, Pedreira Sartor, Ponto Tan1. Símbolos:círculos - $\sigma 1$ (eixo de maior esforço), triângulos - $\sigma 2$ (eixo de esforço intermediário), quadrados - $\sigma 3$ (eixo de menor esforço); $R$ - razão de esforço ( $\sigma 2-\sigma 3 / \sigma 1-\sigma 3$ ); $\alpha$ desvio médio entre as estrias medidas $\theta$ o cisalhamento computado sobre o plano de falha. Setas grandes cheias - eixos compressivos horizontais, setas grandes vazias - eixos distensivos horizontais. Projeções de Schmidt-Lambert, hemisfério inferior. 
Variações do primeiro tipo foram responsáveis pelo controle da intrusão dos diques de traquito de baixo ângulo de mergulho.

\subsubsection{Plug de Itaboraí}

O Plug de Itaboraí, localizado na área urbana da cidade homônima, é um corpo elíptico, alongado na direção NE-SW, com cerca de $2 \mathrm{~km}$ de comprimento e pouco mais de 500 metros de largura, num total de pouco mais de $1 \mathrm{~km}^{2}$ de área. Ele é constituído principalmente por fonolito pórfiro e, subordinadamente, por microssienito (Valença 1980, Dalcolmo et al. 1982). Esse conjunto é cortado por diques de fonolito, fonolito pórfiro e traquito.

Os dados estruturais e de diques referentes ao Plug de Itaboraí foram levantados em seis pontos distintos, sendo cinco dentro do corpo e um na encaixante, junto a sua borda nordeste, na localidade de Venda das Pedras. Nesse local a encaixante apresenta-se como um gnaisse granítico leucocrático e porfiroblástico, com foliação de direção NW-SE, subhorizontal, com caimento suave para SW. Considerando a pequena área do corpo, os dados foram tratados em conjunto, como uma única estação.

\subsubsection{Diques}

Foram caracterizados 11 diques associados ao Plug de Itaboraí, sendo 9 internos ao corpo e dois externos. Do total, 10 são de fonolito e fonolito pórfiro, e um é de traquito. Eles ocorrem, principalmente, cortando os microssienitos, porém as relações de corte entre os diques não foram vistas. Os dois diques que cortam o embasamento são fonolíticos.

Os diques puderam ser separados em dois grupos, um com ângulo de mergulho alto a médio e com direção em torno de WNW-ESE e, outro, com mergulho menor que $40^{\circ} \mathrm{e}$ de direção NNE-SSW (Figura 4.60). Esses últimos são todos de fonolito pórfiro. A espessura dos diques varia entre decimétrica e métrica, podendo atingir pouco mais de três metros. O conjunto de diques com direção WNW-ESE e mergulho acima de $65^{\circ}$, permite posicionar-se o eixo de paleotensões mínimo, $\sigma 3$, na horizontal e ortogonal a eles, 
A)

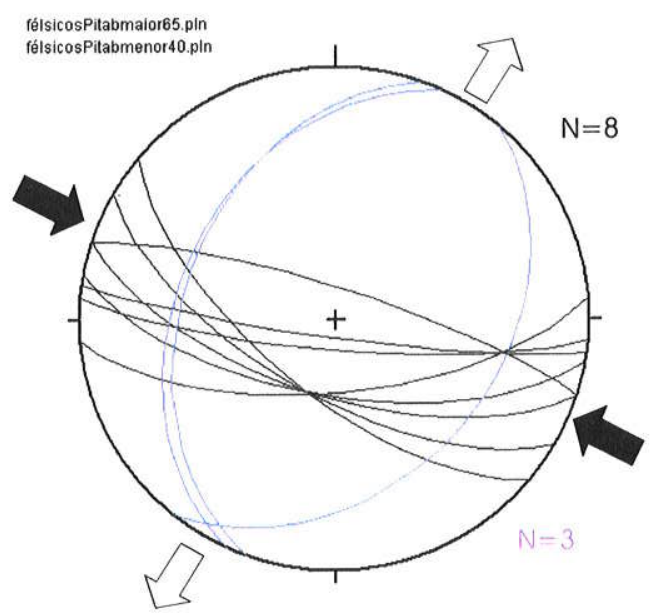

B)

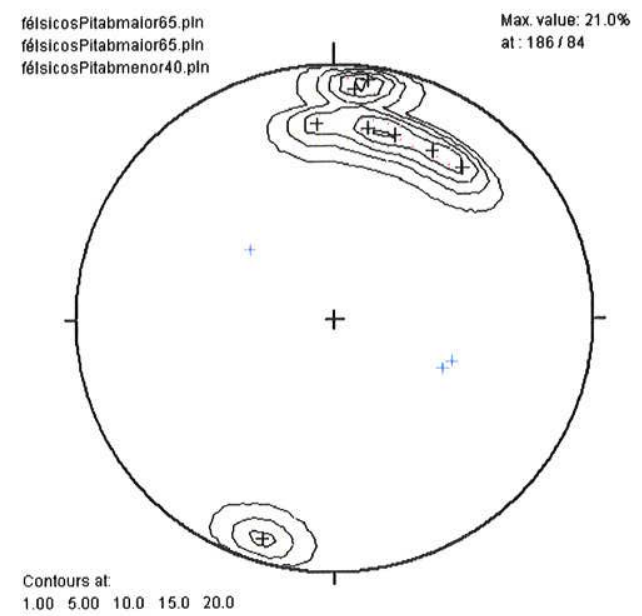

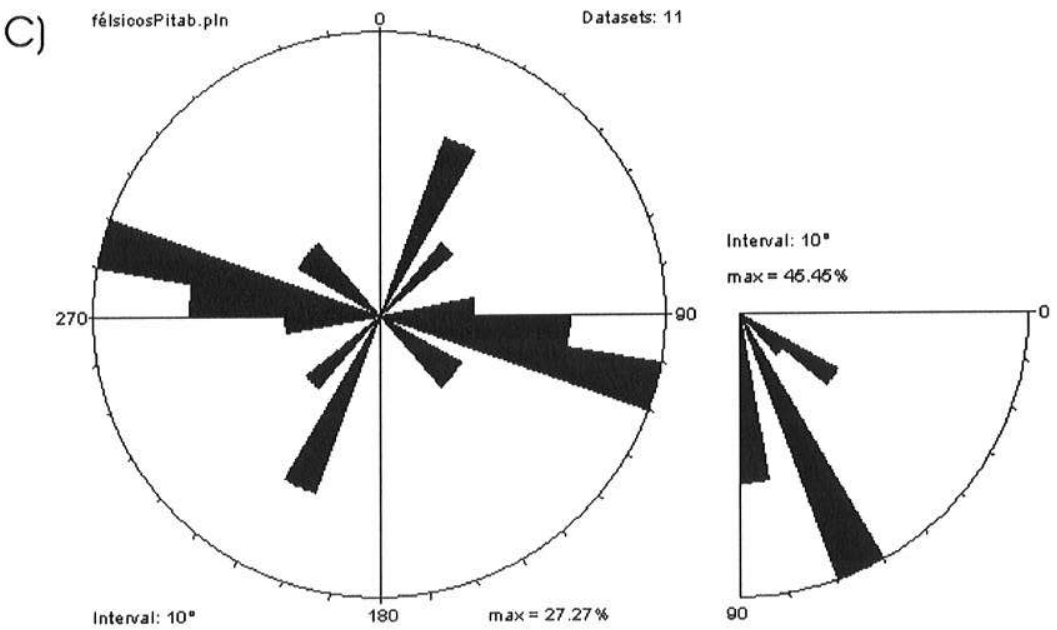

Figura 4.60 - Projeções ciclográficas e polares, e diagramas de rosetas, mostrando as direções e os mergulhos de diques de rochas alcalinas félsicas, traquitos e fonolitos, do Plug de Itaboraí. Em A e B estão separados os diques com ângulo de mergulho maior que 65 graus (preto) e com ângulo de mergulho menor que 40 graus (azul). A orientação principal dos diques com mergulho maior que 65 graus com direção variando entre NW-SE e ENE-WSW, permite posicionar o eixo de tensões horizontal máximo, SHmax (setas cheias), na direção WNW-ESE, e o eixo de tensões mínimo, $\sigma 3$ (setas vazias), na horizontal, segundo a direção NNE-SSW.Ver explanação no texto. Diagramas de Schmidt-Lambert, hemisfério inferior. 
orientado segundo a direção NNE-SSW. Nesse caso, o eixo de paleotensões horizontal máximo, SHmax, pode ser posicionado na direção média dos diques e ortogonalmente a $\sigma 3$, na direção WNW-ESE. Por outro lado, os diques de fonolito pórfiro com ângulo de mergulho abaixo de $40^{\circ}$ exigem que se posicione $\sigma 3$ na vertical, mantendo-se a posição de SHmax, o qual deve ser, necessariamente, o eixo de paleotensões principal, o1. Nesse sentido, ocorreram variações temporais e/ou locais no campo de paleotensões ao durante a intrusão dos diques associados ao Plug de Itaboraí, com variação da posição de $\sigma 3$ e manutenção da direção de SHmax.

\subsubsection{Juntas e Fraturas}

As juntas e fraturas sem estrias caracterizadas no Plug de Itaboraí foram separadas para as litologias que elas afetam, procurando discernir eventuais controles temporais refletidos pelas mesmas. Para cada litologia, separou-se as famílias de fraturas conjugadas de cisalhamento das famílias de juntas e fraturas de baixo ângulo. As de baixo ângulo foram separadas em menores que $65^{\circ}$ e maiores que $40^{\circ}$, consideradas como geradas em um regime extensional, e em menores do que $40^{\circ}$, consideradas como tendo sido geradas em um regime compressivo.

As famílias de fraturas com orientação variando em torno de E-W são as mais antigas, tendo em vista apresentarem maior continuidade e mostrarem-se hidrotermalizadas, por vezes preenchidas com veios de calcedônia. Elas mostram um arranjo anastomosado (Figura 4.61), similar ao padrão em Y de Hancock (1985), típico das geradas em regime direcional. As famílias conjugadas de cisalhamento, com direção NWSE e NE-SW, mostram-se menos contínuas e não hidrotermalizadas.

Nas Figuras 4.62E e $\mathrm{F}$ estão representadas as projeções cilográficas e polares das fraturas, consideradas as mais antigas, que afetam microssienito, as quais têm direção variando entre ENE-WSW e ESE-WNW, que poderiam representar famílias conjugadas de cisalhamento, onde as primeiras seriam as estruturas sintéticas, $\mathrm{R}$, e as últimas, as estruturas $\mathrm{R}^{\prime}$. As fraturas de direção E-W representariam, nesse caso estruturas extensionais, T. Por outro lado, a grande quantidade de fraturas com ângulo de mergulho 

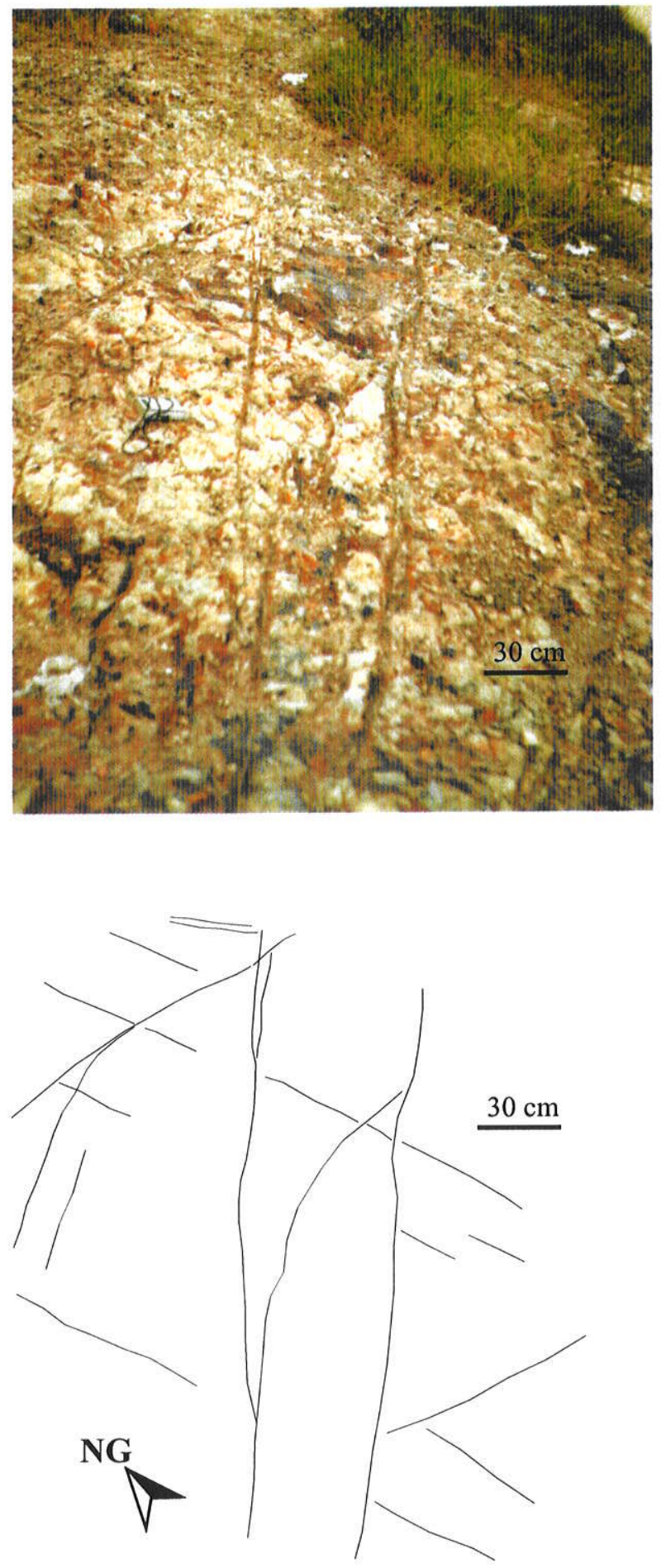

Figura 4.61- Famílias de fraturas conjugadas de cisalhamento, com direção ENE-WSW e WNW-ESE, mais antigas, exibindo arranjo anastomosado, constituindo as famílias de fraturas em Y, de Hancock (1985). Elas são cortadas por fraturas com direção NNW-SSE. As fraturas afetam fonolito pórfiro. Plug de Itaboraí, área urbana de Itaboraí. 

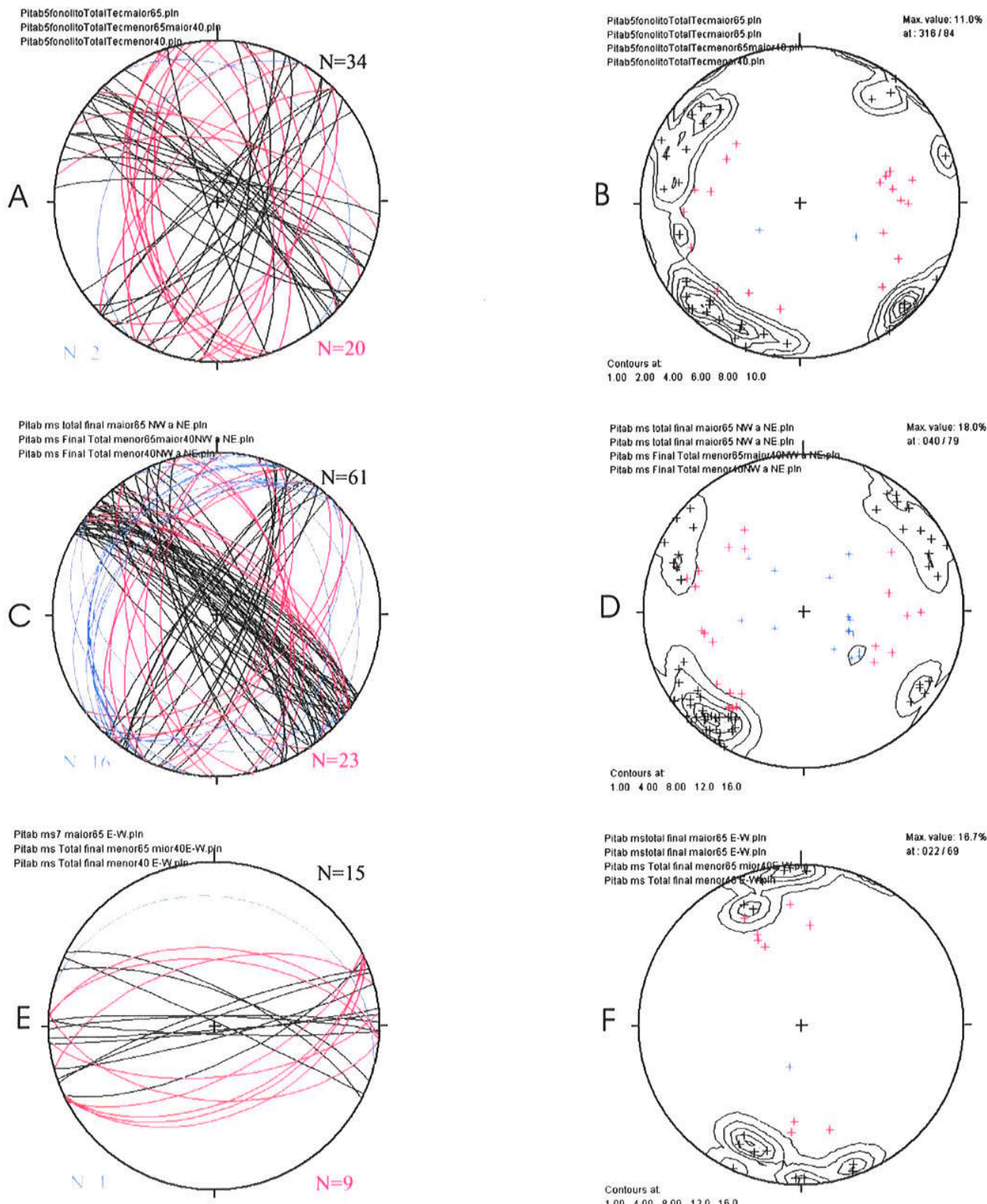

Figura 4.62 - Projeções ciclográficas e polares mostrando as relações geométricas entre juntas conjugadas de cisalhamento com ângulo de mergulho maior que 65 graus e juntas conjugadas com ângulo de mergulho menor que 65 graus, para famílias de direção NNW-SSE e NE-SW, em fonolito (A e B) e microssienito (C e D). Famílias de fraturas de direção E-W, afetando microsssienito, estão representadas nas Figuras E e F. Diagramas de Schimidt-Lambert, hemisfério inferior. Plug de Itaboraí. 
médio, indica uma componente extensional importante, apontando mais para um espectro de fraturas, onde estariam presentes fraturas híbridas e extensionais, além das conjugadas de cisalhamento. Em ambos os casos o eixo de tensões horizontal máximo, SHmax, estaria posicionado na direção E-W, e o Shmin na direção N-S.

Nas Figuras $4.62 \mathrm{C}$ e D, e A e B, estão representadas as projeções ciclográficas e polares das famílias de fraturas de cisalhamento conjugadas, de direção NW-SE e NE-SW, que afetam tanto microssienito, as primeiras, como fonolito pórfiro, as segundas. Para as duas litologias, a família de fraturas NW-SE corresponde às estruturas sintéticas, $\mathrm{R}$, enquanto que as de direção NE-SW representam as antitéticas, R'. Para essas duas famílias conjugadas de cisalhamento, o eixo de paleotensões principal, $\sigma 1$, é horizontal e orienta-se na direção N-S, com o eixo de paleotensões mínimo, $\sigma 3$, também horizontal e orientado ortogonalmente a ele, caracterizando um campo de paleotensões direcional. Em ambos os casos estão presentes fraturas com ângulo de mergulho médio, entre $65^{\circ} \mathrm{e} 40^{\circ}$, que indicam variações locais/temporais no campo de tensões, para um regime com componente extensional mais acentuada. Por outro lado, as famílias de fraturas conjugadas de baixo ângulo, menor que $30^{\circ}$, caracterizadas no fonolito pórfiro (Figuras $4.62 \mathrm{C}$ e D), exigem que o eixo de tensões mínimo, $\sigma 3$, posicione-se na vertical, indicando que elas foram geradas em um campo de paleotensões compressivo. Nesse o eixo de tensões principal, $\sigma 1$, estaria orientado ortogonalmente ao plano de intersecção dos mesmos, aproximadamente na direção WNW-ESE. Essa posição de $\sigma 1$ é compatível com a exigida para o controle da intrusão dos diques com baixo ângulo de mergulho, de traquito e fonolito, associados ao Plug de Itaboraí (Figura 4.60), sugerindo que a geração dessa famílias de fraturas foi contemporânea a dos diques de baixo ângulo.

\subsubsection{Análise Cinemática de Falhas e Microfalhas}

Os dados utilizados na análise cinemática referem-se principalmente a microfalhas. Nas Figuras 4.63E e F estão representadas microfalhas de direção WNW-ESE a ENEWSW, que afetam microssienito, em caráter normal. Essas estruturas fazem parte das famílias de fraturas orientadas em torno de E-W (Figura 4.61E e F). A inversão desses 
A)
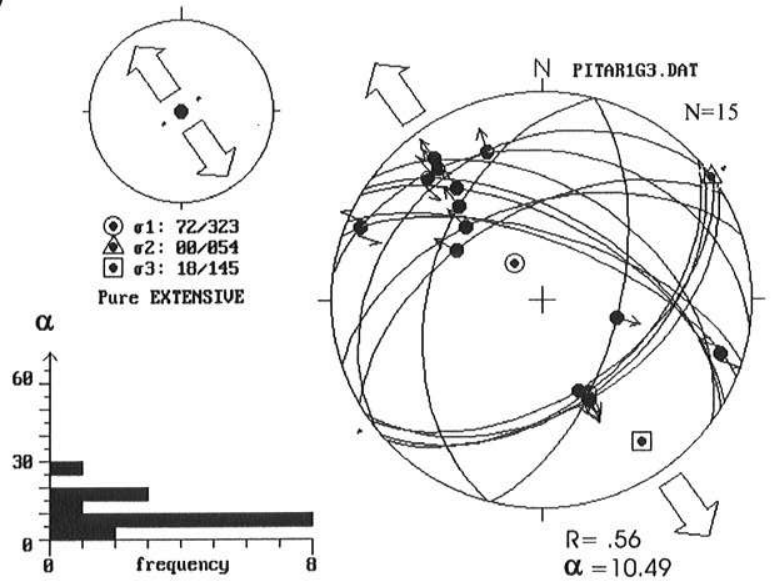

C)
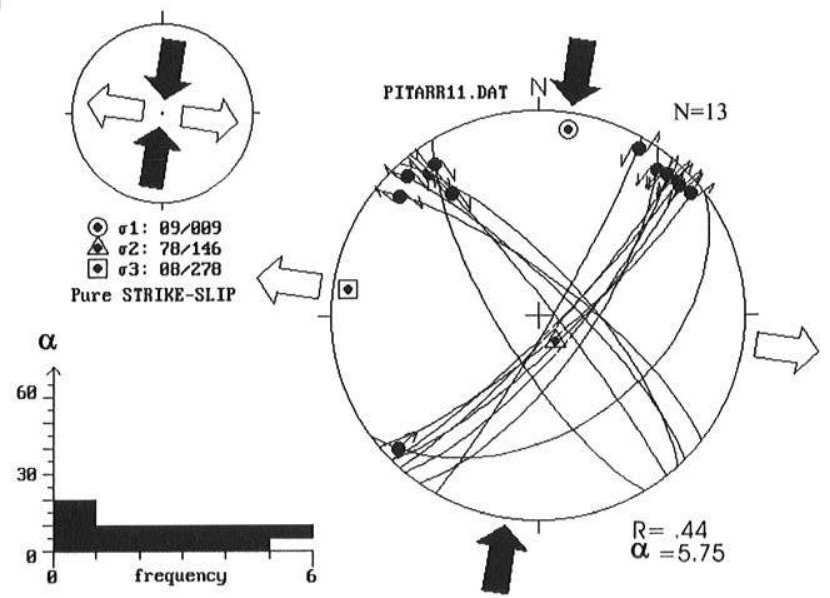

E)
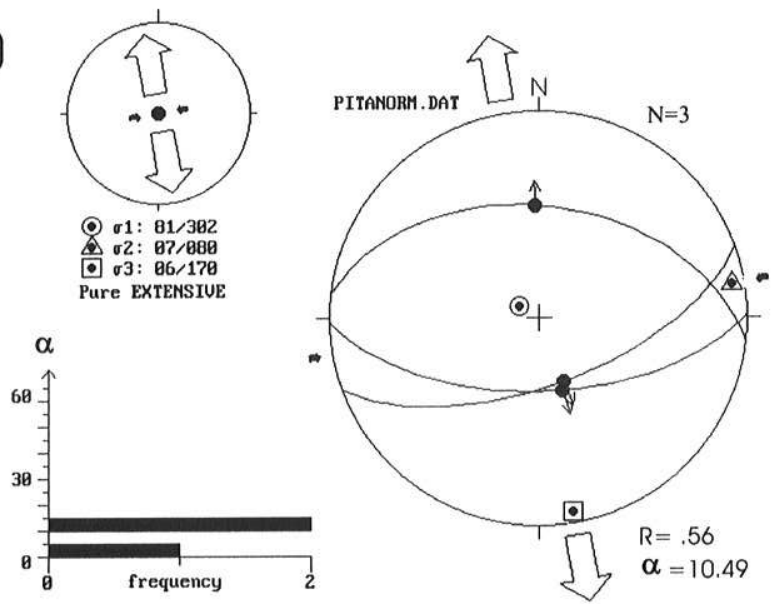

B)
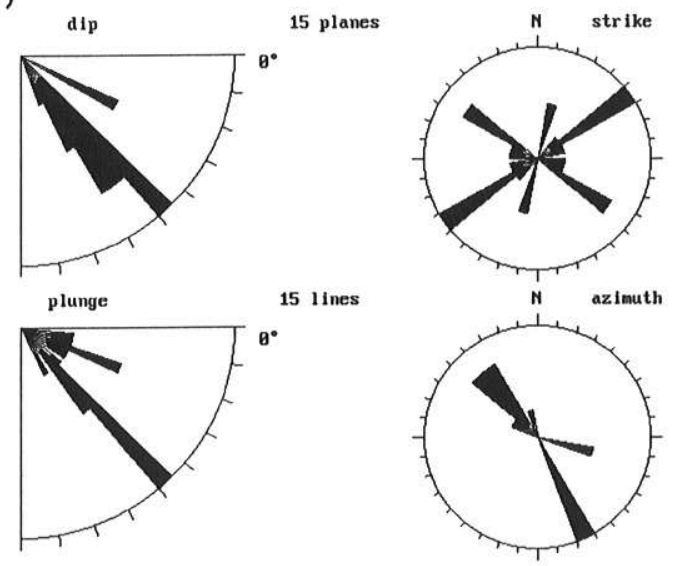

D)
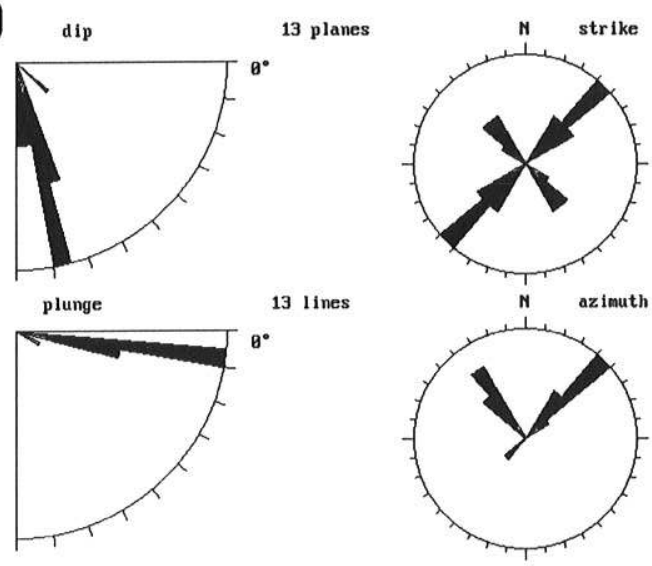

F)
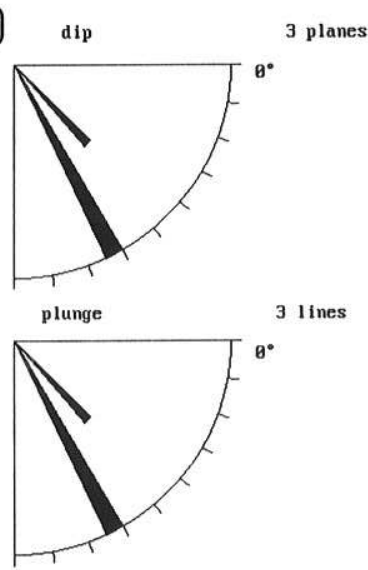
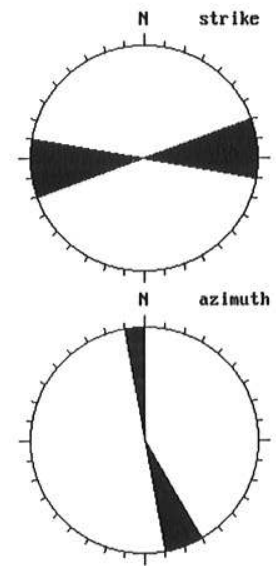

Figura 4.63 - Dados de falhas e respectivos eixos de tensões para o Plug alcalino de Itaboraí. Símbolos:círculos $-\sigma 1$ (eixo de maior esforço), triângulos - $\sigma 2$ (eixo de esforço intermediário), quadrados - $\sigma 3$ (eixo de menor esforço); R - razão de esforço ( $\sigma 2-\sigma 3 / \sigma 1-\sigma 3) ; \alpha$ - desvio médio entre as estrias medidas e e o cisalhamento computado sobre o plano de falha. Setas grandes cheias - eixos compressivos horizontais, setas grandes vazias - eixos distensivos horizontais. Ver texto para explanação. Projeções de Schmidt-Lambert, hemisfério inferior. 
dados indicou que essas estruturas foram geradas em um campo de paleotensões EXTENSIVO Puro (Pure EXTENSIVE), onde o eixo de tensões mínimo, $\sigma 3$, é horizontal e orienta-se na direção NNW-SSE, o eixo de tensões intermediário é, também, horizontal e ortogonal a $\sigma 3$ e, o eixo de tensões principal, $\sigma 1$, é vertical.

Nas Figuras $4.63 \mathrm{C}$ e $\mathrm{D}$ estão representadas microfalhas conjugadas de cisalhamento, que afetam microssienito e fonolito pórfiro, onde as de direção NE-SW representam as sintéticas e as NW-SE as antitéticas. A inversão dos dados mostrou que elas foram geradas em um regime DIRECIONAL Puro (Pure STRIKE-SLIP), com o eixo de tensões máximo, $\sigma 1$, horizontal, orientado na direção NNE-SSW, o eixo mínimo, $\sigma 3$, ortogonal a ele, e o eixo intermediário, $\sigma 2$, vertical.

Nas Figuras 4.63A e B estão representadas microfalhas com rejeito normal, oblíquo e direcional, com direção variada e ângulo de mergulho médio, que afetam microssienito e fonolito pórfiro. A inversão dessas falhas mostrou que elas foram geradas em um regime EXTENSIONAL Puro (Pure EXTENSIVE), onde o eixo de tensões mínimo, $\sigma 3$, é horizontal e orientado na direção NW-SE, com o eixo intermediário, $\sigma 2$, orientado na direção NE-SW, e o eixo de tensões principal, $\sigma 1$, vertical.

A extensão aproximadamente N-S (Figuras 4.63E e F) é compatível com as famílias de fraturas mais antigas que têm a mesma direção (Figuras 4.61E e F) e com o campo de tensões que controlou a intrusão dos diques com alto ângulo de mergulho (Figura 4.60). O campo direcional, com $\sigma \mathrm{l}$ NNE-SSW, é evidenciado tanto pelas microfalhas das Figuras 4.63C e D, como pelas juntas e fraturas, sem estrias evidentes, com mesma orientação que as microfalhas (Figuras 4.61C e D). A extensão NW-SE claramente reativou planos gerados anteriormente, como é indicado pelos rejeitos oblíquos de boa parte das microfalhas. Chama-se atenção que o evento compressivo que controlou a intrusão dos diques de fonolito pórfiro de baixo ângulo com direção NNE-SSW (Figura 4.60) e que gerou famílias de juntas conjugadas sub-paralelas (Figuras 4.61C e D), não foi identificado a partir das populações de microfalhas. A não identificação de relações de corte entre os diques de baixo e alto ângulo dificulta o posicionamento cronológico desse evento. Por outro lado, o preenchimento das estruturas geradas por ele, com o mesmo material que constitui os diques de alto ângulo de mergulho, indica que as fases finais de cristalização do Plug de Itaboraí se deram sob um campo de paleotensões com tensões diferenciais altas $(\sigma 2-\sigma 1)$, sob um regime direcional a puramente compressivo. 


\subsubsection{Plug e Dique de Cabuçu}

O Plug de Cabuçu é um corpo intrusivo hipabissal, constituído de fonolito pórfiro, com menos de $1 \mathrm{~km}^{2}$ de área total e levemente alongado na direção NNE-SSW. Esse corpo possui, associado a ele, um dique, também constituído de fonolito pórfiro, com cerca de 10 metros de espessura, orientado na direção NNE-SSW e com mergulho de alto ângulo (Figura 4.34). Ambos se encontram bastante alterados, preservando-se, aparentemente, apenas a biotita. Esses corpos estão encaixados em bi gnaisses porfíroblásticos, de granulação grossa, com direção de foliação em torno de E-W e caimento variável, com ângulos entre $30^{\circ}$ e $70^{\circ}$. Tais gnaisses foram incluídos na Unidade Cassorotiba por Dalcolmo et al. (1982).

\subsubsection{Juntas e Fraturas}

As juntas e fraturas sem estrias caracterizadas nesses dois corpos foram tratadas em conjunto, tendo sido separadas duas famílias de fraturas conjugadas de cisalhamento, representadas em suas projeções ciclográficas e polares na Figura 4.64. As famílias de fraturas conjugadas com direção geral NE-SW são as mais contínuas e foram consideradas as mais antigas. Separou-se dessas as famílias de fraturas conjugadas com ângulo de mergulho de valor médio, entre $65^{\circ}$ e $40^{\circ}$, e as com ângulo de mergulho abaixo de $40^{\circ}$, consideradas, respectivamente, como geradas em regime extensional e compressivo. As fraturas com ângulo de fraturas médio e baixo foram plotadas em conjunto com as conjugadas de cisalhamento visando discernir as relações geométricas entre elas.

Nas Figuras 4.64A, B, C e D, estão representadas as famílias de fraturas conjugadas de direção geral NE-SW, onde as de direção E-W correspondem a fraturas sintéticas, $\mathrm{R}$, e as de direção NNE-SSW correspondem a fraturas antitéticas, R', indicando que o eixo de tensões principal, $\sigma 1$, é horizontal e orienta-se na direção ENE-WSW (Figura 4.65A). No 

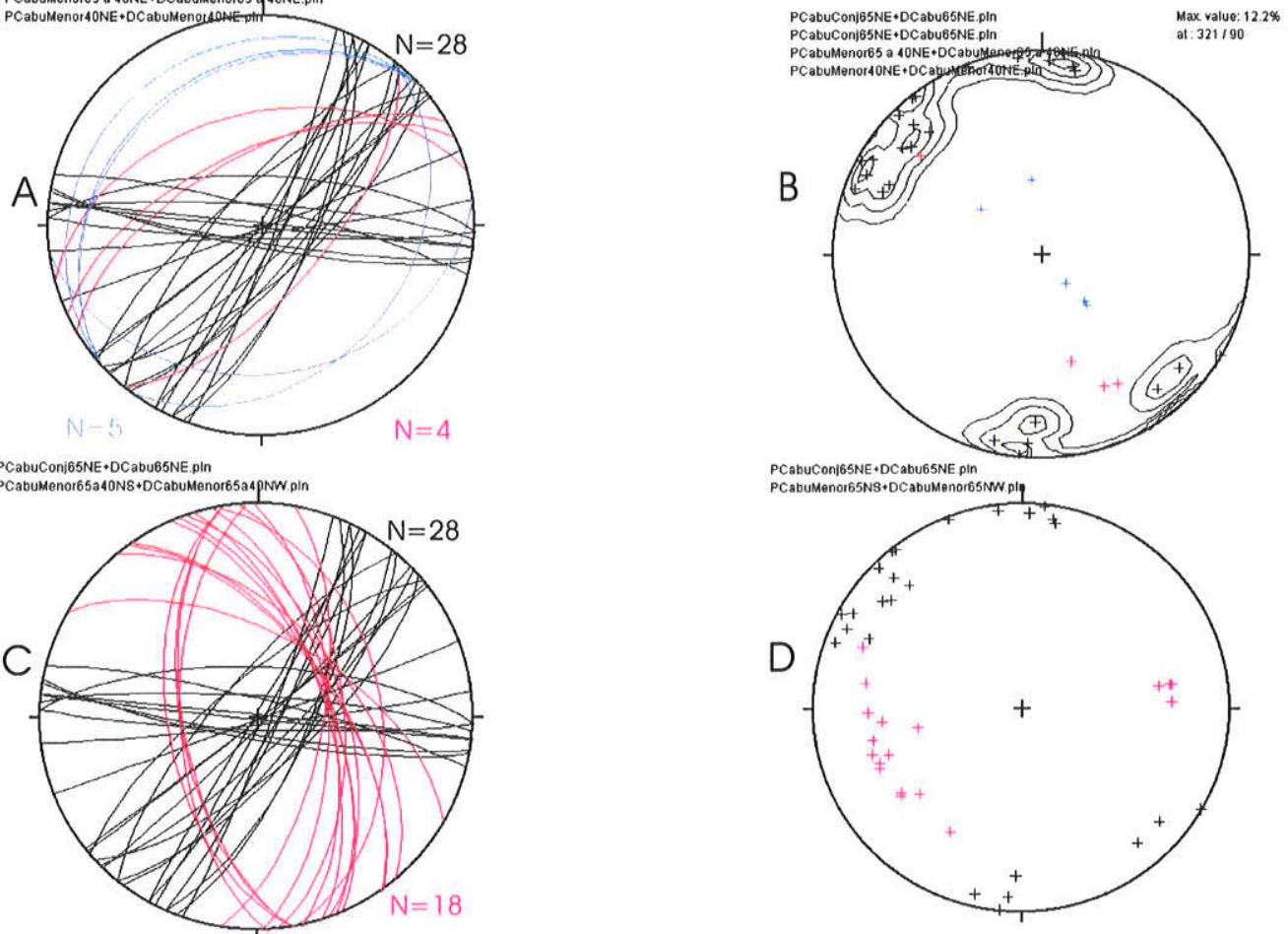

PCabuConi65NW+DCabu65NW.p.
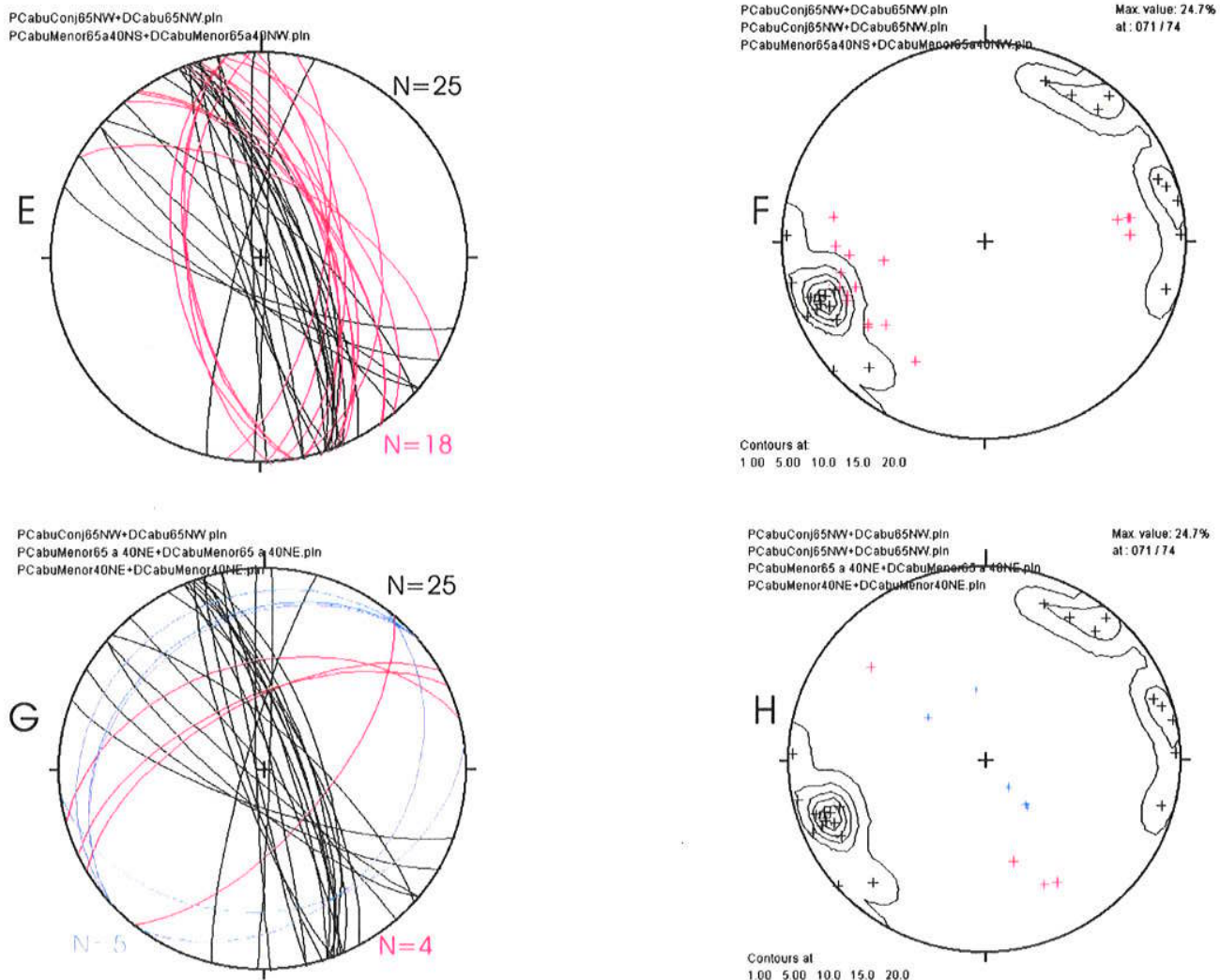

Figura 4.64 - Projeções ciclográficas e polares mostrando as relações geométricas entre juntas conjugadas de cisalhamento com ângulo de mergulho maior que 65 graus e juntas conjugadas com ângulo de mergulho menor que 65 e maior do que 40 graus (vermelho), e menor do que 40 graus (azul), para famílias de direção ENE-WSW e NNW-SSE. Nos estereogramas A, B, E e F, as juntas de baixo ângulo de mergulho são representadas como tendo sido geradas em um regime normal de esforços, e nos estereogramas C, D, G e H, elas são representadas como tendo sido geradas em um regime de esforços reverso. Ver explanação no texto. Diagramas de Schimidt-Lambert, hemisfério inferior. Plug e Dique de Cabuçu, fonolito pórfiro. 

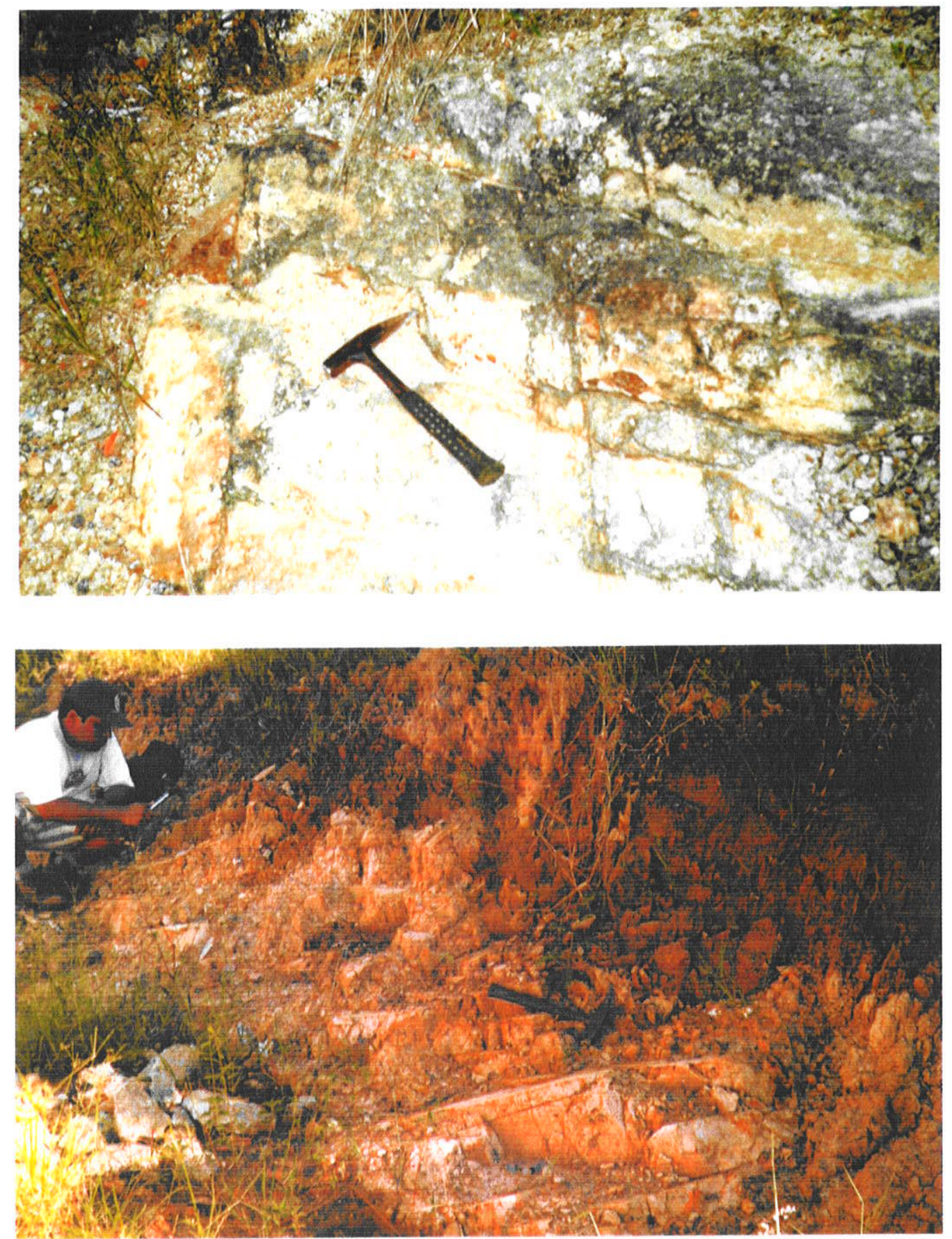

Figura 4.65 - A) Famílias de fraturas de cisalhamento conjugadas, com alto ângulo de mergulho, afetando fonolito pórfiro. $O$ martelo mostra a direção aproximada do eixo de tensões principal, $\sigma 1$, orientado segundo ENE-WSW. Dique de Cabuçu. B) Famílias de fraturas de baixo ângulo de mergulho e direção NE-SW, afetando fonolito pórfiro. Plug de Cabuçu. 
caso das fraturas de alto ângulo conjugadas, de direção geral NNW-SSE, há uma distribuição mais contínua das fraturas, sugerido a possibilidade de tratar-se de espectro de fraturas, onde são observadas além das conjugadas de cisalhamento, R e R', fraturas híbridas e fraturas de extensão, T (Figuras 4.64E, F, G e H). Nesse caso, o eixo de tensões horizontal máximo, SHmax, orienta-se na direção NNW-SSE e o eixo de tensões horizontal mínimo, Shmin posiciona-se ortogonalmente a ele. As relações geométricas entre as famílias de faturas de alto e de médio e baixo ângulo, sugere que tanto as famílias conjugadas de médio ângulo, de direção NNW-SSE, como as de baixo ângulo, de direção NE-SW a ENE-WSW (Figura 4.65B), foram geradas pelo SHmax de direção NNW-SSE, o qual, nesse caso deveria corresponder a $\sigma 1$. Porém, o campo de paleotensões tem que ter variado entre direcional com componente extensional importante, para gerar as fraturas de ângulo médio em conjunto com as conjugadas de cisalhamento de alto ângulo (Figuras 4.64E e F), a compressivo, ou direcional compressivo, para geração das fraturas de baixo ângulo (Figuras $4.64 \mathrm{G} \mathrm{e} \mathrm{H}$ ).

\subsubsection{Análise Cinemática de Microfalhas}

Os dados utilizados referem-se a microfalhas, cujos indicadores cinemáticos são marcas de objetos, facetas polidas e rugosas alternadas e fraturas de cisalhamento sintéticas e antitéticas. Esses dados estão representados na Figura 4.66, podendo-se discernir estruturas conjugadas de cisalhamento, com estruturas sintéticas, R e P, de direção ENEWSW e NE-SW, respectivamente, e estruturas antitéticas, R', de direção NNW-SSE. Estão representadas, também microfalhas reversas conjugas, de direção NE-SW a ENE-SW. A inversão desses dados indicou que essas estruturas foram geradas em um campo de paleotensões DIRECIONAL Puro (Pure STRIKE-SLIP), com o eixo de tensões principal, $\sigma 1$, orientado na direção NW-SE, o eixo de tensões mínimo, $\sigma 3$, também horizontal e ortogonal a ele, e o eixo intermediário, $\sigma 2$, vertical.

O campo de paleotensões obtidos a partir da análise de juntas e de fraturas sem estrias é compatível com o caracterizado a partir de microfalhas. As direções das microfalhas sintéticas indicam que elas podem ter sido reativadas a partir das famílias de fraturas mais antigas de direção NE-SW. Tal reativação poderia explicar a não 


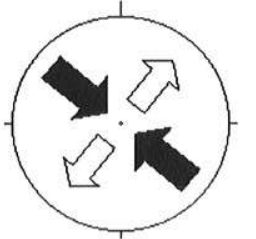

Pure STRIKE-SLIP

A)

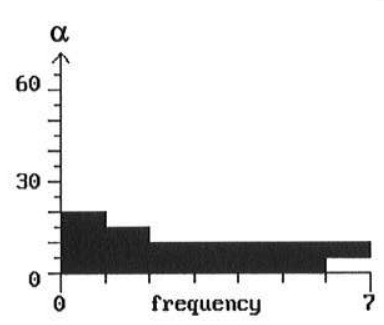

dip

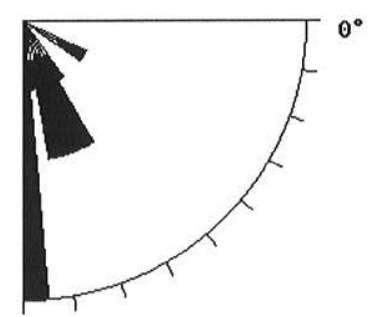

plunge

B)

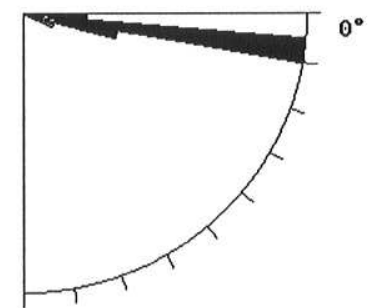

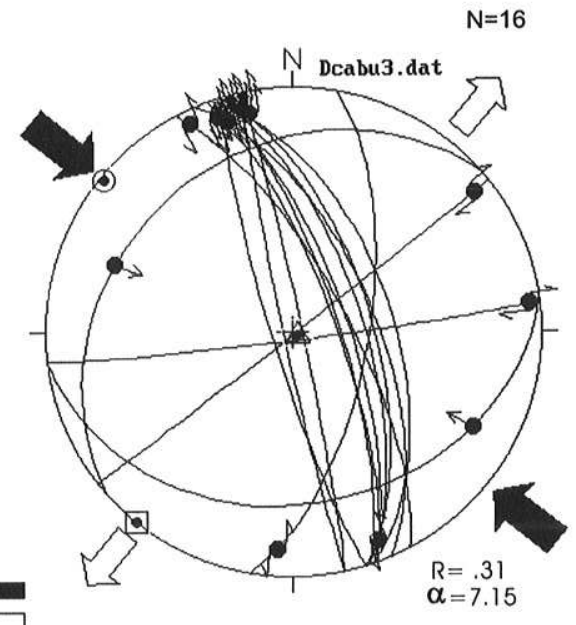

16 planes

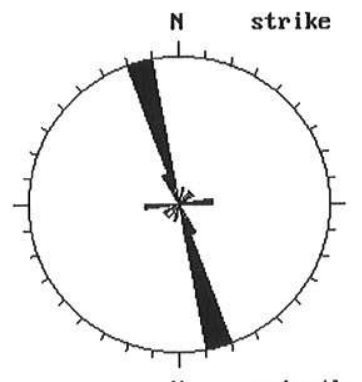

16 lines

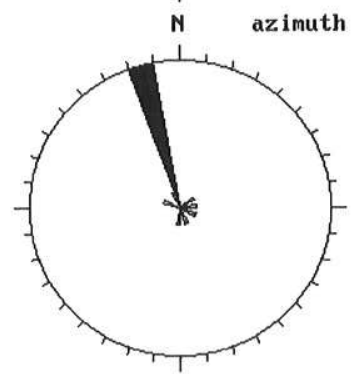

Figura 4.66 - Dados de falhas e respectivos eixos de tensões para o plug e o dique de Cabuçu. Símbolos: círculos - $\sigma 1$ (eixo de maior esforço), triângulos - $\sigma 2$ (eixo de esforço intermediário), quadrados - $\sigma_{3}$ (eixo de menor esforço); R - razão de esforço ( $\sigma 2-\sigma 3 / \sigma 1-\sigma 3$ ); $\alpha$ - desvio médio entre as estrias medidas e o cisalhamento computado sobre o plano de falha. Setas grandes cheias - eixos compressivos horizontais, setas grandes vazias - eixos distensivos horizontais. Ver explanação no texto. Projeções de Schmidt-Lambert, hemisfério inferior. 
caracterização de microfalhas compatíveis com o campo de paleotensões mais antigo, responsável pela geração das fraturas NE-SW.

\subsubsection{Plug de Jardim Cabuçu}

O Plug de Jardim Cabuçu é um corpo intrusivo hipabissal, de contorno aproximadamente circular, constituído de fonolito pórfiro. Ele apresenta um desnível topográfico de aproximadamente 70 metros, com relação aos gnaisses encaixantes e possui um diâmetro de cerca de 800 metros e uma área de menos de $1 \mathrm{~km}^{2}$ (Figura 4.67A). Como característica particular desse plug tem-se a ocorrência de brechas piroclásticas, as quais foram descritas primeiramente por Dalcolmo et al. (1982). Elas estão presentes em amplos lajedos adjacentes ao corpo intrusivo, em um nível topográfico similar ao das encaixantes (Figura 4.67B). Essas brechas, ao contrário das que ocorrem na Suíte de Itaúna (Figura 4), exibem uma grande quantidade de clastos oriundos do embasamento (Figuras 4.67C, D e E), além de fragmentos de fonolito. Tais características indicam que essas rochas piroclásticas tiveram origem em erupções freatomagmáticas, segundo classificação de Fisher \& Schmincke (1994). Dessa forma, sua preservação evidencia a pequena taxa de erosão a que elas foram submetidas desde sua formação.

As fraturas identificadas no Plug de Jardim Cabuçu, as quais constituem uma amostragem mais qualitativa que quantitativa, estão representadas, em projeções ciclográficas e polares, na Figura 4.68. Pode-se distinguir dois grupos de famílias de fraturas de alto ângulo, um com direção NE-SW e, outro, com direção NNW-SSE. Esses dois grupos de fraturas com alto ângulo de mergulho foram reconhecidos tanto no fonolito pórfiro como nas brechas (Figuras 4.68A, B, C e D), indicando que ambas as litologias foram afetadas pelas paleotensões que as gerou.

Nas Figuras 4.68A e B estão representadas as famílias de fraturas de direção NESW. A continuidade de orientação das fraturas de alto ângulo de mergulho indica que elas constituem um espectro de fraturas, onde o eixo de tensões horizontal máximo, SHmax, orienta-se na direção ENE-WSW, com o eixo de tensões horizontal mínimo, Shmin, orientado na direção NNW-SSE. As fraturas com ângulo de mergulho intermediário, entre 

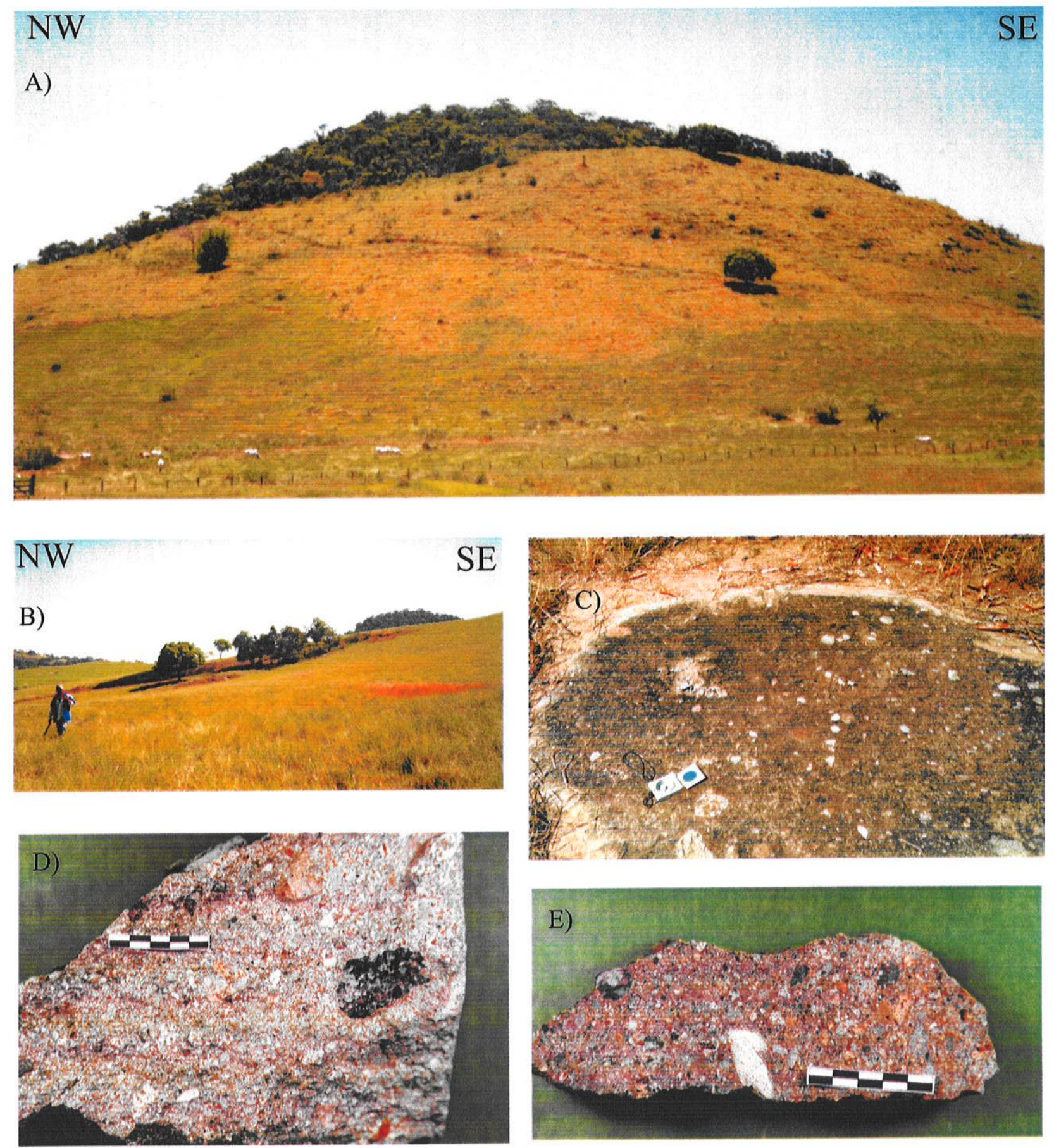

Figura 4.67 - A) Vista geral do Plug de Jardim Cabuçu, constituído por fonolito pórfiro e com depósitos de brechas piroclásticas associados. B) Lajedo com brechas piroclásticas, em segundo plano e ao fundo, no canto direito da foto, vê-se o topo do Plug de Jardim Cabuçu. C) Afloramento de brecha piroclástica. Notar clastos centimétricos a decimétricos de gnaisse leucocrático, junto à bússola. D) Amostra da brecha piroclástica, destacando clasto de gd-bi gnaisse (cor preta) e clastos de fonolito (fragmentos arredondados de cor cinza e forma irregular). E) Amostra de brecha piroclástica serrada, onde destacam-se clastos de gnaisse hololeucocrático (cor branca), feldspato (cor avermelhada, com forma retangular) e de fonolito (cor cinza, arredondados e com forma iregular). Escala $=2,5 \mathrm{~cm}$. 

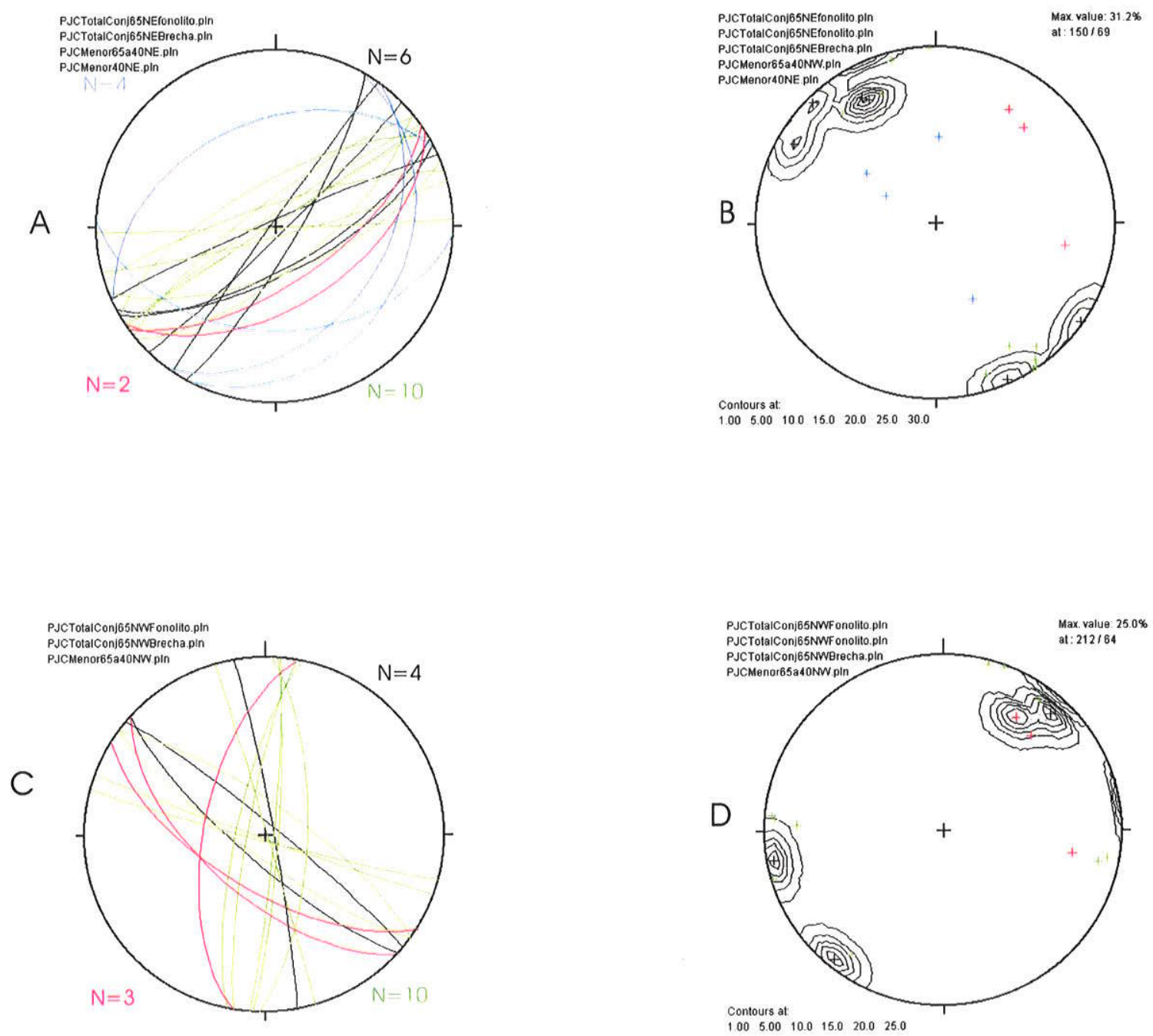

Figura 4.68 - Projeções ciclográficas e polares mostrando as relações geométricas entre fraturas conjugadas de cisalhamento com ângulo de mergulho maior que 65 graus, em fonolito (preto) e em brecha piroclástica (verde), para famílias de direção ENE-WSW e NNW-SSE. Fraturas com ângulo de mergulho menor que 65 e maior do que 40 graus (vermelho), e menor do que 40 graus (azul) foram medidas apenas no fonolito pórfiro. Ver explanação no texto. Diagramas de Schimidt-Lambert, hemisfério inferior. Plug de Jardim Cabuçu. 
65 e 40 graus, foram identificadas apenas no plug de fonolito pórfiro, indicando que a magnitude do eixo de paleotensões vertical, $\sigma z$, foi maior do que a que atuou sobre as vulcânicas, mantendo-se as direções de SHmax e Shmin.

Nas Figuras 4.68C e D estão representadas as famílias de fraturas de alto ângulo de direção NNW-SSE. Sua relações geométricas indicam que se tratam de famílias conjugadas de cisalhamento, com direção N-S e NW-SE, posicionando-se o eixo de tensões máximo, $\sigma 1$, na horizontal segundo a direção NNW-SSE, com o eixo mínimo, $\sigma 3$, também horizontal e orientado na direção ENE-WSW, e o eixo intermediário, $\sigma 2$, vertical.

\subsubsection{Plug de Monjolos}

O Plug de Monjolos é corpo intrusivo hipabissal, de forma elíptica, bastante alongado na direção NE-SW, com cerca de $2,5 \mathrm{~km}$ de eixo maior e 500 metros de eixo menor, compondo um total de pouco mais de $1 \mathrm{~km}^{2}$. Ele é constituído por fonolito pórfiro, à semelhança da maior parte dos outros pequenos plugs da porção central do Graben da Guanabara.

Nesse trabalho datou-se uma amostra do fonolito pórfiro desse plug (Tabela 4.5), com base em sua boa preservação e o resfriamento rápido, indicado pela presença de textura quench, que viabiliza a datação em rocha total. No entanto, não se obteve nenhum platô e sua idade média ponderada forneceu um resultado de 56,6 $\mathrm{Ma}$ (ver Anexo A).

\begin{tabular}{|c|c|c|c|}
\hline 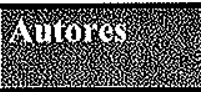 & 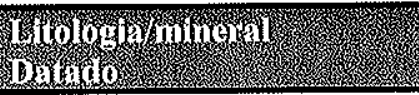 & yolom & 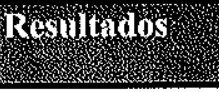 \\
\hline Esse trabalho & Fonolito Pórfiro/rocha total* & $\mathrm{Ar} / \mathrm{Ar}$ & $56,6 \pm 1,2 \mathrm{Ma}$ \\
\hline
\end{tabular}

Tabela 4.5 - Datações radiométricas disponíveis para o Plug de Monjolos

* esse resultado refere-se à idade média ponderada

As condições de afloramento são ruins, com poucos lajedos e amplo predomínio de blocos. Dentre esses últimos, os maiores foram considerados in situ para efeito de coleta de dados estruturais. Considerando-se a coerência dos dados, essa inferência se mostrou plausível. Tendo em vista as condições expostas, os dados coletados restringiram-se a juntas e fraturas sem estrias aparentes, os quais estão representados na Figura 4.69. 
Na Figura 4.69A estão representadas as projeções ciclográficas, polares e rosetas das fraturas conjugadas de cisalhamento, onde as sintéticas, $R$, têm direção ESE-WNW e as antitéticas, R', NE-SW, indicando que o eixo de tensões principal, $\sigma 1$, é horizontal e orienta-se na direção ENE-WSW, o eixo de tensões mínimo, $\sigma 3$, é também horizontal e ortogonal a ele e o eixo intermediário, $\sigma 2$, é vertical, correspondendo a um regime de tensões direcional.

Na Figura 4.69B estão representadas fraturas de alto ângulo de direção variando entre NW-SE e N-S. A continuidade dessas fraturas sugere que elas constituem um espectro, onde estão presentes fraturas conjugadas de cisalhamento, híbridas e de extensão. Nesse caso pode-se inferir que o eixo de tensões máximo horizontal, SHmax, está orientado na direção NNW-SSE e que o eixo de tensões horizontal mínimo, Shmin, orienta-se ortogonalmente a ele, na direção ENE-WSW.

As relações geométricas entre as fraturas de alto e médio ângulo, onde essas últimas apresentam a mesma direção das primeiras, tanto para as famílias ENE-WSW como NW-SE, indicam que elas podem ter sido geradas por variações locais/temporais nesses dois campos de paleotensões, correspondendo a uma maior magnitude na componente extensional.

\subsubsection{Plug do Country Club}

O Plug do Country Club é um corpo subvulcânico, de forma elíptica, alongado na direção NNE-SSW, com cerca de $1,5 \mathrm{~km}$ de comprimento e $1 \mathrm{~km}$ de largura, que ocorre em meio os sedimentos da Formação Macacu, a cerca de $3 \mathrm{~km}$ ao norte do centro de Itaboraí, na estrada Itaboraí-Porto das Caixas (Figura 4.34). Ele destaca-se topograficamente com relação aos sedimentos, em cerca de 20 a 30 metros (Figura 4.70A), e é caracterizado por uma concentração de blocos e matacões. O Plug do Country Club tem sido descrito como uma brecha fonolítica intrusiva (Dalcolmo et al. 1982, Dehira et al. 1998), porém suas características petrográficas apontam para uma origem vulcânica. Ele é constituído por uma matriz vítrea a criptocristalina, com forte orientação de fluxo, onde se 
A)
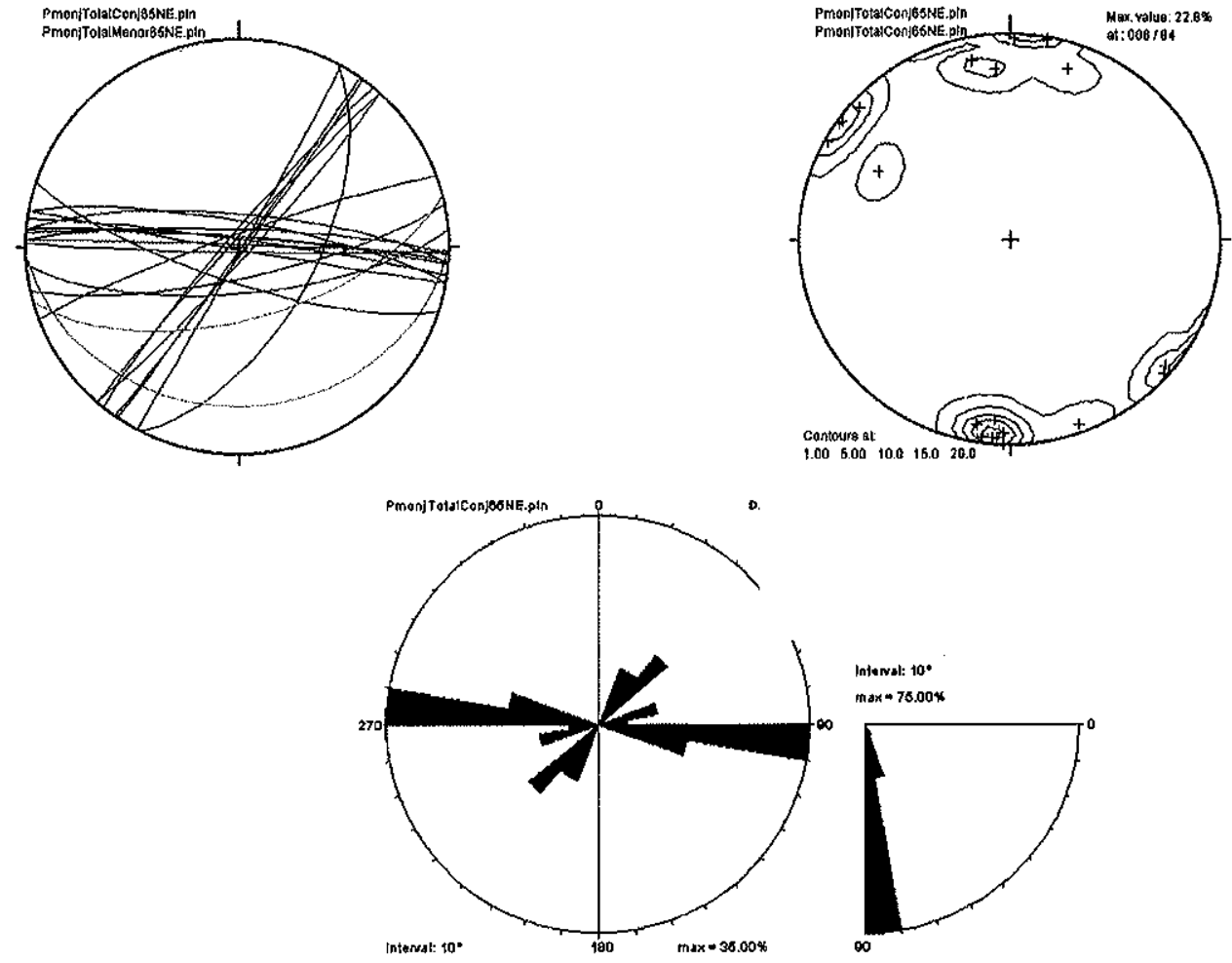

B)
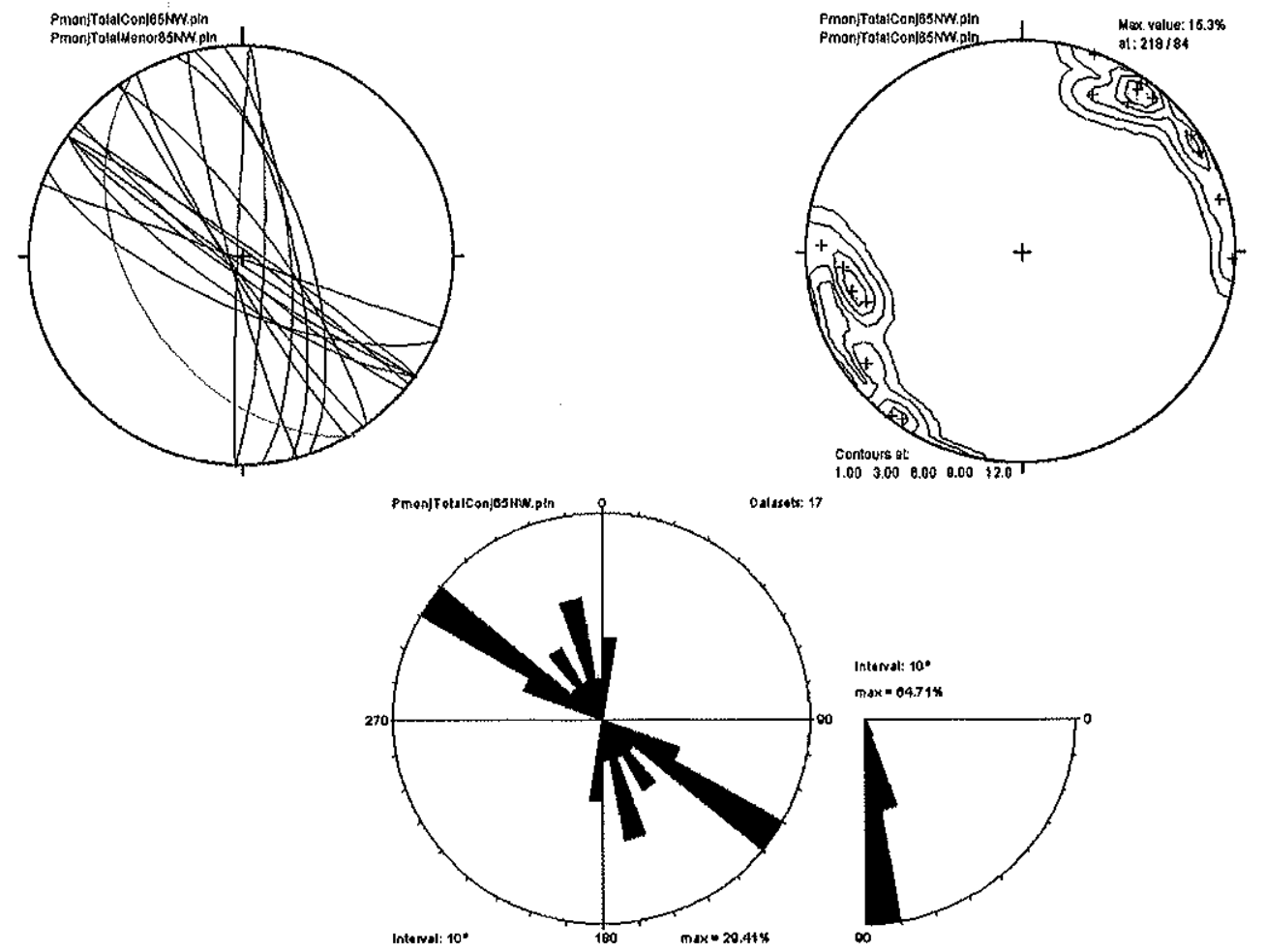

Figura 4.69 - Projeções ciclográficas e polares mostrando as relações geométricas entre juntas conjugadas de cisalhamento com ângulo de mergulho maior que 65 graus e juntas conjugadas com ângulo de mergulho menor que 65 graus, para famílias de direção ENEWSW e NW-SE, em fonolito pórfiro no Plug de Monjolos. Setas grandes cheias representam o eixo de tensões horizontal máximo, SHmax, e as setas vazias representam o eixo de tensões horizontal mínimo, Shmin. Em A SHmax e Shmin correspondem a $\sigma 1$ e $\sigma 3$, respectivamente. Ver explanação no texto. Diagramas de Schimidt-Lambert, hemisfério inferior. 

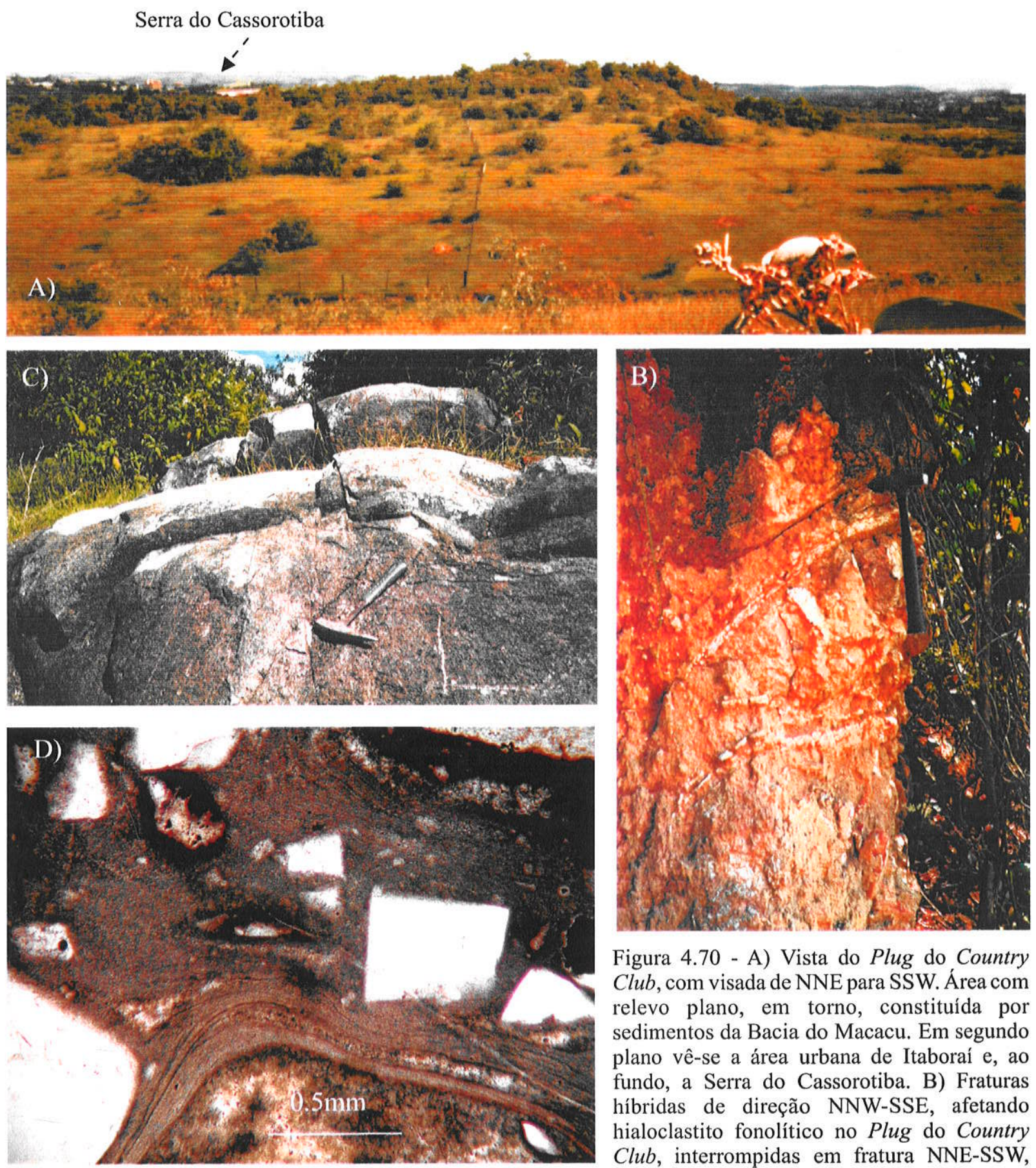

Figura 4.70 - A) Vista do Plug do Country $C l u b$, com visada de NNE para SSW. Área com relevo plano, em torno, constituída por sedimentos da Bacia do Macacu. Em segundo plano vê-se a área urbana de Itaboraí e, ao fundo, a Serra do Cassorotiba. B) Fraturas híbridas de direção NNW-SSE, afetando hialoclastito fonolítico no Plug do Country $C l u b$, interrompidas em fratura NNE-SSW,

Paralela ao martelo; C) Veios de gibsita (de cor branca) em regolito desenvolvido no hialoclastito do Plug do Country Club; D) Fotomicrografia de hialoclastito fonolítico, onde observam-se cristais e fragmentos de nefelina e fragmentos de fonolito, imersos em vidro vulcânico com forte orientação de fluxo. 
encontram imersos fragmentos de cristais e cristais de nefelina, feldspato, piroxênio, opacos e de fonolito (Figura 4.70D).

Essas características permitiram a obtenção de uma boa análise radiométrica pelo método Ar/Ar (Tabela 4.6), a qual indicou uma idade de 65,6 Ma (ver Anexo B), compatível com as das suítes de Tanguá e Itaúna, que ocorrem à nordeste e sudoeste, respectivamente (Figura 4.34).

\begin{tabular}{|c|c|c|c|}
\hline Nin & 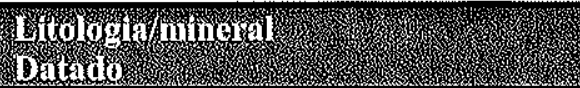 & 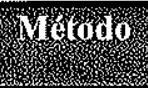 & Rosiluros \\
\hline Dehira et al. (1998) & Brecha fonolitica/ rocha total & $\mathrm{K} / \mathrm{Ar}$ & $62,7 \pm 1,7 \mathrm{Ma}$ \\
\hline Esse trabalho & hialoclastito fonolitico/rocha total - P, I & $\mathrm{Ar} / \mathrm{Ar}$ & $65,6 \pm 0,05 \mathrm{Ma}$ \\
\hline
\end{tabular}

Tabela 4.6 - Datações radiométricas disponíveis para o Plug do Country Club.

P - platô

I - isócrona

Esse novo resultado difere um pouco do obtido anteriormente por Dehira et al. (1998), pelo método K/Ar.

As condições de exposição não são boas, já que predominam os blocos e matacões. Pequenos cortes expõem uma rocha bastante alterada, com veios de gibsita (confirmada por fluorescência) preenchendo fraturas ou em arranjo concêntrico acompanhando a esfoliação esferoidal (Figura 4.70B). Para coleta dos dados estruturais considerou-se os matacões maiores, de dimensões métricas a decamétricas, como material in situ.

Na Figura 4.71 estão representadas as projeções ciclográficas, polares e rosetas das juntas e fraturas identificadas no Plug do Country Club. As estruturas de alto ângulo apontam para a existência de duas famílias conjugadas de cisalhamento, com direção N-S e ENE-WSW, indicando que o eixo de tensões máximo, $\sigma 1$, é horizontal e orienta-se segundo a direção NE-SW, com o eixo de tensões mínimo, $\sigma 3$, também horizontal e ortogonal a ele, e $\sigma 2$ orientado na vertical, caracterizando um campo de paleotensões direcional. Foi identificado, ainda, um outro grupo de fraturas, com direção variando entre NW-SE e NNW-SSE e com ângulos de mergulho altos (Figura 4.70C), que constitui fraturas híbridas, desenvolvidas sob uma extensão de direção NNE-SSW, com SHmax orientando-se na direção WNW-ESE. 
A)

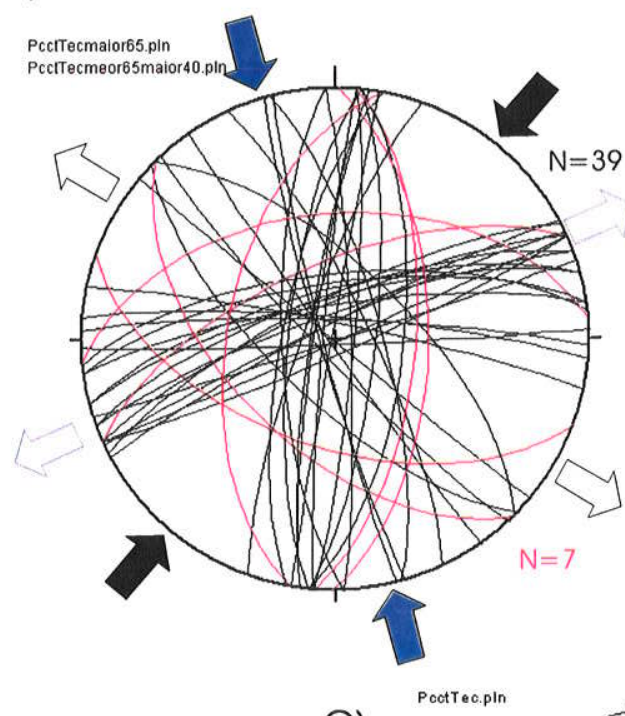

B)

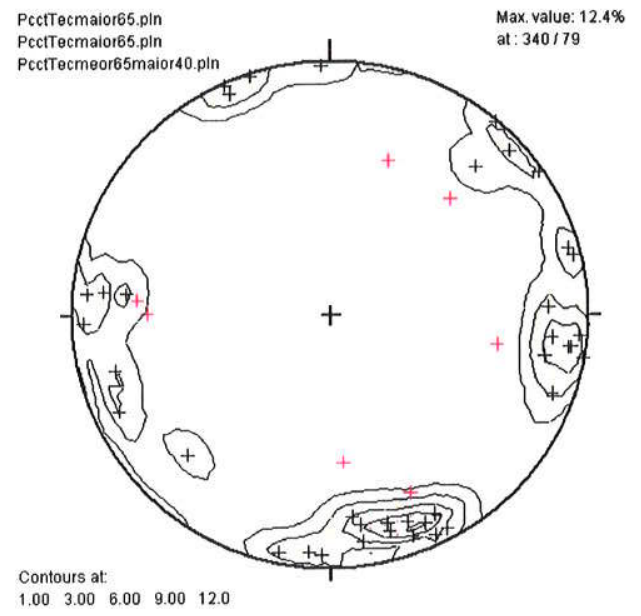

C)

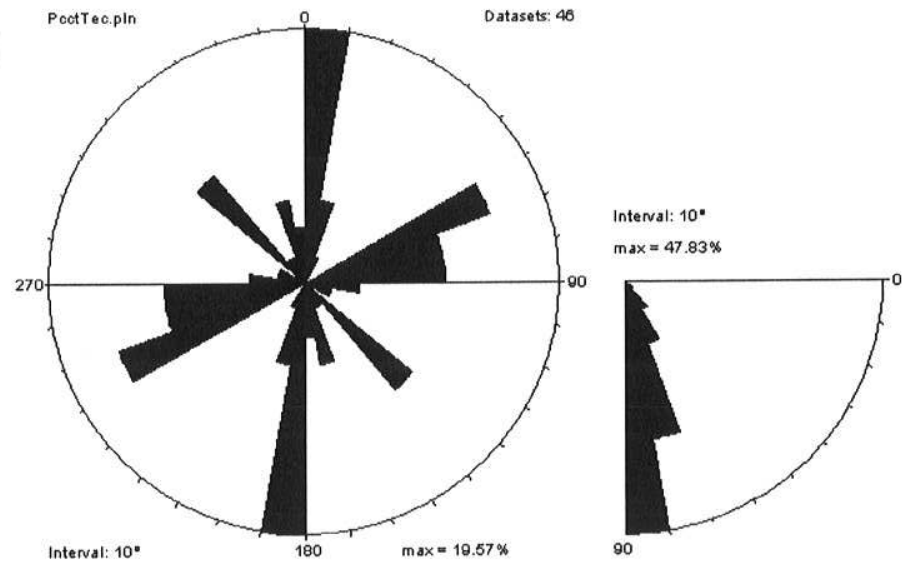

Figura 4.71 - Projeções ciclográficas e polares mostrando as relações geométricas entre juntas conjugadas de cisalhamento com ângulo de mergulho maior que 65 graus e juntas conjugadas com ângulo de mergulho menor que 65 graus, para famílias de direção NNE-SSW e ENE-WSW, em brecha fonolítica no Plug do Country Club. Setas grandes cheias representam o eixo de tensões máximo, $\sigma 1$, e as setas vazias representam o eixo de tensões mínimo, $\sigma 3$ (em preto estão representadas as fraturas mais antigas e em azul as mais novas. Ver explanação no texto. Diagramas de Schimidt-Lambert, hemisfério inferior. 
Na Tabela 4.7 estão resumidas as paleotensões determinadas para os corpos alcalinos da porção central do Graben da Guanabara, excluindo-se a Suíte de Itaúna, a partir de juntas e fraturas sem estrias aparentes.

Essas determinações evidenciam que o campo de paleotensões caracterizou-se por um SHmax inicial orientado entre NE-SW e E-W e outro, posterior, orientado entre NWSE e N-S. Pode-se inferir, também, que o SHmax, nos dois casos, corresponde tanto ao eixo de tensões máximo, $\sigma 1$, como ao eixo de tensões intermediário, $\sigma 2$, correspondendo, no primeiro caso, a um regime predominantemente direcional e, localmente, a um regime puramente compressivo. No segundo caso, o campo de paleotensões corresponde a um regime extensional.

Pode-se caracterizar, ainda, que todas as litologias dos corpos alcalinos foram afetadas por esses dois campos de paleotensões. Incluem-se aí as piroclásticas associadas ao Plug de Jardim Cabuçu e o hialoclastito fonolítico do Plug do Country Club.

\begin{tabular}{|c|c|c|c|c|c|}
\hline \multirow[t]{2}{*}{ Estações } & \multicolumn{2}{|c|}{$\begin{array}{l}\text { lamílias de Fraturas } \\
\text { (direçấo de Shmax) }\end{array}$} & \multicolumn{2}{|c|}{ Tipos de Fraturas } & \multirow[t]{2}{*}{$\begin{array}{l}\text { Litologias } \\
\text { Afetadas }\end{array}$} \\
\hline & + antiga & tnova & + antiga & +nova & \\
\hline $\begin{array}{l}\text { Tanguá - Tan } 1 \\
\text { (Figura 25) }\end{array}$ & $\begin{array}{l}\text { ENE-WSW } \\
\sigma 1\end{array}$ & $\begin{array}{l}\text { NNW-SSE } \\
\sigma 1\end{array}$ & Conj. Cis. & Conj. Cis. & sienito \\
\hline $\begin{array}{l}\text { Tanguá - Tan } 2 \\
\text { (Figura 26) }\end{array}$ & $\begin{array}{l}\text { ENE-WSW } \\
\text { SHmax }\end{array}$ & $\begin{array}{c}\text { NNW-SSE } \\
\sigma 1\end{array}$ & Espectro & Conj.Cis. & sienito \\
\hline $\begin{array}{l}\text { Plug de Itaboral } \\
\text { (Figura 29) }\end{array}$ & $\begin{array}{c}\text { E-W } \\
\text { SHmax }\end{array}$ & & Espectro & & microssienito \\
\hline $\begin{array}{l}\text { Plug de Itaboral } \\
\text { (Figura 29) }\end{array}$ & & $\begin{array}{c}\text { N-S } \\
\sigma 1\end{array}$ & & Conj. Cis. & microssienito \\
\hline $\begin{array}{l}\text { Plug de Itaboraí } \\
\text { (Figura 29) }\end{array}$ & & $\begin{array}{c}\mathrm{N}-\mathrm{S} \\
\sigma 1 \\
\end{array}$ & & Conj. Cis. & fonolito \\
\hline $\begin{array}{l}\text { Plug e Dique de } \\
\text { Cabuçu (Figura } \\
\text { 32) }\end{array}$ & $\begin{array}{l}\text { ENE-WSW } \\
\sigma 1\end{array}$ & $\begin{array}{l}\text { NNW-SSE } \\
\text { SHmax }\end{array}$ & Conj. Cis. & Espectro & fonolito pórfiro \\
\hline $\begin{array}{l}\text { Plug de Jardim } \\
\text { Cabuçu (Figura } \\
\text { 36) }\end{array}$ & $\begin{array}{l}\text { ENE-WSW } \\
\text { SHmax }\end{array}$ & $\begin{array}{c}\text { NNW-SSE } \\
\sigma 1\end{array}$ & Espectro & Conj. Cis. & $\begin{array}{l}\text { fonolito pórfiro e } \\
\text { brecha } \\
\text { piroclástica }\end{array}$ \\
\hline $\begin{array}{l}\text { Plug de Monjolos } \\
\text { (Figura 37) }\end{array}$ & $\begin{array}{l}\text { ENE-WSW } \\
\sigma 1\end{array}$ & $\begin{array}{c}\text { NNW-SSE } \\
\text { SHmax }\end{array}$ & Conj. Cis. & Espectro & fonolito pórfiro \\
\hline $\begin{array}{l}\text { Plug do Country } \\
\text { Club (Figura } 37 \text { ) }\end{array}$ & $\begin{array}{c}\text { NE-SW } \\
\sigma 1\end{array}$ & $\begin{array}{c}\text { NNW-SSE } \\
\text { SHmax }\end{array}$ & Conj. Cis. & Hibridas & brecha fonolítica \\
\hline
\end{tabular}

Tabela 4.7 - Síntese das paleotensões determinadas a partir da análise geométrica de juntas e fraturas sem estrias aparentes, para os corpos alcalinos da área central do Graben da Guanabara, com exceção da Suíte de Itaúna. 


\subsubsection{Síntese das Paleotensóes Determinadas nos Corpos Alcalinos da Área Central}

As paleotensões determinadas na área central do Graben da Guanabara, a partir de diques associados aos corpos alcalinos, além de juntas e fraturas sem estrias e de falhas e microfalhas que afetam esses corpos, estão sintetizadas na Figura 4.72.

As paleotensões determinadas a partir de juntas e de fraturas sem estrias aparentes mostram resultados persistentes nos diferentes corpos de rochas alcalinas investigadas. Foram caracterizados dois campos de paleotensões distintos, a partir de duas gerações de famílias de fraturas, sendo a mais antiga orientada segundo o quadrante nordeste a $\mathrm{E}-\mathrm{W}$ e, a mais nova, no quadrante noroeste a N-S. Essas duas gerações de famílias de fraturas evidenciam tratar-se principalmente de fraturas de cisalhamento conjugadas e, subordinadamente, espectro de fraturas, permitindo que se posicione a direção de SHmax na bissetriz do ângulo agudo entre elas, inicialmente na direção NE-SW a E-W e, posteriormente, na direção NW-SE a N-S, e se estabeleça que esse SHmax representa, principalmente, o eixo de tensões máximo, ol. As direções de Shmin posicionam-se ortogonalmente a essas, caracterizando para ambos os campos de paleotensões um regime dominantemente direcional. A presença de famílias de fraturas de mesma direção que as acima descritas, porém com ângulo de mergulho médio, entre $65^{\circ}$ e $40^{\circ}$, evidencia a presença de uma componente extensional importante e/ou uma proximidade nas magnitudes dos eixos de tensões principal, $\sigma 1$, e intermediário, $\sigma 2$, levando a uma variação temporal/local no regime de esforços, entre direcional e extensional.

Os diques identificados (Figuras 4.72K, $\mathrm{L}$ e M), todos leucocráticos, traquíticos e fonolíticos, indicam uma extensão em torno de N-S. Tendo em vista que esses diques cortam tanto os corpos intrusivos como as encaixantes, pode-se inferir que essa extensão de direção N-S é tardia à intrusão dos corpos maiores e plugs. Essa direção de extensão corresponde a um SHmax de direção E-W, o que permite que se date o evento gerador das famílias de juntas e fraturas mais antigas. A idade e 66,7 Ma determinada para um dique de fonolito da Suíte de Itaúna, pelo método Ar-Ar, indica a idade mínima desse evento, posicionando-o no limite Cretáceo/Terciário. A ocorrência de diques com ângulo de mergulho abaixo de $40^{\circ}$ nos corpos de Itaboraí e do Tanguá, permitem inferir-se uma mudança no regime de esforços para compressivo, uma vez que o eixo de tensões mínimo, 


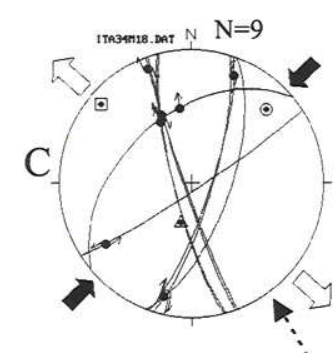

D.
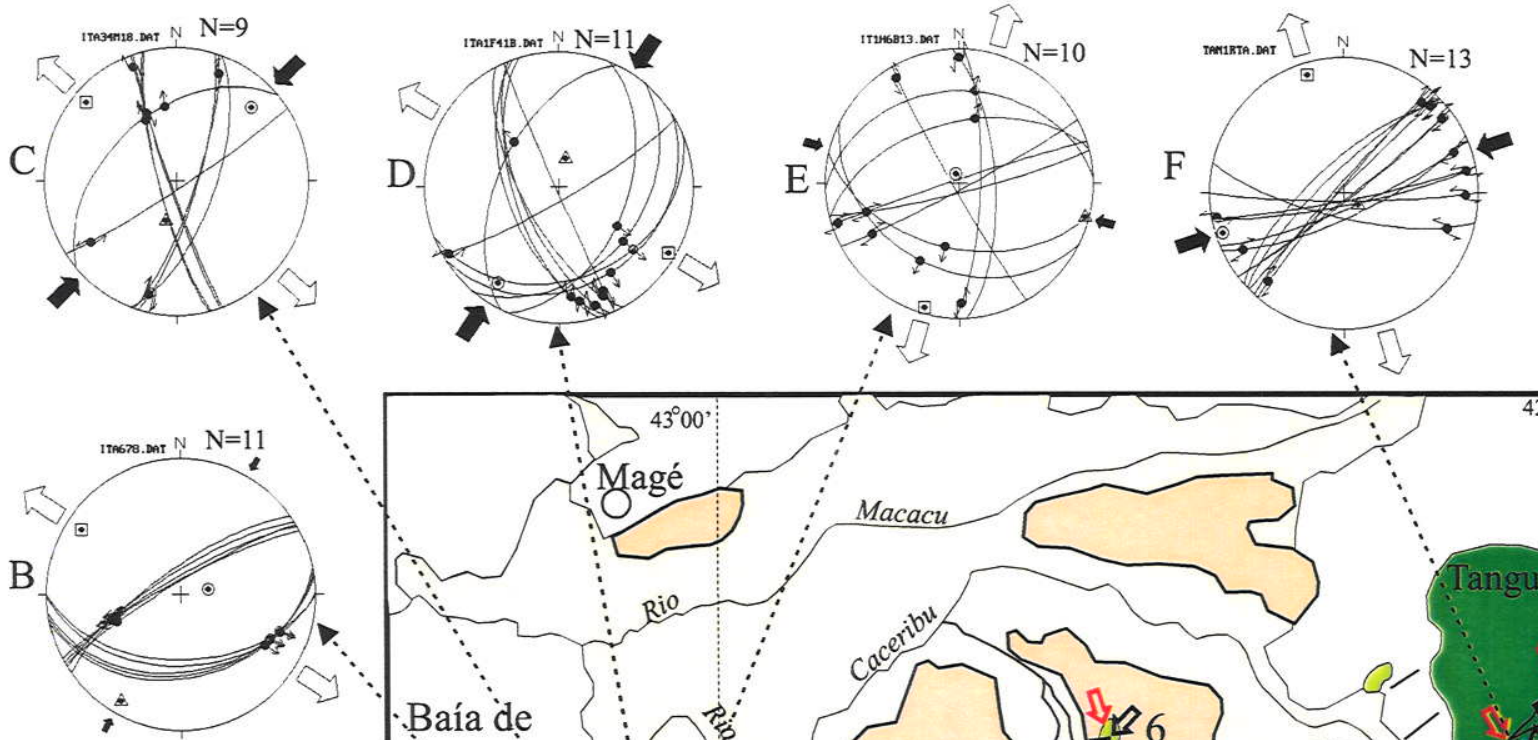

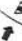

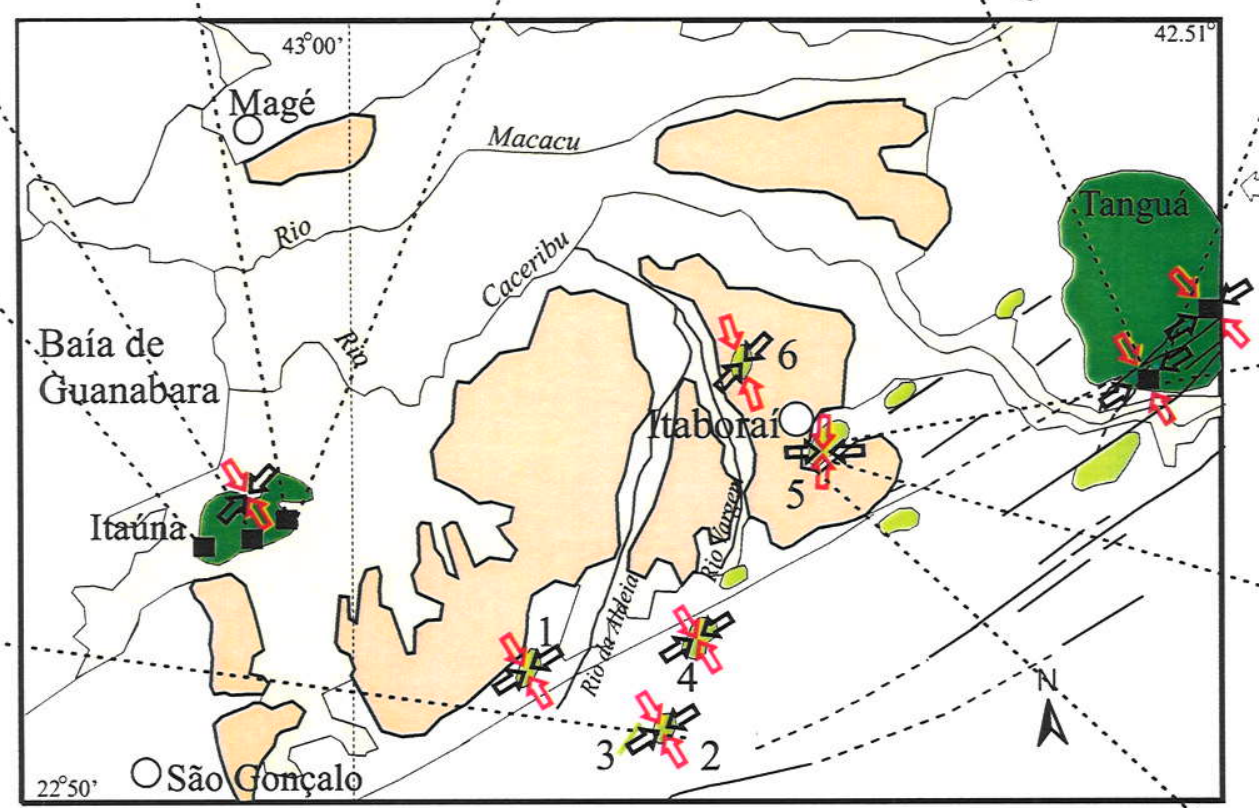

$\mathrm{G}$

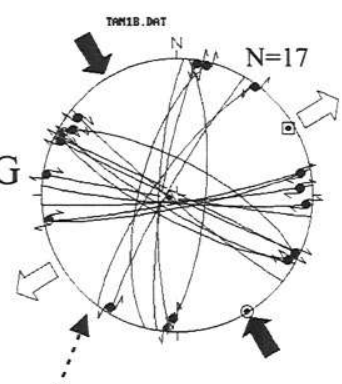
int Prraentinar $\mathrm{N}-13$ 20
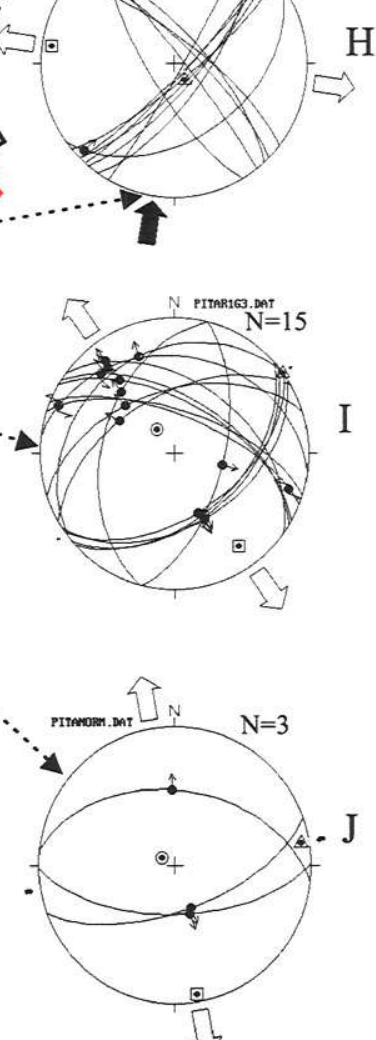

Figura 4.72 - Mapa síntese das paleotensões determinadas para os corpos alcalinos da porção central do Graben da Guanabara. Os estereogramas representam tanto campos de paleotensões determinados a partir de microfalhas, com a indicação da posição dos três principais eixos de tensões, $\sigma 1$ (círculo), $\sigma 2$ (triângulo) e $\sigma 3$ (quadrado), como direções de SHmax e Shmin determinados a partir de diques. As setas vazias, pretas e vermelhas, no interior do desenho, representam as direções de SHmax mais antiga e mais nova, respectivamente, determinadas a partir de juntas e fraturas sem estrias. As direções de SHmax representadas no Complexo de Itaúna referem-se às orientações médias (ver mais detalhes na Figura 23). Geologia de acordo com a Figura 2. 
$\sigma 3$, passa a ser vertical para permitir a intrusão dos diques de baixo ângulo, já que esse eixo posiciona-se sempre ortogonalmente aos diques. Ainda nesse sentido o SHmax representou, temporária ou localmente, o eixo de tensões máximo, $\sigma 1$. Apesar das condições de exposição dos diques associados aos corpos alcalino ser insatisfatória nessa porção central do graben, especialmente se comparada com as áreas oeste e leste, a não identificação de diques com baixo ângulo de mergulho na Suíte de Itaúna indica que esse campo de paleotensões compressivo representa uma variação de caráter local, refletindo uma diminuição relativa na magnitude de $\sigma z$.

Os campos de paleotensões determinados a partir de falhas e, principalmente, de microfalhas, evidenciam, da mesma forma que as juntas e fraturas sem estrias e os diques, variações temporais e locais. Também nesse caso as direções de SHmax determinadas variaram, inicialmente no quadrante NE e posteriormente no NW; porém, aqui, esse eixo de tensões horizontal máximo é claramente o eixo de tensões máximo, $\sigma 1$, correspondendo a regimes direcionais (Figuras $4.72 \mathrm{C}, \mathrm{D}, \mathrm{F}, \mathrm{A}$ e $\mathrm{G}$ ) ou extensional direcional (Figura 4.72E). Localmente predominam estruturas normais e oblíquas, geradas num regime extensional, com as direções de SHmax (NE-SW) e Shmin (NW-SE) compatíveis com as do evento direcional mais antigo (Figuras 4.72B e I), podendo representar variações locais/temporais no campo de paleotensões, onde a magnitude do $\sigma z$ foi relativamente maior. Em um local foi determinada uma extensão pura aproximadamente N-S (Figura 4.72J), compatível com o campo de paleotensões que gerou os diques e que pode representar um evento inicial, porém suas relações de corte com as demais não são conclusivas. Também nesse caso evidencia-se uma diminuição temporal relativa da magnitude de $\sigma \mathrm{z}$, que pode estar relacionada com o resfriamento do corpo intrusivo principal (Geoffroy et al. 1994).

\subsubsection{Conclusões Parciais}

Os três parâmetros utilizados para determinação dos campos de paleotensões que controlaram a intrusão e deformaram os corpos alcalinos na porção central do Graben da Guanabara, forneceram resultados compatíveis e indicam que: 
1) Registra-se a atuação de dois eventos direcionais, um mais antigo, ativo durante e logo após a intrusão dos diques de fonolito e traquito, com $\sigma 1$ de direção NE-SW, e outro, mais novo, sem idade determinada, com $\sigma 1$ de direção NW-SE. O mais antigo caracterizou-se, inicialmente, por uma extensão N-S e SHmax E-W, contemporânea à intrusão dos diques, os quais sofreram rotação anti-horária para NW-SE e NE-SW, respectivamente;

2) A inversão dos dados de falhas e microfalhas e de diques de rochas alcalina félsicas indica uma diminuição temporal na magnitude do eixo de paleotensões vertical, $\sigma z$. Essa maior magnitude inicial pode estar relacionada com o soerguimento associado à intrusão dos corpos alcalinos maiores e, sua diminuição, com a subsidência que acompanhou o resfriamento desses corpos. 


\section{4. ÁREA ORIENTAL DO GRABEN-SUÍTE ALCALINA DA ILHA DE CABO FRIO}

\subsubsection{Introdução}

A Suíte da Ilha de Cabo Frio ocorre principalmente na ilha homônima, que tem pouco mais de $6 \mathrm{~km}^{2}$ de área e, subordinadamente, no Pontal do Atalaia, em uma estreita faixa, junto às Prainhas, e na forma de um pequeno plug isolado, no Morro do Forno (Lima \& Chievegatto 1974, Reis et al. 1976, Araújo 1995, Figura 4.73). O corpo principal, que aflora na Ilha de Cabo Frio, é alongado na direção NE-SW, por cerca de $4 \mathrm{~km}$, tem uma largura média de aproximadamente $2 \mathrm{~km}$. Ele é totalmente constituído por rochas alcalinas félsicas, insaturadas (nefelina sienito) a supersaturadas (quartzo sienito) (Figura 4.73).

Os diques associados à suíte, apesar de serem predominantemente félsicos, traquíticos e fonolíticos, incluem tipos menos evoluídos, como lamprófiros (Lima \& Chievegatto 1974, Reis et al. 1976, Araújo 1995, Thompson et al. 1998) e basalto alcalino (Thompson et al. 1998).

O embasamento da Suíte da Ilha de Cabo Frio é constituído por rochas granitóides e migmatíticas, com característicos metabasitos, da Unidade Região dos Lagos (Reis et al. 1976), de idade transamazônica e com retrabalhamento no Brasiliano (Zimbres et al. 1990). Elas apresentam uma foliação bem marcada, de baixo ângulo, redobrada, o que lhes confere uma atitude variável (Figura 4.73), porém predominantemente orientada segundo a direção NW-SE

As datações radiométricas referentes à Suíte da Ilha de Cabo Frio, disponíveis na literatura, indicam idades entre 72 e $51 \mathrm{Ma}$, com predominância dos resultados entre 52 e 56 Ma. Essas idades se referem tanto a rochas plutônicas, sieníticas, como a hipabissais, tanto félsicas como máficas. Elas foram obtidas através dos métodos $\mathrm{K} / \mathrm{Ar}$ e $\mathrm{Rb} / \mathrm{Sr}$, tanto para rocha total como para minerais. As análises $\mathrm{K}-\mathrm{Ar}$ em biotita e flogopita situam-se entre 54 e $56 \mathrm{Ma}$, e uma única análise Ar-Ar, em rocha total, obtida no presente trabalho, para um dique de fonolito que corta o embasamento, forneceu idade de $52 \mathrm{Ma}$ (ver resultados das datações radiométricas no Anexo A). Os resultados estão sintetizados na Tabela 4.8 


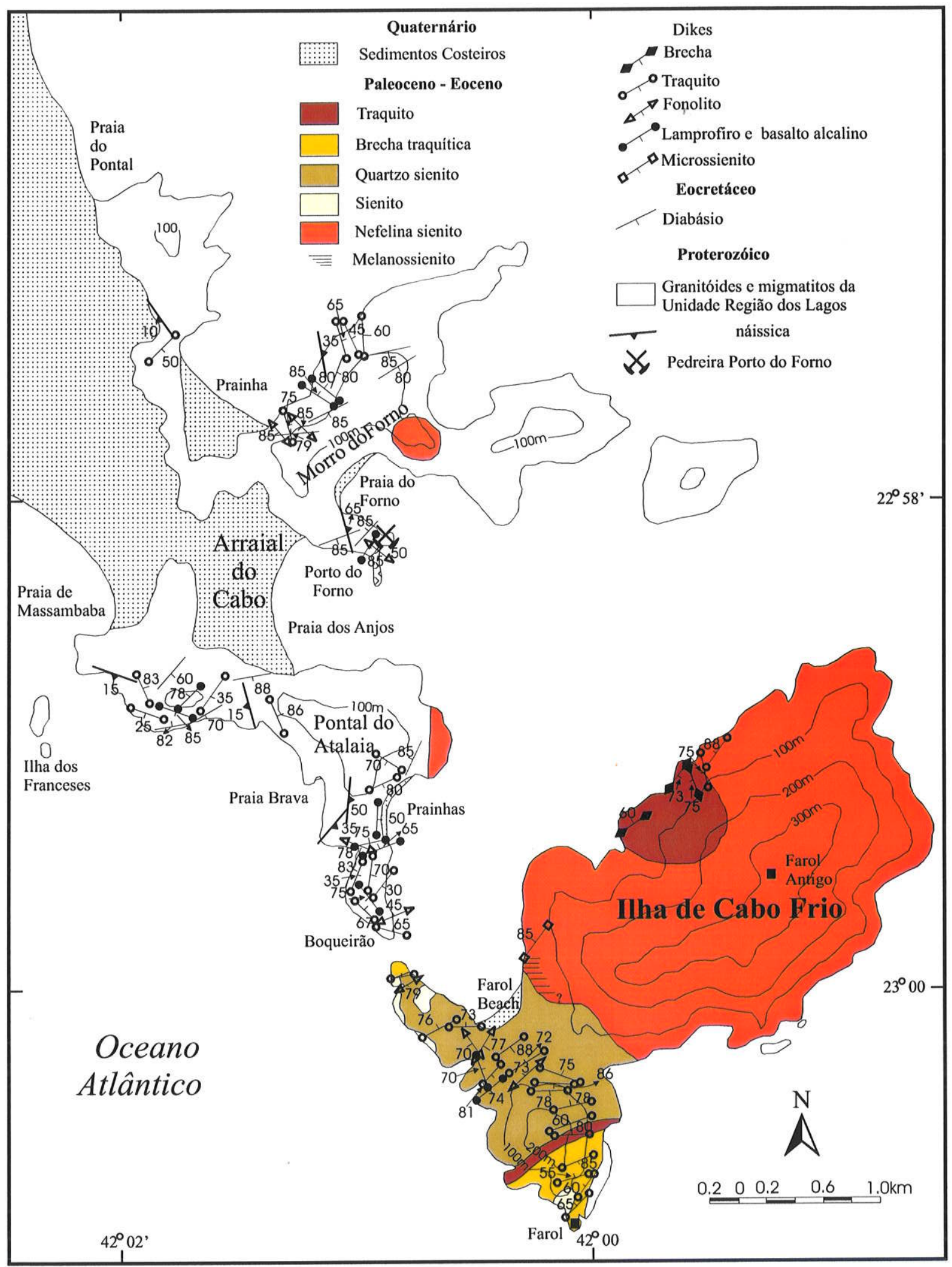

Figura 4.73 - Mapa geológico da região de Arraial do Cabo, RJ, destacando o complexo alcalino da Ilha de Cabo Frio. Modificado de Lima \& Chievegatto (1974), Reis et al. (1976) and Araujo (1995). Distribuição e atitude dos diques a partir desse trabalho. 


\begin{tabular}{|c|c|c|c|}
\hline tincos & 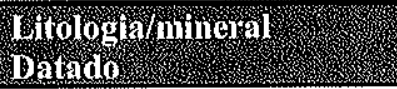 & Metodo & Resultados \\
\hline Sonoki \& Garda 1988 & $\begin{array}{l}\text { tinguaito/rocha total } \\
\text { tinguaíto/rocha total } \\
\text { pulaskito/biotita } \\
\text { tinguaito/feld.alc. }\end{array}$ & $\begin{array}{l}\mathrm{K} / \mathrm{Ar} \\
\mathrm{K} / \mathrm{Ar} \\
\mathrm{K} / \mathrm{Ar} \\
\mathrm{K} / \mathrm{Ar}\end{array}$ & $\begin{array}{l}52.6 \pm 2.0 \mathrm{Ma} \\
50.0 \\
54.0 \pm 2.6 \mathrm{Ma} \\
72.4 \pm 2.9 \mathrm{Ma} \\
\end{array}$ \\
\hline Sichel et al. 1997 & nefelina sienito/rocha total & isócronas $\mathrm{Rb} / \mathrm{Sr}$ & $59.1-52.1 \mathrm{Ma}$ \\
\hline Thompson et al. 1998 & $\begin{array}{l}\text { ?/flogopita } \\
\text { idem } \\
\text { minette/flogopita } \\
\text { idem }\end{array}$ & $\begin{array}{l}\mathrm{K} / \mathrm{Ar} \\
\mathrm{K} / \mathrm{Ar} \\
\mathrm{K} / \mathrm{Ar} \\
\mathrm{K} / \mathrm{Ar}\end{array}$ & $\begin{array}{l}55.5 \pm 1.4 \mathrm{Ma} \\
56.2 \pm 1.4 \mathrm{Ma} \\
53.8 \pm 1.0 \mathrm{Ma} \\
53.8 \pm 1.0 \mathrm{Ma}\end{array}$ \\
\hline Esse trabalho & fonolito/rocha total $-\mathrm{P}, \mathrm{I}$ & $\mathrm{Ar} / \mathrm{Ar}$ & $52.1 \pm 0.8 \mathrm{Ma}$ \\
\hline
\end{tabular}

Tabela 4.8 - Datações radiométricas disponíveis para a Suíte Alcalina da Ilha de Cabo Frio.

P-platô

$\mathrm{I}$ - isócrona

\subsubsection{Fisiografia}

Essa, que é a única suíte alcalina da porção fluminense da Província Alcalina da Serra do Mar (Ulbrich \& Gomes 1981) localizada na costa, tem topo aplainado a cerca de $350 \mathrm{~m}$ (Figura 4.74A), mostra encostas de perfil convexo, características dos maciços constituídos por rochas alcalinas (Costa et al. 1983), e é caracterizada, nas suas faces oceânicas (SW, SE e Leste), pela presença de penhascos com mais de $20 \mathrm{~m}$ de altura, recortados por fendas com alguns a pouco mais de uma dezena de metros de largura, que avançam poucas dezenas de metros maciço adentro. A mais marcante delas é a fenda de Nossa Senhora, próxima ao Boqueirão (Figura 4.74C), onde um dique de fonolito, de cerca de 3 metros de espessura, foi erodido diferencialmente pelo embate das ondas. No lado mais abrigado da Ilha, a NW, localiza-se sua única praia de areia, a Praia do Farol (Figura 4.74B), e os costões rochosos são muitas vezes encobertos por tálus que chegam até a água. Praias de seixos podem ser vistas em alguns locais, como nas proximidades da Fenda de Nossa Senhora. A porção SW da ilha constitui uma pequena península alongada na direção NW-SE, mostra, também, um relevo mais aplainado, porém com altitudes menores que o restante da ilha (Figura 4.73). A face oceânica da porção com relevo mais acentuado, a SE, apresenta maior declividade que a voltada para NW (Figura 4.74D). 

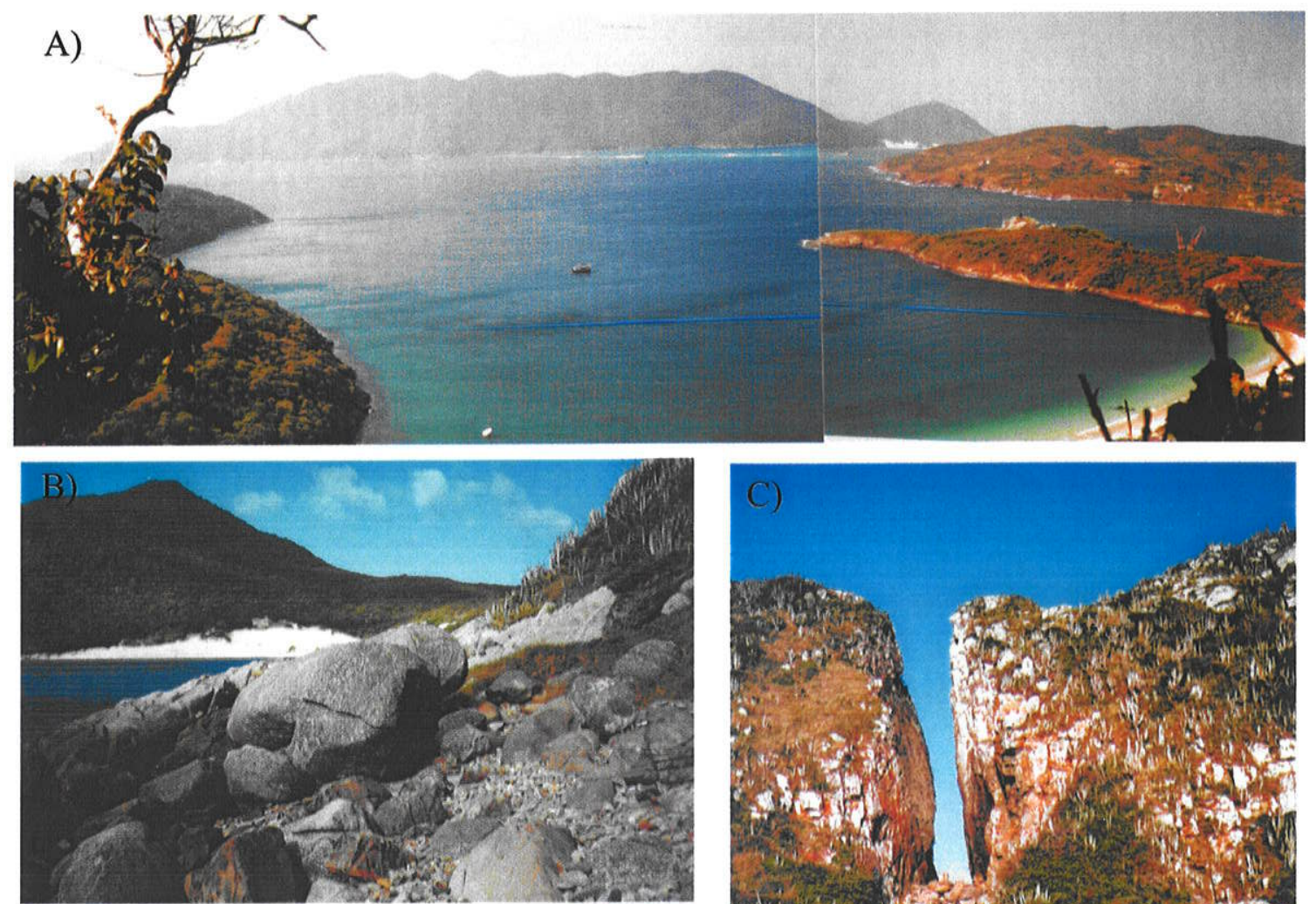

D)

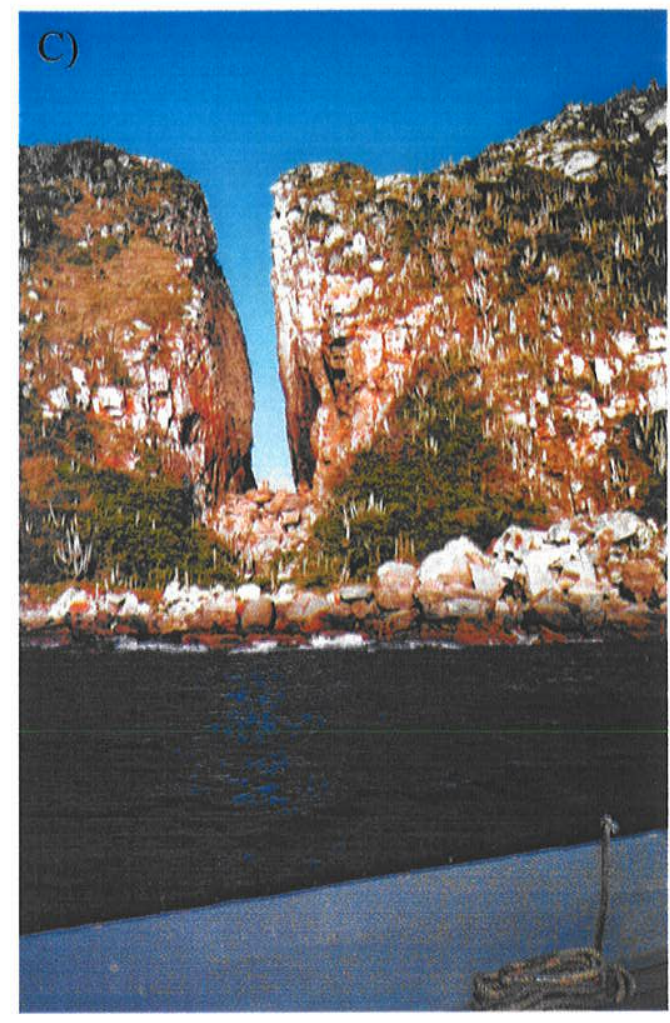

Figura 4.74 - A) Vista geral da Ilha de Cabo Frio, de NW para SE, a partir do Morro do Forno. Destaca-se o topo aplainado da ilha, com altitudes em torno de $350 \mathrm{~m}$. No lado direito da ilha vê-se, com altitudes ma-is baixas, a área de ocorrência do quartzo sienito, em parte escondida pelo Pontal do Atalaia, B) Praia do Farol, vista de SW para NE a partir das proximidades do Ponto Arr42. Em primeiro plano vê-se praia de seixos, C) Fenda de Nossa Senhora, formada por erosão marinha sobre dique de fonolito de direção NE-SW, ponto Arr42, vista de NE para SW, D) Vista da face oceânica (SE) da Ilha de Cabo Frio, a partir do ponto Arr17, de SW para NE. 


\subsubsection{Controle Tectônico da Intrusão}

Os contatos da suíte alcalina com o embasamento, na porção continental, são inferidos, tanto no Morro do Forno, onde ocorrem apenas blocos de nefelina sienito grosso com bolsões pegmatóides, como no Pontal do Atalaia, junto às Prainhas, onde podem ser vistos alguns afloramentos junto ao mar. $\mathrm{Na}$ face sudeste da ilha, o contato com o embasamento se faz por uma faixa espessa de brecha de matriz traquítica, com xenólitos de sienito, traquito, fonolito e gnaisse, com até mais de $1 \mathrm{~m}$ de eixo maior (Figura 4.73). Devese salientar que essa brecha é cortada por diques de traquito com até 1,5m de espessura. Brechas semelhantes ocorrem nos contatos do traquito com o nefelina sienito, onde puderam ser caracterizadas como intrusivas, constituindo diques intrudidos no traquito, com xenólitos de traquito e nefelina sienito (Figura 4.73). No contato sudoeste ocorre um único dique de brecha com pouco mais de $30 \mathrm{~cm}$ de espessura, enquanto no contato nordeste ocorre dois diques, um deles, de direção NE-SW, com aproximadamente $20 \mathrm{~m}$ de espessura, com xenólitos até métricos. Os quartzo sienitos que ocorrem na porção sudoeste da ilha mostram uma nítida orientação de fluxo, acentuada pelo achatamento de xenólitos de anfibolito e gnaisse digeridos, que pode chegar a caracterizar uma foliação, como nos pontos Arr8 e 38 (Figura 4.75), com direções 050/70 e 285/85, respectivamente, subparalelas ao atual contorno do corpo nessa porção. Essa orientação de fluxo não é vista no sienito, que possui granulação média a grossa e pode conter muita biotita, ou no nefelina sienito, que se apresenta sempre como uma rocha de granulação grossa com bolsões pegmatóides. O nefelina sienito, nas proximidades do contato com o quartzo sienito (inferido), apresenta uma faixa de melanossienito (Figura 4.76A), rico em biotita, o qual é encontrado em enclaves, dentro do nefelina sienito, cada vez menores à medida que se afasta do contato (Figura 4.76B).

Com base nas características descritas acima, pode-se inferir a estratigrafia da Suíte Alcalina da Ilha de Cabo Frio (Tabela 4.9). 


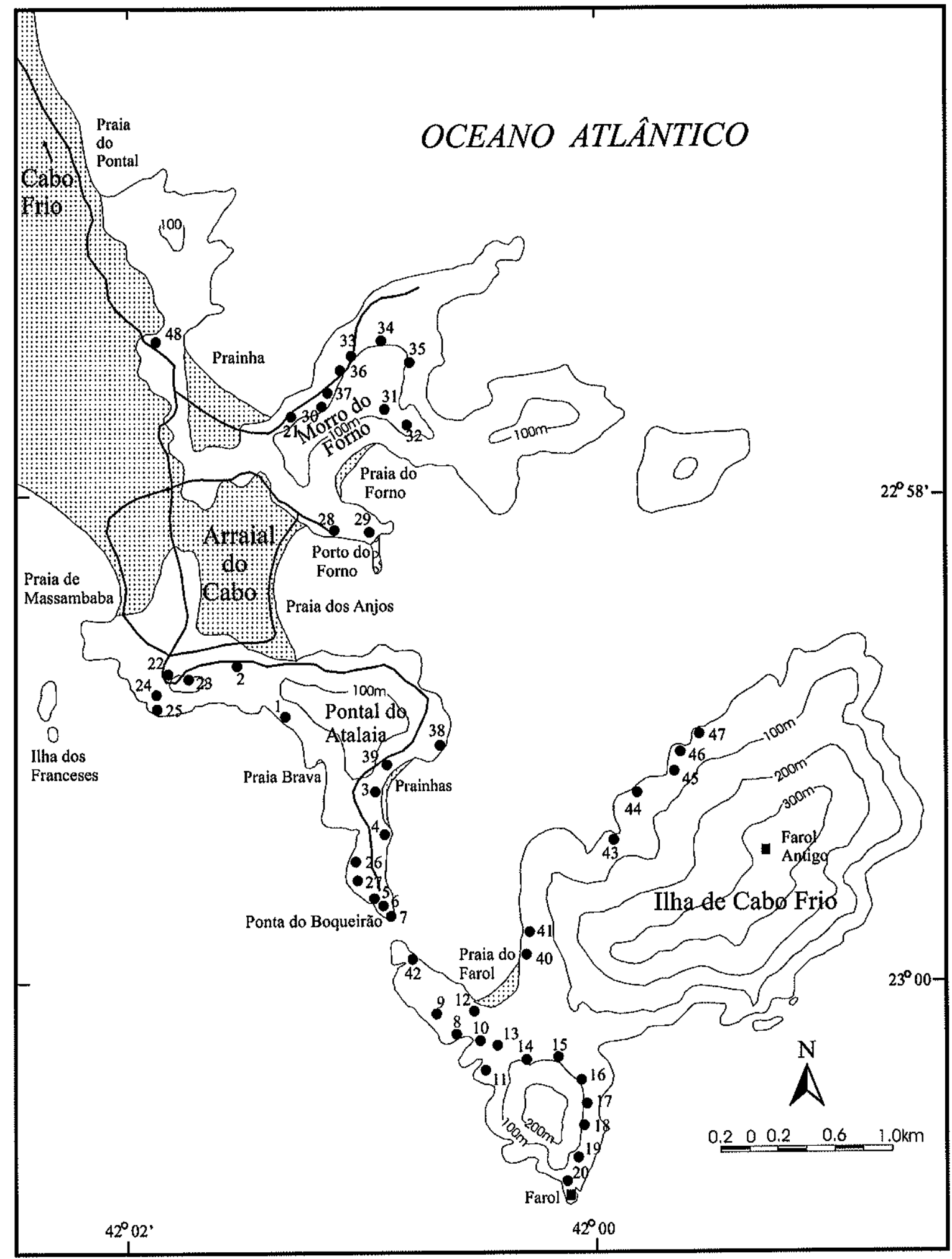

Figura 4.75 - Mapa dos pontos com afloramentos descritos e amostrados nesse trabalho. Complexo alcalino da Ilha de Cabo Frio e área adjacente, Município de Arraial do Cabo. 
A)

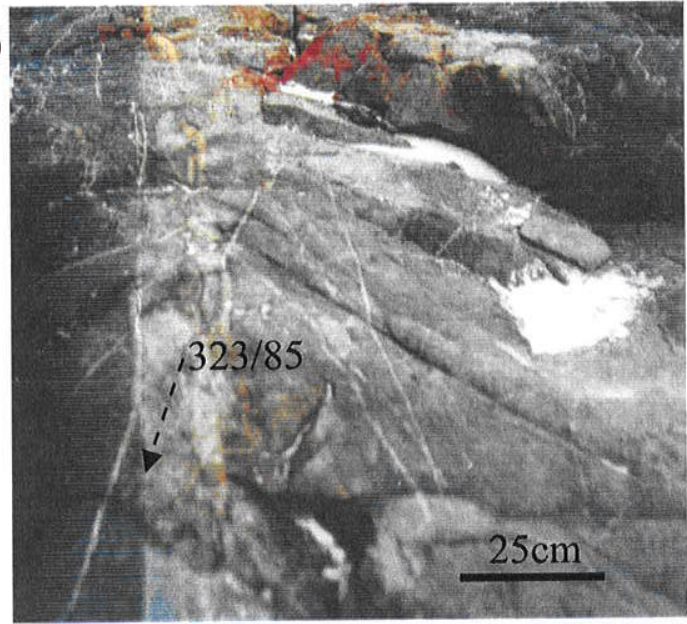

C)

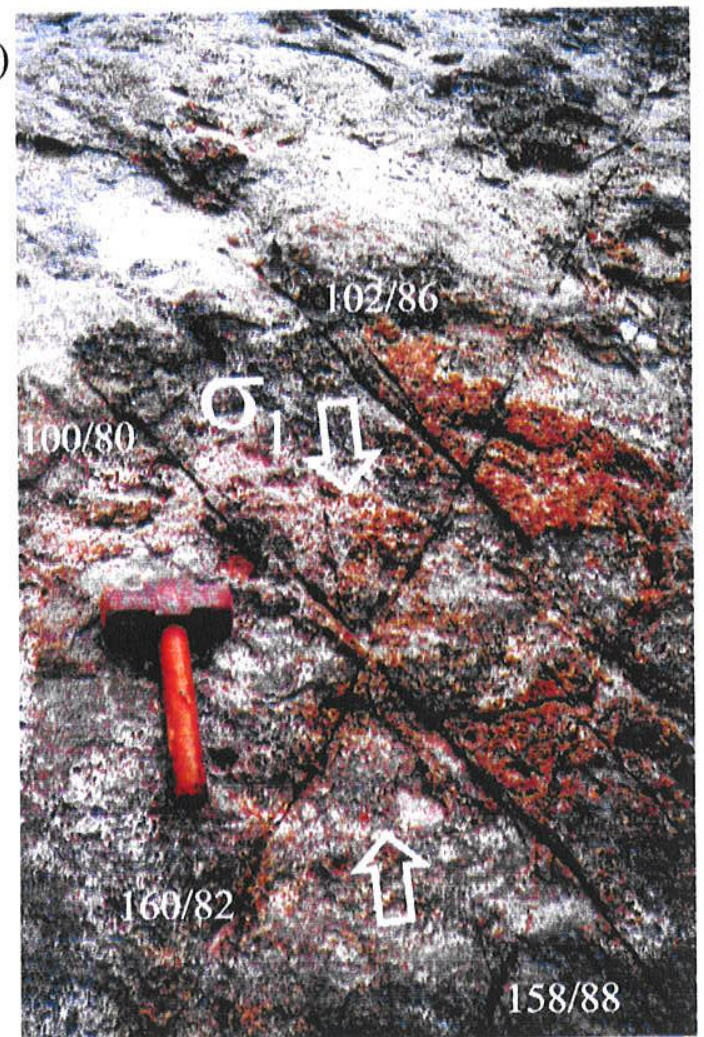

Figura 4.76 - A) Dique de microssienito cortando melanossienito, Ponto Arr40; B) Autoenclaves de melanossienito em nefelina sienito, parcialmente digeridos, Ponto Arr 40; C) Fraturas conjugadas de cisalhamento em nefelina sienito (Ponto Arr38); D) Dique de traquito cortando nefelina sienito, ambos alterados. Em primeiro plano blocos de nefelina sienito, Ponto Arr 47; E) Dique de traquito orbicular cortando dique de diabásio, Ponto Arr21. As atitudes dos diques e das fraturas estão representadas segundo o azimute do mergulho e $o$ ângulo de mergulho (medida CLAR). Vista em planta para todas as fotos, com excessão da foto $\mathrm{E}$. O Cabo da marreta possui $25 \mathrm{~cm}$ de comprimento.
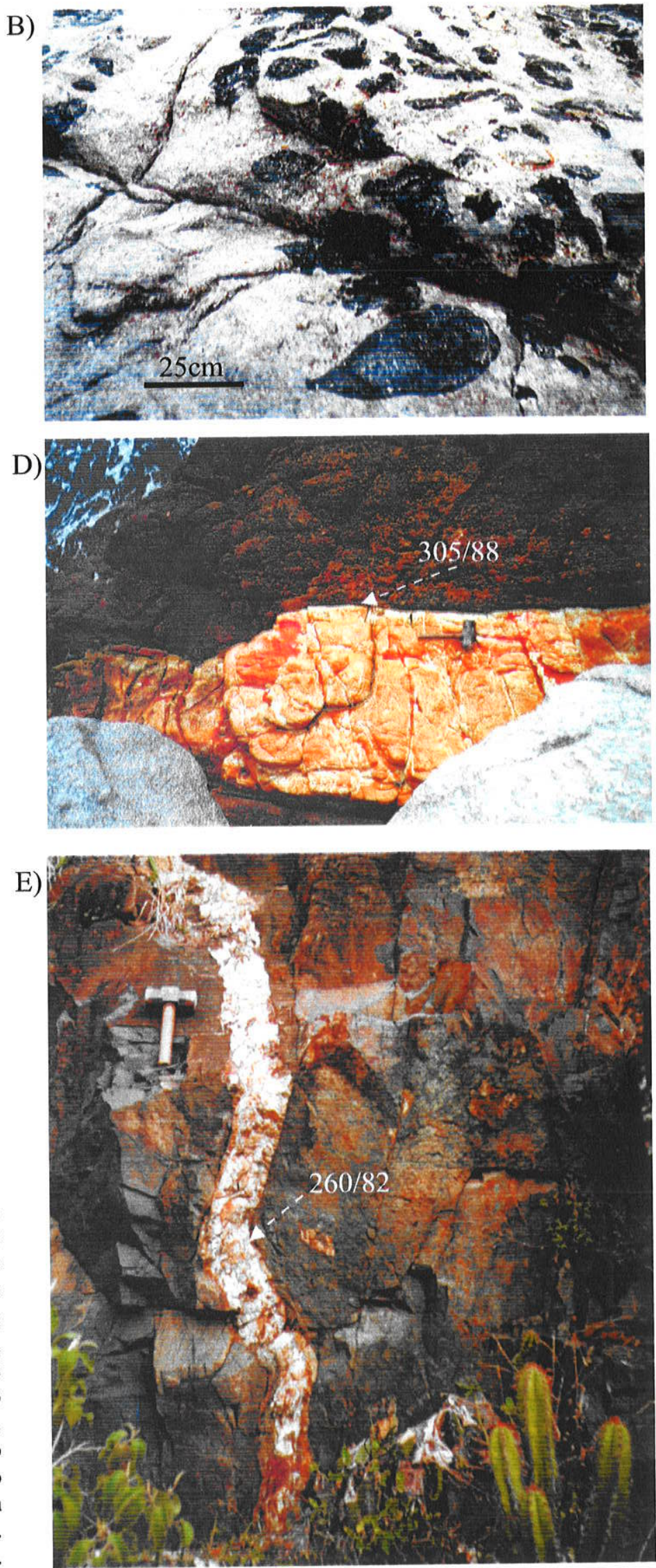


\begin{tabular}{|c|c|c|c|}
\hline & Hologas & Relarododo contato & Texturalestrutura \\
\hline \multirow[t]{7}{*}{ Mais novo } & $\begin{array}{l}\text { diques félsicos } \\
\text { (traquito e fonolito) }\end{array}$ & $\begin{array}{l}\text { cortam todas as litologias } \\
\text { anteriores e o } \\
\text { embasamento gnáissico }\end{array}$ & Variada \\
\hline & $\begin{array}{l}\text { diques máficos } \\
\text { (lamprófiros e basalto } \\
\text { alcalino) }\end{array}$ & $\begin{array}{l}\text { cortam quartzo sienito e } \\
\text { embasamento gnássico }\end{array}$ & Variada \\
\hline & $\begin{array}{l}\text { brecha de matriz } \\
\text { traquitica }\end{array}$ & enclaves das anteriores & Enclaves até métricos \\
\hline & Traquito & corta o nefelina sienito & Aplítica e traquítica \\
\hline & nefelina sienito & não definidas & Isotrópica \\
\hline & melano sienito & $\begin{array}{l}\text { enclaves no nefelina } \\
\text { sienito }\end{array}$ & $\begin{array}{l}\text { Isotrópica (fácies de } \\
\text { borda do nef sienito?) }\end{array}$ \\
\hline & Sienito & corta quartzo sienito & Isotrópica \\
\hline Mais antigo & quartzo sienito & & $\begin{array}{l}\text { Orientação de fluxo - } \\
\text { fácies de borda }\end{array}$ \\
\hline
\end{tabular}

Tabela 4.9 - Sintese das relaçóes de contato da Suite Alcalina da Iha de Cabo Frio com o embasamento gnáissico e entre as diversas litologias que o constituem.

\subsubsection{Diques}

Os diques de rochas alcalinas são abundantes em toda a área de Arraial do Cabo, cortando tanto o embasamento proterozóico como a suíte alcalina. Foram mapeados 71 diques de rochas alcalinas na área, sendo 13 de rochas alcalinas máficas, lamprófiros e basaltos alcalinos, e 58 de rochas alcalinas félsicas. Os diques de rochas alcalinas félsicas são principalmente traquitos e subordinadamente fonolitos. Esses diques foram descritos petrograficamente em detalhe por Araújo (1995) e Thompson et al. (1998) (Tabela 4.10).

\begin{tabular}{|c|c|c|c|c|c|c|c|c|c|c|}
\hline $\begin{array}{l}4 \\
y_{1}^{2}\end{array}$ & 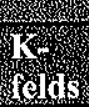 & ${ }^{2}$ & r & (x) & 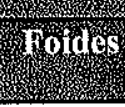 & (3) & $011 y$ & $\mathrm{Car}$ & Titan & Apat \\
\hline Lamprófiro & 1 & & 3 & 2 & 5 & 4 & & & & 6 \\
\hline Lamprófiro & & 3 & 1 & 5 & 4 & & 2 & & & 6 \\
\hline Basalto alcalino & & 1 & 2 & 3 & 5 & & 4 & & & \\
\hline Fonolito & 1 & & 3 & 4 & 2 & 5 & & & 6 & \\
\hline Traquito & 1 & & 2 & 5 & & 3 & & 4 & & \\
\hline
\end{tabular}

Tabela 4.10 - Tipos litológicos dos diques de lamprófiros e de rochas alcalinas máficas e félsicas da região de Arraial do Cabo, RJ. Os números indicam a abundância relativa dos minerais para cada tipo litológico. Os dados incluem uma compilação dos dados de Araújo (1995) e Thompson et al. (1998). 
Relações de corte permitem que se determine a idade relativa dos diques, onde os mais antigos são os de lamprófiros, que ocorrem principalmente encaixados no embasamento proterozóico. Um dique de lamprófiro, com pórfiros de biotita, e um de basalto alcalino foram identificados cortando os quartzo sienitos da Suíte Alcalina da Ilha de Cabo Frio (Figuras 4.73 e 4.77C). Os diques de lamprófiros são cortados por diques de rochas alcalinas félsicas (Figuras 4.77A e B). Entre esses últimos pode-se distinguir dois grupos, um com mergulhos altos, maiores do que $65^{\circ}$, e outro com mergulhos mais baixos, iguais ou menores que $65^{\circ}$, mais novo (Figura 4.78). No primeiro grupo os diques são tanto traquíticos como fonolíticos, e algumas vezes os fonolílitos aparecem cortando os traquíticos (Figura 4.79). No grupo dos diques de baixo ângulo foram identificados apenas os de composição traquítica.

$\mathrm{Na}$ Figura 4.80 estão representadas as direções e os mergulhos dos diques, separados em dois grandes grupos: de rochas alcalinas félsicas (A) e de lamprófiros (B). $\mathrm{O}$ primeiro grupo ainda foi subdividido em dois, um com ângulo de mergulho maior que $65^{\circ}$ e outro com ângulo de mergulho menor e igual a $65^{\circ}$. Os diques de lamprófiros mostram uma orientação principal na direção NE-SW e mergulhos dominantemente maiores que $65^{\circ}$. No outro grupo as direções E-W, para os diques com mergulho acima de $65^{\circ}$, e ENEWSW, para os diques com mergulho menor e igual a $65^{\circ}$, são as predominantes. Nos dois casos, considerando uma extensão ortogonal aos diques, pode-se inferir um eixo de esforços mínimo, $\sigma 3$, horizontal e orientado segundo o quadrante NW-SE. Pode-se inferir, também, que houve uma persistência da direção de SHmax, segundo o quadrante NE-SW. As variações nos ângulos de mergulho, para valores mais baixos, evidenciadas nos diques félsicos, indicam que os eixos de esforços principal, $\sigma 1$, e intermediário, $\sigma 2$, podem ter se alternado, gerando variações no campo de esforços, de direcional para normal.

A espessura dos diques varia desde alguns centímetros até $20 \mathrm{~m}$, com maior concentração até $50 \mathrm{~cm}$ (Figura 4.81). Os diques de lamprófiros têm espessura média menor do que os diques de rochas alcalinas félsicas, com mais de $85 \%$ dos diques mostrando espessura de até $50 \mathrm{~cm}$. Dentre os diques de rochas alcalinas félsicas, há também uma concentração daqueles com espessura de até $50 \mathrm{~cm}$, porém são comuns os com espessura de até $1,5 \mathrm{~m}$. Dentre esses, os traquitos com alto ângulo de mergulho são os únicos a terem espessuras decamétricas, como nos pontos Arr22 (15m) e Arr39 (20m) (Figura 4.75). 
B)

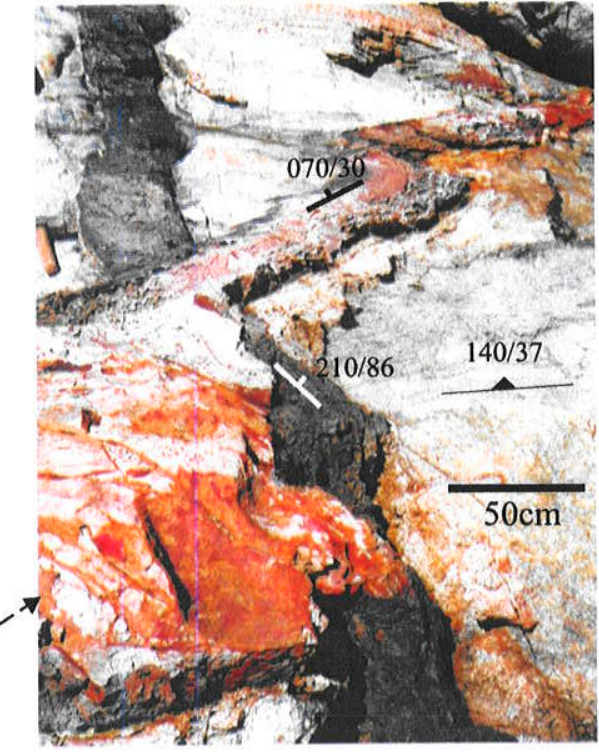

A)
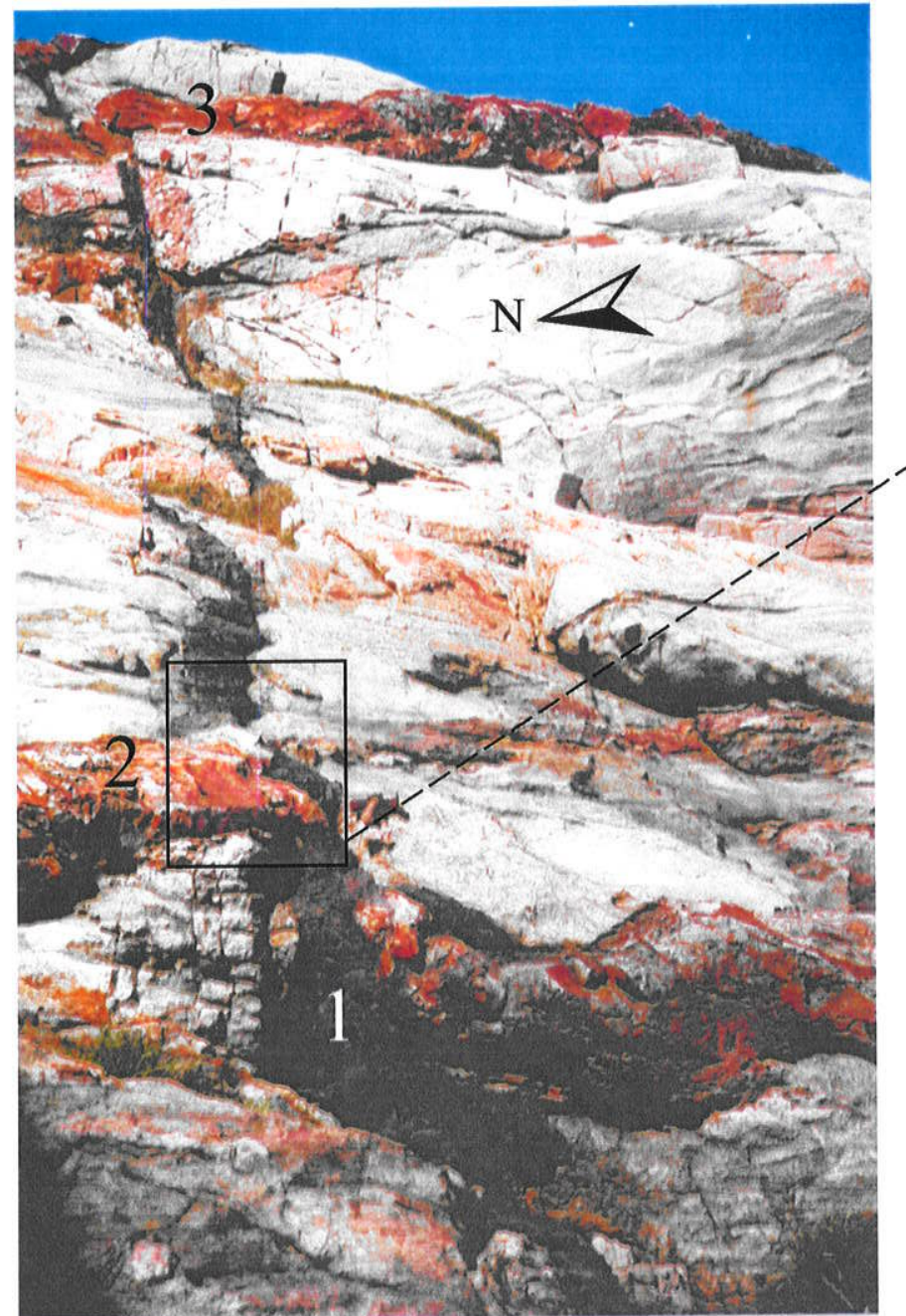

C)

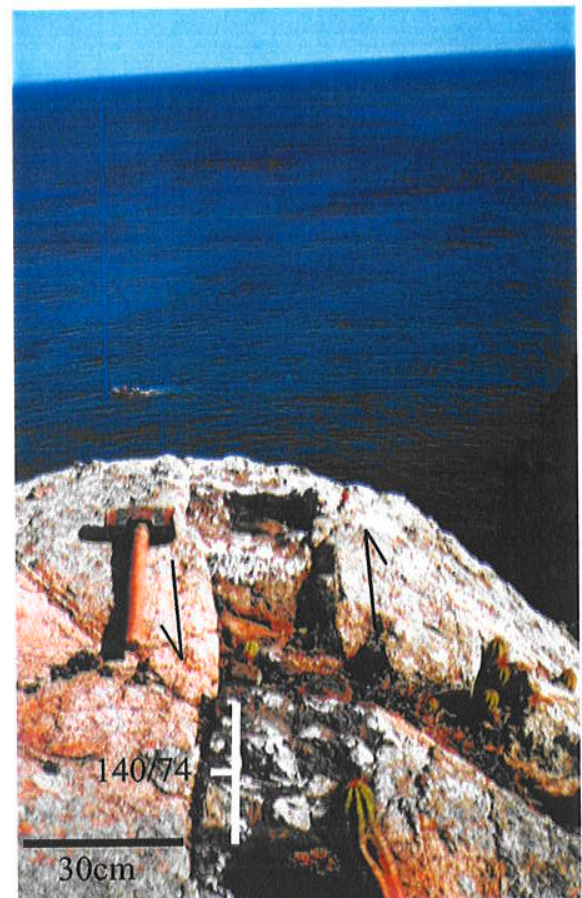

Figura 4.77 - A) Dique de basalto alcalino de direção WNW-ESE, (1), cortado por diques de traquito (2 e 3 ) com baixo ângulo de mergulho. A direção da foliação do gnaisse é indicada pelos níveis mais escuros (biotíticos) dentro dele. $\mathrm{O}$ dique de traquito que corta o de basalto alcalino, no topo do afloramento (3), tem $1,5 \mathrm{~m}$ de espessura. Pontal do Atalaia, ponto Arr27; B) Detalhe mostrando dique de traquito de baixo ângulo de mergulho, com pouco mais de $10 \mathrm{~cm}$ de espessura, cortando o basalto alcalino; C) Dique de lamprófiro, de direção NE-SW, cortando quartzo sienito. As fraturas deslocadas de um lado e outro do dique, indicam movimentação com componente sinistral paralela a ele. Ilha de Cabo Frio, ponto Arr11. As medidas indicam o azimute do mergulho e o mergulho dos diques (CLAR). Traço com um triângulo cheio - foliação do gnaisse. 

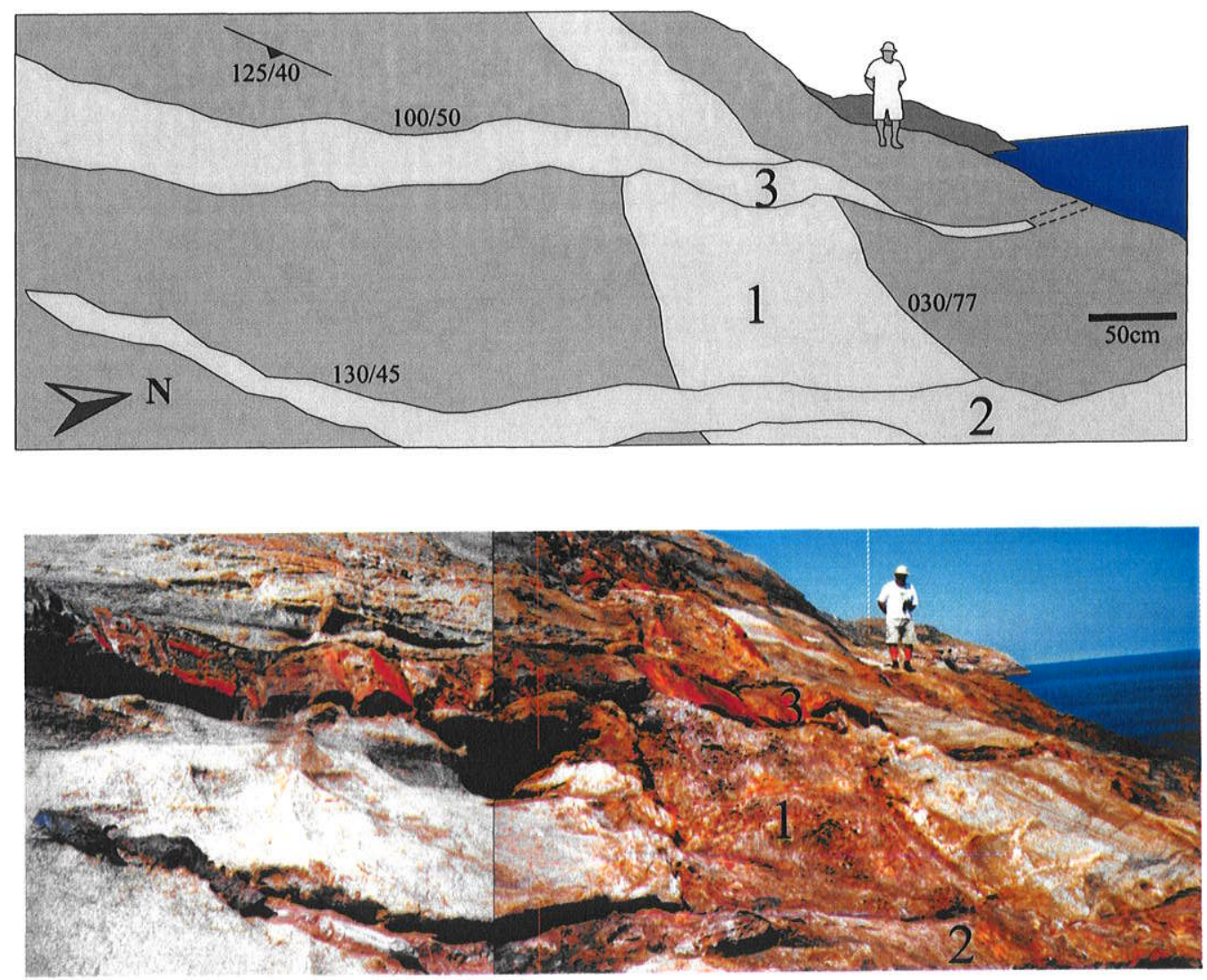

Figura 4.78 - Dique de traquito com mergulho de alto ângulo (1), cortado por dois diques de traquito com mergulho de baixo ângulo (2 e 3). Pontal do Atalaia, Ponto Arr26. Em segundo plano a Ilha de Cabo frio. As medidas indicam o azimute do mergulho e o mergulho dos diques (CLAR).Notar que a foliação do ganisse hololeucocrático do embasamento, representada por um traço com um triângulo, é sub-paralela aos diques de baixo ângulo. 


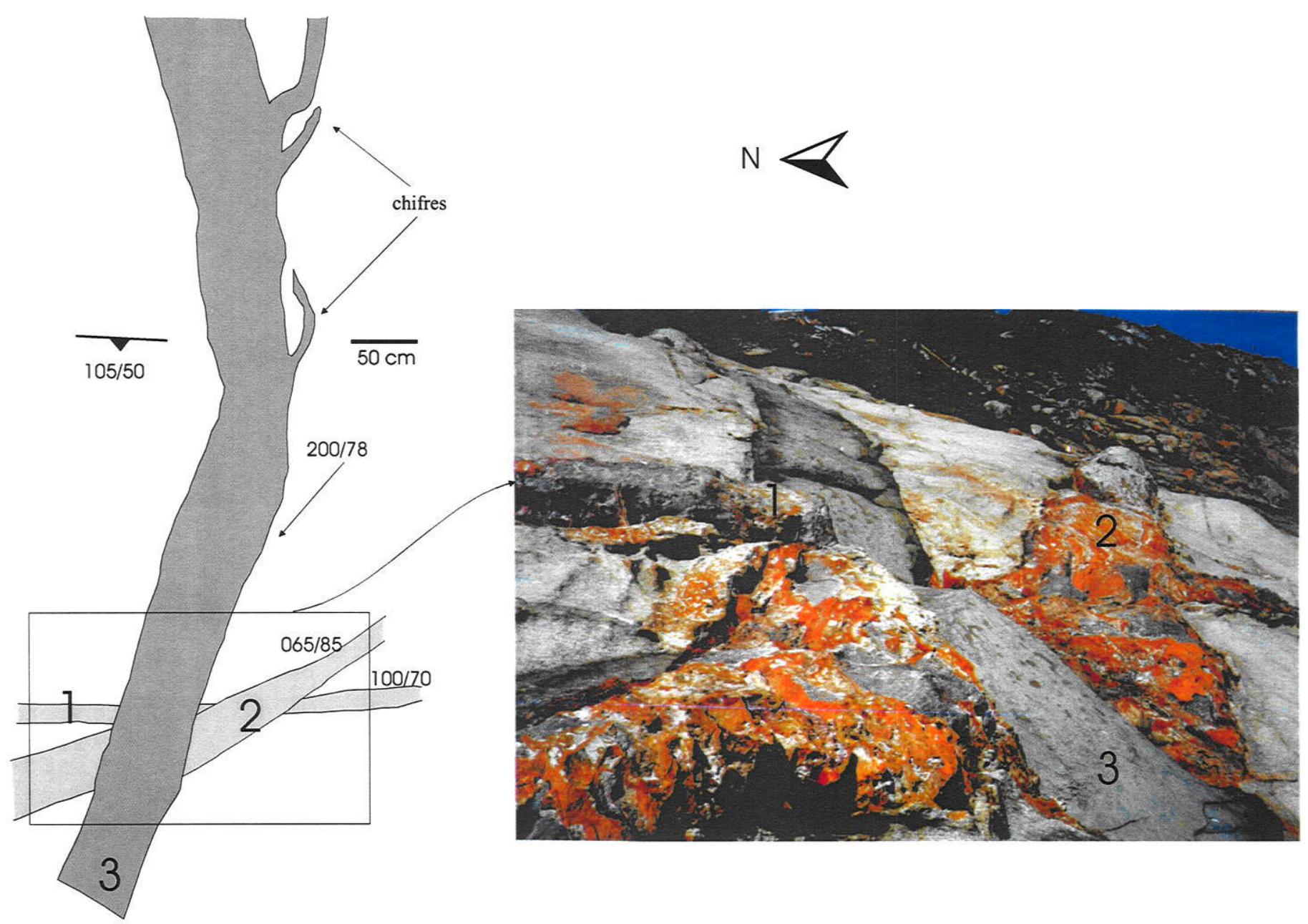

Figura 4.79-Relações de corte entre diques alcalinos félsicos no Pontal do Atalaia, Município de Arraial do Cabo, ponto Arr 27. Os diques são numerados por ordem de intrusão, do mais antigo (1) para o mais novo (3). Os diques 1 e 2 são de traquito, e o mais novo é de fonolito. As medidas indicam o azimute do mergulho e o mergulho dos diques (CLAR). O traço com um triângulo indica a atitude da foliação do granitóide encaixante. A ordem de intrusão indica uma rotação local de $\sigma 3$, anti-horária, de WNW para NE e NNE. Notar que os chifres mantém a direção de propagação principal do dique. 
A)
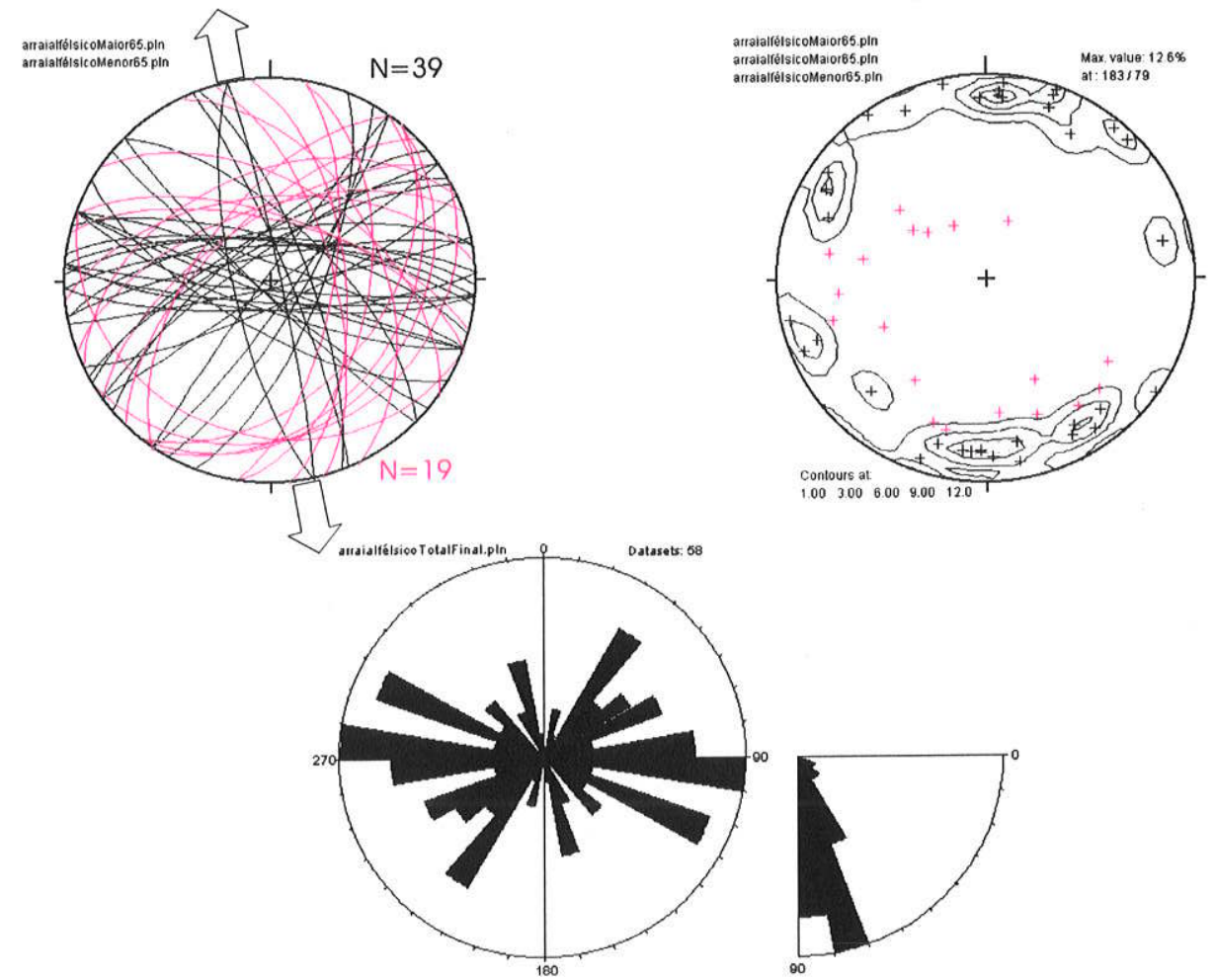

B)
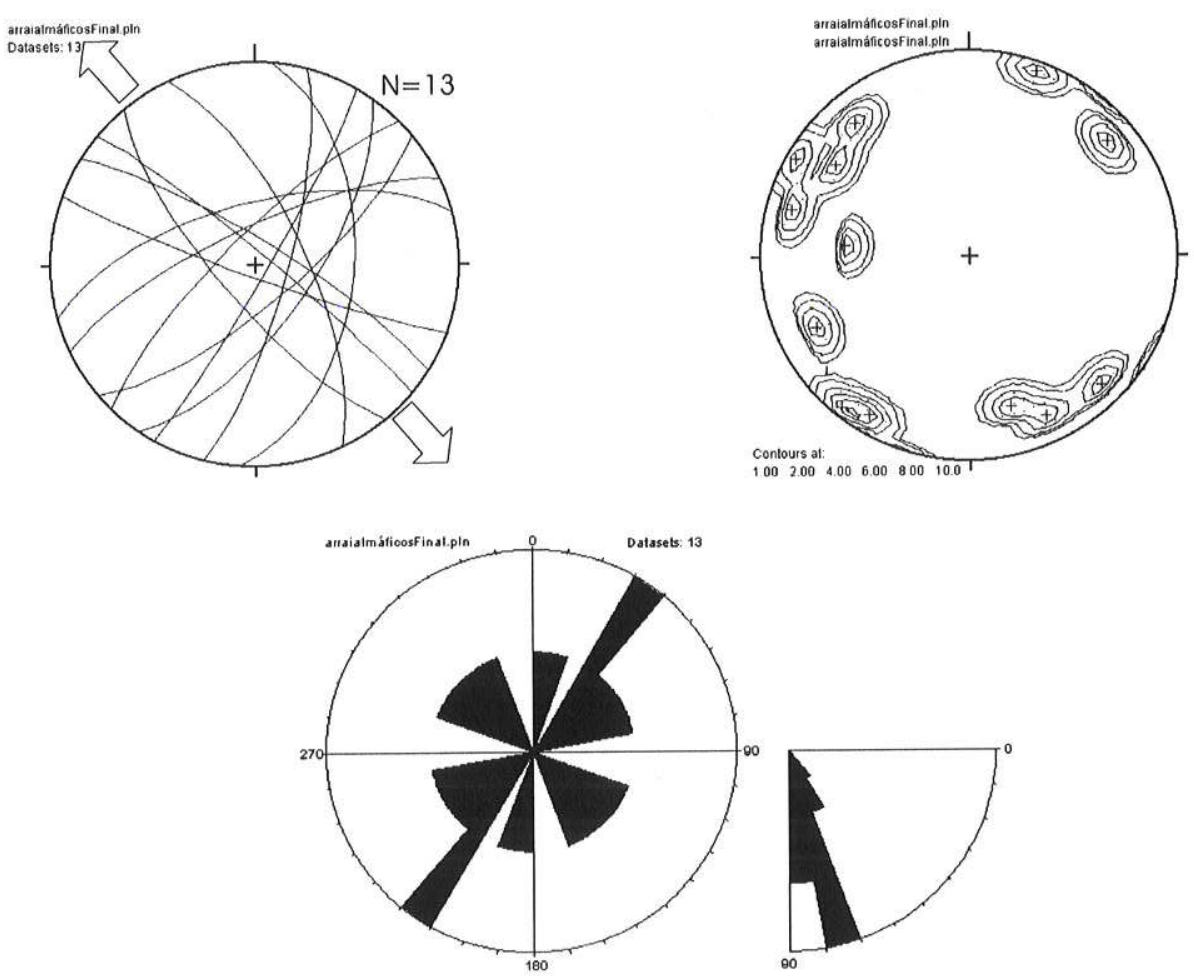

Figura 4.80 - Projeções ciclográficas e polares, e diagramas de rosetas, mostrando as direções e os mergulhos de diques de rochas alcalinas félsicas (A) e de lamprófiros (B), do Complexo Alcalino da Ilha de Cabo Frio. Em A, são separados aqueles com ângulo de mergulho maior que 65 graus (preto), daqueles com ângulo de mergulho menor e igual a 65 graus (vermelho). Nesse caso, a orientação principal dos diques na direção E-W (com mergulho maior que 65 graus) a ENE-WSW (mergulho menor e igual a 65 graus), permite posicionar o eixo de menor esforço, $\sigma 3$, na horizontal, segundo a direção NNW-SSE. Em B, a direção NE-SW da maioria dos diques, indica que o eixo de menor esforço, $\sigma$ 3, é horizontal, de direção NW-SE. Em ambos os casos há uma persistência da orientação de SHmax, no quadrante NE. Os diques com mergulho abaixo de 65 graus, de mesma direção que os de mergulho mais alto, permitem inferir uma variação local/temporal no campo de esforços.Diagramas de Schmidt-Lambert, hemisfério inferior. 


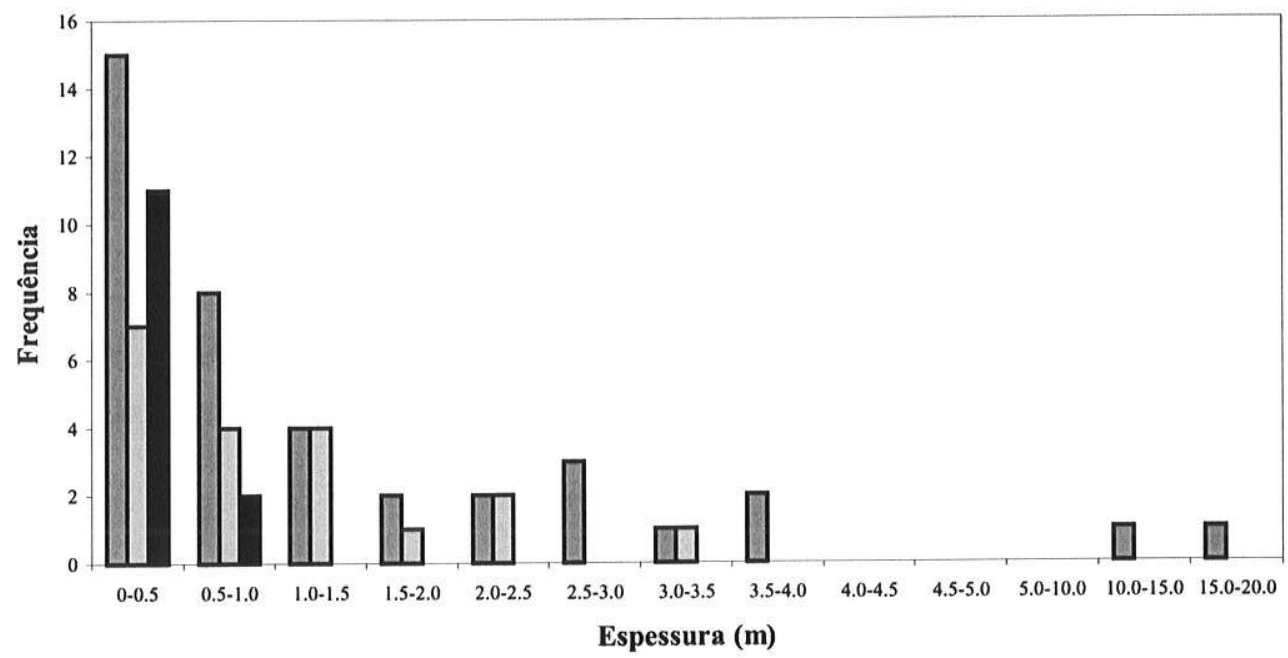

Figura 4.81 - Distribuição da espessura dos diques de lamprófiros (preto), de rochas alcalinas félsicas com ângulo de mergulho maior que $65^{\circ}$ (cinza escuro), e de rochas alcalinas félsicas com ângulo de mergulho menor ou igual a $65^{\circ}$ (cinza claro). Inclui diques que cortam o embasamento e/ou a suíte alcalina. Total de 71 diques.

A influência das estruturas do embasamento sobre o magmatismo alcalino terciário foi efetiva, em parte, apenas no caso dos diques traquíticos de baixo ângulo de mergulho. Esse controle das estruturas preexistentes, especialmente da foliação, pode ser visto nas Figuras 4.77, 4.78 e 4.82. Na Figura 4.77A, um dique de basalto alcalino, com cerca de 40 $\mathrm{cm}$ de espessura e com mergulho de alto ângulo, com direção quase ortogonal à da foliação, é cortado por dois diques de traquito com baixo ângulo de mergulho, subparalelos à foliação, a qual, como em toda a área, possui baixo ângulo de mergulho. Quando olhado em detalhe, o dique de basalto alcalino apresenta separações (desvios na direção de propagação), ora à esquerda, ora à direita, ligadas por conectores que seguem a direção da foliação do embasamento (Figura 4.82C).

Os diques de diabásio do Cretáceo Inferior, correlatos ao magmatismo da Formação Serra Geral, parecem funcionar como zonas de fraqueza, ou zonas de reativação preferencial, tendo em vista que os diques terciários ocorrem, algumas vezes, bordejandoos. Nesse sentido, a situação apresentada na Figura 4.82A e B é esclarecedora, tendo em vista principalmente a grande amplitude da exposição, em planta. Nesse local, um dique de traquito, com mergulho de alto ângulo, e espessura de pouco mais de $1 \mathrm{~m}$, corta um espesso 


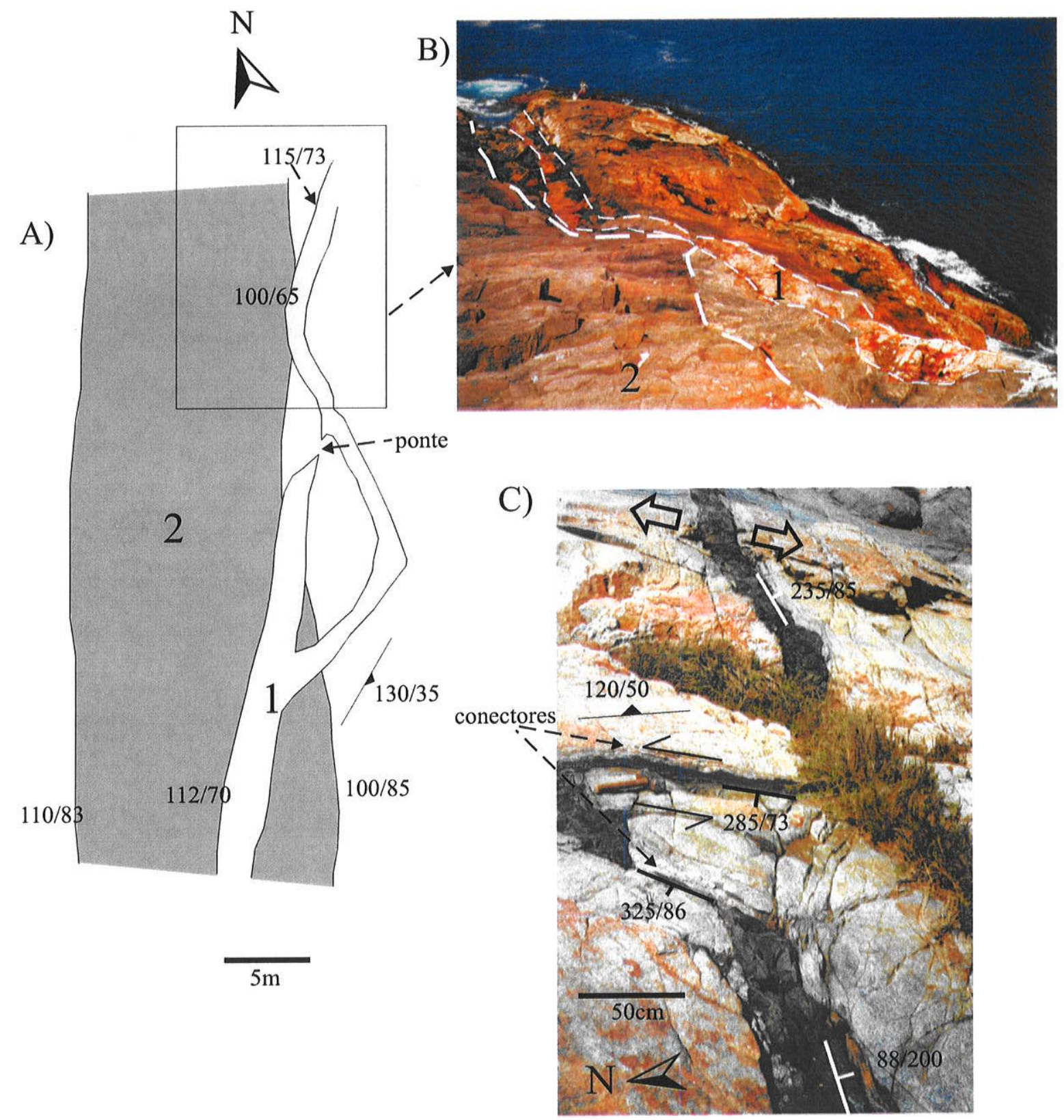

Figura 4.82 - Aspectos do controle estrutural do embasamento sobre os diques terciários da região de Arraial do Cabo. Em A, vê-se dique de traquito (1), orientado segundo a direção NNE-SSW, cortando dique de diabásio, sub-paralelo a ele (2), e o embasamento. Pode-se observar que o dique de traquito desvia-se localmente, paralelizando-se à direção da foliação no local, para posteriormente retomar a orientação original. Pode-se observar, ainda, que forma-se pequena ponte entre o segmento original do dique e o novo segmento. Em B vê-se foto de parte do afloramento. Pontal do Atalaia, ponto Arr26. Em C um dique de basalto alcalino de direção WNW-ESE, sofre um desvio na sua direção de propagação, gerando dois conectores com espessura mais fina, paralelizando-se localmente com a foliação do embasamento. Pontal do Atalaia, ponto Arr27.As medidas indicam o rumo do mergulho e o mergulho. O traço com um triângulo indica a atitude da foliação do embasamento. Setas largas indicam a direção de extensão. Setas finas indicam movimentação direcional local. 
dique de diabásio $(15 \mathrm{~m})$, e apesar de sofrer um pequeno desvio em sua trajetória, por influência da foliação do embasamento, segue aproximadamente paralelo ao dique de diabásio. Outras vezes, os diques terciários podem ter orientação totalmente discrepante dos diques de diabásio e do próprio embasamento, como no caso dos diques de traquito orbicular e fonolito que cortam um de diabásio na prainha, no ponto Arr21 (Figura 4.76E). Dessa forma, a direção de propagação desses diques parece responder principalmente aos esforços regionais e, secundariamente, às descontinuidades locais. Tanto os diques de rochas alcalinas máficas como os de rochas alcalinas félsicas, evidenciam uma extensão ortogonal a eles, como no caso da Figura C. Nesses casos, os eventuais conectores, com orientação oblíqua ou ortogonal a eles, vão apresentar movimentação direcional (Figura 4.82C), por vezes com feições de cisalhamento associadas (Figura 4.83). Mais raramente, pode-se caracterizar uma componente direcional paralela ao dique, como no caso do dique de lamprófiro do ponto Arr11 (Figura 4.77C), onde fraturas oblíquas são deslocadas sinistralmente, com rejeito aparente de cerca de $10 \mathrm{~cm}$. Nesse caso pode-se notar uma pequena endentação do dique nessas fraturas, indicando que a movimentação direcional é tardia à intrusão do dique.

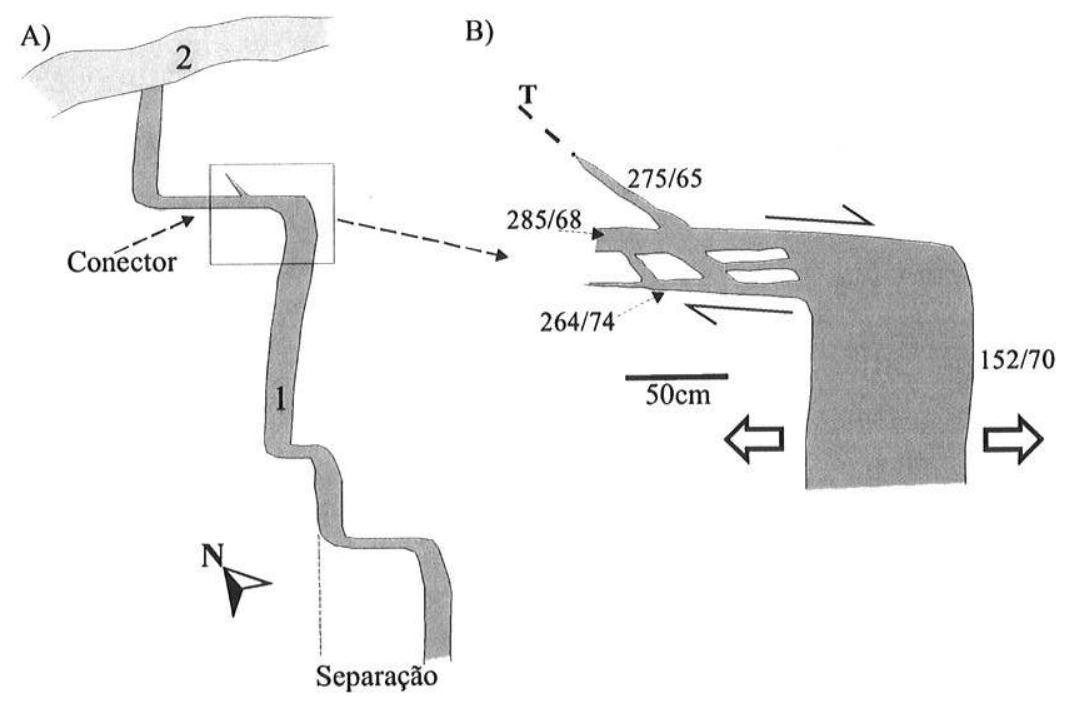

Figura 4.83 - A) Dique de Lamprófiro (1) de direção ENE-WSW, cortado por dique de traquito com baixo ângulo de mergulho (2). O dique de lamprófiro mostra segmentos deslocados à esquerda, com separações até métricas, interligados por conectores com espessura mais fina que os segmentos do dique. B) Detalhe de um dos conectores evidenciando deslocamento com componente direcional dextral, gerando binário dextral local. Notar que os xenólitos do gnaisse encaixante são fragmentados segundo a direção $\mathrm{T}$ do binário gerado, paralela ao eixo de maior esforço, $\sigma 1$. Pontal do Atalaia, ponto Arr25. 
Para análise do campo de esforços que controlou a intrusão dos diques de rochas alcalinas, eles foram separados em três grandes grupos: A) diques de rochas alcalinas félsicas com ângulo de mergulho menor ou igual a $65^{\circ}, \mathrm{B}$ ) diques de rochas alcalinas félsicas com ângulo de mergulho maior que $65^{\circ}$, e C) diques de lamprófiros e de basaltos alcalinos (Figura 4.84). Todos os diques foram plotados como fraturas de tração, considerando que todos sofreram dominantemente extensão ortogonal a eles.

$\mathrm{Na}$ Figura 4.84C estão representados os diques de rochas alcalinas máficas. Nesse grupo predominam amplamente os de mergulho acima de $75^{\circ}$, separados em dois subgrupos com direção NE-SW, o mais abundante, e NW-SE. A inversão desses dados indicou um campo de esforços Extensivo puro (Pure EXTENSIVE), com o eixo de esforços principal, $\sigma 1$, na vertical, o eixo de esforços intermediário, $\sigma 2$, na direção NE-SW, e o eixo de esforços mínimo, $\sigma 3$, na direção NW-SE. Deve-se ressaltar o caráter extensional de $\sigma 2$, aproximando-o de $\sigma 3$, aproximando o campo de esforços resultante de uma EXTENSÃO radial (Radial EXTENSION). Essa característica é corroborada pelo valor de $\mathrm{R}$, muito próximo de 0.25 .

Os diques de rochas alcalinas félsicas com ângulo de mergulho maior do que $65^{\circ}$, estão representados na Figura 4.84B. Pode-se distinguir um grupo, amplamente predominante, com uma concentração em torno de E-W, e outro, subordinado, na direção NNW-SSE. A inversão desses dados resultou num campo de esforços puramente EXTENSIVO (Pure EXTENSION), com o eixo principal de esforços, $\sigma 1$, vertical, o eixo de esforços intermediário, $\sigma 2$, horizontal e de direção ENE-WSW, e o eixo de menor esforço, $\sigma 3$, de direção NNW-SSE.

Os diques de rochas alcalinas félsicas com ângulo de mergulho abaixo e igual a $65^{\circ}$, estão representados na Figura 4.84A. Esse conjunto mostra dois sub-grupos, um de direção NW-SE a NNE-SSW, com mergulhos baixos predominantes, e outro de direção ENEWSW, com ângulos de mergulho intermediários a baixos. $O$ resultado da inversão foi um campo de esforços COMPRESSIVO puro (Pure COMPRESSIVE), com o eixo de esforços máximo, $\sigma 1$, horizontal e de direção NE-SW, o eixo de esforços intermediário, $\sigma 2$, ortogonal a ele, e o eixo de esforços mínimo, $\sigma 3$, vertical. $\mathrm{O}$ caráter levemente extensional de $\sigma 2$ indica o campo de esforços tende a ser transpressivo, o que também é indicado pelo valor de $\mathrm{R}$. 

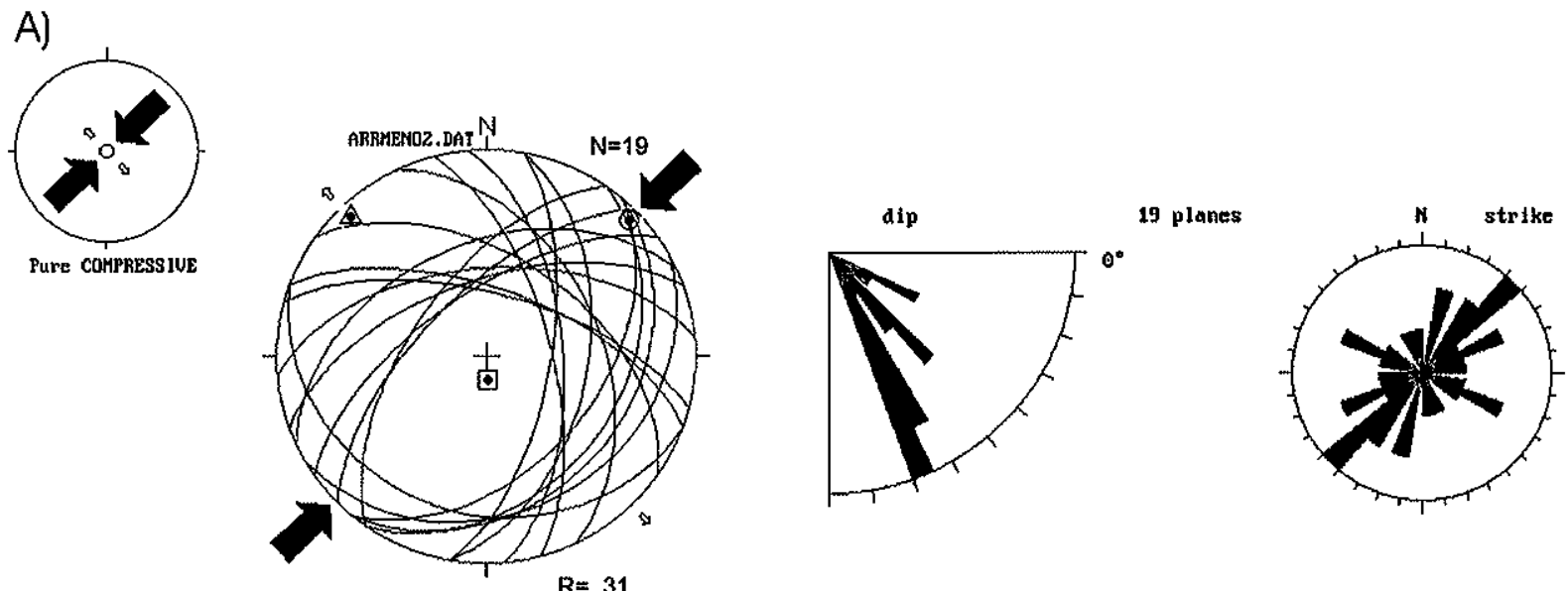

$R=.31$

B)

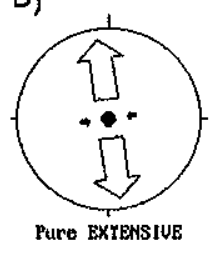

C)
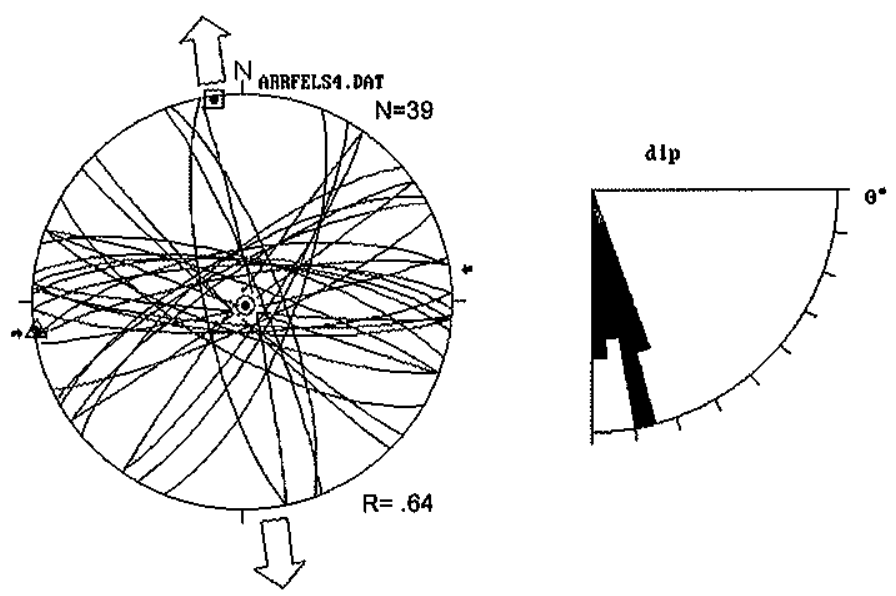

39 planes
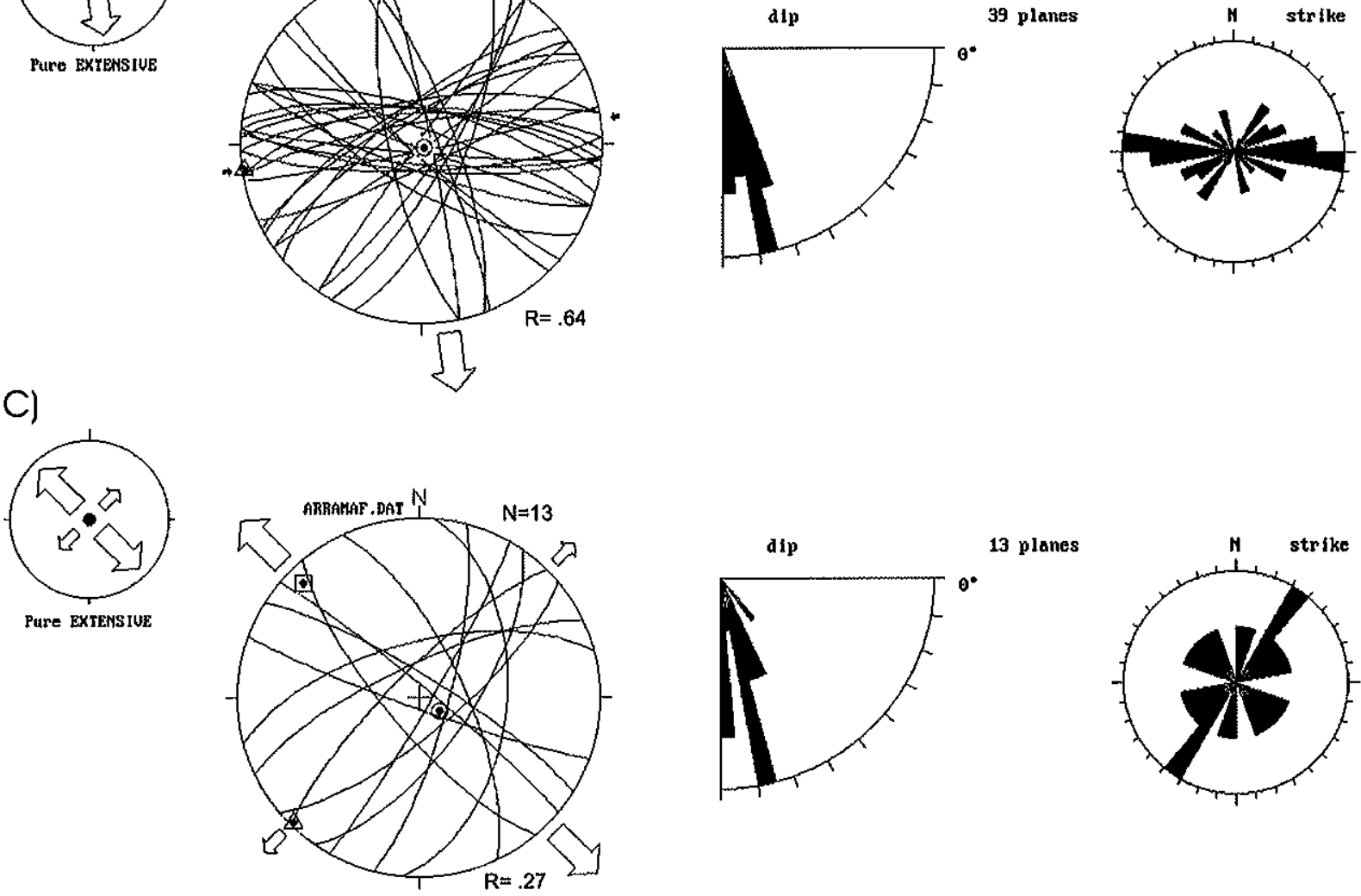

13 planes

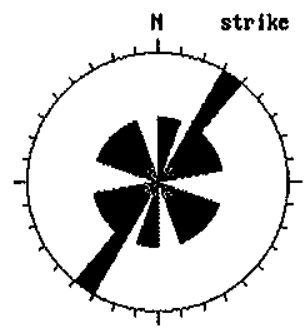

Figura 4.84 - Diques de traquito e fonolito, com ângulo de mergulho maior que 65 graus (B) e menor e igual a 65 graus (A), e diques de lamprófiros e basalto alcalino (C), intrudidos no embasamento proterozbico e no complexo alcalino da Ilha de Cabo Frio. Símbolos: círculos - $\sigma 1$ (eixo de maior esforço), triângulos $-\sigma 2$ (eixo de esforço intermediário), quadrados - $\sigma 3$ (eixo de menor esforço); setas grandes cheias - eixos compressivos horizontais, setas grandes vazias - eixos distensivos horizontais. $R$ - razão de esforço $(\sigma 2-\sigma 3 / \sigma 1-\sigma 3)$. Todos os diques são plotados como fraturas de tração. Projeções de Schmidt-Lambert, hemisfério inferior. Diagramas de rosetas, com direção e mergulho dos diques. 


\subsubsection{Juntas e Fraturas na Suíte Alcalina da Ilha de Cabo Frio e nos Diques Associados}

Os dados de fraturas referem-se tanto a juntas como a microfalhas sem cinemática devidamente caracterizada. A análise desses dados foi realizada tanto sob um enfoque geométrico, como sob um enfoque cinemático, nos casos em que fraturas conjugadas, normais ou de cisalhamento, foram caracterizadas, porém onde não puderam ser observadas estrias na superfície de falha.

\subsubsection{Análise Geométrica}

Todas as fraturas medidas para a Suíte Alcalina da Ilha de Cabo Frio, tanto na ilha como no continente, são apresentadas na Figura 4.85. Elas foram tratadas de forma independente para cada um dos tipos litológicos principais, com o intuito de caracterizar eventuais variações temporais no campo de esforços. As fraturas estão separadas em dois grandes grupos, as com ângulo de mergulho acima de $65^{\circ}$ e as com mergulho igual e menor que $65^{\circ}$. Considerando as do primeiro grupo como tendo sido geradas em um regime de esforços direcional, e as demais em regime normal ou inverso, sendo que nesse último caso são incluídas as fraturas com ângulo de mergulho menor ou igual a $30^{\circ}$.

As relações angulares entre famílias com ângulo de mergulho maior que $65^{\circ}$ permite inferir que a Suíte Alcalina da Ilha de Cabo Frio foi afetado por dois campos de esforços, de regime direcional, distintos. Esses dois campos estão bem caracterizados no nefelina sienito (Figura 4.85B) e no traquito (Figura 4.85C). A atuação de cada um desses campos gerou um conjunto de três famílias de fraturas, sendo as duas principais as conjugadas de cisalhamento, sintética $(R)$ e antitética $\left(R^{\prime}\right)$, e as de tração $(T)$, que as bissetam e têm direção paralela ao eixo de esforço principal - $\sigma 1$. Os campos foram denominados 1, o mais novo, e 2, o mais antigo, gerando dessa forma as fraturas conjugadas de cisalhamento R1, R1' e R2, R2', e as de tração T1 e T2. O Campo 1 tem o eixo de maior esforço, $\sigma 1$, horizontal e de direção NW-SE a NNW-SSE, enquanto que o eixo de esforço mínimo, $\sigma 3$, é ortogonal a ele e tem direção NE-SW, e o eixo de esforço intermediário, $\sigma 2$, é vertical. O Campo 2 tem o eixo de maior esforço, $\sigma 1$, de direção NE- 

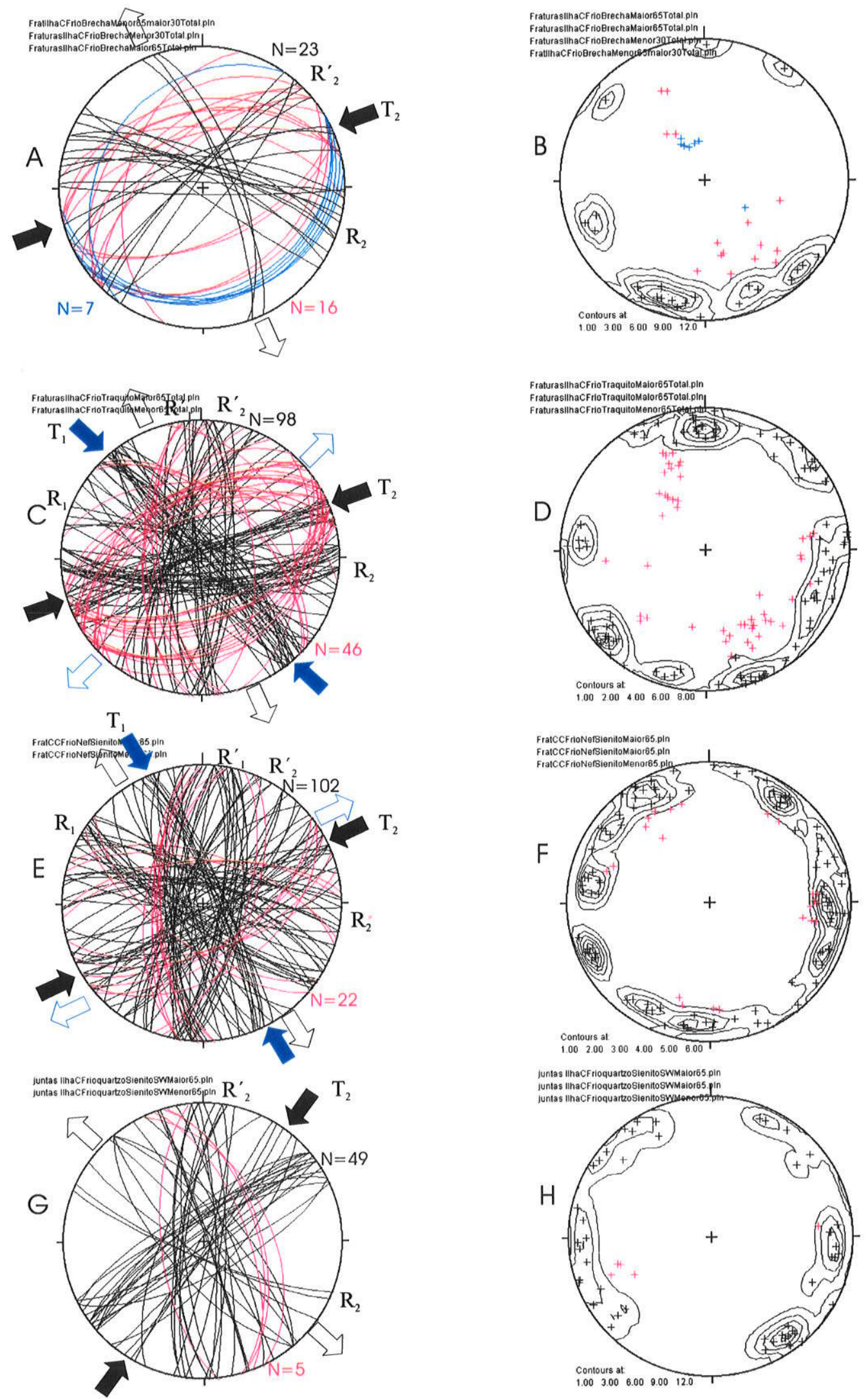

Figura 4.85 - Projeções ciclográficas e polares com relações geométricas entre famílias de fraturas com mergulho maior que $65^{\circ}$ (preto), menor e igual a $65^{\circ}$ (vermelho) e menor e igual a $30^{\circ}$ (azul), em brecha (A), traquito (B), nefelina sienito (C) e quartzo sienito (D). A partir das famílias com mergulho maior que $65^{\circ}$ pode-se inferir dois grupos de fraturas de cisalhamento conjugadas: 1 (mais novo, cor azul) e 2 (mais antigo, cor preta). As notações R e R'correspondem a fraturas de cisalhamento conjugadas sintéticas e antitéticas, respectivamente, e T às fraturas de tração. Diagramas de Schmidt-Lambert, hemisfério inferior. 
SW, enquanto que o eixo de esforço mínimo, $\sigma 3$, tem direção NW-SE e o de esforço intermediário, $\sigma 2$, é vertical.

As famílias de fraturas com ângulo de mergulho menor ou igual a $65^{\circ}$, têm uma concentração que coincide, principalmente, com as direções $\mathrm{T}$, mas também com as conjugadas de cisalhamento, tanto as sintéticas como as antitéticas, sugerindo variações locais e/ou temporais nos dois campos de esforços direcionais, em especial no Campo 2. A amostragem heterogênea com relação aos planos de fraturas com ângulo de mergulho menor que $65^{\circ}$, está relacionada, no caso dos quartzo sienitos (Figura 4.85D), ao tipo de ocorrência de seus afloramentos visitados, mais planos e lisos que os das demais litologias.

\subsubsection{Análise Cinemática}

O detalhamento das fraturas que afetam a Suíte Alcalina da Ilha de Cabo Frio, com a identificação das famílias de fraturas conjugadas de cisalhamento e, eventualmente, das fraturas de tração geneticamente relacionadas, preenchidas ou não, permite uma aproximação da distribuição dos eixos de tensão e, ainda, da razão de deformação R. Em alguns casos, onde foram identificados menos de três planos com estrias, não permitindo a inversão dos dados para determinação do campo de esforços que os gerou, optou-se por plotá-los junto com as fraturas. Nesse caso, são apresentados, também, os valores de caimento e azimute dos três eixos de tensão principais e o valor de $\alpha$. Nesses casos o valor do ângulo $\alpha$ permite determinar a pertinência do dado de falha e estria (dado pareado) àquele campo de paleotensões, considerando que essa pertinência é sindicada por valores médios iguais ou menores que $22^{\circ}$ (Angelier 1989).

\section{A) Juntas e Fraturas em Rochas Plutônicas}

As famílias de fraturas conjugadas de cisalhamento identificadas nas rochas plutônicas da Suíte Alcalina da Ilha de Cabo Frio, quartzo sienito e nefelina sienito, são mostrados na Figura 4.86. 
A)
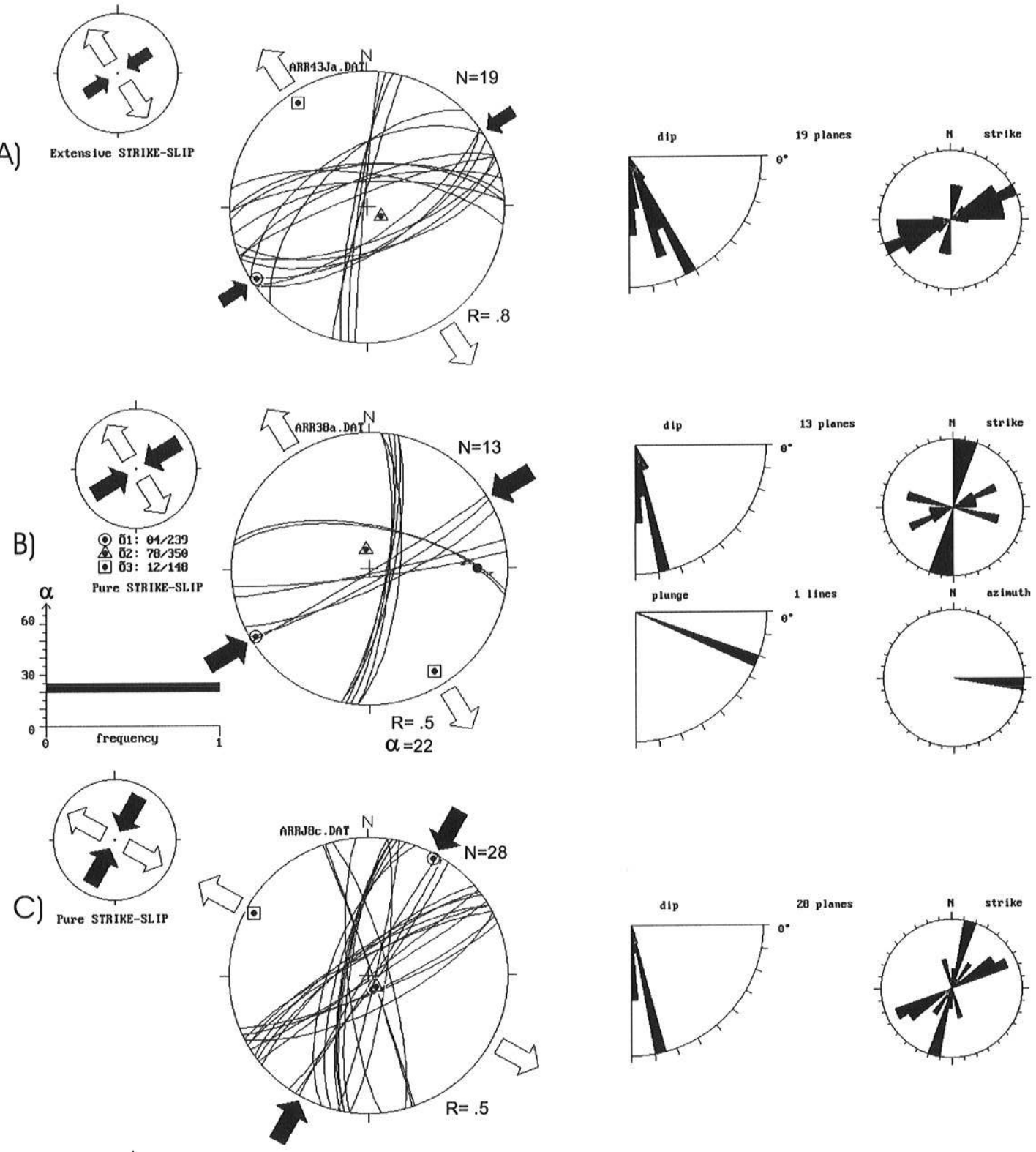

D)
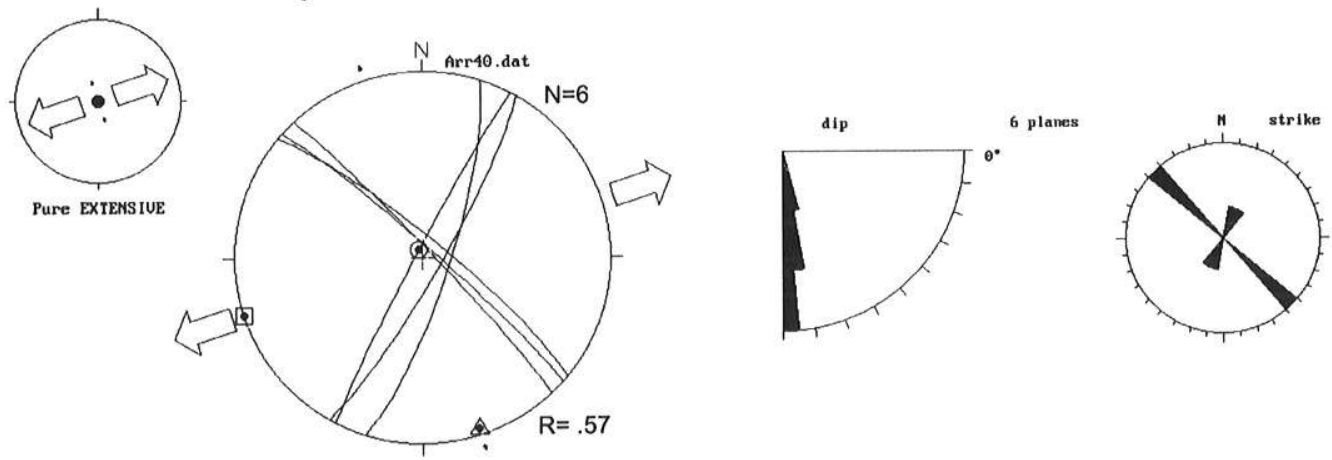

Figura 4.86 - Dados de fraturas e falhas, com os respectivos eixos de tensões, afetando Nefelina Sienito (A, B e D) e Quartzo Sienito (C). Município de Arraial do Cabo, pontos Arr43 (A), 38 (B), 8 e 9 (C) e 40 (D). Símbolos: círculos - $\sigma_{1}$ (eixo de maior esforço), triângulos - $\sigma 2$ (eixo de esforço intermediário), quadrados - $\sigma 3$ (eixo de menor esforço); R razão de esforço $\left(\sigma_{2}-\sigma_{3} / \sigma_{1}-\sigma_{3}\right) ; \alpha$ - desvio médio entre as estrias medidas e o cisalhamento computado sobre o plano de falha. Setas grandes cheias - eixos compressivos horizontais, setas grandes vazias - eixos distensivos horizontais. Bola preta - estria, seta pequena - sentido de movimento dos blocos. Em A, os planos sem estrias representam fraturas de cisalhamento (E-W e NNE-SSW), e fraturas de tração (NE-SW). Em B, as fraturas de cisalhamento têm direção E-W e NNE-SSW, e as de tração têm direção ENE-WSW. Em C, as fraturas N-S e NNE-WSW são de cisalhamento, e as NE-SW de tração (cf.Figura ). Em D, estão representadas fraturas preenchidas com minerais máficos. Projeções de SchmidtLambert, hemisfério inferior. Diagramas de rosetas com direção e mergulho dos planos, e caimento e azimute das estrias. 
As fraturas preenchidas por minerais máficos, que ocorrem no nefelina sienito, no ponto Arr40 (Figura 4.86D), foram consideradas as mais antigas, tardias à cristalização do corpo. $\mathrm{O}$ caráter en echelon das fraturas relacionadas a ambas as famílias de fraturas, NWSE e NNE-SSW, sugere que elas tiveram uma componente direcional, apesar do preenchimento de ambas. Nesse caso, o eixo de esforço intermediário, $\sigma 2$, poderia ter uma magnitude relativa maior, aproximando-se do eixo de esforço principal, $\sigma 1$, vertical, caracterizando um regime extensional com componente direcional, ou seja, EXTENSIONAL direcional (Strike-slip EXTENSIVE), e não apenas EXTENSIONAL puro (Pure EXTENSIVE), como indicado pelo programa.

No quartzo sienito, pontos Arr8 e 9, as famílias de fraturas de direção em torno de N-S e ENE-WSW, representam conjugadas de cisalhamento antitéticas ( $\left.R^{\prime}\right)$ e sintéticas (R), respectivamente, e as NE-SW são fraturas de tração a elas geneticamente relacionadas (Figura 4.86C e 4.87). Aqui, o eixo de esforço principal, ol, é horizontal e tem direção NNE-SSW, paralela aos planos $\mathrm{T}$, o eixo de menor esforço, $\sigma 3$, é também horizontal e ortogonal a $\sigma 1$, enquanto que o eixo intermediário $\sigma 2$, é vertical. O regime de esforços é DIRECIONAL puro (Pure STRIKE-SLIP), uma vez que o valor de R é 0.5.

Na Figura 4.86B, ponto Arr38, na porção continental da Suíte Alcalina da Ilha de Cabo Frio, as famílias conjugadas de cisalhamento, presentes no nefelina sienito, apresentam direção NNE-SSW (R') e E-W (R), enquanto que as fraturas de tração têm direção NE-SW. O eixo de esforço principal, $\sigma 1$, é horizontal, paralelo às fraturas de tração, com $\sigma 3$ horizontal e ortogonal, e $\sigma 2$ vertical. Também nesse caso, o valor de $\mathrm{R}=0.5$ implica em um regime de esforços DIRECIONAL puro (Pure STRIKE-SLIP). Um dos planos conjugados, de direção E-W, apresenta estrias com baixa obliqüidade, compatíveis com o campo de esforços calculado, como indica o valor de $\alpha=22$. No ponto Arr43 (Figura 4.86A), na Ilha de Cabo Frio, o nefelina sienito apresenta fraturas conjugadas e de tração com mesma orientação que no ponto Arr38, porém os valores intermediários $\left(\sim 60^{\circ}\right)$ dos mergulhos dos planos de tração, geraram, na inversão dos dados, um campo de esforços com uma componente extensional relativamente mais intensa, resultando em um regime DIRECIONAL extensivo (Extensive STRIKE-SLIP).

As paleotensões obtidas para as rochas plutônicas da Suíte Alcalina da Ilha de Cabo Frio, a partir do estudo do seu fraturamento, estão sintetizadas na Figura 4.88. O mapa da Figura 4.88 mostra as paleotensões obtidas para o Maciço alcalino da Ilha de Cabo Frio, 
tanto no continente como na ilha, a partir, principalmente de dados de fraturas. Apenas no Pontal do Atalaia (Figura 4.88A) pode-se caracterizar estrias associadas a um desses planos de fraturas. Na Iha de Cabo Frio (Figura 4.88D) os dados utilizados referem-se a fraturas preenchidas com minerais máficos, as quais foram consideradas tardias à cristalização do nefelina sienito, e mais antigas às demais fraturas tratadas. As paleotensões obtidas a partir das fraturas não preenchidas mostraram-se bastante persistentes em toda a área, indicando um regime de esforços direcional, com o eixo máximo de esforços, $\sigma 1$, de direção NE-SW. As fraturas preenchidas evidenciaram um campo de esforços distinto desse, relacionando-se a uma extensão pura ENE-WSW, praticamente ortogonal à extensão associada ao campo de esforços direcional que a sucedeu.

A)

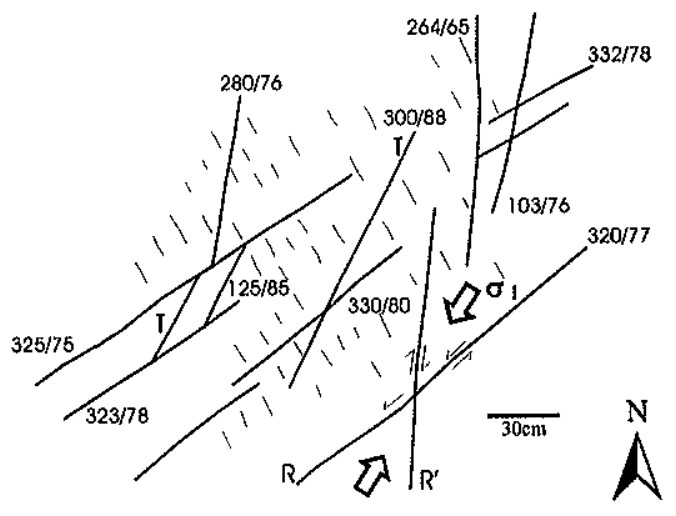

B)

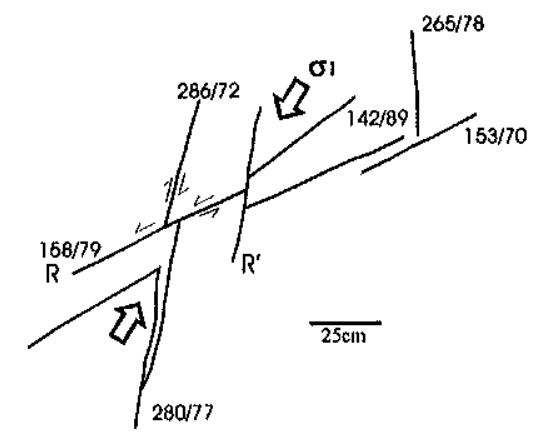

Figura 4.87 - Fraturas de cisalhamento conjugadas sintética (R) e antitéticas (R'), e fraturas de tração (T), em quartzo sienito, Ilha de Cabo Frio, Pontos Arr8 (A) e 9 (B). O eixo de tensão principal, $\sigma 1$, posiciona-se na bissetriz aguda das fraturas de cisalhamento conjugadas, orientando-se na direção NEmSW. Os traços curtos representam a foliação de fluxo magmático do quartzo sienito, com atitude 050/70. Vista em planta. 


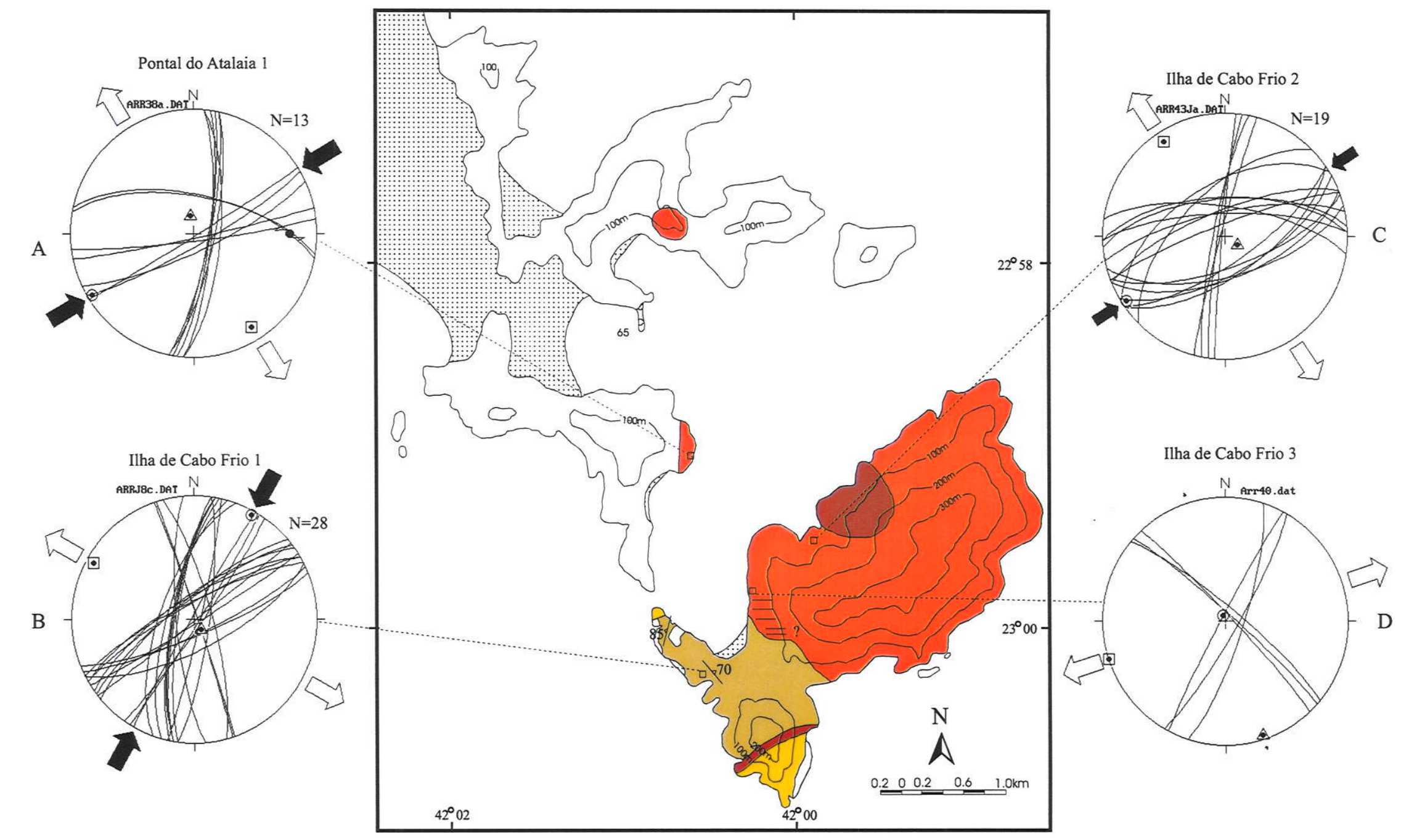

Figura 4.88 - Mapa das paleotensões caracterizadas nas rochas plutônicas do Complexo alcalino da Illha de Cabo Frio. Tais dados referem-se principalmente ao fraturamento que as afeta $(\mathrm{A}, \mathrm{B} \mathrm{e} \mathrm{C})$, o qual, em apenas um caso, inclui planos de falhas com estrias visíveis (A). Em D foram utilizados planos de fraturas preenchidos com minerais máficos, considerados tardios à cristalização do nefelina sienito e anteriores às fraturas não preenchidas. Símbolos: círculos - $\sigma 1$ (eixo de maior esforço), triângulos - $\sigma 2$ (eixo de esforço intermediário), quadrados - $\sigma 3$ (eixo de menor esforço); Setas grandes cheias - eixos compressivos horizontais, setas grandes vazias - eixos distensivos horizontais. Bolas pretas - estrias, setas pequenas - sentido do movimento dos blocos. Projeções de Schmidt-Lambert, hemisfério inferior. Traços com triângulos - orientação de fluxo. Geologia, de acordo com a Figura 1. 
B) Juntas e Fraturas em Rochas Hipabissais

As famílias de fraturas de cisalhamento conjugadas, caracterizadas no traquito da Suíte Alcalina da Ilha de Cabo Frio, são mostradas na Figura 4.89. Elas referem-se tanto ao corpo principal como a diques mais espessos a ele associados.

A Figura $4.89 \mathrm{C}$ refere-se a veios pegmatóides intrudidos no traquito e no nefelina sienito, Pontos Arr44 e 40, com crescimento de cristais de anfíbólio em prismas alongados perpendicularmente aos contatos, ou caracterizando estruturas sigmóides (cf. Figura 4.90) evidenciando sua cristalização sintectônica paralela à direção de tensão mínima $\sigma 3$. Esses veios foram plotados como fraturas de tração, e sua inversão resultou num campo de esforços EXTENSIONAL puro (Pure EXTENSIVE), com o eixo de esforço mínimo, $\sigma 3$, horizontal, na direção NW-SE, o eixo de esforço intermediário, $\sigma 2$, ortogonal a ele, e o eixo de esforço principal, $\sigma 1$, vertical. As anistropias apresentadas pelas estruturas sigmóides evidenciam componentes direcionais, dextrais nos veios N-S e sinistrais nos WNW-ESE (cf. Figura 4.90), que são compatíveis com o campo de esforços determinado. A mudança de orientação dos cristais de anfibólio, para uma direção ortogonal às paredes dos veios, indica que, com a progressão da deformação, verificou-se, também, uma extensão ortogonal à primeira, na direção ENE-WSW, gerando uma extensão quase radial.

A Figura 4.89B mostra famílias de fraturas de cisalhamento conjugadas, de direção NNE-SSW (R') e E-W (R), e de tração, de direção NE-SW, em traquito da Ilha de Cabo Frio, Ponto Arr17. A inversão desses dados indicou um campo de esforços EXTENSIONAL direcional (Strike-slip EXTENSIVE), com o eixo de tensão mínimo, $\sigma 3$, horizontal e de direção NW-SE, o eixo de tensão intermediário, $\sigma 2$, também horizontal e ortogonal a ele, e o eixo de tensão principal, $\sigma 1$, vertical. Os ângulos de mergulho de valor intermediário apresentado por alguns planos $T$ e mesmo $R^{\prime}$, foram decisivas na caracterização de um campo principalmente extensional, porém com um valor de $\mathrm{R}=.91$, indicando que $\sigma 1$ e $\sigma 2$ têm magnitude muito próximas. As estrias caracterizadas em apenas um dos planos, com forte componente normal, mostraram-se totalmente compatíveis com o campo de esforços determinado, com um $\alpha=3.8$.

$\mathrm{Na}$ Figura 4.89A, referente a um dique de traquito de espessura anômala, com cerca de $15 \mathrm{~m}$, que corta o embasamento gnáissico no Ponto Arr22, no Pontal do Atalaia, as famílias de fraturas de cisalhamento conjugadas têm direção NNE-SSW (R') e WNW-ESE 
A)
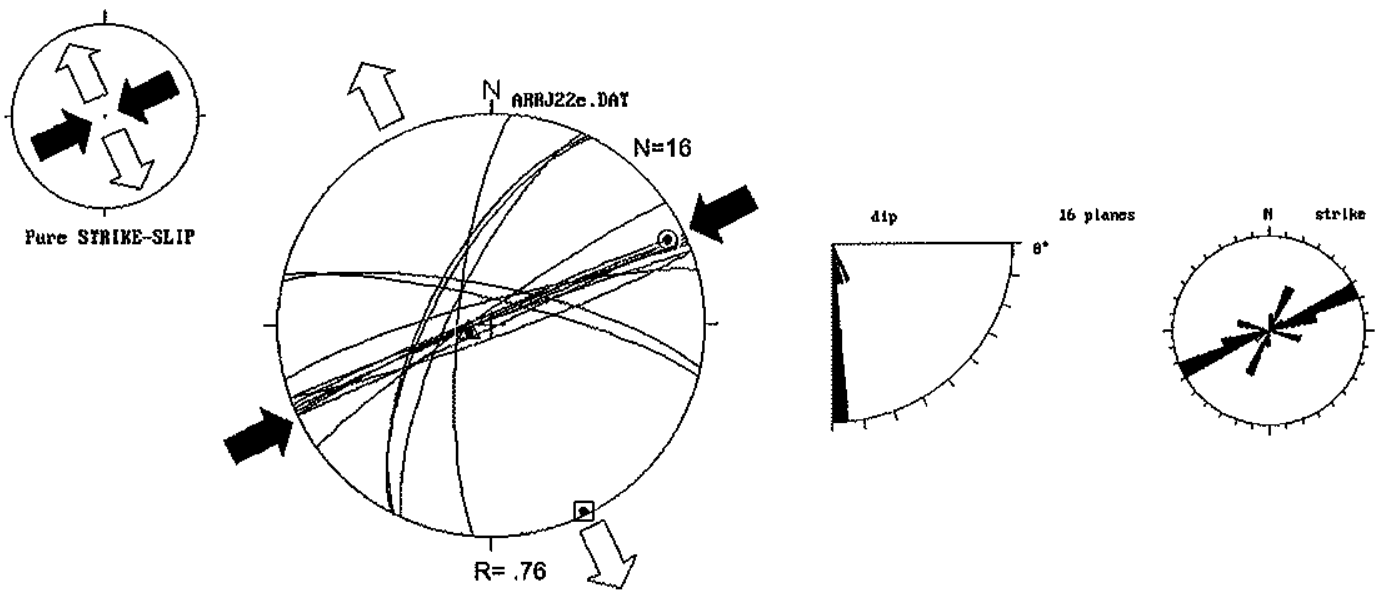

B)

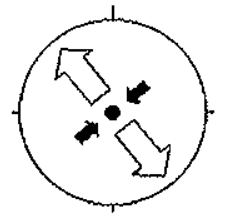

Q б1: $81 / 926$

政: $00 / 051$ Strike-slip EXTENSIUE
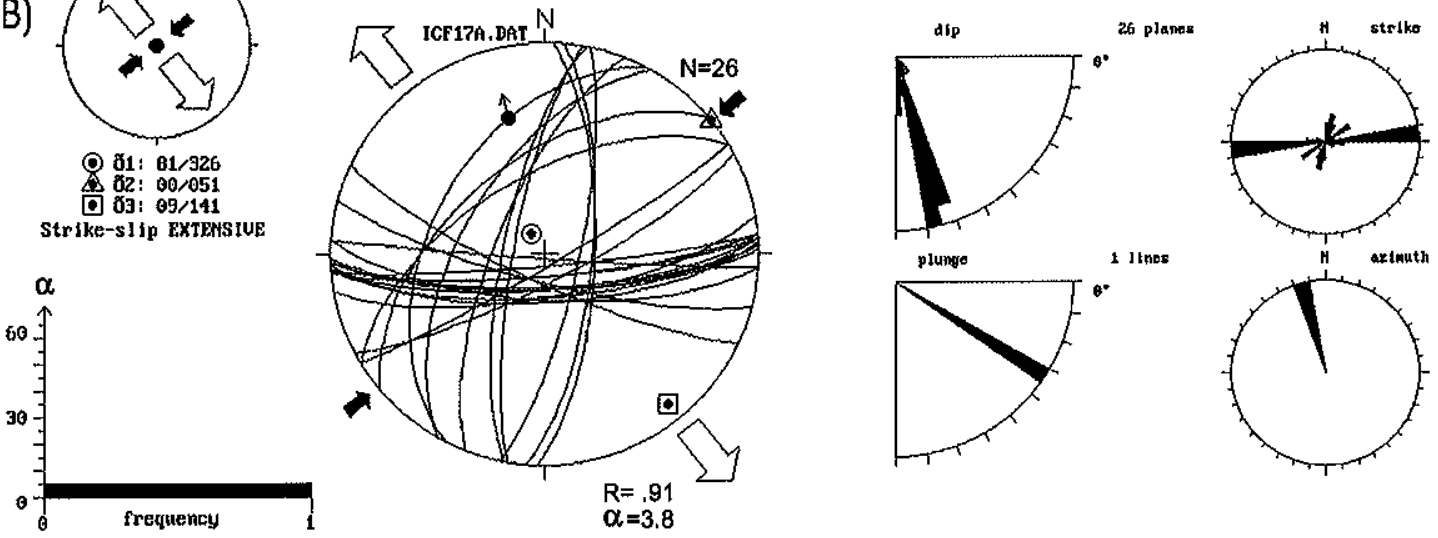

C)
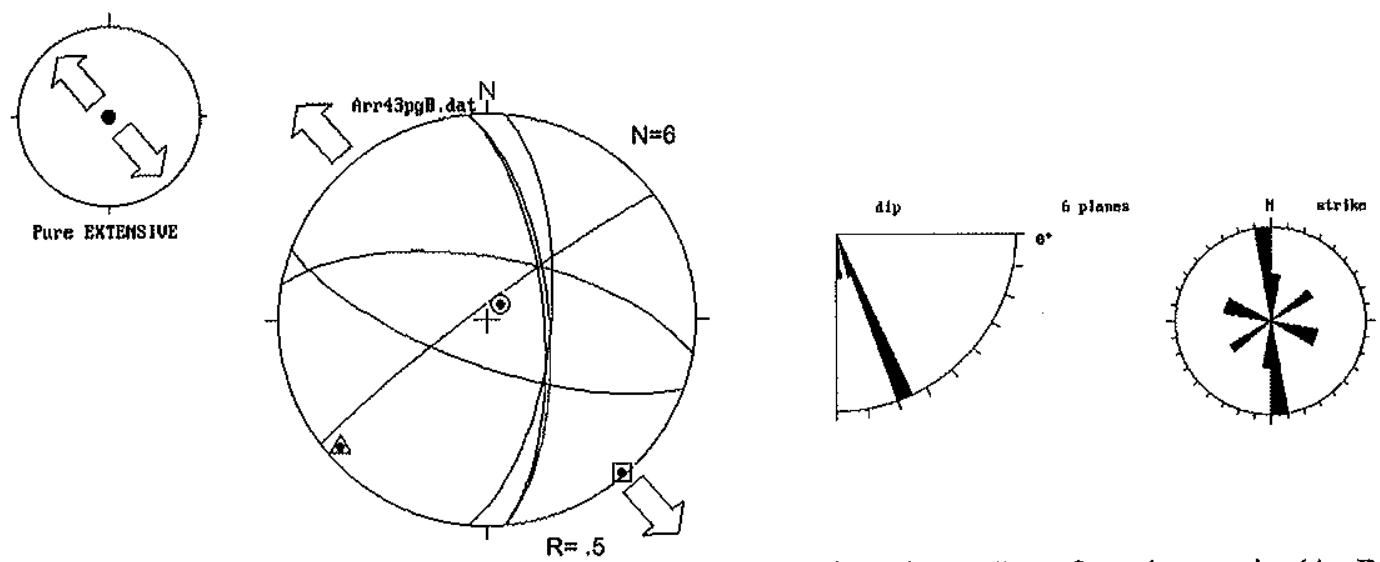

Figura 4.89-Dados de fraturas e falhas, com os respectivos eixos de tensões, afetando traquito (Ae B) e preenchidas por veios pegmatóides (C). Complexo alcalino da llha de Cabo Frio, Município de Arraial do Cabo, pontos Arr22 (A), 17 (B) e 40 (C). Símbolos: círculos - $\sigma 1$ (eixo de maior esforço), triângulos - $\sigma 2$ (eixo de esforço intermediário), quadrados $-\sigma 3$ (eixo de menor esforço); $R$ - razão de esforço $(\sigma 2-\sigma 3 / \sigma 1-\sigma 3) ; \alpha$-desvio médio entre as estrias medidas e o cisalhamento computado sobre o plano de falha. Setas grandes cheias - eixos compressivos horizontais, setas grandes vazias - eixos distensivos horizontais. Bola preta - estria, seta pequena - sentido do movimento dos blocos. Em A, as familias de fraturas NNE-SSW e WSW-ESE são conjugadas de cisalhamento e as ENE-WSW são fraturas de tração $T$. Em B, os planos sem estrias representam fraturas de cisalhamento (E-W e NNESSW), e fraturas $T$ (NE-SW). Em C, estão representadas fraturas preenchidas por veios pegmatóides com sigmóides (cf. Figura ). Projeções de Schmidt-Lambert, hemisfério inferior. Diagramas de rosetas com direção e mergulho dos planos, e caimento e azimute das estrias. 


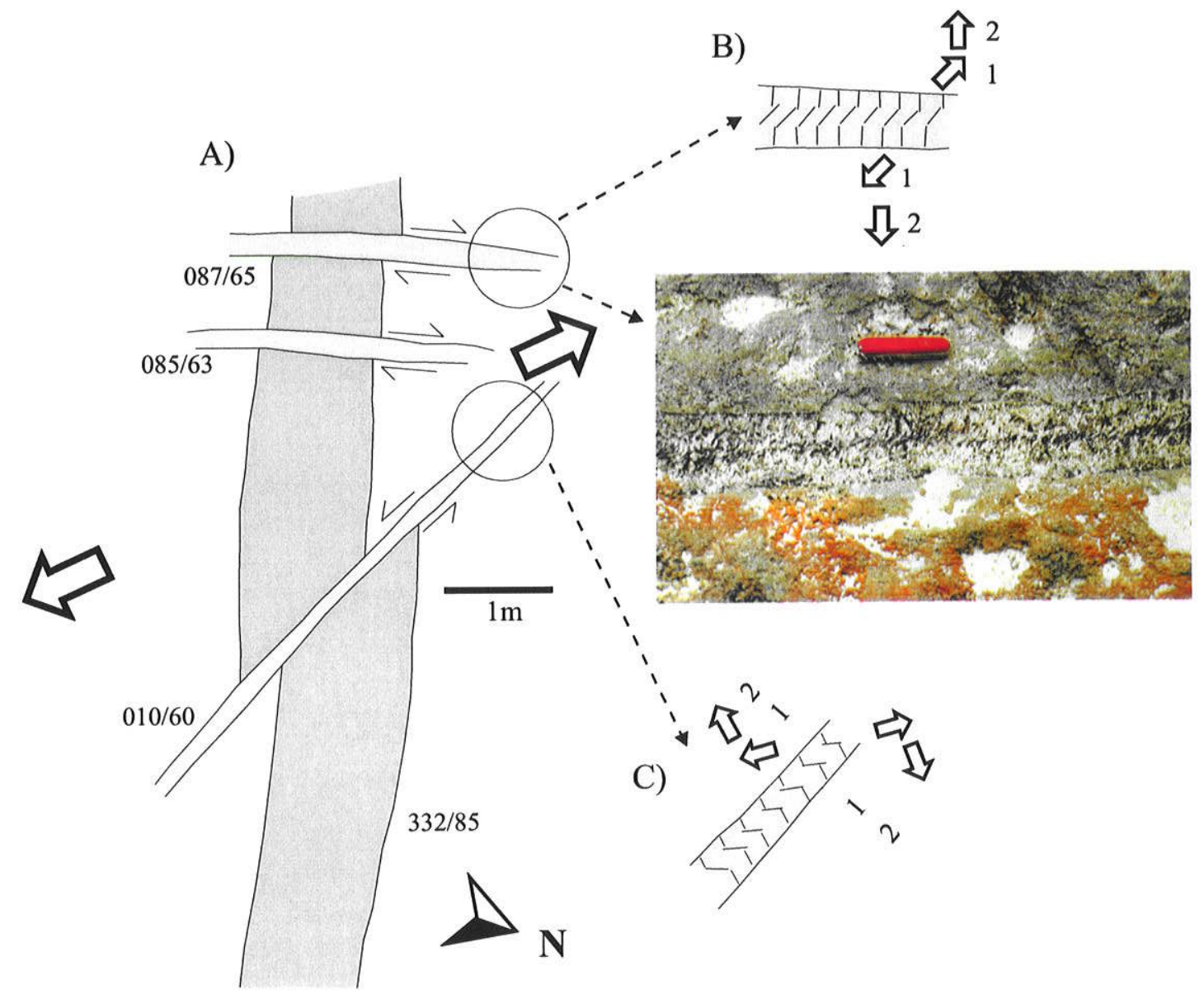

Figura 4.90 - A) Veios pegmatóides de espessura centimétrica cortando dique de microssienito encaixado em melassienito. $\mathrm{O}$ dique de microssienito sofre deslocamentos direcionais, dextrais e sinistrais, ao longo dos veios pegmatóides. A presença de estruturas sigmóides internas aos veios $(\mathrm{B} \mathrm{e} \mathrm{C})$, formadas por cristais aciculares de anfibólio, indica que a injeção desses veios se deu, inicialmente, em uma extensão pura NWSE (1) (cf. Figura 4.89C), com uma progressão subseqüente para uma componente de extensão também na direção ENE-WSW (2), resultando numa extensão quase radial. 
(R). As fraturas T têm direção ENE-WSW e estão escalonadas à direita e à esquerda, relacionando-se às estruturas sintéticas $(R)$ e antitéticas ( $\left.R^{\prime}\right)$ respectivamente (cf. Figura 4.91).

A inversão dos dados resultou em um campo DIRECIONAL puro (Pure STRIKESLIP), onde o eixo de menor esforço, $\sigma 3$, é horizontal e tem direção NW-SE, o eixo de esforço principal, $\sigma 1$, é ortogonal a ele e tem direção NE-SW, e o intermediário, $\sigma 2$, é vertical. A predominância de estruturas $\mathrm{T}$ sobre as conjugadas de cisalhamento indica que, nesse local, a atuação desse campo de esforços foi incipiente (Tchalenko 1970, Wilcox et al. 1973, Reches 1999).

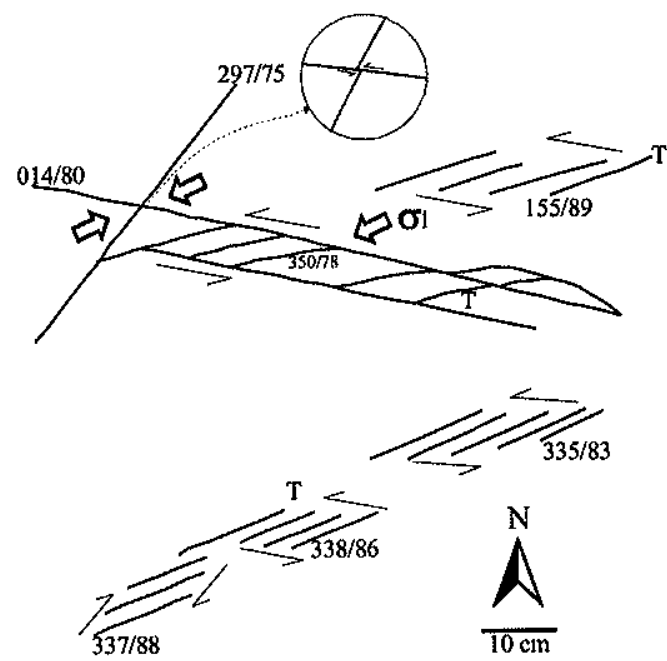

Figura 4.91 - Juntas de tração, T, escalonadas à direita e à esquerda, associadas a fraturas conjugadas de cisalhamento. $O$ eixo de tensão principal posiciona-se na bissetriz aguda das fraturas conjugadas, e é paralelo às juntas de tração, orientando-se segundo a direção NE-SW. Arraial do Cabo, Pontal do Atalaia, Ponto Arr22, em dique de traquito com cerca de $15 \mathrm{~m}$ de espessura. Vista em planta.

\subsubsection{Falhas e Microfalhas que Afetam a Suíte Alcalina da Ilha de Cabo Frio e os Diques Associados}

4.4.6.1. Falhas e Microfalhas em Rochas Hipabissais 
Dados de falhas afetando traquito, fonolito e basalto alcalino são apresentados na Figura 4.92. Trata-se, essencialmente, de microfalhas caracterizadas por planos estriados, que ocorrem na borda e internamente a diques (casos A, C e D), como no interior do plug de traquito que ocorre na Ilha de Cabo Frio.

Os dados de falhas representados na Figura 4.92D referem-se a falhamentos normais acompanhados da formação de faixas cataclásticas, localmente injetadas por veios de basalto alcalino, os quais também se encontram cataclasados (cf. Figura 4.93). Essas estruturas afetam gnaisses graníticos, na Pedreira do Porto do Forno (Ponto Arr29). A inversão dos dados indicou que eles foram gerados em um campo de tensões EXTENSIONAL Puro (Pure EXTENSIVE), com o eixo de esforço máximo, $\sigma 1$, vertical, o eixo de esforço intermediário, $\sigma 2$, horizontal e orientado na NNE-SSW, e o eixo de esforço mínimo, $\sigma 3$, ortogonal a ele, orientado na direção WNW-ESE. A falha oblíqua de direção WNW-ESE, com mergulho alto, indica que planos preexistentes foram reativados.

A Figura 4.92C mostra projeções ciclográficas de microfalhas, direcionais e reversas, afetando dique de traquito, com aproximadamente $20 \mathrm{~m}$ de espessura, encaixado no embasamento gnáissico no Pontal do Atalaia, Ponto Arr39. A inversão dos dados mostrou que eles foram gerados em um campo de esforços COMPRESSIVO direcional (Strike-slip COMPRESSIVE), com o eixo de esforço máximo, $\sigma 1$, horizontal, com direção ENE-WSW, o eixo intermediário, $\sigma 2$, também horizontal e ortogonal a ele, e o eixo de esforço mínimo, $\sigma 3$, vertical. $O$ baixo valor da razão de esforço, $R=0.1$, indica que $\sigma 2$ tem magnitude muito próxima de $\sigma 3$, permitindo a geração de falhas direcionais e reversas. A separação, no histograma, de dois grupos com valores de $\alpha$ distintos, indica a existência de planos reativados.

Na Figura 4.92B estão representadas microfalhas de rejeito direcional e normal, que afetam o plug de traquito que ocorre na Ilha de Cabo Frio. Elas foram geradas em um campo de esforços DIRECIONAL extensional (Extensive STRIKE-SLIP), com o eixo de esforço principal, $\sigma 1$, horizontal e com direção NNE-SSW, o eixo de menor esforço, $\sigma 3$, também horizontal e ortogonal a ele, e o eixo de esforço intermediário, $\sigma 2$, vertical. $\mathrm{O}$ alto valor da razão de esforço, $\mathrm{R}=0.81$, indica que $\sigma 1$ e $\sigma 2$ têm magnitudes próximas.

A Figura 4.92A mostra microfalhas que afetam um dique de fonolito que ocorre na Pedreira do Porto do Forno, Ponto Arr29. São planos de alto ângulo com rejeito oblíquo dextral a normal, geradas por um campo de esforços DIRECIONAL Puro (Pure STRIKE- 

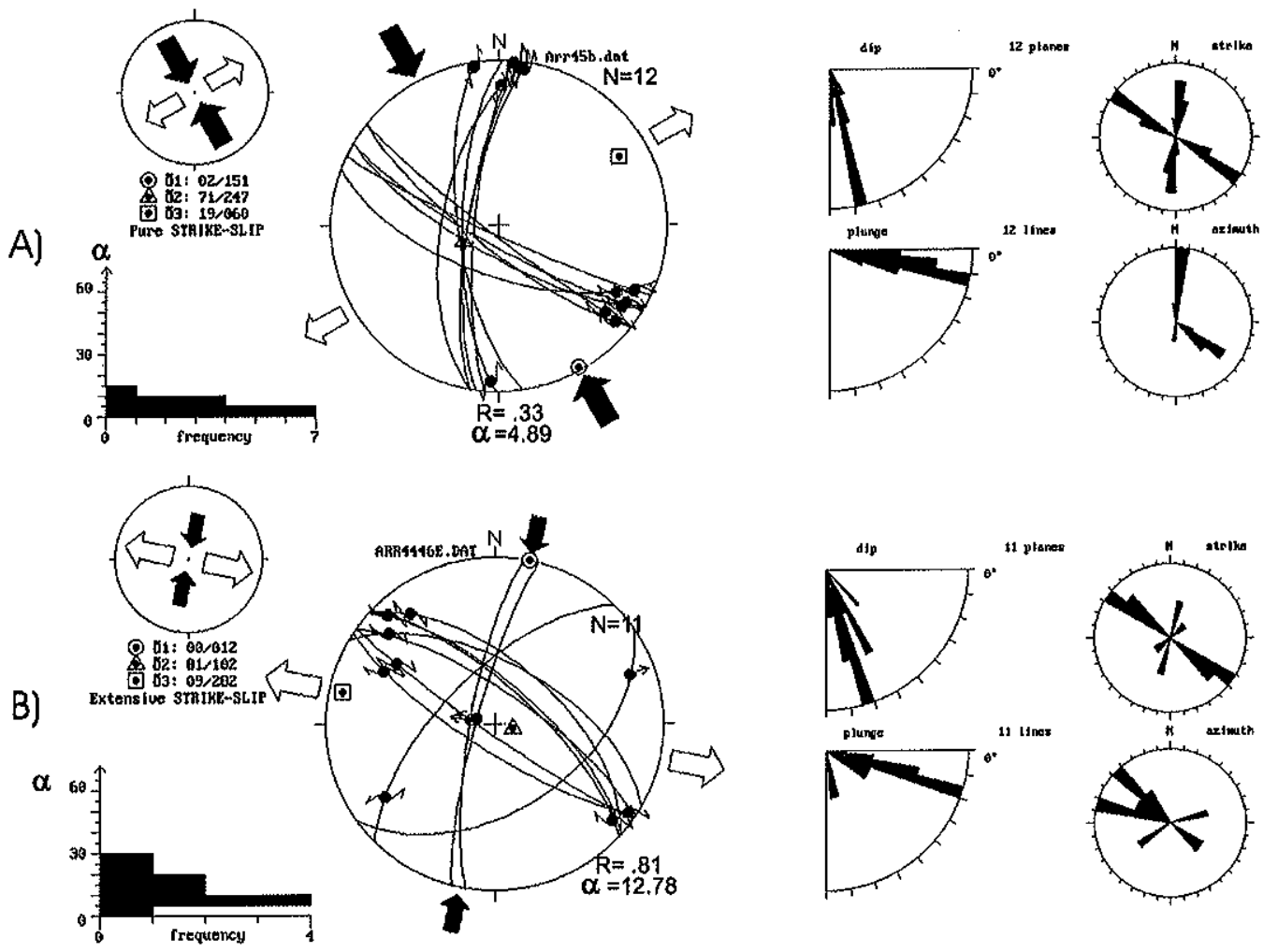

\section{C)}
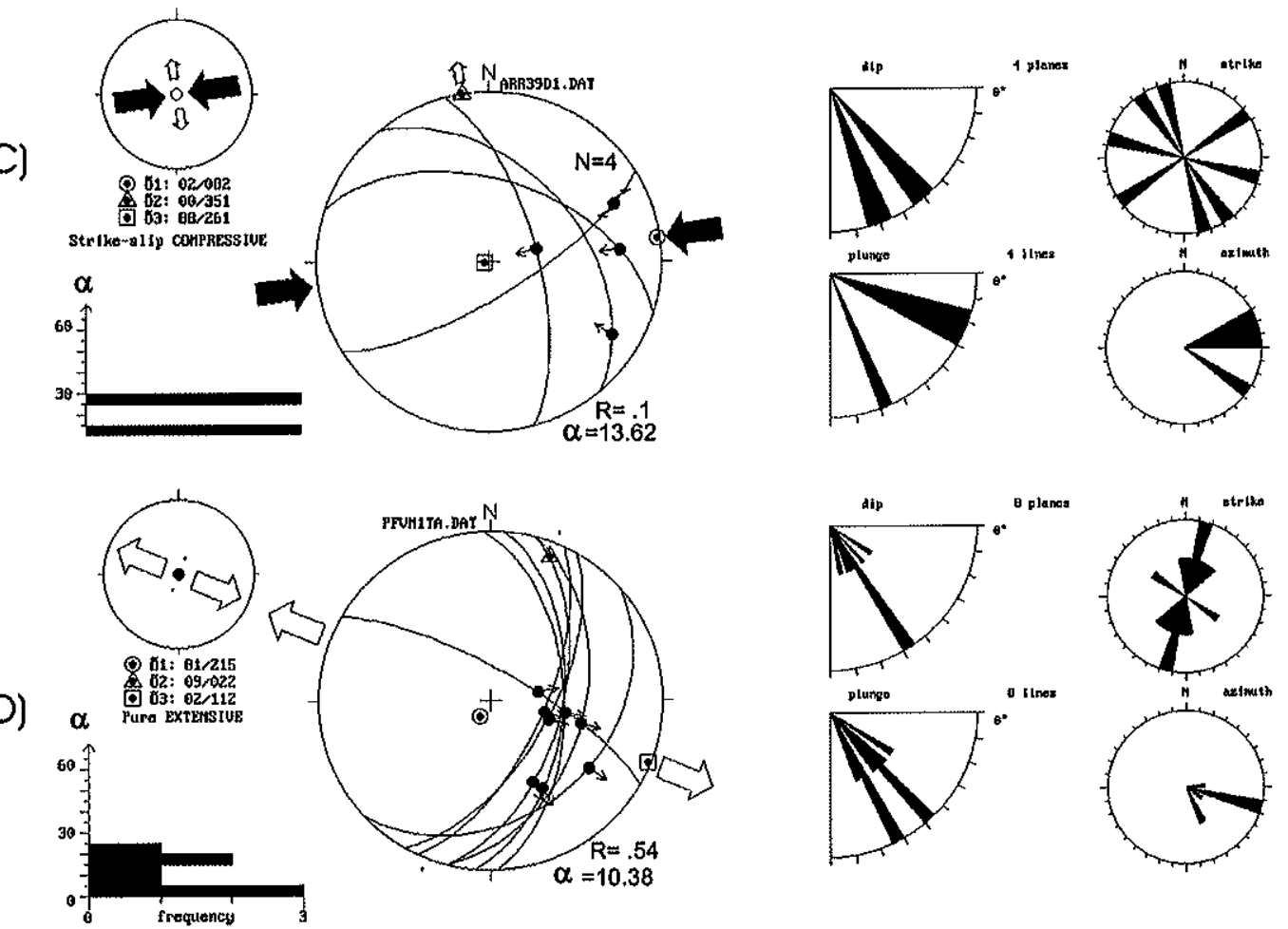

Figura 4.92 - Dados de falhas e respectivos eixos de tensões, afetando traquito (A, B e C), e basalto alcalino (D), Arraial do Cabo, pontos Arr45 (A), $42-46$ (B), 39 (C) e 29 (D). Símbolos: círculos $\sigma 1$ (eixo de maior esforço), triângulos - $\sigma_{2} 2$ (eixo de esforço intermediário), quadrados $-\sigma_{3}$ (eixo de menor esforço); $\mathrm{R}$ - razão de esforço ( $\left.\sigma_{2}-\sigma_{3} / \sigma_{1}-\sigma_{3}\right) ; \alpha$ - desvio médio entre as estrias medidas e o cisalhamento computado sobre o plano de falha. Setas grandes cheias - eixos compressivos horizontais, setas grandes vazias - eixos distensivos horizontais. Bolas pretas - estrias, setas pequenas - sentido do movimento dos blocos. Projeções de Schmidt-Lambert, hemisfério inferior. Diagramas de rosetas mostrando direção e mergulho dos planos, e caimento e azimute das estrias. 

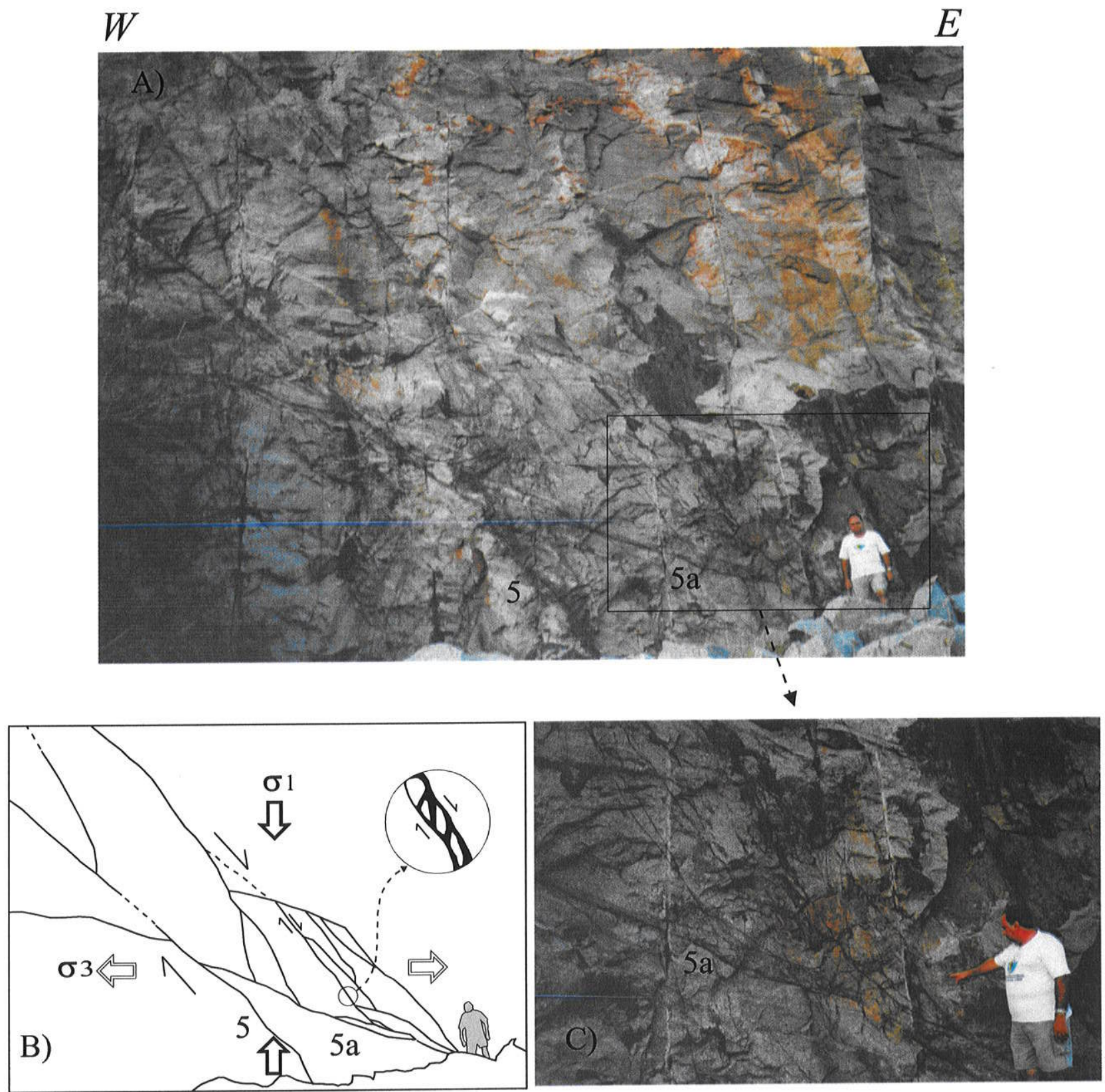

Figura 4.93 - A) Faixas cataclasadas em granitóide, com espessura centimétrica e direção NNE-SSW, encaixados em zona de falha com rejeito normal, afetados por cisalhamento rúptil aconpanhado de cataclase. Essas faixas são localmente injetadas por veios de basalto alcalino, B) Croqui desenhado sobre a foto A, C) Detalhe da foto A. Setas largas indicam as posições dos eixos de tensões máximo, $\sigma 1$, e mínimo, $\sigma_{3}$. A encaixante é um granitóide leucocrático, de granulação grossa, localmente semi-porfiroblástico. Pessoa como escala com $165 \mathrm{~cm}$ de altura. Pedreira Porto do Forno, Ponto Arr29, Município de Arraial do Cabo, RJ. 
$S L I P$ ), com o eixo de tensões principal, $\sigma 1$, horizontal e de direção NW-SE, o eixo mínimo de tensões, $\sigma 3$, também horizontal e ortogonal a ele, e o eixo de tensões intermediário, $\sigma 2$, vertical. $O$ valor relativamente baixo da razão de esforço, $R=0.33$, indica que a magnitude de $\sigma 2$ se aproxima da de $\sigma 3$, tendendo a um regime DIRECIONAL Compressivo.

\subsubsection{Síntese das Paleotensões Determinadas na Porção Leste do Graben da Guanabara}

As paleotensões caracterizadas nas rochas hipabissais associadas à Suíte Alcalina da Ilha de Cabo Frio, a partir do estudo do seu fraturamento e das microfalhas que as afetam, estão sintetizadas na Figura 4.94. As paleotensões, apresentadas no mapa da Figura 4.94, referem-se tanto a fraturamento, sem estrias visíveis, em dique de traquito intrudido no embasamento proterozóico (A, cf. Figura 4.89 A), e na suíte alcalina (C, cf. Figura 4.89B), como a planos de falhas estriados afetando diques de traquito ( $\mathrm{B}$, cf. Figura 4.91C), basalto alcalino (D, cf. Figura 4.91D) e fonolito (E, cf. Figura 4.91A), intrudidos no embasamento, e ainda a planos de falhas estriados afetando o plug de traquito interno à suíte alcalina (F, cf. Figura 4.91B). Os dados da Figura 4.94G referem-se a veios pegmatóides, por vezes com estruturas sigmóides, que cortam o nefelina sienito e o traquito interno a ele (cf. Figuras $4.89 \mathrm{C} \mathrm{e} \mathrm{4.90)}$ ). As paleotensões obtidas a partir de fraturas e falhas indicam uma dominante persistência de SHmax na direção NE-SW a ENE-WSW. Apenas as falhas que controlam a injeção dos veios de basalto alcalino na Pedreira do Porto do Forno e as que afetam o plug de traquito interno ao nefelina sienito mostram um SHmax com direção NNE-SSW. Em quase todos esses casos o SHmax corresponde ao eixo de esforço máximo, $\sigma 1$, e, na maior parte deles, o regime de esforços encontrado foi o direcional, sendo que nos casos $\mathrm{C}, \mathrm{E}$ e $\mathrm{F}$, como a magnitude do esforço deviatório extensional resultou relativamente maior do que o compressivo, o regime de esforços encontrado foi o direcional extensional. A inversão dos dados referentes aos veios pegmatóides (Figura 4.94G), indicou um campo de esforços puramente extensional, com o eixo de esforços mínimo, $\sigma 3$, de direção NW-SE, e com a persistência da orientação de SHmax segundo a direção NE-SW. 


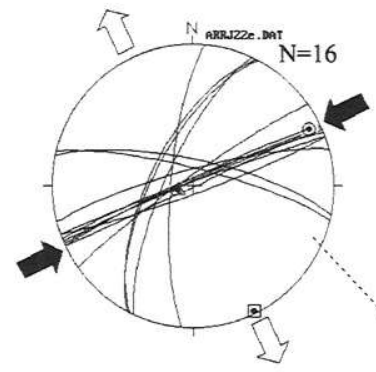

Pontal do Atalaia 1

B

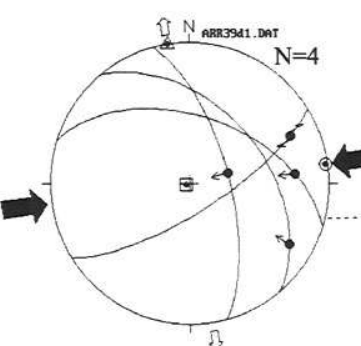

Pontal do Atalaia 2

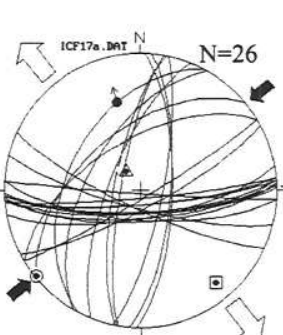

Ilha de Cabo Frio 1
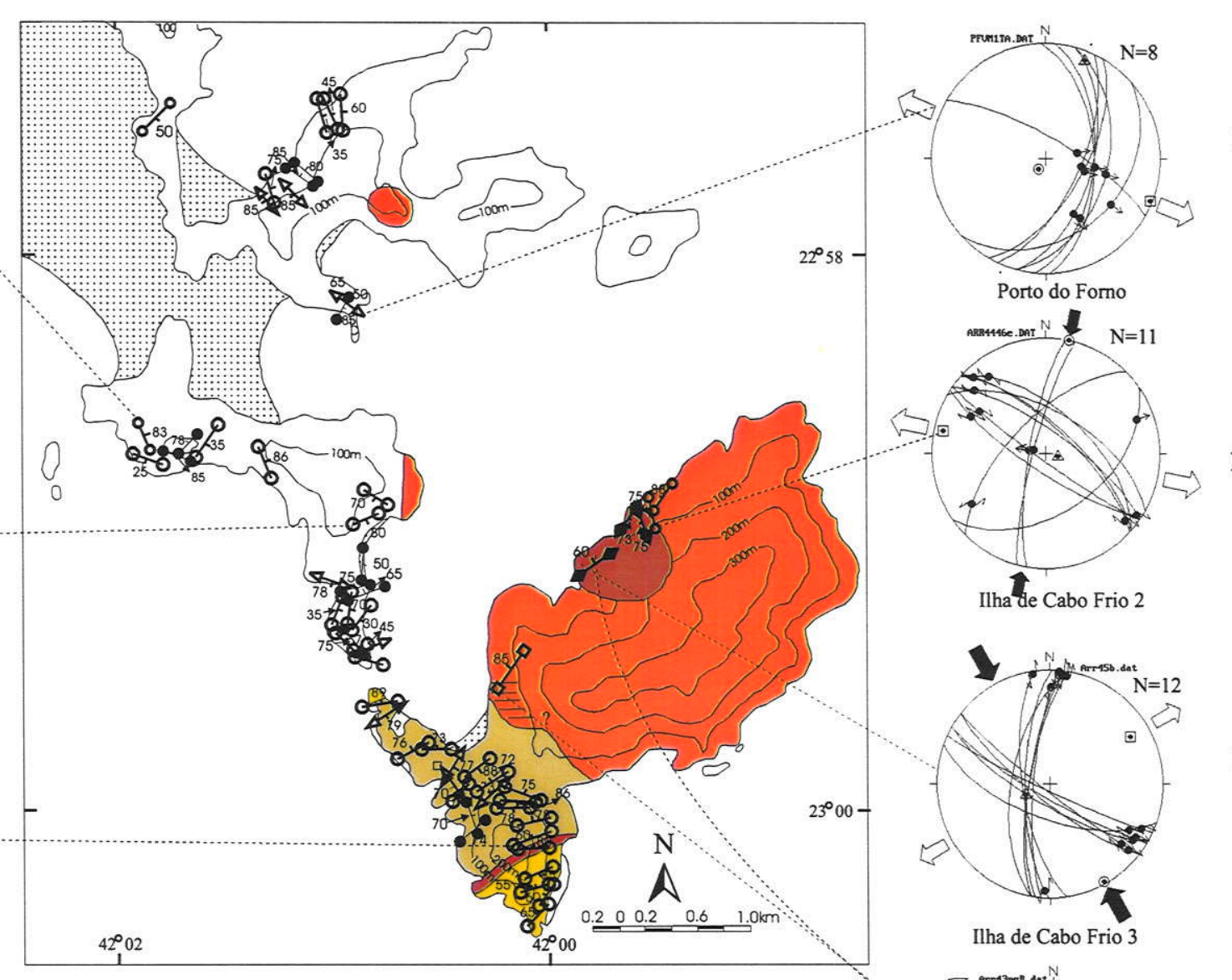

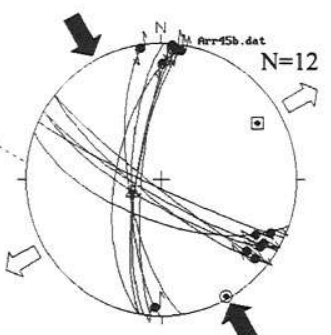

Illha de Cabo Frio 3

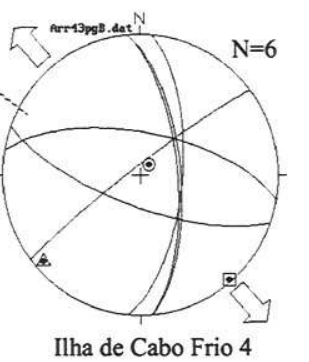

Illha de Cabo Frio 4
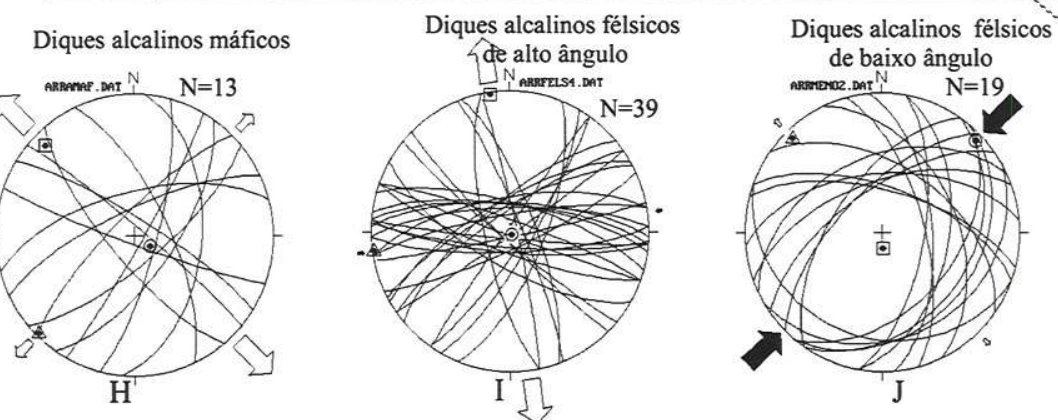

Figura 4.94 - Mapa das paleotensões caracterizadas nas rochas hipabissais do Complexo alcalino da Ilha de Cabo Frio, referentes ao fraturamento que as afeta, por vezes incluindo (C) ou restringindo-se (B, D, E, F) aos planos de falhas com estrias visíveis. Em G foram plotados planos de fraturas preenchidos por veios pegmatóides, localmente com estruturas sigmóides. São também apresentados dados de paleotensões referentes aos diques de rochas alcalinas máficas $(\mathrm{H})$, e de rochas alcalinas félsicas com ângulo de mergulho acima (I) e abaixo (J) de 65 graus. Símbolos: círculos - $\sigma 1$ (eixo de maior esforço), triângulos - $\sigma 2$ (eixo de esforço intermediário), quadrados - $\sigma 3$ (eixo de menor esforço); Setas grandes cheias - eixos compressivos horizontais, setas grandes vazias - eixos distensivos horizontais. Bolas pretas - estrias, setas pequenas - sentido do movimento dos blocos. Projeções de Schmidt-Lambert. hemisfério inferior. Tracos com triângulos - orientacão de fluxo no auartzo sienito. Geologia. de acordo com a Figura 1. 
O mapa da Figura 4.94 mostra também as paleotensões obtidas com a inversão dos dados de atitude dos diques de lamprófiros $(\mathrm{H})$, de rochas alcalinas félsicas com ângulo de mergulho maior $(\mathrm{I})$ e menor $(\mathrm{J})$ do que $65^{\circ}$. No caso dos lamprófiros, as paleotensões obtidas indicam um regime de esforços de extensão pura, com o eixo de esforços mínimo, $\sigma 3$, orientado na direção NW-SE, tendo em vista a predominância de diques de lamprófíro orientados na direção NE-SW. Porém, a ocorrência de um número relativamente alto desses diques na direção NW-SE, resultou em um eixo de tensões intermediário, com uma magnitude do esforço deviatório também extensional, indicando um regime de esforços quase extensional, o que é confirmado pelo valor de $\mathrm{R}=0.27$, muito próximo de 0.25 , que é o valor limite entre os regimes de esforços puramente extensional e de extensão radial. Para os diques de rochas alcalinas félsicas, com alto ângulo de mergulho, o eixo de esforços mínimo, $\sigma 3$, manteve a orientação segundo o quadrante NW (NNW-SSE), com o eixo de esforços intermediário, $\sigma 2$, que constitui o SHmax, orientado na direção ENEWSW, mantendo-se o regime de extensão pura. A inversão dos dados relativos aos diques de rochas alcalinas félsicas de baixo ângulo de mergulho, indicou um campo puramente compressivo, com a manutenção da direção de SHmax, nesse caso representado pelo eixo de tensão máxima, $\sigma 1$.

Uma variação na direção do eixo de maior tensão horizontal SHmax para a direção NW-SE pode ser caracterizada tanto nos fácies plutônicos como nos hipabissais (Cf. Figuras 4.85B, C e 4.92A). Nos dois primeiros casos esse SHmax foi inferido como sendo o eixo principal de tensões, $\sigma 1$. Tal assertiva foi confirmada para o nefelina sienito, no Ponto Arr45 (Figura 4.92A).

\subsubsection{Discussão e Conclusões Parciais}

Considerando-se que há uma cronologia relativa entre os diques de lamprófiros e de basalto alcalino, com relação aos de rochas alcalinas félsicas de alto ângulo e de rochas alcalinas félsicas de baixo ângulo, onde os primeiros são os mais antigos e os últimos os mais novos, pode-se inferir uma progressão na deformação, onde se verificou uma diminuição na magnitude do esforço deviatório vertical, $\sigma \mathrm{z}$, acompanhada de um aumento na magnitude do esforço deviatório compressional horizontal, SHmax, de direção ENE- 
WSW a NE-SW. Nesse sentido, as fraturas e microfalhas identificadas nas rochas plutônicas e hipabissais da região de Arraial do Cabo, que mostram um SHmax orientado predominantemente na direção NE-SW, e representado pelo eixo principal de máxima tensão, $\sigma 1$, tiveram seu desenvolvimento concomitante, principalmente, à intrusão dos diques de rochas alcalinas félsicas com alto ângulo de mergulho, e, secundariamente, com a dos diques de baixo ângulo de mergulho.

A relação linear entre o eixo de tensão principal vertical, $\sigma z$, e a espessura da coluna litostática, permite que se relacione a progressão na deformação identificada na Suíte da Ilha de Cabo Frio e no enxame de diques associado a ele, com uma progressiva denudação da área. Nesse sentido, a extensão quase radial, que controlou as manifestações magmáticas iniciais relacionadas à Suíte Alcalina da Ilha de Cabo Frio, na forma dos diques de lamprófiros e de basalto alcalino, pode ter sido conseqüência do soerguimento verificado em resposta ao aquecimento da crosta, que precedeu a intrusão do corpo alcalino. A diminuição da magnitude de $\sigma z$ que acompanhou a progressão da deformação está provavelmente relacionada com a denudação que acompanhou esse soerguimento. Outro fator que deve ser considerado como um dos causadores da diminuição na magnitude de $\sigma z$ é a subsidência causada pelo resfriamento do corpo intrusivo (Geoffroy et al. 1993).

As direções de SHmax e Shmin determinadas a partir dos diques de rochas alcalinas máficas e félsicas concordam com as determinadas por Motoki et al. (1988). Porém esses autores assumiram uma variação de $\sigma z$ relacionada com a ascensão na coluna litológica, que seria evidenciada pela variação do mergulho de um dos diques de traquito, de alto para baixo ângulo em direção à superfície. A observação de que diques félsicos com baixo ângulo de mergulho cortam os com alto ângulo, indica que a variação de $\sigma z$ foi também temporal. Tal variação pode estar relacionada com as duas hipóteses já levantadas.

A persistência de uma direção de extensão NW-SE no campo de paleotensões que controlou a intrusão dos diques de rochas alcalinas, indica que a variação para uma extensão NE-SW se deu após a consolidação da Suíte Alcalina da Ilha de Cabo Frio. 


\subsection{BRECHAS TECTÔNICAS SILICIFICADAS}

\subsubsection{Introdução}

As falhas acompanhadas por brechação e silicificação estão presentes tanto nas bordas noroeste e sudeste do Graben da Guanabara como no seu interior.

Essas estruturas são mais abundantes na borda sudeste do graben onde constituem um sistema de falhas que se estende por dezenas de quilômetros na direção ENE-WSW. Desse sistema fazem parte a Zona de Falha de Rio Bonito, definida por Almeida (1976), a Falha de São José, que limita a Bacia de São José do Itaboraí a sudeste, e a Falha das Paineiras, localizada na estrada homônima, no Parque Nacional da Tijuca (Figura 4.95). A Zona de Falha de Rio Bonito controlou a intrusão de parte dos corpos alcalinos que ocorrem na poção central do graben, como foi visto no Capítulo 4.3, e foi reativada para a implantação da Bacia do Macacu (ver Capítulo 6.2). Já a Falha das Paineiras contitui-se em uma das principais da borda sudeste do Graben da Guanabara, tanto pela continuidade lateral por vários quilômetros, como pela espessura da caixa de falha de mais de uma dezena de metros. Essa falha, de direção ENE-WSW, posiciona-se no vale entre o Corcovado e o corpo principal do Maciço da Tijuca.

Na borda norte do Graben da Guanabara essas falhas têm ocorrência menos conspícua, concentrando-se na região de Petrópolis, seja no limite ocidental da Serra dos Órgãos, onde apresentam direção NE-SW, ou nos Vales de Araras e das Videiras. Nesses vales elas se apresentam como uma estrutura contínua por mais de uma dezena de quilômetros, com direção E-W, que é aqui denominada aqui Falha das Videiras (Figura 4.95). No extremo nordeste do graben, em Casemiro de Abreu, essas estruturas são contínuas por mais de 10 quilômetros e orientam-se na direção NNESSW. Nesse caso, à semelhança do que ocorre em Petrópolis com as falhas de direção NE-SW, elas limitam blocos com orientação transversal ao graben.

No interior do graben as falhas acompanhadas de brechação e silicificação ocorrem de maneira esparsa e, em geral apresentam direção NE-SW.

Na Figura 4.96 estão representadas as direções, medidas em mapa, das brechas tectônicas silicificadas que ocorrem no Graben da Guanabara e na porção oeste do Graben do Paraíba do Sul, nas proximidades das bacias de Resende e Volta Redonda. 


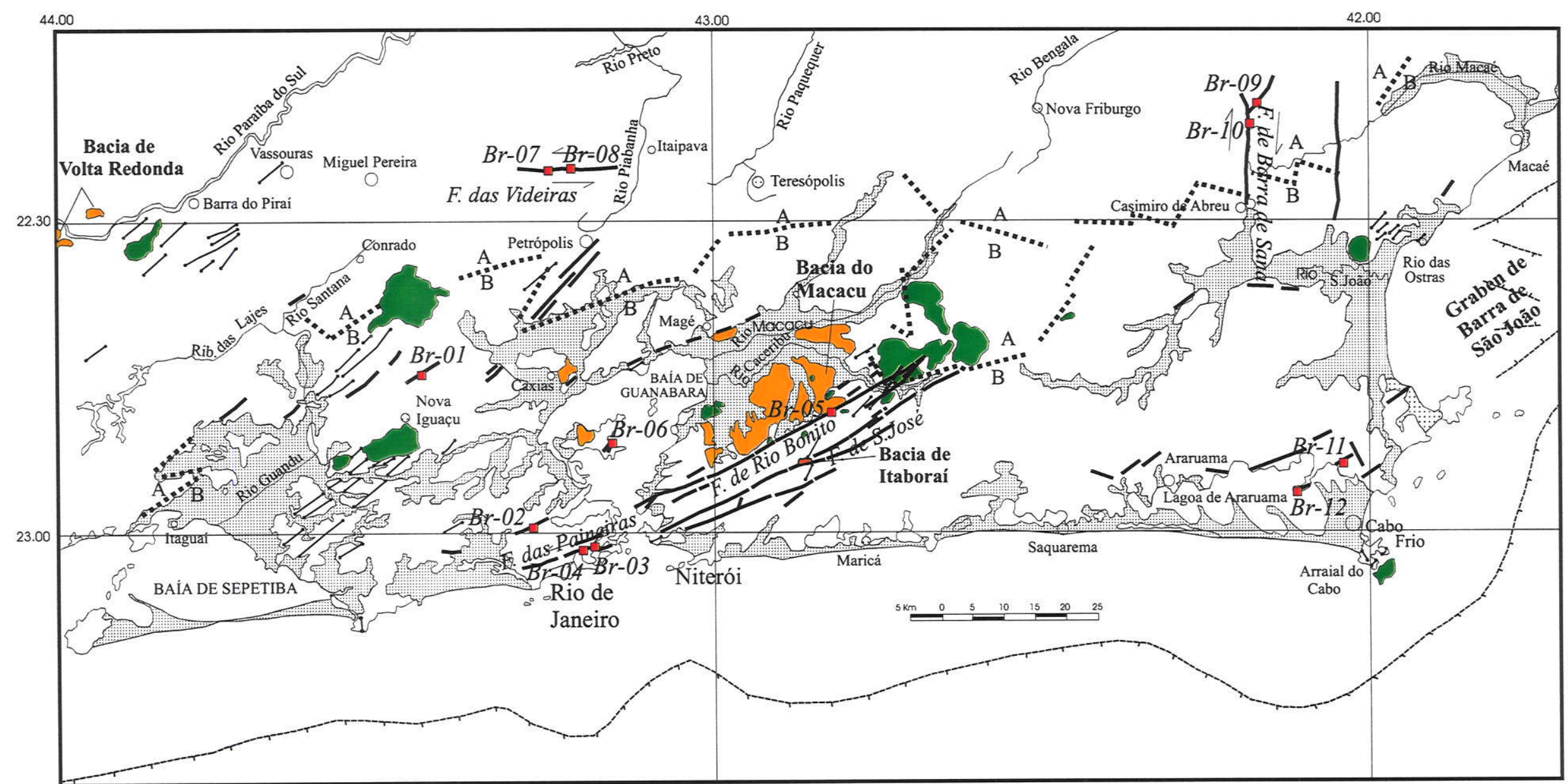

Figura 4.95 - Mapa de pontos de coleta de dados estruturais, indicando a distribuição das falhas com brechação e silicificação. Geologia de acordo com a legenda da Figura 4.1. 
Esses dados foram compilados a partir de mapas em escala 1:50000 (Hembold et al. 1965, Penha et al. 1980, Barbosa et al. 1981, 1983, Dalcolmo et al. 1982), em grande parte realizados pelo Projeto Carta Geológica desenvolvido pelo Departamento de Recursos Minerais do Estado do Rio de Janeiro - DRM/RJ, ou a partir de integrações desses mapas (Mohriak et al. 1992). Também foram utilizados dados levantados pela equipe do IPT/SP (Melo et al. 1985a e b) e teses de mestrado e de doutorado (Castro 1979, Riccomini 1989). Esses dados evidenciam a predominância das brechas tectônicas silicificadas com direções NE-SW a ENE-WSW.

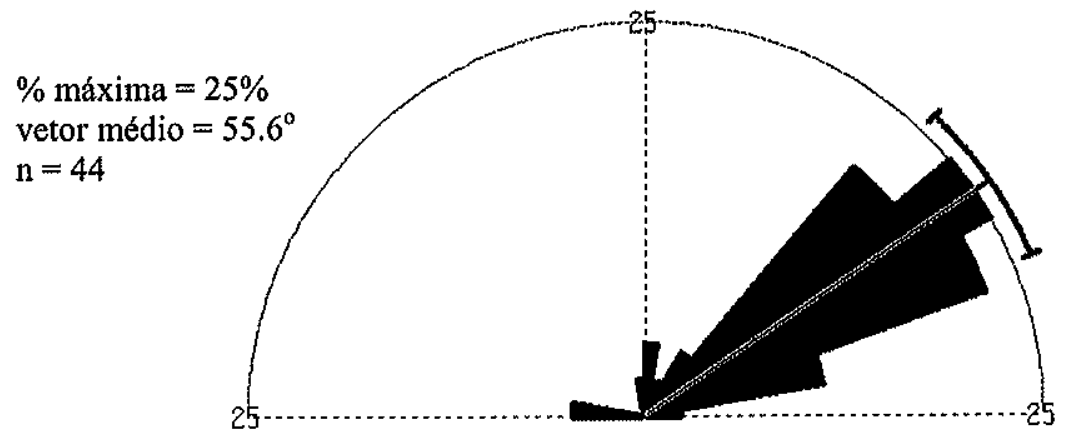

Figura 4.96 - Diagrama de roseta com distribuição das direções das falhas com brechas tectônicas hidrotermalizadas, medidas em mapa.

\subsubsection{Trabalhos Anteriores}

Brechas tectônicas silicificadas, localmente acompanhadas por mineralizações de fluorita ou de barita, vem sendo descritas desde meados do século passado por diversos autores, tais como Abreu (1965), Menezes \& Klein (1973), Valença (1975) e Castro (1979).

Considera-se que essas brechas estão associadas a falhas contemporâneas à hidrotermalização que acompanhou as fases finais do magmatismo alcalino e provocou intensa silicificação nos diques de fonolito e, em especial, nos de traquito (Valença 1975, Dalcolmo et al. 1982, Coelho et al. 1986, Coelho \& Dardene 1987, Becker et al. 1997, Valente 1997).

Apesar da relação direta que existe entre a proximidade de corpos alcalinos e a maior abundância dessas brechas silicificadas, para Coelho \& Dardene (1987) e Coelho et al. (1990) não existe uma relação genética direta entre eles. Esses autores 
apontam que a baixa salinidade das inclusões fluidas das fluoritas associadas a essa atividade hidrotermal indicam que ela não está ligada a uma fase magmática, mas sim a águas meteóricas aquecidas. Nesse caso, as rochas alcalinas teriam atuado como fonte de calor. Para Coelho et al. (1986) e Becker et al. (1997) a mineralização de fluorita do Maciço do Tanguá foi controlada tectonicamente pela reativação, em regime direcional, de zonas de cisalhamento do embasamento, de direção N50E.

Uma única datação disponível para essa mineralização, associada a brechas tectônicas silicificadas, foi obtida em uma adulária, pelo método $\mathrm{K}-\mathrm{Ar}$, e forneceu idade de 50,7 +/- 1,2 Ma (Santos 1994). O diacronismo entre a cristalização dos sienitos e a da mineralização, de cerca de $16 \mathrm{Ma}$, levou esta autora a descartar uma relação genética entre a mineralização e o magmatismo alcalino, como sugerido por Valença (1975). No entanto, esta idade mais nova é compatível com as idades das lavas ankaramíticas nas bacias de São José do Itaboraí e de Volta Redonda (Riccomini et al. 1983, Riccomini \& Rodrigues Francisco 1992) e do magmatismo eocênico do Alto de Cabo Frio (Dias et al. 1988, Mohriak \& Barros 1990), o que pode sugerir um evento de aquecimento regional no RCSB.

Ressalta-se, ainda, a discrepância entre a profundidade de formação dos pseudo-leucita sienitos que constituem o Maciço do Tanguá, de cerca de 2 a $3 \mathrm{~km}$ de profundidade (Valença 1975 e 1980, Dalcolmo et al. 1982, Joel Gomes Valença comunicação verbal, 1989), e a da mineralização de fluorita, de cerca de 0,5 a $1,0 \mathrm{~km}$ (Coelho \& Dardene 1987). Tal discrepância, que implica num tempo de denudação, reforça as indicações de diacronismo entre os dois eventos.

\subsubsection{Análise Cinemática de Falhas e Microfalhas}

Foram realizados levantamentos de campo em falhas com brechas tectônicas silicificadas, visando a caracterização das estruturas rúpteis contemporâneas ao hidrotermalismo e as eventuais reativações dessas estruturas. Foram reconhecidas falhas e microfalhas, nas quais buscou-se caracterizar a cinemática, bem como estruturas que controlaram a intrusão de veios de calcedônia maciços, aqui consideradas estruturas extensionais. 


\subsubsection{1. Área Ocidental do Graben}

A) Queimados

Nas Figuras 4.97A e C estão representadas microfalhas que afetam brecha tectônica silicificada no Município de Queimados, em corte da Rodovia Presidente Dutra, 200 metros após a entrada para Queimados no sentido Rio - São Paulo (Ponto Br-01, Figura 4.95). Tratam-se de microfalhas direcionais e normais, onde as últimas parecem, com base em relações de corte no plano de falha, mais novas do que as primeiras.

Na Figura 4.97A estão representadas duas famílas de microfalhas direcionais, onde as microfalhas de direção WNW-ESE a E-W, com rejeito sinistral, representam estruturas sintéticas $\mathrm{R}$ e as de direção NNW-SSE, com rejeito dextral, representam estruturas antitéticas X. A inversão desses dados indicou que essas famílias de microfalhas foram ativadas por um campo de paleotensões DIRECIONAL Puro (Pure STRIKE-SLIP), onde o eixo de tensões máximo, $\sigma 1$, é horizontal e orienta-se na direção NE-SW, o eixo de tensões mínimo, $\sigma 3$, é também horizontal e orienta-se na direção NW-SE, posicionando-se o eixo intermediário, $\sigma 2$, na vertical.

$\mathrm{Na}$ Figura 4.97C estão representadas microfalhas com rejeito normal, com direção em torno de WNW-ESE. A sua inversão permitiu verificar que elas foram ativadas em um campo de paleotensões EXTENSIVO Puro (Pure EXTENSIVE), com o eixo de tensões principal máximo, $\sigma 1$, posicionado na vertical, o eixo de tensões mínimo, $\sigma 3$, posicionado na horizontal segundo a direção NNW-SSE, e o eixo intermediário, $\sigma 2$, posicionado também na horizontal, na direção ENE-WSW.

B) Jacarepaguá

Na Figura 4.98A estão representadas duas famílias de microfalhas direcionais caracterizadas no Ponto $\mathrm{Br}-02$. Nesse caso as falhas de direção NE-SW apresentam rejeito sinistral e as de direção NNW-SSE mostram rejeito dextral. A inversão dos dados indicou que as microfalhas foram ativadas por um campo de paleotensões DIRECIONAL Puro (Pure STRIKE-SLIP), com o eixo de tensões máximo, $\sigma 1$, 
A)

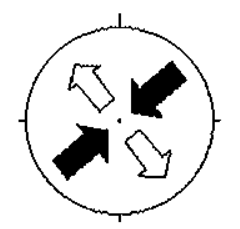

Pure STRIKE-SLIP

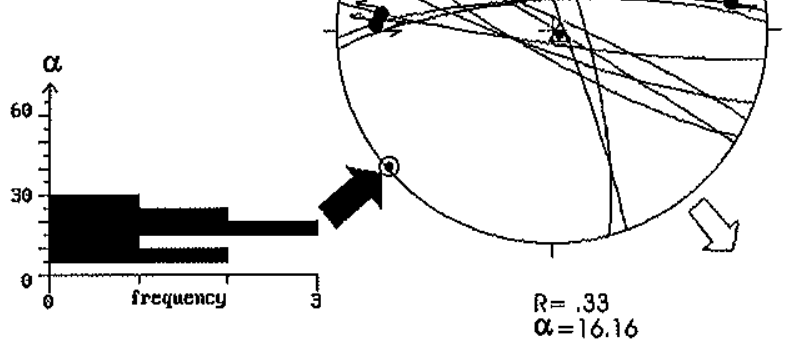

C)
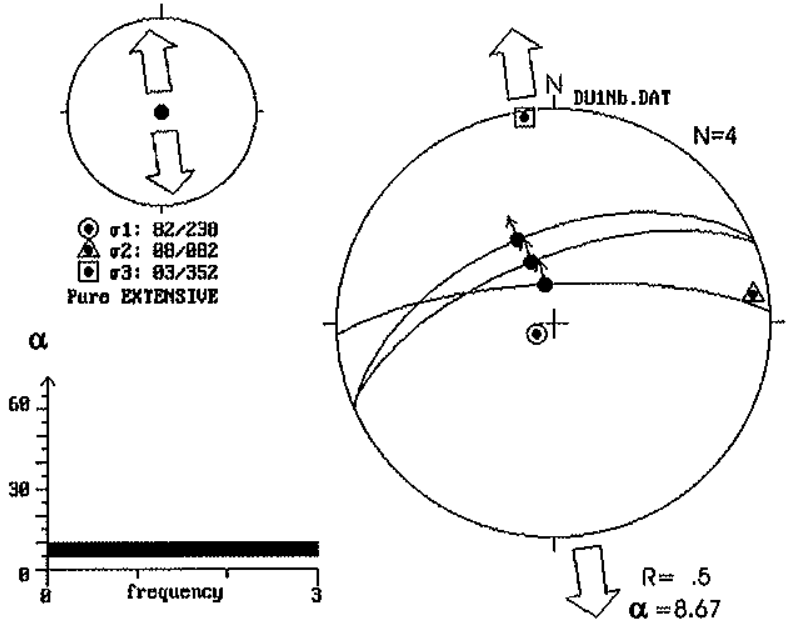

B)
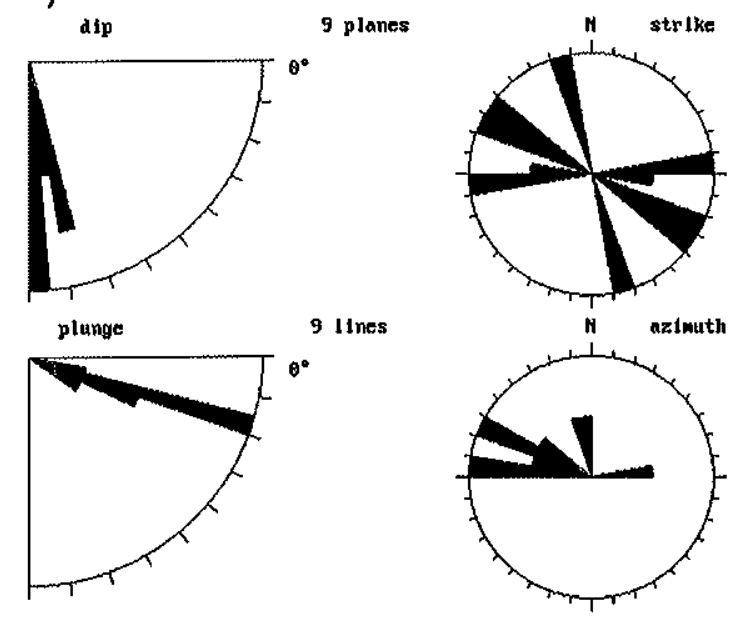

D)
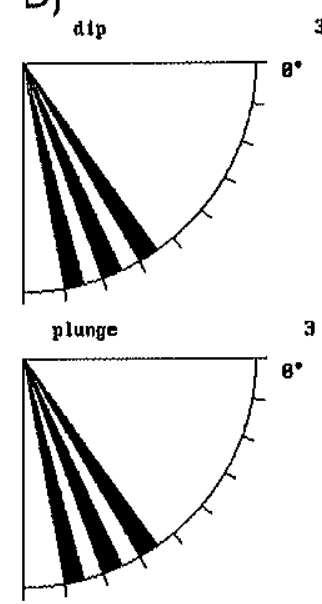

3 planes

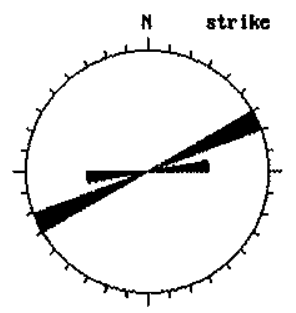

Itnes

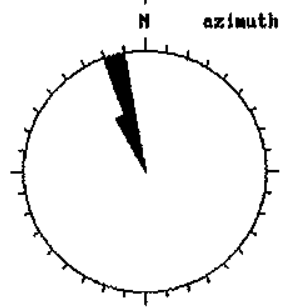

Figura 4.97- Dados de falhas e respectivos eixos de tensões para brechas tectônicas silicificadas, corte na Rodovia Presidente Dutra, entrada para Queimados, Ponto Br-01. Símbolos:círculos $-\sigma 1$ (eixo de maior esforço), triângulos - $\sigma 2$ (eixo de esforço intermediário), quadrados - $\sigma 3$ (eixo de menor esforço); $R$ - razão de esforço $(\sigma 2-\sigma 3 / \sigma 1-\sigma 3) \alpha-$ desvio médio entre as estrias medidas e o cisalhamento computado sobre o plano de falha. Setas grandes cheias - eixos compressivos horizontais, setas grandes vazias - eixos distensivos horizontais. Projeções de Schmidt- Lambert, hemisfério inferior. 


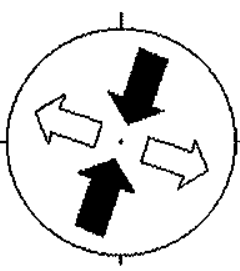

A)

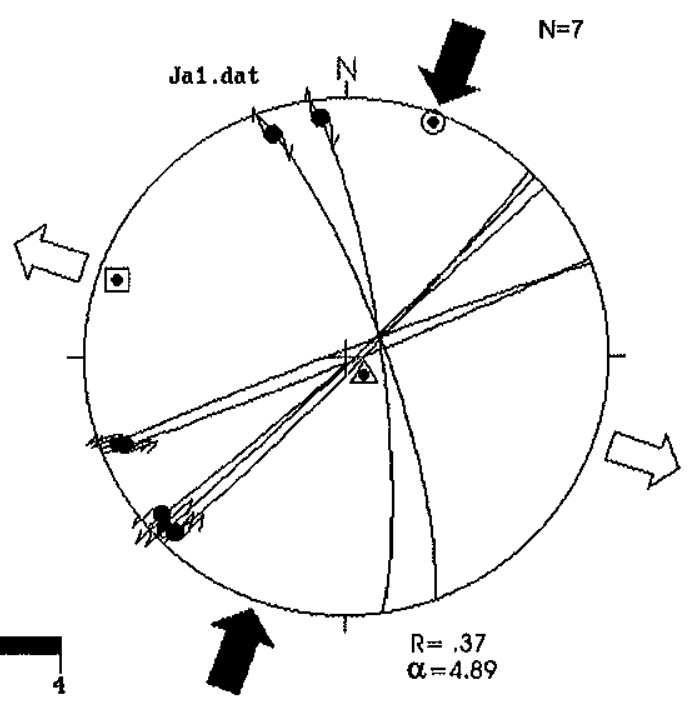

B)

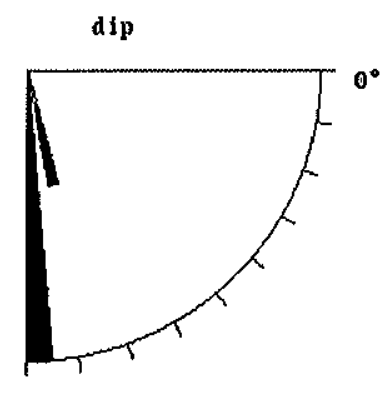

7 planes

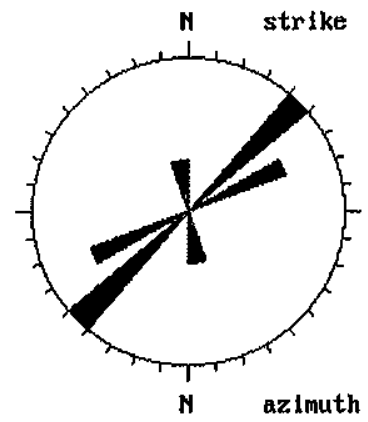

plunge

7 lines

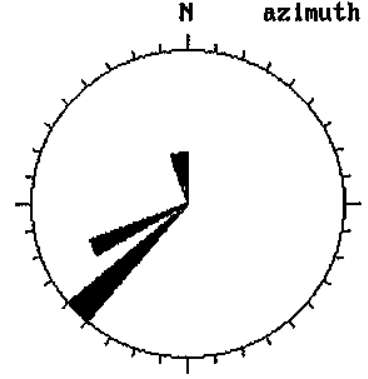

Figura 4.98 - Dados de falhas e respectivos eixos de tensões para brechas tectônicas silicificadas, Bairro de Jacarepaguá, Rio de Janeiro, Ponto Br-02. Símbolos:círculos - $\sigma 1$ (eixo de maior esforço), triângulos - $\sigma 2$ (eixo de esforço intermediário), quadrados - $\sigma 3$ (eixo de menor esforço); $\mathrm{R}$ - razão de esforço ( $\sigma 2-\sigma 3 / \sigma 1-\sigma 3) ; \alpha$-desvio médio entre as estrias medidas e o cisalhamento computado sobre o plano de falha. Setas grandes cheias eixos compressivos horizontais, setas grandes vazias - eixos distensivos horizontais. Projeções de Schmidt- Lambert, hemisfério inferior. 
posicionado na horizontal segundo a direção NNE-SSW, o eixo de tensões mínimo, $\sigma 3$, também posicionado na horizontal e na direção WNW-ESE, e o eixo intermediário, $\sigma 2$, vertical.

C) Falha das Paineiras

$\mathrm{Na}$ Falha das Paineiras foram levantados dados em duas estações distintas, sendo a primeira na Estrada do Corcovado, 600 metros após a entrada no Parque Nacional da Tijuca pelo Bairro do Cosme Velho (Ponto Br-03), e a segunda na Estrada das Paineiras, $2 \mathrm{~km}$ após o entroncamento para o Corcovado (Ponto Br-04). Em ambos os locais essas brechas destacam-se na paisagem, constituindo paredões com alguns metros de altura. No ponto $\mathrm{Br}-04$ a caixa de falha possui vários metros de espessura e pouco mais de 10 metros de altura. Nesse local a parede formada é utilizada para o treinamento de rapel, por alpinistas. Em ambos os locais as brechas mostram planos de microfalhas nos quais estão presentes estrias com baixo ângulo de caimento, evidenciando seu caráter dominantemente direcional. Localmente vê-se estrias com alta obliquidade, indicativas de movimentação normal, as quais se sobrepõem às direcionais, indicando serem mais novas. No Ponto $\mathrm{Br}-04$ pode-se observar que o hidrotermalismo, representado pela injeção de veios de calcedônia, foi controlado por um campo de paleotensões direcional (Figura 4.99).

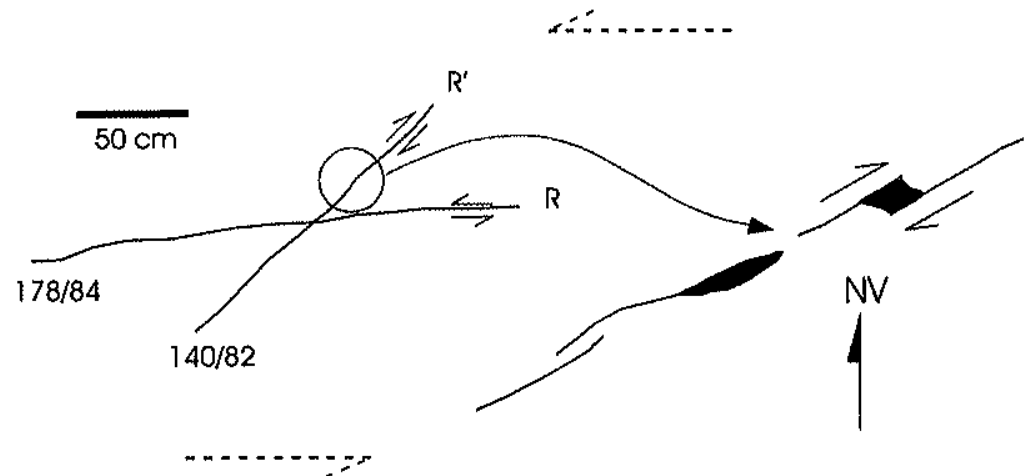

Figura 4.99 - Veios de calcedônia injetados no gnaisse leptinítico, cataclasado e silicificado, Estrada das Paineiras, Parque Nacional da Tijuca, Município do Rio de Janeiro, Ponto Br-04. No plano de direção NE-SW o sentido do movimento é indicado pelo preenchimento dos espaços pela calcedônia, $e$ no de direção E-W, as estrias sugerem movimentação sinistral. 
$\mathrm{Na}$ Figura 4.100 estão representadas famílias de falhas e microfalhas direcionais conjugadas, identificadas no Ponto Br-03. Elas são constituídas pelas sinistrais, de direção ENE-WSW, e pelas dextrais, de direção NNW-SSE. A inversão desses dados indicou que essas estruturas foram ativadas por um campo de paleotensões DIRECIONAL Puro (Pure STRIKE -SLIP), com o eixo de tensões máximo, $\sigma 1$, horizontal e orientado na direção NNE-WSW, o eixo de tensões mínimo, $\sigma 3$, também horizontal e orientado na direção WNW-ESE e o eixo de tensões intermediário, $\sigma 2$, posicionado na vertical.

$\mathrm{Na}$ Figura 4.101A estão representadas falhas e microfalhas direcionais sintéticas com rejeito sinistral, identificadas no Ponto Br-04, onde as de direção ENEWSW representam estruturas $\mathrm{R}$ e as de direção WNW-ESE representam estruturas $P$. A inversão dessas estruturas indicou que elas foram ativadas por um campo de paleotensões DIRECIONAL Puro (Pure STRIKE-SLIP), onde o eixo de tensões máximo, $\sigma 1$, posiciona-se na horizontal, segundo a direção NNE-SSW, o eixo de tensões mínimo, $\sigma 3$, é também horizontal e orienta-se na direção WNW-ESE, e o eixo de tensões intermediário, $\sigma 2$, é vertical.

$\mathrm{Na}$ Figura 4.101C estão representadas microfalhas normais de direção NNESSW e ENE-WSW, identificadas no Ponto Br-04. A inversão dos dados indicou que essas estruturas foram ativadas por um campo de paleotensões EXTENSIONAL Puro (Pure EXTENSIVE), onde o eixo de tensões máximo, o1, posiciona-se na vertical, o eixo de tensões mínimo, $\sigma 3$, é horizontal e orienta-se na direção WNW-ESE, e o eixo de tensões intermediário, $\sigma 2$, posiciona-se também na horizontal, na direção NNEWSW. As relações de corte entre estrias associadas às movimentações direcional e normal, em um mesmo plano de falha, onde as estrias com alta obliquidade cortam as com baixa obliquidade, permitem que se determine que a atuação do campo de paleotensões direcional foi anterior à do campo normal. 
A)

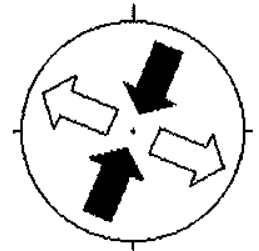

Pure STRIKE-SLIP

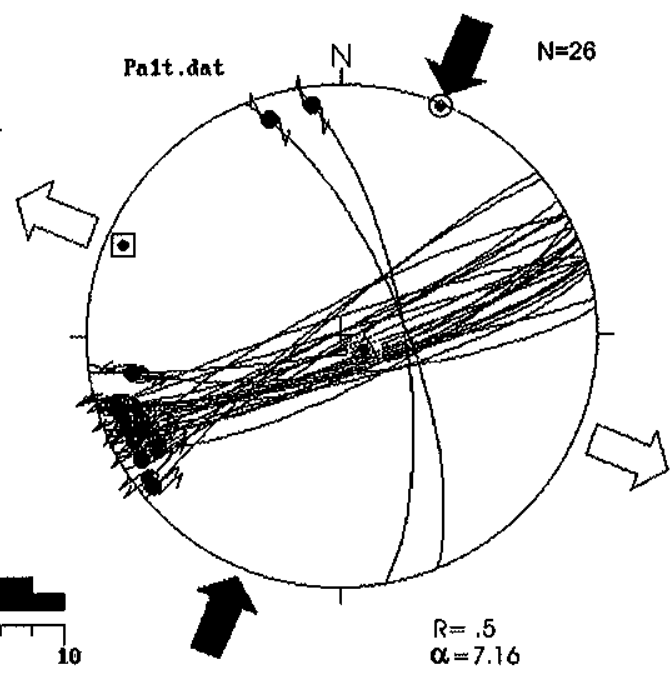

B)

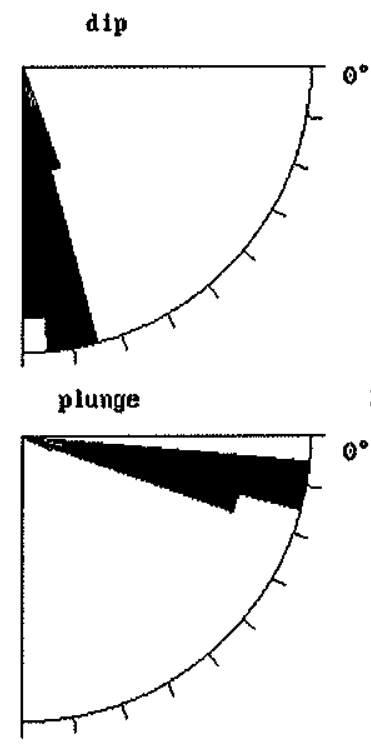

26 planes

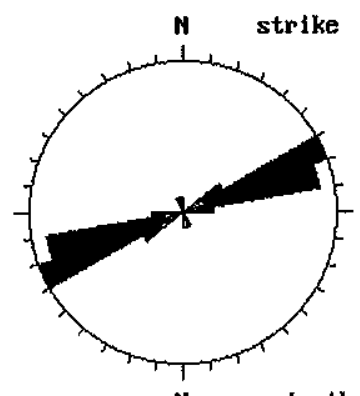

26 lines

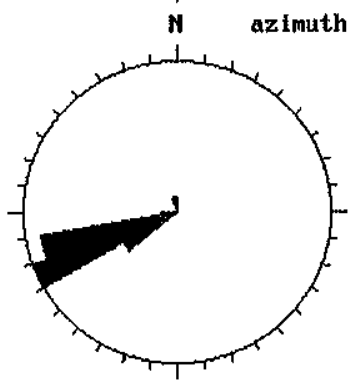

Figura 4.100 - Dados de falhas e respectivos eixos de tensões para brechas tectônicas silicificadas, Estrada das Paineiras, Floresta da Tijuca, Rio de Janeiro, Ponto br-03. Símbolos:círculos - $\sigma 1$ (eixo de maior esforço), triângulos $-\sigma 2$ (eixo de esforço intermediário), quadrados - $\sigma 3$ (eixo de menor esforço); $\mathrm{R}$ - razão de esforço ( $\sigma 2-\sigma 3 / \sigma 1-\sigma 3$ ); $\alpha$ - desvio médio entre as estrias medidas e o cisalhamento computado sobre o plano de falha. Setas grandes cheias - eixos compressivos horizontais, setas grandes vazias - eixos distensivos horizontais. Projeções de Schmidt- Lambert, hemisfério inferior. 
A)

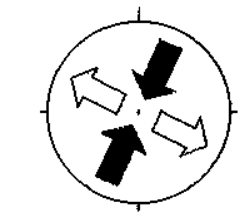

Pure STRIKE-SLIP
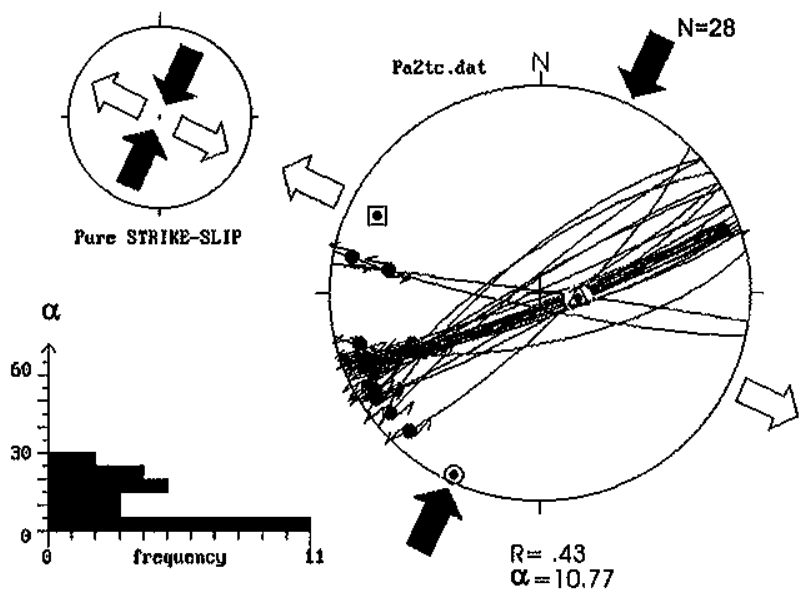

C)

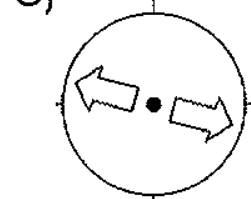

Q $01: 75 / 306$

03: 14/185 Pure EXTENSIUR
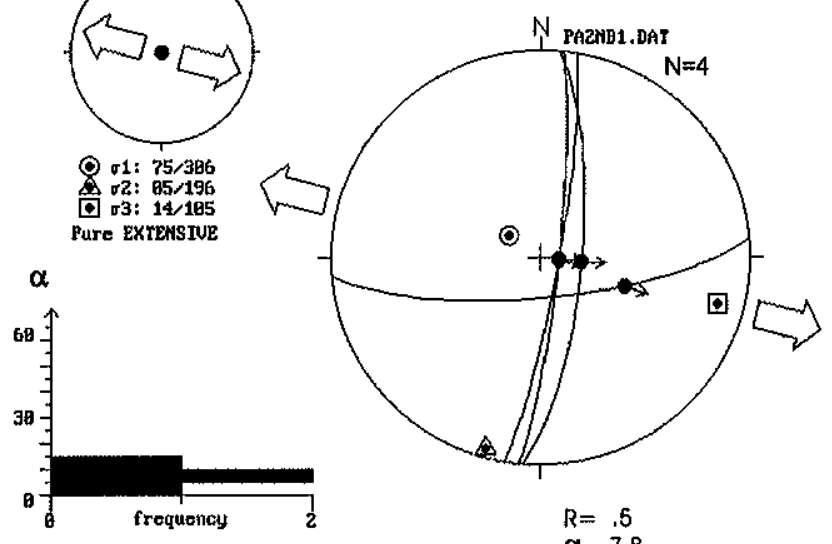

$R=.5$
$\alpha=7.8$
B)

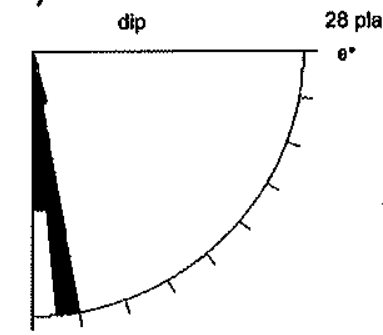

28 planes strike
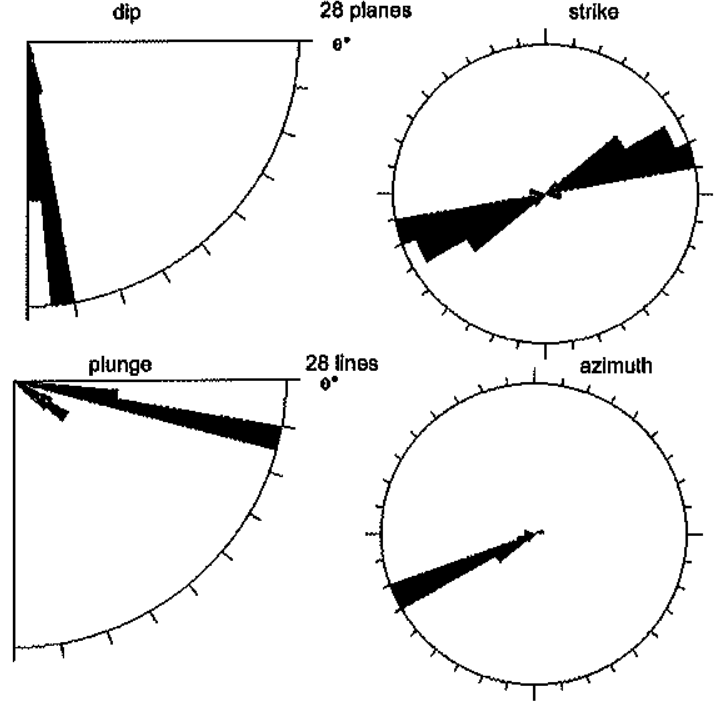

D) ${ }_{\mathrm{dtp}}$

4 planes
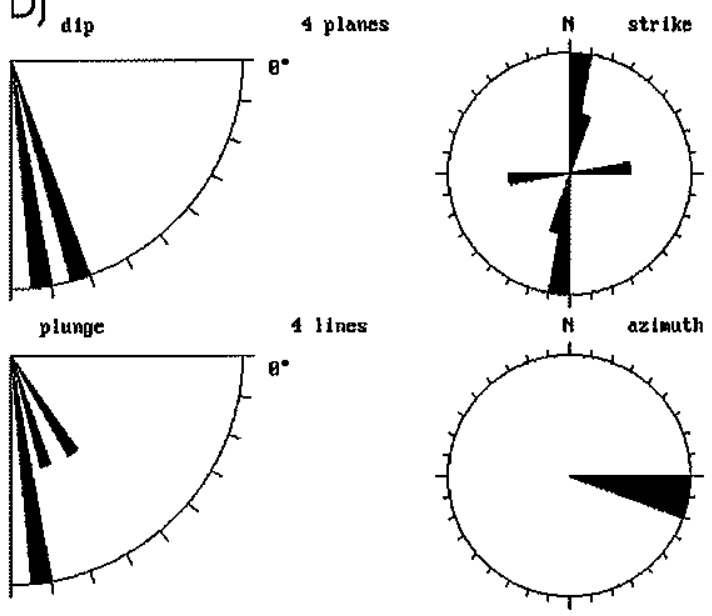

Figura 4.101- Dados de falhas e respectivos eixos de tensões para brechas tectônicas silicificadas, Estrada das Paineiras, Parque Nacional da Tijuca, Rio de Janeiro, Ponto Br-04. Símbolos:círculos - $\sigma 1$ (eixo de maior esforço), triângulos - $\sigma 2$ (eixo de esforço intermediário), quadrados - $\sigma 3$ (eixo de menor esforço); $R$ - razão de esforço ( $\sigma 2-\sigma 3 / \sigma 1-\sigma 3$ ); $\alpha-$ desvio médio entre as estrias medidas e o cisalhamento computado sobre o plano de falha. Setas grandes cheias - eixos compressivos horizontais, setas grandes vazias - eixos distensivos horizontais. Projeções de Schmidt- Lambert, hemisfério inferior. 


\subsubsection{2. Área Central do Graben}

A) Itaboraí

$\mathrm{Na}$ região de Itaboraí, apesar de terem sido mapeadas diversas falhas com brechas silicificadas por Dalcolmo et al. (1982) (ver Figura 4.95), a grande maioria foi determinada pelo alinhamento de blocos de brecha com matriz de calcedônia. As estruturas apresentadas na Figura 4.102 foram caracterizadas em corte da rodovia BR101 (Ponto Br-05), onde ocorrem ortognaisses cobertos por sedimentos da Formação Macacu. Nos sedimentos não foram identificados brechação e silicificação, indicando que esses fenômenos estão restritos ao embasamento. Ainda nesse sentido, as estruturas presentes nos sedimentos são exclusivamente de caráter normal, enquanto que as do embasamento, acompanhadas por cataclase e silicificação, têm caráter direcional.

Na Figura 4.102 estão representadas duas famílias de microfalhas direcionais, com direção ENE-WSW e WNW-ESE, ambas com rejeito sinistral. A inversão desses dados de microfalhas indicou que elas foram ativadas por um campo de paleotensões direcional, onde o eixo de tensões máximo, $\sigma 1$, posiciona-se na horizontal e orienta-se na direção NE-SW, o eixo de tensões mínimo, $\sigma 3$, é também horizontal e orienta-se na direção NW-SE e o eixo de tensões intermediário, $\sigma 2$, é vertical. Assim, pode-se inferir que as microfalhas de direção ENE-WSW são estruturas sintéticas $\mathrm{R}$ e que as de direção WNW-ESE são também sintéticas, porém do tipo $\mathrm{P}$.

B) Ilha do Governador

$\mathrm{Na}$ Ilha do Governador as microfalhas foram caracterizadas na borda de veios de calcedônia. Esses veios foram identificados em corte junto à Praia do Zumbi, onde ocorrem injetados em granito porfirítico. A ocorrência de barita a associada a brechas silicificadas, localizada na Ponta da Ostra, mapeada por Dalcolmo et al. (1982) e estudada por Chaves et al. (1993), não foi identificada por estar coberta por benfeitorias recentes. Esses últimos autores a descrevem como uma faixa brechada 

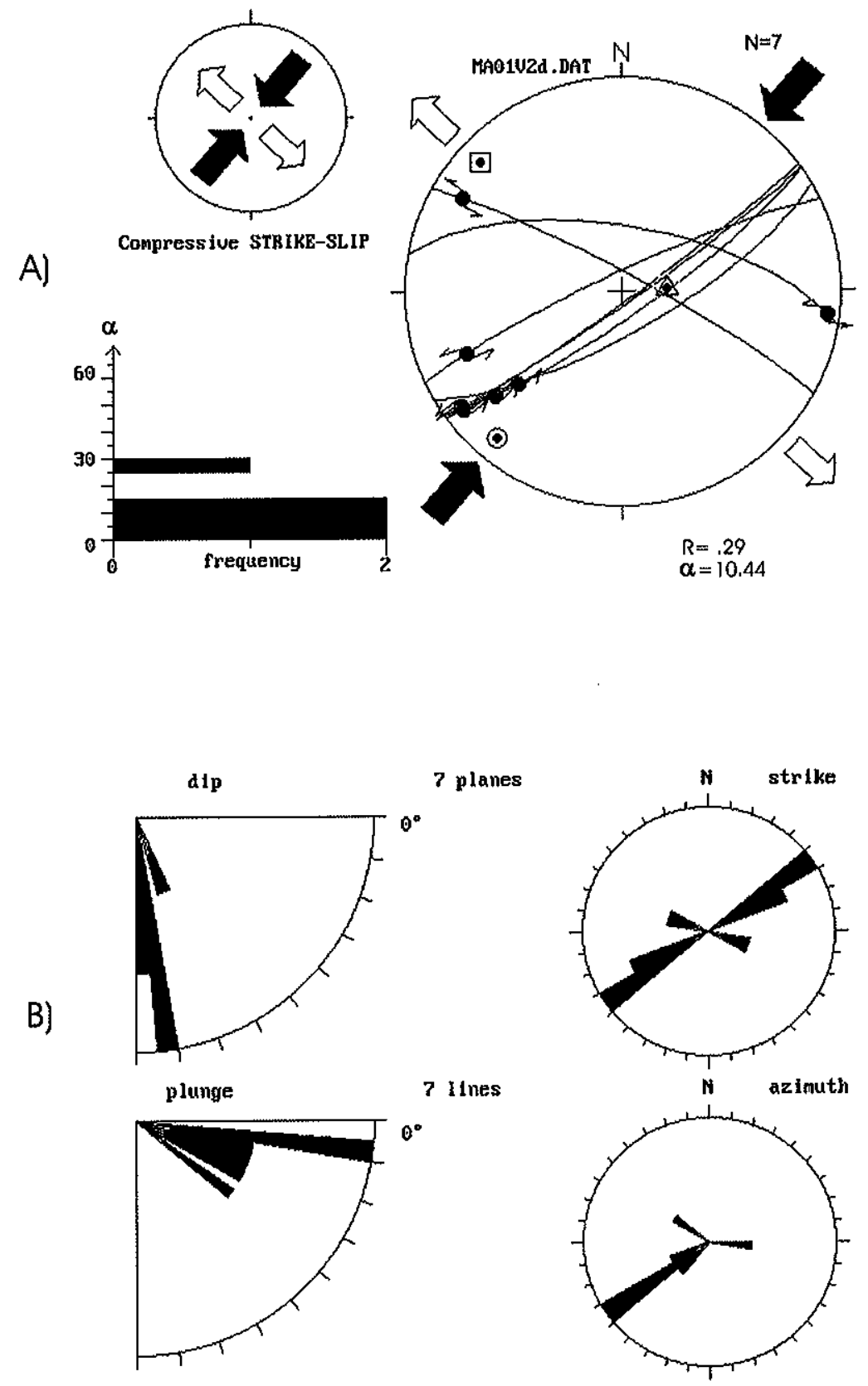

Figura 4.102 - Dados de falhas e respectivos eixos de tensões para brechas tectônicas silicificadas, BR-101, Município de Itaboraí, Ponto Br-05. Símbolos:círculos - $\sigma 1$ (eixo de maior esforço), triângulos $-\sigma 2$ (eixo de esforço intermediário), quadrados $-\sigma_{3}$ (eixo de menor esforço); $R$ - razão de esforço $(\sigma 2-\sigma 3 / \sigma 1-\sigma 3) ; \alpha$-desvio médio entre as estrias medidas e o cisalhamento computado sobre o plano de falha. Setas grandes cheias - eixos compressivos horizontais, setas grandes vazias - eixos distensivos horizontais. Projeções de SchmidtLambert, hemisfério inferior. 
com cerca de $80 \mathrm{~cm}$ de espessura, orientada na direção NE-SW e com mergulho subvertical, à qual se associam veios de barita sub-paralelos, com até $5 \mathrm{~cm}$ de espessura. De acordo com esses autores essa ocorrência se alinha com uma outra, para SW, com um dique de fonolito localizado a NE, em uma pequena ilha no interior da Baía de Guanabara, e com o Maciço de Itaúna.

$\mathrm{Na}$ Figura 4.103 estão representadas microfalhas normais de direção NNESSW. A inversão dessas estruturas indicou que elas foram ativadas por um campo de paleotensões EXTENSIONAL Puro (Pure EXTENSIVE), onde o eixo de tensões máximo, $\sigma 1$, posiciona-se na vertical, e os eixos de paleotensões mínimo, $\sigma 3$, e intermediário, $\sigma 2$, são horizontais e orientam-se nas direções WNW-ESE e NNESSW, respectivamente.

C) Vale das Videiras

No Vale das Videiras, localizado no Município de Petrópolis, as brechas tectônicas silicificadas têm continuidade por vários quilômetros, ao longo de praticamente todo o vale, orientando-se segundo as direção ENE-WSW a E-W. A sua extensão para leste, no Vale de Araras, é menos contínua, mas pode ser perseguida também por alguns quilômetros. Nos dois casos as brechas estão afetando o granito gnaissico do Batólito Serra dos Órgãos. Essas brechas têm espessura métrica e, localmente, destacam-se no relevo por erosão diferencial (Figura 4.104B).

Localmente ocorrem clastos de traquito, sugerindo uma associação com o magmatismo alcalino e/ou reativação de planos de fratura preexistentes. Aqui as brechas permitem a observação de sua feição estrutural mais característica, que é a presença de faixas cataclasadas, constituindo brechas ou verdadeiros cataclasitos, entremeadas com veios maciços de calcedônia que se comportam como material intrusivo (Figura 4.105A e B). As relacões geométricas entre eles permite infirir que o hidrotermalismo foi acompanhado de deformação de caráter direcional. A ocorrência dos veios maciços e cataclasados evidencia que o hidrotermalimo se deu em pulsos diversos (Figura 4.104G). Localmente, pode-se observar que as brechas constituídas de fragmentos de calcedônia envolvidos por calcedônia mais nova, mostram evidências de terem sofrido extensão em mais de uma das direções dos eixos de 

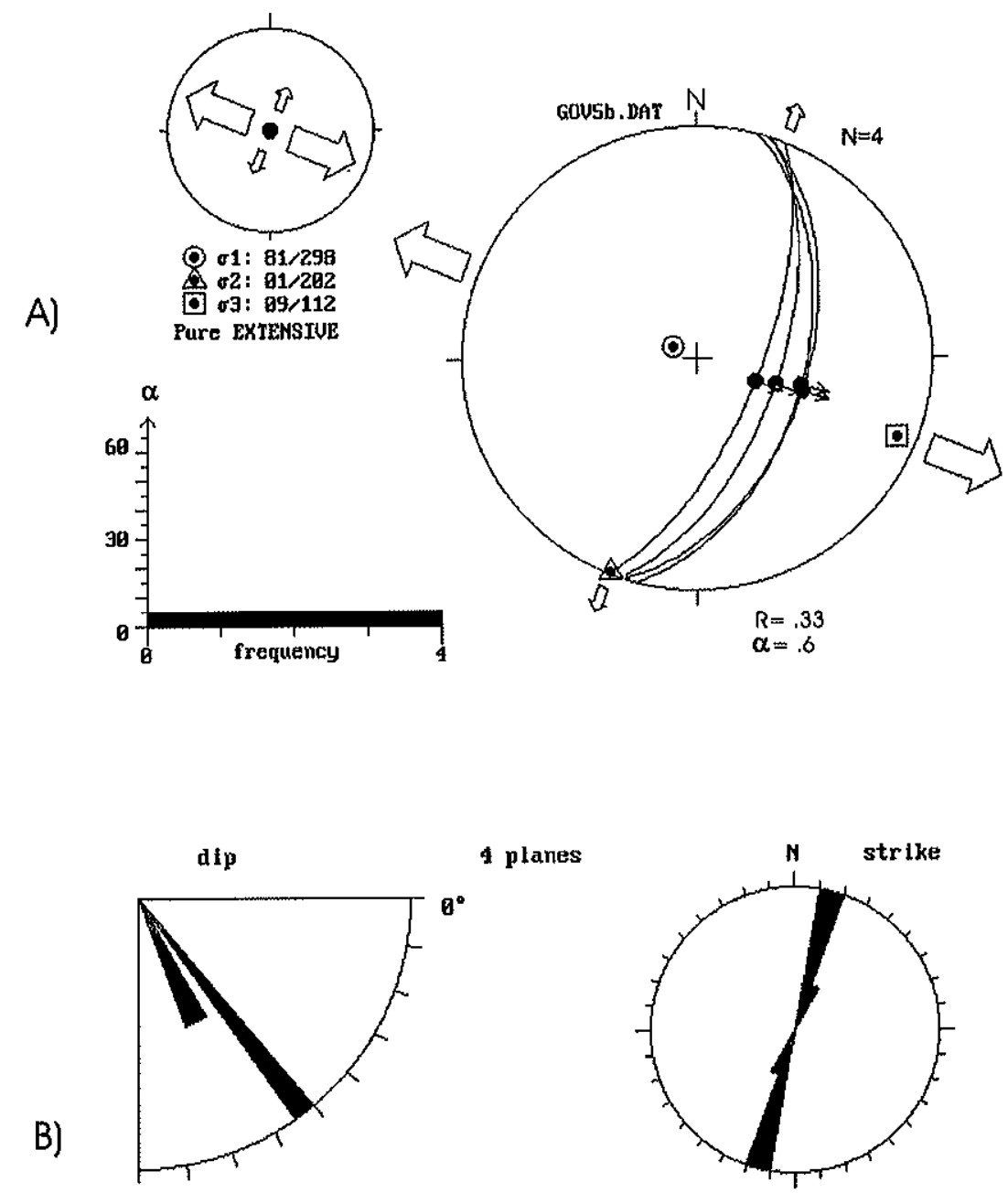

4 planes
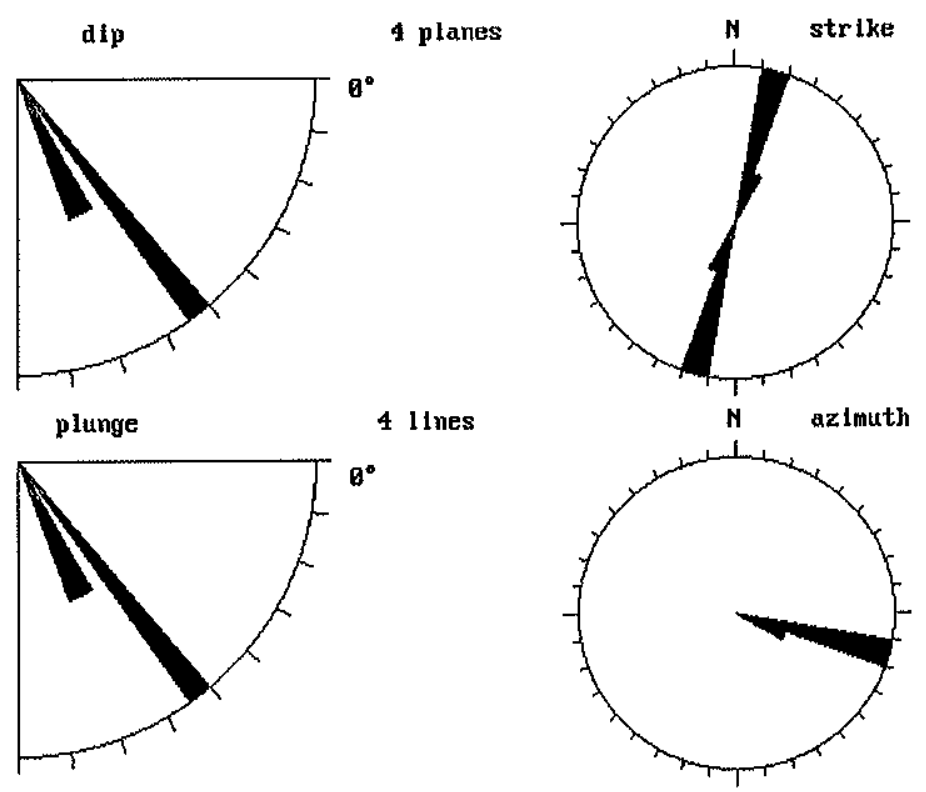

Figura 4.103 - Dados de falhas e respectivos eixos de tensões para brechas tectônicas silicificadas, Praia do Zumbi, Ilha do Governador, Município do Rio de Janeiro, Ponto Br-06. Símbolos:círculos $-\sigma 1$ (eixo de maior esforço), triângulos $-\sigma 2$ (eixo de esforço intermediário), quadrados - $\sigma 3$ (eixo de menor esforço); $R$ - razão de esforço $(\sigma 2-\sigma 3 / \sigma 1-\sigma 3$ ); $\alpha$ - desvio médio entre as estrias medidas e o cisalhamento computado sobre o plano de falha. Setas grandes cheias - eixos compressivos horizontais, setas grandes vazias - eixos distensivos horizontais. Projeções de Schmidt- Lambert, hemisfério inferior. 

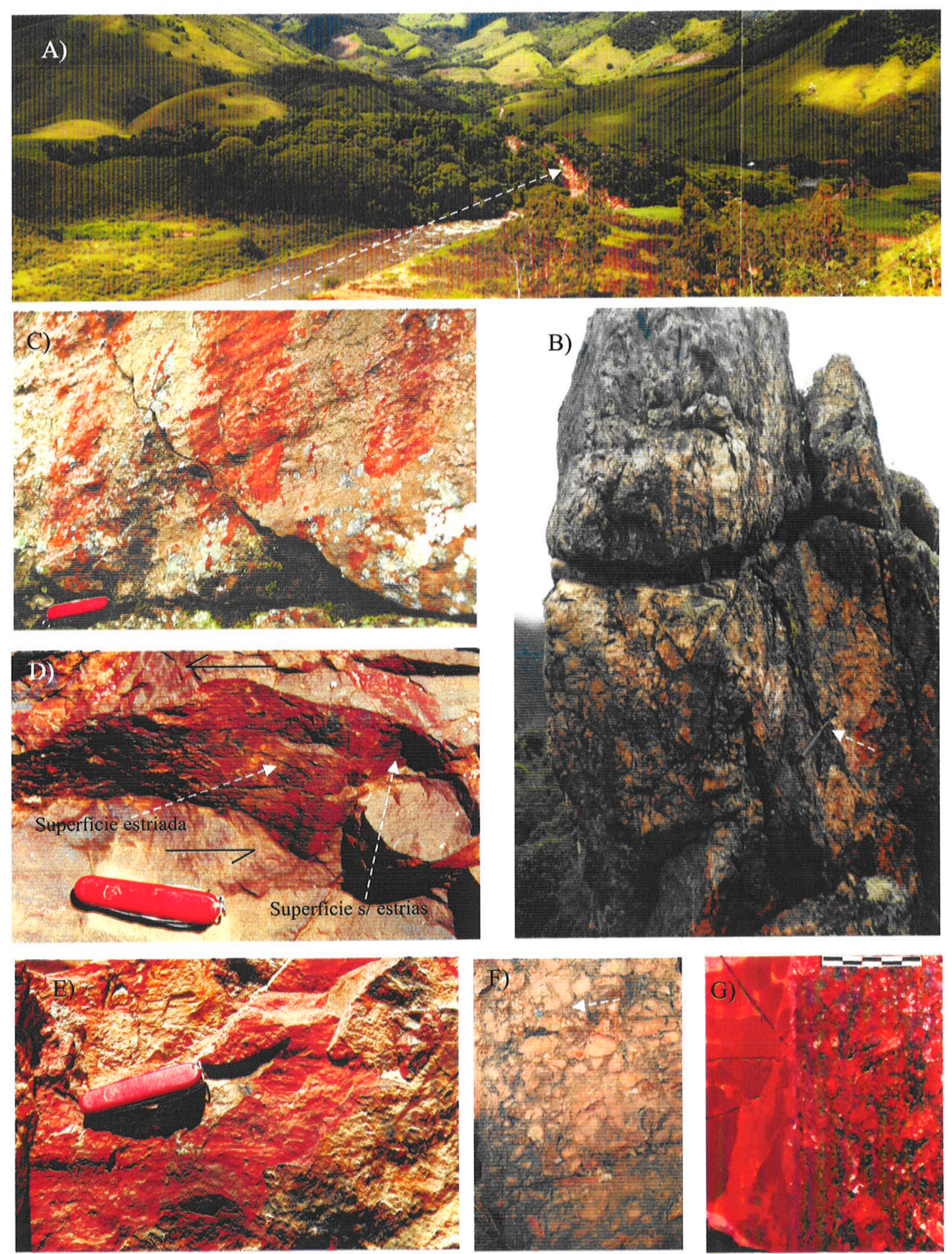

Figura 4.104 - A) Paredão de brecha tectônica silicificada com cerca de 10 metros de altura e direção NNE-SSW, em visada de WNW para ESE. Essa feição provoca um desvio no curso do Rio Macaé, Distrito de Barra de Sana, Casemiro de Abreu, Ponto Br10; B) Pináculo de brecha tectônica silicificada, de direção ENE-WSW e com cerca de 3 metros de altura, destacado por erosão diferencial. Vale das Videiras, Petrópolis, Ponto Br-08. A seta aponta martelo usado como escala; C) Plano de falha em brecha silicificada, de direção NNE-SSW, mostrando estrias com suave caimento para SSW. Barra do Sana, Ponto Br-10; D) Microfalha em brecha silicificada, com variação na sua direção, evidenciando porções com e sem estrias, indicando rejeito sinistral. Vale das Videiras; E) Estrias subhorizontais em brecha silicificada, indicando movimentação direcional sinistral. Vale das Videiras, Ponto $\mathrm{Br}-08$; F) Brecha silicificada com fragmentos irregulares de calcedônia, que indicam extensão nas três direções principais de tensão. Vale das Videiras, Ponto Br-07. A Seta indica a posição da ficha de telefone usada como escala, ; G) Veio de calcedônia maciça, à esquerda, cortando calcedônia brechada com fragmentos de gnaisse e de calcedônia. Escala $=2,5 \mathrm{~cm}$. Vale das Videiras, Ponto Br-08. 
tensão principais (Figura 4.104F), indicando que a pressão de fluídos superou as tensões regionais.
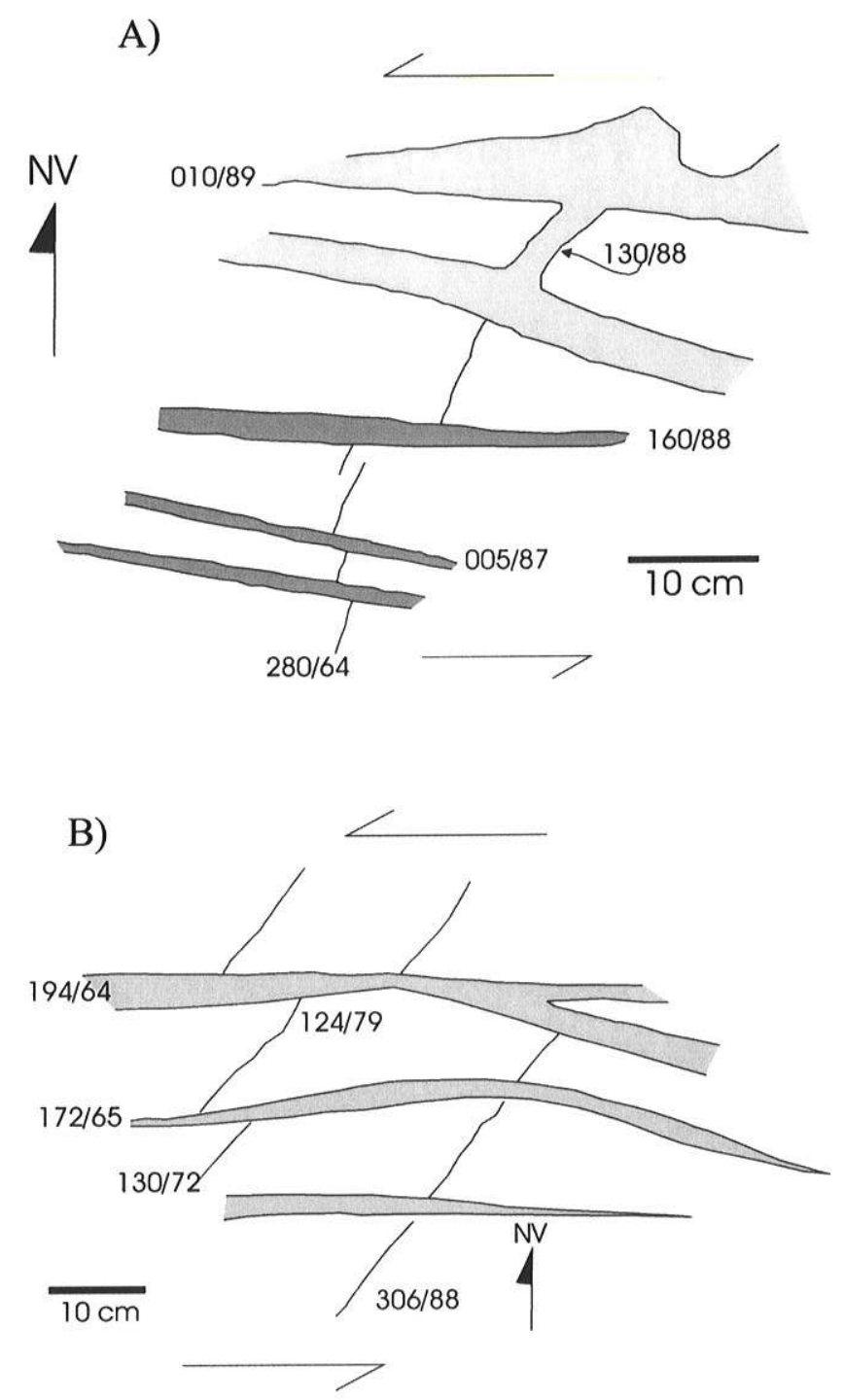

Figura 4.105 - Relação entre deformação e injeção de soluções silicosas, representadas por calcedônia e localmente por drusas de quartzo, na falha do Vale das Videiras. A) Gnaisse granítico do Batólito Serra dos Órgãos cataclasado (branco), injetado por veios de calcedônia com fragmentos de calcedônia e de gnaisse (cinza) e por veios de calcedônia maciça (cinza escuro), ambos de direção em torno de EW, que interceptam e deslocam juntas de direção NE-SW a NNE-SSW, preenchidas com calcedônia. B) Veios de calcedônia com fragmentos de calcedônia, de dirę̧ão aproximadamente E-W (cinza), e juntas preenchidas por calcedônia, de direção NE-SW. Ambas cortam calcedônia mais antiga (branca). Em ambos os casos parecem estar representadas as direções de cisalhamento sintéticas de Riedel (R e P), em torno de E-W, e a direção de tração (T), em torno de NE-SW. Vista em planta.

Na Figura 4.106 estão representadas microfalhas direcionais identificadas no Ponto Br-07, onde as famílias de direção ENE-WSW a WNW-ESE apresentam rejeito 
A)

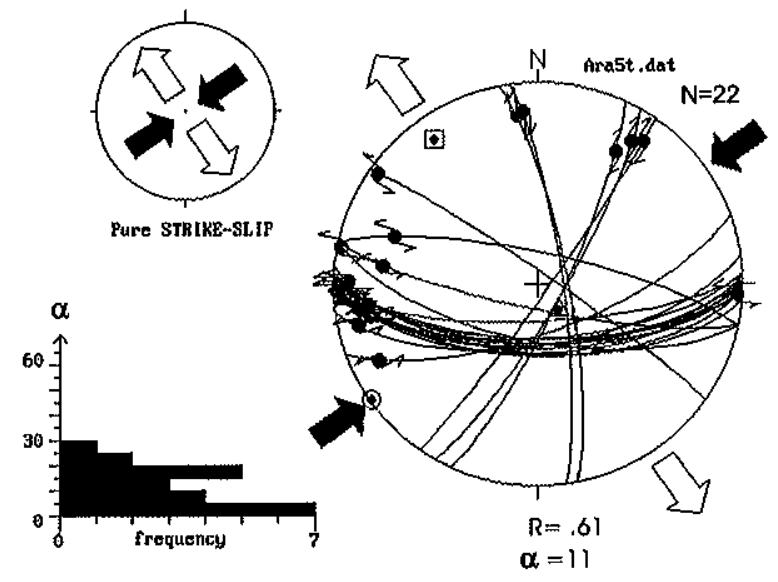

C)

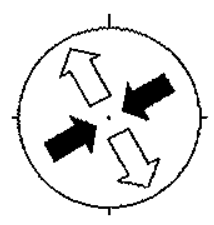

Pure STHIKE--SLIP
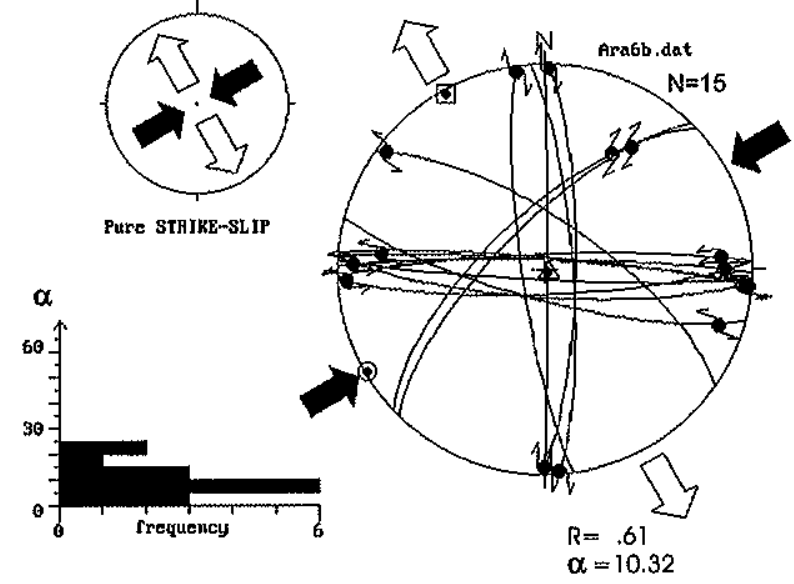

B)
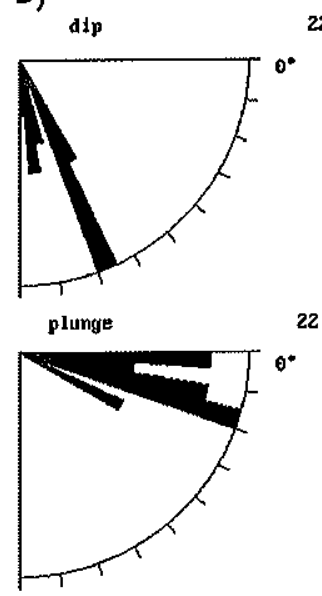

22 planes

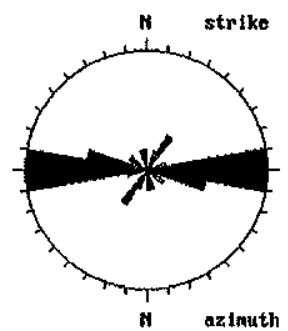

22 Ines

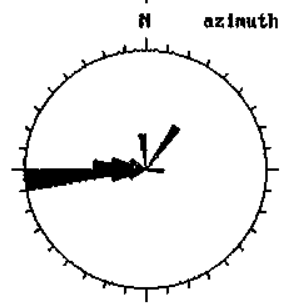

D)
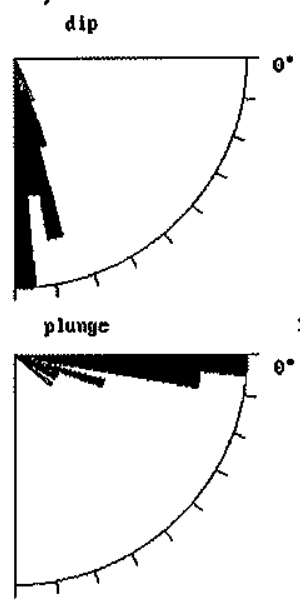

15 planes

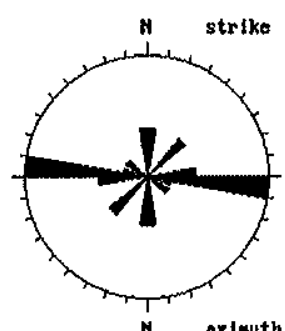

15 lines

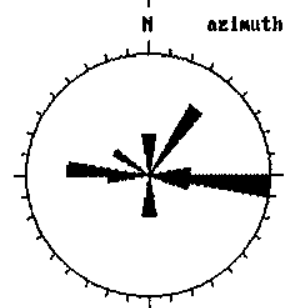

Figura 4.106 - Dados de falhas e respectivos eixos de tensões para brechas tectônicas silicificadas, Vale das Videiras, município de Petrópolis, Pontos Br-07 e Br-08. Símbolos:círculos - $\sigma 1$ (eixo de maior esforço), triângulos - $\sigma 2$ (eixo de esforço intermediário), quadrados - $\sigma 3$ (eixo de menor esforço); $\mathrm{R}$ - razão de esforço ( $\sigma 2-\sigma 3 / \sigma 1-\sigma 3$ ); $\alpha$ - desvio médio entre as estrias medidas e o cisalhamento computado sobre o plano de falha. Setas grandes cheias - eixos compressivos horizontais, setas grandes vazias - eixos distensivos horizontais. Projeções de Schmidt- Lambert, hemisfério inferior. 
sinistral (Figuras 4.95D e E) e as de direção NNE-WSW e NNW-ESE apresentam rejeito dextral. A inversão desses dados indicou que essas microfalhas foram ativadas por um campo de paleotensões DIRECIONAL Puro (Pure STRIKE-SLIP), onde o eixo de tensões principal, $\sigma 1$, posiciona-se na horizontal, segundo a direção NE-SW, o eixo de tensões mínimo, $\sigma 3$, é também horizontal e orienta-se na direção NW-SE, e o eixo de tensões intermediário, $\sigma 2$, é vertical. Esse campo de paleotensões indica que as microfalhas sinistrais são estruturas sintéticas, do tipo R e P, e que as dextrais são antitéticas, $\mathrm{R}^{\prime} \mathrm{e} \mathrm{X}$.

$\mathrm{Na}$ Figura 4.106C estão representadas microfalhas direcionais, onde as de direção E-W e WNW-ESE mostram rejeito sinistral e as de direção NE-SW e N-S apresentam rejeito dextral. A inversão desses dados evidenciou que essas microfalhas foram ativadas em um campo de paleotensões DIRECIONAL Puro (Pure STRIKESLIP), onde o eixo de tensões máximo, $\sigma 1$, posiciona-se na horizontal orientando-se segundo a direção ENE-WSW, o eixo de tensões mínimo, $\sigma 3$, é também horizontal e orienta-se na direção NNW-SSE e o eixo intermediário é vertical. Esse paleocampo permite afirmar que as falhas sinistrais são estruturas sintéticas, $R$ e $P$, e que as dextrais são antitéticas, $\mathrm{R}^{\prime} \mathrm{e} \mathrm{X}$.

\subsubsection{3. Área Oriental do Graben}

A) Falha de Barra de Sana

A Falha de Barra de Sana se estende por mais de uma dezena de quilômetros na direção NNE-SSW e limita, a oeste, um bloco falhado adernado para NE (Figura 4.95). Essa falha apresenta brechação e silicificação de forma descontínua e que, localmente, chega a apresentar uma espessura de aproximadamente 10 metros. Nessa falha foram coletados dados em duas estações distintas, localizadas em Barra de Sana (Ponto Br-10) e em Sana (Ponto Br-09), distritos do Município de Casemiro de Abreu. Em ambas as estações ficou evidenciado o caráter direcional dessa falha, como pode ser visto pelo baixo ângulo de caimento das estrias (Figura 4.104C). No Ponto Br-09, localizado $2 \mathrm{~km}$ ao norte de Sana, nos lajedos do Rio Sana, a falha se evidencia por 
planos cataclasados cortando um granito leucocrático, isotrópico, de granulação grossa, aos quais localmente estão associados veios de calcedônia. $O$ arranjo anastomosado e a geometria das estruturas secundárias indicaram uma movimentação direcional dextral para essa falha (Figura 4.107). Em Barra de Sana as brechas destacam-se por erosão diferencial, constituindo um paredão de cerca de 10 metros de altura que desvia o curso do Rio Macaé (Figura 4.104A).

$\mathrm{Na}$ Figura 4.108A estão representadas duas famílias de microfalhas e falhas direcionais que afetam as brechas tectônicas silicificadas em Barra de Sana, Ponto Br10, onde as de direção NNE-SSW apresentam rejeito dextral e as de direção NW-SE mostram rejeito sinistral. A inversão dos dados indicou que essas estruturas foram ativadas por um campo de paleotensões DIRECIONAL Puro (Pure STRIKE-SLIP), onde o eixo de tensões máximo, $\sigma 1$, posiciona-se na horizontal segundo a direção NESW, o eixo de tensões mínimo, $\sigma 3$, é também horizontal e orienta-se na direção NW$\mathrm{SE}$ e o eixo intermediário, $\sigma 2$, é vertical.

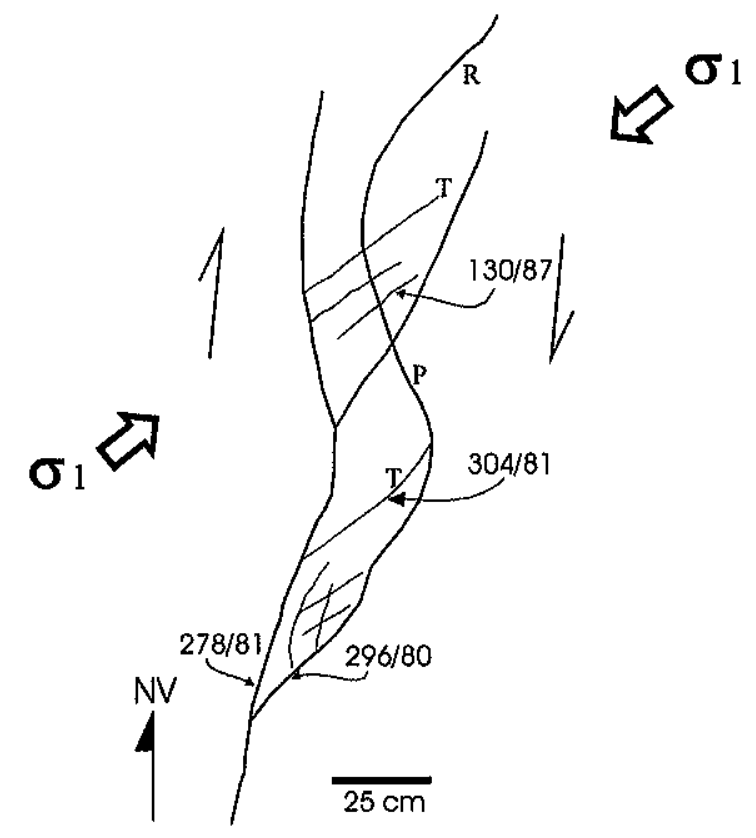

Figura 4.107 - Faixas anastomosadas de granito cataclasado (Granito Sana) de direção NNE-SSW a NNW-SSE, percoladas por calcedônia, interceptando e, localmente, interceptadas por juntas de extensão preenchidas por calcedônia maciça, de direção NE-SW. Esse arranjo é compatível com uma movimentação direcional dextral aproximadamente N-S. Lajedo do Rio Sana, aproximadamente $2 \mathrm{~km}$ ao norte de Sana e cerca de $25 \mathrm{~km}$ ao norte de Casemiro de Abreu (Ponto Br-09). 
A)

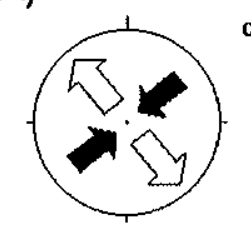

Pure SIRIKE-SLIP

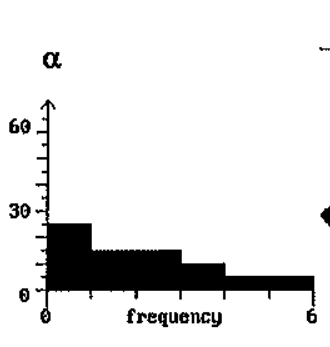

cao1a.dat
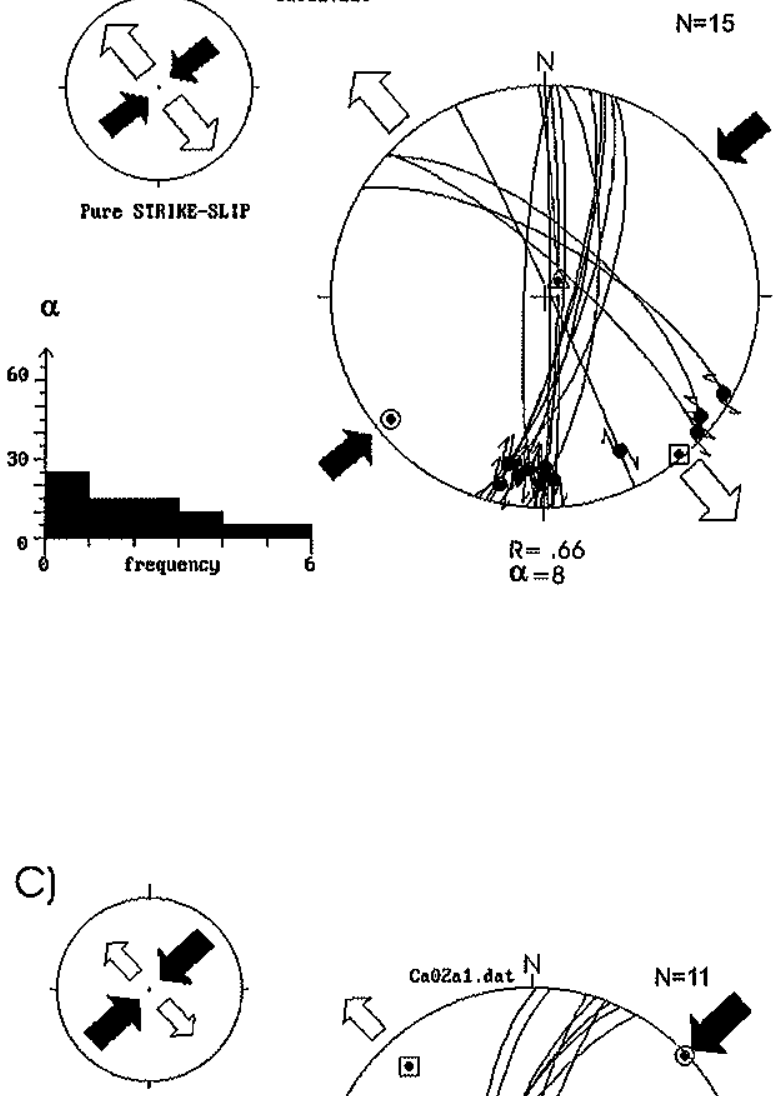

Compress Ive STRIKE-SLIP

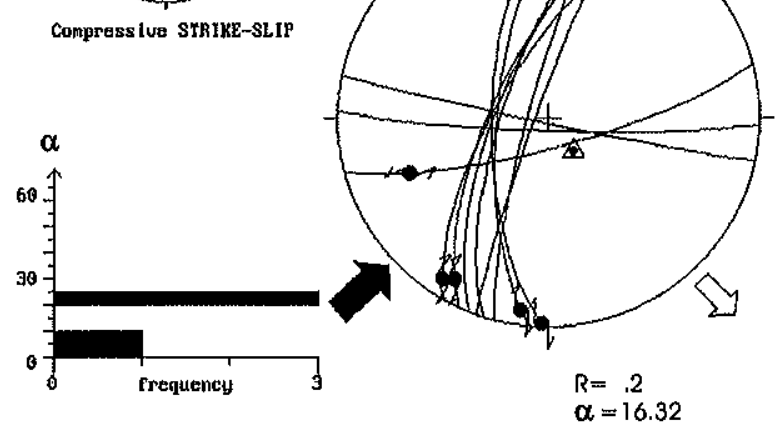

B)
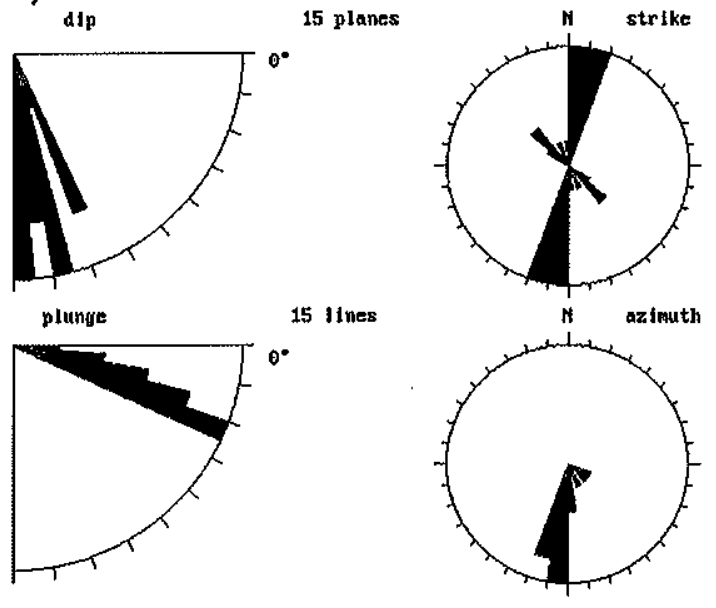

Figura 4.108- Dados de falhas e respectivos eixos de tensões para brechas tectônicas silicificadas, Município de Casemiro de Abreu, distritos de Barra de Sana, Ponto Br-10, e Sana, Ponto Br-09. Símbolos:círculos - $\sigma 1$ (eixo de maior esforço), triângulos $-\sigma 2$ (eixo de esforço intermediário), quadrados - $\sigma 3$ (eixo de menor esforço); $R$ - razão de esforço $(\sigma 2-\sigma 3 / \sigma 1-\sigma 3) ; \alpha$ - desvio médio entre as estrias medidas e o cisalhamento computado sobre o plano de falha. Setas grandes cheias - eixos compressivos horizontais, setas grandes vazias - eixos distensivos horizontais. Projeções de Schmidt- Lambert, hemisfério inferior. 
$\mathrm{Na}$ Figura 4.108C estão representadas duas famílias de microfalhas conjugadas que afetam bordas de veios de calcedônia injetados em granito, na localidade de Sana, Ponto Br-09. As microfalhas de direção E-W apresentam rejeito sinistral, enquanto que as de direção NNE-SSW possuem rejeito dextral. Na família de microfalhas de direção E-W foram incluídos, como fraturas de cisalhamento, dois veios de calcedônia cataclasados nos quais não foi possível medir as estrias. A inversão desse conjunto de dados indicou que essas estruturas foram ativadas por um campo de paleotensões DIRECIONAL Puro (Pure STRIKE-SLIP), no qual o eixo de tensões máximo, $\sigma 1$, posiciona-se na horizontal e orienta-se na direção NE-SW, o eixo de tensões mínimo, $\sigma 3$, posiciona-se também na horizontal segundo a direção NW-SE e o eixo intermediário, $\sigma 2$, é vertical.

\section{B) Cabo Frio}

Em Cabo Frio foram caracterizadas brechas tectônicas silicificadas na entrada da cidade, junto à ponte sobre o Canal Palmer (Ponto Br-11). Essas brechas apresentam espessura métrica e alongam-se na direção ENE-WSW. Elas são afetadas por microfalhas cujas estrias mostram alta obliqüidade, evidenciando o seu caráter normal. Na Figura 4.109 estão representadas microfalhas normais com direção em torno de E-W e com mergulho para norte. A inversão desses dados indicou que essas microfalhas foram ativadas por um campo de paleotensões EXTENSIONAL Puro (Pure EXTENSIVE), onde o eixo de tensões máximo, $\sigma 1$, posiciona-se na vertical, o eixo de tensões mínimo, $\sigma 3$, é horizontal e orienta-se na direção NNW-SSE e o eixo intermediário, $\sigma 2$, também horizontal, orienta-se na direção ENE-WSW.

C) São Pedro da Aldeia

No Município de São Pedro da Aldeia foram identificadas brechas tectônicas silicificadas na Praia Linda, localizada na Lagoa de Araruama, no Bairro do Boqueirão (Ponto Br-12). Elas orientam-se na direção ENE-WSW e sua projeção 


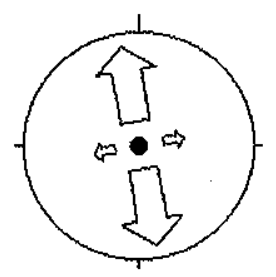

Pure EXTENSIUE

A)

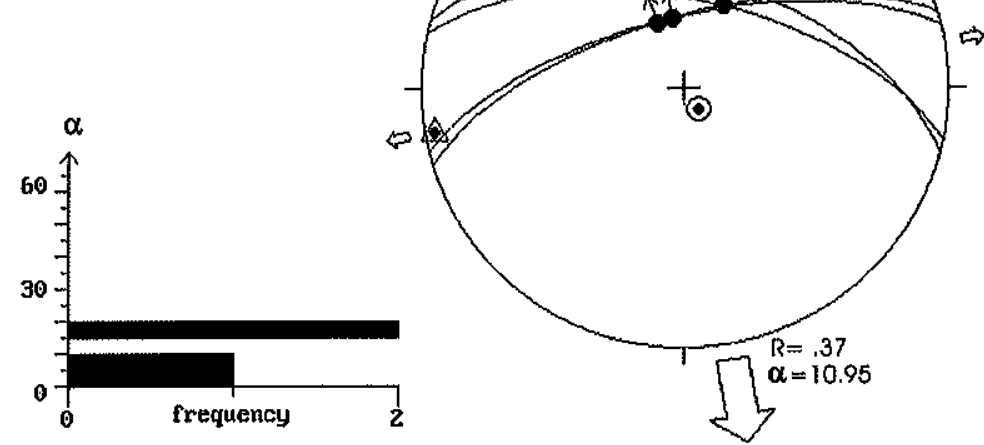

B)

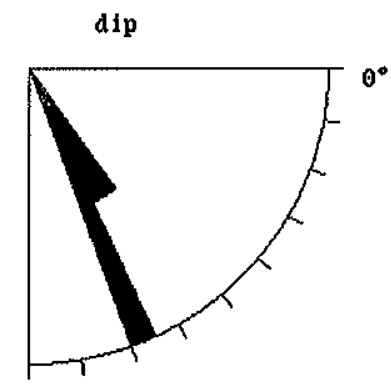

4 planes

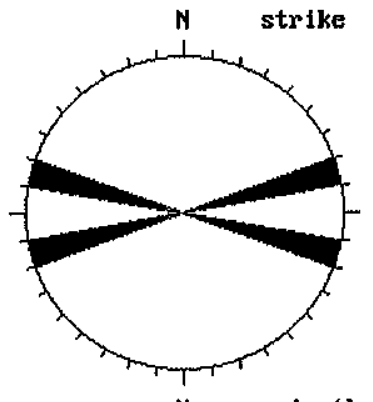

plunge

4 lines
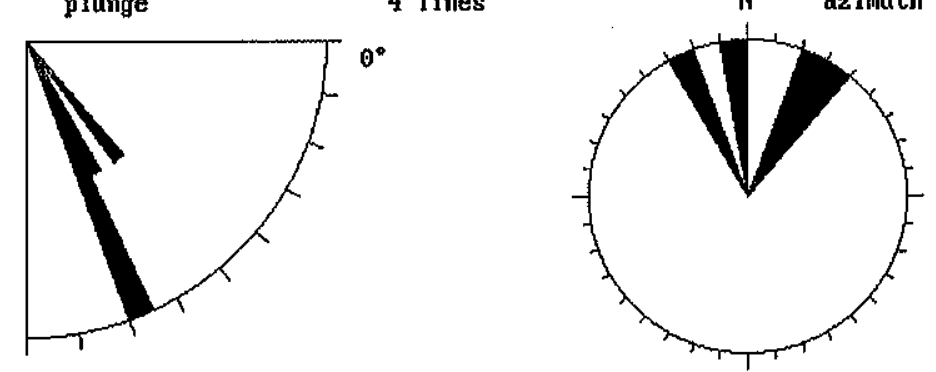

Figura 4.109 - Dados de falhas e respectivos eixos de tensões para brechas tectônicas silicificadas, Cabo Frio, junto à ponte sobre o Canal Palmer. Ponto Br-11. Símbolos:círculos - $\sigma 1$ (eixo de maior esforço), triângulos $-\sigma 2$ (eixo de esforço intermediário), quadrados - $\sigma 3$ (eixo de menor esforço); $\mathrm{R}$ - razão de esforço ( $\sigma 2-\sigma 3 / \sigma 1-\sigma 3$ ); $\alpha$ - desvio médio entre as estrias medidas e o cisalhamento computado sobre o plano de falha. Setas grandes cheias - eixos compressivos horizontais, setas grandes vazias - eixos distensivos horizontais. Projeções de Schmidt- Lambert, hemisfério inferior. 
lateral alinha-se com as identificadas junto ao Canal Palmer, em Cabo Frio (Ponto Br11), podendo representar uma única falha. As brechas afetam migmatitos graníticos bandados, ocorrendo ainda veios de calcedônia, com ângulo de mergulho em torno de $65^{\circ}$, nos quais localmente pode-se identificar estrias nas bordas. $\mathrm{Na}$ Figura 4.110 estão representadas microfalhas normais com direção em torno de $\mathrm{E}-\mathrm{W}$ e veios de calcedônia onde não foram identificadas estrias e não há evidencias de cataclase. Esses veios foram plotados como estruturas extensionais. A inversão dos dados indicou que essas estruturas foram ativadas por um campo de paleotensões EXTENSIONAL Puro (Pure EXTENSIVE), onde o eixo de tensões máximo, ol, posiciona-se na vertical, os eixos de tensões mínimo, $\sigma 3$, e intermediário, $\sigma 2$, são horizontais e orientam-se segundo as direçõe NNW-SSE e ENE-WSW, respectivamente.

\subsubsection{Síntese das Paleotensões Determinadas para as Brechas Tectônicas Silicificadas}

As paleotensões determinadas a partir das brechas tectônicas silicificadas estão sintetizadas na Figura 4.111. Essas paleotensões foram caracterizadas principalmente a partir das microfalhas e falhas presentes na borda e no interior das brechas, mas também a partir da direção de veios de calcedônia maciços, injetados nas brechas ou no embasamento, os quais, em São Pedro da Aldeia, foram tratados como diques. Tais dados evidenciam uma persistência na orientação do eixo de tensão máxima horizontal, SHmax, segundo a direção NNE-SSW e ENE-WSW, o qual na maior parte dos locais representa o eixo de tensões máximo, $\sigma 1$, indicando a atuação de um regime de paleotensões direcional. Esse regime de paleotensões foi responsável por uma movimentação sinistral das falhas de direção ENE-WSW e pela movimentação dextral das de direção NNE-SSW. Em alguns locais, como nas falhas das Paineiras, das Videiras e de Barra de Sana, as relações geométricas entre os veios de calcedônia maciça e as brechas silicificadas permitem inferir que esse campo de paleotensões foi concomitante com o hidrotermalismo.

Esse hidrotermalismo mostra evidências de ter sido controlado, mais restritamente, por um regime de tensões extensional, como pode ser visto na Ilha do 


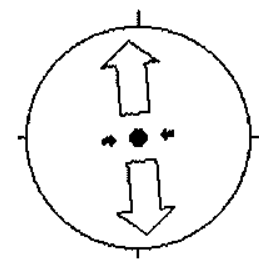

Pure Extensive

A)

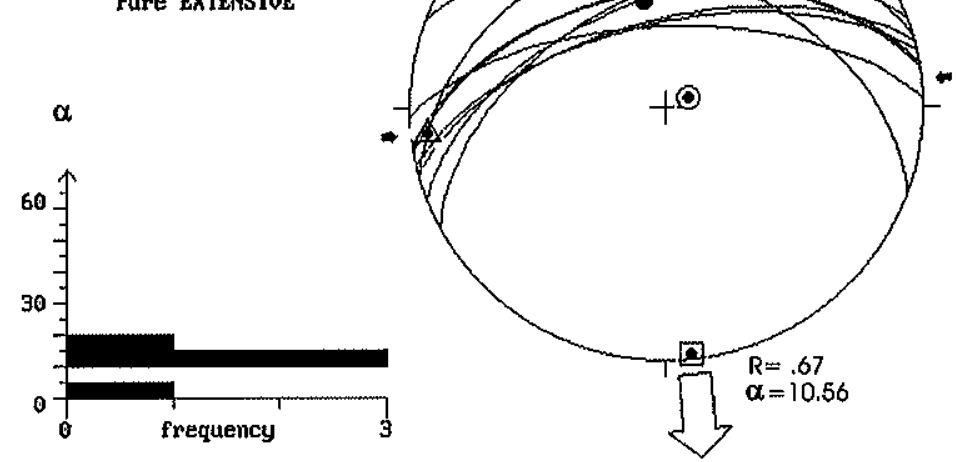

B)

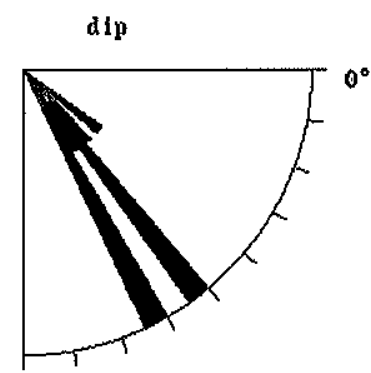

9 planes

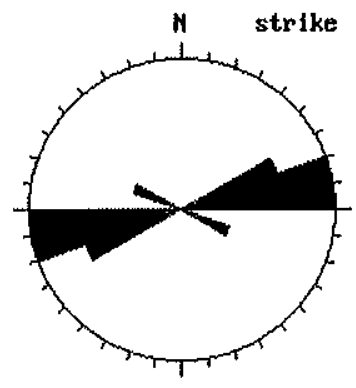

plunge

5 lines

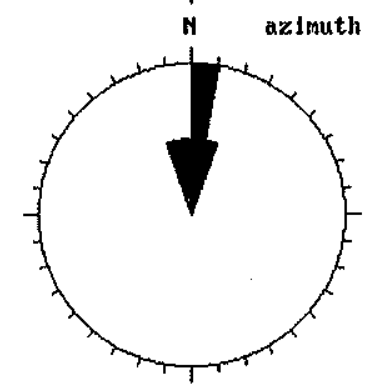

Figura 4.110-Dados de falhas e respectivos eixos de tensões para brechas tectonicas silicificadas de São Pedro da Aldeia, Praia Linda. Bairro do Boqueirão, Ponto Br-12. Símbolos: círculos - $\sigma 1$ (eixo de maior esforço), triângulos $-\sigma 2$ (eixo de esforço intermediário), quadrados $-\sigma 3$ (eixo de menor esforço); $\mathrm{R}$ - razão de esforço ( $\sigma 2-\sigma 3 / \sigma 1-\sigma 3) ; \alpha$-desvio médio entre as estrias medidas e o cisalhamento computado sobre o plano de falha. Setas grandes cheias - eixos compressivos horizontais, setas grandes vazias - eixos distensivos horizontais. Em A os planos sem estrias representam veios de calcedônia, plotados como planos de tração " $T$ ". Projeções de Schmidt-Lambert, hemisfério inferior. 


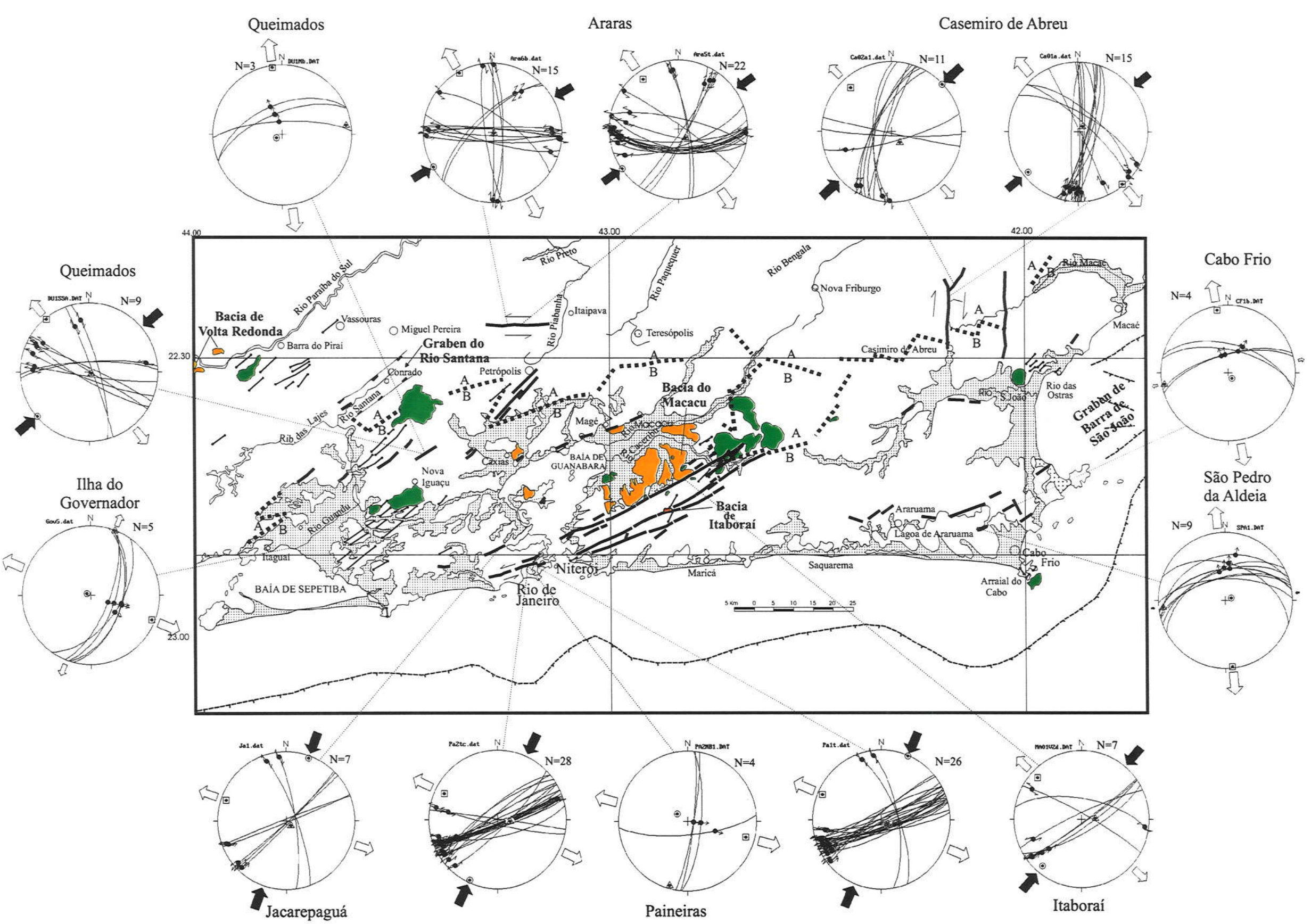

Figura 4.111 - Mapa síntese das paleotensões determinadas nas brechas tectônicas silicificadas, a partir de falhas e microfalhas. Símbolos: círculos $-\sigma_{1}$ (eixo de tensão máxima), triângulos - $\sigma_{2}$ (eixo de tensão intermediária), quadrados - $\sigma_{3}$ (eixo de tensão mínima); Setas grandes cheias - eixos compressivos horizontais, setas grandes vazias - eixos distensivos horizontais. Bolas pretas - estrias, setas pequenas - sentido do movimento dos blocos. Projeçoes de Schmidt-Lambert, hemisfério inferior. Geologia de acordo com a legenda da Figura 4.1. 
Governador e em Cabo Frio e São Pedro da Aldeia, na Região dos Lagos, onde estão presentes veios de calcedonia maciços, com ângulo de mergulho de valor intermediário, em alguns casos com borda falhada em caráter normal. Nesses casos registra-se uma variação na orientação de SHmax, entre a direção NNE-SSW, na Ilha do Governador, e E-W, na Região dos Lagos.

$\mathrm{Na}$ Falha das Paineiras e em Queimados foram regitradas evidências de uma movimentação normal dessas estruturas. Tal movimentação, porém, foi posterior à direcional, como indica a superposição de estrias nos planos de falha. Nesse caso, a movimentação normal foi posterior ao hidrotermalismo.

\subsubsection{Discussão}

A ausência de bom controle geocronológico para essas brechas tectônicas silicificadas impede que se determine a abrangência temporal do campo de paleotensões direcional que as controlou. A idade $\mathrm{K}$-Ar de $50 \mathrm{Ma}$ determinada para a mineralização de fluorita de Tanguá (Santos 1994), indica que esse campo de paleotensões atuou pelo menos até o Eoceno Inferior. A discrepância dessa idade com relação às dos outros corpos alcalinos intrusivos da área central do graben, todos com idades do limite Cretáceo Superior-Terciário Inferior, e sua compatibilidade de idade com o vulcanismo tardio, representado pelas lavas ankaramíticas (Riccomini et al.1983, Riccomini \& Rodrigues Franciasco, 1992), contemporâneas ao magmatismo alcalino do Alto de Cabo Frio (Mohriak \& Barros 1990), sugere que as brechas tectônicas silicificadas poderiam representar um evento tectônico regional tardio ao magmatismo alcalino. Por outro lado, o hidrotermalismo que gerou os veios de calcários travertinos paleocênicos da Bacia de São José do Itaboraí mostra que esse tipo de processo atuou anteriormente ao evento que gerou os derrames máficos. Ainda nesse sentido, os campos de paleotensões determinados a partir dos maciços alcalinos e dos diques a eles associados, também de caráter direcional e com o eixo de tensões máximo, $\sigma 1$, orientado na direção NE-SW, apontam a possibilidade de que as brechas tectônicas silicificadas tenham a idade dos corpos aos quais elas são periféricas, sendo nesse caso mais antigas na área ocidental e mais novas na oriental. 
A variação local para um regime de paleotensões puramente extensional pode estar relacionada tanto a uma permutação na posição dos eixos de paleotensões máximo e intermediário, associada a um aumento na magnitude de $\sigma z$, como à um aumento na pressão de fluidos associada ao hidrotermalismo. A ocorrência na Ilha do Governador e São Pedro da Aldeia de veios maciços de calcedônia, com mergulho de valor intermediário, intrudidos sob um regime puramente extensional, sugere que a primeira hipótese é a mais provável.

Essas variações locais para um campo de paleotensões extensional contrapõese à tendência para um campo de paleotensões direcional compressivo identificado em alguns locais. Tais discrepâncias sugerem ser mais provável a hipótese de que as falhas com brechas tectônicas silicificadas foram geradas em eventos diacrônicos, acompanhando o resfriamento dos corpos aos quais elas são periféricas.

\subsubsection{Conclusões Parciais}

1) A análise geométrica dos veios de calcedônia maciça que cortam as brechas tectônicas silicificadas e o embasamento, bem como a análise cinemática das falhas e microfalhas que as afetam indicam que o evento tectônico que as gerou foi controlado por um campo de paleotensões direcional, onde $\sigma 1$ orientava-se na direção NE-SW e $\sigma 3$ na direção NW-SE;

2) Variações locais nesse campo de paleotensões para um regime puramente extensional, mantendo-se as direções de SHmax e Shmin, foram caracterizadas na Ilha do Governador e na Região dos Lagos e parecem estar associadas a uma permutação dos eixos de paleotensões máximo e intermediário, associada a um aumento na magnitude de $\sigma \mathrm{z}$;

3) A única datação disponível para essas brechas tectônicas silicificadas, obtida na mineralização de fluorita de Tanguá (Santos 1994), indica que o campo de paleotensões que as gerou atuou até pelo menos o Eoceno Inferior (50Ma); 
4) A ocorrência de brechas tectônicas silicificadas sotopostas a sedimentos da Formação Macacu, não afetados por elas, indica que o evento que as formou precede a implantação da Bacia do Macacu. 


\section{INDICADORES CINEMÁTICOS RÚPTEIS}

\subsection{INTRODUÇÃO}

A caracterização do sentido do movimento das falhas é condição básica para que se realize a inversão adequada dos pares de dados representados por falhas e estrias, visando a determinação do campo de paleotensões responsável pela sua geração. Essa caracterização tem como parâmetros clássicos o deslocamento relativo de marcadores anteriores à falha e às dobras de arrasto.

Porém, no caso de rochas ígneas, como os corpos e diques de rochas alcalinas tratadas no presente trabalho, essas feições muitas vezes não estão presentes, principalmente as dobras de arrasto. Essa dificuldade é acentuada no caso de microfalhas, devido ao pequeno rejeito. Em tais situações a cinemática das falhas é caracterizada com base nos indicadores cinemáticos rúpteis desenvolvidos sobre e nas bordas dos planos de falhas (ver Capítulo 3.1.2.1.). Mais raramente, no caso do presente trabalho, foi possível caracterizar a cinemática a partir do preenchimento sincinemático de veios, como pode ser visto na Figura 4.90.

\subsection{EXEMPLOS DE INDICADORES CINEMÁTICOS DETERMINADOS NAS ROCHAS DO EMBASAMENTO}

Diversos indicadores cinemáticos rúpteis, presentes nas rochas alcalinas, foram mostrados nos Capítulos 4.2., 4.3. e 4.4. Em geral esses indicadores são caracterizados no próprio afloramento, como por exemplo nas Figuras 4.5, 4.7 e 4.10 e 4.104D. No caso da Figura 4.10 foi possível conjugar as indicações de marcadores anteriores à falha com indicadores cinemáticos, que no caso são fibras de calcita.

Em outros casos essa caracterização só é confirmada em amostras de mão, como por exemplo no caso da Figura 4.11. 


\subsubsection{Caracterizados a Olho $\mathrm{Nu}$}

Na Figura 5.1 vê-se uma amostra de um plano de falha de caráter normal, com atitude $107 / 67$, na qual pode-se identificar duas famílias de estrias, uma levemente oblíqua e outra vertical. Nessa falha, que ocorre no Complexo de Itaúna (Ponto 1, da Figura 4.35) afetando microssienito, as estrias verticais se sobrepõem às levemente oblíquas evidenciando que foram produzidas por um pulso mais recente da falha. As marcas de objetos relacionadas a cada um dos pulsos (Figuras 5.1A e 5.1C) indicam que ambos tiveram caráter normal. Ambas as marcas terminam na porção mais larga do traço formado com o arraste do objeto pelo bloco perdido. No caso da Figura 5.1C ficou marcado o buraco assimétrico gerado pelo objeto daí retirado. A profundidade maior do buraco se posiciona no sentido do movimento do bloco perdido.

Na Figura 5.2 vê-se amostra de superfície de falha que afeta a borda de um dique de basalto alcalino, na Pedreira Emasa (dique 4 da Figura 4.9). Na Figura 5.2B podem ser observados planos de tração preenchidos por calcita (tension gashes), ortogonais ao sentido de movimento do bloco perdido. As orientações dos planos de fraturas secundárias, $\mathrm{R}, \mathrm{P}$ e $\mathrm{T}$, vistos em cortes ortogonais ao plano de falha $\mathrm{e}$ paralelos às estrias, confirmam a cinemática da referida falha.

A Figura 5.3 refere-se a planos estriados associados a uma falha reversa que afeta fonolito no Complexo de Itaúna (Ponto 1 da Figura 4.35). Na Figura 5.3A temse marcas de objetos, constituídos por pequenos grãos de sanidina, tanto na forma de relevo positivo alongado como de rastros côncavos, que terminam sempre no grão responsável pela sua geração. Dessa forma, essas caudas apontam no sentido oposto ao do movimento do bloco perdido. A Figura 5.3B apresenta uma imagem dessa superfície de falha, obtida no MEV, na qual estão evidenciadas marcas de objetos. $O$ aumento de 150X com o qual essa imagem foi obtida, indica que, nessa amostra, tal indicador pode ser observado em meso e microescala. Na Figura $5.3 \mathrm{C}$ vê-se uma cunha convexa sobre o plano de falha, onde o declive do lado estriado e "desbastado" aponta no sentido oposto ao do movimento do bloco perdido. 

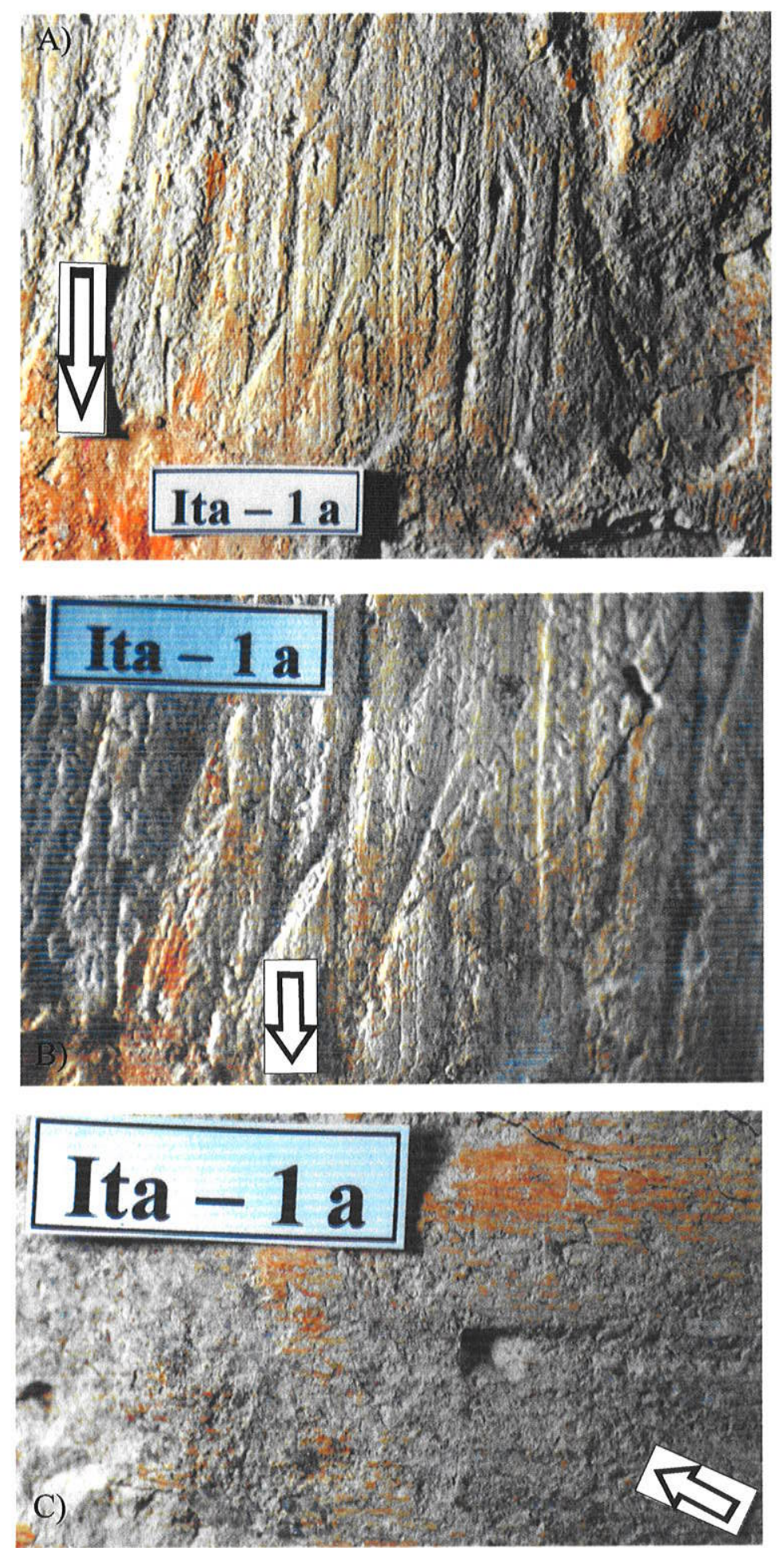

Figura 5.1 - Fotos de plano de falha, de caráter normal, que afeta microssienito no Maciço de Itaúna (Ponto 1 da Figura 4.35). A) Duas famílias de estrias distintas, onde as levemente oblíquas são as mais antigas, mostrando-se superimpostas e interceptadas pelas estrias verticais. A seta, com 2,5 cm de comprimento, indica o sentido do movimento mais recente do bloco perdido; B) Detalhe da situação anterior. Seta com 1,0 cm de comprimento; C) Marca de objeto associada ao grupo de estrias mais antigo, com amostra rotacionada de 90 graus no sentido horário. Notar a assimetria da cavidade formada pela compressão do objeto pelo bloco perdido. A seta, de 0,5 de comprimento, indica o sentido do movimento do bloco perdido, gerador das estrias oblíquas. 

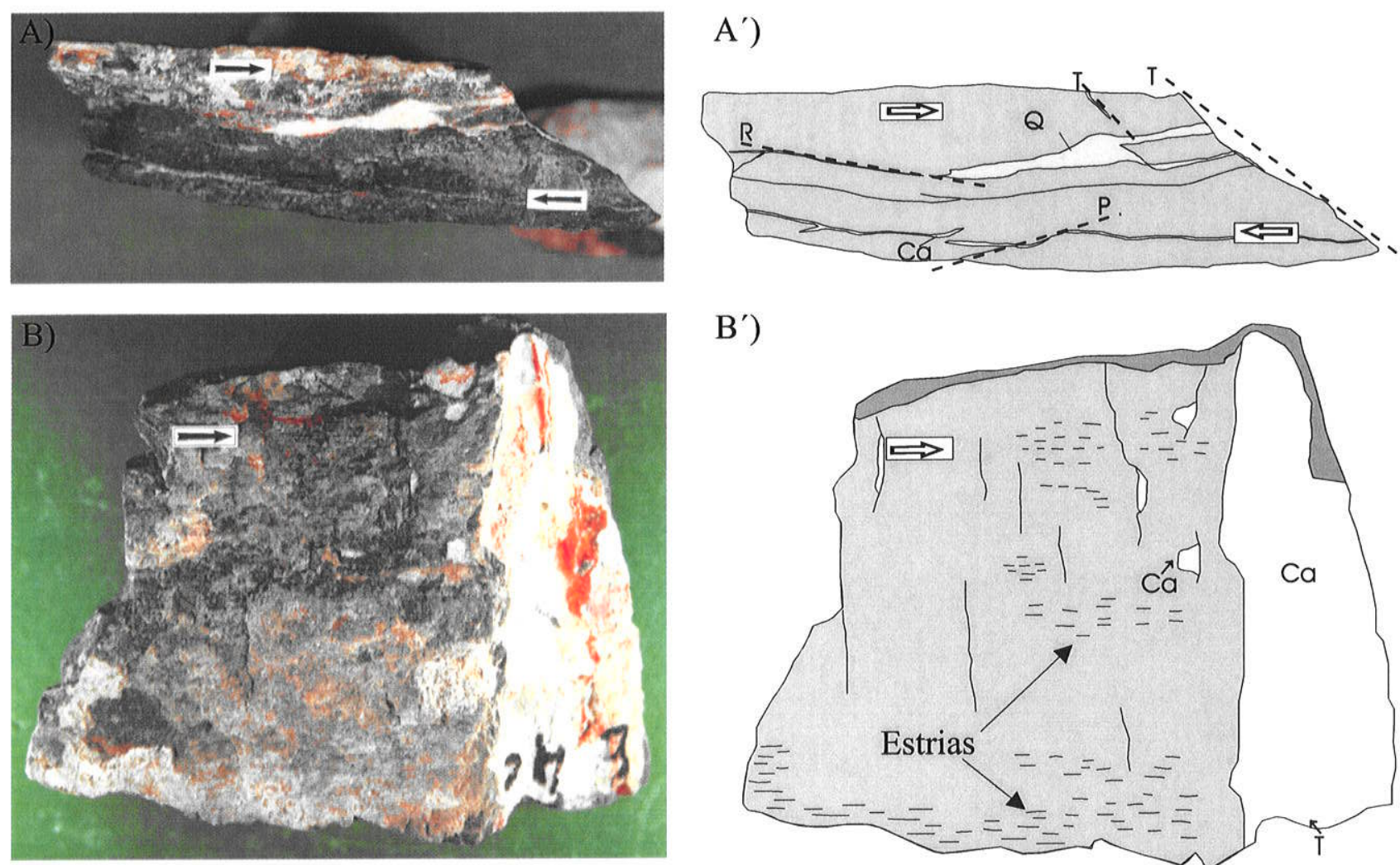

$\mathrm{B}^{\prime}$ )
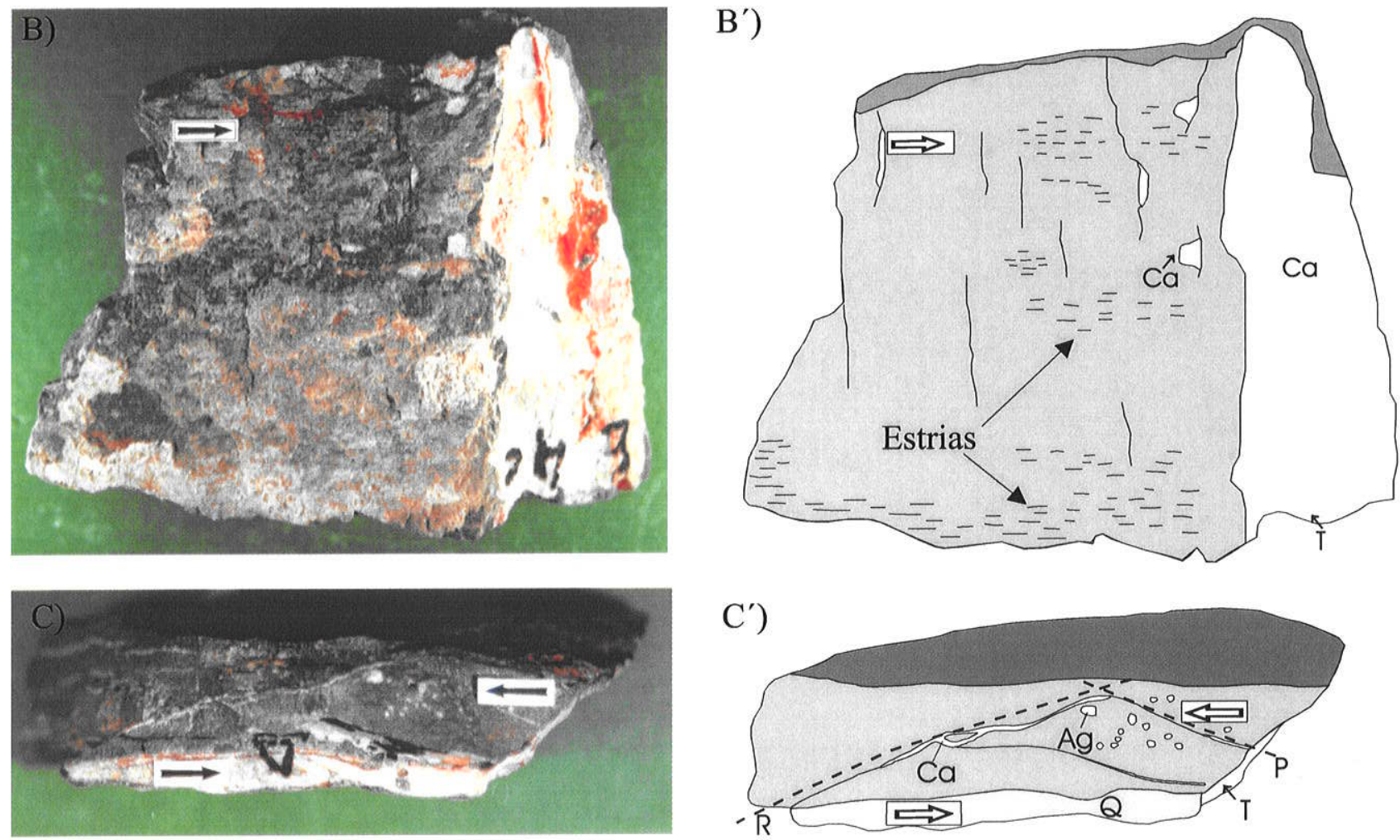

Figura 5.2 - Fotos de amostras evidenciando falha direcional sinistral em borda de dique de basalto alcalino, com atitude 160/86, que ocorre na Pedreira Emasa (dique 4 da Figura 4.9). B) e B') Estrias sub-horizontais e fraturas de extensão preenchidas por calcita (Ca); A) e $\mathrm{A}^{\prime}$ ) e C) e $\mathrm{C}^{\prime}$ ) Vista dos perfis de topo e de base da amostra, respectivamente, evidenciando planos secundários, especialmente os planos de tração, T, preenchidos por calcita. R e P representam planos sintéticos de Riedel, Ag indica amígdalas com calcita e Q representa quartzo. 
A)

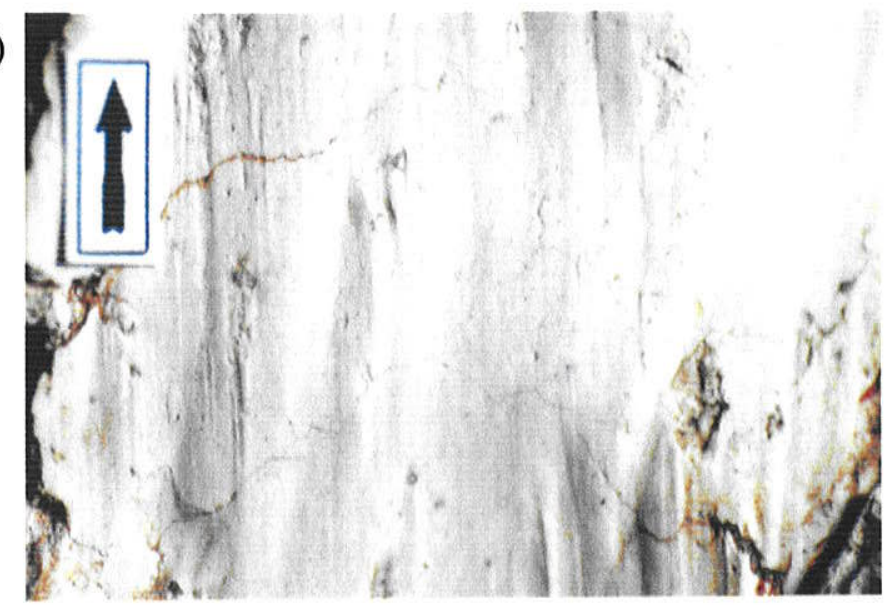

B)

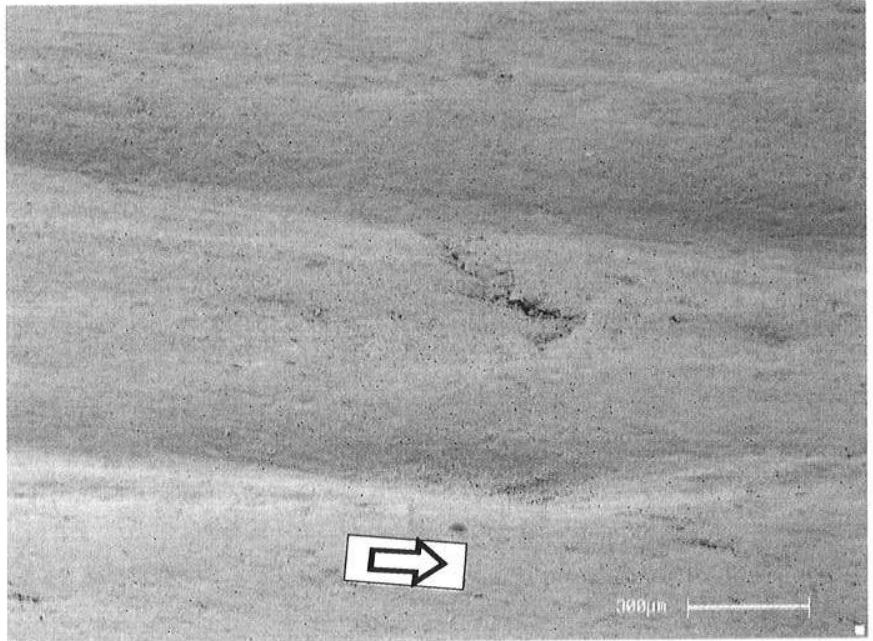

C)

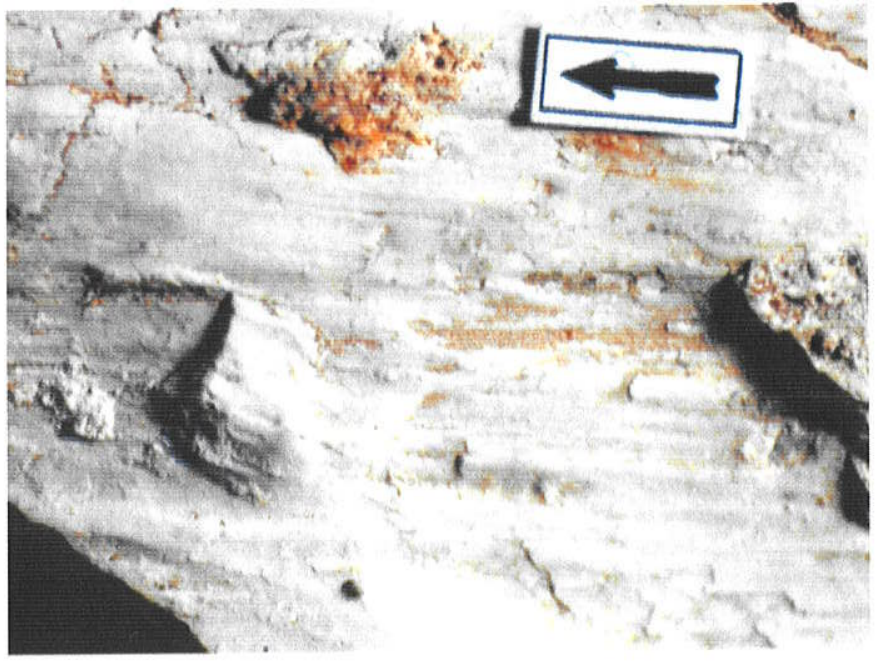

Figura 5.3 - Fotos e imagem de MEV de amostras de plano de falha reversa que afeta fonolito no Maciço de Itaúna (Ponto 1 da Figura 4.35). A) Marcas de objetos gerados pelo movimento dos blocos de falha sobre grãos de sanidina. As marcas constituem caudas, com relevo positivo e negativo, que apontam no sentido oposto ao do movimento do bloco perdido. Seta com 0,5 cm; B) Imagem obtida no MEV, mostrando marcas de objetos com relevo negativo. Mesma amostra anterior, girada de 90 graus no sentido horário. Aumento de 150X; C) Mesmo plano de falha, com amostra girada de 90 graus com relação à anterior, no sentido anti-horário, mostrando cunha convexa isolada pela falha. O lado estriado e de relevo mais suave aponta no sentido oposto ao do movimento do bloco perdido. Seta com $0,5 \mathrm{~cm}$. 


\subsubsection{Caracterizadas no Microscópio Eletrônico de Varredura - MEV}

Amostras de alguns planos de falhas foram selecionados para investigação com microscópio eletrônico de varredura - MEV, visando principalmente a melhor caracterização da morfologia desses planos e subordinadamente a análise qualitativa dos eventuais materiais de preenchimento dessas falhas, com o auxílio do EDS.

Na Figura 5.4 podem ser vistas imagens obtidas com o MEV, da superfície de uma falha de caráter normal que afeta microssienito no Complexo de Itaúna (Ponto 1 da Figura 4.35). Nas Figuras 5.4A e B são vistos planos secundários de tração, $T$, subordinados à falha, apresentando arranjo escalonado. A orientação dos cristais neoformados indica que a extensão foi ortogonal às fraturas. A imagem da Figura 5.3C, obtida com o detector de elétrons retroespalhados (QBSD) indica que os cristais neoformados tem composição semelhante à rocha original, tendo em vista que não estão presentes alterações de tonalidade.

$\mathrm{Na}$ Figura 5.5A pode ser vista a imagem de uma superfície de falha de caráter normal, com atitude 215/50, desenvolvida em fonolito no Complexo de Itaúna (Ponto 16 da Figura 4.35). A presença de uma cunha, gerada pela retirada de material da superfície da falha, indica o sentido do movimento do bloco perdido.

De fato, as melhores caracterizações de hidrotermalismo associado a falhas, com o auxílio do MEV, foram obtidas no diabásio da Pedreira Simgra (dique 1 da Figura 4.6), apesar de termos bons exemplos visíveis a olho nú, como é o caso das Figuras 4.10C e 4.11B. Mesmo que as paleotensões associadas à intrusão dos diques de diabásio não estejam sendo discutidas no presente trabalho, tais feições estão sendo mostradas, tendo em vista o seu caráter diagnóstico e o fato de que outras semelhantes foram identificadas nas falhas que afetam as rochas alcalinas do Cretáceo Superior e Paleógeno.

As Figuras 5.5B e C ilustram exemplos de minerais cristalizados sobre o plano de falha durante o movimento, caracterizados como fibras de calcita. Na Figura 5.5B pode-se observar que esses minerais se cristalizam em espaços que são criados com o movimento. Essa feição foi identificada em uma falha direcional sinistral desenvolvida na borda de um dique de diabásio presente na Pedreira Simgra.

Na Figura 5.6A tem-se, novamente, um exemplo colhido em uma amostra do diabásio da Pedreira Simgra afetado por falha, onde uma superfície estriada desenvolvida no diabásio é coberta por carbonato maciço após a cessação do 
A)

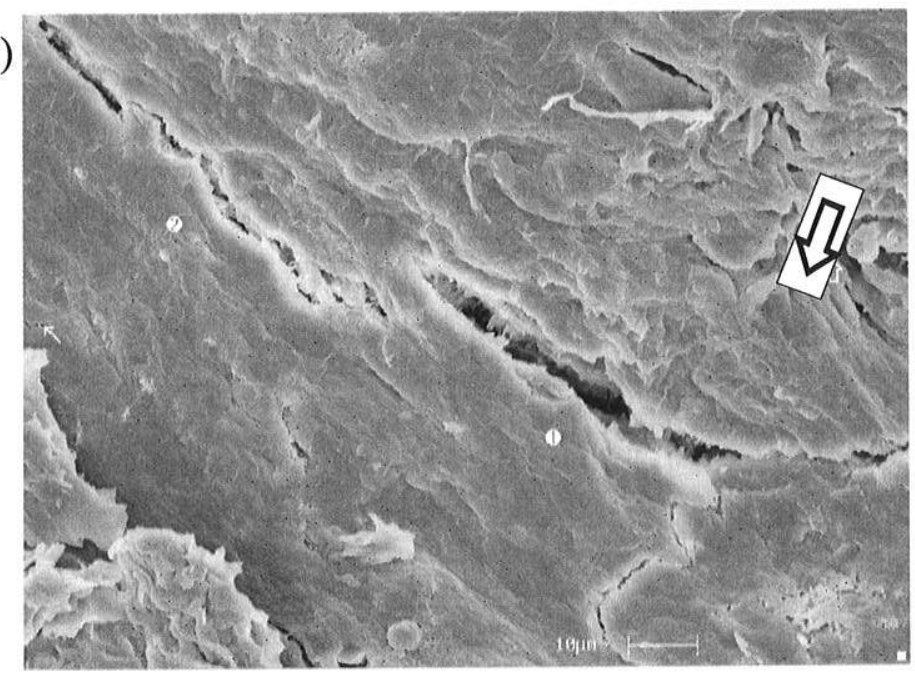

B)

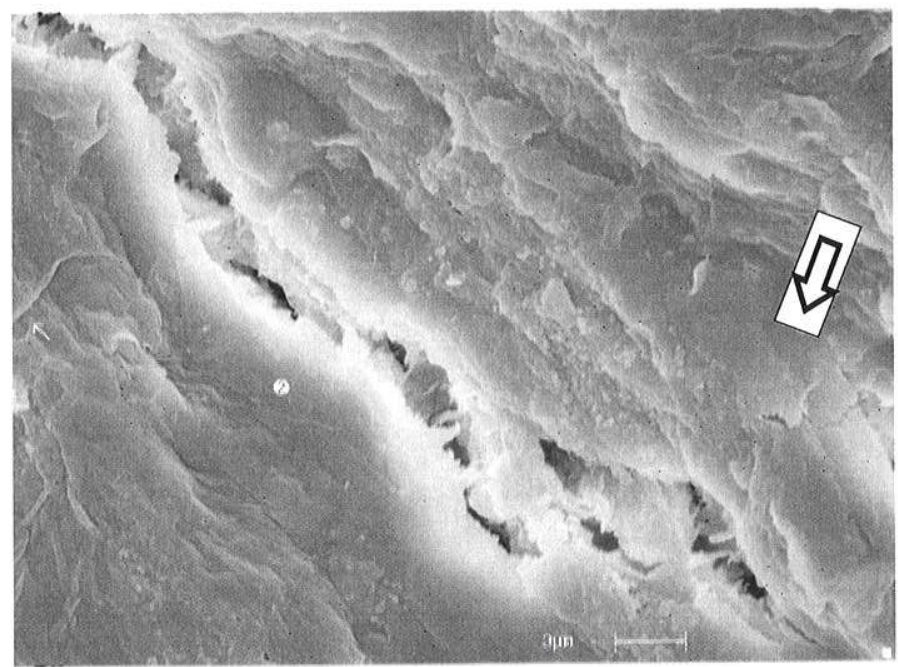

C)

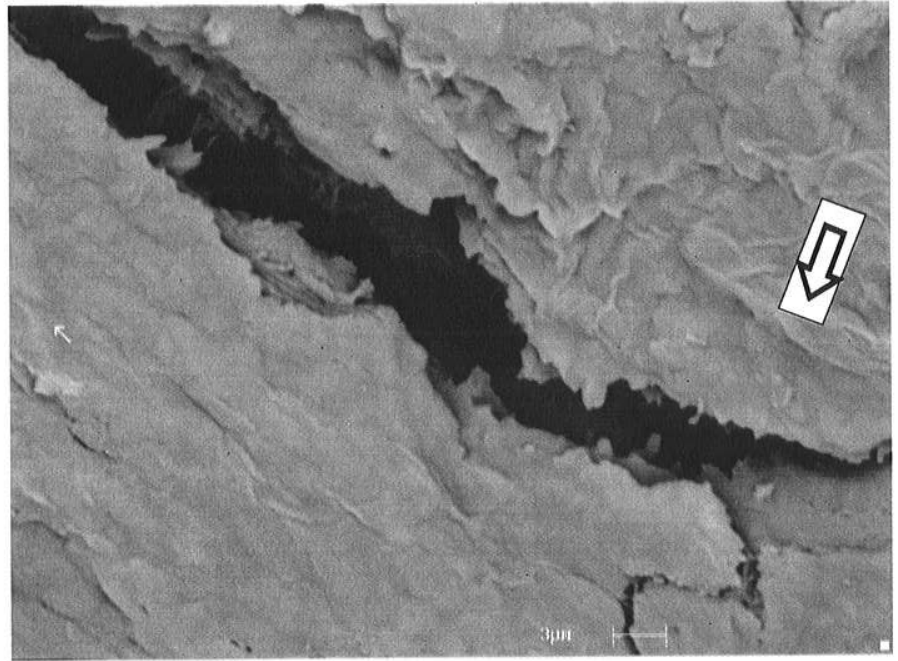

Figura 5.4- Imagens obtidas por MEV. Desenvolvimento de planos secundários de tração, associados a falha normal que afeta microssienito no Maciço de Itaúna (Ponto 1 da Figura 4.35). Mesma amostra apresentada na Figura 5.1. A) Fraturas de tração com arranjo escalonado mostrando neoformação de cristais, ortogonalmente às paredes. Aumento de 2500X; B) Detalhe da imagem anterior. Aumento de $6500 \mathrm{X}$ e C) Imagem micrográfica obtida pelo detector de elétrons retroespalhados (QBSD). A ausência de mudança de tonalidade entre a rocha e os minerais neoformados indica que eles possuem composição semelhante. Aumento de $8500 \mathrm{X}$. As setas indicam o sentido do movimento do bloco perdido. 
A)

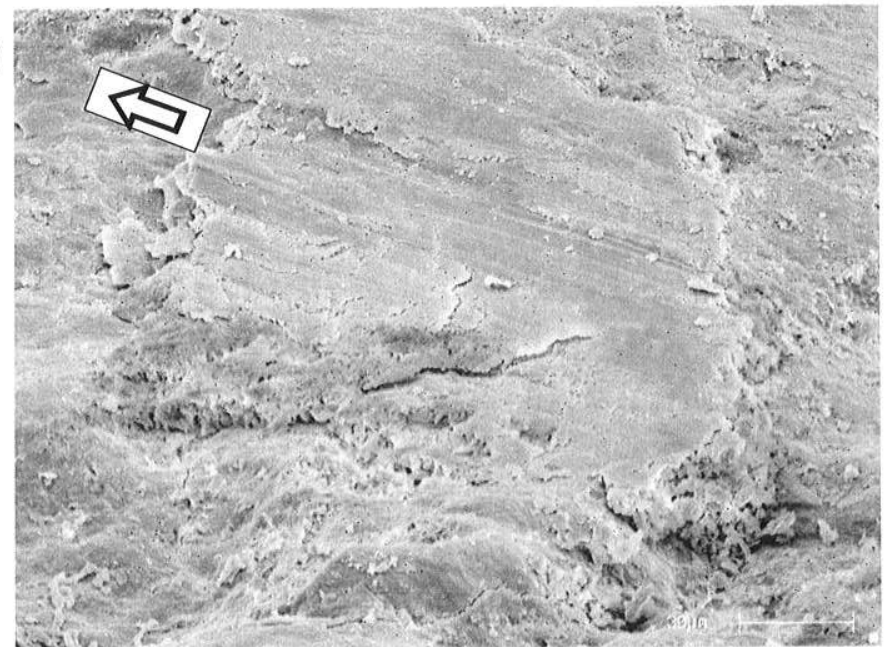

B)

C)

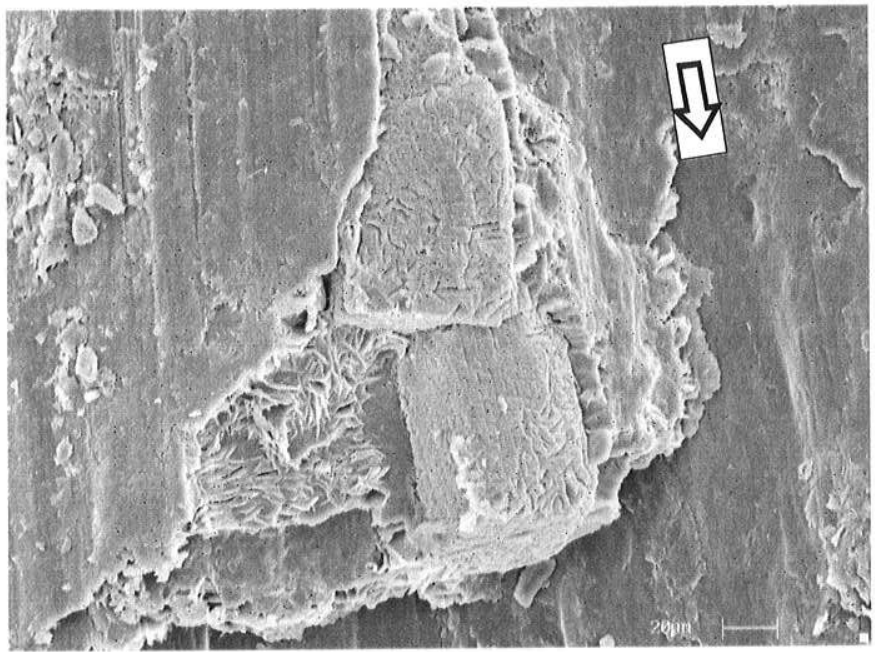

)

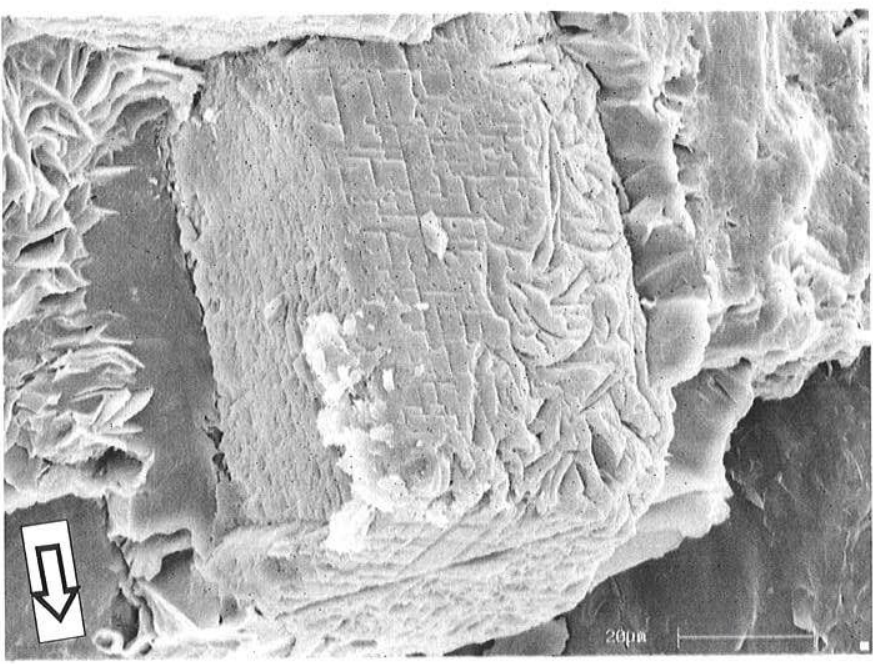

Figura 5.5 - Imagens de planos de falhas obtidas por MEV. A) Estrias associadas a falha normal com atitude 215/50, que afeta fonolito no Complexo de Itaúna (Ponto 16 da Figura 4.35). Notar cunha arrancada no local onde está posicionada a seta; B) Fibras de calcita associadas a falha direcional sinistral que afeta borda de dique de diabásio, com atitude 175/85, na Pedreira Simgra (Dique 1 da Figura 4.6).O degrau formado pela fibra de calcita aponta no sentido do movimento do bloco perdido. Os cristais com aspecto de pétalas, posicionados ao lado das fibras de calcita, são filossilicatos (provavelmente argilas esmectíticas) crescidas após a última movimentação da falha. Aumento de 1500X; C) Detalhe da imagem anterior, evidenciando a clivagem da calcita. Aumento de 2500x. As setas incidam o sentido do movimento do bloco perdido. 
A)

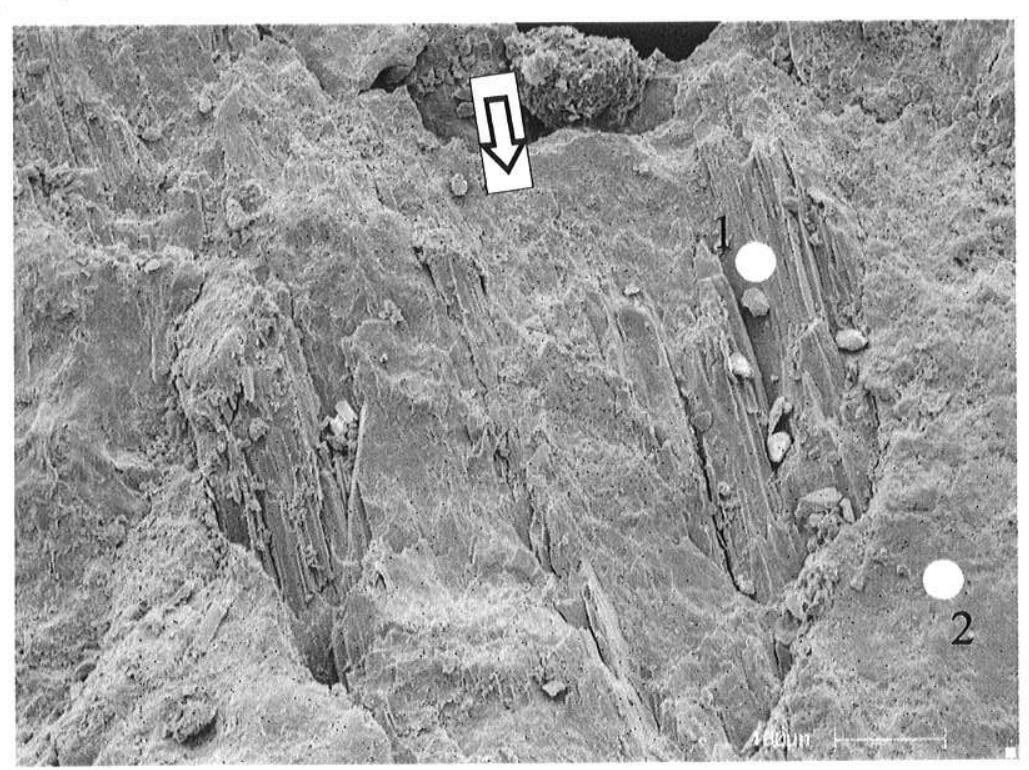

1)

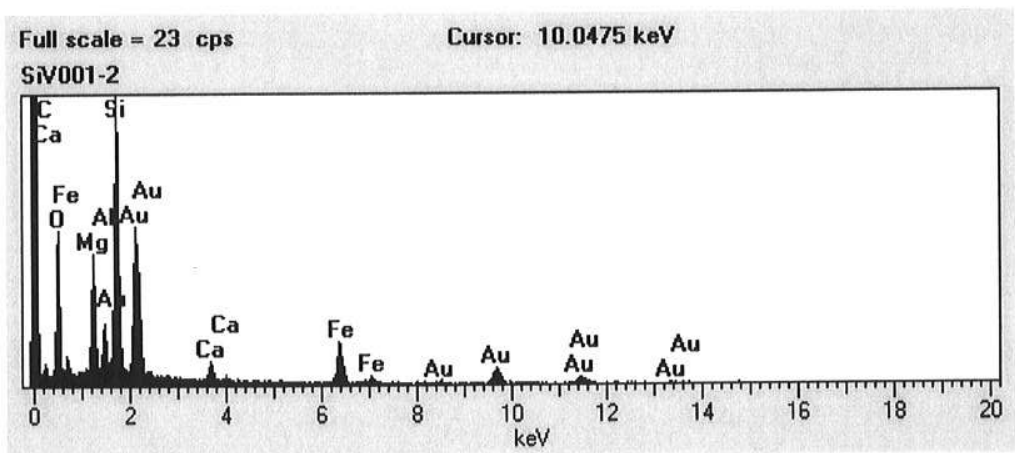

2)

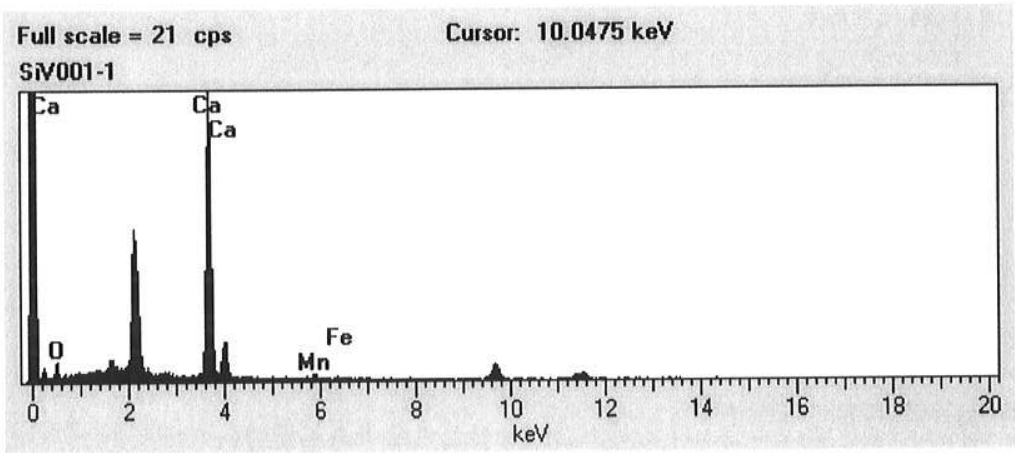

Figura 5.6 - Imagens obtidas com MEV. A) Plano de falha direcional sinistral em borda de dique de diabásio, com atitude 170/85, situado na Pedreira Simgra (diuqe 1 da Figura 4.6, mesmo dique das Figuras 5.5B e C). São evidenciadas estrias no diabásio, recobertas por capa de carbonato maciço preciptado após a última movimentação da falha; aumento de $600 \mathrm{X}$; B) e C) Resultados das análises qualitativas realizadas no basalto (1) e no carbonato,(2) respectivamente, com o EDS acoplado ao MEV. Seta indica o sentido do movimento do bloco perdido. Os picos de ouro referem-se à metalização da amostra. 
movimento da falha. As análises qualitativas realizadas com o EDS acoplado ao MEV, confirmaram tratar-se de diabásio (Figura 5.6.1) e de carbonato (Figura 5.6.2).

$\mathrm{Na}$ Figura 5.7A temos a presença de planos de tração secundários à falha, preenchidos por calcita (tension gashes), posicionados ortogonalmente ao sentido do movimento do bloco perdido. Na Figura 5.7B apresenta-se uma análise química semiquantitativa linear (line scan), realizada com o EDS acoplado ao $\mathrm{MEV}$, que confirma a alternância de faixas com carbonato e faixas de basalto. 
A)

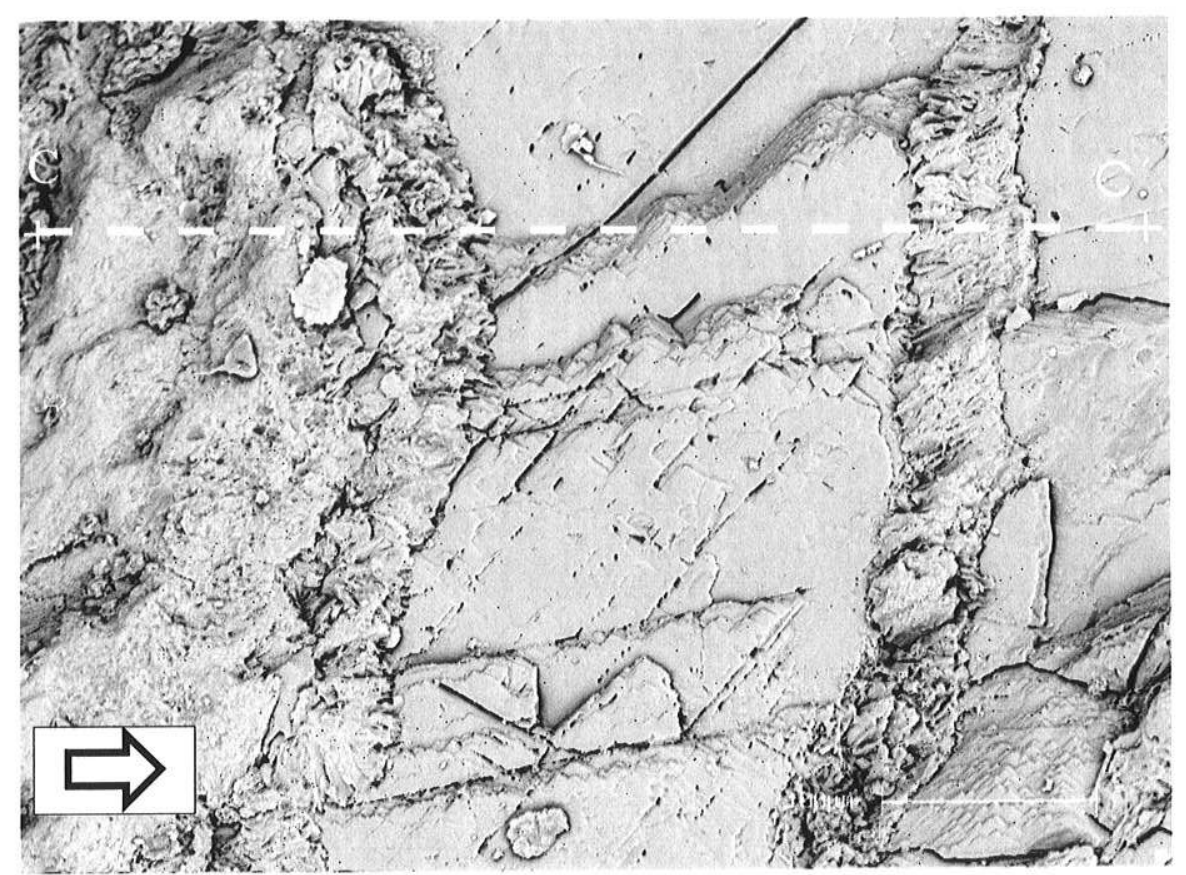

B)

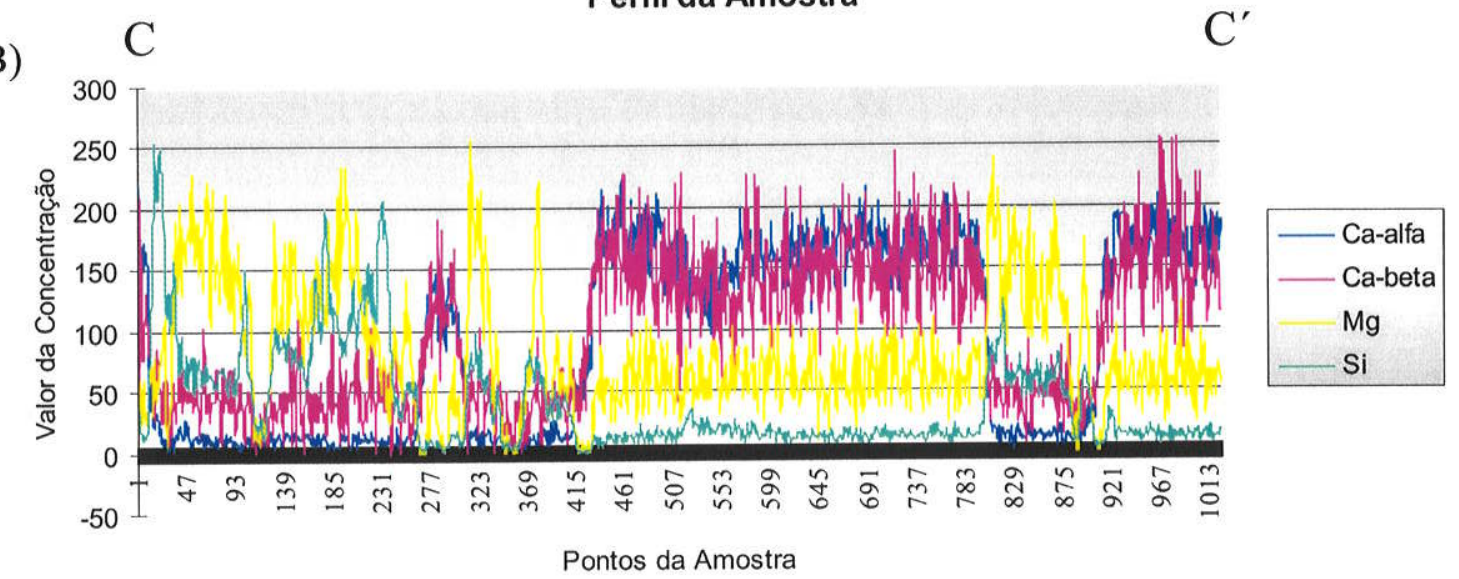

Figura 5.7 - A) Imagem de superfície de falha que afeta diabásio na Pedreira Simgra (dique 1 da Figura 4.6). Podem ser observados veios de calcita preenchendo fraturas de tração (tension gashes). Os veios mostram alto ângulo com relação ao sentido do movimento do bloco perdido, indicado pela seta. Imagem obtida com o detector de elétrons retroespalhados (QBSD) do MEV. Aumento de 600x; B) Análise química semiquantitativa linear (line scan), a partir de EDS acoplado ao MEV, realizado ao longo da reta C-C'. Notar a diminuição marcante dos valores relativos de $\mathrm{Si} \mathrm{Mg}$ nos veios de calcita. 


\subsection{BACIA DE SÁO JOSÉ DO ITABORAÍ}

\subsubsection{Introdução}

A Bacia de São José do Itaboraí foi explotada por 53 anos para extração de calcário pela Companhia Nacional de Cimento Portland (CNCP) - Cimento Mauá. Após o encerramento das atividades, em 1985, a cava da mina foi abandonada, gerando um lago (Figuras 6.1A e 6.2A), que é hoje utilizado pela comunidade do distrito de São José para o abastecimento de água e é gerenciado pela Cooperágua, por concessão da prefeitura do Município de Itaboraí. O alagamento e o rejeito deixado no entorno da bacia, em especial na borda sudeste sobre a Falha de São José, dificultam hoje a total compreensão da sua história geológica. Nesse sentido, é necessário que se utilize os dados dos trabalhos previamente realizados para uma melhor aproximação da evolução da bacia.

\subsubsection{Trabalhos Anteriores}

\subsubsection{Estratigrafia}

A bacia possui aproximadamente $1,5 \mathrm{~km}$ de comprimento e $0,5 \mathrm{~km}$ de largura, alonga-se na direção ENE e é limitada ao sul pela Falha de São José. Ela possui uma espessura máxima de 125 metros de sedimentos, em grande parte carbonáticos (Rodrigues Francisco et al. 1986). As diversas colunas estratigráficas propostas para a bacia estão sintetizadas na Tabela 6.1. O modelo clássico para evolução do preenchimento da bacia considera que existem três seqüências distintas (Rodrigues Francisco \& Cunha, 1978):

1) Seqüência Inferior - calcários travertinos, denominados fitados por Leinz (1938), intercalados com calcários cinzentos, localmente conglomeráticos;

2) Seqüência Intermediária - margas e calcários cinzentos, preenchendo cavernas de dissolução na seqüência anterior; 

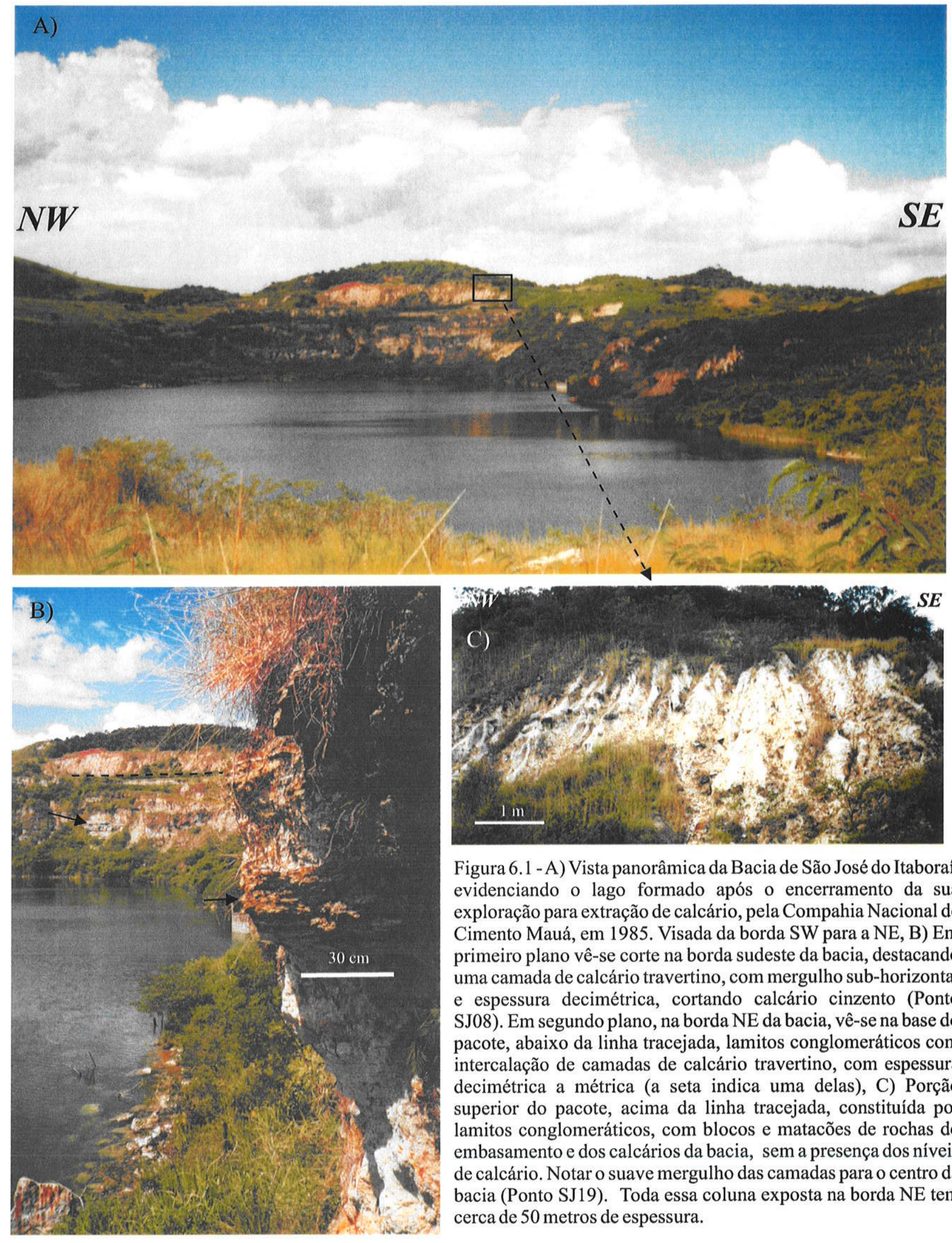

Figura 6.1 -A) Vista panorâmica da Bacia de São José do Itaboraí, evidenciando o lago formado após o encerramento da sua exploração para extração de calcário, pela Compahia Nacional de Cimento Mauá, em 1985. Visada da borda SW para a NE, B) Em primeiro plano vê-se corte na borda sudeste da bacia, destacando uma camada de calcário travertino, com mergulho sub-horizontal e espessura decimétrica, cortando calcário cinzento (Ponto SJ08). Em segundo plano, na borda NE da bacia, vê-se na base do pacote, abaixo da linha tracejada, lamitos conglomeráticos com intercalação de camadas de calcário travertino, com espessura decimétrica a métrica (a seta indica uma delas), C) Porção superior do pacote, acima da linha tracejada, constituída por lamitos conglomeráticos, com blocos e matacões de rochas do embasamento e dos calcários da bacia, sem a presença dos níveis de calcário. Notar o suave mergulho das camadas para o centro da bacia (Ponto SJ19). Toda essa coluna exposta na borda NE tem cerca de 50 metros de espessura. 

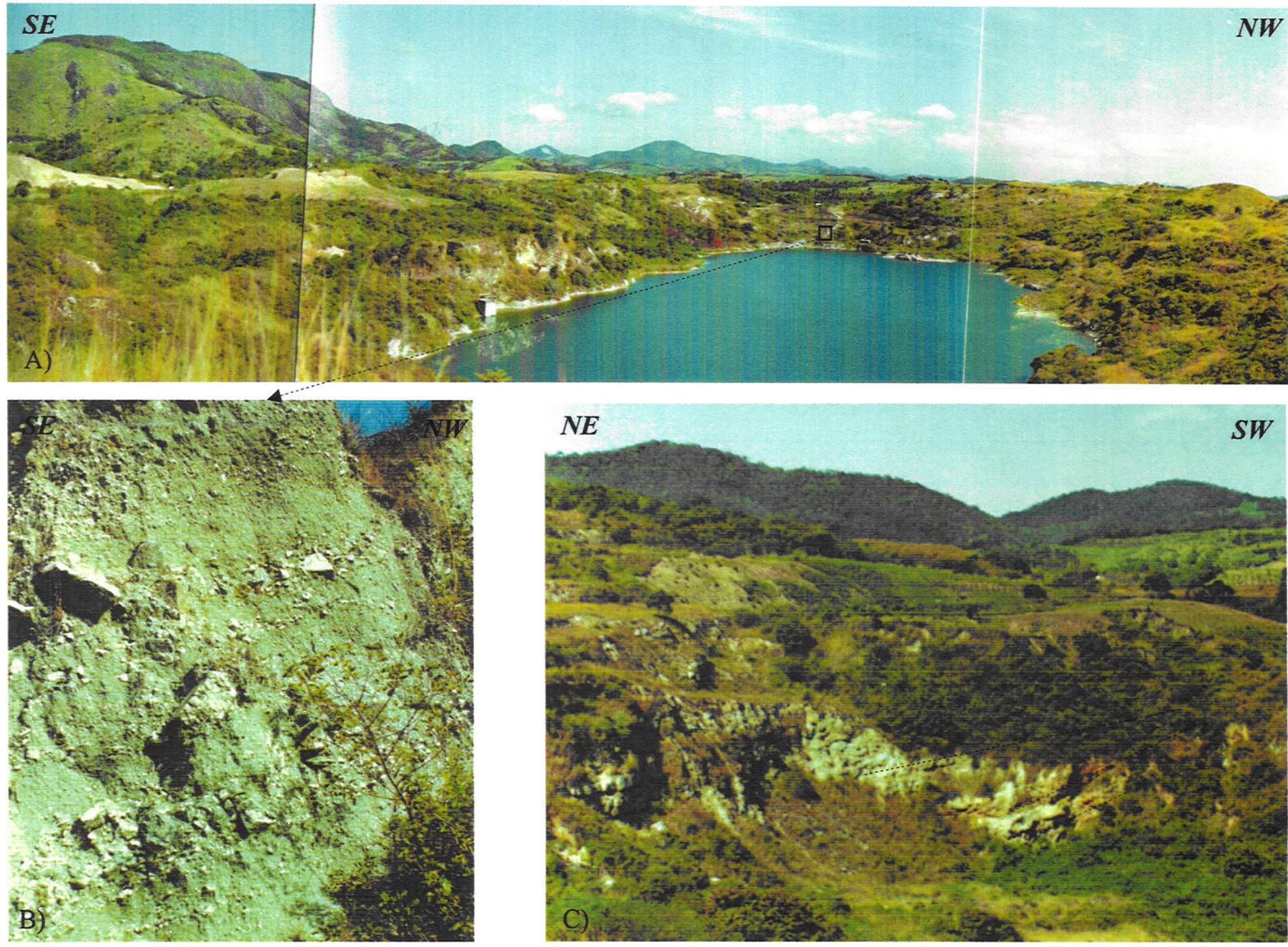

Figura 6.2 - A) Vista panorâmica da Bacia de São José do Itaboraí, com visada de NE para SW, destacando a Serra do Cassorotiba a SE, com altitude de cerca de $400 \mathrm{~m}$. A construção de concreto localizada na borda esquerda do lago é a antiga casa de bombas da mina. B) Lamitos conglomeráticos aflorantes na borda SW da bacia (Ponto SJ11). Notar o adernamento, de até 35 graus, para SE. C) Lamitos conglomeráticos intercalados com calcários travertinos, evidenciando adernamento para NE. Notar que o mergulho das camadas se torna mais suave para o topo do pacote. 


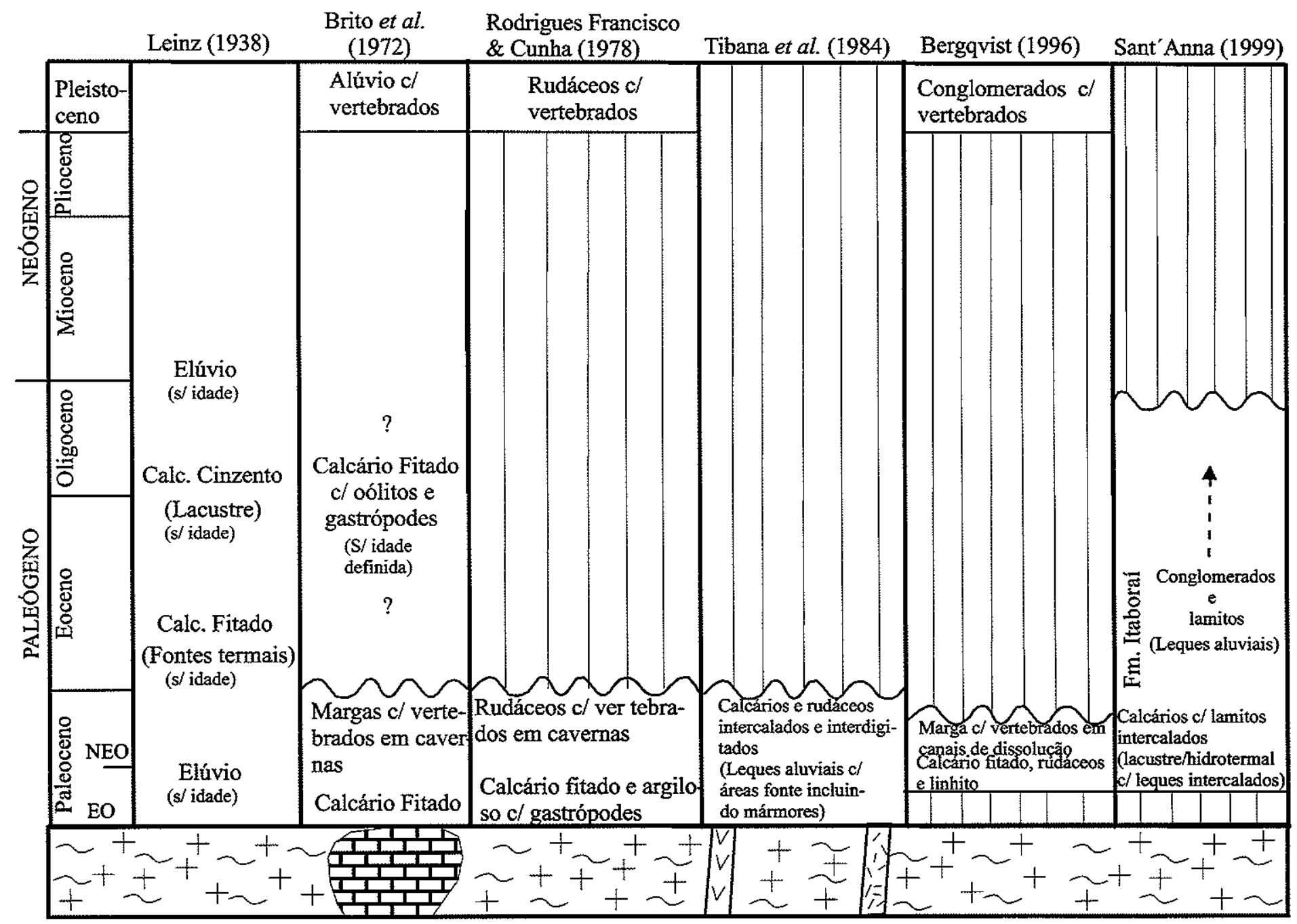

Tabela 6.1 - Síntese das colunas estratigráficas propostas para o preenchimento sedimentar da Bacia de São José do Itaboraí. Ver detalhes no texto. 
3) Sequêencia Superior - depósitos rudáceos, com até 20 metros de espessura (Leinz 1938).

A Sequêencia Inferior, rica em gastrópodes e com vertebrados, folhas e pólens, data do limite Eo - Neopaleoceno (Paula Couto 1953, Bergqvist 1996) e a Seqüência Intermediária possui restos de vertebrados neopaleocênicos (Paula Couto 1952, Bergqvist 1996), tendo sido incluídas na Formação Itaboraí (Oliveira 1956). Na sequêencia Superior ocorreriam restos de vertebrados neopleistocênicos (Price \& Campos 1970). A localização dos fósseis utilizados para a determinação da idade dos terrígenos da sequêencia Superior, a pouco mais de 100 metros ao sul da falha de borda da bacia (Price \& Campos 1970, Brito et al. 1972, Figura 2, e Benedito Humberto Rodrigues Francisco 2000, informação verbal), junto aos aluviões do Rio do Carro, torna questionável essa idade. As características sedimentológicas dos depósitos em que eles foram encontrados, alternando ortoconglomerados ("com clastos de quartzo e sílex") e arenitos grossos (Price \& Campos 1970), indicam suas diferenças com relação aos depósitos da seqüência Superior da bacia. Em adição, Klein \& Rodrigues Francisco (1981) apontam que na porção sudeste da bacia esses sedimentos da Seqüência Superior mostram, também, um adernamento em direção à Falha de São José, evidenciando que sua deposição foi controlada por ela (Figura 6.3).

Sant'Anna (1999) incluiu, informalmente, os sedimentos terrígenos da Seqüência Superior na Formação Itaboraí e atribui-lhes uma idade eocênicaoligocênica com base na presença de argilas esmectíticas na sua matriz e na sua semelhança com os lamitos conglomeráticos da Formação Resende. Esses mesmos sedimentos foram denominados Formação Macacu por Sant'Anna et al. (2000), por comparação com os que ocorrem na bacia homônima (Meis \& Amador 1972, Lima et al. 1996, Ferrari \& Silva 1997).

Para Tibana et al. (1984) a intercalação dos carbonatos com diamictitos e conglomerados desde a Seqüência basal, como também apontado por Leinz (1938), indica uma formação a partir de leques aluviais em clima semi-árido, com áreas-fonte incluindo mármores. A ocorrência de clastos dos calcários fitados nos diamictitos e no calcário cinzento indica, segundo eles, retrabalhamento na bacia.

De acordo com Leinz (1938) os carbonatos eram mais abundantes na porção central da bacia e os lamitos passavam a dominar em direção ao topo da seqüência, formando uma "capa" com até $20 \mathrm{~m}$ de espessura. Ele foi pioneiro em sugerir uma 
origem hidrotermal para o calcário fitado, “talvez em conseqüência da última fase das ações vulcânicas cretáceas", enquanto que o calcário cinzento teria tido uma origem lacustre. A origem hidrotermal para o calcário fitado foi reafirmada por Beurlen \& Sommer (1954), Rodrigues Francisco \& Cunha (1978), Tibana et al. (1984), Hessel et al. (1993), Bergqvist (1996), Sant'Anna et al. (1998), Sant'Anna (1999) e Sant'Anna et al. (2000). Segundo os três últimos trabalhos, dados isotópicos indicam uma origem a partir da dissolução de mármores do embasamento por soluções meteóricas aquecidas. De acordo com Sant'Anna et al. (2000) a Falha de São José teria atuado como o conduto principal de aporte para essas soluções. A maior espessura dos calcários na borda sul, junto à Falha de São José (Beurlen \& Sommer 1954, Rodrigues Francisco \& Cunha 1978) corrobora essa idéia. A existência de veios de calcário travertino no gnaisse (Brito et al. 1972, Rodrigues Francisco \& Cunha 1978 e Ferrari \& Riccomini 1999), reforçam a hipótese de sua origem a partir de fontes hidrotermais e indicam que o hidrotermalismo foi acompanhado por tectonismo.

Um aspecto importante dentro da evolução tectono-sedimentar da Bacia de São José do Itaboraí refere-se aos ankaramitos, descritos por Klein \& Valença (1984a) como derrames de lavas com estrutura almofadada, datados pelo método $\mathrm{K} / \mathrm{Ar}$ em 52 Ma (Riccomini \& Rodrigues Francisco 1992). Segundo Klein \& Valença (1984a) esse derrame foi alimentado por um dique de direção N45E, com cerca de 10 metros de espessura e 150 metros de comprimento. Ainda segundo esses autores o derrame de ankaramito separaria as sequências Inferior e Intermediária (paleocênicas), da Superior (considerada por eles pleistocênica), sendo que o topo do derrame teria sido erodido antes da deposição da Sequiência Superior. Com relação a esse derrame é necessário ressaltar que:

1) As estruturas almofadadas foram reconhecidas nas bordas do dique alimentador $e$ teriam tido, de acordo com Klein e Valença (1984a), a seguinte origem: “... penetrando ao longo da fratura e entrando em contato com a água, o magma provocou explosões e fortes correntes de convecção, originando além das almofadas,...". Ou seja, as estruturas almofadadas observadas não se originaram em um derrame, mas sim no contato do magma com o lençol freático;

2) A discordância erosiva pós-derrame e pré-Sequência Superior assumida por Klein \& Valença (1984) não é descrita por esses autores ou por qualquer outro.

Dessa forma os dados expostos por Klein \& Valença (1984a) são indicadores de uma intrusão ao nível do freático e não necessariamente de um derrame em um 
lago. Nesse sentido, também a discordância pós-derrame assumida por eles é discutível, tendo em vista que ela é apenas inferida.

Das características estratigráficas resumidas acima, destaca-se:

1) Os sedimentos clásticos que se intercalam com as camadas de calcário são quase que invariavelmente descritos como oriundos de fluxo de detritos - diamictitos (Tibana et al. 1984) ou lamitos conglomeráticos (Sant'Anna 1999). Os primeiros autores referem-se a camadas com estratificação cruzada e a folhelhos e linhitos, ambos de forma localizada. Tais características, reforçadas pela presença local de calcretes nos lamitos (Tibana et al. 1984, Sant'Anna 1999), têm sido interpretadas, em geral, como indicativas de um clima semi-árido a árido. No entanto, chama-se atenção para que a predominância dos depósitos de fluxo de detritos pode ser gerada em clima úmido, estando relacionada tanto a um relevo acentuado da área fonte (Boogs 1995), como a uma área de captação de drenagem do(s) leque(s) pouco desenvolvida (Zarza et al. 1993) (ver Capítulo 6.2.10.2). De qualquer forma fica evidenciada a importância dos eventos de sedimentação episódica na bacia, representados pelos depósitos de leques aluviais, que no caso da Bacia de São José do Itaboraí são sempre proximais;

2) Os níveis carbonáticos, provindos essencialmente das águas aquecidas a partir da Falha de São José, foram considerados como depositados em ambiente lacustre (Rodrigues Francisco \& Cunha 1978, Sant'Anna 1999). A ocorrência esporádica de folhelhos carbonosos e de linhitos (Rodrigues Francisco \& Cunha 1978, Tibana et al. 1984, Lima \& Cunha 1986) evidencia que esse lago teve, também, épocas sem aporte de soluções carbonáticas, mostrando o caráter intermitente destas;

3) Rodrigues Francisco \& Cunha (1978) e Klein \& Rodrigues Francisco (1981) apontam que o registro sedimentar da bacia é iniciado por lamas carbonáticas, depositadas em ambiente lacustre. Tal característica sugere uma origem tectônica para a bacia, responsável pela geração de espaço (bacia faminta) e na presença de soluções carbonáticas;

4) A inclusão dos lamitos da Seqüência Superior na Formação Macacu, como proposto por Sant'Anna et al. (2000), requer que tenha havido uma continuidade entre as bacias de São José do Itaboraí e do Macacu. Essa hipótese parece, a princípio, pouco provável tendo em vista o forte controle tectônico da borda sul da Bacia do Macacu (Lima et al. 1996, Ferrari \& Silva 1997 e Capítulo 6.2, no presente trabalho). Nesse caso, poder-se-ia subdividir a Formação Itaboraí 
informalmente em Membro Inferior, incluindo as seqüências inferior e intermediária, caracterizado pela presença de lamitos e calcários, e Membro Superior, constituído pela Seqüência Superior, caracterizado pela presença de lamitos.

\subsubsection{Tectônica}

Evidências de tectonismo na Bacia de São José do Itaboraí foram apontadas por diversos autores (Ruellan 1944, Beurlen \& Sommer 1954, Brito et al. 1972, Rodrigues Francisco \& Cunha 1978, Klein \& Rodrigues Francisco 1981, Hessel et al. 1993, Bergqvist 1996):

1) O marcante controle exercido pela Falha de São José, de direção N62E e mergulho alto com caimento para norte, que a limita ao sul;

2) $\mathrm{O}$ adernamento das camadas em até $35^{\circ}$ em direção à falha, na porção oeste da bacia, e de $10^{\circ}$ para NE, na sua porção leste;

3) Camadas de rudáceos mal selecionados, em meio aos calcários travertinos;

4) Dique clástico de direção NE-SW;
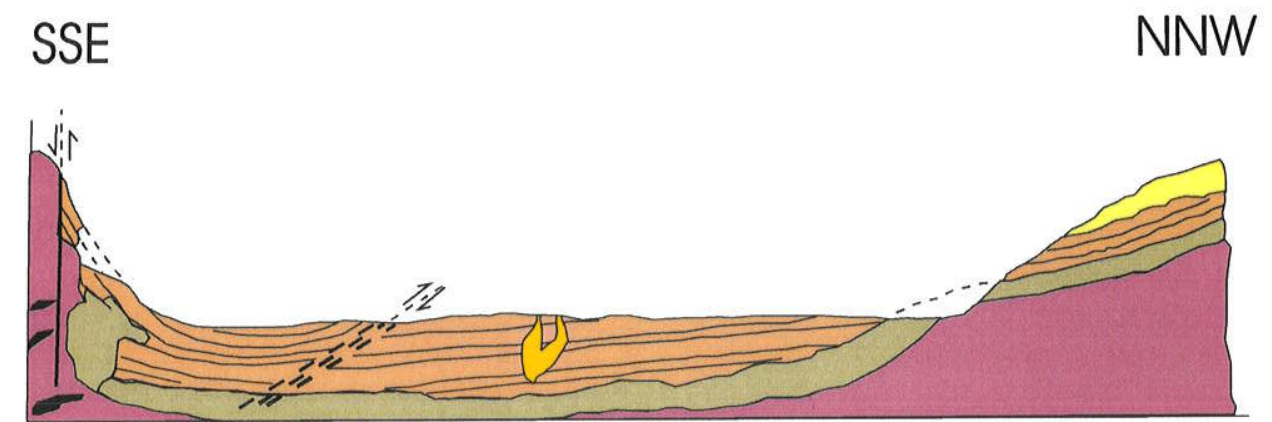

$\square$ Sedimento Quaternário
Margas em cavernas c/ vertebrados (Paleoceno Superior)
Calcário travertino (Paleoceno Inferior)
Calcário com gastrópodes (Paleoceno Inferior)
Gnaisse com mármore (Pré-Cambriano)

Figura 6.3 - Perfil N-S na porção mais tectonizada da bacia (lado sudoeste). (Segundo Klein \& Rodrigues Francisco 1981). Pode-se notar que os sedimentos tidos como quaternários são concordantes com os calcários e também mergulham em direção a falha da borda sul.

5) Falha reversa dentro da bacia, paralela a falha de São José; 
6) "Estrutura transversal" representada por falha direcional NW-SE, com brechação e silicificação associadas, deslocando canais de dissolução preenchidos pela sequiência intermediária e separando dois compartimentos da bacia com comportamento estrutural distinto;

7) Camadas com mergulho de alto ângulo junto à falha de borda;

8) Blocos do embasamento por cima dos sedimentos, junto à Falha de São José;

9) Dique de ankaramito orientado na direção N45E, com 10 metros de espessura e 150 metros de comprimento.

A estrutura transversal, de direção NW, parece ter tido grande importância na evolução da bacia, compartimentando-a em um bloco ocidental mais deformado, com maior espessura de sedimentos e onde as camadas apresentam mergulhos de até $35^{\circ}$, e outro, oriental, compondo aproximadamente $2 / 3$ da bacia "pouco deformado" (Rodrigues Francisco \& Cunha 1978). Riccomini \& Rodrigues Francisco (1992) consideram a estrutura transversal uma estrutura antitética associada a um binário transcorrente dextral E-W, o qual, dentro do modelo regional para o RCSB (Riccomini 1989, 1995a), teria atuado no Pleistoceno. No entanto, deve-se lembrar que a brechação associada à estrutura NW é acompanhada por silicificação, regionalmente relacionada à fase final do magmatismo alcalino e datada, na mineralização de fluorita do Tanguá, em $50 \mathrm{Ma}$, ou seja, Eoceno Inferior a Médio (Santos 1994). Neste sentido, o evento pleistocênico pode ter sido de reativação, mas não de geração da falha transversal.

Hessel et al. (1993) consideram que a bacia se formou a partir de uma extensão NW-SE, fase durante a qual se depositaram os calcários cinzentos. Estes calcários teriam sido dissolvidos, gerando cavernas horizontais "concordantes com o tectonismo distensional", que foram preenchidas por brechas de colapso, sinter e pérolas de caverna. Ainda segundo esses autores, posteriormente desenvolveram-se cavernas verticais, facilitadas pelo fraturamento associado a uma transcorrência sinistral. Estas cavernas verticais foram preenchidas por brechas de colapso e pelas margas com vertebrados do Paleoceno Superior. Ressalta-se que o desenvolvimento das cavernas horizontais não seria facilitado pelos esforços extensionais, como indicado por Hessel et al. (1993), e sim por esforços compressivos, com o eixo de eixo de tensões mínimo, $\sigma 3$, se posicionando na vertical. Por outro lado, a atuação de 
um regime de esforços direcional sinistral propiciando a deposição das margas, com vertebrados do Paleoceno Superior, concorda com a proposição de Riccomini \& Rodrigues Francisco (1992) para o controle do magmatismo ankaramítico na bacia, com idade, segundo eles, de $52 \mathrm{Ma}$ (Eoceno Inferior).

Ressalta-se, a partir do descrito acima, que algumas características estruturais da bacia favorecem uma origem a partir de um regime direcional:

1) o alto ângulo de mergulho da falha de borda (Christie-Blick \& Biddle 1985, Sylvester 1988, Zolnai 1991);

2) a espessura de sedimentos relativamente grande, comparada com as dimensões da bacia (Reading 1980, Mann et al. 1983, Christie-Blick \& Biddle 1985, Sylvester 1988, Nilsen \& Sylvester 1995);

3) a localização do depocentro principal da bacia na sua borda $\mathrm{SW}$, considerando-a gerada por uma movimentação sinistral da Falha de São José, segundo modelo de evolução de bacias strike-slip de Kingma 1958.

\subsubsection{Estruturas e Evolução Tectônica da Bacia}

As deformações que vêm sendo relatadas ao longo de mais de 60 anos de estudos realizados na Bacia de Itaboral deixam claras as suas particularidades com relação às demais bacias terciárias do sudeste brasileiro, incluídas no RCSB. Têm-se aqui evidências de estiramento mais intenso do que nas outras bacias, pelo mergulho de até $35^{\circ}$ das camadas, ímpar entre as demais bacias do RCSB. Além disso, diferentes taxas de estiramento são evidenciadas pela variação do mergulho das camadas na bacia, associadas à sua compartimentação em dois blocos estruturalmente distintos, separados por uma falha transversal de direção NW.

Os levantamentos realizados na bacia, no presente trabalho, mostraram que boa parte das estruturas descritas anteriormente pelos pesquisadores que lá trabalharam, não se encontram mais expostas, não apenas pelo alagamento e pelos rejeitos acumulados ao seu redor, mas também pela recuperação da vegetação, como pode ser visto na Figura 6.2A. A maior dificuldade, nesse sentido, foi a caracterização estrutural da Falha de São José, tendo em vista que ela se encontra exposta em um único local. Por outro lado, pode-se observar que ainda são visíveis famílias de 
microfalhas, principalmente nos níveis carbonáticos. Verificou-se também que o calcário travertino assume um arranjo bastante particular junto à falha da borda sul, constituindo um enxame de veios de calcário maciço a bandado de pequena espessura, denominados aqui veios, sub-paralelos a ela. Esses veios são visíveis inclusive cortando os gnaisses do embasamento, junto à Falha de São José. Ressalta-se que a ocorrência de veios de calcário travertino bandado ou maciço, encaixados em falhas ativas de caráter extensional, tem sido reportada em diversas áreas onde eles foram utilizados como indicadores cinemáticos (Hancock et al. 1999). A descoberta desses veios de calcário travertino com arranjo peculiar, junto à falha de borda, é surpreendente, considerando-se que não há qualquer referência a eles nos trabalhos realizados anteriormente.

Outra característica da estruturação da bacia, que não foi devidamente considerada nos trabalhos anteriores, refere-se ao adernamento das camadas sedimentares na porção oriental da bacia (os $2 / 3$ menos tectonizados de acordo com Klein \& Rodrigues Francisco 1981), que apresentam um mergulho de até $20^{\circ}$ para NE.

\subsubsection{Veios de Calcário Travertino}

Os veios de calcário travertino são abundantes junto à Falha de São José, constituindo um enxame sub-paralelo a ela e com mergulho de alto ângulo, com espessura máxima, hoje preservada, de até cerca de 3 metros. Esses veios apresentam em geral estrutura maciça e, mais raramente, estrutura bandada. Eles têm espessura centimétrica a decimétrica e se mostram contínuos por alguns metros (Figura 6.4C). Esse conjunto de veios é cortado por outro, menos numeroso, com baixo ângulo de mergulho, também constituído por veios maciços a bandados e contínuos (Figura 6.4C). Ambas as famílias de veios cortam também o embasamento junto à falha de borda (Figura 6.4A e B). Elas foram tratadas como fraturas de extensão preenchidas, à semelhança dos diques, considerando-se nesse caso que cada veio representa um evento de extensão ortogonal a ele (Hancock et al. 1999).

$\mathrm{Na}$ Figura 6.5A estão representadas as projeções ciclográficas, polares e os diagramas de rosetas dos veios de calcário travertino com alto ângulo de mergulho (maior do que $65^{\circ}$ ). A maior concentração dos diques segundo a direção ENE-WSW 

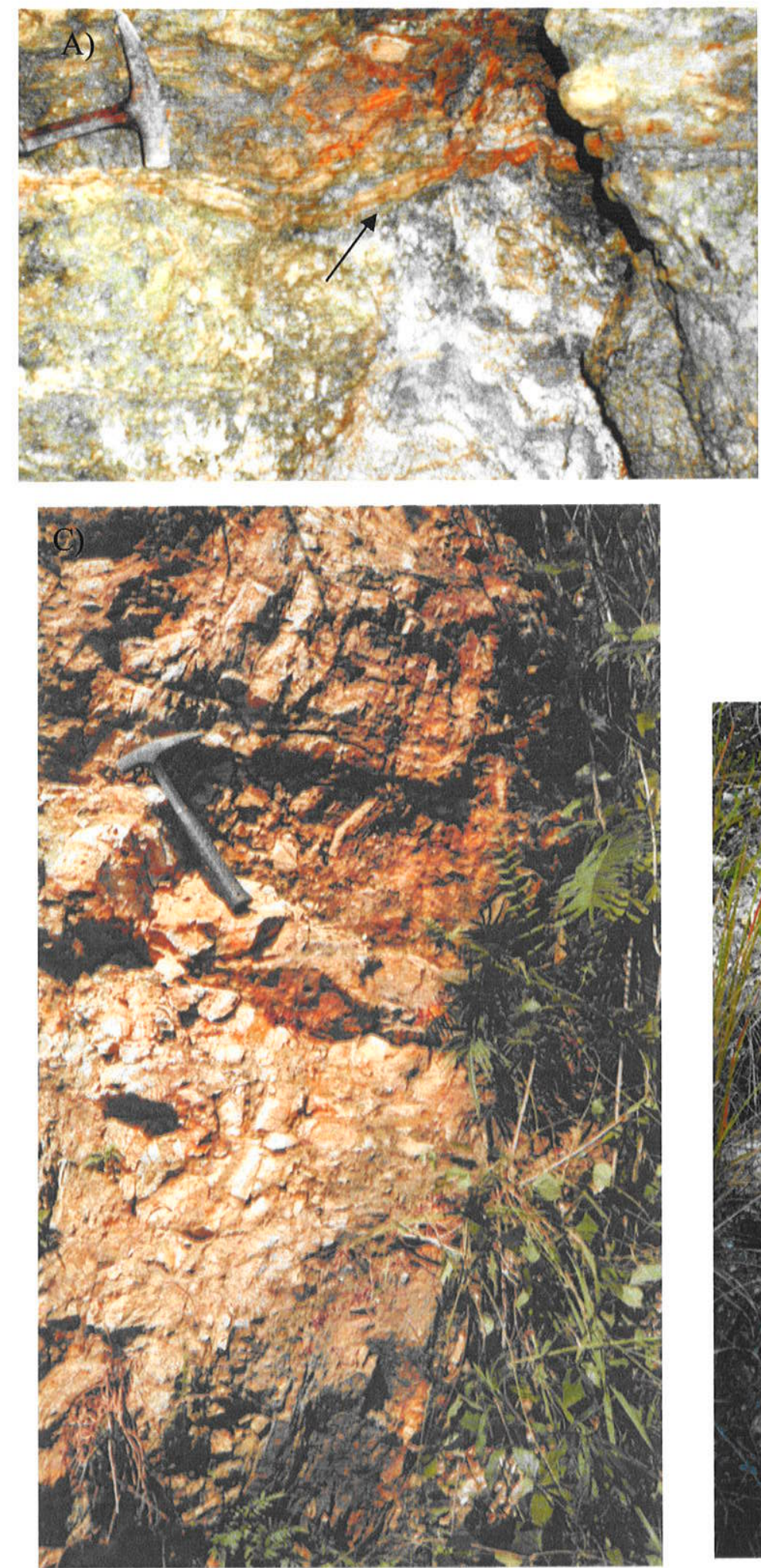
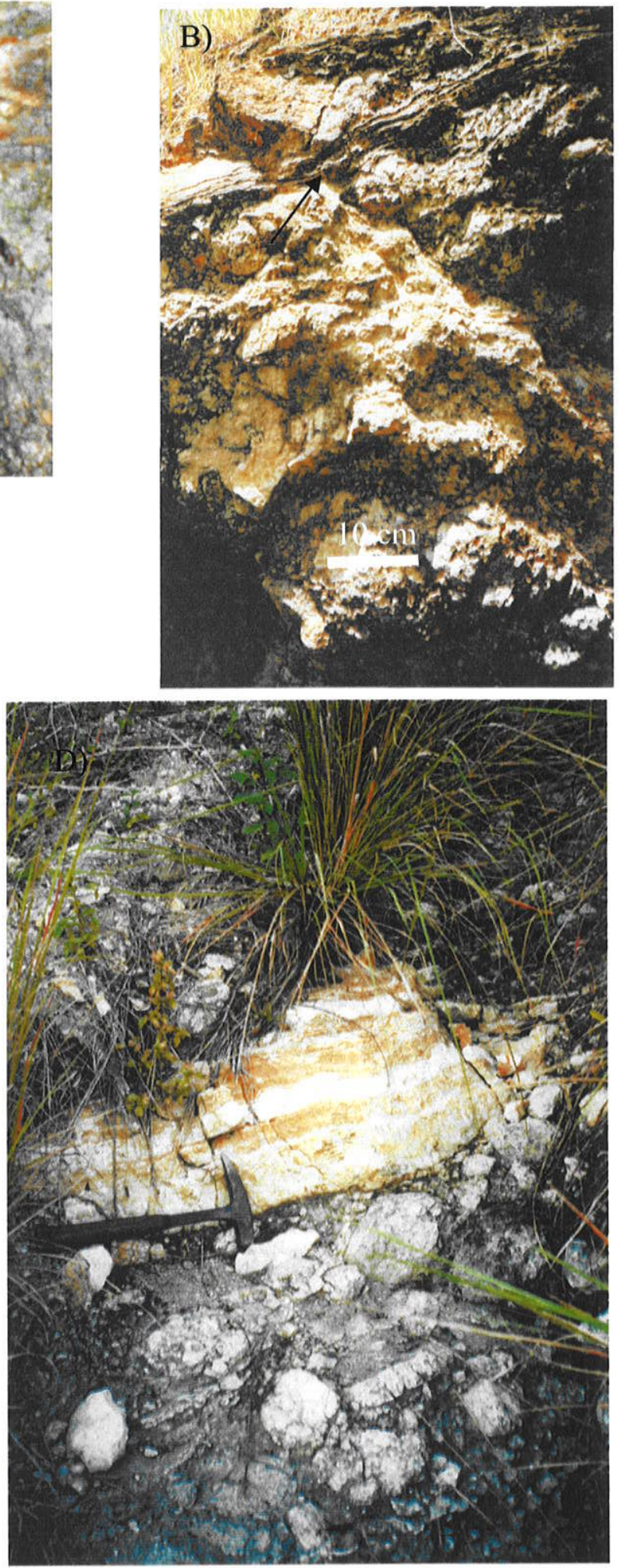

Figura 6.4 - Bacia de São José do Itaboraí: A) Veio de calcário travertino bandado, sub-horizontal e de espessura centimétrica, cortando migmatito estromático com dobras de pequena amplitude (posição do veio indicada pela ponta do martelo). Ponto SJ03, borda sul da bacia junto à Falha de São José, B) Veios de calcário travertino bandados horizontais, cortando gnaisse junto à Falha de São José (indicado pela seta), Ponto SJ08; C) Veios de calcário travertino maciço a bandados, sub-verticais, cortados por veio de calcário travertino maciço sub-horizontal, de espessura decimétrica (posição indicada pelo cabo do martelo). Ponto $\mathrm{Sj} 08$, borda sul da bacia, junto à Falha de São José; D) Camada de calcário travertino bandado (calcário fitado) em meio a lamito conglomerático. Ponto SJ12, borda NW da bacia. 
A)
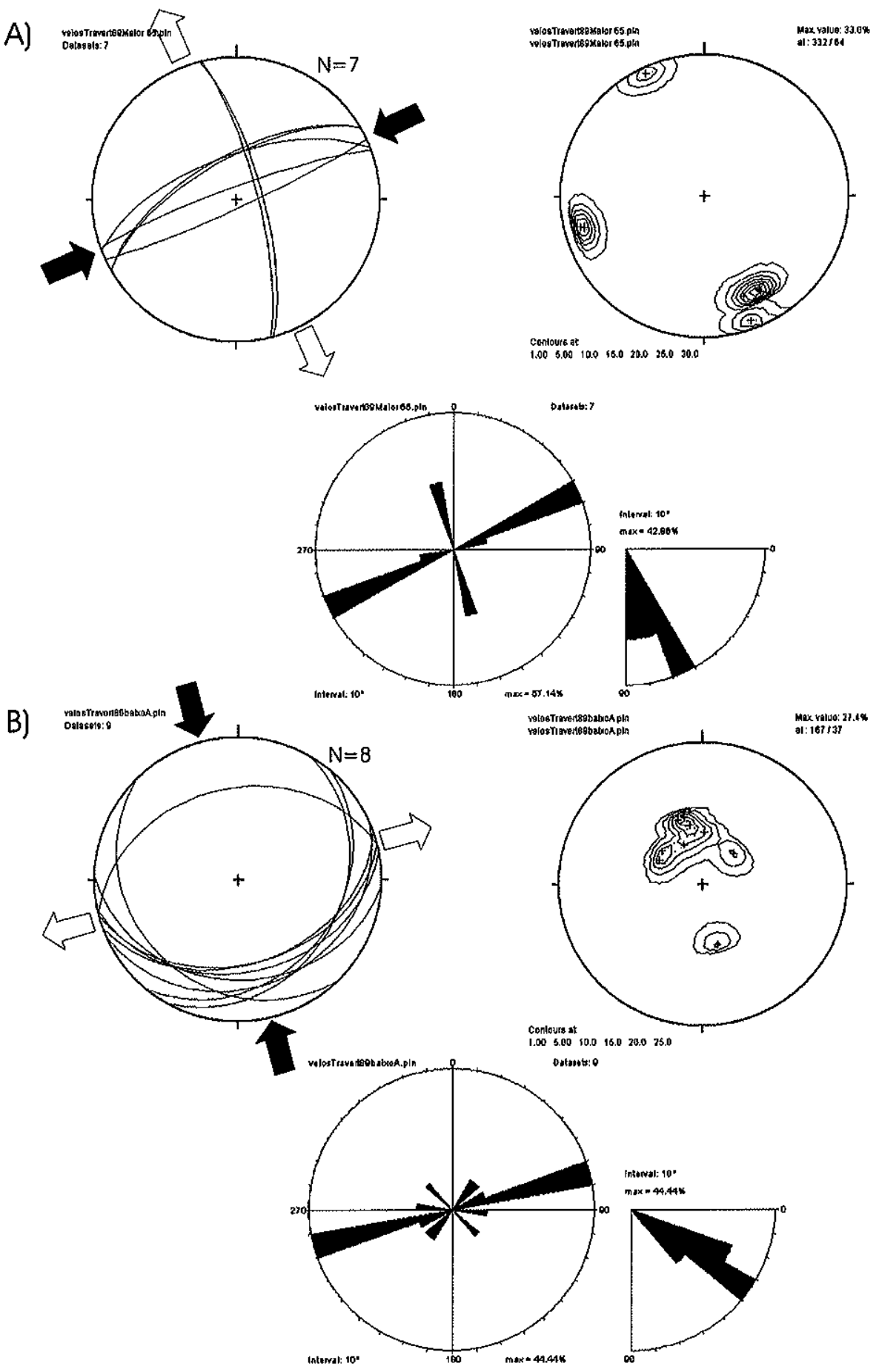

Figura 6.5- Projeções ciclográficas, polares e diagramas de rosetas, mostrando as direções e os mergulhos de veios de calcário travertino com ângulos de mergulho maiores do que 65 graus (A) e com ângulo de mergulho menor do que 50 graus. Ver detalhes no texto. Setas grandes vazias indicam tanto a posicão do eixo de tensões mínimo, $\sigma_{3}$, em A, como o eixo de tensões intermediário, $\sigma_{2}$, em B. Setas grandes cheias indicam a posição do eixo de tensões horizontal máximo, SHmax. Ver explanação no texto. Diagramas de Schmidt-Lambert, hemisfério inferior. 
permite que se posicione o eixo de tensões mínimo, $\sigma 3$, ortogonal a eles, na direção NNW-SSE, e o eixo de tensões horizontal máximo, SHmax, paralelo aos veios, na direção ENE-WSW.

$\mathrm{Na}$ Figura 6.5B estão representadas as projeções ciclográficas, polares e os diagramas de rosetas dos veios de calcário travertino com baixo ângulo de mergulho (menor do que $50^{\circ}$ ). Esses veios constituem duas famílias conjugadas de baixo ângulo, com direção predominante ENE-WSW, as quais permitem posicionar o eixo de tensões mínimo, $\sigma 3$, na vertical, e o eixo de tensões máximo, $\sigma 1$, na horizontal e ortogonal aos veios, na direção NNW-SSE, com o eixo intermediário, $\sigma 2$, também horizontal e orientado na direção ENE-WSW. Essa distribuição corresponde a um regime de paleotensões inverso.

\subsubsection{Falhas e Microfalhas}

As microfalhas determinadas na bacia foram identificadas sempre nos níveis carbonáticos e, dentre esses, principalmente nos calcários maciços. Nessas litologias os indicadores cinemáticos são as fibras de calcita e, mais restritamente, facetas polidas e rugosas alternadas, além de fraturas de cisalhamento sintéticas e antitéticas associadas. Foram coletados ainda dados de estruturas rúpteis nos leucognaisses aflorantes na borda sul da bacia, junto à falha de borda. Estes dados referem-se a falhas com faixas cataclásticas, com superfícies sem estrias. Nas que não foi possível caracterizar as estrias procurou-se inferir o sentido de movimento a partir do deslocamento relativo da foliação do gnaisse. Esses planos foram plotados como fraturas de cisalhamento, em conjunto com os dados pareados.

Ressalta-se que no único local em que se pode observar a Falha de São José (Ponto SJ 07), não foi possível determinar indicadores cinemáticos sobre o plano de falha ou mesmo estruturas secundárias que permitissem inferir a sua cinemática.

Foram caracterizados dois conjuntos de microfalhas ativados em dois campos de paleotensões distintos, ambos associados a regimes direcionais.

Na Figura 6.6 estão representadas microfalhas que afetam calcário cinzento, travertino e maciço, além de gnaisses junto à Falha de São José. A família de estruturas com direção NNE-SSW inclui planos cataclasados sem estrias, plotados 
A)

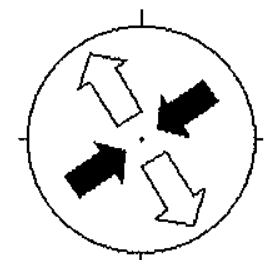

( ) $1: 12 / 055$

$\Delta$ \%2: $70 / 269$
б3: $15 / 149$

Pure STRIKE-SL.IP
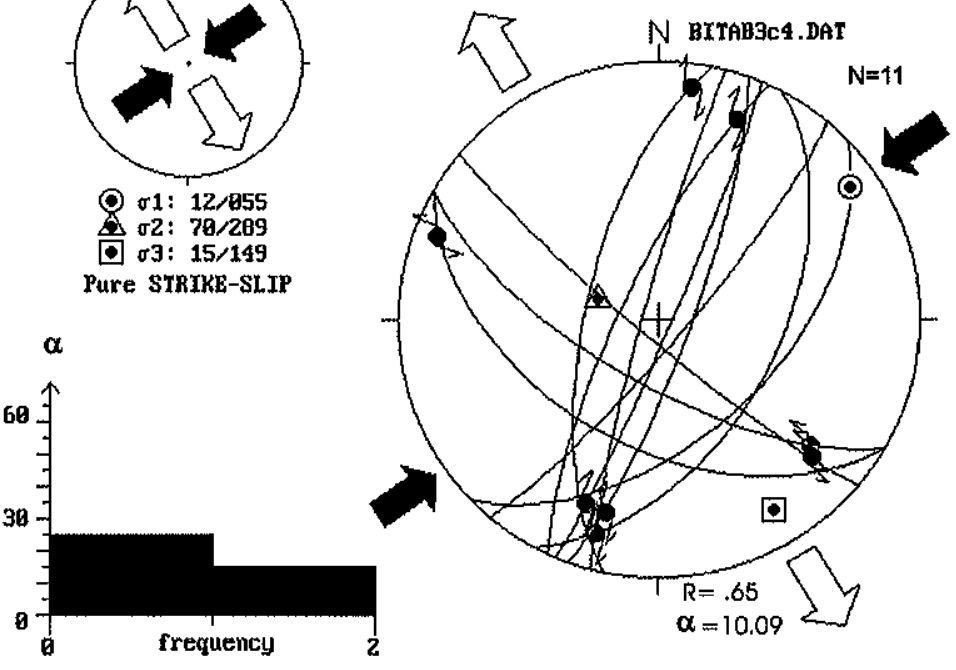

B)
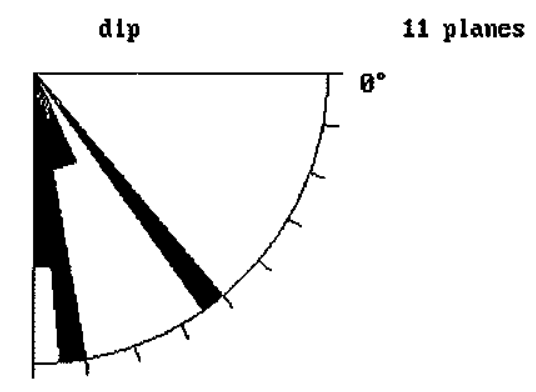

$$
\text { plunge }
$$

B lines
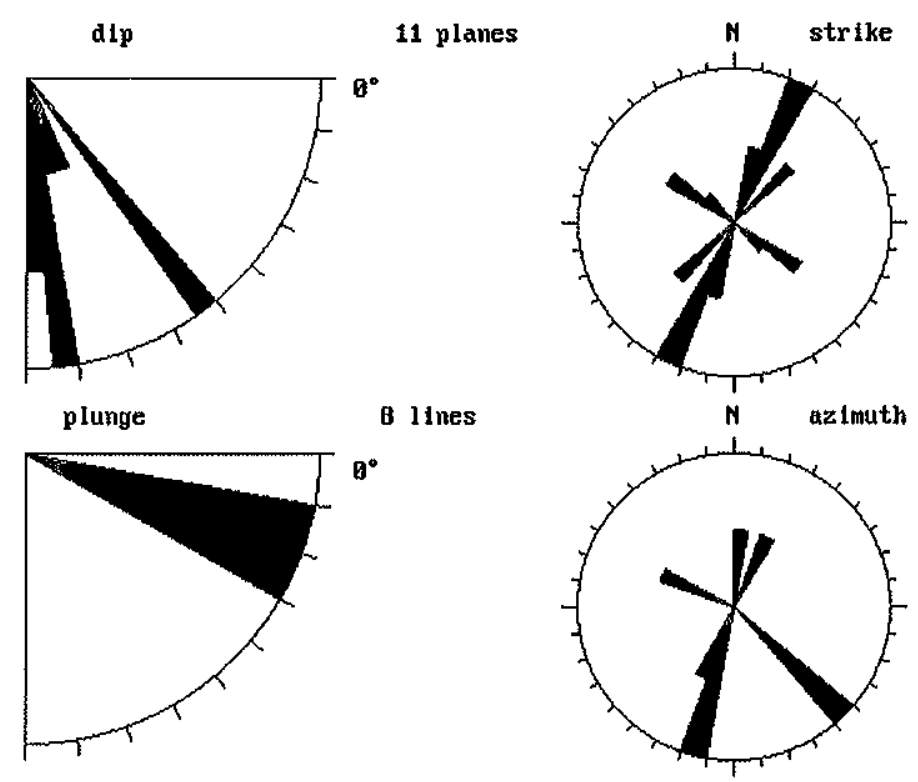

Figura 6.6 - Dados de microfalhas e respectivos eixos de tensões, afetando calcário travertino e calcário maciço, dentro da Bacia de São José do Itaboraí, e gnaisse, junto à falha de São José. Os dados incluem 3 planos de microfalhas, com cataclasitos, sem estrias determinadas. Ver explanação no texto. Símbolos:círculos - $\sigma_{1}$ (eixo de maior esforço), triângulos $-\sigma 2$ (eixo de esforço intermediário), quadrados - $\sigma_{3}$ (eixo de menor esforço); $\mathrm{R}$ - razão de esforço $(\sigma 2-\sigma 3 / \sigma 1-\sigma 3) ; \alpha$ - desvio médio entre as estrias medidas e o cisalhamento computado sobre o plano de falha. Setas grandescheias - eixos compressivos horizontais, setas grandes vazias - eixos distensivos horizontais. Projeções de Schmidt-Lambert, hemisfério inferior. 
como fraturas de cisalhamento. Essa família é caracterizada por movimentação dextral. As microfalhas de direção WNW-ESE, que afetam calcário, mostram rejeito sinistral. A inversão dos dados indicou que esse conjunto de estruturas foi ativado por um campo de paleotensões DIRECIONAL Puro (Pure STRIKE-SLIP), onde o eixo de tensões máximo, $\sigma 1$, é horizontal e orienta-se na direção NE-SW, com o eixo de tensões mínimo, $\sigma 3$, também horizontal e ortogonal a ele, e com o eixo intermediário, $\sigma 2$, vertical.

Na Figura 6.7 estão representadas microfalhas que afetam calcário maciço e calcário cinzento. Esse conjunto de estruturas é caracterizado por duas famílias conjugadas de cisalhamento, de direção ENE-WSW e NW-SE, e por uma falha inversa de direção NNE-WSW. A inversão dos dados indicou que essas estruturas foram ativadas em um campo de paleotensões COMPRESSIVO Direcional (StrikeSlip COMPRESSIVE), com o eixo de tensões máximo, $\sigma 1$, horizontal e orientado segundo a direção WNW-ESE, o eixo de tensões mínimo, $\sigma 3$, também horizontal e ortogonal a ele, e o eixo intermediário, $\sigma 2$, vertical.

\subsubsection{Arcabouço Estrutural da Bacia a Partir de Dados de Sondagens}

Com o intuito de melhor aproximar o arcabouço da Bacia de São José do Itaboraí, foram interpretados os perfis construídos pela CNCP (1965) a partir de pouco mais de uma centena de furos de sondagens. Esses perfis, traçados transversalmente à bacia, a cada $100 \mathrm{~m}$, não indicam as litologias, e sim horizontes com diferentes teores de $\mathrm{CaCO}_{3}$ (Figura 6.8). Além de intervalos com teor maior do que $60 \%$, entre $30 \%$ e $60 \%$ e menor do que $30 \%$, é indicada a posição onde o furo de sondagem encontra gnaisse ou granito, ou seja, quando é atingido o embasamento. A análise dos perfís mostrou que os horizontes basais com teor de $\mathrm{CaCO}_{3}$ abaixo de $30 \%$, foram sistematicamente deixados de fora na delimitação do contorno da bacia, como pode ser visto nos perfis 400 e 500 da Figura 6.8. A inclusão desses horizontes permitiu uma visão mais realista do preenchimento da bacia, não apenas com relação à espessura de sedimentos, mas, também, à largura da bacia, a qual, no perfil 400 , chegou a dobrar (Figura 6.9). Nos perfís em que se tem a indicação da profundidade 
A)

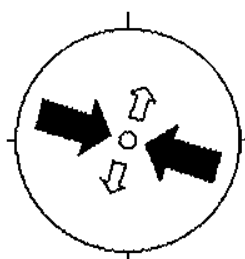

C) 1 1: $99 / 28$ ?

б2: 11/B19

0 ชง: $75 / 15$ ? strike-slip COMPRESSIUE
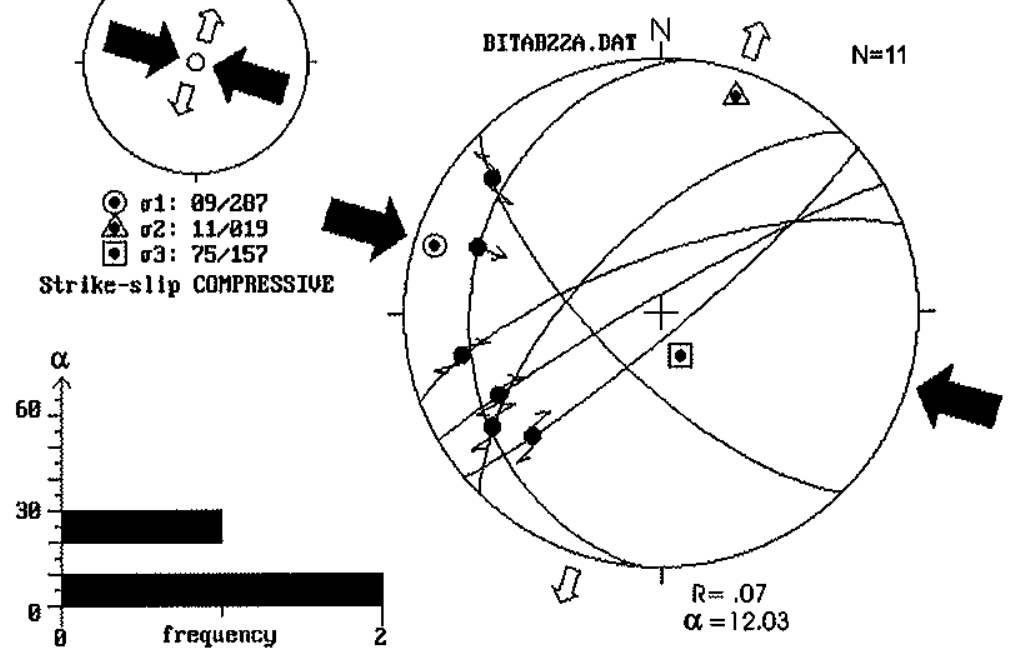

B)

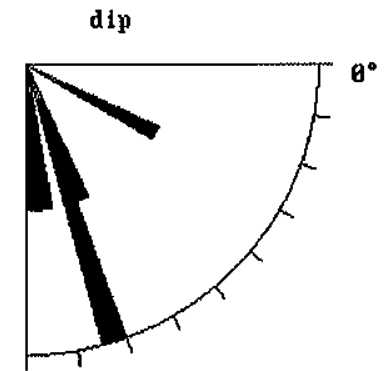

6 planes

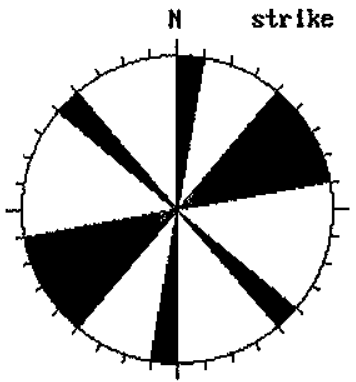

plunge

6 lines

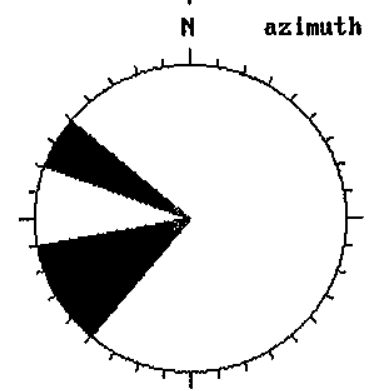

Figura 6.7 - Dados de microfalhas e respectivos eixos de tensões, afetando calcário maciço e calcário cinzento, na Bacia de São José do Itaboraí. Ver explanação no texto. Símbolos:círculos - $\sigma 1$ (eixo de maior esforço), triângulos - $\sigma 2$ (eixo de esforço intermediário), quadrados - $\sigma 3$ (eixo de menor esforço); $\mathrm{R}$ - razão de esforço

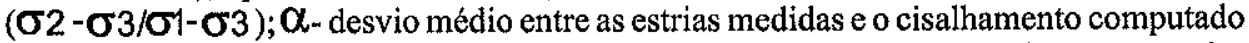
sobre o plano de falha. Setas grandescheias - eixos compressivos horizontais, setas grandes vazias - eixos distensivos horizontais. Projeções de Schmidt-Lambert, hemisfério inferior. 


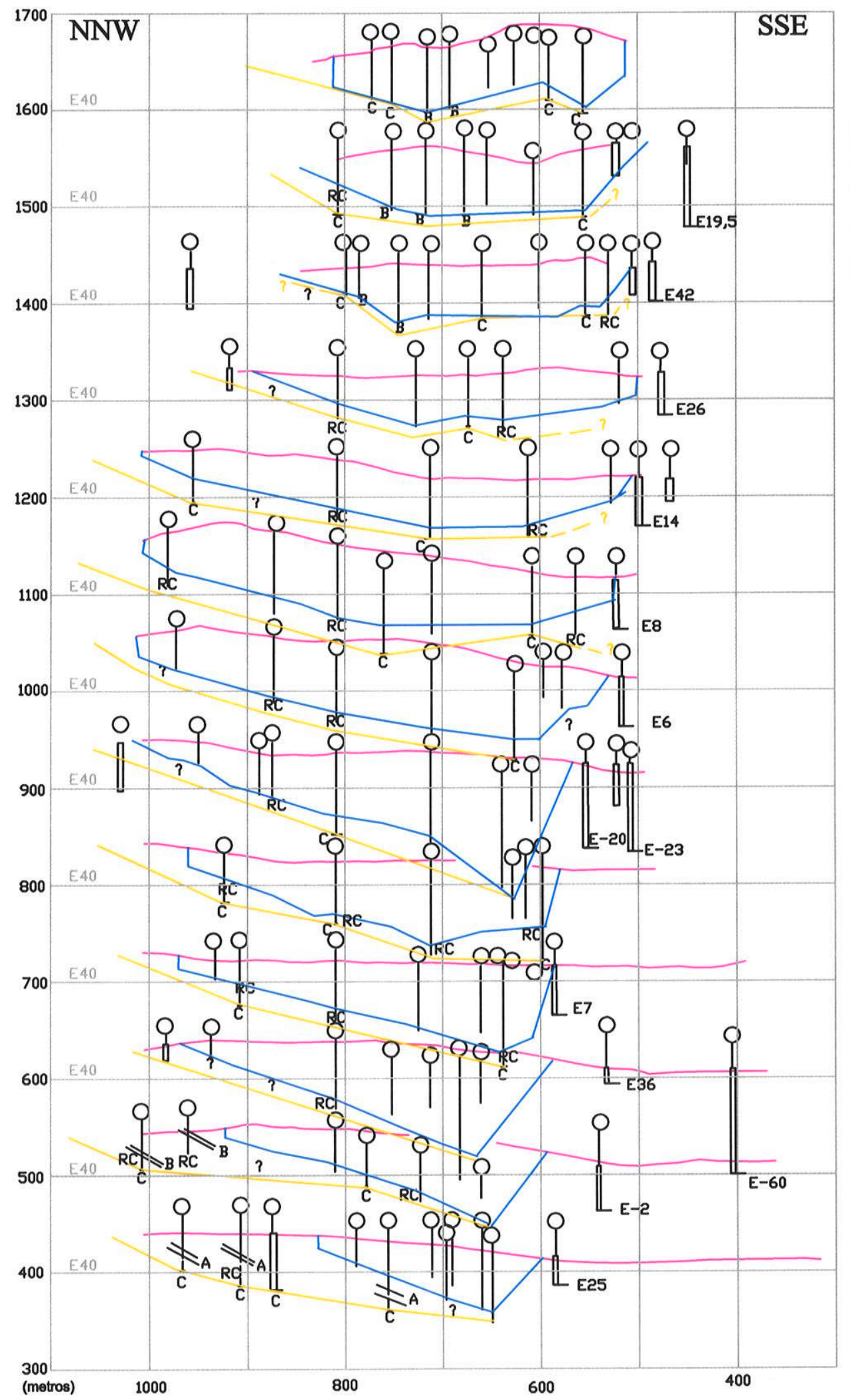

$\checkmark$ Relevo original

Embasamento da bacia segundo a Cimento Portland

\section{Embasamento da bacia} reinterpretado

\section{Calcário com}

A mais de $60 \%$ de $\mathrm{CaCo} 3$

B Calcário com $\mathrm{CaCo} 3$ entre 30 e $60 \%$

Calcário com

RQ (-) de $30 \%$ de $\mathrm{CaCo} 3$

C Gnaisse ou granito

E Elevação, em metros

T Furo de sondagem com calcário

Q Furo de sondagem sem calcário

$\mathrm{V}: \mathrm{H}=1$

Figura 6.8 - Perfis de sondagens, modificados a partir de Companhia Nacional de Cimento Portland (1965). 


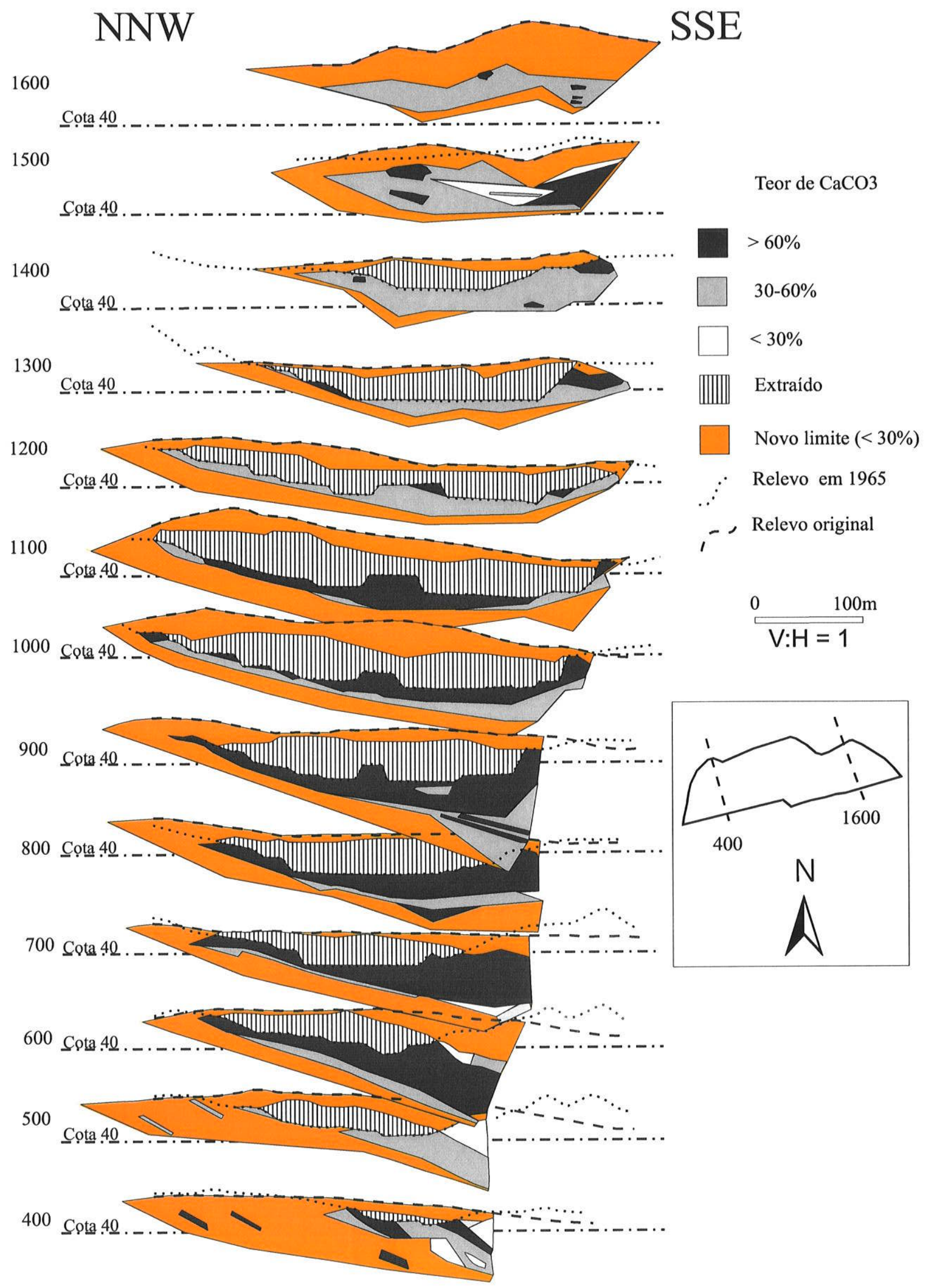

Figura 6.9 - Perfis transversais à bacia montados a partir de sondagens da Companhia Nacional de Cimento Portland (1965), incorporando os sedimentos com teor de $\mathrm{CaCO} 3$ menor do que $30 \%$, posicionados na base e no topo do pacote. 
do embasamento em apenas um furo de sondagem, a sua nova posição foi traçada paralelamente ao anteriormente definido pela $\mathrm{CNCP}$, a partir da nova profundidade.

O contorno da bacia assim obtido foi plotado em mapa, em conjunto com aquele anteriormente definido pelos técnicos da CNCP (Figura 6.10). O novo contorno mostra uma parcial concordância com o definido anteriormente, nas suas porções central e oriental, tendo apenas ampliado a sua área. Porém, no limite oeste da bacia, nos perfis 400 e 500, houve uma marcante alteração no contorno e uma ampliação de quase $100 \%$ da área da bacia. $\mathrm{O}$ novo contorno mostra o traçado recortado da borda norte, com alternância das direções ENE e NW. Na borda sul, foi mantido o limite determinado anteriormente pela $\mathrm{CNCP}$, devido às indeterminações apresentadas nos perfis de sondagens com relação à continuidade das camadas em direção à Falha de São José e, ainda, assumindo-se que a posição da falha estivesse de fácil determinação àquela época, durante a explotação da jazida de calcário. Ainda nesse sentido, foi alterado parcialmente o traçado dessa falha com relação ao indicado por Rodrigues Francisco \& Cunha (1978), que haviam inferido um traçado retilíneo para a falha ao longo de toda a sua borda sudeste.

Os perfis de sondagem indicam um maior volume de calcário junto à falha de borda, a sudeste, corroborando o seu papel como conduto principal para as soluções aquecidas.

$\mathrm{O}$ aumento progressivo na profundidade do embasamento da bacia para $\mathrm{SW}$ indica que aí se situava seu depocentro. Adicionalmente, pode-se observar que a espessura máxima da bacia deve ter atingido um pouco mais do que os $125 \mathrm{~m}$ referidos por Rodrigues Francisco et al. (1986). No perfil 900 (Figura 6.9) tem-se uma espessura de aproximadamente $140 \mathrm{~m}$.

Com base na interpretação dos perfis de sondagem aqui realizada, deve-se entender o embasamento anteriormente definido para a bacia apenas como um "embasamento econômico". Nesse caso, fica claro que os limites da bacia adotado por diversos autores, como Brito et al. (1972), Rodrigues Francisco \& Cunha (1978), Tibana et al. (1984), Bergqvist (1996), não correspondem ao seu contorno real. 


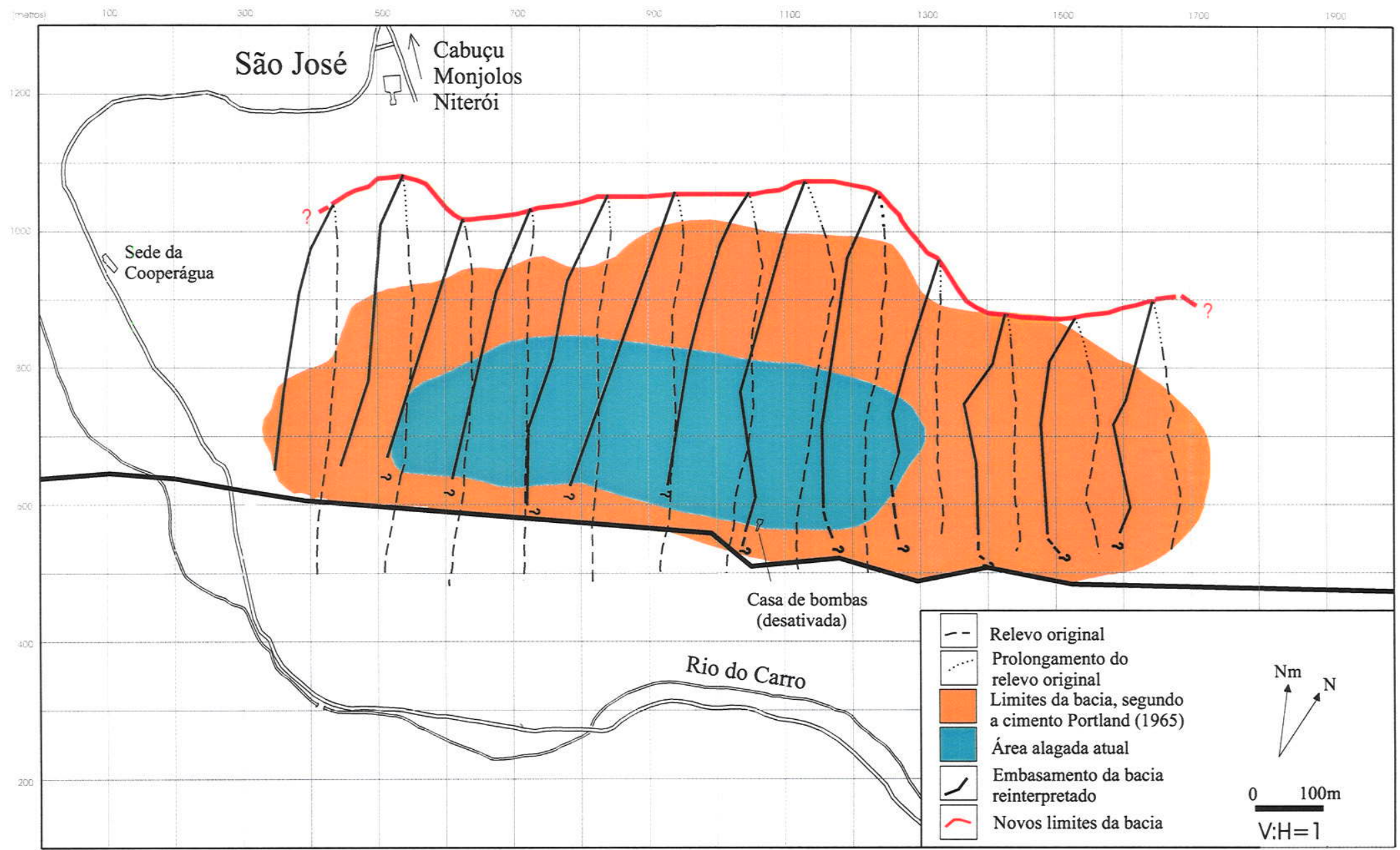

Figura 6.10 - Perfis rebatidos indicando os novos limites da Bacia de São José do Itaboraí, reinterpretados a partir dos perfis de sondagens da Companhia Nacional de Cimento Portland (1965). No limite sudeste, dado pela Falha de São José, foi mantido um traçado muito próximo do indicado por Rodrigues Francisco \& Cunha (1978), que acompanha praticamente todo o limite inferido pela Cimento Portland, tendo em vista as indeterminações com relação à continuidade das camadas em direção à falha, nos dados originais. As as variações na sua direção à leste destes perfis, seguem o traçado original da Cimento Portland, também adotado por Rodrigues Francisco \& Cunha (1978). Dados planimétricos segundo a Companhia Nacional de Cimento Portland (1965). 


\subsubsection{Estiramento da Bacia}

A arquitetura da bacia, redefinida com base nos perfis de sondagens da $\mathrm{CNCP}$, permite que se calcule a taxa de extensão ou estiramento verificada, considerando que numa bacia rift a posição do seu depocentro indica a largura original daquele segmento da crosta (Morley 1988). Nesse sentido, a taxa de extensão pode ser aproximada a partir da relação:

$\mathrm{E}=\mathrm{L}_{1}-\mathrm{L}_{0} / \mathrm{L}_{0}$ (Morley 1988$)$

Onde $\mathrm{L}_{1}=$ largura final da bacia, $\mathrm{L}_{0}=$ largura inicial reconstituída da bacia

Este mesmo parâmetro foi denominado estiramento $(\beta)$ por Mckenzie (1978) e pode ser aproximado, também, pelo modelo em dominó (Roberts \& Yielding 1994). Esta aproximação tem como premissa, bastante simplificadora, que toda a extensão ocorreu em um regime puramente extensional, que as falhas da bacia são planares (pouco provável tendo em vista a acentuada rotação das camadas) e que a bacia se situa sobre um bloco único, limitado por duas falhas, que é rotacionado em conjunto com outros. Desta forma, na equação abaixo se considera o ângulo de mergulho do fundo da bacia $(\psi)$ e o ângulo entre o plano de falha principal e o fundo da bacia $(\theta)$ :

$\beta=\operatorname{sen} \theta / \operatorname{sen}(\theta-\psi),($ Roberts \& Yielding 1994)

Então, considerando os valores obtidos a partir dos perfis 600 e 900, posicionados na porção SW da bacia (Figura 6.11), onde se encontra a maior espessura de sedimentos e onde as camadas mostram-se adernadas em até $35^{\circ}$, tem-se os seguintes valores de extensão (E):

1) Para o perfil $600 \rightarrow \mathrm{E}=363-315 / 315=48 / 315=15,2 \%$

2) Para o perfil $900 \rightarrow E=453-395 / 395=58 / 395=14,6 \%$ 
NNW

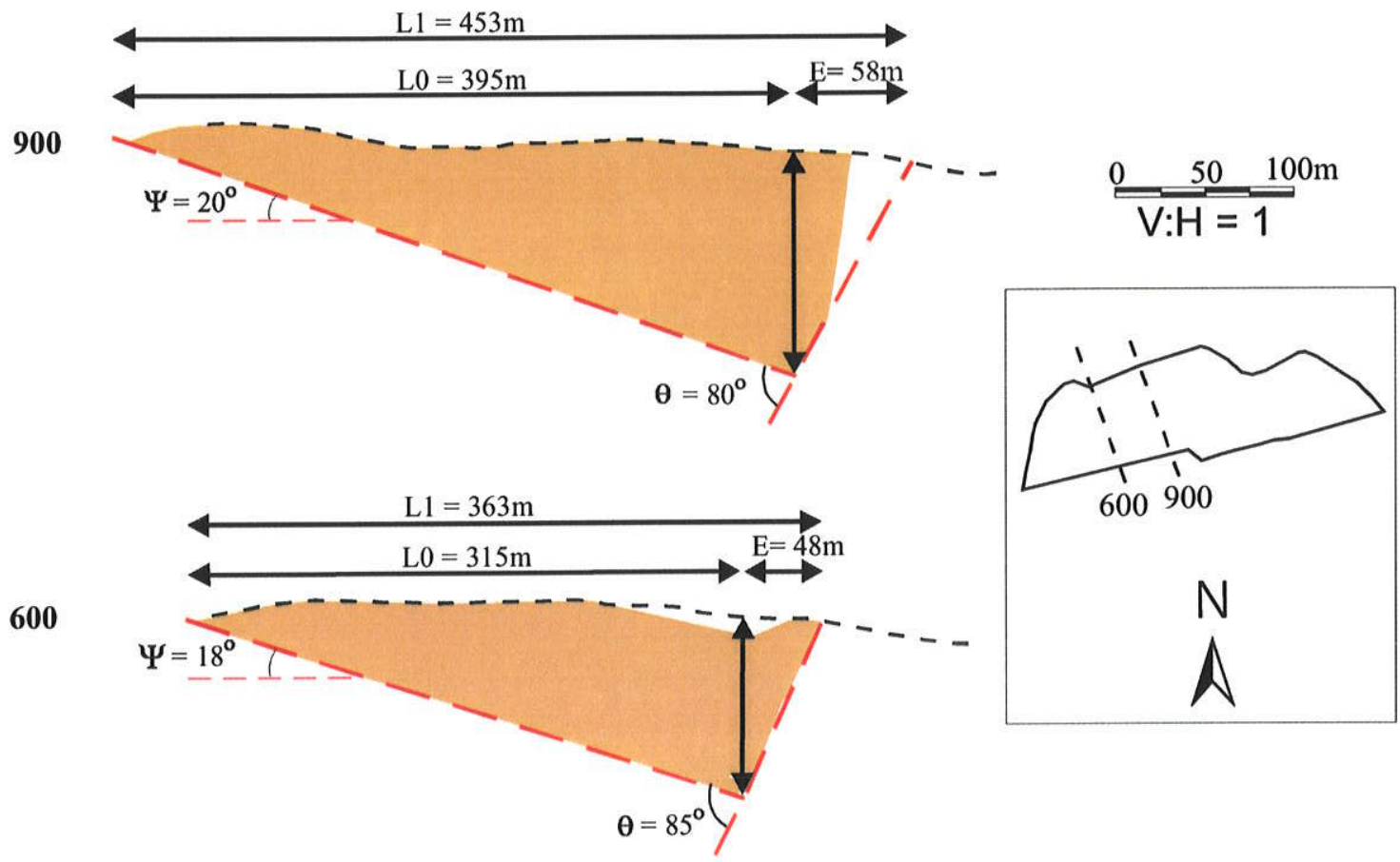

Figura 6.11 - Perfis geológicos esquemáticos da Bacia de Itaboraí construídos a partir de sondagens (Companhia Nacional de Cimento Portland, 1965 - mesma legenda da Figura 6.9). São indicados a largura total da bacia $\left(\mathrm{L}_{1}\right)$ e o aumento na largura causado pela extensão (E). A largura inicial, pré extensão $\left(\mathrm{L}_{0}\right)$, é obtida subtraindo-se a extensão sofrida da largura total $\left(\mathrm{L}_{0}=\mathrm{L}_{1}-\mathrm{E}\right)$. São indicados ainda o ângulo de mergulho do fundo da bacia $(\psi)$ e o ângulo entre a falha principal e o fundo da bacia $(\theta)$. Traçado do fundo da bacia de acordo com Figura 6.9.

\subsubsection{Adernamento das Camadas}

Da mesma forma, a partir dos perfis de sondagem mostrados na Figura 6.11, pode se calcular os valores do estiramento $(\beta)$ para os perfis 600 e 900 :

1) para o perfil $600 \rightarrow \beta=\operatorname{sen} 85 / \operatorname{sen}(85-18)=\operatorname{sen} 85 / \operatorname{sen} 63=1,11(11 \%)$

2) para o perfil $900 \rightarrow \beta=\operatorname{sen} 80 / \operatorname{sen}(80-20)=\operatorname{sen} 80 / \operatorname{sen} 60=1,13(13 \%)$ 
Os valores obtidos a partir dos dois métodos mostram taxas de estiramento semelhantes, com valores pouco maiores do que 10\%. Essas taxas se referem ao bloco mais deformado da bacia, à oeste da falha transversal de direção NW-SE. Tais taxas são bem maiores do que as de $2-3 \%$ determinadas para a Bacia de Taubaté (Azevedo Júnior et al. 1993).

Frente ao mergulho de até $35^{\circ}$ para $\mathrm{SE}$ apresentado pelas camadas da bacia à oeste da falha transversal (Figura 6.12), o mergulho das camadas do lado leste dessa falha foi pouco discutido, tendo sido essa porção da bacia considerada "menos tectonizada" por Klein e Rodrigues Francisco (1981). Porém, essas camadas inclinamse com até $20^{\circ}$, para NE, na base do pacote exposto na borda nordeste da bacia, e com cerca de $10^{\circ}$, também para $\mathrm{NE}$, no topo do pacote com lamitos e carbonatos intercalados (Figura 2C). Nos lamitos sem carbonatos intercalados essa inclinação de cerca de $10^{\circ}$ para NE a NNE persiste (Figura $1 \mathrm{C}$ ), evidenciando que todo o pacote foi afetado por esse tectonismo e que a sua intensidade diminuiu com a evolução da bacia, tendo sido mais efetivo no Paleoceno.

Como pode ser visto no item anterior, os adernamentos tectônicos de camadas no interior das bacias, que se referem de fato a um adernamento do seu embasamento, implicam na geração de espaços. Para que tais espaços sejam criados faz-se necessário que a bacia seja extendida ortogonalmente ao eixo de rotação das camadas. Considerando-se o mergulho apresentado pelas camadas na porção NE da bacia, para nordeste, esse adernamento indica uma extensão na direção NE-SW e exige a existência de uma estrutura na borda $\mathrm{NE}$, com orientação transversal à falha principal, que adapte essa movimentação. Essa estruturação sugere que a leste da falha transversal o depocentro se deslocava da Falha de São José para a essa falha de borda, localizada a NE. Tal característica permite reafirmar a importância das estruturas transversais na estruturação da Bacia de São José do Itaboraí. Ademais, a provável contemporaneidade dos adernamentos, tanto para SW em direção à Falha de São José, como para NE, indica a complexidade da distribuição das tensões na bacia. 


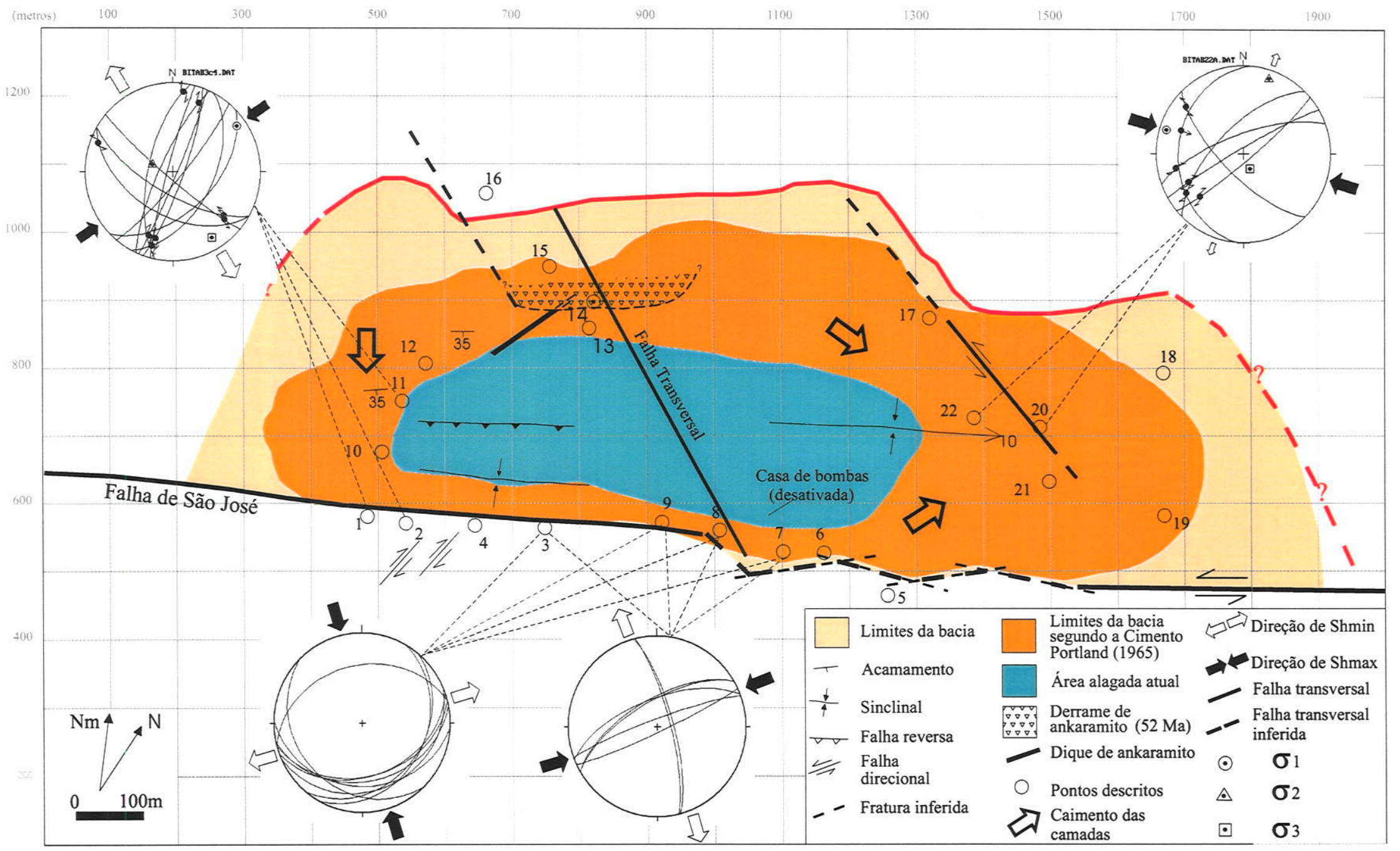

Figura 6.12 - Mapa estrutural da Bacia de São José do Itaboraí, incorporando dados publicados (Rodrigues Francisco \& Cunha 1978, Klein \& Rodrigues Francisco 1981, Klein \& Valença 1984a), dados novos, e o novo contorno da bacia, definido a partir da interpretação dos perfis de sondagem da Companhia Nacional deCimento Portland(1965). 


\subsubsection{Síntese dos Eventos Deformacionais}

Uma síntese dos eventos deformacionais que afetaram a Bacia de São José do Itaboraí é apresentada na Figura 6.12, incluindo o novo contorno da borda NW da Bacia de São José do Itaboraí em conjunto com os novos dados estruturais coletados nesse trabalho e com os dados estruturais disponíveis na literatura.

Os veios de calcário travertino indicam uma variação no campo de paleotensões que afetou a bacia. Registra-se, nesse caso, a atuação inicial de uma extensão NW-SE, responsável pela intrusão dos veios com alto ângulo de mergulho encaixado na Falha de São José, seguido de uma compressão NW-SE, que controlou a intrusão dos veios com mergulho de baixo ângulo que cortam os anteriores. Essa característica indica que a inversão da bacia, ou pelo menos parte dela, foi realizada contemporaneamente ao hidrotermalismo que gerou os veios de calcários travertinos. Dessa forma, considerando-se a efetiva contemporaneidade entre os veios que preenchem as falhas e os que constituem as camadas de travertinos e tufa depositados lateralmente a elas (Hancock et al. 1999), pode-se inferir que parte da inversão da Bacia de São José do Itaboraí ocorreu no Paleoceno Inferior a Médio.

A análise cinemática das falhas e microfalhas que afetam os sedimentos da Bacia de São José do Itaboraí e os gnaisses junto à sua borda sudeste, também indicou que a bacia foi afetada por dois campos de paleotensões distintos, ambos relativos a regimes direcionais. Um caracterizado por um eixo de tensões máximo, $\sigma 1$, orientado na direção NE-SW e outro com esse eixo posicionado na direção NW-SE. Não foi possível caracterizar a idade relativa entre esses dois campos de paleotensões.

Com base no conjunto de dados preexistentes e nos coletados nesse trabalho, pode-se relacionar a história tectônica da Bacia de São José de Itaboraí a dois campos de paleotensões distintos:

a) Extensão NW-SE, responsável pela formação da bacia, pela deposição do seu preenchimento, pelo adernamento das camadas contra a Falha de São José, pela intrusão dos veios de calcário travertino verticais e pela intrusão do dique de ankaramito; 
b) Compressão NW-SE, responsável pela inversão da bacia, gerando a falha reversa de direção ENE-WSW interna a ela, as fatias do embasamento sobre os sedimentos da bacia e os veios de calcário travertino horizontais. A extensão ortogonal a essa compressão, de direção NE-SW pode ter gerado o adernamento das camadas da porção oriental da bacia para NE.

\subsubsection{Discussão}

A extensão NW-SE pode ter ocorrido em um regime puramente extensional, com $\sigma_{1}$ vertical, ou mesmo direcional, com $\sigma 1$ horizontal, associado a uma movimentação transcorrente sinistral da Falha de São José. Essa assertiva é válida, também, para a compressão NW-SE, a qual pode ter sido puramente compressiva ou associada a um regime transpressivo.

Os dados estruturais de microfalhas e de veios de travertinos não são conclusivos para a natureza dos regimes de esforços, tendo em vista que:

1) não se sabe a idade das microfalhas, uma vez que elas podem ser totalmente posteriores ao preenchimento da bacia;

2) os veios de travertinos indicam a direção do eixo de tensões mínimo, $\sigma 3$, que permitiu a sua intrusão, mas não sob que regime de paleotensões essa extensão teria se dado.

Por outro lado algumas evidências indicam que a tectônica na bacia foi mais intensa durante a geração dos calcários (no Paleoceno):

1) a espessura dos depósitos com presença de camadas de calcário é bem maior do que a dos sedimentos puramente clásticos que encerram a história deposicional da bacia;

2) as camadas sedimentares mostram uma diminuição no seu adernamento, da base para o topo (Figura 6.2C).

Dessa forma, as feições estruturais identificadas na bacia permitem que se levante três hipóteses para a sucessão de eventos responsáveis pela sua evolução tectônica: 


\section{Hipótese 1}

Evento I - extensão pura NW-SE (ativação normal da Falha de São José) $\rightarrow$ geração da bacia, adernamento de camadas contra a Falha de São José e intrusão de veios de calcário travertino verticais paralelos a essa falha;

Evento II - transcorrência sinistral (ativação direcional sinistral da Falha de São José) $\rightarrow$ formação de microfalhas sinistrais WNW-ESE e dextrais NNE-SSW;

Evento III - transcorrência dextral (ativação direcional dextral da Falha de São José) $\rightarrow$ intrusão de veios de calcários travertinos horizontais, formação de microfalhas dextrais ENE-WSW e sinistrais NW-SE, geração de falha de empurrão interna à bacia, de dobras paralelas à Falha de São José (incluindo o grande sinclinal com eixo caindo para NE) e da falha transversal;

Evento IV - extensão NW-SE $\rightarrow$ intrusão do dique de ankaramito (o dique é posterior ou tardio à injeção dos veios de calcário travertino, pois esse "derrame" separa a Formação Itaboraí dos lamitos sem calcário) e adernamento dos lamitos pósankaramito (da Seqüência Superior).

\section{Hipótese 2}

Evento I - transcorrência sinistral $\rightarrow$ responsável pela geração das feições atribuídas aos eventos I e II da hipótese 1. Nesse caso a bacia já teria sido gerada como uma bacia direcional, a partir da movimentação direcional sinistral da Falha de São José; Evento II - transcorrência dextral $\rightarrow$ gerador das feições geradas pelo evento III da hipótese 1;

Evento III - extensão NW-SE $\rightarrow$ responsável pelas feições atribuídas ao evento IV da hipótese anterior.

\section{Hipótese 3}

Evento I - transcorrência sinistral (responsável pela geração de todas as feições estruturais caracterizadas na bacia)

No caso da hipótese 1, a suposição de uma extensão pura inicial (Evento I) viria a contemplar a principalmente a intrusão dos veios de travertino verticais, na Falha de São José, considerando-se eles comumente ocorrem associados a esse tipo de 
regime (Hancock et al. 1999). A hipótese 2 assume que inclusive a injeção desses veios pode ter se realizado sob movimentação direcional da falha de São José, em locais de relaxamento (releasing bends). Já a hipótese 3 assume que um regime transcorrente sinistral poderia originar as estruturas observadas na bacia, incluindo as associadas à compressão NW-SE, como os veios de travertino de baixo ângulo e os dobramentos das camadas, com eixos sub-paralelos à Falha de São José.

Considera-se aqui que a hipótese 3 é a mais provável. Tal assunção baseia-se nos seguintes aspectos:

1) variações na direção ou no sentido de caimento da Falha de São José, podem ter produzido locais de relaxamento (releasing) e de restrição (restraining) (CristieBlik \& Biddle 1985) em diversas escalas na bacia, gerando os denominados efeitos golfinho (Zalàn 1987) ou ribbon (Zolnai 1991), respectivamente. Dessa forma teriam se alternado segmentos onde predominou uma componente reversa, com outros onde predominou uma componente normal ao longo da Falha de São José. Nesse caso, as dobras sinclinais, que ocorrem tanto na porção ocidental da bacia como na oriental (Figura 6.12), poderiam ter sido geradas ainda sob um regime de transcorrência sinistral. Ainda nesse sentido, uma eventual rotação de blocos pode causar compressão local, considerando-se as discrepâncias entre o comprimento inicial dos blocos transversais à bacia e a sua largura (Figura V-8 de Zolnai 1991);

2) a extensão NW-SE associada à intrusão do dique de ankaramito, de direção N45E (Klein \& Valença 1984a), posterior à deposição da Formação Itaboraí e, portanto, também à intrusão dos veios de calcário travertino horizontais, pode ter sido associada a um regime direcional sinistral, como proposto por Riccomini \& Rodrigues Francisco (1992). Esse campo de paleotensões poderia explicar o não aproveitamento da Falha de São José, de direção N62E (Beurlein \& Sommer 1954), para intrusão do dique, tendo em vista que, nesse caso, essa estrutura seria reativada como falha direcional sinistral. Ao contrário, sob uma extensão pura de direção NW-SE a Falha de São José tenderia a ser reativada com falha extensional atuando como provável conduto para esse magmatismo;

3) a silicificação acompanhada de brechação verificada na falha transversal de Rodrigues Francisco \& Cunha (1978) reforça essa hipótese, por exigir que ela tenha acompanhado a evolução da bacia desde a sua implantação; 
4) o adernamento das camadas para NE na porção oriental da bacia pode ser adaptado de maneira mais simples em um regime transcorrente sinistral, considerando-se que o adernamento exige uma extensão na direção NE-SW para acomodá-lo e, ainda, a presença de uma falha de borda, localizada no limite NE da bacia. Por outro lado, o fato desse adernamento diminuir de intensidade da base para o topo do pacote sugere que ele é sin-deposicional e que esse adernamento e o de $35^{\circ}$ para $\mathrm{SW}$, presente a leste da falha transversal, são contemporâneos e concomitantes à deposição dos carbonatos, no Paleoceno. Dessa forma, a bacia teria sofrido extensão simultânea NW-SE e NE-SW, possível apenas em uma bacia direcional, segmentada em blocos;

5) no caso de um regime puramente extensional, de bacias rift, os adernamentos de camadas estão forçosamente associados à(s) falha(s) de borda, que no caso seria a Falha de São José. Nessas bacias os depocentros podem ser deslocados de uma borda a outra na direção da extensão máxima, por intermédio de falhas de transferência posicionadas internamente à bacia, mas nunca nas extremidades opostas à extensão principal, as quais são caracterizadas por rejeitos despreziveis nas falhas mestras (Roberts \& Yielding 1994).

Nessa hipótese de a Bacia de São José do Itaboraí ter sido gerada por transcorrência associada à Falha de São José deve-se considerar a questão do rejeito necessário ao longo da falha para que a bacia fosse formada. Tomando-se como premissa uma espessura crustal semelhante à determinada para Bacia de Taubaté, de aproximadamente $32 \mathrm{~km}$, sem a verificação de afinamento (Padilha et al. 1991), podese estimar que uma movimentação da falha de pouco menos do que 100 metros seria suficiente para gerar os 140 metros de sedimentos da bacia (Figura VIII-5/C de Zolnai 1991). Dessa forma, a Falha de São José precisaria ter tido uma taxa de movimentação de cerca de $2 \mathrm{~cm} / 1000$ anos para compreender os aproximadamente 6 $\mathrm{Ma}$ indicados pelo seu preenchimento, entre o limite Paleoceno Inferior/Paleoceno Superior (Bergqvist 1996) e o limite Paleoceno Superior/Eoceno Inferior (Lima \& Cunha 1986).

Ressalta-se ainda, nesse sentido, a contemporaneidade do desenvolvimento da Bacia de São José do Itaboraí com o magmatismo alcalino e com o hidrotermalismo tardio desencadeado por ele, que exibem diversas evidências de terem sido controlados por um binário sinistral E-W (ver Capítulo 4), reforçando uma possível geração em um regime direcional. A idade de 52 Ma obtida por Riccomini \& 
Rodrigues Francisco (1992) para o ankaramito, indica que esse campo de paleotensões pode ter atuado na Bacia de São José do Itaboraí até o Eoceno Inferior.

\section{Conclusões Parciais}

1) A análise cinemática das microfalhas caracterizadas na bacia de São José do Itaboraí indica a atuação de dois campos de paleotensões direcionais distintos. Um com o eixo de paleotensões máximo, $\sigma 1$, na direção NE-SW, e outro com $\sigma 1$ de direção NW-SE;

2) A variação de uma extensão NW-SE, mais antiga, para uma compressão nessa direção, mais nova, é indicada também pelos veios de calcário travertino maciço a bandados, com alto e baixo ângulos de mergulho respectivamente, encaixados na Falha de São José e no embasamento junto a ela. Essa característica aponta que a inversão da bacia foi, pelo menos em parte, concomitante com o hidrotermalismo que gerou os calcários travertinos paleocênicos;

3) A interpretação de perfis de sondagens permitiu que se caracterizasse um novo arcabouço estrutural para a bacia, evidenciando que o seu contorno utilizado na literatura corresponde a um limite econômico de ocorrência das fácies carbonáticas;

4) As taxas de estiramento determinadas para a porção da bacia à oeste da Falha Transversal, de pouco mais de $10 \%$, são bem maiores que as determinadas para as outras bacias do RCSB;

5) As características estruturais da bacia podem ser melhor aproximadas se considerarmos a sua geração e evolução em um regime de paleotensões direcional, com a falha de São José se movimentando sinistralmente, correspondendo a um binário sinistral E-W. Nesse modelo a bacia teria se originado, provavelmente, a partir de uma zona de relaxamento (releasing bend) e as inversões poderiam estar associadas a zonas de restrição (restraining bends) ou a rotações de blocos. A atuação da falha transversal de Rodrigues Francisco \& Cunha (1978) desde o Paleoceno Inferior e a necessidade de uma falha de borda a NE, também desde o Paleoceno Inferior, para acomodar o adernamento dos sedimentos da porção oriental da bacia para $\mathrm{NE}$, reforçam as evidências de uma estruturação em blocos. 


\subsection{BACIA DO MACACU}

\subsubsection{Introdução}

\subsubsection{Trabalhos Anteriores}

Depósitos sedimentares continentais cenozóicos são conhecidos em áreas adjacentes à Baía de Guanabara desde o século 19, quando foram correlacionados ao Grupo Barreiras (Hartt 1870). Tal correlação persistiu até o final da década de 70 e início da de 80 , com os primeiros trabalhos sistemáticos de Meis \& Amador $(1972,1974,1977)$ e Dalcolmo et al. (1982) (Tabela 6.2).

Nos trabalhos clássicos de Meis \& Amador $(1972,1977)$ os depósitos continentais cenozóicos que ocorrem no recôncavo da Baía de Guanabara, foram subdivididos em Camadas Pré-Macacu, tidos por eles como do Terciário Médio, e Formação Macacu, considerada plio-pleistocênica e correlata ao Grupo Barreiras. Ambas teriam sido formadas em ambiente de leques aluviais, com melhor preservação dos feldspatos na primeira e maior participação fluvial na última. Esses autores advogaram uma discordância erosiva entre as duas, não claramente explicitada e, ao contrário, todas as seções apresentadas mostram as duas unidades em concordância. As duas unidades foram reunidas posteriormente em uma única por Dalcolmo et al. (1982), denominada Formação Barreiras, para a qual atribuíram idade plio-pleistocênica.

Com base em seu contexto tectônico, Almeida (1976) relacionou essas unidades sedimentares ao Rift da Guanabara, parte do Sistema de Rifts da Serra do Mar (SRSM), em conjunto com aqueles que preenchem as bacias de Curitiba, São Paulo, Taubaté, Resende, Volta Redonda e São José do Itaboraí, por ele denominadas de "bacias tafrogênicas terciárias do Sudeste do Brasil". Evidências de que as bacias de São Paulo, Taubaté, Resende e Volta Redonda teriam evoluído a partir de uma única bacia, levaram Riccomini (1989) a reunir todo conjunto de bacias continentais do SRSM no Rift Continental do Sudeste do Brasil (RCSB). 
A não identificação da discordância referida por Meis \& Amador (1977), a descoberta de camadas de linhito, com palinomorfos de idade eocênica a oligocênica (Cicatricosisporites dorogensis e Retriticolporites quadrosi, entre outros), e o seu controle tectônico, levaram Lima et al. (1996) a reuni-los dentro da Formação Macacu e a correlacionar esses depósitos com outros de mesma idade do RCSB. Para esses autores a Formação Macacu seria constituída por um sistema deposicional de leques aluviais, na base, fluvial entrelaçado, na sua porção intermediária, e fluvial meandrante, no topo, com camadas de linhito. Da mesma forma, Ferrari \& Silva (1997) consideraram que esses depósitos constituem uma única unidade litoestratigráfica, a Formação Macacu, formada por depósitos de leques aluviais, com depósitos lacustres na base, e defíniram a Bacia do Macacu, caracterizando seus limites e a tectônica deformadora que a afetou.

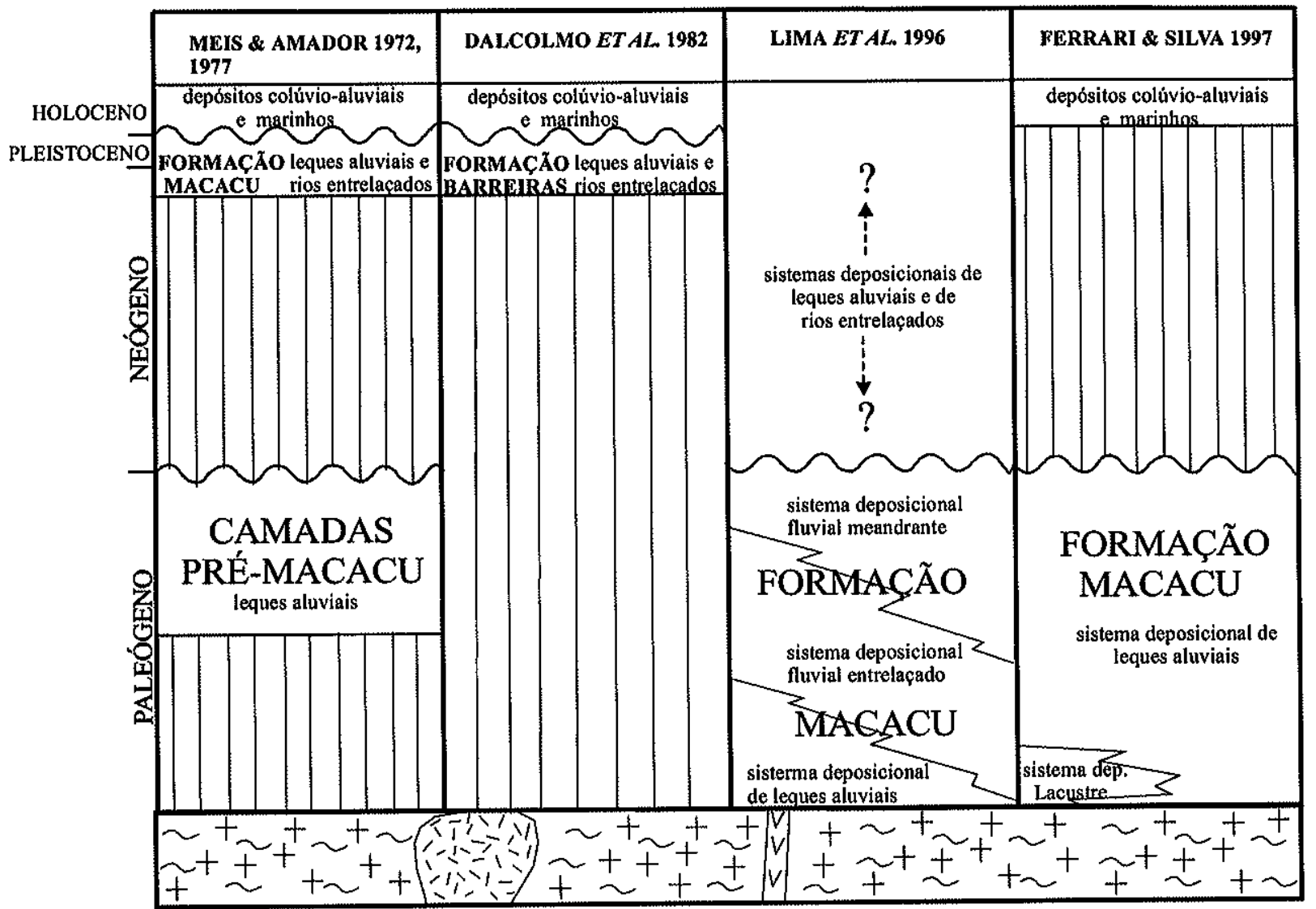

Tabela 6.2 - Síntese das colunas estratigráficas propostas para a Formação Macacu. 
Deve-se salientar que em nenhum dos trabalhos citados acima foram descritas as fácies sedimentares e as associações de fácies dos depósitos que preenchem a Bacia do Macacu.

\subsubsection{Características Gerais}

A Bacia do Macacu, preenchida pela formação homônima (Ferrari \& Silva 1997), tem sua principal área de ocorrência concentrada junto ao limite nordeste da Baía de Guanabara, se estendendo na direção ENE por cerca de $25 \mathrm{~km}$, com largura aproximada de $20 \mathrm{~km}$, perfazendo mais de $400 \mathrm{~km}^{2}$ nos Municípios de Itaboraí, Magé e São Gonçalo (Figura 6.13). Ocorrências isoladas dessa formação, com cerca de $4 \mathrm{~km}^{2}$ cada, localizadas a oeste/sudoeste da principal, são encontradas na Ilha do Governador e no Município de Duque de Caxias.

\section{A) Espessura do Pacote de Sedimentos}

O relevo aplainado, raramente ultrapassando a cota de 30 metros, e o mergulho subhorizontal das camadas, faz com que a porção exposta da bacia tenha uma espessura de aproximadamente 40 metros, que somados aos pouco mais de 110 metros conhecidos através de sondagens para água subterrânea (Meis \& Amador 1977; Figura 6.14, nesse trabalho), indicam um total de pelo menos 150 metros.

A partir da interpretação de dados gravimétricos, que evidenciaram uma anomalia negativa com amplitude de até $20 \mathrm{mgal}$, Haralyi et al. (1982) apontaram para uma espessura de até 800 metros para os sedimentos da Formação Macacu, imediatamente a norte de Itaboraí. Esses dados foram recontornados e reinterpretados por Ferrari \& Ferraz (1988), com base na coincidência do mínimo gravimétrico com um plug de rocha alcalina, aflorante em meio aos sedimentos da bacia a cerca de $3 \mathrm{~km}$ ao norte de Itaboraí (Figura 6.14). Essa reinterpretação mostrou que a anomalia observada pode ser gerada por um stock sienítico não aflorante, com pequeno contraste negativo de densidade com relação às rochas 


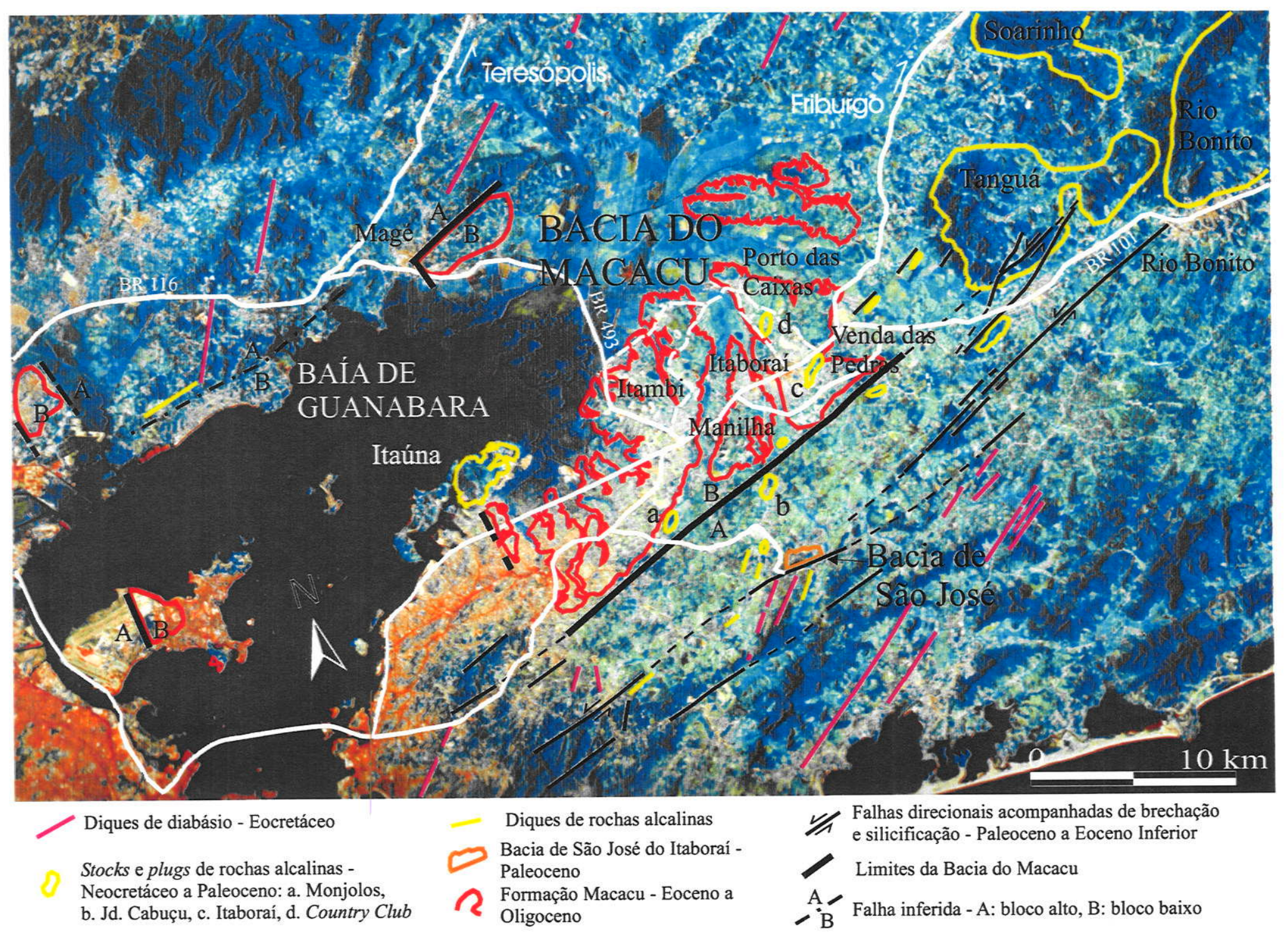

Figura 6.13 - Geologia simplificada do Cretáceo e Paleógeno na porção central do Rift da Guanabara, modificada a partir de Meis \& Amador (1977), Penha et al. (1979), Dalcolmo et al. (1982), Valença \& Klein (1984), Ferrari (1990) e Coelho et al. (1987). Base cartográfica imagem LANDSAT TM em escala original 1:250.000. Áreas urbanas (tons de cor marrom); áreas densamente vegetadas (cor azul escura). 


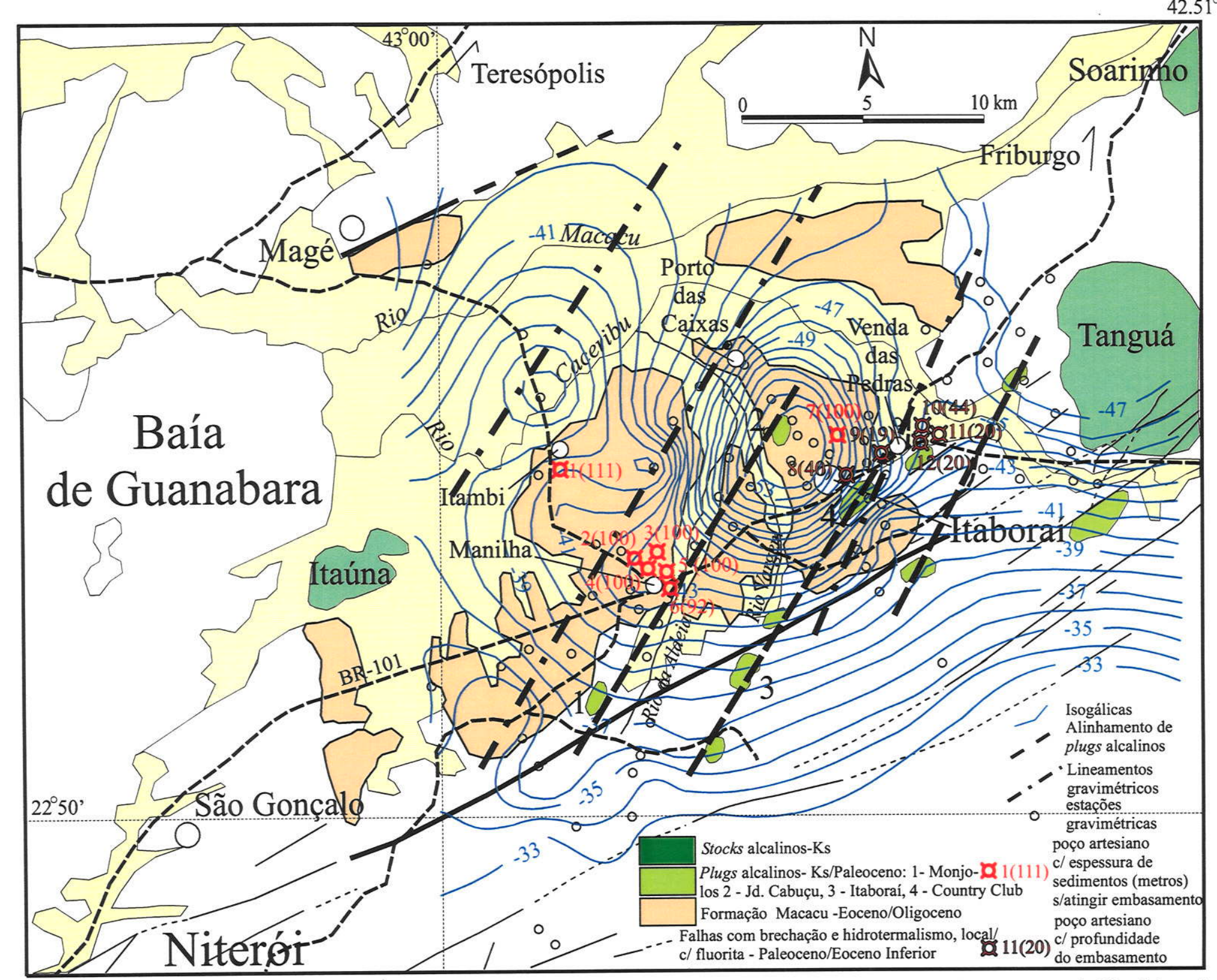

Figura 6.14 - Arcabouço estrutural da Bacia do Macacu. Isogálicas segundo Ferrari \& Ferraz (1988), a partir do levantamento de Haralyi et al. (1982), com um total de 72 estações. Traços finos longos representam falhas terciárias e traços grossos indicam os limites da Bacia do Macacu. Os poços artesianos em vermelho não atingiram o embasamento e têm a profundidade do poço indicada. Geologia modificada de Meis \& Amador (1977), Penha et al. (1979), Dalcolmo et al. (1982), Valença \& Klein (1984), Coelho et al. (1987), Ferrari (1990) e Dehira et al. (1998). Dados de poços a partir de Hidrogesp (1), Geoplan (2-5 e 7), INX-Hidrogeologia (6), RC-RIO Engenharia Ltda. (8 e 9), SONDOPOÇO (10-12). 
encaixantes, conjugado com uma cobertura sedimentar de no máximo 200 metros de espessura. Segundo Ferrari e Ferraz (1988), o plug aflorante em meio aos sedimentos da Formação Macacu, representa um paleorelevo do embasamento da Bacia do Macacu.

Dados de sondagens para poços artesianos, mais recentes, têm revelado uma espessura maior de sedimentos em Manilha e Itambi (Figuras 6.14 e 6.24), onde foram atravessados até pouco mais de 110 metros de sedimentos sem encontrar o embasamento. Por outro lado, os poços perfurados na área urbana de Itaboraí, no distrito de Venda das Pedras, e na BR-101, junto à borda sudeste da bacia, atingiram o embasamento a profundidades, em geral, menores que 40 metros. $O$ embasamento tem sido descrito, nos perfis dos poços, principalmente como gnáissico e, subordinadamente, como constituído por rocha alcalina fonolítica. Parte desses dados que referem-se a um total de 16 poços, perfurados pelas firmas GEOPLAN (8 poços), HIDROGESP (1 poço), RC-RIO Engenharia Ltda. ( 2 poços), INX - HIDROGEOLOGIA ( 1 poço), GEOSERV ( 1 poço) e SONDOPOÇO (3 poços), são analisados em detalhe na Figura 6.24.

A análise dos dados gravimétricos em conjunto com os de sondagens para poços artesianos profundos (Figura 6.14), permite algumas inferências importantes com relação ao arcabouço estrutural da Bacia do Macacu:

1) O "baixo gravimétrico de Itaborai" (Haralyi et al. 1982) corresponde, essencialmente, a uma feição do embasamento da Bacia do Macacu, como sugerido por Ferrari \& Ferraz (1988), tendo em vista que as áreas de mínimo gravimétrico não correspondem, necessariamente, às maiores espessuras de sedimentos. Nesse sentido chama-se atenção para o poço 8, perfurado no Hospital Municipal de Itaboraí, junto ao mínimo gravimétrico, que encontrou o embasamento a 40 metros de profundidade. Em adição, os poços que perfuraram os pacotes sedimentares mais espessos estão, em geral, fora da anomalia principal, em áreas com valores próximos da média regional. $\mathrm{O}$ poço 1 , em especial, perfurado em Itambi e que se posiciona nas proximidades de um alto gravimétrico, atravessou mais de 110 metros de sedimentos, sem atingir 0 embasamento. Esse mascaramento da reposta gravimétrica do pacote sedimentar da Bacia do Macacu pode ter sido potencializado pela segmentação da bacia por processos tectônicos e erosivos pós deposicionais, 
2) A espessura de 100 metros de sedimentos atravessada pelo Poço 7, localizado junto ao mínimo gravimétrico, em isogálica adjacente à do Poço 8 (Figura 6.14), reforça a existência de um paleorelevo irregular no embasamento da bacia, junto aos plugs de rochas alcalinas do Country Club e de Itaboraí,

3) A coincidência entre as direções dos lineamentos gravimétricos e dos alinhamentos de rochas alcalinas, ambos NE-SW, reforça a vinculação entre o embasamento da bacia e a anomalia gravimétrica. A localização de diversos poços com espessuras em torno de 100 metros a oeste do Rio da Aldeia, sugere que estruturas com direção NE-SW podem ter sido reativadas e controlado blocos com movimentos verticais diferenciados no embasamento da bacia. Nesse sentido, o alinhamento entre os plugs de Monjolos e do Country Club, pode ter exercido um papel importante nessa estruturação. Futuras sondagens na região de Porto das Caixas poderiam testar esse modelo.

B) Geomorfologia da Bacia do Macacu e do seu Entorno

Tanto o embasamento em torno da Bacia do Macacu, como a própria bacia, mostram um relevo aplainado e parcialmente dissecado pelas drenagens atuais. $O$ embasamento é caracterizado pela presença dos mares de morros em meia laranja, cujos topos raramente ultrapassam os 60 metros, e vales entulhados por aluviões subatuais e atuais. Os sedimentos da Bacia do Macacu sustentam morros com formas bem mais amplas e irregulares, com topo chato e encostas suavemente convexas, que raramente ultrapassam a cota de 30 metros.

Destacam-se em meio aos sedimentos, alcançando cotas diferenciais de até 30 metros, os plugs de rocha alcalina do Country Club e de Itaboraí (Figuras 6.13, 6.14 e 6.15A), que constituem um relevo residual do embasamento da bacia, formando verdadeiros inselbergs. Feições similares podem ser observadas junto ao limite sudeste da bacia, correspondendo aos plugs de Monjolos, Cabuçu e Jardim Cabuçu (Figura 6.15A), também destacados topograficamente no meio do mar de morros que os envolve, atingindo cotas de até 70 metros. Essa característica é ainda mais marcante no caso dos stocks de 

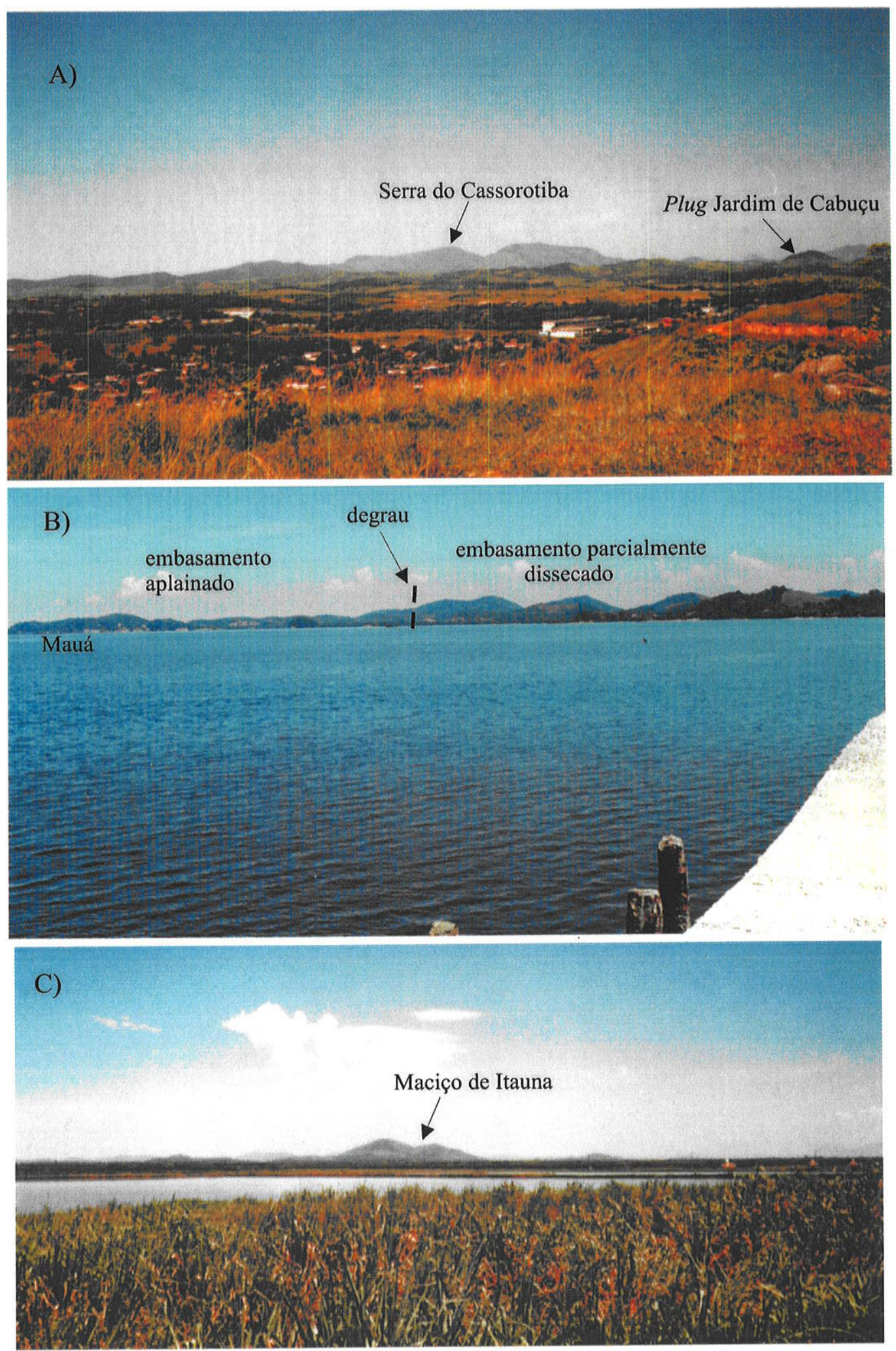

Figura 6.15 - A) Borda sudeste da Bacia do Macacu vista a partir do topo aplainado do plug alcalino de Itaboraí (cf. Figura 1), destacando, ao fundo, a Serra do Cassorotiba aos pés da qual se situa a Bacia de São José do Itaboraí e, num plano intermediário, os morrotes do embasamento junto à borda sudeste da bacia, entre os quais se destaca, como um pequeno inselberg, o plug alcalino de Jardim Cabuçu (cf. Figura 1). Visada para SSW; B) Região de Mauá, porção norte da Baía de Guanabara, vista de NE para SW, destacando degrau entre o embasamento aplainado, ao sul, e o embasamento parcialmente dissecado, ao norte; C) Maciço de Itaúna visto de NNE para SSW, a partir das proximidades do Ponto 27 (Figura 6.14), ao sul de Magé. 
Itaúna e Tanguá, a oeste e a leste, respectivamente (Figuras 6.13 e 6.14). Esses últimos atingem cotas de 280 (Figura 6.15C) e de 600 metros, respectivamente, e o Tanguá apresenta o topo aplainado e já parcialmente dissecado.

Por vezes o embasamento apresenta um relevo fortemente aplainado, ainda não dissecado e sem os morrotes em meia laranja, sugerindo superfícies de aplainamento que sofreram exumação recente, indicando atividade neotectônica. Tal característica pode ser vista principalmente na llha do Governador e junto ao limite norte da Baía da Guanabara, no distrito de Mauá (Figura 6.13). Nesse último local, vê-se um degrau entre o embasamento fortemente aplainado e o embasamento mais dissecado, ao norte, podendo-se inferir uma falha entre os dois domínios (Figura 6.15B), a qual coincide lateralmente com o degrau que se observa entre o embasamento e o limite norte da Bacia do Macacu, em Magé (Figura 6.13).

Essa superfície aplainada, parcialmente dissecada, em que se situa a Bacia do Macacu, faz parte do domínio morfo-tectônico do Vale de Afundimento (sic) Campo Grande - Guanabara - Rio Bonito (Freitas 1951), ou Rift da Guanabara (Almeida 1976, Ferrari 1990). Esse último foi definido por Almeida (1976), estendendo-se desde Sepetiba, a oeste, até Barra de São João, a leste, por mais de $200 \mathrm{~km}$. Esse relevo aplainado ou levemente dissecado, em que se destacam os inselbergs constituídos por rochas alcalinas, contrasta com o da escarpa da Serra dos Órgãos, localizada cerca de $10 \mathrm{~km}$ ao norte do limite setentrional da Bacia do Macacu (Figuras 6.13 e 6.16), que se eleva a partir dos mares de morros até pouco mais de 2000 metros, em média. No seu ponto culminante, na Pedra do Sino, ela alcança 2280 metros de altitude, constituindo, por sua vez, uma superfície aplainada e já bastante dissecada, que corresponde à Superfície Japi (Almeida 1964, 1976) ou Sul-Americana (King 1956). Para o sul, em direção aos maciços litorâneos, essa passagem é bem menos acentuada, atingindo cotas em torno de 500 metros de altitude, junto ao litoral. Nessa borda da bacia a quebra de relevo mais marcante é dada pela Serra do Cassorotiba, que atinge cerca de 300 metros de altitude (Figura 6.15A). Para Almeida (1976) tais desníveis topográficos seriam tectônicos, correspondendo ao desnivelamento da Superfície Japi, a qual teria sua altitude original situada entre 1200 e 1400 metros. 

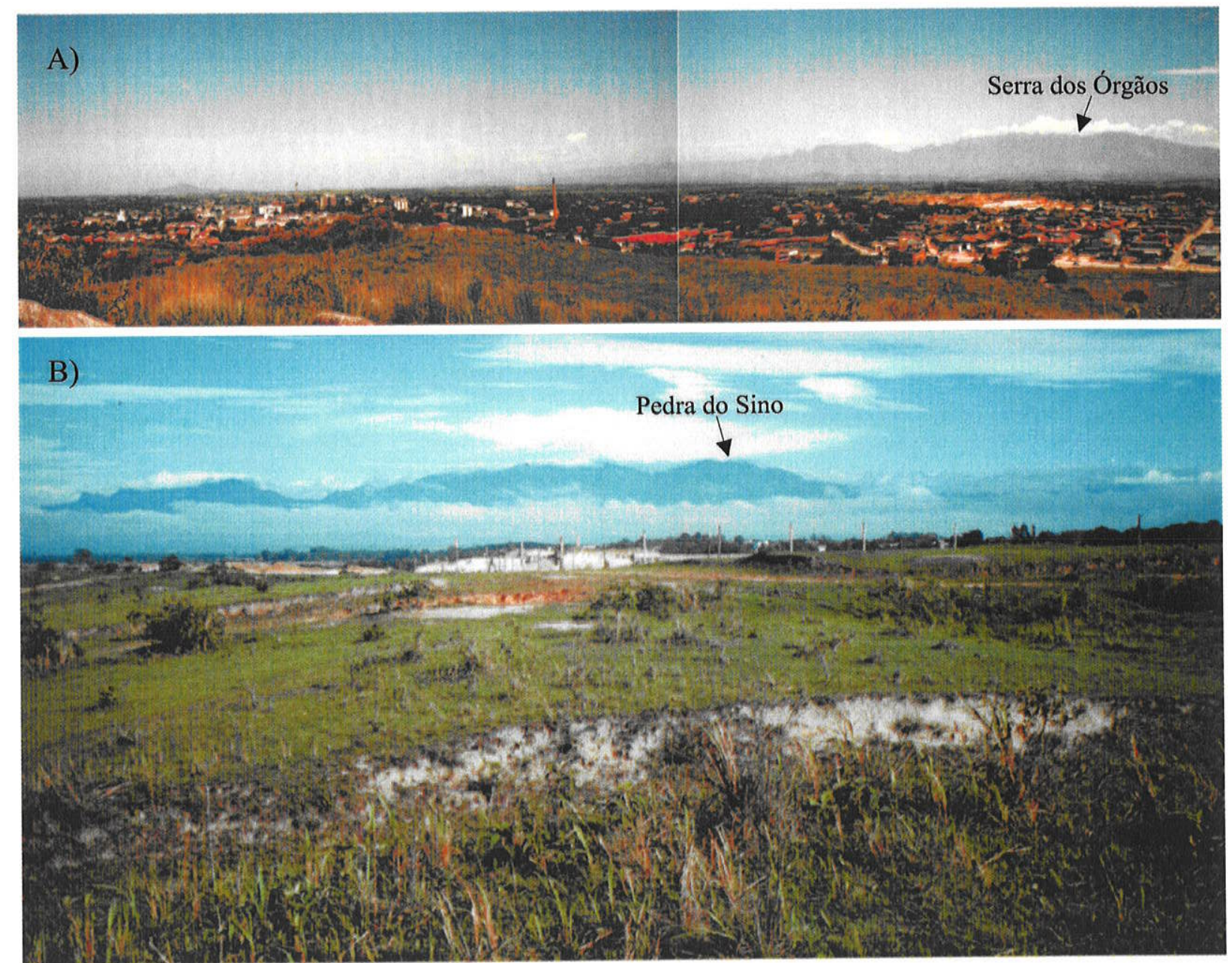

Figura 6.16 - A) Vista panorâmica do relevo aplainado da Bacia do Macacu, na área urbana de Itaboraí, a partir do topo aplainado do plug alcalino de Itaboraí (cf. Figura 1), com altitude de aproximadamente 60 metros. Ao fundo vêse a silhueta da Serra do Mar, no seu segmento imediatamente ao norte da Baía da Guanabara, denominado Serra dos Órgãos. Visada de SE para NW. B) Serra dos Órgãos, com altitude máxima de 2280 metros, na Pedra do Sino, e desnível topográfico médio de 2000 metros com relação à Bacia do Macacu. Visada de SE para NW, a partir das proximidades do distrito de Porto das Caixas (cf. Figura 1). 
C) Limites da Bacia

Os limites atuais da bacia, a sudeste e a noroeste, parecem ter um controle tectônico já parcialmente recortado pelos processos associados aos eventos erosivos neogênicos, especialmente a sudeste, os quais dificultam a identificação das falhas de borda. $\mathrm{Na}$ borda sudeste o limite é dado por uma passagem brusca entre o domínio geomorfológico da bacia e do embasamento, coincidente com a Zona de Falha de Rio Bonito (Almeida 1976, Ferrari 1990), de direção ENE, parecendo corresponder a uma reativação da mesma. Nessa borda estão presentes diversos stocks, plugs e diques de rochas alcalinas, que tiveram sua intrusão controlada pela Zona de Falha de Rio Bonito em conjugação com as estruturas NNE, transversais à bacia, tendo em vista o alinhamento subordinado desses corpos intrusivos segundo essa última direção (Figura 6.14). Esses corpos de rochas alcalinas intrusivas são datados como do Cretáceo Superior ao Paleoceno (Cordani \& Teixeira 1979, Sonoki \& Garda 1988, Dehira et al. 1998) (Figura 6.13). A ocorrência de sedimentos rudáceos junto à borda sudeste da bacia (Lima et al. 1996), reforça a sua condição de borda ativa. Tal característica é reforçada pelos dados coletados no presente trabalho. $\mathrm{Na}$ borda noroeste, nas proximidades de Magé, o limite é dado por um degrau entre o embasamento e os sedimentos da bacia, também de direção ENE, onde, localmente, se encaixa um vale, que pode ser seguido por mais de uma dezena de quilômetros. Na borda oeste pode-se inferir um limite aproximadamente N-S, obliterado pela sedimentação marinha holocênica. Falhas normais com essa direção e rejeito de até 5 metros, foram caracterizadas ao sul de Magé (Ponto 26, Figuras 6.13 e 6.17). Na borda nordeste o limite não é claro e a caracterização dos depósitos da bacia é impedida pela ausência de afloramentos. As duas áreas isoladas de ocorrência dos sedimentos da Formação Macacu, parecem ser, também, limitadas por estruturas N-S. Falhas com essa direção foram caracterizadas, também, na Ilha do Governador (Ponto 24, Figuras 6.13 e 6.17). Falhas, sin e, principalmente, pósdeposicionais, têm ocorrência comum na bacia, mostrando invariavelmente caráter normal, cujos rejeitos têm em média amplitude decimétrica. $O$ aparecimento de juntas sistemáticas é bastante restrito, tendo sido observadas apenas no Ponto 1 . 


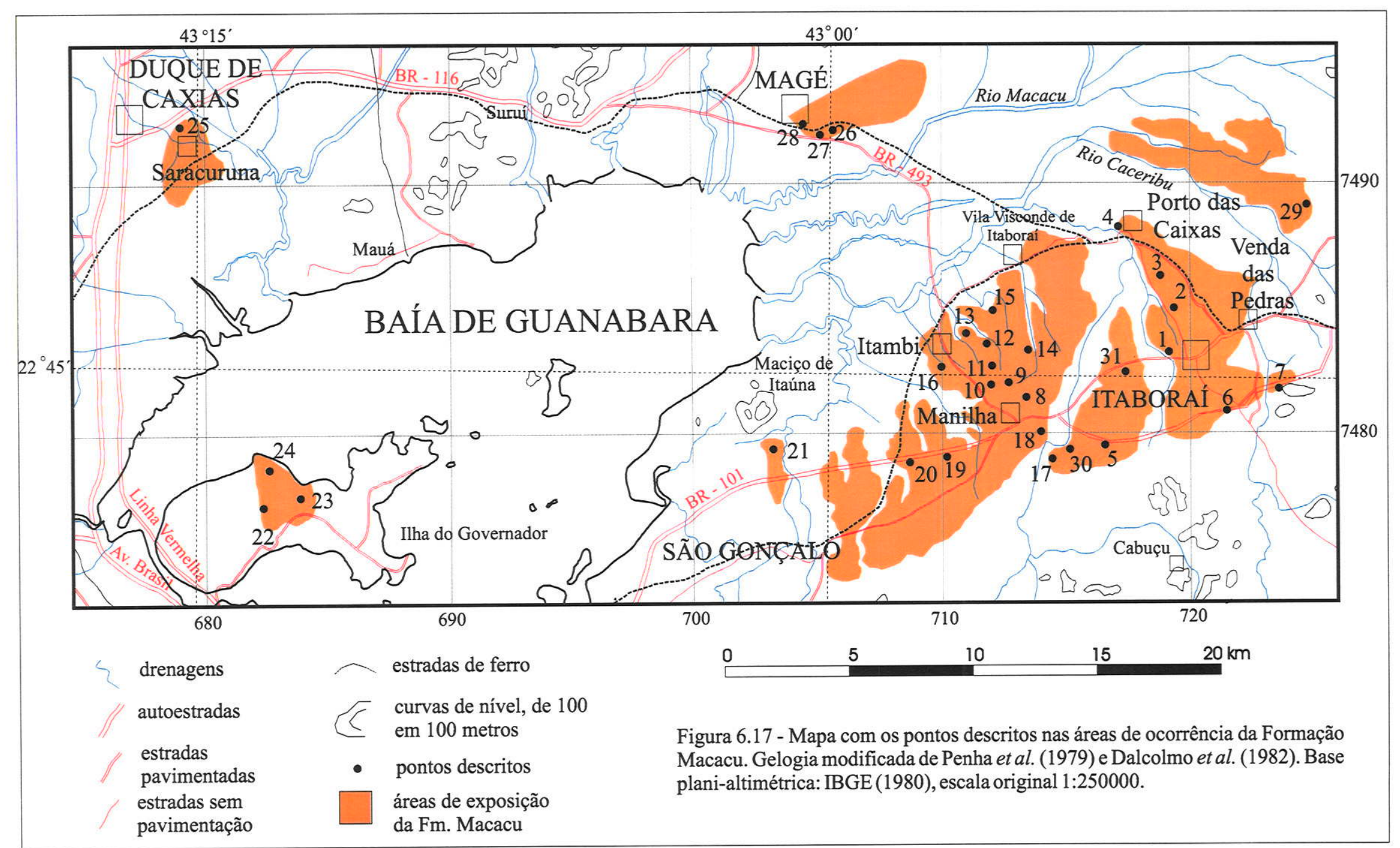




\section{D) Áreas de Exposição}

As áreas de exposição do preenchimento da bacia, representado pela Formação Macacu, se restringem a cortes de estrada e a pouco mais de uma dezena de escavações para exploração de argila, denominados "barreiros". Esses últimos mostram suas melhores exposições em perfis que podem chegar a mais de 20 metros de espessura, especialmente na região de Itambi, nos barreiros Santa Isabel (Ponto 12) e Colonial (Ponto 15); em Itaboraí, no Barreiro São João Batista (Ponto 1; Figura 6.18A) e em Porto das Caixas, no Barreiro Portuense (Ponto 4). Nas áreas de ocorrência isolada de sedimentos da Formação Macacu, encontram-se boas exposições em um barreiro pertencente à prefeitura de Duque de Caxias, localizado no distrito de Saracuruna (Ponto 25).

\section{E) Características Litológicas}

Os depósitos da Formação Macacu se caracterizam pela alternância de lamitos seixosos maciços com arenitos estratificados, localmente conglomeráticos, e lamitos laminados. As cores intempéricas são avermelhadas, amareladas e esbranquiçadas e, quando mais preservadas, possuem cor verde clara a verde escura e cinza. As estruturas sedimentares são, muitas vezes, parcial a totalmente obliteradas pela alteração intempérica, denunciada pelo aspecto friável e pela incipiente laterização dos sedimentos. As palhetas de muscovita, até centimétricas, e as pintas brancas de pseudomorfos de feldspato caulinizado, tanto nos lamitos maciços como nos arenitos "arcoseanos", são bastante comuns. Os fragmentos líticos, na forma de seixos, calhaus e blocos, se restringem às litofácies francamente conglomeráticas da borda sul da bacia (Ponto 7), e aos níveis mais superiores encontrados em Porto das Caixas (Ponto 4) e em Itambi (Ponto 15). Os clastos variam de angulosos, nos lamitos maciços, a subangulosos, subarredondados e arredondados, nos arenitos e conglomerados. Localmente ocorrem sedimentos carbonosos, em meio aos lamitos laminados, na base da sucessão aflorante da bacia. Falhas, sin a pós-deposicionais são comuns e têm rejeito de caráter normal amplamente predominante. 

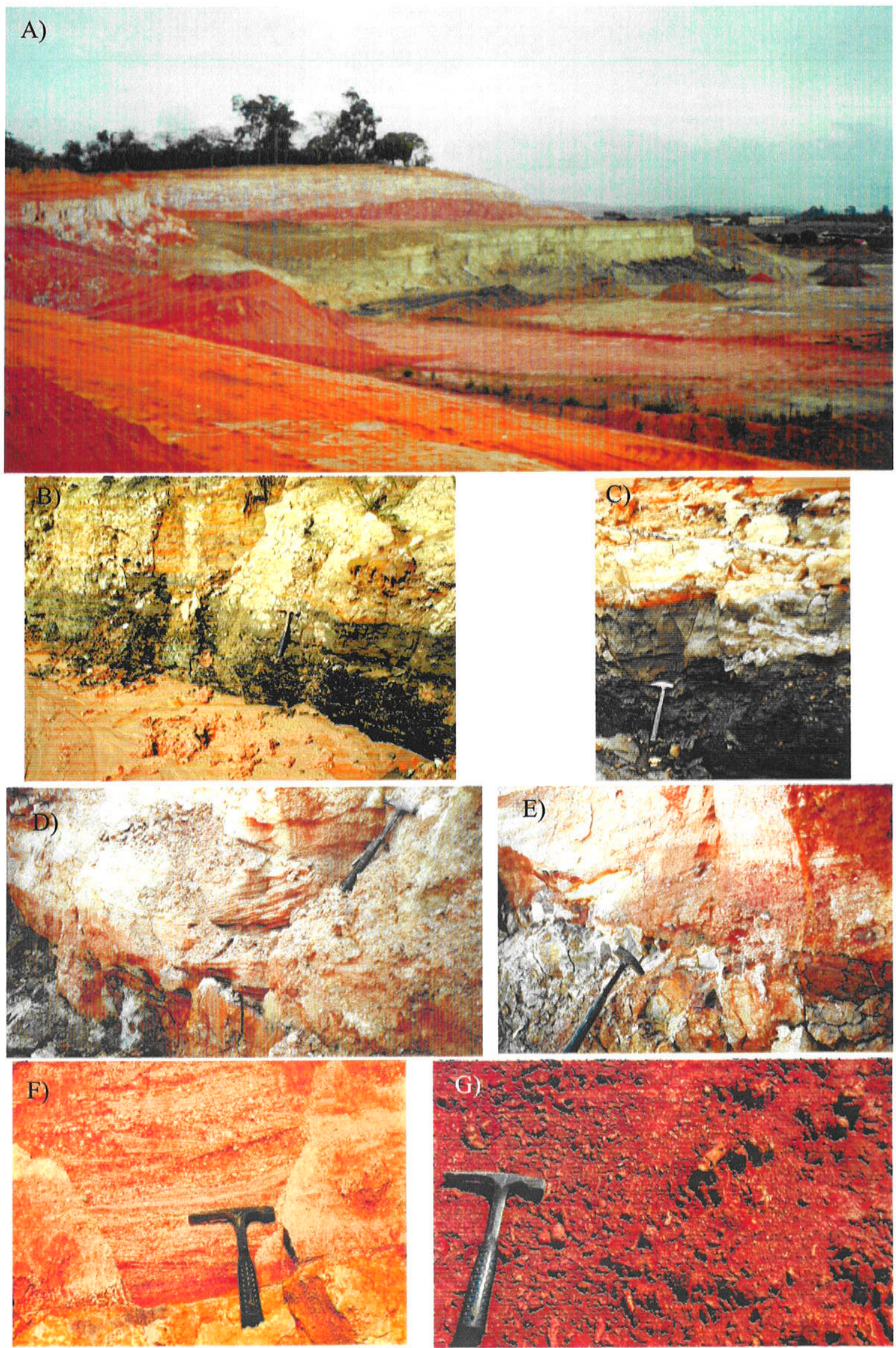

Figura 6.18 -A) Perfil de cerca de 25m na Formação Macacu no Barreiro São João Batista, Ponto 1, destacando linhito, da fácies $\boldsymbol{L I I}$, na base (preto), coberto por lamitos argilosos e seixosos da fácies $\boldsymbol{L A s \boldsymbol { m }}$. A coloração avermelhada da porção superior do pacote reflete a oxidação do ferro e mosqueamento; B e C) Detalhes da foto anterior com linhito em meio a lamito laminado da fácies $\mathbf{L l m}$ (cinza) com arenito maciço, da fácies $\boldsymbol{A m}$, no topo (amarelo); D) Base de canal, preenchida por arenito com estratificação cruzada acanalada, da fácies $\boldsymbol{A C \boldsymbol { C }}$, sobre lamito seixoso da fácies $\boldsymbol{L A s m}$, Barreiro Portuense, Ponto 4; E) Idem, destacando intraclastos de lamito;F) Arenito feldspático com estratificação cruzada de baixo ângulo, da fácies $\boldsymbol{A c p b}$, Ponto 4, Barreiro Portuense, Porto das Caixas; G) Concreções tubulares e esféricas de gibsita, em lamitos laterizados, da fácies $\boldsymbol{L} \boldsymbol{A} \boldsymbol{m}$. Magé, Ponto 26. 
Depósitos coluvionares areno-argilosos capeiam a sucessão estudada, separados por linhas de seixos de quartzo e fragmentos lateríticos. Sedimentos marinhos holocênicos, correlativos ao nível de mar alto de 5000 anos AP (Amador \& Ponzi 1974, Dalcolmo et al. 1982, Suguio et. al. 1988, Amador 1997) e aluviões atuais dos rios Macacu e Caceribu recobrem parcialmente as unidades anteriores.

Nesse capítulo serão descritas as fácies e as associações de fácies da Formação Macacu, identificadas no presente trabalho, bem como a evolução tectono-sedimentar da bacia. Será dada especial atenção à análise cinemática das estruturas que interessam à bacia, buscando determinar as paleotensões que controlaram sua implantação e evolução.

\subsubsection{Fácies Sedimentares da Formação Macacu}

Foram reconhecidas doze fácies sedimentares na Bacia do Macacu (Tabela 6.3). Elas são representadas por códigos, onde as letras maiúsculas indicam a litologia e as minúsculas indicam as estruturas, adaptados de Miall (1977). Cada fácies pode pertencer a mais de uma associação, tendo em vista que o processo que as gerou pode se repetir em ambientes distintos. As diversas fácies reconhecidas, sintetizadas nos perfis colunares da Figura 6.19, são descritas abaixo:

\begin{tabular}{|l|l|l|}
\hline \multicolumn{1}{|c|}{ FÁCIBS } \\
\multicolumn{1}{|c|}{ Lil } \\
$\begin{array}{l}\text { Linhito com fragmentos de } \\
\text { vegetais }\end{array}$ & Laminação plano-paralela & $\begin{array}{l}\text { Pcúmulo em áreas de baixa energia, com } \\
\text { vegetação abundante próxima }\end{array}$ \\
\hline $\begin{array}{l}\text { Lamito puro com raros } \\
\text { niveis ricos em matéria } \\
\text { orgânica, localmente com } \\
\text { grãos de areia }\end{array}$ & $\begin{array}{l}\text { Laminação plano-paralela bem } \\
\text { marcada a incipiente, ou com } \\
\text { acamamento maciço. Concreçôes } \\
\text { tubulares e esféricas de gibsita, } \\
\text { bioturbação, traços fósseis de } \\
\text { raízes e de Taenidium }\end{array}$ & $\begin{array}{l}\text { Deposição por suspensão em áreas de } \\
\text { baixa energia. Exposição subaérea com } \\
\text { atuação de processos pedogenéticos, } \\
\text { relacionados à colonização por vegetação } \\
\text { e retrabalhamento por organismos }\end{array}$ \\
\hline \multicolumn{1}{|c|}{ LAc } & $\begin{array}{l}\text { Laminação cruzada, } \\
\text { Laminação cruzada cavalgante } \\
\text { (climbing ripple-cross lamination) } \\
\text { e acamamento heterolítico } \\
\text { intercalados }\end{array}$ & $\begin{array}{l}\text { Migração de marcas onduladas. } \\
\text { Alternância de deposição por suspensão e regime de fluxo inferior }\end{array}$ \\
\hline
\end{tabular}

Tabela 6.3 - Fácies sedimentares reconhecidas na Formação Macacu. 


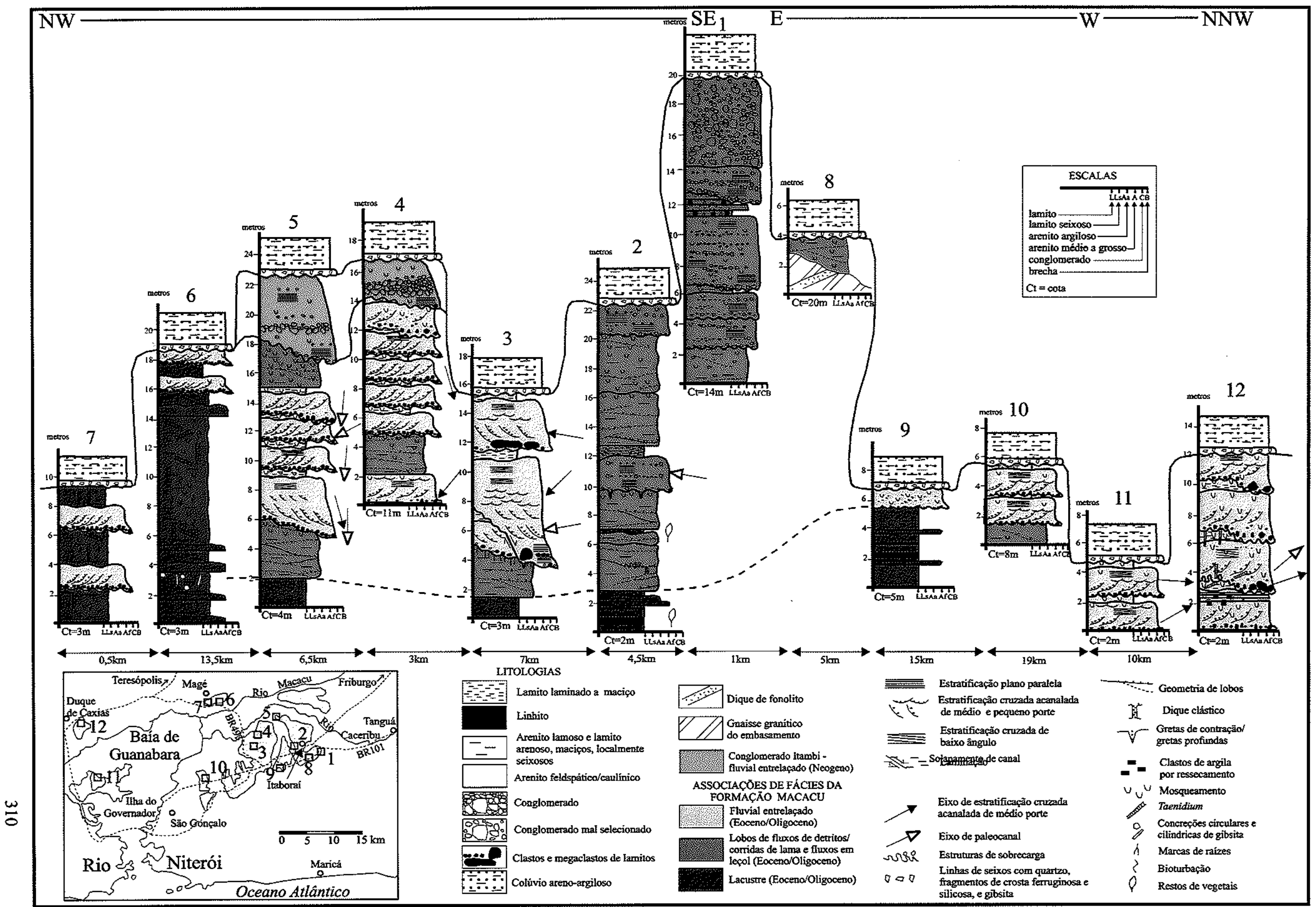

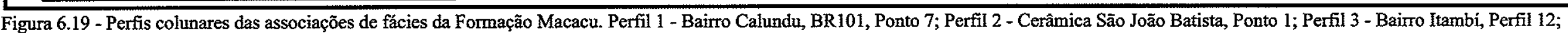

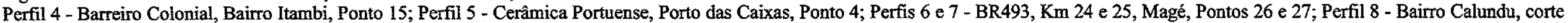

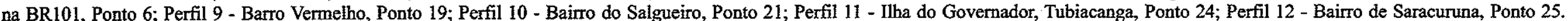




\begin{tabular}{|c|c|c|}
\hline FícIES & $\begin{array}{l}\text { ESTRUTURAS } \\
\end{array}$ & $\begin{array}{l}\text { PROCESSOS } \\
\end{array}$ \\
\hline $\begin{array}{l}\qquad \mathrm{LSm} \\
\text { Lamito e arenito lamoso, com } \\
\text { grấos, grânulos e seixos de quartzo } \\
\text { e feldspato }\end{array}$ & $\begin{array}{l}\text { Acamamento maciço. Estruturas de } \\
\text { sobrecarga, diques clásticos, gretas } \\
\text { de ressecamento e fraturamento }\end{array}$ & $\begin{array}{l}\text { Deposição subaérea em lobos de } \\
\text { corridas de lama e de fluxos de } \\
\text { detritos. Exposição subaérea com } \\
\text { atuação de processos pedogené- } \\
\text { ticos, alternada com sedimentação } \\
\text { rápida }\end{array}$ \\
\hline $\begin{array}{l}\qquad \operatorname{Lam} \\
\text { Lamito com até } 20 \% \text { de grãos de } \\
\text { quartzo }\end{array}$ & $\begin{array}{l}\text { Acamamento maciço, com contato } \\
\text { basal não erosivo }\end{array}$ & $\begin{array}{l}\text { Deposição por fluxos de alta } \\
\text { viscosidade, não confinados, em } \\
\text { áreas alagadas, associados a } \\
\text { eventos de inundação } \\
\end{array}$ \\
\hline $\begin{array}{l}\qquad A c p b \\
\text { Arenito feldspático/caulínico, de } \\
\text { granulação média a grossa, } \\
\text { localmente conglomerático }\end{array}$ & $\begin{array}{l}\text { Estratificação cruzada de baixo } \\
\text { ângulo e estratificação plano- } \\
\text { paralela }\end{array}$ & $\begin{array}{l}\text { Correntes trativas, em regime de } \\
\text { fluxo superior, com formação de } \\
\text { lençóis de areia }\end{array}$ \\
\hline $\begin{array}{l}\qquad A m \\
\text { Arenito feldspático/caulínico, com } \\
\text { matriz lamosa escassa a abundante }\end{array}$ & $\begin{array}{l}\text { Acamamento maciço, contato basal } \\
\text { não erosivo }\end{array}$ & $\begin{array}{l}\text { Deposição por fluxos não } \\
\text { confinados ou por fluxo de } \\
\text { detritos, em áreas de baixa energia }\end{array}$ \\
\hline $\begin{array}{l}\qquad A m p \\
\text { Arenito fino com grãos de } \\
\text { feldspato caulinizado }\end{array}$ & $\begin{array}{l}\text { Acamamento maciço a laminação } \\
\text { plana incipiente, estruturas de } \\
\text { sobrecarga e acamamento } \\
\text { convoluto }\end{array}$ & $\begin{array}{l}\text { Deposição por suspensão e } \\
\text { parcialmente processos de } \\
\text { liquefação e ajustamento } \\
\text { hidroplástico }\end{array}$ \\
\hline $\begin{array}{c}A p \\
\text { Arenito grosso com grânulos, } \\
\text { seixos e calhaus esporádicos de } \\
\text { quartzo, por vezes constituindo } \\
\text { níveis conglomeráticos. } \\
\text { Localmente pode ser feldspático }\end{array}$ & Estratificação plano-paralela & $\begin{array}{l}\text { Correntes trativas em lençol, sob } \\
\text { regime de fluxo superior }\end{array}$ \\
\hline $\begin{array}{l}\qquad A c a \\
\text { Arenito feldspático/caulínico, } \\
\text { conglomerático na base, com } \\
\text { seixos e clastos de lamito e de } \\
\text { quartzo. Localmente possui clastos } \\
\text { e megaclastos angulosos de lamito, } \\
\text { na base, constituindo brecha }\end{array}$ & $\begin{array}{l}\text { Estratificação cruzada acanalada de } \\
\text { médio e pequeno porte. Geometria } \\
\text { de canal. Laminação cruzada e, } \\
\text { localmente, acamamento de } \\
\text { megaôndulas. Intraclastos } \\
\text { lamíticos. }\end{array}$ & $\begin{array}{l}\text { Migração de barras de crista } \\
\text { sinuosa em regime de fluxo } \\
\text { inferior, migração de marcas } \\
\text { onduladas. Solapamento de } \\
\text { margens argilosas por atividade } \\
\text { erosiva do canal. Formas de leito } \\
\text { preservadas por suspensão. }\end{array}$ \\
\hline $\begin{array}{l}\qquad C m \\
\text { Paraconglomerado pobremente } \\
\text { selecionado, com seixos e blocos } \\
\text { de quartzo, rochas alcalinas, } \\
\text { gnaisse e calcedônia }\end{array}$ & Acamamento maciço & $\begin{array}{l}\text { Deposição por fluxos de detritos } \\
\text { com alta viscosidade em leques } \\
\text { secos }\end{array}$ \\
\hline $\begin{array}{l}C \mathrm{Cmp} \\
\text { Ortoconglomerado quartzoso a, } \\
\text { mais raramente, polimítico }\end{array}$ & $\begin{array}{l}\text { Acamamento maciço a } \\
\text { gradacional, com estratificação } \\
\text { plano-paralela e imbricação de } \\
\text { seixos. }\end{array}$ & $\begin{array}{l}\text { Migração por fluxos em lençol, } \\
\text { sob regime de fluxo superior }\end{array}$ \\
\hline
\end{tabular}

Tabela 6.3 - Fácies sedimentares reconhecidas na Formação Macacu (continuação).

1) Linhito laminado $(\boldsymbol{L} \boldsymbol{I} \boldsymbol{l})$ - A fácies $\boldsymbol{L} \boldsymbol{I} \boldsymbol{l}$ forma camadas lateralmente contínuas, por várias dezenas de metros, de linhito laminado, com até $60 \mathrm{~cm}$ de espessura, ocorrendo 
intercalada com lamito laminado puro, sem grãos de areia, da fácies $\mathbf{L l m}$. Trata-se de uma rocha de cor castanha escura a preta, com laminação plana acentuada e com fragmentos centimétricos de restos vegetais (Figuras 6.18A, B e C; Figura 6.19, perfis colunares 2 e 9 ).

2) Lamito laminado a maciço $(\boldsymbol{L l m})$ - Esta fácies é constituída por lamito com laminação plano paralela, por vezes incipiente ou, localmente com acamamento maciço (Figuras 6.18B e C; Figura 6.19, perfis colunares 4, 5, 11 e 12). Possui, em geral cor cinza esverdeada a, mais raramente, junto ao linhito, cor creme. Constitui-se, em geral, por argila com palhetas de muscovita milimétricas até centimétricas, posicionadas na horizontal. Pode apresentar até 5\% de areia fina disseminada ou em lentes. A transição dessa fácies para o linhito, numa zona de aproximadamente $15 \mathrm{~cm}$, é caracterizada pelo enriquecimento no teor de matéria orgânica, que lhe confere uma cor cinza clara a cinza chumbo. Localmente mostra coloração avermelhada intensa, bioturbação, traços fósseis de raízes e de Taenidium (Figura 6.21D).

3) Lamito/arenito com laminação cruzada $(\boldsymbol{L A c})$ - Lamito e arenito fino com laminação cruzada, muitas vezes do tipo cavalgante (climbing ripple-cross lamination). Ocorrem sempre em camadas tabulares com espessura de até $40 \mathrm{~cm}$ e com extensão lateral variando desde uns poucos metros até pouco mais de uma dezena de metros. As camadas menos extensas lateralmente ocorrem em meio aos arenitos grossos a conglomeráticos da fácies $\boldsymbol{A C a}$, e as mais extensas ocorrem em meio aos arenitos finos da fácies $A m p$ e aos lamitos da fácies $\mathbf{L l m}$. Em alguns locais essa fácies desenvolve estrutura heterolítica, com até $50 \mathrm{~cm}$ de espessura, onde é comum a presença de acamamento convoluto e estrutura de sobrecarga (Figuras 6.21B e 6.22A, B, e C).

4) Lamito seixoso maciço $(\boldsymbol{L S m})$ - A fácies $\boldsymbol{L S m}$ é constituída por lamito seixoso e arenito médio a grosso com matriz lamosa, com grânulos e seixos de quartzo e feldspato caulinizado, além de palhetas de muscovita orientadas isotrópicamente (Figuras 6.18A e 6.20B). Formam camadas lenticularizadas, com acamamento maciço, de espessura métrica a decimétrica, com extensão métrica configurando formas lobadas, 

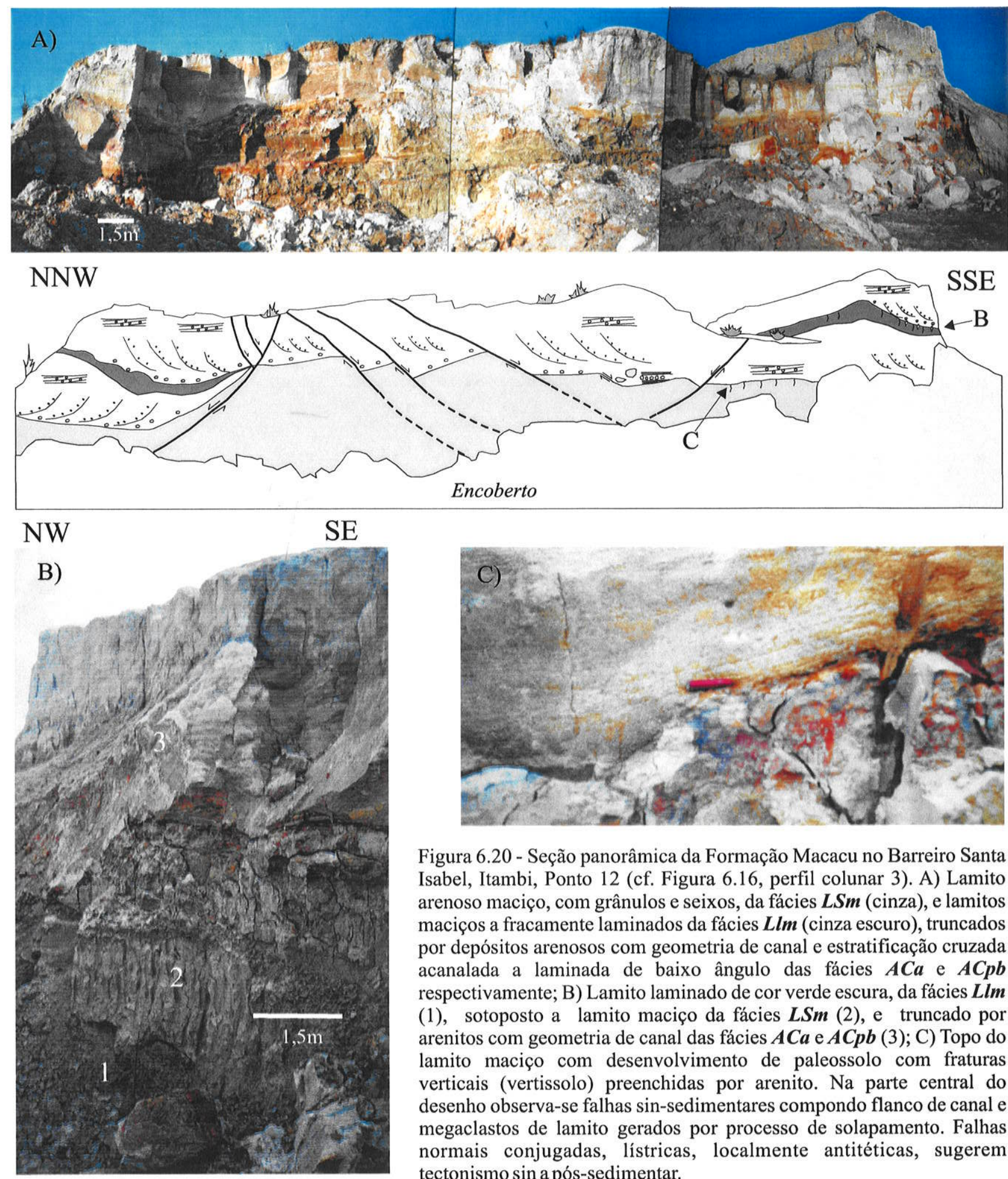

Figura 6.20 - Seção panorâmica da Formação Macacu no Barreiro Santa Isabel, Itambi, Ponto 12 (cf. Figura 6.16, perfil colunar 3). A) Lamito arenoso maciço, com grânulos e seixos, da fácies $\boldsymbol{L S} \boldsymbol{m}$ (cinza), e lamitos maciços a fracamente laminados da fácies $\boldsymbol{L} \boldsymbol{l} \boldsymbol{m}$ (cinza escuro), truncados por depósitos arenosos com geometria de canal e estratificação cruzada acanalada a laminada de baixo ângulo das fácies $\boldsymbol{A C \boldsymbol { a }}$ e $\boldsymbol{A C p \boldsymbol { b }}$ respectivamente; B) Lamito laminado de cor verde escura, da fácies $\mathbf{L l m}$ (1), sotoposto a lamito maciço da fácies $\mathbf{L S m}$ (2), e truncado por arenitos com geometria de canal das fácies $\boldsymbol{A C a}$ e $\boldsymbol{A} \boldsymbol{C p b}$ (3); C) Topo do lamito maciço com desenvolvimento de paleossolo com fraturas verticais (vertissolo) preenchidas por arenito. $\mathrm{Na}$ parte central do desenho observa-se falhas sin-sedimentares compondo flanco de canal e megaclastos de lamito gerados por processo de solapamento. Falhas normais conjugadas, lístricas, localmente antitéticas, sugerem tectonismo sin a pós-sedimentar. 

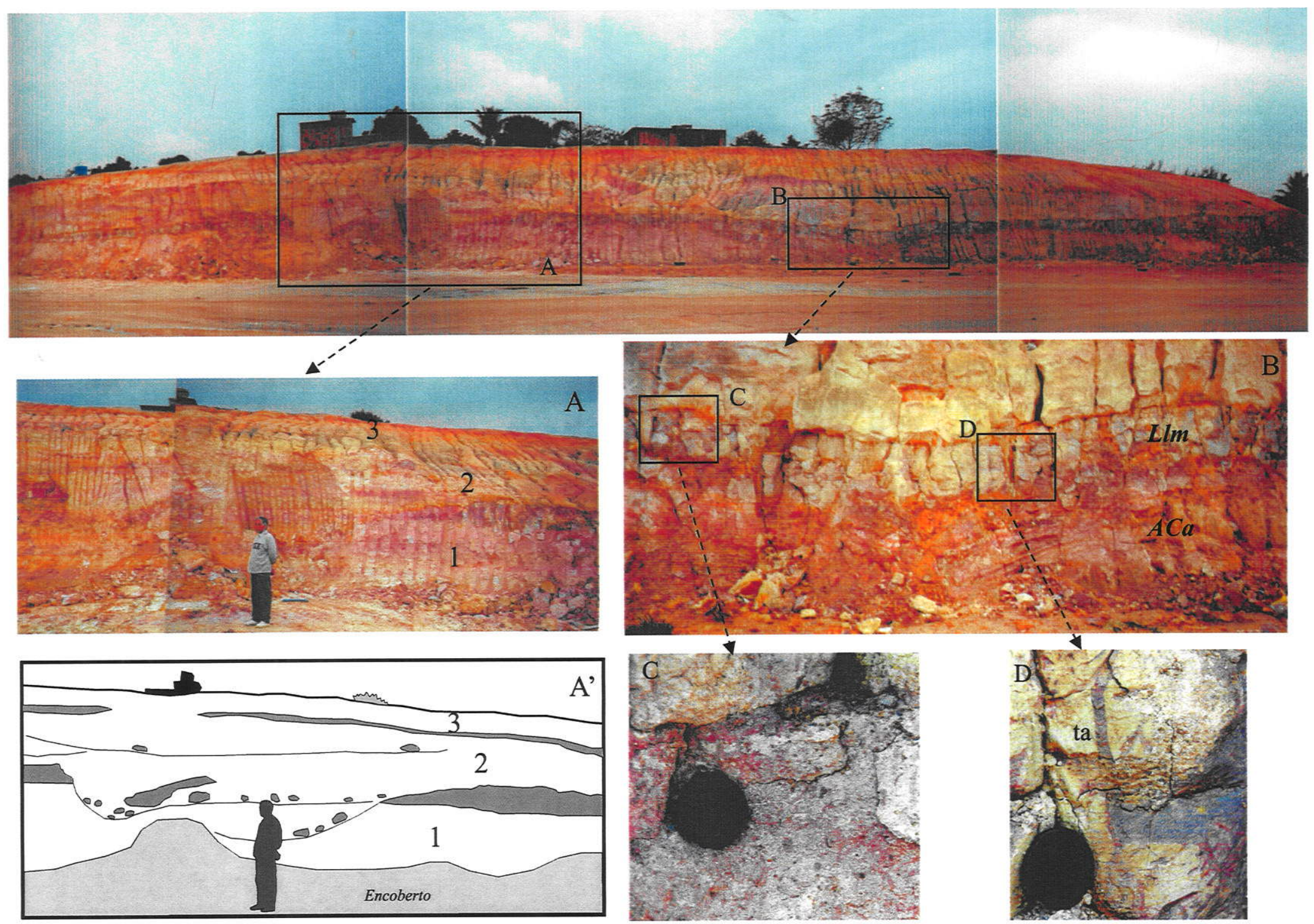

Figura 6.21 - Seção panorâmica da Formação Macacu, Duque de Caxias, Ponto 25. Associação de fácies de canal fluvial entrelaçado, mostrando três paleocanais superpostos (1,2 e3), cada um em continuidade lateral por aproximadamente 80m. Ae A') Arenitos das fácies $A c a$ e $A c p b$ (1,2e 3), com clastos e megaclastos de lamito, com até 1,5 m de eixo maior, capeados por arenitos finos e lamitos argilosos das fácies Amp e $\mathbf{l} \boldsymbol{l m}$ (cor cinza); B) Lamito/arenito com estrutura heterolítica, da fácies $L A c$, com acamamento de megaôndula refletindo a forma preservada de dunas subaquosas. Esse conjunto é abruptamente capeado por lamito laminado da fácies $\mathbf{L l m}$. C) Nível da fácies $A m p$ com intensa bioturbação, mostrando icnofósseis de Taenidium em posições diversas - manchas escuras alongadas e circulares. D) Detalhe do Taenidium (ta), destacando meniscos com concavidade voltada para cima. Pessoa como escala $=175 \mathrm{~cm}$. 
5) muitas vezes amalgamadas e constituindo pacotes com espessuras de até 7 metros. Os lobos individuais mostram, localmente, granodecrescência para o topo. Estruturas de sobrecarga ocorrem, localmente, no limite arenito-lamito, na forma de convoluções, diques clásticos de ejeção e pseudonódulos. Localmente, no topo dos pelitos, ocorrem fraturas, gretas de ressecamento e gretas profundas, além de marcas de raízes (Figura 6.19 , perfis colunares 2,4 e 5 ; Figura $6.20 \mathrm{C}$ ).

6) Lamito arenoso maciço $(\boldsymbol{L A m})$ - Esta fácies é constituída por lamitos maciços com até $20 \%$ de grãos de quartzo, constituindo camadas tabulares com espessura de até 9 metros e extensão lateral de várias dezenas de metros (Figura 6.19, perfil colunar 6). Apresenta intensa bioturbação que pode obliterar completamente a sua estrutura primária, destacando-se traços fósseis de Taenidium e de raízes. Apresenta níveis com concreções tubulares e esféricas de limonita e, mais raramente, de gibsita, cuja composição foi confirmada através de difratograma (Anexo 1). As concreções esféricas podem ter pouco mais de $5 \mathrm{~cm}$ de diâmetro (Figura 6.18G) e as tubulares podem atingir em torno de $10 \mathrm{~cm}$ de comprimento e pouco mais de $1 \mathrm{~cm}$ de diâmetro. Localmente as concreções podem sugerir, erroneamente, uma granulação mais grossa para esses lamitos.

7) Arenito maciço $(\boldsymbol{A m})$ - Correspondem a arenitos de granulação média a grossa muitas vezes com matriz lamosa, contendo grânulos de feldspato caulinizado e palhetas de muscovita milimétricas a centimétricas. As palhetas de muscovita orientam-se isotropicamente. Mostra estrutura maciça. Ocorre em meio aos lamitos laminados a maciços da fácies $\boldsymbol{L l m}$ e intercalados com os lamitos arenosos da fácies $\boldsymbol{L A} \boldsymbol{A}$, na forma de camadas lenticulares, com base não erosiva, e com espessura máxima de aproximadamente $80 \mathrm{~cm}$. Essas lentes se estendem lateralmente por poucas dezenas de metros.

7) Arenito com estrutura maciça a plano paralela ( $A m p)$ - Arenito de granulação fina, com grãos de feldspato caulinizados e palhetas de muscovita milimétricas. Apresentam estrutura maciça a estratificação plano-paralela incipiente. Constituem camadas 
tabulares com até $70 \mathrm{~cm}$ de espessura, que se estendem lateralmente por várias dezenas de metros. Ocorrem recobrindo as fácies $A C a, A C p b$ e $\mathbf{L l m}$. Os sedimentos dessa fácies são invariavelmente cobertos por lamitos da fácies $\mathbf{L l m}$. Eles podem apresentar bioturbação intensa (Figura 6.21C).

8) Arenito com estratificação plano-paralela $(A p)$ - Arenito grosso com grânulos, seixos e calhaus esporádicos de quartzo, com estratificação plano-paralela (Figura 6.22D). Ocorrem em associação com os conglomerados da fácies $C m p$ ou, mais raramente, intercalados com os lamitos seixosos da fácies $\mathbf{L S m}$. A presença de feldspato é, em geral, rara no primeiro caso e comum no segundo. Nos depósitos de leques proximais da borda sudeste (Ponto 7; perfil colunar 1, da Figura 6.19), onde ocorrem em associação com conglomerados polimíticos da fácies $\mathbf{C m}$, eles possuem grande quantidade de litoclastos, em especial de rochas alcalinas (Figuras 6.23B e C). Constituem camadas com pouco mais de 1 metro de espessura.

9) Arenito/conglomerado com estratificação plano-paralela e laminação cruzada de baixo ângulo $(A C p b)$ - A fácies $A C p b$ é constituída por arenito de granulação média a grossa, com grânulos e seixos de quartzo e feldspato (muitas vezes caulinizado), constituindo níveis conglomeráticos. Apresenta estratificação plano-paralela e estratificação cruzada de baixo ângulo. Essa fácies ocorre principalmente na porção superior dos depósitos de canais e, mais raramente, na base (Figuras $6.18 \mathrm{~F}$ e $6.20 \mathrm{C}$ ), alcançando até $1 \mathrm{~m}$ de espessura.

10) Arenito/conglomerado com estratificação cruzada acanalada $(\boldsymbol{A C a})$ - A fácies $\boldsymbol{A C a}$ é constituída por arenitos de granulação média a grossa e é, em geral, conglomerática na base, com grânulos e seixos centimétricos de quartzo, e intraclastos subarredondados a arredondados de lamito da fácies $\boldsymbol{L l m}$ (Figuras 6.18D e E, e 6.22A). Esses clastos, por vezes com até 1 metro de eixo maior (matacões), podem constituir verdadeiras brechas na base dos canais. Mais raramente podem ocorrer litoclastos arredondados de rocha alcalina afanítica (fonolito/traquito), como no Ponto 25. As estruturas dessa fácies são as estratificações cruzadas acanaladas de pequeno a médio porte e, localmente, ela 

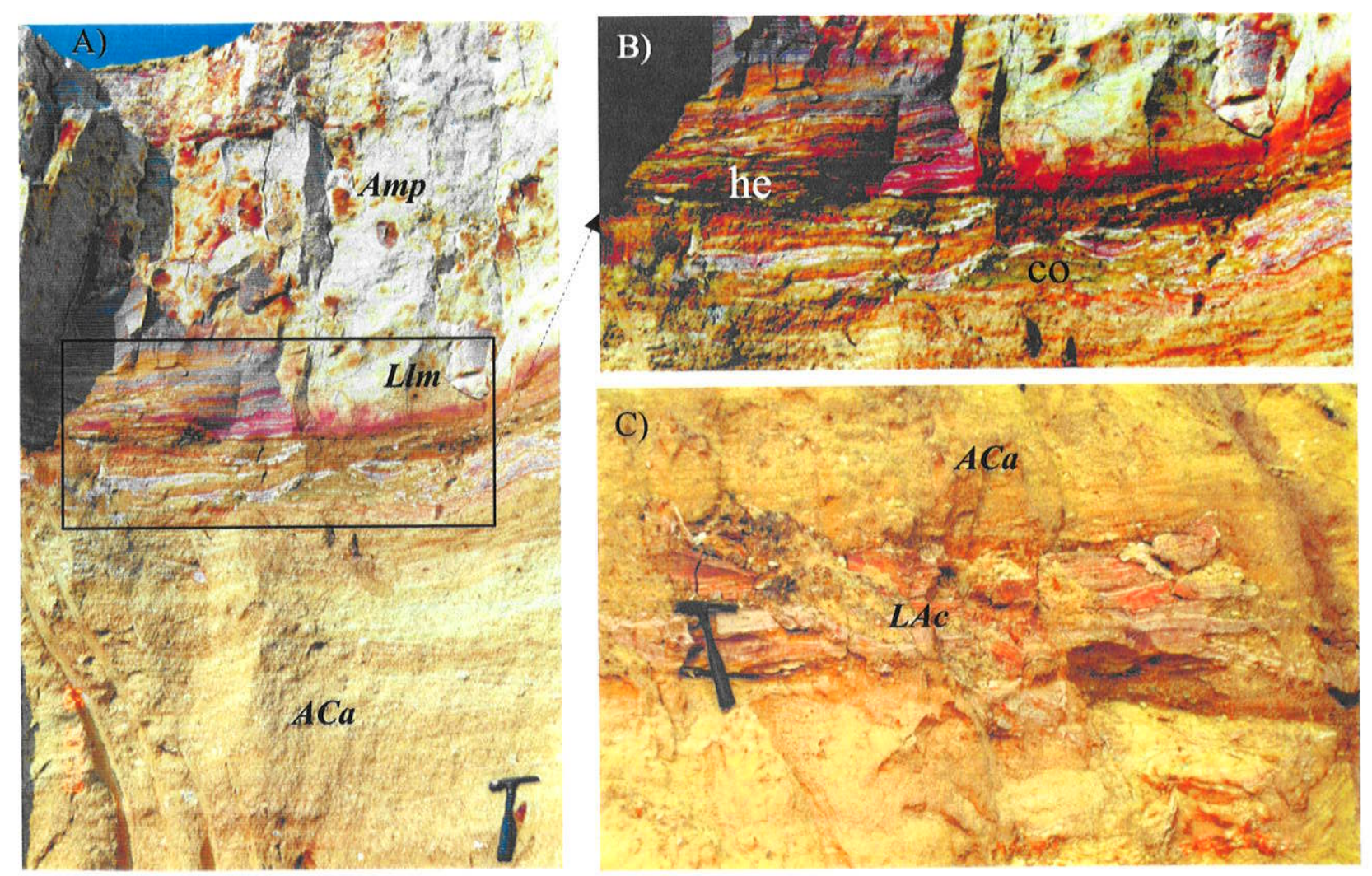

Figura 6.22 - A) Passagem brusca dos arenitos feldspáticos das fácies $\boldsymbol{A C a}$, para os lamitos da fácies $\boldsymbol{L} \boldsymbol{l m}$. B) Detalhe dessa passagem que se caracteriza, localmente, por uma estrutura heterolítica (he), da fácies $\boldsymbol{L} \boldsymbol{A} \boldsymbol{c}$, com níveis argilosos convolucionados (co). C) Megaclasto de arenitos finos e lamitos interestratificados, com laminação cruzada cavalgante (climbing ripple-cross lamination), da fácies $\mathbf{L A c}$, em base de canal. Duque de Caxias, Saracuruna, Ponto 25.
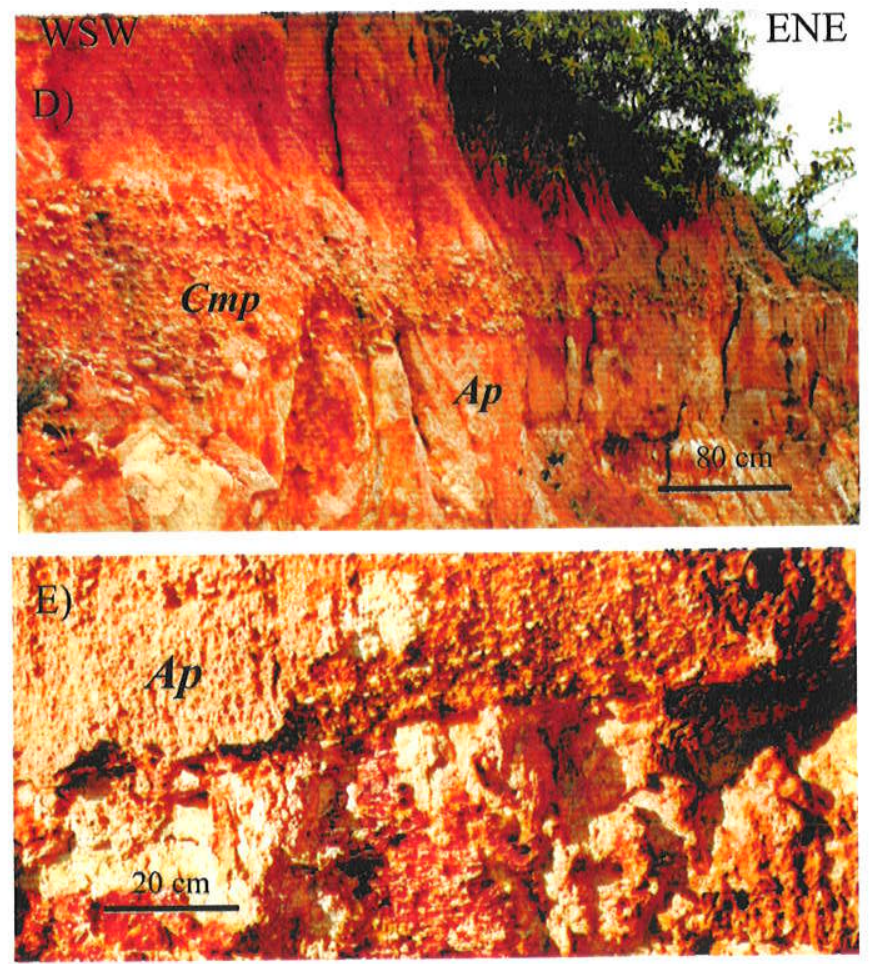

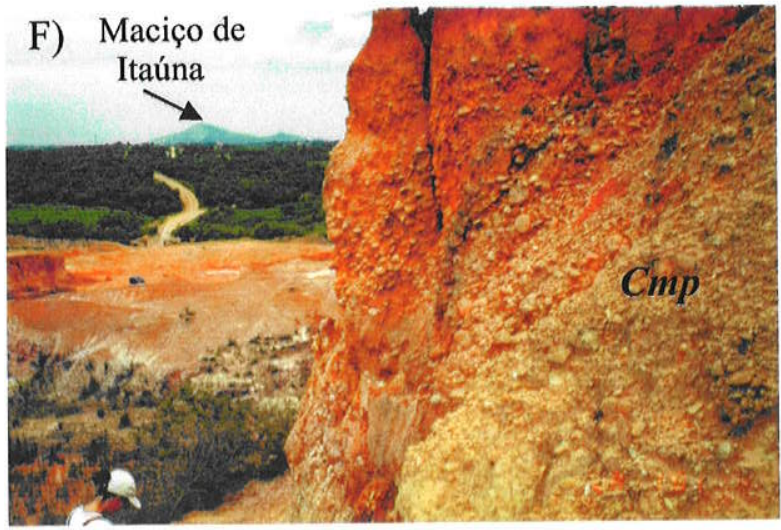

D) Conglomerado quartzoso, da fácies $C \boldsymbol{m p}$, em meio a arenito quartzoso grosso com níveis conglomeráticos, da fácies $\boldsymbol{A p}$, sobreposto aos sedimentos da Formação Macacu. Os blocos de quartzo no nível de conglomerado quartzoso chegam a ter $30 \mathrm{~cm}$ de eixo maior. E) Idem a D, com indicação de paleocorrente a partir da imbricação de seixos. Os seixos achatados tem face voltada para o observador (ENE) e imbricação no sentido do Maciço de Itaúna (WSW), visível ao fundo. Ponto 15, Barreiro Colonial, Itambi. F) Detalhe do contato basal de arenito grosso da fácies $\boldsymbol{A p}$, evidenciando sua estratificação plano-paralela. Ponto 4, Barreiro Portuense, Distrito de Porto das Caixas. 

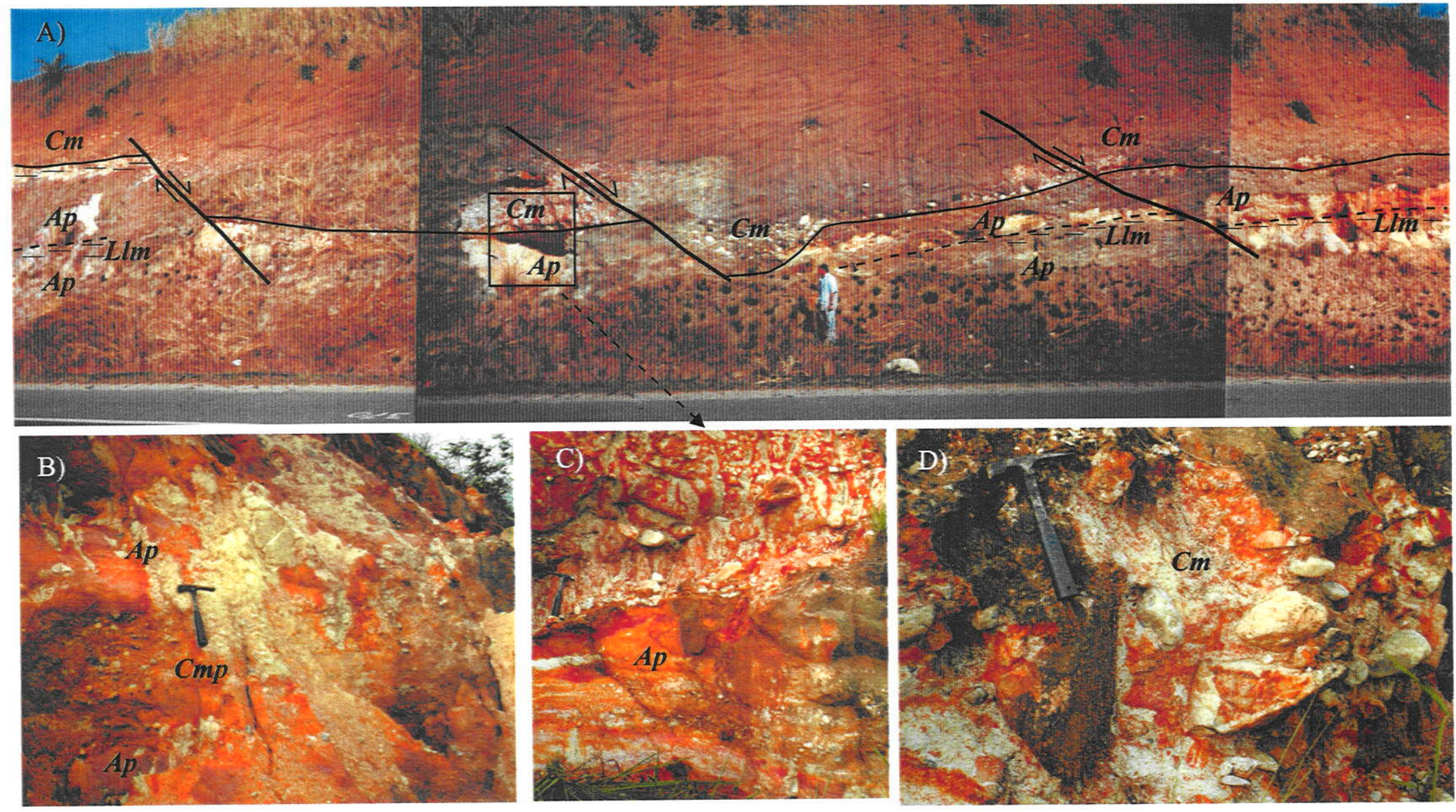

Figura 6.23 - A) Seção panorâmica de afloramento na borda sudeste da bacia (Ponto 7) mostrando depósitos de leques úmidos proximais (fácies $A p$ ), sobrepostos por depósitos de fluxo de detritos da fácies $C m$. As fácies sedimentares estão identificadas no afloramento. Os depósitos da fácies $A p$ exibem tendência geral de afinamento para o topo, localmente com intercalações sílticas/argilosas (fácies $\mathbf{L l m}$ ) com gretas e fitoturbação (cf. Figura 6.16, perfil colunar 1). B) Conglomerados polimíticos, da fácies $C m p$, ocorrem intercalados com os arenitos da fácies $A p$, ambos com estratificação plano-paralela . colunar 1). B) Conglomerados polimiñ argilosa constituido paraconglomerados. O conjunto é cortado por falhas de direção NW-SE e mergulho intermediário a alto, com rejeito de componente normal predominante, com provável componente direcional sugerida pelo rejeito distinto de camadas com mesma atitude; C) Paraconglomerado da fácies $\mathrm{Cm}$ sobre arenito com níveis conglomeráticos, da fácies $A p$. D) Detalhe de paraconglomerado polimítico da fácies $C \boldsymbol{m}$. Pessoa como escala $=185 \mathrm{~cm}$. 
desenvolve acamamento de megaôndula (Figuras 6.21B e 6.22A). Laminação cruzada é geralmente encontrada no topo dessa fácies. A espessura máxima das camadas dessa unidade é de 2,5 metros.

11) Conglomerado maciço $(\boldsymbol{C m})$ - A fácies $\boldsymbol{C m}$ é constituída por paraconglomerados, maciços e mal selecionados. Esses conglomerados são polimíticos, com clastos subarredondados de quartzo, gnaisse, traquito, fonolito, calcedônia e, mais raramente lamito, com até $70 \mathrm{~cm}$ de eixo maior. Eles ocorrem junto ao limite SE da bacia (Ponto 7, Figura 6.23A). Essa fácies pode ter até 5 metros de espessura.

12) Conglomerado com acamamento maciço e estratificação plano-paralela ( $C m p)$ - A fácies Cmp é constituída por ortoconglomerados, com acamamento maciço e estratificação plano-paralela. Localmente observa-se incipiente acamamento gradacional e imbricação de seixos. Os seixos e blocos, podem ser tanto exclusivamente de quartzo e bem arredondados, com até $30 \mathrm{~cm}$ de eixo maior (Figuras $6.22 \mathrm{D}$ e E), como podem ser mal selecionados e polimíticos. No primeiro caso, eles ocorrem tanto na base dos pacotes, como nas suas porções medianas, e podem ter até $1 \mathrm{~m}$ de espessura. No segundo caso eles ocorrem nas porções proximais da borda sudeste da bacia e apresentam clastos subangulosos a subarredondados (Figura 6.23B).

\subsubsection{Associações de Fácies Sedimentares da Formação Macacu}

As doze fácies sedimentares descritas acima estão geneticamente relacionadas a três associações de fácies:

- Associação A $\rightarrow$ lacustre;

- Associação B $\rightarrow$ de lobos de fluxo de detritos/lama e fluxo em lençol;

- Associação C $\rightarrow$ de canal fluvial entrelaçado, com afogamentos episódicos;

- Associação D $\rightarrow$ de canal fluvial entrelaçado. 
A associação D, apesar de tratada nesse capítulo, não é considerada como pertencente à Formação Macacu por apresentar litotipos e estilo deposicional distintos, além de ser sobreposta aos depósitos Macacu (Figura 6.19). Essa associação, como será mostrado no ítem 6.2.10, representa uma unidade litoestratigráfica distinta, denominada Conglomerado Itambi.

Essas associações de fácies sedimentares são sintetizadas na Tabela $6.4 \mathrm{e}$ apresentadas em perfis colunares na Figura 6.16 .

\begin{tabular}{|c|c|c|c|}
\hline TIPO & $\begin{array}{c}\text { ASSOCIACÃO } \\
\text { DE FÁCIES }\end{array}$ & DESCRIÇÃO & IN'TRRPRE'TAÇÃO \\
\hline $\mathbf{A}$ & $L I l, L l m, A m$ & $\begin{array}{l}\text { Linhito e lamitos laminados a maciços, de cor } \\
\text { verde, com geometria tabular e restos vegetais. } \\
\text { Presença de arenitos argilosos maciços e lamitos } \\
\text { arenosos a seixosos maciços, lenticulares }\end{array}$ & Lacustre \\
\hline $\mathbf{B}$ & $\begin{array}{l}L S m, L l m, A p \\
\quad C m, C m p\end{array}$ & $\begin{array}{l}\text { Lamitos seixosos e arenitos lamosos maciços, } \\
\text { constituindo depósitos com geometria lobada, com } \\
\text { intercalaçóes localizadas de lamitos laminados e de } \\
\text { arenitos grossos com níveis conglomeráticos e } \\
\text { estratificação plano-paralela. Localmente ocorrem } \\
\text { ortoconglomerados, com estratificação plano } \\
\text { paralela. Os lamitos laminados podem conter } \\
\text { restos vegetais. Nas porç̃es proximais ocorrem } \\
\text { paraconglomerados e conglomerados polimíticos } \\
\text { maciços }\end{array}$ & $\begin{array}{l}\text { Leques aluviais secos e } \\
\text { úmidos }\end{array}$ \\
\hline $\mathbf{C}$ & $\begin{array}{c}L l m, L A c, L A m \\
A m p, A p, A C p b \\
A C a\end{array}$ & $\begin{array}{l}\text { Arenitos grossos feldspáticos/caulínicos e com» } \\
\text { glomerados, localmente de arcabouço fechado, } \\
\text { com geometria de canal. Esses depósitos possuem } \\
\text { granodecrescência ascendente, com laminação } \\
\text { cruzada, indicando fluxo menos canalizado para o } \\
\text { topo. São, em geral, capeados por arenitos finos e } \\
\text { lamitos, maciços a pobremente laminados, em } \\
\text { contato brusco. Foram identificados bioturbação e } \\
\text { traços fósseis de Taenidium nos lamitos laminados } \\
\text { e, mais raramente, nos arenitos finos }\end{array}$ & $\begin{array}{l}\text { Fluvial entrelaçado com } \\
\text { afogamentos episódicos }\end{array}$ \\
\hline$\overline{\mathbf{D}}$ & $A m p, C m p$ & $\begin{array}{l}\text { Arenitos grossos e conglomerados quartzosos com } \\
\text { estratificação plano paralela e imbricação de } \\
\text { clastos }\end{array}$ & Fluvial entrelaçado \\
\hline
\end{tabular}

Tabela 6.4 - Principais características das associações de fácies reconhecidas na Formação Macacu (associações A, B e C) e no Conglomerado Itambi (associação D). 


\subsubsection{Associação de Fácies A - Lacustre}

Constitui o nível mais inferior da porção aflorante da Formação Macacu e é constituída pelas fácies $\boldsymbol{L I} \boldsymbol{l}, \boldsymbol{L I m}$ e $\boldsymbol{A m}$, que formam, no seu conjunto, camadas tabulares com até 6 metros de espessura (Figura 6.19, perfil colunar 9). Seu contato basal não foi observado e seu contato superior se faz tanto com os lamitos seixosos e arenitos lamosos maciços, das fácies $\boldsymbol{L S} \boldsymbol{m}$ e $\boldsymbol{A m}$, como com os arenitos feldspáticos da fácies $\boldsymbol{A C a}$. Os lamitos laminados a maciços, de cor verde, constituem cerca de $70 \%$ do volume total de sedimentos dessa associação. Depósitos semelhantes, da Formação Tremembé, na Bacia de Taubaté, foram interpretados como uma fácies de borda do lago (Riccomini 1989, Riccomini et al. 1996) ou fases de maior aporte de sedimentos ao lago (Riccomini et al. 1987).

No linhito ocorrem fragmentos vegetais fósseis, e seu conteúdo polínico foi datado como eocênico a oligocênico (Lima et al. 1996). Essa associação de fácies indica deposição por suspensão em água estagnada, e a presença do linhito indica que localmente tinha-se vegetação abundante, propiciando seu acúmulo. Sua extensão lateral pode ser inferida, a partir da correlação dos depósitos, por aproximadamente $7 \mathrm{~km}$, entre os Pontos 1 e 17, (Figura 6.17 e Figura 6.19, perfis colunares 2 e 9), tendo em vista a ocorrência nesses dois locais de dois níveis de linhito, em meio ao argilito laminado. Em ambos os locais o nível basal possui 50 a $60 \mathrm{~cm}$ de espessura, e o nível superior possui em torno de $10 \mathrm{~cm}$ de espessura. Esse arranjo sugere uma deposição coetânea e recorrente das camadas de linhito, em um ambiente lacustre perene. Níveis de lamitos laminados com restos vegetais, com espessura decimétrica e intercalados a lobos de fluxos de detritos (Figura 6.19, perfil colunar 2), sugerem deposição em áreas alagadas interlobos.

As camadas lenticulares e com espessura decimétrica de arenitos maciços da fácies $\boldsymbol{A m}$, em geral com matriz lamosa, indicam o aporte abrupto de material no lago, gerados tanto por fluxos tabulares não confinados, em inundações, no caso dos que não possuem matriz argilosa, ou por fluxo de detritos, no caso dos arenitos maciços com matriz argilosa (Bentham et al. 1993, Boogs 1995). A recorrência desses níveis indica a existência de fan deltas lacustres pouco desenvolvidos. 


\subsubsection{Associação de Fácies B - Leque Aluvial com Lobos de Fluxo de Detritos/Corridas}

de Lama e de Fluxo em Lençol

A Associação de Fácies B é constituída dominantemente pela fácies $L S m$ e, subordinadamente, pelas fácies $C m, A p, C m p$ e $L l m$. Ela tem geometria tabular a lenticular e chega a ter 7,5 metros de espessura máxima.

A composição mal selecionada da maior parte desses depósitos, representados pelas fácies $\boldsymbol{L S m}$ e $\boldsymbol{C m}$, e a predominância de acamamento maciço (Figuras 6.23C e D), indicam uma origem a partir de fluxos gravitacionais, relacionados a fluxos de detritos/corridas de lama, em "leques secos" (Nilsen 1982, Leeder 1992) ou dominados por "fluxos de sedimentos por gravidade" (Blair \& McPherson 1994a), ou ainda, de "fluxos de gravidade" (Reading 1996). A organização em lobos indica superposição de pulsos de sedimentação. A ausência de gradação granulométrica na grande maioria dos lobos indica que eles se originaram de fluxos com viscosidade média (Neton et al. 1994).

Arenitos feldspáticos, com granulometria grossa, com níveis conglomeráticos e com estratificação plano-paralela (fácies $A p$ ), ocorrem localmente em meio aos sedimentos não estruturados e são interpretados como gerados em leques úmidos (Nilsen 1982, Leeder 1992) ou dominados por "fluxos de fluídos por gravidade", em caráter não confinado, constituindo lençóis de areia (Blair \& McPherson 1994a). Localmente, junto à borda sudeste da bacia (Ponto 7, perfil colunar 1), esses arenitos contém uma grande quantidade de litoclastos, dominantemente de composição alcalina, podendo constituir ortoconglomerados da fácies $\mathrm{Cmp}$ (Figuras 6.23B e C). Esse conjunto de arenitos e conglomerados com estratificação plano-paralela compreendem menos de $20 \%$ dos depósitos da Associação B, indicando, também, que os leques aluviais da Formação Macacu desenvolveram-se essencialmente em condições secas.

A presença de níveis de lamito com evidências de exposição subaérea, como clastos angulosos (rip-up clasts) e curvados (curled flakes), indica o desenvolvimento de paleossolos imaturos, relacionados a sedimentação intermitente (Nilsen 1982, Reading 1996).

A ocorrência de camadas convolucionadas, indica a existência de ajustamentos hidroplásticos locais (Figura 6.19, perfil colunar 2), relacionados com sedimentação rápida 
(Nilsen 1982). Localmente, a ocorrência nesses níveis de estruturas deformacionais formadas por liquefação e fluidização, com grande persistência lateral, indica que eles podem ser induzidos por tectonismo sin-sedimentar (Seilacher 1984). Por outro lado, a recorrência de estruturas de ressecação, inclusive gretas profundas (Figura 6.16, perfil colunar 2), localmente com traços fósseis de raízes, indica sucessivas fases de exposição, acompanhadas de litificação parcial. A alternância desses dois processos indica sedimentação espasmódica.

A ocorrência rara de laminação cruzada incipiente em arenitos da fácies $A p$, pode indicar tanto a migração de pequenas formas de fundo por fluxos efêmeros, em regime de fluxo inferior (McKee 1965, Joppling \& Walker 1968), como antidunas geradas em regime de fluxo superior, como sugerido por Blair \& McPherson (1994a). Tendo em vista a associação desta fácies com os depósitos de leques aluviais, caracterizados pelo regime de fluxo superior e pelo não confinamento (Blair \& McPherson 1994a), a última hipótese é a mais provável.

Em vários locais essa associação ocorre intercalada ou sobre os depósitos lacustres da Associação A, sendo representada tanto pela fácies $\boldsymbol{A m}$, que parece representar fluxos de detritos avançando sobre o lago, constituindo fan deltas, como pela fácies $\mathbf{L S m}$, já colmatando o lago. Mais raramente, os lamitos seixosos da fácies $\mathbf{L S m}$ aparecem cobrindo os depósitos da Associação C, como pode ser observado em Itambi, no Ponto 15, e em Porto das Caixas, no Ponto 4 (Figura 6.19, perfis colunares 4 e 5). Porém, em ambos os casos não foi possivel determinar as relações verticais e horizontais entre os depósitos das duas associações.

Os parâmetros utilizados para diferenciar os depósitos de leques úmidos, gerados por fluxos em lençol (sheetflood), daqueles depósitos relativos à planície aluvial entrelaçada, foram o caráter eminentemente confinado, e a abundância de estratificações cruzadas acanaladas desses últimos, feições ausentes dos depósitos de leques aluviais como sugerido por Blair \& McPherson (1994a). Esses autores apontam que a declividade alta dos depósitos de leques, proporciona um regime hidráulico particular, distinto dos rios, que condiciona fluxos de regime superior, responsáveis pela geração de estratificação planoparalela ou de antidunas. 
Na borda sul da bacia, depósitos dessa associação podem ocorrer assentados diretamente sobre o embasamento, na forma de lamitos maciços seixosos (Figura 6.19, perfil colunar 2).

\subsubsection{Associação de Fácies C - Canal Fluvial Entrelaçado com Afogamentos Episódicos}

A Associação de Fácies $\mathrm{C}$ inclui predominantemente os arenitos grossos, com níveis conglomeráticos, das fácies $\boldsymbol{A C p b}$ e $\boldsymbol{A C a}$, e os conglomerados da fácies $\boldsymbol{C m p}$. Organizamse em ciclos granodecrescentes, com as fácies Amp, Llm e Lac.

Os depósitos das fácies $A C p b$ e, principalmente, $A C a$ possuem geometria de canal com base côncava, sempre erosiva, escavando até 3 metros nas unidades sotopostas, erodindo diferentes ciclos granodecrescentes (Figura 6.19, perfis colunares 1, 3, 4, 5 e 12). Algumas vezes os lamitos sotopostos são totalmente erodidos e dão lugar a conglomerados e brechas, com clastos intraformacionais de lamitos da fácies $\boldsymbol{L} \boldsymbol{l} \boldsymbol{m}$, de dimensão até métrica (Figura 6.19, perfis colunares 3 e 12, Figuras 6.23A e A'). Essas brechas e conglomerados podem ser interpretados como base de canal e representam os litotipos intraformacionais que comumente ocorrem nas fácies $\boldsymbol{A C a}$ e $\boldsymbol{A C p b}$.

Os canais apresentam base plana ou côncava com bordas suaves. Mais raramente eles apresentam uma incisão mais profunda e concentrada, com bordas de inclinação acentuada (Figuras 6.23A e A'). Essas bordas de canal mais inclinadas estão associadas à

presença de níveis de lamito mais endurecido (Browne \& Plint 1994). É comum a associação desse tipo de borda com a presença de megaintraclastos de lamito, gerados por solapamento de canal (Figuras 6.23A e A'). A profundidade dos canais pode ser inferida pelo espaçamento entre as superfícies de erosão que marcam as bases de canais sucessivos (Browne \& Plint 1994), as quais não ultrapassam 3 metros. A espessura dos sets de estratificação cruzada acanalada, tipicamente de pequeno a médio porte, não ultrapassando 1 metro, e organizadas em cosets formando camadas lateralmente extensas por, pelo menos, mais de uma cento e vinte metros (Figura 6.23), indicam canais rasos e muito amplos, com alta razão largura profundidade. Essa relação largura/profundidade, com certeza maior que 
40, é típica de canais dominados por carga de tração (bed load) e, provavelmente, de rios entrelaçados (Schumm 1968).

Os arenitos com estratificação cruzada acanalada das fácies $\boldsymbol{A C a}$ e $\boldsymbol{A C p b}$, representam a migração de dunas subaquosas em canais (Walker \& Cant 1984, Miall 1981). A frequiência dessas fácies indica que o fluxo confinado era bem desenvolvido.

Os arenitos finos e lamitos laminados a maciços das fácies $\mathbf{A m p}$ e $\mathbf{L l m}$, e os arenitos grossos com níveis conglomeráticos das fácies $A C p b, A C a$, formam ciclos que apesar de indicarem uma tendência geral granodecrescente ascendente, não mostram transição granulométrica, nem adelgaçamento ascendente das camadas mais grossas para as mais finas. Pelo contrário, as fácies de sedimentos mais grossos são bruscamente sobrepostos pelas fácies mais finas, em contato brusco, porém não erosivo. Em diversos locais esses lamitos estendem-se por centenas de metros e assentam-se sobre a topografia ondulada (acamamento de megaôndula) de dunas de canal, preservando-as (Figura 6.19, perfis colunares 3, 5 e 12; Figuras 6.21B). Raramente, como no Ponto 25, essa passagem se faz de forma "transicional", em poucos decímetros, constituindo estruturas heterolíticas caracterizadas por ritmitos arenito-lamito, onde também podem ser identificadas pequenas formas de leito (dunas) arenosas, capeadas por argila (Figuras 6.22A e B). A preservação dessas morfologias por suspensão, indica a migração de ondas sob baixíssima energia (Reineck \& Singh 1980).

Estas cracterísticas indicam muito mais episódios de rápido afogamento da planície aluvial entrelaçada, formando extensas áreas alagadas, do que períodos de migração autocíclica do canal sobre uma planície de inundação. $\mathrm{O}$ acúmulo de pacotes métricos de lamito, por suspensão, e o retrabalhamento por organismos, indicam que essas áreas permaneceram longe da ação erosiva dos canais, por períodos relativamente longos. Estruturas de liquefação corroboram a presença de sedimentos saturados em água. Por outro lado, a exposição subaérea, dessas áreas é indicada pela presença, local, de clastos de argilas angulosos (rip-up clasts) e curvados (curled flakes), gretas de contração e fraturas verticais, interpretadas como vertissolos. Essas estruturas são consideradas indicadoras da atuação de processos pedogenéticos sob marcante sazonalidade (Millot 1970, Marriot \& Wright 1993). A retomada dessas áreas pelo canal é evidenciada pela erosão dos depósitos argilosos, com a formação de intraclastos mais ou menos angulosos, indicando diferentes 
graus de pedogenização. Localmente, a resistência dos lamitos aos processos erosivos, indicada pela sua preservação lateral por dezenas de metros, sugere uma litificação pedogenética mais acentuada, dando origem a canais com flancos mais íngremes (Figura 6.21A). $\mathrm{O}$ aporte esporádico de areia para dentro das áreas alagadas é indicado pela presença de níveis de arenitos com laminação plana e cruzada cavalgante. Localmente, os arenitos dessa fácies ultrapassam os limites dos canais propriamente ditos e cobrem áreas maiores da planície fluvial entrelaçada (Pontos 4, 12, 24 e 25), parecendo representar fluxos efêmeros, não canalizados, em meio aos afogamentos esporádicos da planície fluvial entrelaçada.

Por vezes os lamitos podem conter até cerca de $20 \%$ de areia (fácies $\mathbf{L A m}$ ) e constituir pacotes com até 9 metros de espessura, com intensa bioturbação. Essa bioturbação está associada, principalmente à presença de Taenidium, indicando a persistência de uma área alagada. Esses lamitos são intercalados com camadas tabulares e lenticulares de arenitos maciços da fácies $A m$, com espessura de até 1 metro e com base não erosiva, e com depósitos de canais das fácies $A C a$ e $A C p b$, pouco espessos e com base erosiva. Esse conjunto foi interpretado como uma área de inundação com aporte de corridas de lama, constituindo fan deltas, onde os arenitos estariam associados a fluxos não confinados (fácies $\boldsymbol{A m}$ ) (Bentham et al. 1993), ou a canais pouco desenvolvidos (fácies $A C a$ e $A C p b$ ), em um contexto distal (Zarza et al. 1993). A identificação, em algumas camadas argilosas desse pacote, de uma coloração vermelha mais intensa que em camadas superpostas e sotopostas, conjugada com a presença de concreções tubulares e esféricas de gibsita (perfil colunar 6, da Figura 6.16), indicam a atuação de processos pedogenéticos de laterização. A presença da gibsita indica um período de intenso intemperismo químico em solos bem drenados e em ecossistemas de grande biomassa e estabilidade, como as florestas tropicais, por períodos longos, de cerca de 50000 anos (Retallack 1990).

Essa associação de fácies é atribuída a canais entrelaçados, com base em:

a) freqüente presença de estratificação cruzada acanalada, de pequeno a médio porte, indicando a migração de dunas de cristas sinuosas em canais rasos, em associação com estratificação plano-paralela e estratificação cruzada planar, 
b) a acresção lateral limitada, concomitante com acresção frontal e vertical exibida pelos sedimentos dessa associação de fácies, caracterizando corpos arenosos múltiplos (multistorey/multilateral sheet sandstones), no sentido de Reading (1996),

c) o padrão unimodal de paleocorrentes,

d) a relação largura/profundidade dos canais acima de 40 .

\subsubsection{Associação de Fácies D - Canal Fluvial Entrelaçado}

Os conglomerados da fácies $C m p$ ocorrem, nessa associação de fácies, nas porções distais da bacia, posicionando-se nos níveis topográficos mais altos, como em Itambi (Ponto 15) e em Porto das caixas (Ponto 4). Eles se associam sempre aos arenitos grossos da fácies $A p$, ocorrendo tanto na base como intercalados com eles, truncando os depósitos sotopostos (Figura 6.19, perfis colunares 4 e 5). Esses conglomerados são quartzosos, no sentido de Boogs (1992), com seixos, calhaus e blocos de quartzo, de até $30 \mathrm{~cm}$ de eixo maior e bem arredondados. A estratificação plano-paralela sugere condições de alta energia e deposição por fluxos em lençol (sheet flow), geralmente atribuídos a barras longitudinais em domínios proximais de rios entrelaçados e planícies aluviais (Rust \& Koster 1984), similar à associação C. Por vezes esses depósitos são claramente erosivos, contendo clastos até decimétricos da unidade sotoposta, como pode ser observado em Itambi (Ponto 15). Em Porto das Caixas essa fácies parece colmatar um paleovale escavado por cerca de 5 metros na Formação Macacu (Figura 6.19, perfil colunar 5).

Os conglomerados quartzosos da fácies $C m p$ apresentam, localmente, imbricação de seixos, como no Ponto 15. Apesar de não terem sido tomadas medidas sistemáticas, a imbricação é nitidamente voltada para WSW, como pode ser visto nas Figuras 6.22D e F.

$\mathrm{Na}$ associação de Fácies D, os conglomerados das fácies $C m p$ se restringem a ocorrências esporádicas no interior da bacia (Pontos 4 e 15). Esses conglomerados ocorrem 
sempre no topo do pacote, truncando as camadas sotopostas pertencentes à Formação Macacu (perfis colunares 4 e 5, Figura 6.19).

\subsubsection{Ocorrência do Icnofóssil Taenidium}

Foram identificados traços fósseis endicniais preenchidos, de forma cilíndrica e alongada, com seção transversal circular a aproximadamente elíptica. Seu comprimento médio é de $5 \mathrm{~cm}$ e seu diâmetro médio de aproximadamente $1 \mathrm{~cm}$. Os maiores chegam a ter quase $2 \mathrm{~cm}$ de diâmetro e $12 \mathrm{~cm}$ de comprimento (Figura 6.21D). Os traços são retilíneos a suavemente encurvados e se posicionam na camada, tanto na vertical como com inclinações mais próximas da horizontal. São características as estruturas anelares, suavemente côncavas, denominadas "meniscos" (Squires \& Advocate 1984) quando observados em perfil longitudinal (Figura 6.21D), que são determinantes para a sua classificação no icnogênero Taenidium (Heer 1877, apud Squires \& Advocate 1984). Os meniscos, refletem a alternância de material digerido e selecionado pelo animal que construiu o tubo, com material da rocha hospedeira. Nesse sentido o preenchimento do tubo é considerado "ativo" (Squires \& Advocate 1984, Smith et al. 1993).

Os traços fósseis ocorrem nas porções superiores dos níveis argilosos da fácies $\boldsymbol{L l m}$ e $\boldsymbol{L A} \boldsymbol{A}$, bem como nos níveis de areia fina da fácies $\boldsymbol{A m p}$ (Figura 6.19, perfis colunares 6, 7 e 12), sempre associados aos eventos de inundação. Eles são particularmente abundantes nas porções mais distais da planície aluvial, nas proximidades de Magé (Pontos 26 e 27, perfis colunares 6 e 7 da Figura 6.19). Nesses locais com grande concentração eles se entrecruzam e podem gerar bioturbação intensa (Figura 6.23C). Sua ocorrência nos níveis arenosos da fácies $\boldsymbol{A C p b}$ é rara (Figura 6.19, perfil colunar 12).

Esse tipo de icnofóssil não é um bom indicador de ambiente ou mesmo de idade, tendo em vista que eles são comuns em depósitos cenozóicos de diferentes épocas, em vários lugares do mundo, podendo ocorrer tanto em ambientes flúvio-lacustres como em planícies de maré (Squires \& Advocate 1984, Smith et al. 1993, Rossetti 2000).

Ainda nesse sentido, não se sabe a identidade do animal que dá origem a esse tipo de escavação, porém há consenso em que eles são gerados sempre em ambientes 
subaquosos rasos. Para Squires \& Advocate (1984) eles podem ter sido gerados por oligoquetos aquáticos, que vivem nas partes mais rasas dos lagos. Segundo Smith et al. (1993), esses traços podem ter sido construídos por artrópodes, em lagos episódicos, logo após a fase de inundação principal.

\subsubsection{Formação Macacu em Sub-superfície - Perfis de Sondagens de Poços Artesianos Profundos}

Dos 15 perfis de poços artesianos profundos analisados, todos no Município de Itaboraí, apenas 6 apresentam descrições mais detalhadas das rochas perfuradas. Coincidentemente, esses 6 poços atravessaram apenas sedimentos da Formação Macacu, não chegando a atingir o embasamento. Desses 6, 5 estão localizados em Manilha e $1 \mathrm{em}$ Itambi (Figura 6.14). Dentre os demais poços, apenas 1 cortou sedimentos da Formação Macacu (Poço 8, Figura 6.14), antes de atingir o embasamento aos 40 metros de profundidade; entretanto, nem os sedimentos, nem o embasamento foram descritos. Os demais atravessaram solo ou aluviões, antes de atingir o embasamento.

Os 6 poços melhor descritos tiveram seus perfis sintetizados na Figura 6.24. Esses poços referem-se a 1 perfurado pela HIDROGESP em Itambi (poço 1), 4 perfurados pela GEOPLAN em Manilha (poços 2 a 5), e 1 perfurado pela INX - HIDROGEOLOGIA, também em Manilha, junto ao Rio da Aldeia e da BR101 (poço 6).

A descrição de campo dos perfis dos poços é heterogênea, mesmo dentro de uma mesma firma (GEOPLAN), por vezes dando maior importância a aspectos distintos entre um poço e outro. Nesse sentido procurou-se homogeneizar os parâmetros de descrição, segundo os exemplos abaixo:

1) Referem-se a um nível arenoso como "bem selecionado", em um poço, e "limpo", ou seja sem silte e argila (bem selecionado) em outro. Nesse caso específico, as características texturais foram padronizadas para "bem selecionado"; 


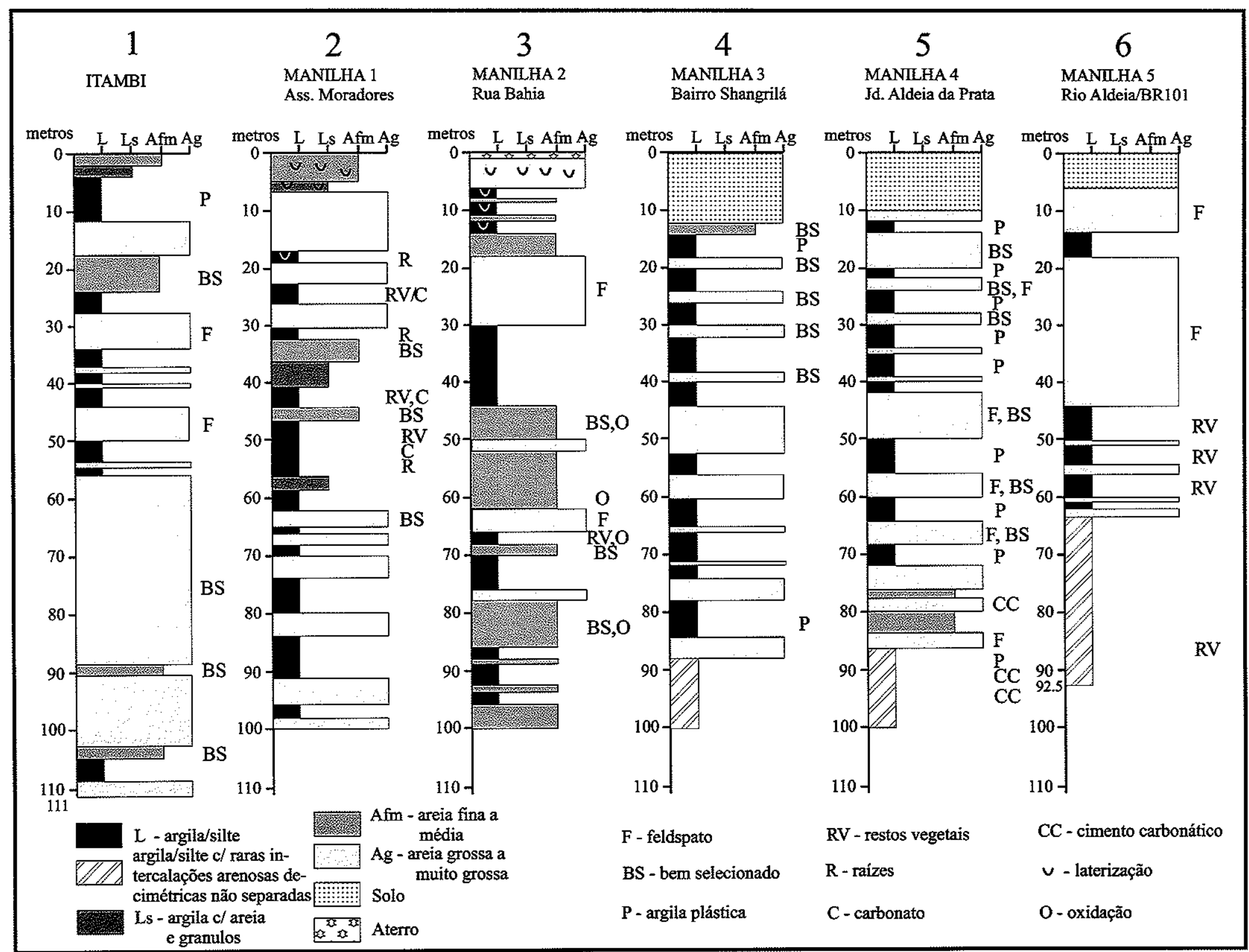

Figura 6.24 - Poços artesianos profundos que não atingiram o embasamento na Bacia do Macacu (localização na Figura 2, com mesma numeração). Firmas: HIDROGESP (poço 1), GEOPLAN (poços 2a 5) e INX - HIDROGEOLOGIA(Poço6). 
2) Em alguns perfís são descritos níveis "lateríticos", sempre nas porções mais rasas, e em outros, sedimentos "avermelhados". Nesse caso foi mantido o termo laterização, para os primeiros, e utilizado o termo oxidação para os segundos.

3) Os níveis não descritos como "lateríticos" ou "avermelhados" são invariavelmente descritos como de cor esverdeada, cinza esverdeada, ou ainda "com glauconita", no caso dos argilosos, e de cor cinza esbranquiçada ou verde clara, os arenosos. Como essas categorias são persistentes e indicam a predominância dos minerais de argila do grupo das esmectitas, são apresentadas apenas as exceções a esse padrão, ou seja os níveis mais oxidados;

4) Para alguns níveis argilosos são descritas "raras intercalações de arenito", sem definir o número delas, o intervalo de profundidade, ou sua espessura. Nesses casos foram representadas 2 a 3 intercalações, em posições aleatórias, com espessura de no máximo 1 metro. Essa situação é encontrada nos seguintes poços:

- Poço $5 \rightarrow$ entre as profundidades de 86 e 100 metros,

- Poço $4 \rightarrow$ entre as profundidades de 88 e 100 metros,

- Poço $6 \rightarrow$ entre as profundidades de 64 e 80 metros.

5) A indicação de "cimento carbonático" foi mantida de acordo com as descrições de campo, porém a categoria "carbonato" foi introduzida para os níveis originalmente descritos como tendo apresentado "forte reação ao $\mathrm{HCl}$ e "reação ao $\mathrm{HCl}$ ". Os níveis com "fraca reação ao $\mathrm{HCl}$ " não foram representados, tendo em vista a "margem de erro" muito maior que essa classificação representa, numa descrição de campo, quando comparada com as outras duas. 


\subsubsection{Interpretação}

Os perfís dos poços artesianos profundos mostram uma alternância de níveis arenosos e lamosos. A espessura dos diferentes níveis não é homogênea, com intervalos por vezes bastante espessos, de predominância de um ou de outro, por exemplo:

a) Espessos pacotes arenosos podem ser vistos nos seguintes intervalos:

poço $1 \rightarrow 12-25 \mathrm{~m}, 57-105 \mathrm{~m}$;

poşo $2 \rightarrow 0-18 \mathrm{~m}, 33-41 \mathrm{~m}, 62-74 \mathrm{~m}$;

poço $3 \rightarrow 15-30 \mathrm{~m}, 45-65 \mathrm{~m}, 77-87 \mathrm{~m}$;

poço $4 \rightarrow 45-52 \mathrm{~m}$;

poço $5 \rightarrow 7-15 \mathrm{~m}, 18-45 \mathrm{~m}$.

b) Espessos pacotes com predominância de níveis lamosos podem ser vistos nos intervalos:

poço $1 \rightarrow 4-12 \mathrm{~m}, 35-45 \mathrm{~m}, 50-56 \mathrm{~m}$;

poço $2 \rightarrow 42-62 \mathrm{~m}, 73-80 \mathrm{~m}, 84-92 \mathrm{~m}$;

poço $3 \rightarrow 6-15 \mathrm{~m}, 31-45 \mathrm{~m}, 67-76 \mathrm{~m}, 87-96 \mathrm{~m}$;

poço $4 \rightarrow 15-45 \mathrm{~m}, 61-75 \mathrm{~m}, 78-85 \mathrm{~m}, 88-100 \mathrm{~m}$;

poço $5 \rightarrow 30 \sim 42 \mathrm{~m}, 50-56 \mathrm{~m}, 87-100 \mathrm{~m}$;

poço $6 \rightarrow 44-92,5 \mathrm{~m}$.

Se forem tomados como parâmetro os depósitos da Formação Macacu expostos (Figura 6.19), onde os canais fluviais geram depósitos de no mínimo 2 metros e no máximo 3 metros de espessura, pode-se supor que os níveis arenosos com espessura acima de 2 metros representem depósitos de canal das fácies $A C p b$ e $A C a$, ou mesmo os depósitos de leques gerados por fluxo em lençol, das fácies $A p$ e $C m p$. Nesse sentido, os ainda mais espessos poderiam representar o empilhamento de depósitos de diversos canais (multistorey sandbodies), como foi identificado em campo na área de Saracuruna (Ponto 25). Por outro 
lado, pode-se considerar que os níveis lamosos com até 3 metros de espessura possam representar depósitos de preenchimento de canais que sofreram avulsão. Os níveis argilosos mais espessos que 3 metros devem ser correlacionados com depósitos lacustres, sejam perenes ou efêmeros, gerados pelos afogamentos esporádicos da planície fluvial entrelaçada. A presença de níveis pouco espessos (com menos de 2 metros) de arenito, dentro dos lamitos, e de restos vegetais, indicam que podem estar presentes as fácies $\mathbf{L l m}$, $\boldsymbol{L} \boldsymbol{l}$ e $\boldsymbol{A m}$. Os níveis com depósitos incluídos na categoria Ls (lamito seixoso) (Figura 6.24), que são descritos como argilosos com grãos e grânulos de quartzo, poderiam representar lobos de fluxos de detritos e corridas de lama.

Chama atenção nos perfis a indicação de níveis com carbonatos (os lamosos), ou com "cimento carbonático" (no caso dos arenosos), identificados em campo pela reação com o $\mathrm{HCl}$, uma vez que eles não foram identificados em superfície. Como não há descrições adicionais desse material, não é possível saber se o carbonato está relacionado com processos primários ou secundários. Em especial, no caso dos lamitos, nas demais bacias do RCSB eles são comumente secundários, uma vez que calcretres são comuns nos lamitos da Formação Resende (Riccomini 1989, Riccomini et al. 1996) e da Bacia de São José do Itaboraí (Tibana et al. 1984, Riccomini et al. 1987, Sant'Anna 1999).

A análise dos perfis de sondagens para poços artesianos profundos indica que as associações de fácies sedimentares dos depósitos da Formação Macacu, identificados em superfície, podem ser extrapoladas, em caráter preliminar, para sub-superfície, na região de Manilha e Itambi, até pelo menos 110 metros de profundidade.

\subsubsection{Paleogeografia}

\subsubsection{Distribuição Geográfica das Associações de Fácies}

As associações de fácies sedimentares mostram um nítido padrão de distribuição na Bacia do Macacu e nas áreas de ocorrência isoladas da Formação Macacu (Figura 6.18):

- A associação A, lacustre, ocorre comumente na base do pacote aflorante, como pode ser observado em Itaboraí, Porto das Caixas, Manilha e Itambi, junto à borda sudeste e na 
porção central da bacia. A ocorrência de dois níveis de linhito em meio aos argilitos laminados dessa associação, um mais espesso na base e outro mais fino no topo (Pontos 1 e 18; perfis colunares 2 e 9, da Figura 6.19), permite que se assuma que esses depósitos são contínuos por pelo menos $8 \mathrm{~km}$, junto à borda sudeste da bacia. Se considerarmos que os níveis de argilito laminado que ocorrem em Itambi (Ponto 12; perfil colunar 3, da Figura 6.19) e em Porto das Caixas (Ponto 4; perfil colunar 5, da Figura 6.19) estão em continuidade com os da borda sudeste que contêm os níveis de linhito, teremos um paleolago de aproximadamente $40 \mathrm{~km}^{2}$, se estendendo da borda sudeste até a porção central da Bacia do Macacu.

- A associação $B$, de leques aluviais, representados predominantemente por lobos de camadas de detritos/corridas de lama e, subordinadamente por depósitos de fluxo em lençol (sheet flood), é mais expressiva junto à borda sudeste da bacia. Nos Pontos $1 \mathrm{e} 7$ essa associação chega a constituir $90 \%$ e $100 \%$ do pacote sedimentar aflorante (Figura 6.19, perfis colunares 1 e 2). Os depósitos proximais dessa associação, com blocos e matacões de natureza diversificada, constituindo ortoconglomerados e paraconglomerados polimíticos, ocorrem exclusivamente no Ponto 6, na borda sudeste $\mathrm{da}$ bacia. A associação B tem ocorrência restrita na Ilha do Governador. Essa associação está ausente da borda $\mathrm{NW}$ da bacia, tanto da região de Magé da área de Duque de Caxias. Nesse último local foram identificados unicamente depósitos da associação $\mathrm{C}$, enquanto que em Magé estão presentes apenas fan deltas, ricos em icnofósseis indicativos de ambientes alagados em um contexto distal.

- A Associação de Fácies C, de canal fluvial entrelaçado, ocorre em quase toda a bacia, estando ausente apenas da borda sudeste. $\mathrm{Na}$ borda noroeste da bacia, na área de ocorrência isolada dos sedimentos da Formação Macacu, em Duque de Caxias (Ponto 25, perfil colunar 12, da Figura 6.19), ela foi a única associação identificada. Nessa área há um maior volume relativo de lamitos argilosos e arenitos finos das fácies $\mathbf{L l m} \mathrm{e}$ $A m p$, quando comparado com as outras áreas, evidenciando uma maior recorrência dos afogamentos da planície fluvial entrelaçada e, também uma melhor preservação dos depósitos gerados por elas. Situação semelhante pode ser vista em Magé, onde os 
lamitos arenosos e arenitos maciços, das fácies $\mathbf{L A m}$ e $\mathbf{A m}$, ocorrem intercalados, parecendo constituir fan deltas e indicando a pronta geração de espaço nessa porção da bacia. Ressalta-se também que em Duque de Caxias e Magé verificou-se a ocorrência do icnofóssil Taenidium, característico de lagos rasos e de áreas alagadas.

\subsubsection{Paleocorrentes}

A amostragem de paleocorrentes compreende um total de 41 medidas, entre eixos de estratificação cruzada acanalada e eixos de paleocanais (Figura 6.25). Embora seja uma amostragem essencialmente qualitativa, em parte devido a obliteração de estruturas sedimentares pelo intemperismo, ela foi utilizada tendo em vista a sua boa distribuição geográfica, e as interessantes indicações de paleodeclividade e tectônicas advindas da sua análise.

Procurou-se, nas camadas com nítido adernamento tectônico, discriminar sua magnitude e azimute a partir da atitude de camadas formadas por decantação. $\mathrm{Na}$ borda sudeste, por exemplo, no Ponto 7, o mergulho de aproximadamente $7^{\circ}$, para SSE, das camadas de lamito argiloso, não foi suficiente para alterar o caimento para WNW das medidas de paleocorrente.

Se, no seu conjunto, tanto as medidas de eixos de estratificação cruzada acanalada, quanto as de eixos de paleocanais mostram concentrações bimodais, para os quadrantes NE e SW (Figura 6.25), quando analisadas por afloramento elas exibem um padrão aproximadamente unimodal.

Nesse sentido, a plotagem em mapa das médias das medidas de paleocorrentes, calculadas para cada afloramento, mostra uma predominância de orientações para o quadrante SW, variando entre sul-sudoeste (azimute $190^{\circ}$ ) e oeste-noroeste (azimute $280^{\circ}$ ) (Figura 6.26), apontando para um depocentro a SW, mais próximo da borda sul.

Orientações distintas dessas, principalmente voltadas para o quadrante NE, foram encontradas nas áreas isoladas de ocorrência da Formação Macacu, na Ilha do Governador (Ponto 24) e em Duque de Caxias (Ponto 25), situadas a leste da área principal. Essas medidas voltadas para o quadrante NE, tanto na Ilha do Governador como em Duque de 
Caxias, relacionam-se a depósitos francamente fluviais, com canais bem desenvolvidos e contínuos, da Associação de Fácies C. A presença, em ambos os locais, de lamitos laminados da fácies $\boldsymbol{L} \boldsymbol{l} \boldsymbol{m}$, assentados sobre os depósitos de canal (Figura 6.19), permite um bom controle de eventuais adernamentos das camadas, tendo em vista que as mesmas se depositam na horizontal, por suspensão.
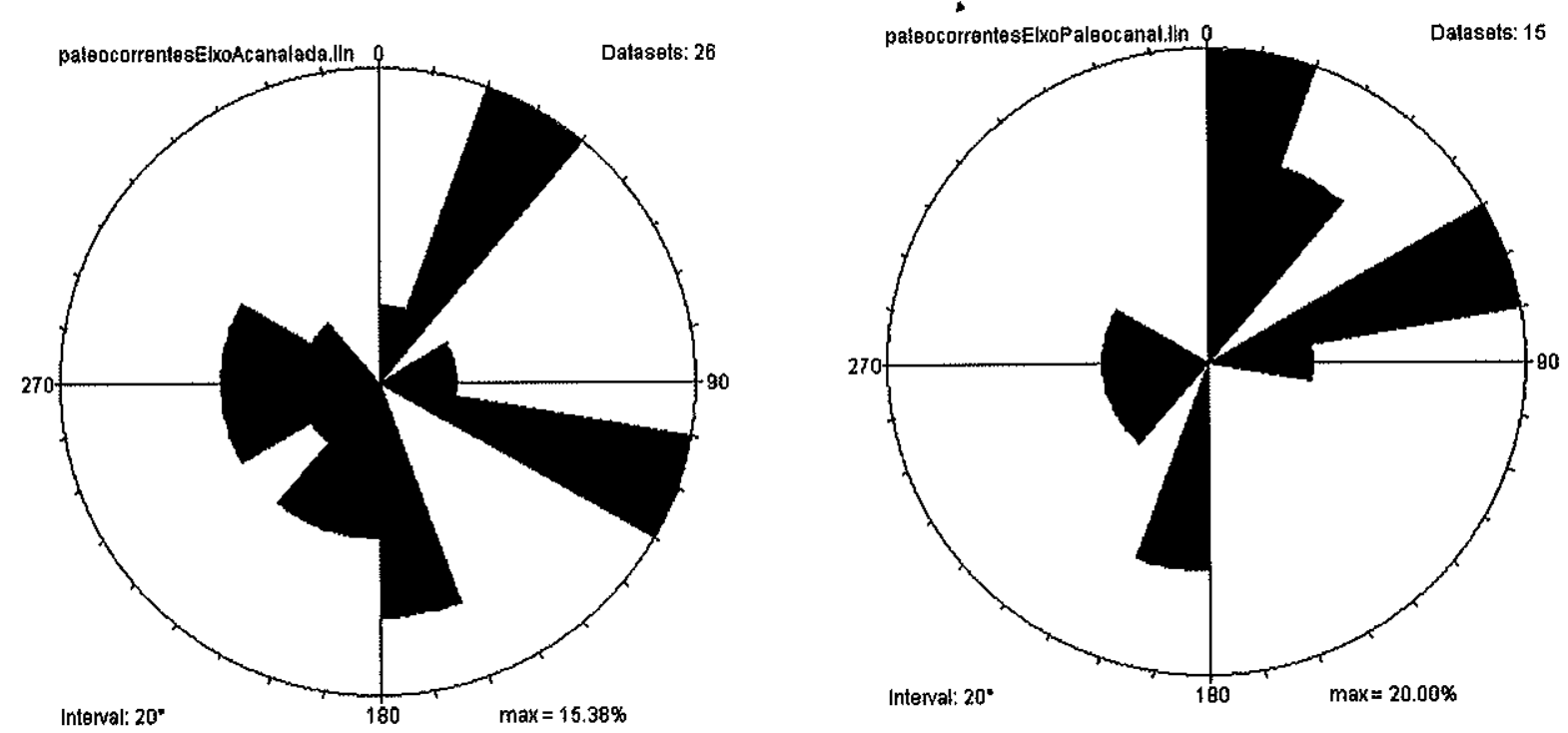

Figura 6.25 - Rosetas com medidas de paleocorrentes nos depósitos da Formação Macacu. A) Medidas de eixos de estratificação cruzada acanalada, B) Medidas de eixos de paleocanais.

A análise da distribuição geográfica das paleocorrentes médias (Figura 6.26) evidencia um conjunto de medidas voltado para WSW, ao sul do Rio Caceribu, e um conjunto voltado para ENE, ao norte do mesmo rio.

A coerência na orientação das paleocorrentes, somada às características litológicas e estruturais das associações de fácies sedimentares presentes nas duas áreas de ocorrência isolada dos sedimentos da Formação Macacu, na Ilha do Governador e em Duque de Caxias, indica que elas representam pedaços de uma bacia maior, em conjunto com a Bacia do Macacu. 


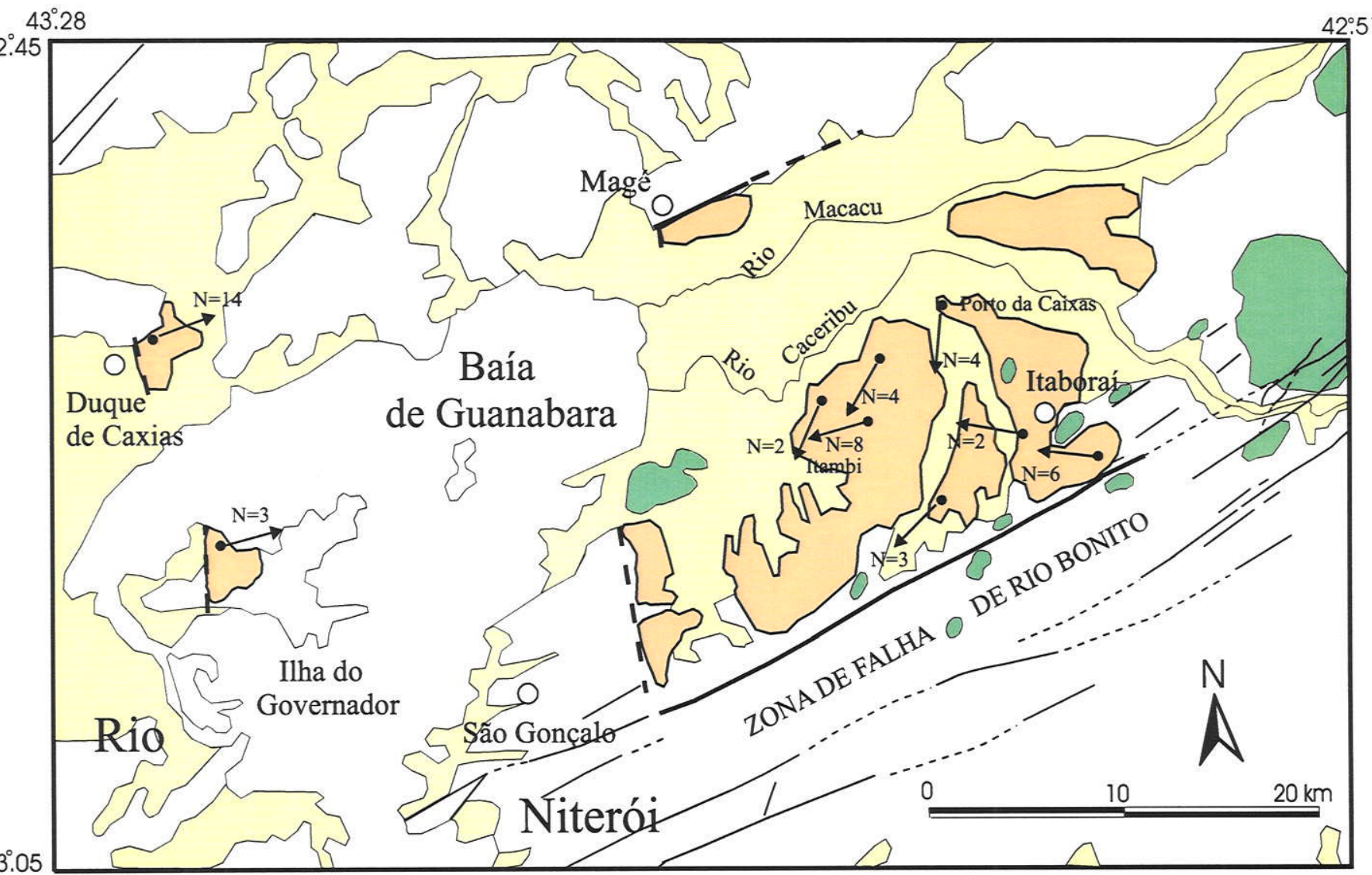
$23^{\circ} .05$

Figura 6.26 - Direç̃es médias de paleocorrentes da Formação Macacu (cf. Figura 10). Setas pretas indicam direção média de eixo de estratificação cruzada acanalada e de paleocanais. Stocks e plugs de rochas alcalinas do Cretáceo Superior em cor verde. Traços finos longos representam falhas terciárias e traços grossos indicam os limites da Bacia do Macacu e das ocorrências isoladas na Ilha do Governador e em Duque de Caxias. Esses limites são tracejados quando inferidos, como na borda oeste da área principal e nas áreas isoladas. Geologia modificada de Meis \& Amador (1977), Penha et al. (1979), Dalcolmo et al. (1982), Valença \& Klein (1984) e Coelho et al. (1986). 


\subsubsection{Litoestratigrafia}

As unidades sedimentares que constituem o preenchimento sedimentar da Bacia do Macacu têm sido descritas, sistematizadas e empilhadas de formas distintas desde o trabalho pioneiro de Meis \& Amador (1972) e seu detalhamento por Meis (1976) e Meis \& Amador (1977), os quais definiram a Formação Macacu e as "Camadas Pré-Macacu" como constituídas por depósitos de leques aluviais. A separação dessas unidades, por eles, foi baseada unicamente em modificações secundárias apresentadas na unidade denominada Formação Macacu, como caulinização do feldspato e ferruginização. A descrição de ambas foi essencialmente litológica, praticamente não envolvendo as estruturas sedimentares dos depósitos e suas relações genéticas. Dalcolmo et al. (1982) restringiram-se a reunir as duas unidades estratigráficas em uma única, denominada Formação Barreiras, sem detalhamento ou proposição formal. Lima et al. (1996) também reuniram as duas unidades estratigráficas definidas por Meis \& Amador (1977) em uma única, denominada Formação Macacu, constituída por três sistemas deposicionais distintos: de leques aluviais (na base), fluvial entrelaçado e fluvial meandrante (no topo). Segundo Lima et al. (1996) sedimentos de leques aluviais e de canais fluviais entrelaçados, do Neógeno ou Quaternário, cobririam, em discordância erosiva, a Formação Macacu. Ferrari \& Silva (1997), sem fazer proposições formais, restringiram a Formação Macacu aos depósitos de leques aluviais e canais entrelaçados e reconheceram como um sistema deposicional lacustre, aquele anteriormente descrito por Lima et al. (1996) como fluvial meandrante. Esses autores correlacionaram a Formação Macacu à Formação Resende, e os depósitos lacustres à Formação Tremembé.

$\mathrm{Na}$ área de estudo foram descritas doze fácies sedimentares distintas (Tabela 6.3), combinadas em quatro associações de fácies (Tabela 6.4 e Figura 6.16): a) Associação A lacustre, b) Associação B - de leques aluviais, com lobos fluxos de detritos/corridas de lama e de fluxo em lençol, c) Associação C - canal fluvial entrelaçado com afogamentos episódicos e d) Associação D - canal fluvial entrelaçado, sendo as três primeiras pertencentes à Formação Macacu.

Com base nos novos dados apresentados nesse trabalho, e nas características das diferentes propostas litoestratigráficas existentes, parcialmente conflitantes e sem 
formalização adequada, é apresentada uma nova proposta litoestratigráfica, segundo Petri et al. (1986), para o preenchimento sedimentar da Bacia do Macacu (Figuras 6.27 e 6.28):

1) Propõe-se criar a denominação Membro Rio Vargem, para os depósitos da associação A. Essa formação constituída de lamitos laminados, com níveis de linhito e de arenito, das fácies $\boldsymbol{L l m}, \boldsymbol{L I} \boldsymbol{l}$ e $\boldsymbol{A m}$, tem seu holoestratótipo na porção inferior do perfil colunar 2, da Figura 6.16, localizado na área urbana de Itaboraí, no barreiro da Cerâmica São João Batista, com ocorrência de linhito. O nível inferior do perfil colunar 9, da Figura 6.19, na localidade de Barro Vermelho, Município de Itaboraí, constitui um importante paraestratótipo, onde também está presente o linhito.

2) Cria-se a denominação Membro Porto das Caixas para os depósitos das associações B e $\mathrm{C}$, litologicamente constituídos por arenitos, conglomerados e lamitos, das fácies $\boldsymbol{A C a}$, $A C p b, A m p, L A c, L l m, L A s m, C m p$ e $C m$. Os holoestratótipos dessa formação estão representados na porção intermediária do perfil colunar 5, da Figura 6.19, no Barreiro Portuense, no Distrito de Porto das Caixas. Como paraestratótipo inclui-se as porções intermediária e superior do perfil colunar 2, da Figura 6.19, no Barreiro São João Batista, área urbana de Itaboraí e os conglomerados polimíticos da seção representada pelo perfil colunar 1, da Figura 6.19, em corte da BR-101, no Bairro de Calundu, Município de Itaboraí. Os arenitos intercalados com lamitos, representados na seção colunar 12, da Figura 6.19, em Saracuruna, Município de Duque de Caxias, correspondem ao hipoestratotipo. Nesse último, vêm-se os mais completos depósitos de canais entrelaçados do Membro Porto das Caixas.

3) Propõe-se denominar os conglomerados quartzosos, localmente com seixos arredondados de quartzo com até $30 \mathrm{~cm}$ de eixo maior, das fácies $C m p$ e $A p$, que assentam em discordância erosiva sobre a Formação Macacu, de Conglomerado Itambi. Esse conglomerado tem sua área de ocorrência tipo no Barreiro Colonial, no Bairro de Itambi, Município de Itaboraí, representado no perfil colunar 4, Figura 6.19. 
A)

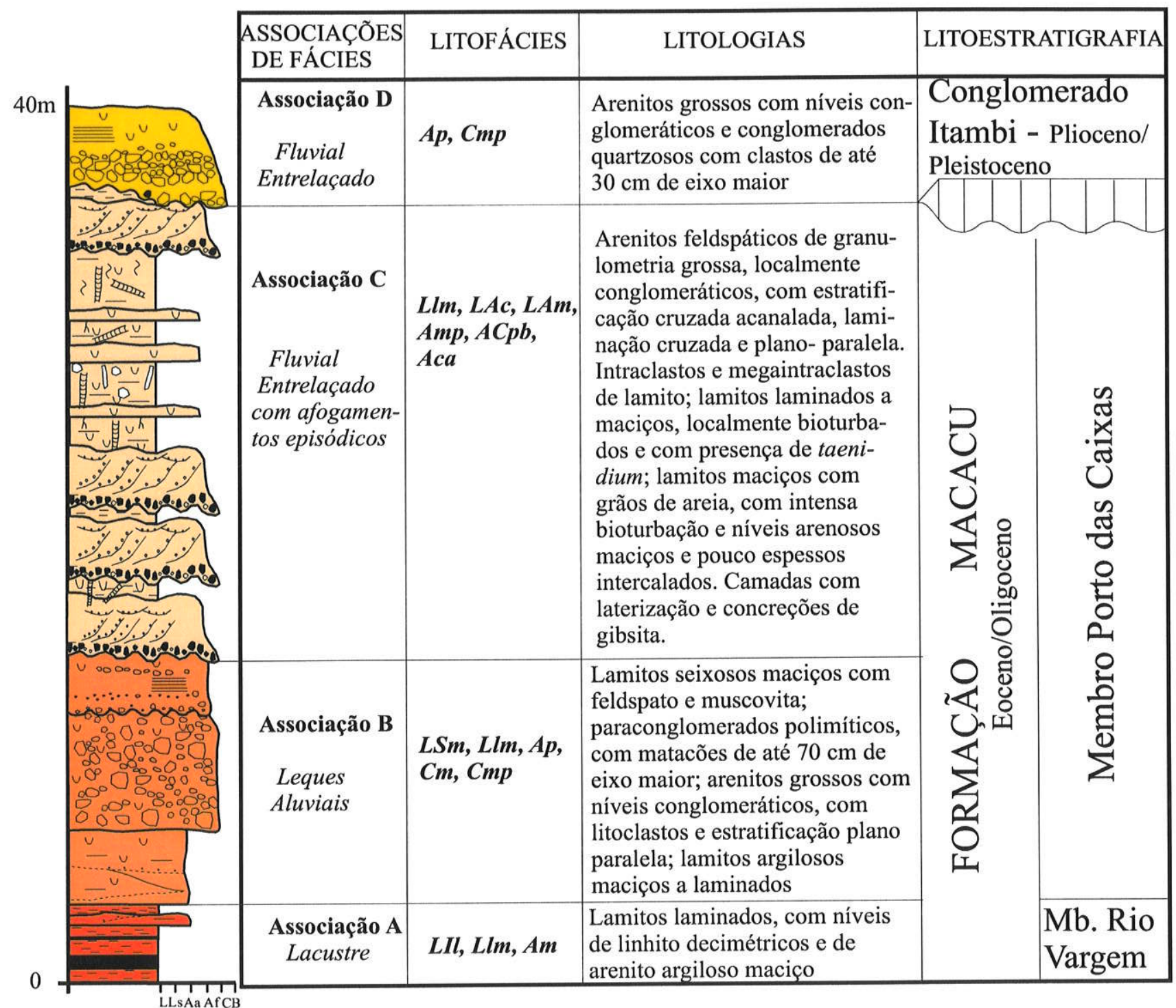

B)

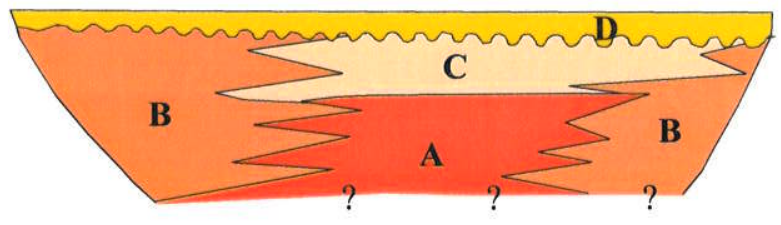

Figura 6.27 - A) Coluna geológica esquemática dos depósitos sedimentares da Formação Macacu, com nova proposta litoestratigráfica. Simbologias utilizadas na coluna geológica estão de acordo com a legenda da Figura 6.19 B) Perfil esquemático mostrando a distribuição das associações de fácies na Bacia do Macacu. 


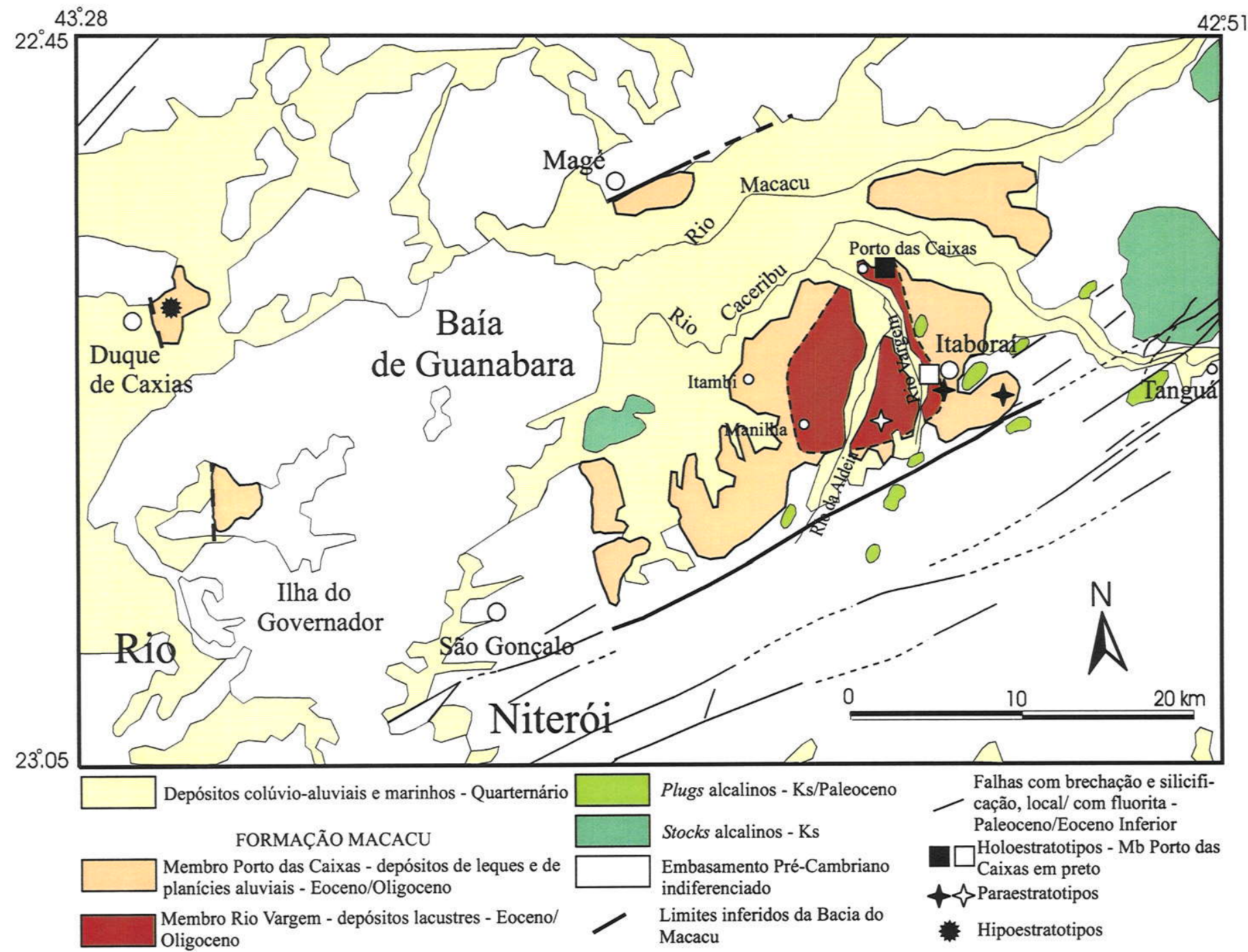

Figura 6.28 - Subunidades litoestratigráficas da Formação Macacu. Geologia modificada de Meis \& Amador (1977), Penha et al. $(1979,1980)$, Dalcolmo et al. (1982), Valença \& Klein (1984) e Coelho et al. (1986). 
É necessário ressaltar que as associações integrantes de um sistema deposicional são contemporâneas, com limites aproximadamente sincrônicos, ao contrário das unidades litoestratigráficas que possuem limites diacrônicos. Entretanto, a proposta apresentada nesse trabalho chega ao nível de "membro", o qual se confunde com a associação de fácies, justificando uma correlação direta entre ambos.

O Membro Rio Vargem tem idade eocênica a oligocênica, determinada a partir de palinomorfos encontrados nos linhitos. Essa unidade pode ser correlacionada com a Formação Tremembé, tendo em vista as suas características tectono-sedimentares e o interrelacionamento com as demais unidades sedimentares da Bacia do Macacu. A interdigitação entre os litotipos do Membro Rio Vargem e os do Membro Porto das Caixas, permite extrapolar uma idade eocênica a oligocênica para todo o pacote. As características litológicas e a idade do Membro Porto das Caixas, permite correlacioná-lo com a Formação Resende como definida por Amador (1975) e revista por Riccomini (1989).

Para o Conglomerado Itambi, não se tem datação, porém a maior maturidade e o longo tempo de residência, quando comparado com os sedimentos da Formação Macacu, sugerindo inclusive um retrabalhamento de sedimentos mais antigos, indicam uma idade mais nova que a dos depósitos da Formação Macacu. A maior maturidade indica deposição em clima úmido. Nas suas características sedimentológicas o Conglomerado Itambi se assemelha às unidades colúvio-aluvial e aluvial da Formação Caceribu, como definidas por Amador (1980). Segundo esse autor essa formação seria constituída por leques e sistemas aluviais entrelaçados, de idade pleistocênica, sobrepostos à Formação Macacu. Porém, o fato de serem sotopostos às linhas de seixos que marcam o topo de colinas dissecadas, a altitudes acima de 15 metros, as quais teriam idade plio-pleistocênica (Claudio Limeira Melo, informação verbal, 2001), indica que o Conglomerado Itambi pode ser mais antigo que o Pleistoceno. Por outro lado, o Conglomerado Itambi se assemelha também aos depósitos de conglomerados quartzosos que assentam sobre o embasamento nas falésias fósseis do entorno da Lagoa de Maricá, os quais foram denominados Formação Barreiras por Dalcolmo et al. (1982). Ocorrências de conglomerados quartzosos semelhantes aos do aqui denominado Conglomerado Itambi, podem ser vistas também na Taquara, junto à Linha Amarela, no Bairro de Jacarepaguá, no Rio de Janeiro. Esses depósitos foram correlacionados por Amador (1997) aos depósitos aluviais da Formação Caceribu. 


\subsubsection{Tectônica}

Os depósitos da Formação Macacu foram afetados por uma tectônica deformadora, visível em quase todos os afloramentos, caracterizada por falhas normais mesoscópicas identificadas a partir de parâmetros estratigráficos (Figura 6.29). Essas falhas têm rejeitos desde centimétricos até pouco mais de 5 metros, com a predominância dos rejeitos centimétricos a decimétricos - microfalhas. Os maiores rejeitos foram identificados em Porto das Caixas e em Magé (Pontos 4 e 26, respectivamente). São comuns as falhas com ângulo de mergulho médio e alta obliqüidade, ocorrendo também falhas com ângulo de mergulho alto, as quais, localmente, puderam ser caracterizadas como falhas antitéticas associadas a falhas lístricas, como em Porto das Caixas e em Itambi (Pontos 4 e 12, respectivamente, Figura 6.20). Algumas falhas possuem obliqüidade média (falhas oblíquas) e têm, em geral, alto ângulo de mergulho.

As pouco mais de 120 microfalhas e falhas identificadas foram caracterizadas pela direção e o mergulho do plano de falha e pelo azimute e caimento das estrias geradas pelo movimento ao longo do plano, além do sentido de movimento dos blocos. Esses dados foram invertidos para obtenção das paleotensões responsáveis pela sua geração, com base no princípio de que as estrias são paralelas ao esforço cisalhante máximo exercido sobre o plano de falha (Carey \& Brunier 1974, Angelier \& Mechler 1977, Angelier 1984, 1989, 1990, 1994). A inversão dos dados de falhas foi efetuada computacionalmente, com a utilização do programa TENSOR (Delvaux 1993, modificado de Angelier 1984, 1990), para obtenção dos eixos de tensão reduzidos, incluindo a orientação dos principais eixos de tensões $\sigma 1, \sigma 2$, e $\sigma 3$, onde $\sigma 1 \geq \sigma 2 \geq \sigma 3$ (compressão considerada positiva), a razão de esforço $\mathrm{R}=\sigma 2-\sigma 3 / \sigma 1-\sigma 2,0 \leq \mathrm{R} \leq 1$, e o ângulo $\alpha=$ desvio médio entre as medidas e o cisalhamento computado sobre o plano de falha.

As análises geométrica, cinemática e das relações estratigráficas das falhas que afetam os depósitos da Formação Macacu, permitiram a separação de três grupos distintos gerados em diferentes eventos de extensão: 1) Extensão NW-SE, 2) Extensão NE-SW e 3) Extensão E-W a WNW-ESE. 


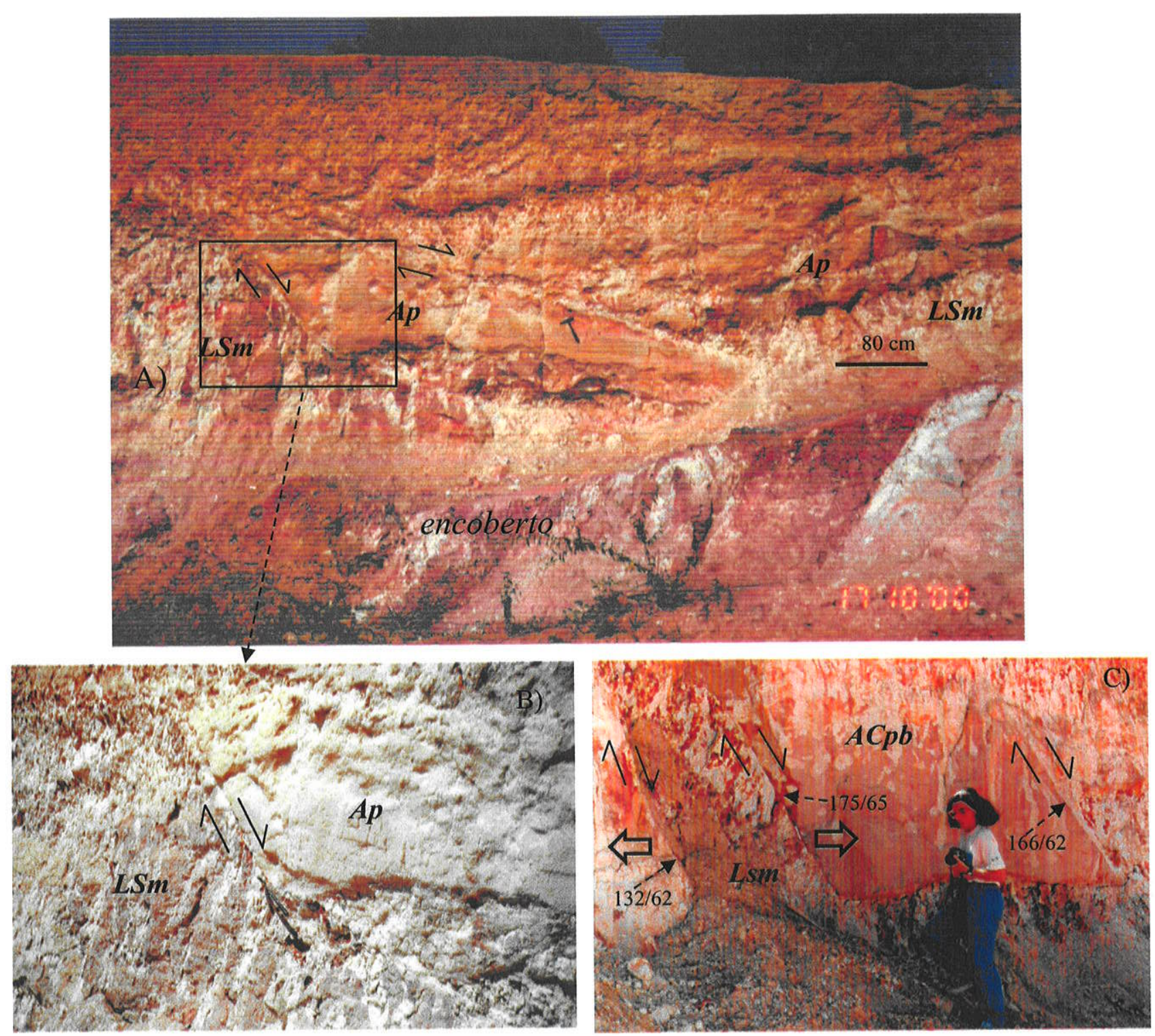

Figura 6.29 -A, B e C - Falhas normais, de alto ângulo e lístricas, afetando sedimentos da Formação Macacu: A) Lamitos maciços (fácies $\mathbf{L S m}$ ) e arenitos grossos com níveis conglomeráticos (fácies $\boldsymbol{A m} \boldsymbol{m}$ ) de leques aluviais, afetados por falhas normais de direção NE-SW. Notar adernamento dos arenitos da fácies $\boldsymbol{A m p}$. Barreiro São João Batista, Ponto 1, B) Detalhe da foto anterior mostrando falha normal de alto ângulo seccionando os arenitos grosseiros com estratificação plano-paralela, C) Falha normal de alto ângulo seccionando paleocanal com arenitos da fácies $\boldsymbol{A C p b}$, com lamito da fácies $\boldsymbol{L S} \boldsymbol{m}$ injetado no plano de falha, Ponto 3, Country Club. As falhas mostradas foram geradas pela extensão NW-SE. 


\subsubsection{Extensão NW-SE}

A extensão NW-SE gerou falhas normais de direção NE-SW a ENE-WSW, com mergulhos médios a altos e estrias com obliqüidade alta. Bons exemplos podem ser vistos no barreiro da Cerâmica Portuense, no distrito de Porto das Caixas (Ponto 4), onde os rejeitos alcançam até $5 \mathrm{~m}$, na Cerâmica São João Batista, Ponto 1, e no barreiro abandonado do Country Club, Ponto 2 (Figuras 6.30A, B e C, e Figura 6.29C). Nos Pontos 1 e 4 essas falhas são tanto sin-deposicionais, controlando solapamento de canais, como pósdeposicionais. Elas são cortadas pelas falhas de direção NW-SE, relativas à extensão NESW. Em todos esses casos as falhas geradas são compatíveis com uma EXTENSÃO Pura (Pure EXTENSION), onde o eixo principal de menor esforço, $\sigma 3$, se orienta na direção NW-SE a NNW-SSE, o eixo principal intermediário, $\sigma 2$, é ortogonal a ele, e o eixo principal de maior esforço, $\sigma 1$, é vertical. Localmente, em Itaboraí, pôde-se caracterizar juntas geradas pela extensão NW-SE (Figura 6.30D), constituindo um espectro de fraturas, no sentido de Hancock (1994), com juntas de extensão, juntas híbridas de cisalhamento e fraturas conjugadas de cisalhamento, orientadas segundo as direções NNE-SSW a ENEWSW. As fraturas conjugadas de cisalhamento não foram claramente identificadas em campo, mas apenas inferidas pela bissetriz aguda entre elas em torno de $60^{\circ}$ a $70^{\circ}$. Nesse sentido optou-se por considerá-las como geradas em um regime de extensão pura, com o $\sigma 1$ vertical, $\sigma 3$ na direção NW-SE e $\sigma 2$ horizontal, ortogonal a ele, segundo a direção NE-SW, compatível com a extensão NW-SE.

\subsubsection{Extensão NE-SW}

A extensão NE-SW gerou falhas normais de direção NW-SE a NNW-SSE, com mergulhos baixos a altos, localmente com rejeitos oblíquos (Figura 6.31). Em alguns casos as falhas de alto ângulo são antitéticas, associadas a falhas lístricas (Figura 6.20A). A inversão desses dados indicou que essas falhas foram geradas em um regime de EXTENSÃO Pura (Pure EXTENSION), com o eixo de tensão principal mínimo, $\sigma 3$, 

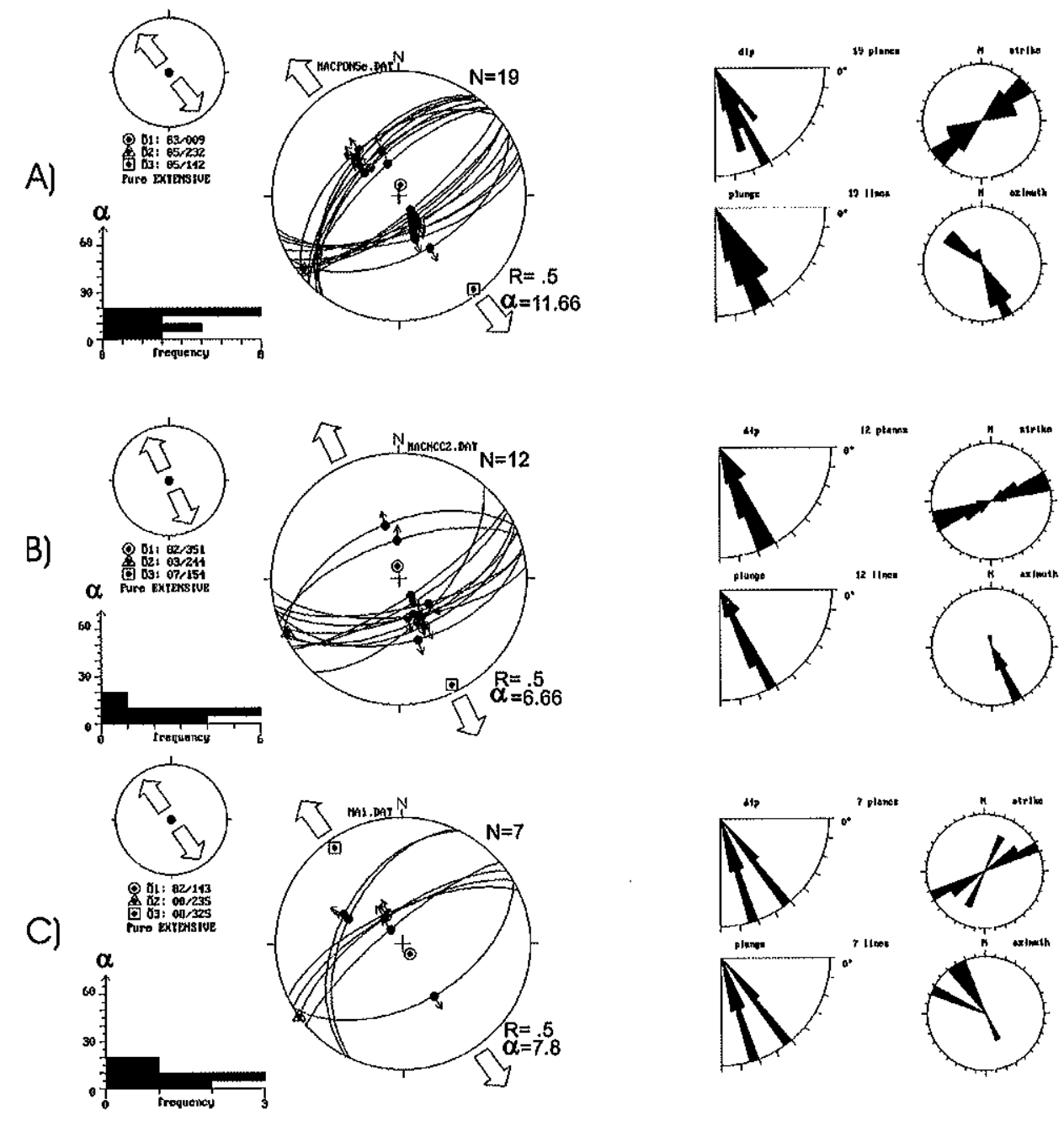

D)
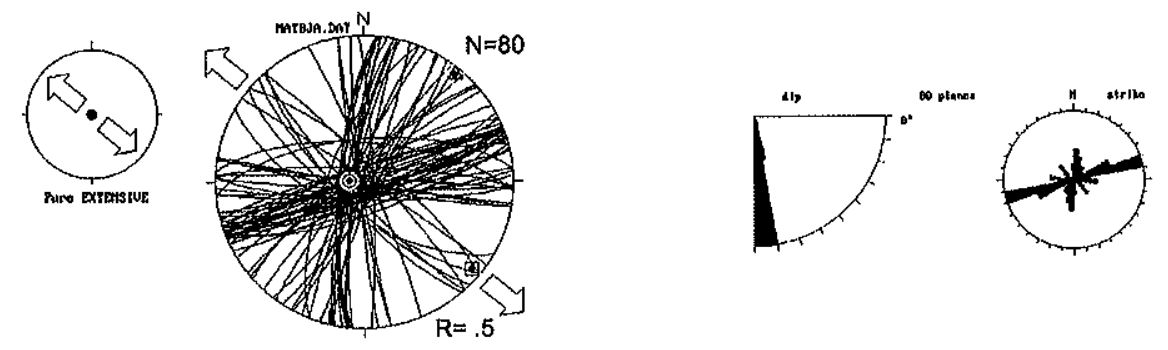

Figura 6.30 - Falhas e fraturas (juntas) geradas pela extensão NW-SE, afetando a Formação Macacu. Símbolos: círculos $-\sigma_{1}$ (eixo de maior esforço), triângulos $-\sigma_{2}$ (eixo de esforço intermediário), quadrados $-\sigma_{3}$ (eixo de menor esforço); $R$ - razão de esforço $\left(\sigma_{2}-\sigma_{3} / \sigma_{1}-\sigma_{3}\right) ; \alpha$ - desvio médio entre as estrias medidas e o cisalhamento computado sobre o plano de falha. Setas grandes cheias - eixos compressivos horizontais, setas grandes vazias - eixos distensivos horizontais. Bola preta - estria, seta pequena - sentido de movimento dos blocos. A) Distrito de Porto das Caixas, Itaboraí, Ponto 4; B) Country Club, Itaboraí, Ponto 2; C) Bairro Calundu, Itaboraí, Ponto 6; D) Itaboraí, Ponto 1. Projeções de Schmidt-Lambert, hemisfério inferior. Diagramas de rosetas com direção e mergulho dos planos, e caimento e azimute das estrias. 

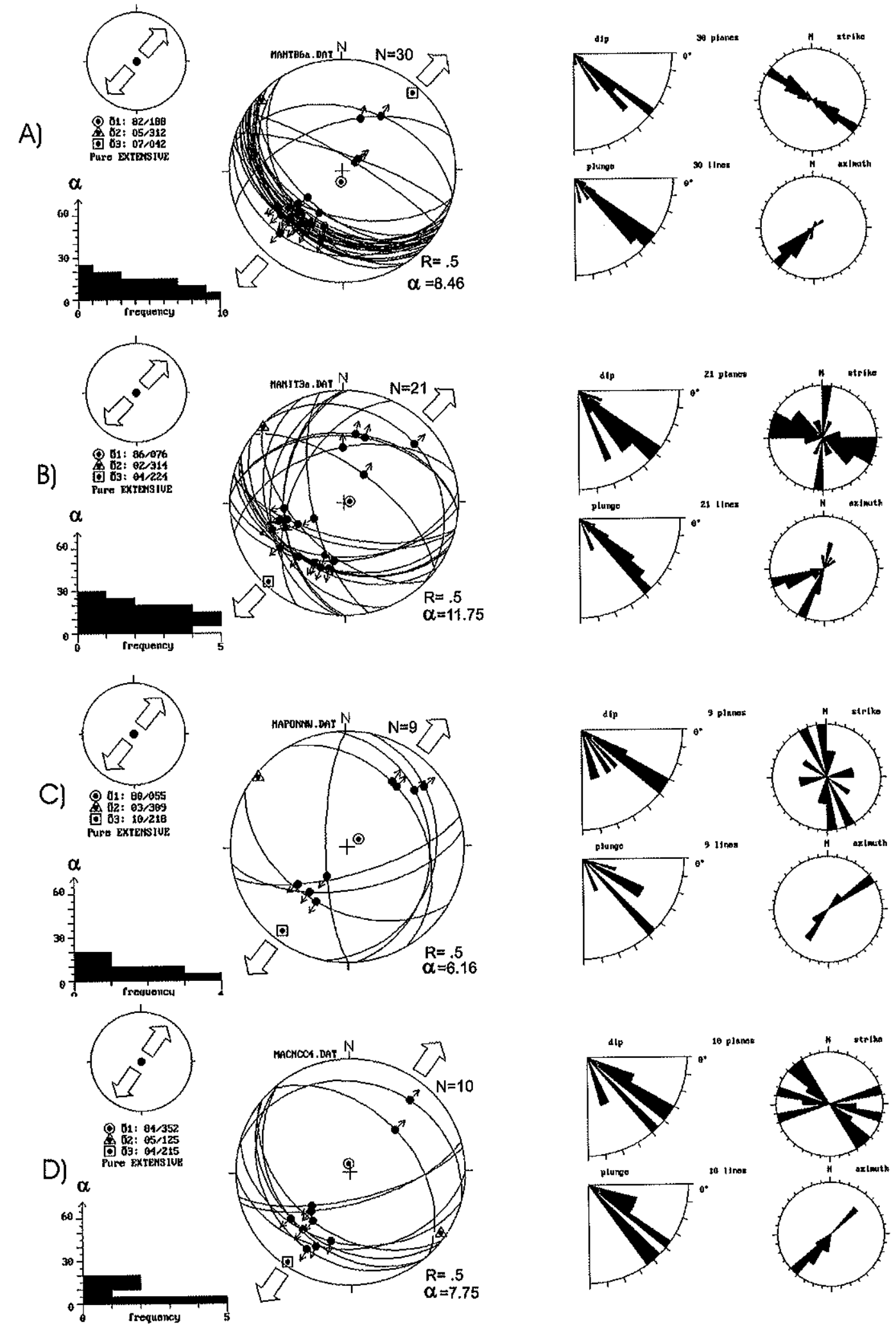

Figura 6.31 - Falhas geradas ou reativadas pela extensão NE-SW, afetando a Formação Macacu. Símbolos: círculos $-\sigma 1$ (eixo de maior esforço), triângulos $-\sigma_{2}$ (eixo de esforço intermediário), quadrados $-\sigma 3$ (eixo de menor esforço); $\mathrm{R}$ - razão de esforço $(\sigma 2-\sigma 3 / \sigma 1-\sigma 3) ; \alpha$ - desvio médio entre as estrias medidas e o cisalhamento computado sobre o plano de falha. Setas grandes cheias - eixos compressivos horizontais, setas grandes vazias - eixos distensivos horizontais. Bola preta - estria, seta pequena - sentido de movimento dos blocos. A) Itaboraí, Ponto 1; B) Bairro de Itambí, Ponto 12; C) Distrito de Porto das Caixas, Ponto 4 e D) Country Club, Ponto 2. Projeçôes de Schmidt-Lambert, hemisfério inferior. Diagramas de rosetas com direreção e mergulho dos planos, e caimento e azimute das estrias. 
horizontal, orientado na direção NE-SW, o eixo de tensão principal intermediário, $\sigma 2$, ortogonal a ele, e o eixo tensão principal máximo, $\sigma 1$, vertical.

\subsubsection{Extensão E-W a WNW-ESE}

A extensão E-W a WNW-ESSE gerou falhas de direção N-S a NNE-SSW, com mergulhos intermediários a altos, por vezes com rejeito oblíquo (Figura 6.32). São muito bem desenvolvidas em Magé (Ponto 26) e na Ilha do Governador (Ponto 24), sendo que no primeiro caso mostram rejeito de mais de 5 metros. A inversão dos dados indicou que essas falhas foram geradas por uma EXTENSÃO Pura (Pure EXTENSION), com o eixo de esforço principal mínimo, $\sigma 3$, orientado na direção E-W a WNW-ESSE, o eixo de esforço principal intermediário, $\sigma 2$, ortogonal a ele, na direção N-S a NNE-SSW, e o eixo de esforço principal máximo, $\sigma 1$, vertical.

Em alguns casos, falhas preexistentes foram reativadas por essa extensão, como as de direção ENE-WSW e rejeito oblíquo, em Itambi (Figura 6.32C).

\subsubsection{Síntese dos Eventos Geradores e Deformadores da Bacia do Macacu}

As paleotensões identificadas a partir das falhas e microfalhas que afetam os sedimentos da Formação Macacu estão sintetizados no mapa da Figura 6.33 (cf. Figuras $6.30,6.31$ e 6.32). Destaca-se o fato de que apenas estruturas extensionais foram identificadas. Somente no caso do espectro de fraturas sistemáticas do Ponto 1 (Figuras 6.30D e 6.33I) pode-se suspeitar de que o SHmax de direção NE-SW tivesse sido o eixo de tensão principal de maior magnitude, $\sigma 1$. Nesse caso, esse espectro de fraturas poderia ter sido gerado por um regime direcional extensional, ou híbrido na concepção de Hancock (1987, 1994), podendo, representar uma extensão oblíqua. Em todos os outros casos a inversão dos dados cinemáticos indicou a atuação de regimes puramente extensionais. 


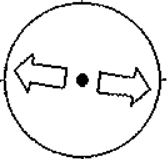

A)
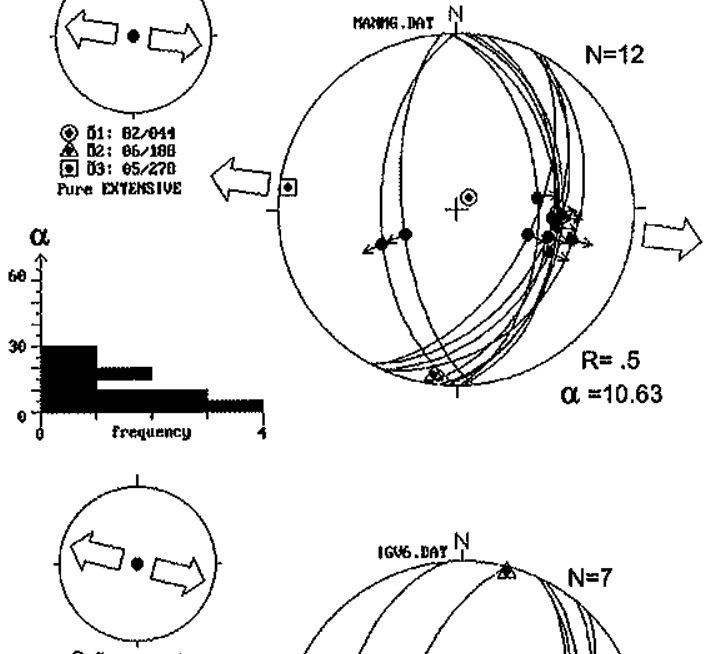

B)
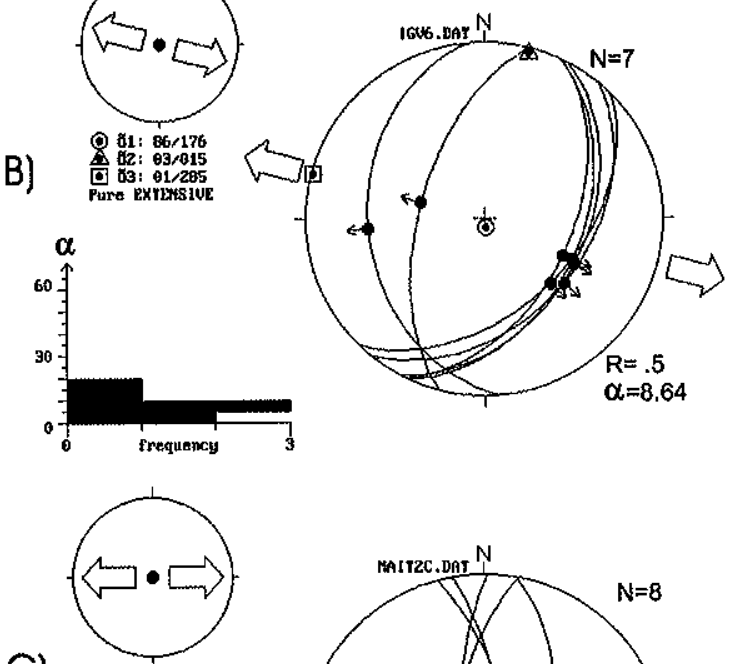

C)

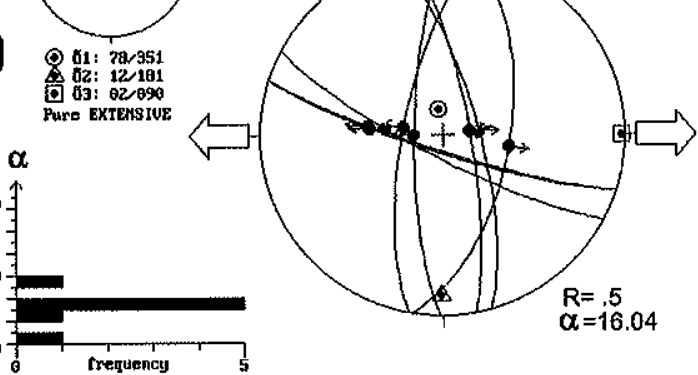

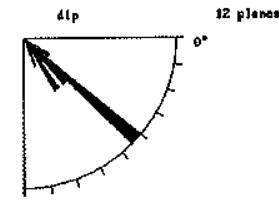
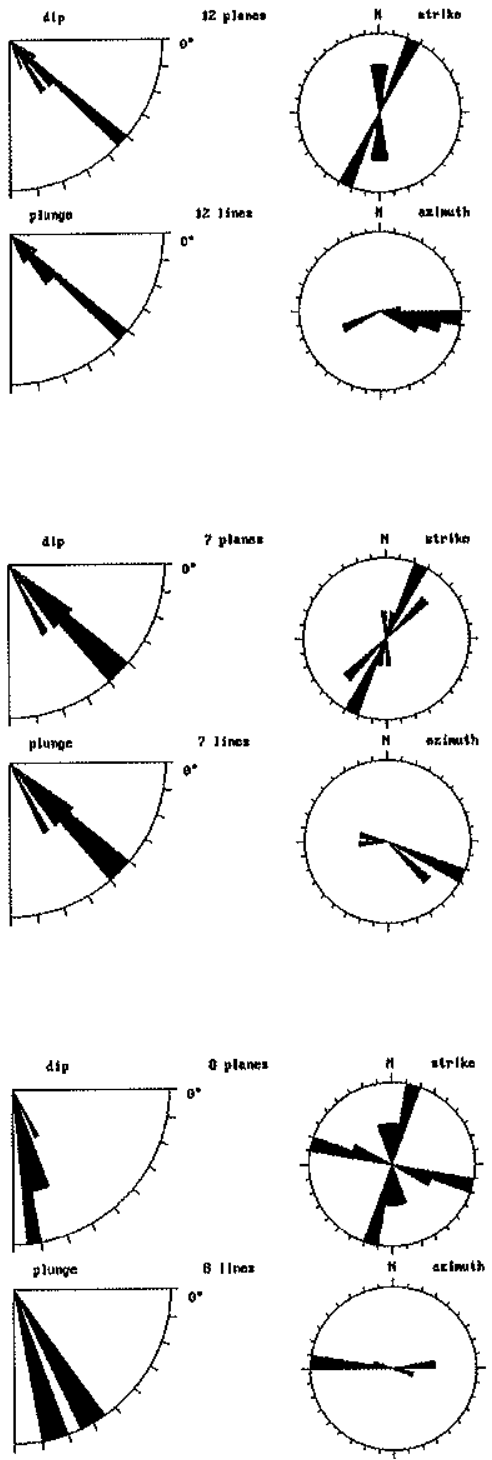

Figura 6.32 - Falhas geradas ou reativadas pela extensão E-W a WNW-ESE, afetando a Formação Macacu e colúvio. Símbolos: círculos - $\sigma 1$ (eixo de maior esforço), triângulos $-\sigma 2$ (eixo de esforço intermediário), quadrados - $\sigma_{3}$ (eixo de menor esforço); $\mathrm{R}$ - razão de esforço $\left(\sigma 2-\sigma_{3} / \sigma_{1}-\sigma_{3}\right) ; \alpha-$ desvio médio entre as estrias medidas e o cisalhamento computado sobre o plano de falha. Setas grandes cheias - eixos compressivos horizontais, setas grandes vazias - eixos distensivos horizontais. Bola preta estria, seta pequena - sentido de movimento dos blocos. A) Magé, Ponto 26; B) Ilha do Governador, Ponto 24; C) Bairro de Itambí, Ponto 12. Projeções de Schmidt-Lambert, hemisfério inferior. Diagramas de rosetas com direção e mergulho dos planos, e caimento e azimute das estrias. 


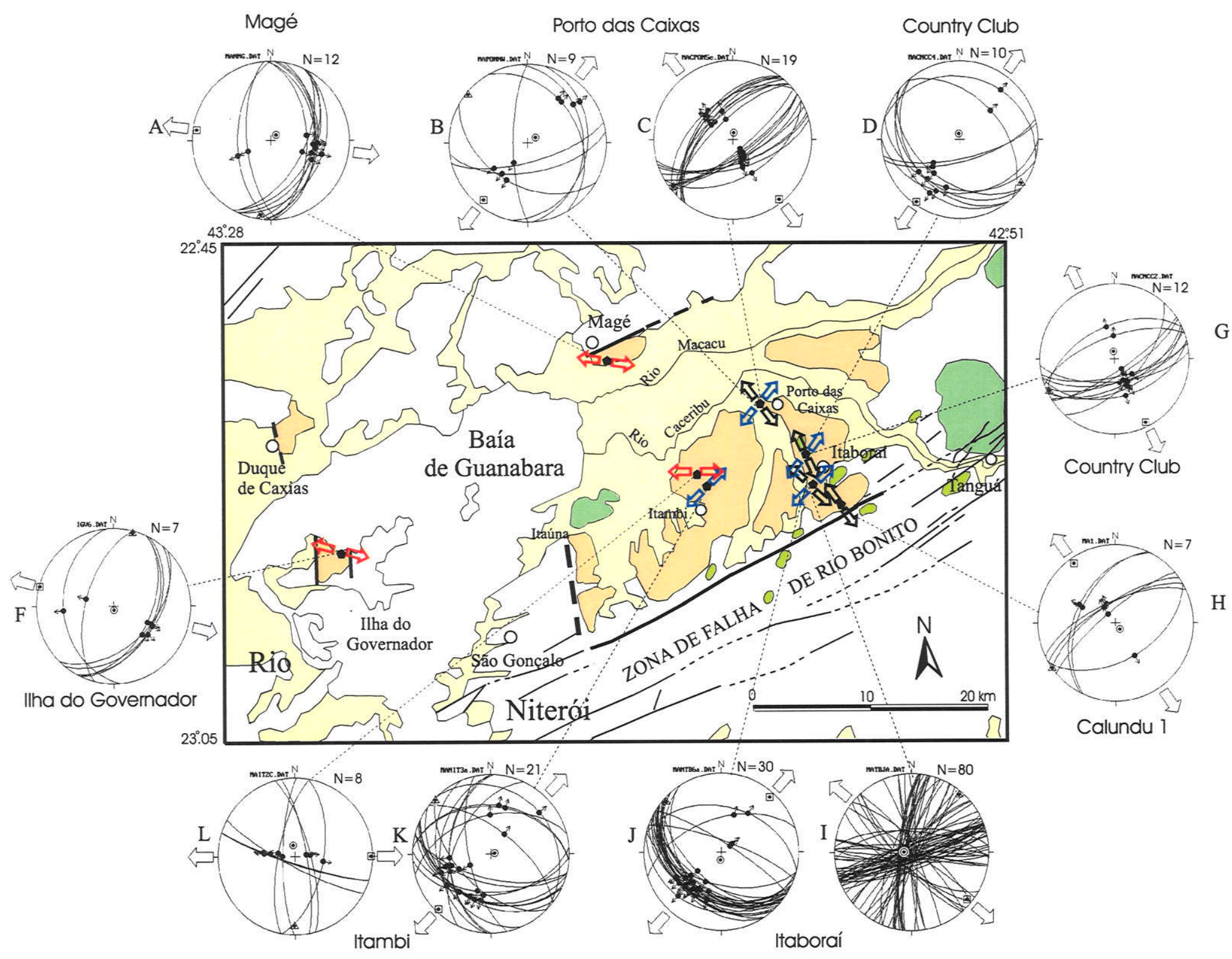

Figura 6.33 - Mapa das paleotensões caracterizadas nos sedimentos da Bacia do Macacu e nas ocorrências isoladas da Formação Macacu, a partir de microfalhas, falhas e, subordinadamente, juntas (I). Símbolos: círculos - $\sigma 1$ (eixo de tensão máxima), triângulos - $\sigma 2$ (eixo de tensão intermediária), quadrados - $\sigma 3$ (eixo de tensão mínima); Setas grandes cheias - eixos compressivos horizontais, setas grandes vazias - eixos distensivos horizontais. Bolas pretas - estrias, setas pequenas - sentido do movimento dos blocos. Projeções de Schmidt-Lambert, hemisfério inferior. 
As falhas de direção N-S, associadas à extensão E-W, constituem verdadeiras zonas de falha em Magé e na Ilha do Governador (Figuras 6.30A e F). A coincidência entre a posição e orientação do limite oeste da Bacia do Macacu, no primeiro caso, e dos limites da área de ocorrência isolada da Formação Macacu, no segundo caso, ambos com orientação aproximadamente N-S, indica uma provável relação causal com os falhamentos de direção N-S. Dessa forma, a fase de extensão E-W teria sido responsável não apenas pela determinação de parte dos limites atuais da bacia, mas também pela sua segmentação, dando origem às áreas isoladas de ocorrência da Formação Macacu, na Ilha do Governador e em Duque de Caxias.

Na borda sudeste da bacia, no Ponto 7, a identificação de um adernamento de até $7^{\circ}$ para SSE de camadas de lamito argiloso, depositado por decantação, na horizontal, indica atividade tectônica pós-deposicional na borda da bacia.

Ainda no Ponto 7, foram identificadas apenas falhas de direção NW-SE. (Figura 6.23A), em parte, possivelmente, devido ao corte paralelo à borda da bacia. Apesar de não terem sido caracterizados planos estriados, que permitissem a determinação do campo de tensões responsável pela geração dessas falhas, pode-se verificar que as mesmas têm uma componente normal importante, como pode ser deduzido por critérios estratigráficos. Por outro lado, a presença de componentes de rejeito vertical distinto de camadas com mesma atitude, ao longo da mesma falha, como pode ser visto na falha à direita da Figura 6.23A, sugere que elas podem ter tido uma componente direcional. Essa característica reforça a possibilidade do evento de extensão NE-SW ter sido gerado por em um regime direcional, por um eixo de tensões máximo $(\sigma 1)$ horizontal, de direção NW-SE, porém com uma componente extensional importante.

\subsubsection{Idade dos eventos de extensão}

A cronologia relativa entre os três grupos de falhas, na qual as falhas de direção NESW são secionadas pelas de direção NW-SE, e as de direção em torno de N-S afetam colúvio, indica que a Extensão NW-SE é a mais antiga, e que a Extensão E-W a WNWESE é a mais nova. 
Das três, apenas duas permitem uma boa datação por critérios estratigráficos:

- a fase de extensão mais antiga, de direção NW-SE, que apresenta estruturas sinsedimentares, evidenciando sua contemporaneidade com os depósitos da Formação Macacu, de idade eocênica a oligocênica (Lima et al. 1996). A Extensão NW-SE, por sua ortogonalidade ao eixo maior da Bacia do Macacu, pode ser inferida como provável responsável pela implantação da bacia. Esse mesmo tipo de inferência foi feito anteriormente por Riccomini (1989), que considerou-a responsável pela formação das bacias dos segmentos central e meridional do RCSB;

- a Extensão E-W a WNW-ESSE, uma vez que falhas geradas por ela afetam sedimentos já laterizados, colocando lado a lado sedimentos vermelhos alterados e sedimentos totalmente brancos sãos, e colúvio, deslocando linhas de seixos. As linhas de seixos marcam, regionalmente, o limite Pleistoceno-Holoceno (Riccomini et al. 1989, Salvador \& Riccomini 1995, Carmo 1996, Hiruma 1998), indicando uma idade holocênica para essa extensão.

Essas idades são compatíveis com as das extensões NW-SE e E-W reconhecidas regionalmente por Riccomini (1989), Riccomini et al. (1989), Salvador \& Riccomini (1995), Melo (1997) e Silva \& Ferrari (1997b).

A Extensão NE-SW, de posição estratigráfica relativa intermediária, é apenas deformadora dos sedimentos e pode ser correlacionada ao binário $\mathrm{E}-\mathrm{W}$ dextral reconhecido regionalmente por Riccomini (1989), Riccomini et al. (1989), Salvador \& Riccomini (1995) e Melo (1997), e tido como de idade pleistocênica.

\subsubsection{Modelo Tectono-Sedimentar}

As características dos depósitos sedimentares descritos na Formação Macacu indicam que as suas três áreas de ocorrência constituíam uma única bacia, tectonicamente segmentada. As fácies sedimentares descritas foram agrupadas em 3 associações de fácies sedimentares, cujas características composicionais, estruturais, e de distribuição geográfica, estão sintetizadas nos perfis colunares apresentados na Figura 6.19, a saber:

- Associação A $\rightarrow$ lacustre 
- Associação B $\rightarrow$ leques aluviais

- Associação C $\rightarrow$ canal fluvial entrelaçado com afogamentos episódicos

A distribuição geográfica das associações de fácies se caracteriza pela presença das fácies proximais do sistema de leques, representadas pela Associação B, na borda sudeste da bacia, especialmente nas proximidades da Cidade de Itaboraí. Nessa borda ocorrem os únicos conglomerados polimíticos identificados na bacia. A Associação B pode ocorrer, localmente, em porções internas da bacia, como em Itambi e Porto das Caixas, onde é representada por lamitos seixosos maciços. Na borda noroeste da bacia, ela está ausente da área de ocorrência isolada da Formação Macacu, em Duque de Caxias e, em Magé, limitase aos lamitos arenosos, interpretados como fan deltas, estando ausentes os depósitos de rudáceos caracteristicamente proximais.

A Associação A ocorre na porção sudeste da bacia, na base do pacote sedimentar exposto, onde é coberta pelas associações B e C, como na porção central da bacia, em Porto das Caixas e em Itambi. Ela não ocorre nas áreas isoladas de Duque de Caxias e da Ilha do Governador, ou mesmo em Magé. Os dados de sondagens profundas para poços artesianos (Figura 6.23), permitem que se extrapole essa assinatura da sedimentação na borda sudeste, até 100 metros de profundidade, tendo em vista os perfís dos poços 2 a 5 , localizados em Manilha, nos quais alguns dos horizontes lamosos têm mais de 10 metros de espessura e, em alguns casos, contêm restos vegetais. $\mathrm{O}$ avanço dos depósitos de leques sobre os sedimentos lacustres, nas proximidades dessa borda, indica uma mobilidade dos locais de acumulação de sedimentos finos e grossos na bacia.

A Associação $\mathrm{C}$ tem a mais ampla distribuição na bacia, predominando em toda a sua porção central e nas áreas de ocorrência isolada na Ilha do Governador, em Duque de Caxias, e mostrando ocorrência mais limitada em Magé. Em Duque de Caxias ela foi a única associação reconhecida. Os dados de paleocorrentes indicam um fluxo sub-paralelo às bordas sudeste e noroeste da bacia, porém em sentidos contrários, com sentido de fluxo para SW junto à borda sudeste e para ENE na borda NW.

Em bacias rift, particularmente nos hemi-grabens e nos grabens assimétricos, as "fácies finas", sejam associadas a lagos ou a planícies aluviais, se posicionam sobre o local de maior subsidência e próximo à borda de maior soerguimento (Leeder \& Gawthorpe 
1987, Blair 1987, Blair \& Bilodou 1988, Mack \& Seager 1990). Nessas bacias as fases de estabilidade tectônica implicam numa migração das fácies sedimentares grossas, de borda, representadas pelos leques aluviais, para dentro da bacia, em parte pela diminuição dos espaços gerados na bacia e, também, pela taxa mais lenta de desestabilização das encostas soerguidas, responsáveis pela geração dos leques aluviais (Leeder \& Gawthorpe 1987, Blair 1987, Blair \& Bilodou 1988, Mack \& Seager 1990). Dessa forma, o avanço dos leques sobre os depósitos lacustres indicam uma estabilização tectônica da borda sudeste da bacia. Por outro lado, a presença da associação de fácies fluvial junto à borda noroeste, indica atividade tectônica também nessa borda, contemporânea ou não à da borda sudeste. A alternância de direção de fluxo das paleocorrentes permite supor que a atividade tectônica foi diacrônica. A idade eocênica/oligocênica dos linhitos da borda sudeste indica que essa borda foi ativa desde a implantação da bacia, o que implica em que a implantação da drenagem axial a noroeste, com sentido de fluxo contrário à então vigente, deve ter se dado já no desenvolvimento da bacia.

Dessa forma, a distribuição das associações de fácies na bacia, em conjugação com os eventos de deformação identificados, em especial a extensão NW-SE, responsável pela geração da bacia e pela implantação das falhas de borda, a SE e NW, permitem o estabelecimento do modelo tectono-sedimentar para a Bacia do Macacu apresentado no bloco diagrama da Figura 6.34. Esse modelo advoga que a evolução tectono-sedimentar da Bacia do Macacu teria se dado em três fases principais, a saber:

I) Implantação da bacia, em reposta à extensão NW-SE, como um hemi-graben com borda ativa a SE. Nessa fase inicial teriam se depositado os sedimentos lacustres, junto à borda ativa, sobre o eixo de subsidência máxima da bacia. A ampliação da bacia leva à migração dos leques de borda, e do lago, para porções mais internas da bacia;

II) Preenchimento do lago e implantação de drenagem axial, de caráter entrelaçado, junto à borda SE, com sentido de fluxo para SW;

III) Migração da drenagem axial para a borda NW, que passa a ser a de maior subsidência, em resposta à maior ativação das falhas de borda a NW. Essa migração de depocentro 

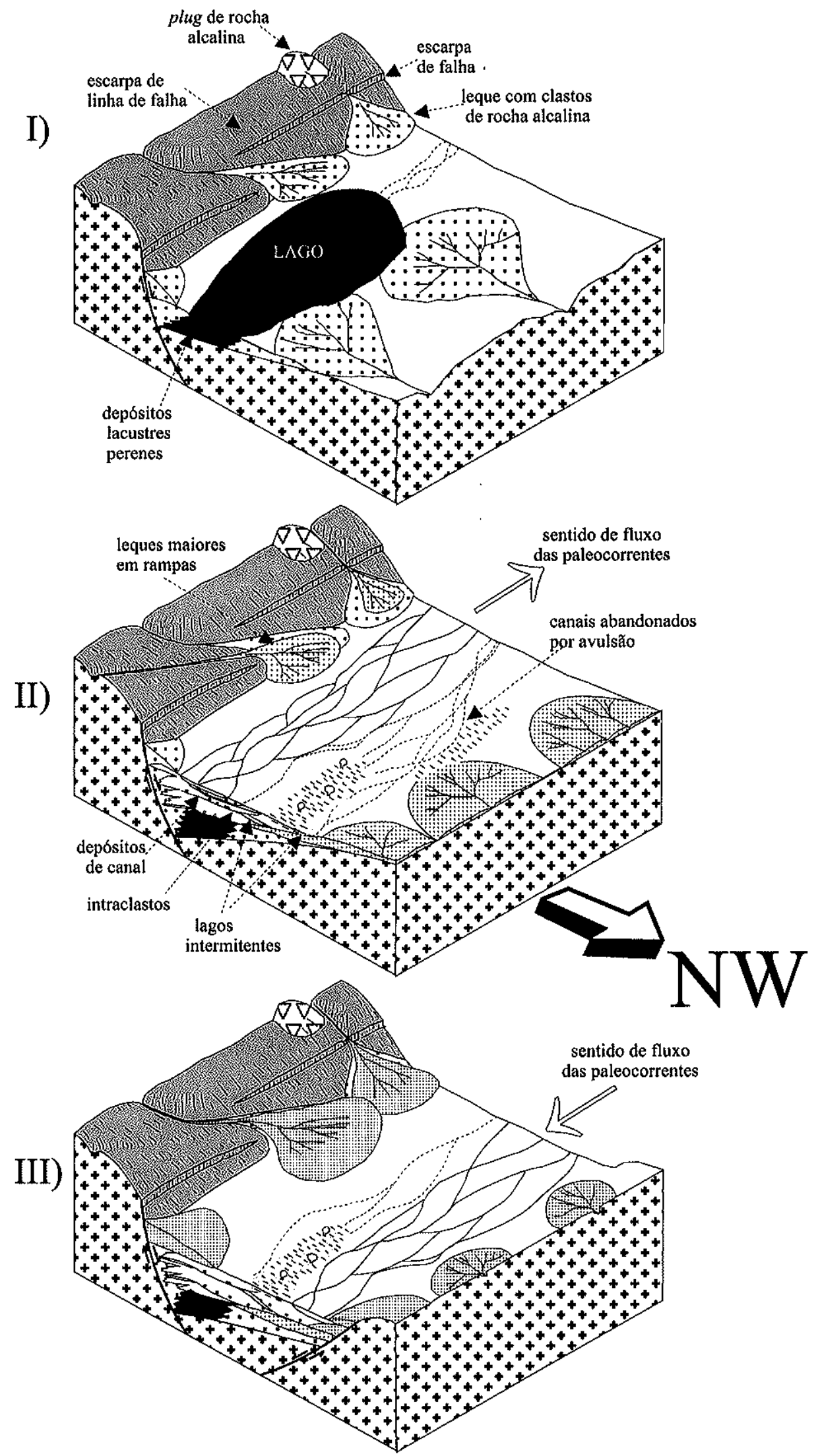

Figura 6.34 - Modelo tectono-sedimentar para a evolução da Bacia do Macacu. Sedimentação em graben assimétrico adaptada de Leeder \& Gawthorpe (1987), Blair (1987), Blair \& Bilodou (1988) e Mack \& Seager (1990). I) Implantação da bacia com borda ativa a sudeste. Deposição da associação lacustre sobre o eixo de subsidência máxima da bacia, II) Implantação de planície fluvial entrelaçada sobre eixo de subsidência máxima, com sentido de fluxo das paleodrenagens para SW, III) Migração da drenagem axial para a borda NW da bacia, acompanhada de inversão do sentido de fluxo das paleodrenagens de SW para NE. Para maiores detalhes ver o texto. 
caracteriza a bacia como um graben assimétrico, com borda ativa inicialmente a sudeste e, posteriormente, a noroeste.

Os efeitos da tectônica da bacia podem ser os responsáveis pelo caráter episódico das inundações e sua recorrência na sucessão associação C. Esse registro sugere um controle alocíclico na sedimentação, provavelmente induzido por pulsos tectônicos (Figura 6.35). Embora os eventos de avulsão de canal sejam comuns em rios entrelaçados intermitentes, eles podem ocorrer em decorrência de atividade tectônica (Miall 1982). Tal possibilidade é reforçada, no presente caso, pela sua amplitude, abrangendo extensas áreas da planície aluvial e pelo seu caráter brusco. Tais pulsos promoveriam subsidência localizada da planície entrelaçada, possivelmente controlada pelas estruturas transversias de direção NE-SW, causariam rápido afogamento das drenagens nas áreas mais subsidentes $\mathrm{e}$ avulsão de canais em outras. A estagnação de parte dos depósitos gerados nestas áreas afogadas é indicada pelos depósitos de lamitos de espessura métrica e pela bioturbação subaquosa (Taenidium) (Figura 6.35 - 6). A retomada dos canais, provavelmente em caráter essencialmente autocíclico, promoveu incisões mais profundas ou mais rasas, gerando conglomerados e brechas intraformacionais, condicionadas pelo maior ou menor grau de litificação dos lamitos sotopostos, os quais foram parcial a totalmente removidos. Nesse último caso eles são identificados apenas pela presença dos conglomerados e brechas intraformacionais preenchendo geometria de canal (Figura 6.35 - 4 e 5). Essa alternância de fatores alocíclicos e autocíclicos, dentro da sucessão estudada, representa provavelmente a assinatura tectônica na sedimentação desses depósitos eocênicos/oligocênicos.

Essas características contrastam com a ocorrência dos conglomerados quartzosos da fácies $C m p$, relacionados à nova unidade proposta nesse trabalho - o Conglomerado Itambi, com blocos de quartzo arredondados de até $30 \mathrm{~cm}$ de eixo maior, capeando em discordância erosiva a Formação Macacu, em Itambi e Porto das caixas, no interior da bacia. A ausência de argila, a composição e o arredondamento dos clastos, indicam a maturidade e o longo tempo de residência desses conglomerados (Folk 1974), podendo, inclusive, ser resultado de mais de um ciclo de transporte (Boogs 1995). Por outro lado, esses conglomerados indicam um avanço das fácies proximais para dentro da bacia, relacionado a uma diminuição no espaço de sedimentação, associada à redução da atividade tectônica nas falhas de borda da Bacia do Macacu. 


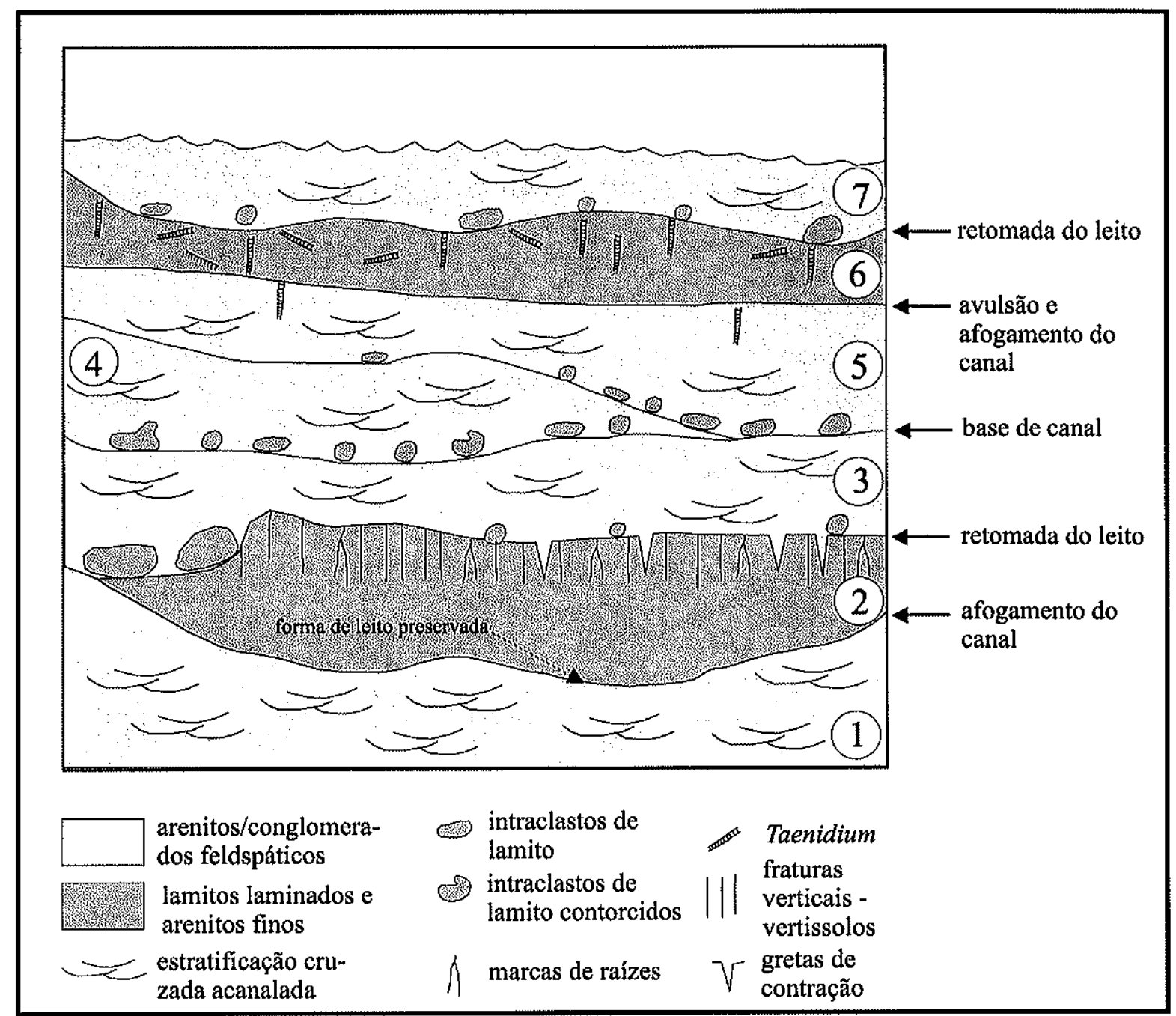

Figura 6.35 - Assinatura tectônica da sedimentação da associação de fácies de canal entrelaçado, da Formação Macacu. A alternância da deposição de arenitos/conglomerados feldspáticos, em planície entrelaçada $(1,3,4,5$ e 7), com inundação brusca dos canais em caráter não erosivo, e deposição de lamitos laminados e arenitos finos, preservando as formas de preenchimento dos canais $(2 \mathrm{e} 6)$. O caráter episódico e sua recorrência podem indicam um controle alocíclico, provavelmente induzido por pulsos tectônicos. Esses pulsos causariam afogamento e avulsão em locais distintos da bacia. A variação no período de recorrência do processo autocíclico, com retomada dos canais, refletiu-se nos intraclastosmais ou menos litificados. A maior intensidade do pulso tectônico e/ou clima úmido propiciaram a perenidade dos lagos gerados, evidenciada por bioturbação (Taenidium) (6). Pulsos menos intensos e/ou clima seco são evidenciados por pedogênese, com formação de vertissolos e gretas de contração(2). Nesse caso a retomada dos canais gerou incisões mais profundas, com a formação de megaclastos por desmoronamento de borda de canal (3). Localmente os lamitos sotopostos foram totalmente erodidos, restando apenas os intraclastos na base dos canais. Modelo de afogamento de planície entrelaçada adaptado de Browne \& Plint (1994). 


\subsubsection{Discussão}

\subsubsection{Planícies de Inundação em Sistemas Fluviais Entrelaçados}

A freqüência de sedimentos pelíticos na Associação de Fácies $\mathrm{C}$ é relativamente alta com relação aos depósitos arenosos de canal, se comparada com os exemplos de sistemas fluviais entrelaçados modernos mais referenciados, onde a ausência dos finos dever-se-ia à alta instabilidade do cinturão de canais entrelaçados (cf. Miall 1978 e Cant \& Walker 1978). Tal instabilidade causaria uma pronta erosão dos finos, levando a um completo retrabalhamento da planície entrelaçada num período máximo de até 250 anos (Reinfelds \& Nanson 1993). Por outro lado, em estudos mais recentes, de sucessões fluviais entrelaçadas antigas, têm sido reportados volumes expressivos de sedimentos finos (cf. Shuster \& Steidtmann 1987, Mack \& Seager 1990, Bentham et al. 1993, Dreyer et. al. 1993, Browne \& Plint 1994). Em todos esses casos os sedimentos finos foram tidos como gerados em planícies de inundação bem desenvolvidas, a partir de processos dominantemente autocíclicos mas, também, alocíclicos, de caráter tectônico (Shuster \& Steidtmann 1987, Browne \& Plint 1994), e sua preservação estaria associada, invariavelmente, a fases de altas taxas de subsidência das bacias. No caso da Formação Macacu os depósitos de inundações, foram consideradas rápidos afogamentos da planície fluvial entrelaçada, gerados por eventos alocíclicos desencadeados por tectonismo. A completa remoção dos sedimentos finos, em alguns locais, pela retomada do cinturão entrelaçado, indica que a taxa subsidência da bacia foi de intensidade intermediária, não chegando a isolar as lentes arenosas em meio aos pelitos, como descrito por Shuster \& Steidtmann (1987).

Eventos de inundação da planície fluvial entrelaçada foram interpretados por Ramos (1997) na Formação Resende, unidade cronocorrelata à Formação Macacu e que ocorre na bacia homônima (Amador 1975, Riccomini 1989). Essas inundações foram denominadas por Ramos (1997) "fácies de inundação", geradoras de "lagos muito rasos", que estariam relacionadas a períodos de quiescência tectônica. $O$ mesmo tipo de relação foi feita por ele para a sua "fácies lacustre", a qual teria se acumulado em um lago mais amplo. Também Riccomini (1989) relacionou o acúmulo da associação de fácies sedimentares lacustre da 
Bacia de Taubaté, a Formação Tremembé, a quiescência tectônica. Esse raciocínio é o oposto do desenvolvido no presente trabalho, segundo o qual os afogamentos, formadores de lagos efêmeros sobre a planície fluvial entrelaçada, e a geração do próprio lago perene, são considerados resposta a pulsos tectônicos, responsáveis por subsidência mais acentuada junto à borda ativa da bacia e, provavelmente, às estruturas transversais. $\mathrm{O}$ modelo de correlação entre tectônica e sedimentação adotado no presente trabalho é contrário à intuição geológica e ao paradigma vigente, segundo os quais tectonismo é relacionado com deposição imediata de sedimentos grossos e quiescência tectônica com a acumulação de finos e está de acordo com o proposto por Leeder \& Gawthorpe (1987), Blair (1987), Blair \& Bilodou (1988), Mack \& Seager (1990) e Browne \& Plint (1994), para grabens assimétricos e bacias pull-apart. Nesse sentido, uma associação entre eventos tectônicos e a geração do lago Tremembé foi proposta por Almeida (1976), Melo et al. (1985), Hasui \& Ponçano (1978) e Hasui et al. (1978), a partir de barramento tectônico, no primeiro e segundo casos, e por subsidência tectônica acentuada, no terceiro e quarto.

Por outro lado, além de Ramos (1997), outros autores que têm trabalhado nos últimos anos com os depósitos fluviais entrelaçados da Formação Resende (Riccomini et al. 1987, Riccomini 1989) têm proposto a atuação de processos alocíclicos para explicar os depósitos decantados sobre a planície aluvial. Nesse sentido, todos são unânimes em relacioná-los a eventos de sedimentação episódica associados a inundações - inunditos. Para Riccomini et al. (1987) e Riccomini (1989) esses inunditos incluiriam os arenitos com estratificação cruzada e os lamitos e, para Ramos (1997) eles seriam restritos aos lamitos decantados. No primeiro caso, a presença de estratificação cruzada exige fluxos canalizados (Blair \& McPherson 1984a), ausentes nos inunditos (Seilacher 1982, Della Fávera 1984). Deve-se lembrar ainda, de acordo com esses últimos autores, que os inunditos exigem um meio aquoso de acumulação, no que se assemelham ao modelo de afogamentos episódicos da planície aluvial ora proposto.

\subsubsection{Controle Tectônico x Controle Climático da Sedimentação}

A Bacia do Macacu, tanto em superfície como em sub-superfície, apresenta alternância de fases com alta taxa de sedimentação, representadas pelos leques e pelos 
arenitos feldspáticos dos depósitos de canais entrelaçados, com fases menos intensas de sedimentação, representada pelos depósitos lacustres perenes, ou mesmo pelos afogamentos efêmeros, oriundos do afogamento da planície aluvial. Essa alternância é considerada, nesse trabalho, como desencadeada por eventos tectônicos. Por outro lado, a maior ou menor persistência desses "lagos" tectônicos dependeu, em grande parte, de fatores climáticos, uma vez que em climas úmidos o aporte de material no lago deve ter sido bem menor do que nas fases mais áridas, conforme modelo de Plint \& Browne (1994) para a Formação Boss Point, da Bacia Cumberland, no Canadá. Nesse sentido, estimativas de taxas de erosão indicam que áreas sem cobertura vegetal fornecem um volume de sedimentos cerca de 200 vezes maior do que as áreas florestadas (Selby 1994).

$\mathrm{Na}$ Bacia do Macacu, a ocorrência nos sedimentos lacustres de restos vegetais e de linhito, indicam que eles se acumularam essencialmente em clima úmido. A ocorrência de concreções de gibsita, em níveis isolados nos depósitos de planície de inundação, reforça essa inferência, indicando, ainda, a ocorrência de vegetação abundante (Retallack 1990). A análise de palinomorfos dos níveis de linhito, com variado conteúdo de esporos e de coníferas, também corrobora essas indicações climáticas (Lima et al. 1996). Indicações semelhantes foram obtidas a partir de palinomorfos, de níveis de linhito e de folhelho carbonoso, nas bacias de Resende (Lima \& Amador 1985) e do Graben de Casa de Pedra (Lima et al. 1994), respectivamente. Em ambos os casos foram obtidas idades eocênicas. No caso da Bacia de Resende, Lima \& Amador (1985) referem-se a um clima "tropical a subtropical, com leve tendência a árido". Outra indicação se refere ao volume relativamente pequeno de areia encontrado nos depósitos da Associação A, sugerindo uma baixa disponibilidade de sedimentos, provavelmente controlada por clima úmido com vegetação abundante nas encostas.

A ocorrência de carbonato de cálcio no meio dos sedimentos lamosos, em subsuperfície, indica que houve períodos mais secos durante a sedimentação. $\mathrm{Na}$ Bacia de Taubaté, a associação de fácies lacustre - Formação Tremembé, também apresenta níveis carbonáticos, os quais são, porém, dolomíticos (Riccomini 1989, Riccomini et al. 1996), interpretados como depósitos do tipo playa lake, gerados em épocas de maior aridez (Riccomini 1989, Riccomini et al. 1996). Na referida bacia, o carbonato de cálcio ocorre apenas na forma de calcretes, nos lamitos da Formação Resende (Riccomini et al. 1987, 
Riccomini 1989, Riccomini et al. 1996). Ainda na Bacia de Taubaté, o estudo do conteúdo polínico de 12 níveis de folhelhos papiráceos a sub-pirobetuminos da Formação Tremembé, em testemunhos de sondagem, recuperados de até 200 metros de profundidade, forneceram idade oligocênica e indicaram clima frio e seco.

O conteúdo feldspático das associações $\mathrm{C}$ e B pode ser gerado em clima seco, ou em clima úmido numa bacia com acentuados relevo tectônico nas suas bordas e declividade do seu substrato (Boogs 1995). A predominância, na Associação B, de sedimento oriundos de fluxos de detritos e corridas de lama, que constituem cerca de $80 \%$ do seu volume, indica que os leques aluviais foram, na sua maior parte, secos (Nilsen 1982, Reading 1996) mas, principalmente, que eles se desenvolveram a partir de materiais ricos em argila (Blair \& McPherson 1994a e b, Leeder 1995). Por outro lado, o maior volume localizado de depósitos de leques úmidos, gerados por fluxos em lençol (sheetflow), como no Ponto 7 (Figura 6.23), pode estar relacionado, com a maior amplitude das áreas de captação desses leques, quando comparadas com as dos leques secos (Zarza et al. 1993). Segundo esses autores, em clima semi-árido, leques com pequenas área de captação, por exemplo junto às escarpas de falhas, tendem a ser secos, enquanto que aqueles com grandes áreas de captação serão dominantemente úmidos. Nesse sentido, pode-se supor que rampas e zonas de transferência propiciem o desenvolvimento de áreas de captação maiores.

A presença de vegetação nas encostas, mais abundante em climas temperados e úmidos, além de aumentar sua resistência aos movimentos de gravidade e à erosão por escoamento superficial, age como um catalisador na meteorização química e, consequentemente, na geração de minerais de argila. Dessa forma, a presença de vegetação tem efeitos antagônicos, já que amplia a geração de regolito, produzindo desestabilização das encostas a longo prazo e maior disponibilização de material para transporte nas bacias de drenagens dos leques (Blair \& McPherson 1994b). Esses regolitos, tendo em vista seu alto conteúdo de argila, tenderão a gerar fluxos de detritos/corridas de lama, mesmo em clima úmido (Blair \& McPherson 1994b).

A sismicidade que costuma acompanhar o desenvolvimento de bacias rift, tem como um dos seus papeis principais acelerar a ampliação das bacias de drenagem dos leques, por intermédio da fragmentação do material da área fonte (queda de blocos, escorregamentos) e 
pelo fraturamento, facilitador da meteorização química através da multiplicação de condutos para percolação de água (Keefer 1984, Blair \& McPherson 1994a).

A ampla predominância de argilas esmectíticas nos depósitos de leques aluviais das demais bacias do RCSB, à semelhança da Bacia do Macacu, favorece a inferência de um clima mais seco, como determinado por Riccomini (1989), Riccomini et al. (1996) e Sant'Anna (1999) para a Formação Resende, nas bacias de Resende, Taubaté e São Paulo. A presença local de níveis lamosos, da fácies $\mathbf{L l} \boldsymbol{l}$, endurecidos e com gretas, podendo caracterizar vertissolos, indicam sazonalidade associada a clima semi-árido (Marriot \& Wrigth 1993).

Dessa forma, pode-se inferir que as condições climáticas vigentes durante a deposição da Formação Macacu, correspondem à alternância de períodos mais úmidos e mais secos, nos quais teriam sido favorecidos a deposição da Associação A, em um período dominantemente úmido, e $\mathrm{B}$ e $\mathrm{C}$, em períodos mais secos com fases úmidas (sazonalidade). Inferência semelhante foi feita por Sant'Anna \& Valarelli (1996), com base nas argilas neoformadas da Formação Resende. A predominância de fluxos de detritos/corridas de lama, nos leques aluviais, indica a intensa geração de argila nas áreas fontes desses depósitos, sugerindo a vigência de climas temperados a, no máximo, semi-áridos. Por outro lado, a intensidade e a taxa de recorrência dos pulsos tectônicos parece ter sido um fator importante para a perenidade do lago, coincidindo com a fase de implantação e evolução inicial da bacia. Os pulsos mais intensos e/ou com alta taxa de recorrência, favoreceriam a persistência do lago, inclusive em climas secos, a partir do maior espaço de acomodação gerado (bacia faminta). Os lagos/inundações gerados em pulsos menos intensos e/ou de baixa taxa de recorrência, seriam mais persistentes em fases mais úmidas.

\subsubsection{Deformação da Bacia do Macacu}

A deformação pós-sedimentar verificada na bacia ocasionou tanto a sua segmentação, como afetou a distribuição e preservação dos depósitos.

Com relação às margens deposicionais da bacia, as fácies proximais não estão presentes na borda NW. Essa característica é destoante do esperado para bacias do tipo rift, 
sejam grabens ou grabens assimétricos. Mesmo em hemi-grabens é comum a presença dos leques também do lado em que seu substrato constitui uma rampa mais suave (Leeder \& Gawthorpe 1987). No caso dos grabens simétricos, as planícies aluviais axiais tendem a desenvolver uma ampla planície de inundação, mesmo no caso das planícies fluviais entrelaçadas, limitando os leques às porções proximais em ambos os lados (Mack \& Seager 1990). Essa ausência dos depósitos de leques aluviais na borda NW, é ainda mais marcante se compararmos o desnível topográfico de até 2000 metros, entre a Serra dos Órgãos, com seus contrafortes hoje situados a uma distância de pouco mais de $10 \mathrm{~km}$ ao norte da borda NW da bacia (Figura 6.13), e o observado, hoje ao sul, que atinge umas poucas centenas de metros, na Serra do Cassorotiba, localizada junto à Bacia de São José do Itaboraí, também situada a cerca de $10 \mathrm{~km}$ da borda SE da bacia. Se considerarmos o provável recuo sofrido pela escarpa da Serra dos Órgãos após a implantação da Bacia do Macacu (Azevedo Júnior 1991; Cabral Júnior 1993), tal característica é ainda mais destoante. Nesse sentido, tais características permitem que se formule duas hipóteses:

1) Os sedimentos proximais foram depositados na borda norte e posteriormente erodidos,

2) Os sedimentos proximais não foram depositados na borda norte, e o relevo hoje observado é neogênico, mais novo que a deposição da Formação Macacu.

A hipótese 1 é suportada pela presença dos lamitos arenosos em Magé, iterpretados como fan deltas, os quis constituiriam os produtos distais dos leques da borda NW. Além disso, a nível regional, deve-se considerar as evidências da existência de uma grande área soerguida junto à Bacia de Santos, desde o Turoniano, cuja erosão foi responsável por uma intensa progradação de terrígenos, e que culminou com uma ampla plataforma continental exposta, no Paleoceno Superior e Eoceno Inferior (Pereira et al. 1986, Ferrari et al. 1991, Almeida \& Carneiro 1998, Macedo \& Gamboa 1998). As idades paleocênicas, obtidas por traço de fissão em apatitas, no Maciço da Tijuca (Netto et al. 2000), indicam que um pacote de cerca de $3 \mathrm{~km}$ foi erodido aí, desde o Paleógeno. Inferências de taxas de erosão semelhantes foram feitas por Ferrari (1990) a partir das características mineralógicas e 
texturais dos corpos alcalinos do Rio de Janeiro. Nesse sentido, o Oligoceno Inferior é citado como uma época de intensa erosão nas demais bacias do RCSB (Melo et al. 1985).

Deve-se ressaltar, ainda, a idade pleistocênica dos depósitos proximais associados ao acentuado relevo da Serra dos Órgãos, ao norte da Baía de Guanabara. Esses depósitos, incluídos por Amador $(1980,1997)$ na Formação Caceribu, são descritos como "pequenos cones (aluviais) no sopé da encosta", que teriam sido "depositados próximo às zonas de ruptura de declive dos principais rios serranos" e que transicionam lateralmente para depósitos colúvio-aluviais e aluviais. Os sedimentos da Formação Caceribu ocorrem preenchendo paleovales, que teriam sido esculpidos durante o nível de mar mais baixo da última glaciação e colmatados ainda no final dessa glaciação, no Pleistoceno terminal (Amador 1997). Chama-se atenção, também, para a inexistência de depósitos relativos ao último interglacial, como os encontrados na região de Pariquera-Açu, depositados em um nível de mar 8 a 10 metros acima do atual (Amador 1997). Essas características indicam que a região de baixada do Graben da Guanabara possuiu uma tendência dominantemente ascensional após a sedimentação da Formação Macacu, no Eoceno-Oligoceno. Dados recentes de quantificação de taxas de erosão em margens passivas com elevações altas, indicam que as taxas são mais acentuadas no sopé das escarpas principais (Cockburn et al. 2000), indicando que essa tendência ascensional deve ter sido mais intensa na borda norte da Bacia do Macacu, o que vem de encontro à primeira hipótese. Nesse sentido a acumulação e a preservação dos sedimentos da Bacia do Macacu, em um cenário regional de tendência ascensional, inclusive das porções proximais das Bacias de Santos e Campos, no Paleoceno e Eoceno Inferior (Pereira et al. 1986, Macedo 1989, Ferrari et al. 1991, Almeida \& Carneiro 1998), que a nível local predominou por todo o Terciário, reforça o caráter tectônico da mesma. Como foi caracterizado nesse trabalho, o neotectonismo que afetou a Bacia do Macacu, caracterizado pela extensão E-W, teve importante papel na sua sub-compartimentação. Esse evento neotectônico pode ter sido potencializado por essa tendência ascensional.

A influência da tectônica na sedimentação é evidenciada, desde a sedimentação da Formação Macacu, no Paleógeno, pelas variações no sentido do fluxo fluvial entre as áreas a SE e NW da bacia. Essa variação que foi assumida no modelo tectônico proposto, com 
adernamentos opostos, para SW e para NE em momentos diferentes da sua evolução, seria viabilizada de duas outras formas, ambas de caráter tectônico, se:

1) a bacia fosse segmentada tectonicamente, em duas sub-bacias adernadas em sentidos opostos, por um alto estrutural de direção ENE-WSW, gerado ainda pela própria extensão NW-SE que implantou a bacia, aproximadamente alinhado com o Rio Caceribu, passando imediatamente ao norte do Maciço de Itaúna e ao sul da Ilha do Governador. Esse alto poderia estar relacionado a uma possível zona de transferência entre as duas sub-bacias,

2) as áreas fontes dos depósitos de planície de inundação de Magé tivessem sido erodidos, na borda NW, em conjunto com os sedimentos proximais.

A primeira hipótese exige que a bacia tenha tido bordas ativas a sudeste e noroeste. A ausência das fácies proximais na borda noroeste estaria relacionada com a intensa erosão aí verificada. Nesse sentido, apesar dos depósitos de leques aluviais se concentrarem junto à borda sudeste da bacia, eles ocorrem também no meio da bacia, como pode ser visto nos Pontos 4, 12 e 15, localizados a cerca de 7 a $8 \mathrm{~km}$ de distância da borda ativa da bacia. A presença desses sedimentos nessas áreas, que parecem ter constituído o provável eixo central da bacia, de domínio da planície aluvial, tendo em vista a predominância dos depósitos da Associação $\mathrm{C}$ e as medidas de paleocorrentes, indica que áreas mais elevadas estiveram presentes no interior da bacia, funcionando como áreas fonte para os leques. Tais áreas elevadas poderiam ter sido estabelecidas ao longo da eventual zona de transferência ENE-WSW, ou mesmo reativando as estruturas NNE-SSW (Figura 6.14).

Com relação à segunda hipótese, é difícil compatibilizar os sentidos opostos de paleodrenagem entre essas duas áreas, o que exigiria uma drenagem centrípeta, com escoamento para sul, em direção à plataforma continental, coincidindo com a atual área ocupada pela Baía de Guanabara. Deve-se salientar que sedimentos da Formação Macacu não foram encontrados nas sondagens para construção da ponte Rio-Niterói (Meis \& Amador 1977). Por outro lado, foram identificados lamitos maciços, semelhantes aos da Formação Resende e Formação Macacu, nas escavações das obras do metro do Rio de 
Janeiro, no Bairro de Botafogo (Mario Motidome, informação verbal, 1999). Esse local insere-se em um vale retilíneo, de direção ENE-WSW, limitado a NW pelo Corcovado e Morro Dona Marta e a SE pelo Morro Cara de Cão. Os desníveis topográficos de até 700 metros, constituindo marcante anomalia de relevo, e a identificação de movimentação normal na borda de diques de diabásio sub-paralelos ao vale (Rideg et al. 1989), sugerem um possível controle tectônico para essa ocorrência. Ainda nesse sentido, a contemporaneidade entre a deposição da Formação Macacu e de acentuada erosão na atual plataforma continental da Bacia de Santos, reforça os indícios de que o acúmulo de sedimentos no Graben da Guanabara foi tectonicamente controlado, tendo em vista que em margens continentais passivas com relevo acentuado, as taxas erosivas mais intensas são verificadas junto ao sopé da elevação principal (Cockburn et al. 2000). A ocorrência do Graben de Barra de São João, de idade eocênica, na área de projeção do Graben da Guanabara na plataforma continental do Alto de Cabo Frio, também controlado por falhas de borda de direção ENE-WSW (Mohriak \& Barros 1990), reafirma o caráter regional do RCSB, e a importância das estruturas NE-SW a ENE-WSW no controle da sedimentação continental no Paleógeno, nessa área adjacente às bacias de Santos e Campos.

A ocorrência dos conglomerados quartzosos, em discordância erosiva, no topo do pacote da Bacia do Macacu, também suporta a hipótese de erosão e retrabalhamento das fácies proximais da borda NW.

Os segmentos isolados da Bacia do Macacu, na Ilha do Governador e em Duque de Caxias, bem como a própria área principal, ao norte de São Gonçalo, apresentam os limites atuais com direção principal aproximadamente N-S a NNW-SSE. Em Magé e na Ilha do Governador esses limites coincidem com falhas normais de mesma direção, geradas pela extensão E-W, de idade holocênica, indicando que a segmentação da bacia, responsável por sua configuração atual, pode ter se dado somente no Holoceno, constituindo uma indicação de atividade neotectônica no Graben da Guanabara. 


\subsubsection{Conclusões Parciais}

1) O preenchimento sedimentar da Bacia do Macacu é constituído por quatro associações de fácies sedimentares distintas: 1) Lacustre $\rightarrow$ Associação A, 2) Leques aluviais lobos de fluxos de detritos/corridas de lama e de fluxos em lençol $\rightarrow$ Associação B, 3) Canal fluvial entrelaçado com inundações episódicas $\rightarrow$ Associação C e 4) Canal fluvial entrelaçado $\rightarrow$ Associação D. Propõe-se denominar a Associação A de Membro Rio Vargem, e as associações B e C de Membro Porto das Caixas, integrantes da Formação Macacu. A associação D reflete uma unidade sobreposta distinta, denominada de Conglomerado Itambi.

2) A Bacia do Macacu é uma bacia extensional, do tipo graben assimétrico, com borda ativa inicialmente a SE, indicada pela presença nessa borda dos depósitos lacustres e aluviais axiais e, posteriormente, a NW, tendo em vista a migração dos depósitos aluviais axiais, acompanhada da inversão do sentido de fluxo da drenagem, de SW para NE. Essa inversão no sentido de fluxo da drenagem na Bacia do Macacu, pode ter controlado a migração dos depocentros, de SW para NE, na porção norte da Bacia de Santos e Alto de Cabo Frio, no Paleógeno.

3) O preenchimento da bacia tem uma assinatura tectônica evidenciada tanto pela migração dos depósitos aluviais axiais da borda SE para a NW, como pelos afogamentos episódicos da planície aluvial entrelaçada. A característica episódica e recorrente dessas inundações, sugerem um controle alocíclico, induzido provavelmente por tectonismo. Nesse sentido, tanto os afogamentos, geradores de áreas afogadas efêmeras sobre a planície fluvial entrelaçada, como o lago perene, são considerados resposta a pulsos tectônicos responsáveis por subsidência mais acentuada junto à borda ativa da bacia, em acordo com o proposto por Leeder \& Gawthorpe (1987), Blair (1987), Blair \& Bilodou (1988), Mack \& Seager (1990) e Browne \& Plint (1994) para grabens assimétricos e bacias pull-apart. A interdigitação das três associações de fácies, marcada pelo avanço e o recuo dos leques aluviais com relação aos depósitos 
lacustres e de canais entrelaçados, reforça o controle tectônico na sedimentação da Formação Macacu.

4) As características sedimentológicas e as direções de paleocorrentes identificadas nos depósitos sedimentares isolados, na Ilha do Governador e em Duque de Caxias, permitem inferir que eles foram depositados em uma única bacia, em conjunto com a área de ocorrência principal da Formação Macacu, posteriormente segmentada. Dessa forma, a Bacia do Macacu teria uma extensão original de pelo menos o dobro da atual, com cerca de $40 \mathrm{~km}$ de comprimento e $20 \mathrm{~km}$ de largura.

5) A bacia é alongada na direção ENE-WSW, tendo sido gerada por uma extensão de direção NW-SE. A presença de falhas de caráter normal, pós deposicionais, com direção NE-SW, indica que a extensão NW-SE persistiu mesmo após a deposição da Formação Macacu. Os depósitos da bacia são afetados ainda por falhas normais de direção NW-SE e aproximadamente N-S, mais novas que as de direção NE-SW, indicando a atuação de outras duas fases de distensão, com direções distintas da que gerou a bacia. As falhas $\mathrm{N}-\mathrm{S}$, geradas por uma extensão $\mathrm{E}-\mathrm{W}$, são as mais novas, provavelmente de idade holocênica, uma vez que afetam colúvio. As de direção NW$\mathrm{SE}$, tem idade relativa intermediária.

6) As direções de extensão NW-SE, paleogênica, e E-W, holocênica, estão de acordo com as determinadas regionalmente (Riccomini 1989, Salvador \& Riccomini 1995, Mancini 1995, Silva \& Ferrari 1987b). A extensão NE-SW, com SHmax de direção NW-SE, poderia ser contemporânea ao binário dextral E-W, de idade pleistocênica a holocênica (Riccomini 1989); ressalta-se, porém, que as poucas evidências de movimentação direcional relacionadas às feições estruturais geradas por esse evento, não são conclusivas.

7) A coincidência entre a direção aproximadamente N-S dos limites principais das áreas de ocorrência isolada dos sedimentos da Formação Macacu, e do limite oeste da área principal, com falhas normais de mesma orientação, sugere um controle tectônico para a 
segmentação da Bacia do Macacu, relacionado com a extensão E-W, de idade holocênica. Tal relação indica que a atividade neotectônica teve grande importância na segmentação da cobertura sedimentar do Graben da Guanabara.

8) A ausência dos depósitos de leques aluviais na borda noroeste, junto ao acentuado desnível topográfico do embasamento, de pouco mais de 2000 metros de altitude, representado pela Serra dos Órgãos, indica que essa borda foi intensamente erodida após a deposição da Formação Macacu.

9) A deposição da Formação Macacu concomitante com a marcante erosão e exposição das porções proximais da Bacia de Santos, Alto de Cabo Frio e Bacia de Campos, reforça o caráter tectônico do evento paleogênico que a gerou. A acumulação bastante restrita de sedimentos mais novos que a Formação Macacu, no Graben da Guanabara, indica uma tendência ascensional para toda essa área após a deposição da mesma.

10) A ocorrência dos depósitos do Conglomerado Itambi por toda a área da bacia, indica uma diminuição dos espaços internos da bacia, associada a um arrefecimento da atividade tectônica após a sedimentação da Formação Macacu. 


\section{DISCUSSÃO E CONCLUSÕES FINAIS}

O perfil geológico simplificado do Graben da Guanabara na sua porção central, apresentado na Figura 7.1, destaca o controle tectônico do magmatismo alcalino e do seu preenchimento sedimentar.

Esse controle tectônico foi exercido pelos campos de paleotensões caracterizados na área do Graben da Guanabara, que estão sintetizados na Figura 7.2. Essas paleotensões foram determinadas a partir da análise estrutural de feições rúpteis, presentes tanto nos corpos de rochas alcalinas, anteriores a contemporâneas ao graben, como no seu preenchimento sedimentar, constituído pelas bacias de São José do Itaboraí e do Macacu.

A inversão dos dados estruturais permitiu que se determinasse os campos de paleotensões vigentes entre o Campaniano e o Holoceno, cobrindo um intervalo de aproximadamente $80 \mathrm{Ma}$. Esses campos de paleotensões estão relacionados a quatro eventos de deformação distintos, a saber:

Evento $1 \rightarrow$ Transcorrência Sinistral - $\sigma 1$ de direção NE-SW

Esse campo de paleotensões mais antigo, que atuou entre o Campaniano e o Eoceno Inferior (80-50Ma), foi determinado a partir dos corpos alcalinos e dos diques a ele relacionados, da Bacia de São José do Itaboraí e das brechas tectônicas silicificadas. A intrusão dos diques de rochas alcalinas foi controlada por esse campo. Variações locais para uma extensão de direção NW-SE, podem ser interpretadas como relacionadas a um aumento na magnitude de $\sigma z$ e da pressão de fluídos, conseqüência da intrusão dos corpos alcalinos. A formação da Bacia de Itaboraí e sua evolução sob esse campo de paleotensões indica que o início da formação do Graben da Guanabara se deu em um regime direcional sinistral; 


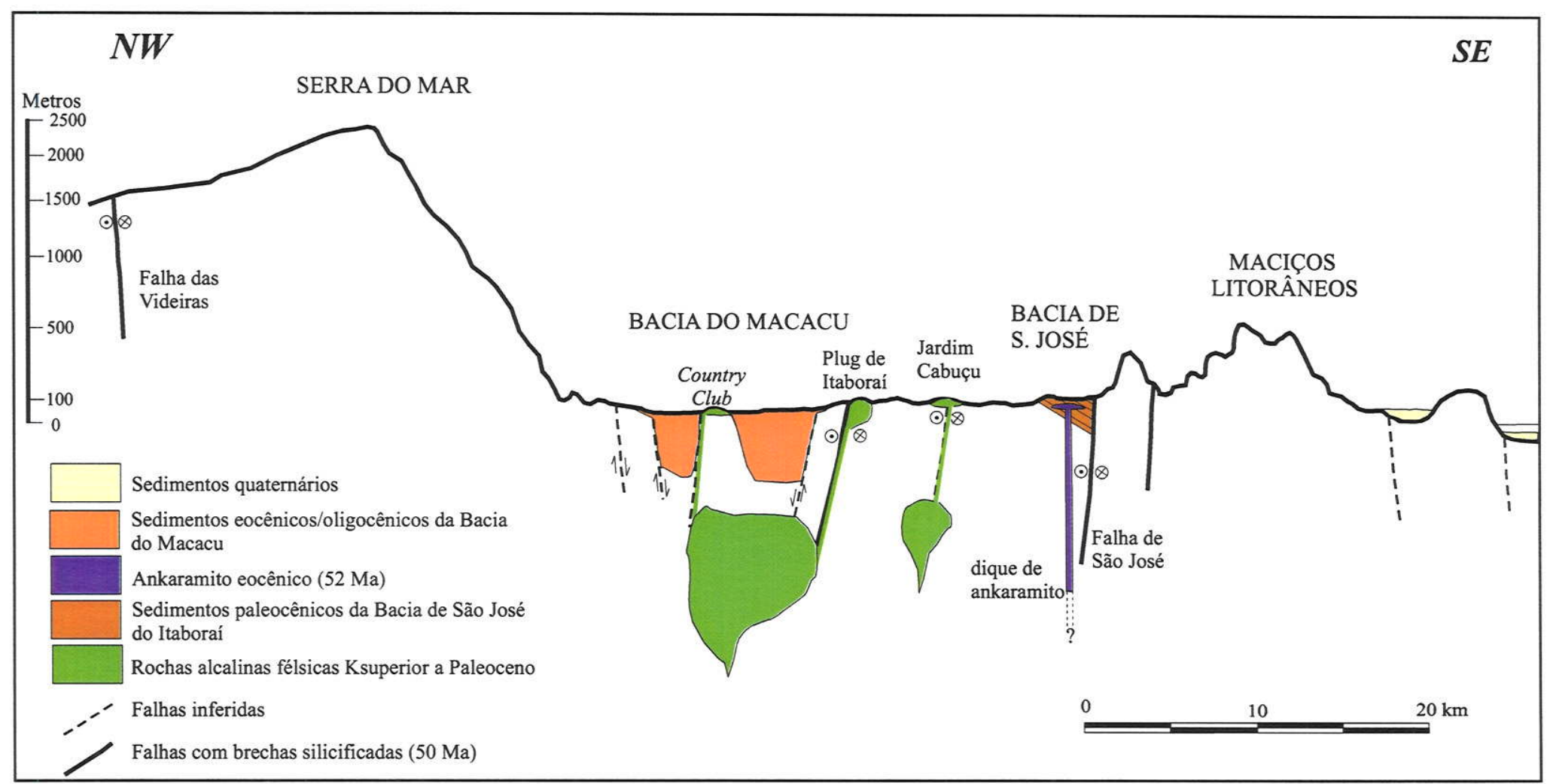

Figura 7.1 - Perfil geológico de direção NW-SE na porção central do Graben da Guanabara. Destaca-se as ocorrências de rochas vulcânicas alcalinas do Country Club (65.7 Ma) e de Jardim Cabuçu. Topografia a partir de Ruellan (1944), com exagero vertical de 10X. Corpo alcalino subjacente à Bacia do Macacu inferido a partir de Ferrari \& Ferraz (1988). 


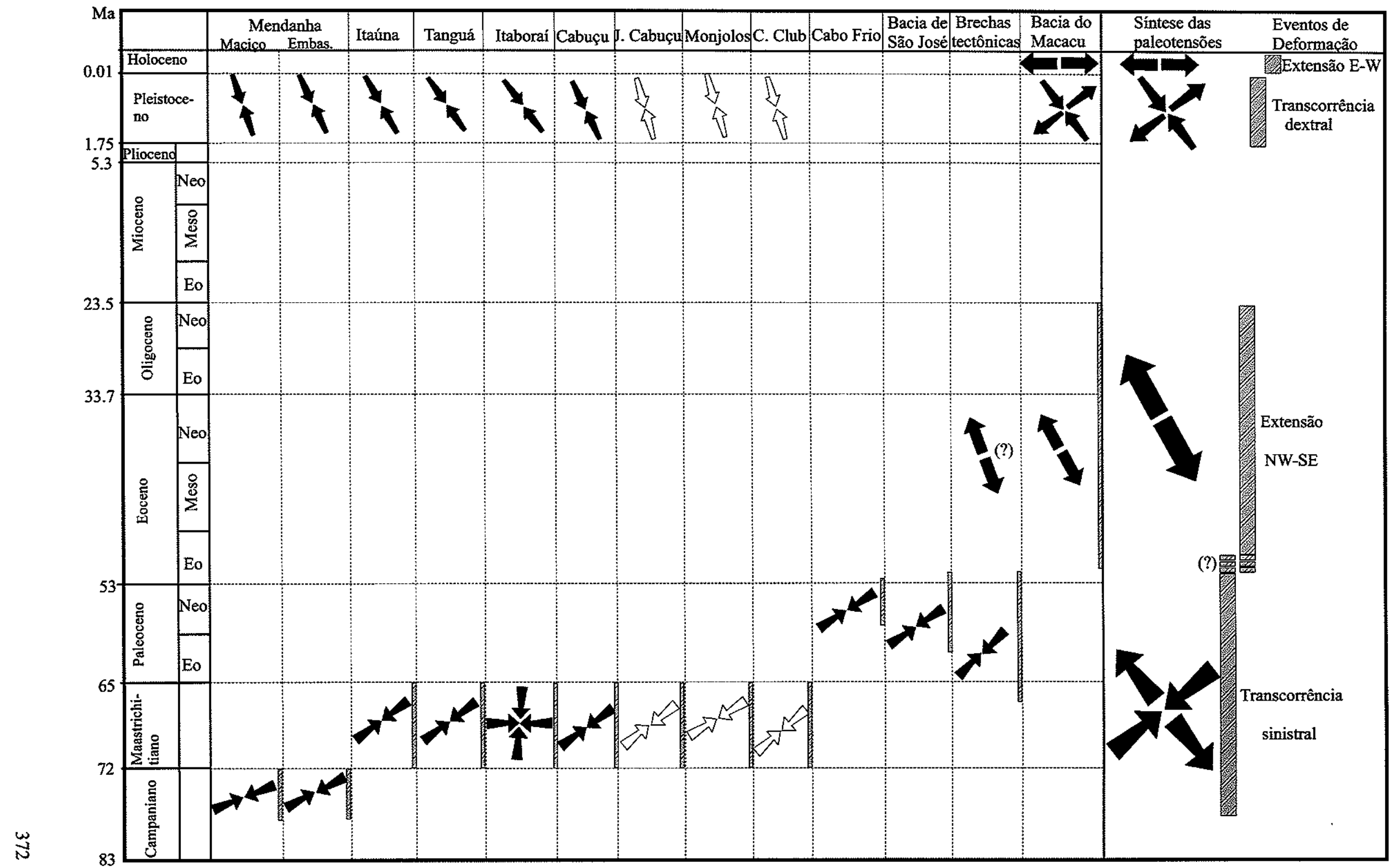

Figura 7.2 - Síntese das paleotensões determinadas no Graben da Guanabara. Setas convergentes pretas representam a direcão do eixo de tensões máximo, $\sigma_{1}$, setas cheias divergentes representam a direção do eixo de tensões mínimo, $\sigma 3$, e as setas convergentes vazadas representam o eixo de tensões horizontal máximo, SHmax. As interrogações indicam dúvida quanto à idade do evento de deformação ou quanto à natureza do regime de paleotensões. Colunas verticais indicam o intervalo de tempo sob atuação de um determinado campo de paleotensões. Ver texto para maiores detalhes.Idades limites entre as subdivisões do tempo geológico segundo Ramane (2000). 
A extensão de direção NW-SE controlou a implantação da Bacia do Macacu e a sedimentação da Formação Macacu, tendo em vista as estruturas sin-deposicionais caracterizadas. A presença de brechas tectônicas silicificadas sotopostas aos sedimentos da Formação Macacu, indica que esses depósitos se acumularem após a geração das brechas, sendo mais novos do que 50Ma. Uma possível componente direcional para esse campo de paleotensões é sugerida pela ocorrência local de um espectro de fraturas com bissetriz aguda de direção NE-SW. De acordo com essa hipótese, o evento de transcorrência sinistral pode ter se estendido, ou retomado, durante ou logo após a deposição da Formação Macacu;

\section{Evento $3 \rightarrow$ Extensão NE-SW (+ Compressão NW-SE ?)}

A extensão NE-SW foi bem caracterizada nos sedimentos da Formação Macacu, onde gerou falhas normais e oblíquas. Falhas de direção NW-SE, com componente direcional, podem ser vistas na borda sudeste da bacia. Apesar da idade de atuação desse campo de paleotensões não ter sido determinada, sabendo-se apenas que ela é posterior à extensão NW-SE e anterior à extensão E-W, pode-se, por analogia e extrapolação dos eventos de deformação determinados em outros segmentos do RCSB, supor-se que a extensão NE-SW é relacionada ao evento de transcorrência pleistocênico determinado por Riccomini $(1989,1995)$, Riccomini et al. (1989), Salvador \& Riccomini (1995), Melo (1997) e Silva \& Ferrari (1997b). Nesse sentido, a presença nos maciços de rochas alcalinas de estruturas geradas em um campo de paleotensões caracterizado por um eixo de paleotensões máximo, $\sigma 1$, horizontal e de direção NW-SE, também com idade não determinada, sugere que esse campo de paleotensões pode ter tido atuação mais efetiva no embasamento do que nas coberturas do Graben da Guanabara. No embasamento ele é posterior ao evento de transcorrência sinistral, como pode ser caracterizado pelas relações de corte de estruturas; 


\section{Evento $4 \rightarrow$ Extensão E-W}

Esse evento gerou falhas normais com direção em torno de $\mathrm{N}-\mathrm{S}$ e reativou falhas de direção WNW-ESE em caráter oblíquo. Essas falhas afetam colúvio e deslocam linhas-de-seixos, indicando uma atuação provável dentro do Holoceno e Pleistoceno, portanto atividade neotectônica no domínio do Graben da Guanabara. As falhas N-S geradas nesse evento parecem ter segmentado a Formação Macacu, separando as áreas de ocorrência isolada da Ilha do Governador e de Duque de Caxias, do corpo principal da Bacia do Macacu.

Os quatro eventos deformacionais determinados para o Graben da Guanabara bem como o magmatismo e a sedimentação a eles relacionados, estão representados na Figura 7.3. Pode-se caracterizar duas fases principais de desenvolvimento do graben, ambas de idade paleogênica:

Fase I - que controlou o magmatismo contemporâneo; o hidrotermalismo tardio, representado pelas brechas tectônicas silicificadas, e a implantação do Graben da Guanabara, com a Bacia de São José do Itaboraí. Essa fase inicial se deu sob regime direcional e se estendeu entre o Paleoceno Inferior e o Eoceno Inferior, encerrando-se com a formação das brechas tectônicas silicificadas e a intrusão do dique de ankaramito na Bacia de São José do Itaboraí;

Fase II - controlou a implantação e a evolução da Bacia do Macacu, a partir do Eoceno Médio até o Oligoceno.

Duas fases neogênicas, fases III e IV, essencialmente deformacionais do Graben da Guanabara, foram responsáveis pela erosão e segmentação da Bacia do Macacu.

O quadro evolutivo esquemático, para o Graben da Guanabara, é apresentado na Figura 7.4. A implantação do graben efetiva-se pela deformação da Superfície de Aplainamento Japi (De Martonne 1944; Ruellan 1944; Almeida 1964, 1976; Asmus \& Ferrari 1978; Riccomini 1989; Almeida \& Carneiro 1998), que teria se desenvolvido no final do Cretáceo e no Paleógeno como consequiência do amplo soerguimento verificado no Sudeste do Brasil. A idade mínima dessa superfície pode ser bem datada nesse segmento do RCSB pela presença, sobre ela, dos hialoclastitos fonolíticos do

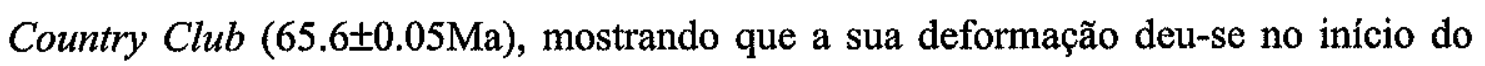




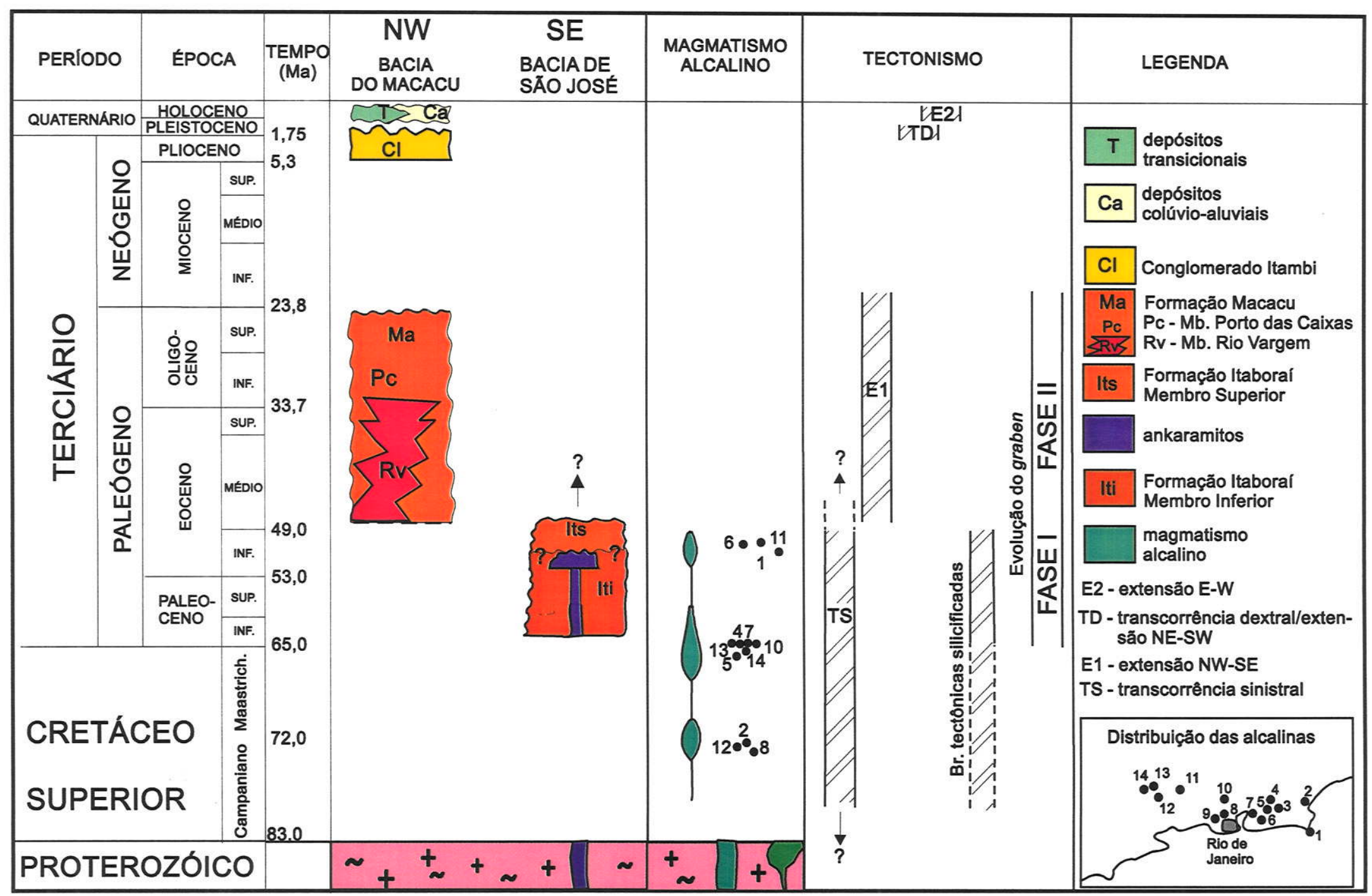

Figura 7.3 - Coluna cronoestratigráfica posicionando o magmatismo, a sedimentação e as paleotensões caracterizadas no Graben da Guanabara, entre o Cretáceo Superior e o Holoceno. Sintetizada e modificada a partir de Rodrigues Francisco \& Cunha (1978), Cordani \& Teixeira (1979), Dalcolmo et al. (1981), Klein \& Rodrigues Francisco (1981), Valença \& Klein (1984), Sonoki \& Garda (1988), Riccomini \& Rodrigues Francisco (1992), Ferrari et al. (1997a, b). Idades dos corpos de rochas alcalinas de acordo com a Figura 4.1. 


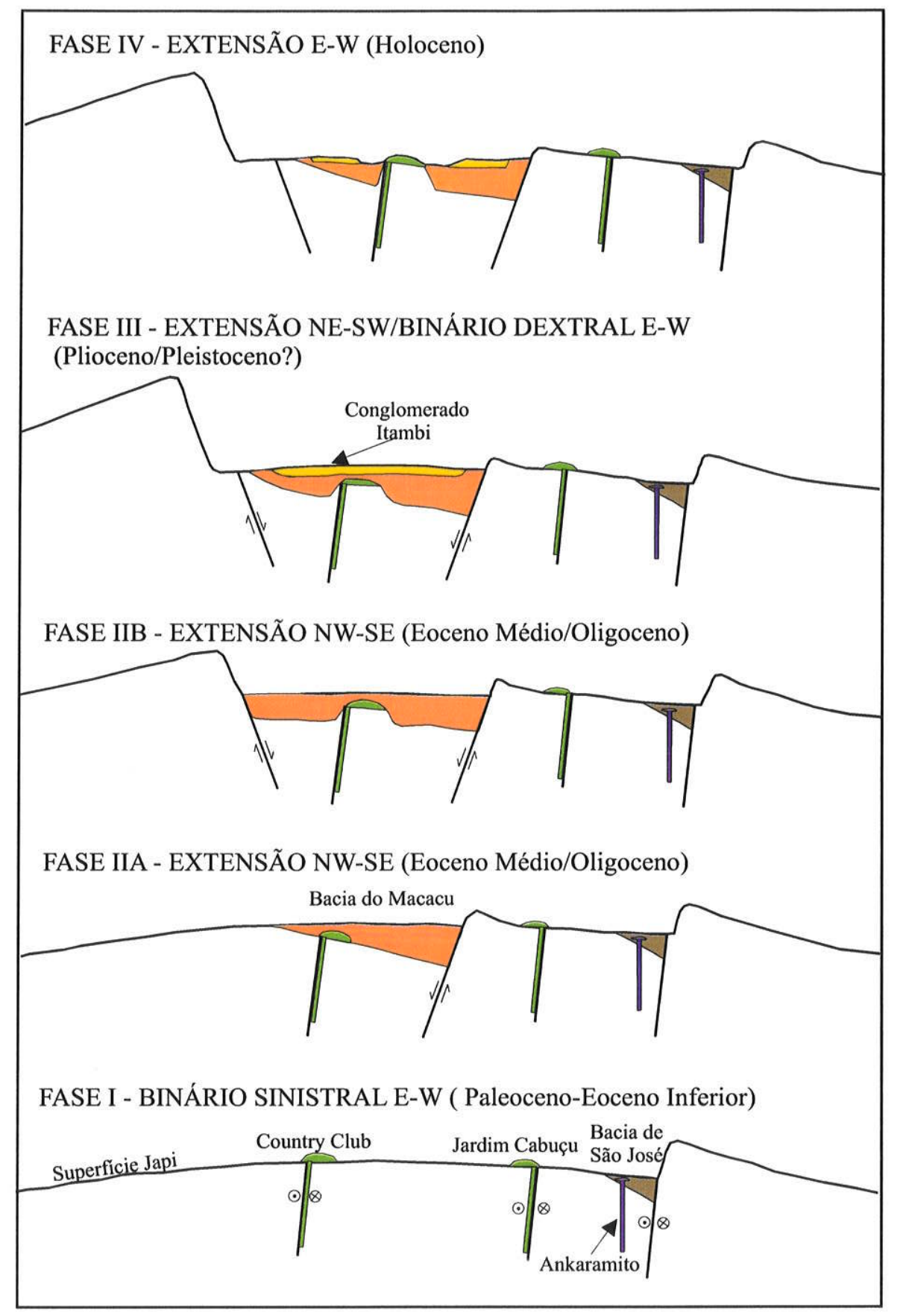

Figura 7.4 - Perfis esquemáticos, com exagero vertical de aproximadamente 10X, mostrando quadro evolutivo proposto para o Graben da Guanabara. A fase I reflete o início da deformação da Superfície Japí, no Paleoceno Inferior, permitindo a preservação das rochas vulcânicas e a implantação da Bacia de São José do Itaboraí. As fases IIA e IIB representam a migração do depocentro da Bacia do Macacu, de SE para NW. A fase III, de deposição do Conglomerado Itambi, evidencia a diminuição de espaços na Bacia do Macacu e foi acompanhada pela erosão da borda norte da bacia. A fase IV é caracterizada por erosão e fragmentação da Bacia do Macacu. 
Paleoceno, sob a atuação do binário sinistral E-W. A evolução do graben continua com a implantação da Bacia do Macacu, no Eoceno Médio, sob a atuação da extensão NW-SE. Essa implantação se dá inicialmente como um hemi-graben, com borda ativa a sudeste, e evolui para um graben assimétrico, com a ativação da borda NW, acompanhada pela migração dos depocentros nesse sentido. A evolução do Graben da Guanabara no Neógeno teve como característica principal o retrabalhamento dos depósitos paleogênicos da Bacia do Macacu, para deposição do Conglomerado Itambi, e a segmentação da bacia que acompanhou a extensão $\mathrm{E}-\mathrm{W}$ de idade holocênica. A deposição do Conglomerado Itambi, tentativamente posicionada no Plioceno-Pleistoceno, acompanhou a intensa erosão da borda norte da Bacia do Macacu, responsável pela retirada dos depósitos de leques aluviais proximais. Esses depósitos estão ausentes desse lado da bacia, justamente caracterizado pelo desnível topográfico mais acentuado, que chega a pouco mais de 2000 metros.

\subsection{DISCUSSÃO}

O quadro evolutivo do Graben da Guanabara mostra que o magmatismo e a sedimentação foram tectonicamente controlados por campos de paleotensões com atuação em todo o seu domínio. Essa característica, já identificada em outros segmentos do RCSB (Riccomini 1989) ou mesmo em outras áreas do sudeste (Riccomini 1995a e b; Melo 1997), remete à possível origem desses campos de paleotensões.

Os modelos tectônicos para a formação do Graben da Guanabara dividem-se entre os que advogam uma relação com campos de paleotensões locais, entre os quais podem ser incluídos os de Almeida (1976), Asmus \& Ferrari (1978) e Fernandes (1993); os que sugerem uma relação com campos de paleotensões regionais, como Riccomini (1989) e Souza (1991).

Por outro lado, a investigação da sismicidade intraplaca e as modelagens numéricas para essas tensões, propõem uma conjugação entre tensões locais e regionais para explicar esse tipo de tectonismo (Assumpção 1992, 1997; Coblentz \& Richardson 1996; Zoback \& Richardson 1996; Ferrari \& Riccomini 1999). 


\subsubsection{Origem dos Campos de Paleotensões no Graben da Guanabara - Tensões Locais x Regionais}

A discussão da origem dos campos de paleotensões que controlaram a implantação e a evolução do Graben da Guanabara deve considerar o seu caráter inicialmente direcional e posteriormente extensional e, ainda, a sua vinculação geográfica com o soerguimento que precedeu a sua implantação.

Situações semelhantes, onde a evolução do rift inicia-se sob a atuação de um regime direcional, foram descritas nos rifts do leste africano, Baikal e na abertura do Oceano Atlântico Setentrional (Delvaux et al. 1992, 1995; Geoffroy et al. 1993, 1994, 1996; San'Kov et al. 1997). Para Vauchez et al. (1998), Tommasi \& Vauchez (2000) e Vauchez et al. (2000) a implantação inicial de um regime de tensões direcional nos rifts continentais, dá-se em resposta às anisotropias mecânicas do manto subjacente. Tais anisotropias seriam evidenciadas pela deformação dúctil e orientação preferencial de eixos cristalográficos de olivina encontradas em xenólitos mantélicos e pelas heterogeneidades na propagação de ondas sísmicas sob esses rifts. Para esses autores essas anisotropias que, além das relativas ao fabric das rochas mantélicas, incluiriam também a presença de bolsões de magma, imporiam uma deformação inicial com forte componente cisalhante, paralela a elas, por suavização da deformação (strain softening). Segundo Vauchez et al. (1998), Tommasi \& Vauchez (2000) e Vauchez et al. (2000) as tensões que contribuiriam para essa resposta teriam origem no soerguimento que antecede a implantação do rift e nas tensões regionais.

No Graben da Guanabara um soerguimento prévio, responsável pelo desenvolvimento da Superficie Japi, esteve presente no Cretáceo Superior (Almeida 1976, Almeida \& Carneiro 1998) e, de acordo com o modelo exposto acima, pode ter sido o desencadeador da formação do rift. Essa formação, se deu a partir do início do Paleoceno, como indicam a preservação das rochas vulcânicas presentes no interior do graben e a implantação da Bacia de São José do Itaboraí.

Com relação ao papel exercido pelas tensões regionais, sabe-se que na placa sul-americana as direções de SHmax são atreladas ao empurrão da placa e aproximadamente paralelas às suas linhas de fluxo (Zoback et al. 1989, Assumpção 1992, Richardson 1992, Stefanick \& Jurdy 1992, Coblentz \& Richardson 1996). Sabese ainda que as linhas de fluxo da placa permaneceram na direção $\mathrm{E}-\mathrm{W}$, pelo menos desde o início do Terciário (Herz 1977, Hartnady \& Le Roex 1985, Crough et al. 
1980, Morgan 1983, O'Connor \& Duncan 1990, Thompson et al. 1998). O campo de tensões atual, com $\sigma 1$ aproximadamente E-W, foi determinado a partir de fraturas de cisalhamento (Salvador \& Riccomini 1995, Mancini 1995) e de mecanismos focais (Berrocal et al. 1993), sendo compatível com o desencadeado pelo empurrão da placa. Também o binário dextral E-W, pleistocênico, identificado no Graben da Guanabara, nos outros segmentos do RCSB (Riccomini 1989, 1995a; Salvador \& Riccomini 1995) e regionalmente (Melo 1997), tem compatibilidade com esse campo de tensões.

Porém, a direção de SHmax NE-SW associada ao binário sinistral E-W, identificado como controlador do magmatismo alcalino e da implantação do Graben da Guanabara, não é compatível com o campo de tensões regionais esperado a partir do empurrão da cordilheira mesoceânica. Mesmo se considerarmos a interação entre as tensões locais e regionais, a partir do modelo de Zoback (1992) (ver Figura 2.10), tem-se que uma extensão ortogonal ao graben geraria uma rotação horária dos eixos de tensões máximas e mínimas horizontais, girando SHmax e Shmin para as direções NW-SE e NE-SW, respectivamente. Ainda segundo esse modelo, a única forma de gerar uma rotação anti-horária de SHmax e Shmin, posicionando-os nas direções NESW e NW-SE, respectivamente, seria a partir de uma compressão local ortogonal ao Graben da Guanabara, ou seja, na direção NW-SE.

Considerando-se que a verificação dessa compressão ortogonal ao graben, entre o Cretáceo Superior e Eoceno Inferior é pouco factível, pode-se supor que a origem do binário sinistral E-W que controlou o magmatismo alcalino e a implantação do Graben da Guanabara está relacionada com as paleotensões locais desencadeadas pelo soerguimento que o precedeu, controladas pelas anisotropias mecânicas do manto subjacente, à semelhança com o caracterizado em diversos rifts continentais (Vauchez et al. 1998, Tommasi \& Vauchez 2000, Vauchez et al. 2000).

\subsection{CONCLUSÕES}

1) A interpretação dos dados permite inferir que a implantação do Graben da Guanabara deu-se no Paleoceno, sob um regime de esforços direcional, tendo sido controlada por um binário sinistral E-W. Sua evolução ao longo do Eoceno e do Oligoceno foi controlada por um regime de esforços extensional, com o eixo de 
extensão posicionado na direção NW-SE. Dessa forma, registrou-se a persistência das direções de SHmax e Shmin, NE-SW e NW-SE respectivamente, entre o Cretáceo Superior e o Oligoceno e a sua variação, para posições ortogonais a essas, apenas no Pleistoceno;

2) A Bacia de São José do Itaboraí, de idade paleocênica, possui a maior taxa de estiramento entre todas as bacias do RCSB, de pouco mais de $10 \%$. A presença de veios de calcário travertino com alto e baixo ângulo de mergulho, cortando o embasamento e preenchendo a Falha de São José; as microfalhas direcionais que afetam o preenchimento da bacia e a contemporaneidade de extensões nas direções NW-SE e NE-SW indicam a complexidade da evolução tectônica da Bacia de São José do Itaboraí e foram interpretadas como geradas por uma transcorrência sinistral dessa falha;

3) $\mathrm{Na}$ Bacia do Macacu, de idade eocênica a oligocênica, foram caracterizadas três associações de fácies, de leques aluviais, fluvial entrelaçada e lacustre. A distribuição das associações de fácies, em conjugação com as estruturas, indicou que essa bacia é do tipo graben assimétrico, e que os depocentros se deslocaram da borda sudeste para a noroeste. As paleocorrentes mostram uma variação no sentido, passando de SW para NE, reforçando a importância do tectonismo na sedimentação da Formação Macacu. Essa relação foi evidenciada, também, pelos afogamentos episódicos da planície aluvial, interpretados como de origem tectônica;

4) A ausência dos depósitos de leques aluviais na borda noroeste, junto ao acentuado desnível topográfico do embasamento, de pouco mais de 2000 metros de altitude, representado pela Serra dos Órgãos, indica que essa borda foi intensamente erodida após a deposição da Formação Macacu. A deposição da Formação Macacu concomitante com a marcante erosão e exposição das porções proximais da Bacia de Santos, Alto de Cabo Frio e Bacia de Campos, reforça o caráter tectônico do evento paleogênico que a gerou. A acumulação bastante restrita de sedimentos mais novos que a Formação Macacu, no Graben da Guanabara, indica uma tendência ascensional para toda essa área após a deposição da mesma;

5) A presença de hialoclastitos fonolíticos no Plug do Country Club, que constitui o embasamento da Bacia do Macacu, com idade de 65,7 Ma (obtida no presente trabalho), indicou que esse segmento do Graben da Guanabara não sofreu erosão desde o Paleoceno Inferior. A localização desse plug próxima aos maciços do 
Tanguá e Rio Bonito, de mesma idade, mostra que as taxas de erosão no interior do Graben da Guanabara foram heterogêneas;

6) A análise geométrica dos veios de calcedônia maciça que cortam as brechas tectônicas silicificadas e o embasamento, bem como a análise cinemática das falhas e microfalhas que as afetam indicam que o evento tectônico que as gerou foi controlado por um campo de paleotensões direcional, onde $\sigma 1$ orientava-se na direção NE-SW e $\sigma 3$ na direção NW-SE. Variações locais nesse campo de paleotensões para um regime puramente extensional, mantendo-se as direções de SHmax e Shmin, foram caracterizadas na Ilha do Governador e na Região dos Lagos e parecem estar associadas a uma permutação dos eixos de paleotensões máximo e intermediário, associada a um aumento na magnitude de $\sigma z ;$

7) O campo de paleotensões responsável pela implantação do Graben da Guanabara parece ter sido gerado pelo soerguimento que o precedeu em conjugação com o controle exercido por anisotropias mecânicas do manto subjacente. $\mathrm{O}$ binário dextral E-W/extensão NE-SW, de provável idade pleistocênica pode estar relacionado com as tensões regionais associadas ao empurrão da cordilheira mesoceânica. 


\section{REFERÊNCIAS BIBLIOGRÁFICAS}

ABREU, S.F. 1965. Recursos Minerais do Brasil, Rio de Janeiro: IBGE, Vol. 2.

AB'SABER, A.N. 1954. Simpósio do Conselho Nacional de Geografia, IBGE, 1-97.

AGUIAR, A. C. K. V. 1997. Estudo gravimétrico da morfologia e da estrutura crustal 3D da porção ocidental do Atlântico-Sul entre os paralelos $18^{\circ} \mathrm{S}$ e $40^{\circ} \mathrm{S}$. Rio de Janeiro, $101 \mathrm{p}$. Dissertação de Mestrado, Observatório Nacional/CNPq.

ALMEIDA, F. F. M. 1964. Fundamentos geológicos do relevo paulista. Bol. IGG, São Paulo, 41: 167- 262 .

ALMEIDA, F. F. M. 1967. Origem e evolução da plataforma brasileira. Bol. DGM/DNPM, 246, 36p. Rio de Janeiro.

ALMEIDA, F. F. M. 1969. Diferenciação tectônica da plataforma brasileira. In: $23^{\circ} \mathrm{CONGRESSO}$ BRASILEIRO DE GEOLOGIA, Salvador. Anais, 1: 29-46.

ALMEIDA, F. F. M. 1976. The system of continental rifts bordering the Santos Basin. An. Acad. Bras. Ci., Rio de Janeiro, 58 (suplemento): 15-26.

ALMEIDA, F. F. M. 1986. Distribuição e relações tectônicas do magmatismo pós-Paleozóico no Brasil. Rev. Bras. Geoc., São Paulo, 16 (4): 325-349.

ALMEIDA, F. F. M. 1991. O alinhamento magmático de Cabo Frio. In: II SIMPÓSIO DE GEOLOGIA DO SUDESTE, SBG, São Paulo. Anais, p. 423-428.

ALMEIDA, F. F. M. \& CARNEIRO, C. D. R. 1998. Origem e evolução da Serra do Mar. Rev. Bras. Geoc., São Paulo, 28 (2): 135-150.

ALVARENGA, H.M.F. 1983. Uma ave Ratitae do Paleoceno brasileiro: Bacia de Itaboraí, Rio de Janeiro, Brasil. Bol. Museu Nacional - N. Ser., Geologia, $\mathrm{n}^{\circ} 41$.

ALVES, E.C. 1981. Estruturas da margem continental sul brasileira e das áreas continentais e oceânicas, adjacentes. In: Estruturas e tectonismo da margem continental brasileira, e suas implicações nos processos sedimentares e na avaliação do potencial de recursos minerais. Série Projeto REMAC, 9: 145-170.

ALVES, E.C.; COSTA, M.P.A. \& FERRARI, A.L. 1989. Integração final entre as Evoluções Estrutural e Estratigráfica da porção rasa da Bacia de Santos e da Serra do Mar. Relatório CNPq. 
ALVES, E.C.; DIAS, M.S.; MELLO, S.L.M. \& SICHEL, S.E. 1997a. Compartimentação tectônica do Sudeste do Brasil e suas relações com as zonas de fraturas oceânicas.In: V CONGRESSO INTERNACIONAL DA SOCIEDADE BRASILEIRA DE GEOFÍSICA, São Paulo. Anais, 1: 48-50.

ALVES, E.C.; SPERLE, M.D. \& SICHEL, S.E. 1997b. Zona de Fratura de Martin Vaz e suas implicações tectônicas no bordo sudeste do Brasil. In: V SIMPÓSIO DE GEOLOGIA DO SUDESTE, SBG, Rio de Janeiro. Anais, p. 92-94.

AMADOR, E. S. 1975. Estratigrafia e sedimentação da Bacia de Resende - RJ. An. Acad. Bras. Ci., Rio de Janeiro, 47 (suplemento): 181-225.

AMADOR, E.S. 1980. Unidades Sedimentares Cenozóicas do Recôncavo da Baía da Guanabara (Folhas Petrópolis e Itaboraí). An. Acad. Bras. Ci., Rio de Janeiro, 52 (4) :743-761.

AMADOR, E. S. 1997. Baía de Guanabara e Ecossistemas Periféricos: Homem e Natureza. Rio de Janeiro: Reproarte, 539 p (edição do autor).

AMADOR, E. S. \& PONZI, V.R.A. 1974. Estratigrafia e sedimentação dos depósitos flúviomarinhos da orla da Baía da Guanabara. An. Acad. Bras. Ci., Rio de Janeiro, 46 (3/4): 693.

AMEEN, M.S. 1995. Fractography and fracture characterization in the Permo-Triassic sandstones and the Lower Palaeozoic Basement, West Cumbria, UK. Geol. Soc. Spec. Publ., 92: 97-147.

ANDERSON, E. M. 1951. The dynamics of faulting and dyke formation with applications to Britain. Edinburg: Oliver \& Boyd, 206 p.

ANDREIS, R.R.; KLEIN, V.C.; RAMOS, R.R.C.; FERRARI, A.L. \& VALENÇA, J.G. 1999. Fluxos piroclásticos estratificados no Morro de Itauna (Município de São Gonçalo, RJ): processos e origem. In: SIMPÓSIO SOBRE VULCANISMO E AMBIENTES ASSOCIADOS, 1, Gramado (RS), Boletim de Resumos, SBG/UFRGS, p. 47.

ANGELIER, J. 1979. Determination of the mean principal directions of stress for a given fault population. Tectonophysics, 56: 17-26.

ANGELIER, J. 1984. Tectonic analysis of fault slip data sets. J. Geophys. Res., 89: 5835-5848.

ANGELIER, J. 1989. From orientation to magnitudes in paleostress determinations using fault slip data. J. Struct. Geol., 11: 37-50.

ANGELIER, J. 1990. Inversion of field data in fault tectonics to obtain the regional stress. III. A new rapid direct inversion method by analytical means. Geophys. J. Int., 103: 363-376. 
ANGELIER, J. 1994. Fault slip analysis and paleostress reconstruction. In: HANCOCK, P. L., (ed.). Continental Deformation. Oxford: Pergamon Press, p. 53-100.

ANGELIER, J. \& MECHLER, P. 1977. Sur une méthode graphique de recherche des contraintes principales, egalement utilisable en tectonique et en seismologie: la méthode des diédres droits. Bull. Soc. Geol. Fr., 7: 1309-1318.

ARAUJO, A. L. N. 1995. Rochas alcalinas de Arraial do Cabo - RJ: Ilha do Cabo Frio $e$ adjacências continentais. Niterói, 90 p. Dissertação de Mestrado, Depto. Geologia/LAGEMAR, Universidade Federal Fluminense.

ASMUS, H. E. 1978. Hipóteses sobre a origem dos sistemas de zonas de fratura oceânicas/ alinhamentos continentais que ocorrem nas regiões Sudeste e Sul do Brasil. In: Aspectos estruturais da margem continental leste e sudeste do Brasil. Série Projeto REMAC, 4: 39-73.

ASMUS, H. E. \& FERRARI, A. L. 1978. Hipótese sobre a causa do Tectonismo Cenozóico na Região Sudeste do Brasil. In: Aspectos Estruturais da Margem Continental Leste Brasileira. Série Projeto REMAC, 4: 75-88.

ASSUMPÇÃO, M. 1992. The regional intraplate stress field in South America. J. Geophs. Res., 97: 11889-11903.

ASSUMPÇÃO, M. 1997. Seismicity and stresses in the Brazilian passive margin. Bull. Seism. Soc. Am., submitted.

ASSUMPÇÃO, M.; DIAS NETO, C. M.; BERROCAL, J.; ANTEZANA, R.; FRANÇA, H. \& ROTEGA, R. 1980. Sismicidade do sudeste do Brasil. In: XXXI CONGRESSO BRASILEIRO DE GEOLOGIA, Camboriú. Anais, 2: 1075-1092.

ASSUMPÇÃO, M.; BARBOSA, J.R.; BERROCAL; J.; BASSINI, A.M.; VELOSO, J.A.V.; MÄRZA, V.I.; HUELSEN, M.G. \& RIBOTTA, L.C. 1997. Seismicity patterns and focal mechanisms in southeastern Brazil. Rev. Bras. Geof., Rio de Janeiro, 15 (2): 119- 131.

AZEVEDO JÚNIOR, M. F. 1991. Integração entre o preenchimento sedimentar Cenozóico das bacias de Campos e Santos e a evolução tectônica e geomorfológica das áreas continentais adjacentes. Ouro Preto, 160 p. Dissertação de Mestrado, Universidade Federal de Ouro Preto. AZEVEDO JÚNIOR, M. F., KARNER, G. D., BENDER, A. A. \& CHEMALE JÚNIOR, F. 1993. The link between the Campos and Santos Cenozoic basin fill and the tectonic and geomorphological evolution of the adjacent continental areas, SE Brazil. In: 14TH INTERNATIONAL SEDIMENTARY CONGRESS, Recife, Anais, G: 7-8. 
BAER, G. \& BEYTH, M. 1990. A mechanism of dyke segmentation in fractured host rock. In: SECOND INTERNATIONAL CONFERENCE MAFIC DYKES EMPLACEMENT MECHANISMS, Adelaide, South Australia. Proceedings, p. 3-11.

BAER, G.; BEYTH, M \& RECHES, Z. 1994. Dikes emplaced into fractured basement, Timna Igneous Complex, Israel. J. Geophys. Res., 99 (B12): 24039-24050.

BARBOSA, A. L. M.; SAD, J. H. G.; PINTO, C. P. \& RIBEIRO, A.C. 1981. Projeto Carta Geológica do estado do Rio de Janeiro - DRM/GEOSOL, Bloco Três Rios, Folhas Três Rios, Paraíba do Sul, Miguel Pereira e Cava. Rio de Janeiro, Relatório Final, v. I, texto inédito.

BARBOSA, A. L. M.; SAD, J. H. G.; PINTO, C. P. \& RIBEIRO, A.C. 1983. Projeto Carta Geológica do Estado do Rio de Janeiro. DRM/GEOSOL: Bloco: Piraí, folhas Piraí, Paracambi, Itaguai, Vassouras e Barra do Piraí. Rio de Janeiro, relatório final, V. I, texto inédito.

BASSET, K.N. \& KLEINSPEIN, K.L. 1996. Mid-Cretaceous transtension in the Canadian Cordillera: Evidence from the Rock Ridge volcanics of Skeena Group. Tectonics, 15 (4): 727 746.

BASSETO, M. \& SZATMARI, P. 1997. Estruturas compressionais em crosta oceânica na margem sul-sudeste brasileira. In: VI SIMPÓSIO NACIONAL DE ESTUDOS TECTÔNICOS, Gramado, Atas, p. 63-64.

BASSINI, A.M. 1986. Levantamentos sismográficos na região sudeste do Brasil. São Paulo, 162 p. Dissertação de Mestrado, Instituto Astronômico e Geofísico, Universidade de São Paulo. BECKER, F.E., VALLE, R.R. \& COELHO, C.E.S. 1997. Depósito de fluorita de Tanguá, Itaboraí Rio de Janeiro. In: SCHOBBENHAUS, C., QUEIROZ, E.T. \& COELHO, C.E.S. (coords.). Principais Depósitos Minerais do Brasil, Vol. IV, Parte B, DNPM, Brasília, 591-611.

BENTHAM, P. A., TALLING, P.J. \& DOUGLAS, W. B. 1993. Braided stream and flood-plain deposition in a rapid agrading basin: the Escanilla Formation, Spanish Pyrenees. In: Best, J. L. \& Bristol, C. S. (eds.). Braided Rivers. Geol. Soc. Spec. Publ., 75:177-194.

BERGQVIST, L.P. 1996. Reassociação do Pós-Crânio às espécies de ingulados da Bacia de São José de Itaborai (Paleoceno), Estado do Rio de Janeiro e Filagenia dos "Candylarthra" $e$ ungulados sul-americanos com base no Pós-Crânio. Rio Grande do Sul, 406p. Tese de Doutorado. Pós-Graduação em Geociências, Universidade Federal do Rio Grande do Sul. 
BERROCAL, J.; FERNANDES, C.; BUENO, A.; SEIXAS, N. \& BASSINI, A. 1993. Seismic activity in Monsuaba (state of Rio de Janeiro), Brazil, between 1988 December and 1989 February. Geophys. J. Int., 113:73-82.

BEURLEN, K. \& SOMMER, F.W. 1954. Restos vegetais fósseis e tectônica da bacia calcária de Itaboraí, Estado do Rio de Janeiro. Bol. DGM/DNPM, Rio de Janeiro, 149, 27p.

BIROT, P. 1959. Esboço morfológico da região litorânea do Estado do Rio de Janeiro. Notícia Geomorfológica, FFCL/UNICAMP, II (3): 1-9.

BLAIR, T.C. 1987. Tectonic and hydrologic controls on cyclic alluvial fan, fluvial, and lacustrine rift-basin sedimentation, Jurassic-lowermost Cretaceous Todos Santos Formation, Chiapas, Mexico. J. Sed. Petrol., 57:845-862.

BLAIR, T.C. \& BILODOU, W.L. 1988. Development of tectonic cyclothems in rift, pull-appart, and foreland basins: Sedimentary response to episodic tectonism. Geology, 16:517-520.

BLAIR, T.C. \& MCPHERSON, J.G. 1994a. Alluvial fans and their natural distinction from rivers based on morphology, hydraulic processes, sedimentary processes, and facies assemblages. $J$. Sed. Res., A64 (3):450-489.

BLAIR, T.C. \& MCPHERSON, J.G. 1994b. Alluvial fan processes and forms. In: ABRAHAMS, A.D. \& PARSONS, A.J. (ed.). Geomorphology of Desert environments. London: Chapman \& Hall, p.354-615.

BOOGS JR., S. 1995. Principles of sedimentology and stratigraphy. Prentice-Hall, $2^{\mathrm{a}}$ ed., 774p.

BRITO, I. M.; FRANKIE, H. F. C. M. \& CAMPOS, D.A. 1972. Geologia e Petrografia do São José do Itaboraí, RJ. An. Acad. Bras. Ci., Rio de Janeiro, 42 (2): 225-234.

BROWNE, G. H. \& PLINT, G. 1994. Alternating braidplain and lacustrine deposits in a strike-slip setting: the Pennsylvanian Boss Point Formation of the Cumberland basin, Maritime Canada. J. Sed. Res., B64:40-69.

CABRAL JUNIOR, M. 1993. Considerações estratigráficas e tectônicas sobre as unidades Macacu e Pré-Macacu - Rifte da Guanabara, Terciário do Estado do Rio de Janeiro. In: SEMINÁRIO DE PÓS-GRADUAÇÃO, IG-USP, São Paulo, Resumos, 1: 56.

CANDE, S. C.; LABREQUE, J.L.; HAXBY, W.F. 1988. Plate kinematics of the South Atlantic: chron 34 to present. J. Geophys. Res., 93: 13497 - 13492.

CAPUTO, R. 1995. Evolution of orthogonal sets of coeval extension joints. Terra Nova, 7: 479-490. 
CAREY, E. \& BRUNIER, B. 1974. Analyse théorique et numérique d'un modèle mécanique élémentaire appliqué à l'étude d'une population de failles. C.R. Acad. Sci. Paris, D 279, p. 891894.

CARMO, I. O. 1996. Análise Estratigráfica de Depósitos Pleistocênicos do Médio Vale do Rio Paraíba do Sul (SP/RJ). Rio de Janeiro, 141p. Dissertação de Mestrado, Departamento de Geologia, Instituto de Geociências, Universidade Federal do Rio de Janeiro.

CASTRO, H.O. 1979. Considerações geoquímicas das brechas de Araruama no Estado do Rio de Janeiro. Niterói, 143 p. Dissertação de Mestrado, Departamento de Geoquímica, Universidade Federal Fluminense.

CHOI, P.Y; ANGELIER, J. \& SOUFACHÉ, B. 1996. Distribution of angular misfits in fault-slip data. J. Struct. Geol., 18(11): 1353-1367.

CHRISTIE-BLICK, N. \& BIDDLE, K.T. 1985. Deformation and basin formation along strike-slip faults. In: Biddle, K. T. \& Christie-Blick, N., eds., Strike-Slip deformation, basin formation, and sedimentation. Soc. Econom. Paleont. Minneral. Spec. Publ., 37: 1-34.

COBLENTZ, D.D. \& RICHARDSON, R.M. 1996. Analysis of the South American intraplate stress field, J. Geophys. Res., 101(B4): 8643-8657.

COCKBURN, H.A.P., BROWN, R.W., SUMMERFIELD, M.A. \& SEIDL, M.A. 2000. Quantifying passive margin denudation and landscape development using a combined fission-track thermochronology and cosmogenic isotope analysis approach. Earth Plan. Sci. Lett., 179:429435.

COELHO, C. E. S. \& DARDENNE, M.A. 1987. Caracterização geoquímica de elementos terrasraras do depósito de fluorita do Distrito de Tanguá - RJ. In: $1^{\circ}$ CONGRESSO BRASILEIRO DE GEOQUÍMICA, Anais, Porto Alegre, v.1: 31 - 51.

COELHO, C. E. S., JOST, H., VALLE, R. C. \& DARDENNE, M. A. 1986. O controle estrutural dos depósitos de fluorita de Tanguá, RJ. In: $34^{\circ}$ CONGRESSO BRASILEIRO DE GEOLOGIA, Belo Horizonte, Anais, 5: 1089-2104.

COELHO, C. E. S.; TOURNAY, J.C.; DARDENNE, M.A. \& BENY, C. 1990. Constraints on hydrotermal solutions from fluid and solid inclusions studies in fluorite: application to the Tangua deposit, Rio de Janeiro, Brazil. Econ. Geol., 85: 1024-1033. 
COIMBRA, A. M., RICCOMINI, C., SANT’ANNA, L. G. \& VALARELLI, J. V. 1996. Bacia de Curitiba: estratigrafia e correlações regionais. In: $34^{\circ}$ CONGRESSO BRASILEIRO DE GEOLOGIA, Belo Horizonte, Anais, 1: 135-137.

CORDANI, U.G. \& TEIXEIRA, W. 1979. Comentários sobre as determinações geocronológicas existentes para as regiões da folhas Rio de Janeiro, Vitória e Iguape. In: SCHOBBENHAUS FILHO, et al. Carta geológica do Brasil ao milionésimo. Folhas Rio de Janeiro SF. 23, Vitória, SF 24 e Iguape SG23. Brasília, DNPM/MME, p. 152-207.

CORREAA GOMES, L.C. 1992. Diques Máficos: Uma reflexão teórica sobre o tema e seu uso no entendimento prático da geodinâmica fissural. Salvador. Tese de Doutorado, Instituto de Geociências, Universidade Federal da Bahia.

COSTA, N.M.C.; PENHA, H.M. \& SOUZA, S.L.A. 1983. Geologia estrutural dos maciços litorâneos do Município do Rio de Janeiro e sua implicação geomorfológica. Relatório CNPq (inédito).

COX, K. G. 1989. The role of mantle plumes in the development of continental drainage patterns. Nature, 342: 873-877.

CROUGH, S. T.; MORGAN, W. J.; HARGAVES, R.B. 1980. Kimberlites: their relation to mantle hot spots. Earth Planet. Sci. Lett., 50: 260 - 274.

CRUIKSHANK, K.M., ZHAO, G. \& JOHNSON, A.M. 1991. Analysis of minor fractures associated with joints and faulted joints. J. Struct. Geol., 13 (8):865-886.

CRUIKSHANK, K.M. \& AYDIN, A. 1994. Role of fracture localization in arch formation, Arches National Park, Utah. Geol. Soc. Am. Bull., 106:879-891.

DALCOLMO, M. T.; FERRARI, A. L.; MELLO, E. F.; VAZ, M. A. A.; BRENNER, T. L.; SILVA, V. P. \& NASSAR, W. M. 1982. Bloco Baía de Guanabara, Folhas: Itaborai, Baia de Guanabara, Maricá e Saquarema. Relatório Final. GEOMITEC - DRM/RJ, Niterói.

DAVIS, W.M. 1902. Base level, grade and peneplain. Journal of Geology, 10, p. 77-111.

DECKART, K.; FÉRAUD, G.; MARQUES, L.S. \& BERTRAND, H. 1998. New time constraints on dyke swarms related to the Paraná-Etendeka magmatic province, and subsequent South Atlantic opening, southeastern Brazil. J. Volc. Geoth. Res., 80: 67-83.

DEHIRA, L.K.; SAAD, A R. \& BISTRICHI, C. A. 1998. Sobre a datação de uma brecha alcalina em Itaboraí, RJ, no Graben da Guanabara. In: XL CONGRESSO BRASILEIRO DE GEOLOGIA, Belo Horizonte, Resumos, p. 89. 
DELANEY,P.T.; POLLARD,D.D.; ZIONY, J.I. \& EDWIN, H.M. 1986. Field relations between dikes and joints: Emplacement processes and paleostress analysis. J. Geophys. Res., 91 (B5): 4920-4938.

DELLA FÁVERA, J.C. 1984. Eventos de sedimentação episódica nas bacias brasileiras. Uma contribuição para atestar o caráter pontuado do registro sedimentar. In: XXXIII CONGRESSO BRASILEIRO DE GEOLOGIA, Rio de Janeiro, Anais, 1: 489-501.

DELVAUX, D. 1993. The Tensor Program for paleostress reconstruction: exemples from the East African and the Baikal rift zones. EUGVII Strasburg, France, 4-8 April 1993. Suplement $n^{\circ} 1$ to Terra Nova, vol. 5, p. 216 (abstract).

DELVAUX, D.; LEVI, K.; KAJARA, R.; SAROTA, J. 1992. Structural Evolution of the Rukwa -Nord Malawi Rift. Bull. Centres. Res. Explor.-Prod. Elf Equitaine, 16: 384-406.

DELVAUX, D.; MOYES, R.; SPATEL, G.; MELNIKOV, A.; ERMIKOV, V. 1995. Paleostress reconstructions and geodynamics of the Baikal region, Central Asia, Part II. Paleozoic and Cenozoic pre-rift evolution. Tectonophysics, 252: 61-101.

DE MARTONNE, E. 1944. Problemas morfológicos do Brasil tropical atlântico. Rev. Bras. Geogr. ano V, n.4: 523-549.

DERBY, O. A. 1891. On nepheline-rocks in Brazil - part II. The Tinguá Massif. Geol. Soc. London Quater. Journ., 47: 251-265.

DEWEY, J. F. 1988. Extensional Collapse of Orogens. Tectonics, 7 (6): 1123-1139.

DIAS, J.L.; SCARTON, J.L.; ESTEVES, F.R.; CARMINATTI, M. \& GUARDADO, L.R. 1990. Aspectos da evolução tectono-sedimentar e a ocorrência de hidrocarbonetos na Bacia de Campos. In: RAJA GABAGLIA, G.P. \& MILANI, E.J. (coords.). Origem e Evolução das Bacias Sedimentares. Rio de Janeiro: PETROBRÁS, p. 333- 360.

DOBLAS, M.; MAHECHA, V.; HOYOS, M. \& LOPES-RUIZ, J. 1997. Slickenside and fault surface kinematic indicators on active normal faults of the Alpine Betic cordilleras, Granada, southern Spain. J. Struct. Geol., 19 (2): 159- 170.

DUNNE, W. M. \& HANCOCK, P. L. 1994. Paleostress analysis of small-scale brittle structures. In: HANCOCK, P. L. (ed.). Continental Deformation, Oxford, Pergamon Press, p. 101-120.

ETCHEBEHRE, M. L. C., HASUI, Y., MAGALHÃES, F. S. \& FRANGIPANI, A. 1992. Análise estrutural aplicada à prospecção de fontes termais no planalto de Poços de Caldas (SP/MG). In: 
HASUI, Y. \& MIOTO, J.A. (coords.). Geologia Estrutural Aplicada. São Paulo, ABGE/Votorantim, p. 439-459.

EYLES, N. \& EYLES, C. H. 1993. Glacial geologic confirmation of an intraplate boundary in the Paraná basin of Brazil. Geology, 21:459-462.

FERAUD, G. \& COMPREDON, R. 1983. Geocronological and structural study of Tertiary and Quaternary dikes in southern France and Sardinia: an example of the utilization of the Swarms as paleostress indicators. Tectonophysics, 98: 297-235.

FERNANDES, F. L. 1993. Arcabouço estrutural e evolução da Bacia de Taubaté - SP. Ouro Preto, 147 p. Dissertação de Mestrado, Universidade Federal de Ouro Preto.

FERNANDES, F.L. \& CHANG, H.K. 1992. Compartimentação e evolução tectônica da Bacia de Taubaté. In: $37^{\circ}$ CONGRESSO BRASILEIRO DE GEOLOGIA, Anais, 1: 570-572.

FERRARI, A. L. 1989. O "Rift" da Guanabara (RJ) na sua porção Centro-Ocidental. In: I SIMPÓSIO DE GEOLOGIA DO SUDESTE, SBG, Rio de Janeiro, Anais, p. 126-127.

FERRARI, A. L. 1990. A geologia do "Rift" da Guanabara na sua porção centro-ocidental e sua relação com o embasamento Pré-Cambriano. In: $36^{\circ}$ CONGRESSO BRASILEIRO DE GEOLOGIA, SBG, Natal, Anais, 6: 2858-2872.

FERRARI, A. L. \& FERRAZ, A. E. P. P.D. 1988. Uma nova interpretação para a Depressão Gravimétrica de Itaboraí - RJ. In: XXXV CONGRESSO BRASILEIRO DE GEOLOGIA, Belém, Anais, 4: 1677-1683.

FERRARI, A. L. \& SILVA, M.A.M. 1997. Bacia do Macacu (RJ): Proposta de uma nova bacia do Rift Continental do Sudeste do Brasil. In: V SIMPÓSIO DE GEOLOGIA DO SUDESTE, SBG, Rio de Janeiro, Anais, p. 32- 34.

FERRARI, A.L. \& RICCOMINI, C. 1999. Campo de esforços pleistocênicos na Ilha da Trindade (Oceano Atlântico Sul, Brasil) e sua relação com a tectônica regional. Revista Brasileira de Geociências, 29 (2): 293-300.

FERRARI, A. L. \& RICCOMINI, C. 2000. The Rio de Janeiro State segment of the Santos-Rio de Janeiro Dike Swarm as a paleostress indicator. In: $31^{\circ}$ CONGRESSO INTERNACIONAL DE GEOLOGIA, Rio de Janeiro, Agosto 2000, Abstracts, CDROM.

FERRARI, A.L.; DUPUY, I.S. \& BRENNER, T.L. 1977. Ocorrência de Rocha alcalina no Município de Piraí, RJ, e sua relação com o Lineamento de Além Paraíba. (Nota Preliminar). An. Inst. Geoc., UFRJ, Rio de Janeiro, 1:114- 121. 
FERRARI, A. L.; SILVA, M.A.M. \& PENHA, H.M. 1997a. Persistência de Shmax com direção NE no segmento nordeste do Rift Continental do Sudeste do Brasil ao longo do Cretáceo Superior e Terciário. An. Acad. Bras. Ci., Rio de Janeiro, 69 (3): 440 (resumos das sessões).

FERRARI, A. L.; SILVA, M.A.M. \& PENHA, H.M. 1997b. Variações no campo de esforços na área emersa adjacente ao Alto de Cabo Frio ao longo do Cretáceo e Terciário. In: $\mathrm{V}$ SIMPÓSIO DE GEOLOGIA DO SUDESTE, SBG, Rio de Janeiro, anais, p. 89m91.

FERRARI, A. L.; APPERSON, D. \& SICHEL, S. E. 1999. Onshore tectonic compartment elements and boundaries. In: APPERSON, D. \& SILVA, C. G. (Coord.) - Tectonic Compartmentalization of Campos and Santos Basins. Convênio Lagemar-UFF/EGIUniversidade de UTAH, $46 \mathrm{p}$.

FERREIRA, F.J.F. 1982. Alinhamentos estrutursais-magnéticos da região centro-oriental da Bacia do Paraná e seu significado tectônico. In: Geologia da Bacia do Paraná - reavalição da potencialidade e prospectividade em hidrocarbonetos. São Paulo, Paulipetro - Consórcio CESP/IPT, p. 143-166.

FOLK, R.L. 1974. Petrology of sedimentary rocks. Austin, Tex.: Hemphill, 182p.

FONSECA, A.C. 1994. Esboço geocronológico do sudeste do Brasil. São Paulo, 186 p. Tese de Doutorado, Instituto de Geociências, Universidade de São Paulo.

FONSECA, A. C. \& POUPEAU, G. 1984. Datação por traço de fissão de algumas rochas metamórficas na região da Cidade do Rio de Janeiro. In: XXXIII CONGRESSO BRASILEIRO DE GEOLOGIA, Rio de Janeiro, Anais, p. 2321-2332.

FONSECA, M.J.G. 1998. Mapa Geológico do Estado do Rio de Janeiro, Escala 1:400000, Texto explicativo. Rio de Janeiro, DNPM/MME, 141p.

FRANCHETEAU, J \& LE PICHON, X. 1972. Marginal fracture zones as structural framework of continental margin in South Atlantic Ocean: AAPG Bull., 56: 991-1007.

FREITAS, R. O. 1951. Relevos policíclicos na tectônica do Escudo Brasileiro. Bol. Paul. Geografia, São Paulo, 7: 3-19.

FREITAS, R. O. 1956. Considerações sobre a tectônica e geologia do Vale do Paraíba. Eng. Miner. Met., XXIV (143): 276-283.

GEIKIE, A. 1988. The history of volcanic action during the Tertiary period in the British Isles. Trans. R. Soc. Edinburg, 35:21- 184. 
GALLAGHER, K.; HAWKESWORTH, C. J. \& MANTOVANI, M. A. M. 1994. The denudation history of the onshore continental margin of SE Brazil inferred from fission track data, $J$. Geophys. Res., 99 (18): 18117-18145.

GAMOND, J.F. 1983. Displacement features associated with fault zones: a comparison between observed examples and experimental models. J. Struct. Geol., 5: 33-45.

GEOFFROY, L.; BERGERAT, F. \& ANGELIER, J. 1993. Modification d un champ de contrainte régional par un champ de contraintes magmatique local. Exemple de l'ile de Skye (Ecosse) au Paléocène. Bull. Soc. Géol. Fr., 164 (4): 541-552.

GEOFFROY, L.; BERGERAT, F. \& ANGELIER, J. 1994. Tectonic evolution of the GreenlandScotland ridge during the Paleocene: New constraints. Geology, 22: 653- 656.

GEOFFROY, L.; BERGERAT, F. \& ANGELIER, J. 1996. Brittle tectonism in relation to the Paleogene evolution of the Thulean/NE Atlantic Domain: A study in Ulster. Geol. J., 31: 259269.

GEYH, M. A. \& SCHLEICHER, H. 1990. Absolute age determination - phisical and chemical dating methods and their application. New York: Springer-Verlag, 503 p.

GIBSON, S. A., THOMPSON, R. N., LEONARDOS, O. H., DICIN, A. P. \& MITCHELL, J. G. 1995. The late Cretaceous impact of the Trindade Mantle Plume: evidence from large-volume, mafic, potassic magmatism in SE Brazil. Journ. Petrol., 36 (1): 189-229.

GILCHRIST, A. R. \& SUMMERFIELD, M. A. 1990. Differencial denudation and flexural isostasy in formation of rifted margin upwarps. Nature, 346: 739-742.

GROSSI SAD, J. H.; PINTO, C. P.; SERRA, J.C.; BARROS DUTRA, J. E.; HETTICH, M. \& ANDRADE, M. T. 1980. Projeto carta geológica do estado do Rio de Janeiro DRM/GEOSOL: Folhas Anta, Duas Barras, Teresópolis e Nova Friburgo. Rio de Janeiro, vol. I, relatório final, texto.

HALLS, H.C. 1982. The importance and potencial of mafic dyke swarms in studies of geodynamic processes. Geoscience Canada, 9:145- 154.

HANCOCK, P. L. 1985. Brittle microtectonics: principles and pratice. J. Struct. Geol., 7 (3/4): 437457.

HANCOCK, P. L. \& Engelder, T. 1989. Neotectonic joints. Geol. Soc. Am. Bull., 101: 1197-1208.

HANCOCK, P. L., CHALMERS, R.M.L., ALTUNEL, E. \& CAKIR, Z. 1999. Travitonics: using travertines in active fault studies. J. Struct. Geol., 21: 903-916. 
HARALYI, W. L. E.; ASSIS, L. T.; LIMA, M. C. B.; AKEHO, R. \& FLEXOR, J. M. 1982. Depressão gravimétrica de Itaboraí (RJ). In: XXXII CONGRESSO BRASILEIRO DE GEOLOGIA, Salvador, Bahia, Anais, 4: 1637-1643.

HARTNADY, W. J. \& LE ROEX, A.P. 1985. Southern ocean hot spot tracks and Cenozoic absolute motion of the African, Antartic and South American plates. Earth Planet. Sci. Lett., 75: 245 257.

HARTT, C.F.S. 1870. Geology and Physical Geography of Brazil. Fields osgood, 620 p.

HASUI, Y. \& PONÇANO, W.L. 1978. Organização estrutural e evolução na Bacia de Taubaté. In: $30^{\circ}$ CONGRESSO BRASILEIRO DE GEOLOGIA, Recife, Anais, 1: 368-381.

HASUI, Y. , CARNEIRO, C. D. R. \& COIMBRA, A. M. 1975. The ribeira folded belt. Rev. Bras. Geoc., São Paulo, 5 (4): 257-266.

HASUI, Y., GIMENEZ, A. F. \& MELO, M. S. 1978. Sobre as bacias tafrogênicas continentais do sudeste brasileiro. In: $30^{\circ}$ CONGRESSO BRASILEIRO DE GEOLOGIA, Recife, Anais, 1: 382-391.

HASUI, Y., MAGAlhãES, F. J., COPPEDE JR., A. \& MAGUTTI, R. L. 1992. Mina de Carbonatito de Jacupiranga (SP): permeabilidade do maciço avaliada pelo modelo geoestrutural. In: HASUI, Y \& MIOTO, J. A. (coords.). Geologia Estrutural Aplicada. ABGE/Votorantim, São Paulo, p. 383-398.

HEMBOLD, P.; VALENÇA, J. G. \& LEONARDOS JR., D. H. 1965. Mapa geológico do estado da Guanabara. DNPM, Rio de Janeiro.

HEILBRON, M. 1993. Evolução tectono-metamórfica da seção Bom Jardim (MG) - Barra de Piraí (RJ). Setor central da faixa ribeira. São Paulo. Tese de Doutorado, Instituto de Geociências, Universidade de São Paulo.

HEILBRON, M.; CHRISPIN, S.; ALVES, R.P. \& SIMÕES, L. S. A. 1982. Geologia do Cabo dos Búzios (Estado do Rio Janeiro), An. Acad. Bras. Ci.., Rio de Janeiro, 54 (3): 553-562.

HEILBRON, M.; MOHRIAK, W.U., VALERIANO, C.M., MILANI, E.J.; ALMEIDA, J. \& TUPINAMBÁ, M. 2000. From Collision to Extension: The Roots of the Southeastern Continental margin of Brazil. In: MOHRIAK, W. \& TALWANI, M. (eds.). Atlantic Rifts and Continental Margins, AGU Geoph. Mon. 115: 1-32.

HERZ, M. 1977. Timing of spreading in the South Atlantic: information from brazilian alcalic rocks. Geol. Soc. Am. Bull., 88: 101-112. 
HESSEL, M.H.R.; AIRES, J.R.; SPADINI, A.R.; AZAMBUJA FILHO, N.C.; BERGQVIST, L.P. \& RODI, A.M. 1993. História geológica da Bacia de Itaboraí. In: III SIMPÓSIO DO SUDESTE, Rio de Janeiro, Bol. Resumos e Breves Comunicações, p. 18-19.

HIRUMA, S.T. 1999. Neotectônica no Planalto de Campos de Jordão, SP. São Paulo, 102p. Dissertação de Mestrado. Instituto de Geociências, Universidade de São Paulo.

JOLLY, R.J.H. \& SANDERSON, D.J. 1995. Variation in the form and distribution of dykes in the Mull Swarm, Scotland. J. Struct. Geol., 17 (11): 1543-1557.

JOPLING, A.V. \& WALKER, R.G. 1968. Morphology and origin of ripple-drift cross-lamination with examples from the Pleistocene of Massachusets. Jour. Sed. Petrology, v. 38, p. 971-984.

KARNER, G. D., USSAMI, N. \& ALKMIM, F. 1994. Tectonic significance of the topography of the Southeastern Brazil: speculations and implications. Rev. Esc. Minas, 47 (1): 18-19.

KATTENHORN, S.A. \& SANDERSON, D.J. 1995. Blunt-Ended dyke segments. J. Struct. Geol., 17 (11): 1535-1542.

KEEFER, D.K. 1984. Landslides caused by earthquakes. Geol. Soc. Am. Bull., 95:406-421.

KING, L. C. 1956. A geomorfologia do Brasil Oriental. Rev. Bras. Geogr., 18 (2): 147-265.

KING, L. C. 1957. The uniformitarian nature of hillslopes. Trans. Edinburgh Geol. Soc., 17: 81102.

KING, L.C. 1967. The Morfology of the Earth. Edinburgh: Oliver \& Boyd.

KLEIN, V. C. 1993. O vulcão alcalino de Nova Iguaçu (Estado do Rio de Janeiro): Controle estrutural e processo de erupção. Rio de Janeiro, 107 p. Tese de Doutorado, Instituto de Geociências, Universidade Federal do Rio de Janeiro.

KLEIN, V. C. \& VIEIRA, A.C. 1980. Uma chaminé vulcânica na serra de Madureira, Nova Iguaçu, Rio de Janeiro. An. Acad. Bras. Cienc., 52 (1): 200. Resumos.

KLEIN, V. C. \& RODRIGUES FRANCISCO, B. H. 1981. Aspectos sedimentares e estruturais na bacia calcária de São José de Itaboraí, RJ, e suas implicações para a paleontologia. An. Acad. Bras. Ci., Rio de Janeiro, 53 (1): 135-142.

KLEIN, V. C. \& VALENÇA, J.C. 1984a. Estruturas almofadadas em derrame ankaramítico na bacia de São José de Itaboraí, RJ. In: XXXIII CONGRESSO BRASILEIRO DE GEOLOGIA, Rio de Janeiro, Anais, p. 4335-4345. 
KLEIN, V. C. \& VALENÇA, J.C. 1984b. Mecanismo de colocação de brechas fluidizadas na área de Cabuçu (Complexo alcalino do Mendanha), RJ. In: XXXIII CONGRESSO BRASILEIRO DE GEOLOGIA, Rio de Janeiro, Anais, 4355-4361.

KLEIN, V. C. \& VALENÇA, J.C. 1989. Inclusões máficas: indício de mistura de magmas e do processo explosivo no complexo alcalino de Cabuçu. $1^{\circ}$ SIMPÓSIO DE GEOLOGIA DO SUDESTE, Rio de Janeiro, Resumos: 183-184.

KLEIN, V. C.; VALENÇA, J. G. E VIEIRA, A.C. 1984. Ignimbritos do vulcanismo de Nova Iguaçu e da "chaminé do Lamego", RJ. In: XXXIII CONGRESSO BRASILEIRO DE GEOLOGIA, Rio de Janeiro, Anais, p. 4346-4354.

KLEIN, V. C., ANTONELLO, L. L. \& VALENÇA, J. G. 1996. Diques basálticos pós-alcalinas no Rio de Janeiro, RJ. In: XXXIX CONGRESSO BRASILEIRO DE GEOLOGIA, SBG, Salvador, Anais, 2: 144-145.

KLEIN, V. C.; ANDREIS, R.R.; RAMOS, R.R.C. \& VALENÇA, J.G. 1999. Depósitos vulcanoclásticos em Itauna (RJ): análise preliminar de sua estratigrafia, estrutura e composição. An. Acad.Ci., 71 (1): 153.

KNIGHT, M.D. \& WALKER, G.P.L. 1988. Magma Flow Directions in Dikes of the Koolau Complex, Oahu, Determined From Magnetic Fabric Studies. J.G.R. 93: 4301-4319.

KUSZNIR, N. J., MARSDEN, G. \& EGAN, S. S. 1991. A flexural-camtilever simple-shear / pureshear model of continental lithosphere extension: applications to the Jeanne D'Arc Basin, Grand Banks and Viking Graben, North Sea. In: ROBERTS, A. M., YIELDING, G. \& FREEMAN, B. (eds.). The Geometry of Normal Faults. Geol. Soc. Spec. Publ., 56: 41-60.

LADEIRA, E. A.; BRAUN, O. P. G.; CARDOSO, R. N. \& HASUI, Y. 1971. O cretáceo em Minas Gerais. In: 25 CONGRESSO BRASILEIRO DE GEOLOGIA, SBG, São Paulo.

LAMEGO, A.R. 1944. A Bacia de Campos na geologia litorânea do petróleo. Bol. DGM/DNPM, $113,69 \mathrm{p}$.

LAMEGO, A.R. 1954. Uma chaminé vulcânica no Distrito Federal. Div. Geol. Min., Bol. 88, 19 p, Rio de Janeiro.

LEEDER, M.R. 1991. Sedimentology, Process and Product. $6^{\mathrm{a}}$ ed. London: Harper Collins Academic, 344p.

LEEDER, M.R. 1995. Continental Rifts and Proto-Oceanic Rift Troughs. In: BUSBY, C.J. \& INGERSOLL, R.V. (eds.) Tectonics of Sedimentary Basins. Oxford: Blackwell Science, 548p. 
LEEDER, M.R. \& GAWTHORPE, R.L. 1987. Sedimentary models for extensional tilt-block/half graben basins. In: COWARD, DEWEY, J. \& HANCOCK, P. (eds.). Continental extensional Tectonics. Geol. Soc. Spec. Publ., 28: 139-154.

LEINZ, V. 1938. Os calcários de São José, Niterói, Estado do Rio. Mineração e Metalurgia, Rio de Janeiro, 3(15):153-155.

LIMA, C. C. 1987. Estruturação pós-rift da porção sergipana da Bacia Sergipe /Alagoas: o papel do basculamento e das descontinuidades do embasamento. Ouro Preto, 378 p. Dissertação de Mestrado, Universidade Federal de Ouro Preto.

LIMA, M.R. \& AMADOR, E.S. 1985. Análise palinológica dos sedimentos da Formação Resende, Terciário do Estado do Rio de Janeiro, Brasil. Série Geologia, Seção de Paleontologia e Estratigrafia, DNPM, 27(2): 371-378.

LIMA, M.R. \& CUNHA, F.L.S. 1986. Análise palinológica de um nível linhítico da Bacia de São José de Itaboraí, Terciário do Estado do Rio de Janeiro, Brasil. An. Acad. Bras. Cienc., 58(4): 557-588.

LIMA, M.R.; RICCOMINI, C. \& SOUZA, P.A. 1994. Palinologia de folhetos do Gráben de Casa de Pedra, Terciário do Estado do Rio de Janeiro, Brasil. Acta Geologica Leopoldensia, 27 (39/2): 485-504.

LIMA, M. R., CABRAL JUNIOR, M. \& STEFANI, F. L. 1996. Palinologia de Sedimentos da Formação Macacu - Rifte da Guanabara, Terciário do Estado do Rio de Janeiro, Brasil. An. Acad. Bras. Ci., Rio de Janeiro, 68 (4): 531- 543.

LIMA, P. R. A. S. 1976. Geologia dos maciços alcalinos do Rio de Janeiro - parte I - localização e geologia dos maciços. Col. trabalhos apresentados I, II e III. Sem. Est. Geol. UFRRJ, Itaguaí, 205-245.

LIMA, P.R.A.S \& CHIVEGATTO, J.R.S. 1974. Relatório parcial das folhas de Cabo Frio e Farol do Cabo, DRM, Niterói.

MACEDO, J. M. 1989. Evolução tectônica da Bacia de Santos e áreas continentais adjacentes. Bol. Geoc. Petrobrás, Rio de Janeiro, 3 (3): 159-173.

MACEDO, J. M.; BACOCCOLI, G. \& GAMBOA, L. A. P. 1991. O tectonismo meso-cenozóico da região sudeste. In: $2^{\circ}$ SIMPÓSIO DE GEOLOGIA DO SUDESTE, SBG, São Paulo. Atas, p. 429-434. 
MACHADO FILHO, L.; RIBEIRO, M.V.; GONZALES, S.R.; SCHENINI, C.A.; NETO, A.S.; PALMEIRA, R.C.B.; PIRES, J.L.; TEIXEIRA, W. \& CASTRO, H.E.F. 1983. Geologia das Folhas Rio de Janeiro e Vitória (SF 23/24) escala 1:1000000, mapa e texto explicativo. In: Projeto Radam Brasil, Ministério das Minas e Energia, p. 27-304.

MACK, G.H. \& SEAGER, W.R. 1990. Tectonic control on facies distribution of the Camp Rice and Palomas Formation (Pliocene-Pleistocene) in the southern Rio Grande Rift. Geol. Soc. Am. Bull., 102:45-53.

MAGALHÃES, J.M. 1987. Evolução estrutural da Bacia de Santos e áreas continentais adjacentes. Ouro Preto. Dissertação de Mestrado, Universidade Federal de Ouro Preto.

MANCINI, F. 1995. Estratigrafia e aspectos da tectônica deformadora da Formação Pindamonhangaba, Bacia de Taubaté, SP. São Paulo, 107 p. Dissertação de Mestrado, Instituto de Geociências, Universidade de São Paulo.

MANN, P., HEMPTON, M. R., BRADLEY, D.C. \& BURKE, K. 1983. Development of pull-apart basins. Journ. Geol., 91: 529-554.

MARQUES, A. 1990. Evolução tectono-sedimentar e perspectivas exploratórias da Bacia de Taubaté, São Paulo, Brasil, B. Geoc., Petrobrás, Rio de Janeiro, 4 (3): 253-262.

MARSH, J. R. 1973. Relationship between transform directions and alcaline igneous rocks in Africa and South America. Earth Planet. Sci. Lett., 18: 317-323.

MCCLAY, K. \& DOOLEY, T. 1995. Analogue models of pull-appart basins. Geology, 23 (8): 711 714.

MCDOUGALL, I \& HARRISON, T. M. 1988. Geochronology and thermochronology by the Ar40/Ar39 method. Oxford monography on geology and geophysics: ${ }^{\circ} 9$, Oxford University Press, 212 p.

MCKEE, E.D. 1965. Experiments on ripple lamination. In: MIDDLETON, G.V. (ed.). Primary sedimentary structures and their hydrodinamic interpretation. Soc. Econ. Paleontologists and Mineralogists Spec. Pub., 12: 66-83.

MCKENZIE, D. 1978. Some remarks on the development of sedimentary basins. Earth Planet. Sci. Lett., $40: 25-32$.

MEIS, M. R. M. S. 1976. Contribuição ao estudo do Terciário Superior e Quaternário da Baixada da Guanabara. Lisboa, 238 p. Tese de Doutorado. Universidade de Lisboa. 
MEIS, M.R.M \& AMADOR, E.S. 1972. Formação Macacu: Considerações a respeito do NeoCenozóico da Baía de Guanabara. An. Acad. Bras. Ci., Rio de Janeiro, 44(3/4): 602.

MEIS, M.R.M \& AMADOR, E.S. 1974. Note on weathered arkosic beds. Journal of Sed. Petrol., 4 (3): 727-737.

MEIS, M. R. M. \& AMADOR, E. S. 1977. Contribuição ao estudo do Neocenozóico da Baixada da Guanabara: Formação Macacu. Rev. Bras. Geoc., São Paulo, 7 (2): 124-150.

MELO, C.L. 1997. Sedimentação e tectônica cenozóicas no Médio Vale do Rio Doce (MG, Sudeste do Brasil) e suas implicações na evolução de um sistema de lagos. São Paulo. Tese de Doutorado, Instituto de Geociências, Universidade de São Paulo.

MELO, M. S.; RICCOMINI, C.; HASUI, H.; ALMEIDA, F. F. M. \& COIMBRA, A.M. 1985a. Geologia e evolução do sistema de bacias tafrogênicas continentais do Sudeste do Brasil. Rev. Bras. Geoc., São Paulo, 15 (3): 193-201.

MELO, M. S., RICCOMINI, C., ALMEIDA, F. F. M. \& HASUI, Y. 1985b. Sedimentação e tectônica da Bacia de Resende, RJ. An. Acad. Bras. Ci., Rio de Janeiro, 57: 467-479.

MELLO, S.L.M. \& DIAS, M.S. 1996. Magnetoestratigrafia da crosta oceânica entre as zonas de fratura de Ascensão e Bode Verde. Rev. Bras. Geofisica, 14(3): 237-251.

MENDIGUREN, J.A. \& RICHTER, F.M. 1978. On the origin of compressional intraplate stresses in South America. Phys. Earth Plant. Inter., 16: 318- 316.

MENEZES, S.O. \& KLEIN, V.C. 1973. Ocorrências de barita em áreas adjacentes a maciços de rochas alcalinas no Estado do Rio de Janeiro. Rev. Min. Metalurgia, 345: $12-16$.

MENEZES, S.O., KLEIN, V.C., OLIVEIRA, J.A.L. \& FRANCISCO, B.H.R. 1977. Complementação do mapeamento geológico da Folha Santa Cruz NE-NO. Relatório Final, Convênio DRM/UFRRJ, 52p.

MIALL, A.D. 1977. A review of the braided-river depositional environment. Earth Science Rev., 13: 1-62.

MIALL, A.D. (ed.). 1978. Fluvial sedimentology. Candian Soc. Petroleum Geologists Mem., 5, 589 p.

MIALL, A.D. 1982. Analysis of fluvial depositional systems. Am. Assoc. Petroleum Geologists Education Course Notes Ser., 20, 75 p.

MILLOT, T. 1970. Geology of Clays. New York: Springer-Verlag, 425 p. 
MIOTO, J. A. 1990. Tentativa de zoneamento sísmico do sudeste brasileiro. Bol. Soc. Bras. Geol., Núcleo Minas Gerais, 11: 33-45.

MOHRIAK, W. U. \& BARROS, A. Z. N. 1990. Novas evidências de tectonismo Cenozóico na região sudeste do Brasil: O Graben de Barra de São Jõao, na plataforma de Cabo Frio, RJ. Rev. Bras. Geoc., São Paulo, 20 (1-4): 187- 196.

MOHRIAK, W. U. \& MAGALHÃES, J.M. 1993. Estratigrafia e evolução estrutural da área norte na Bacia de Santos. In: III SIMPÓSIO DE GEOLOGIA DO SUDESTE, SBG, Rio de Janeiro, Anais, p. 19-26.

MOHRIAK, W. U., BARROS, A. Z. N. \& FUJITA, A. 1990. Magmatismo e tectonismo cenozóico na região de Cabo Frio, RJ. In: XXXVI CONGRESSO BRASILEIRO DE GEOLOGIA, Natal, Anais, 6: 2873-2884.

MOHRIAK, W.U.; SAD, A.R.E. \& REIS, A.P. 1992. Integração das Folhas Geológicas 1:50000 do Estado do Rio de Janeiro. Projeto PETROBRÁS/Departamento de Recursos Minerais do Estado do Rio de Janeiro (DRM,RJ), texto, 64p.

MOHRIAK, W. U.; MAGALHÃES, J.M. \& TARABINI, R. 1993. Estilos estruturais e tectônica de sal na região de Cabo Frio, RJ. In: III SIMPÓSIO DE GEOLOGIA DO SUDESTE, SBG, Rio de Janeiro, p.64- 70.

MOHRIAK, W. U. et al. 1995. Salt tectonics and strucutural styles in the deep-water province of the Cabo Frio region, Rio de Janeiro, Brazil. In: JACKSON, M. P. A., ROBERTS, D. G. \& SNELSON, S. (ed.) Salt Tectonics: A Global Perspective. AAPG Memoir 65, p. 273-304.

MORGAN, W. J. 1983. Hot spot tracks and the early rifting of the of the atlantic. Tectonophysics, 94: $123-139$.

MORLEY, C.K. 1988. Variable extension in the Lake Tanganyka. Tectonics, 7(4): 785- 801.

MORLEY, C.K.; CREVELLO, P. \& ZULKIFLI HAJI AHMAD. 1998. Shale tectonics and deformation associated with active diapirism: the Jerudong Anticline, Brunei Darussalam. $J$. Geol. Soc. London, 155: 475- 490.

MOTOKI, A. 1986. Geologia e petrologia do maciço alcalino da Ilha de Vitória, SP. São Paulo, 254p. Tese de Doutorado, Instituto de Geociências, Universidade de São Paulo.

MOTOKI, A., ÁVILA, C.A. \& ROIG, H.L. 1988. Estudos litológicos e geológicos dos corpos intrusivos tabulares no Município de Arraial do Cabo, RJ. In: XXXV CONGRESSO BRASILEIRO DE GEOLOGIA, Belém, 6: 2727-2739. 
NARDY, A. J. R. \& MARQUES, L. S. 1996. O vulcanismo Mesozóico da Bacia do Paraná: fonte litosférica ou astenosférica? In: $4^{\circ}$ SIMPÓSIO SOBRE O CRETÁCEO DO BRASIL, Águas de São Pedro (SP), Boletim, 1: 229-234.

NASCIMENTO, V. M. R.; SILVA, C.G.; SILVA, T. M. \& FERRARI, A. L. 1994. Compartimentação morfoestrutural da Região Nordeste do Estado do Rio de Janeiro, Brasil. In: XXXVIII CONGRESSO BRASILEIRO DE GEOLOGIA, Camboriú, Anais, 3: 190-192.

NAYLOR, M.A.; MANDL, G. \& SIJPESTEIN, C.H.K. 1986. Fault geometries in basement-induced wrench faulting under different initial stress states. J. Struct. Geol., 8(7): 737- 752.

NETON, M.J.; DORSCH, J.; OLSON, C.D. \& YOUNG, S.1994. Architeture and directional scales of heterogeneity in alluvial-fan aquifers. J. Sedim.Res., B64 (2): 245-257.

NETTO, A.M.; VALERIANO, C.M.; POUPEAU, G. \& LABRIN, E. 2000. Apatite fission-track thermocronology of the Sugar Loaf, Rio de janeiro, Brasil. In: $31^{\circ}$ CONGRESSO INTERNACIONAL DE GEOLOGIA, Rio de Janeiro, Agosto 2000, Abstracts, CDROM.

NICHOLSON, R. \& POLLARD, D.D. 1985. Dilation and linkage of echelon cracks. J. Struct. Geol., 7(5): 583-590.

NILSEN, T.H. 1982. Alluvial fan deposits. In: Scholle, P.A. \& Spearing, D. (Eds.), Sandstone Depositional environments. American Assoc. Petrol. Geol. Mem., 31:49-86.

NILSEN, H. \& SYLVESTER, A.G. 1995. Strike Slip Basins. In: BUSBY, C.J. \& INGERSOLL, R.V. (eds.). Tectonics of Sedimentary Basins. Oxford:Blackwell Science, 548p.

O'CONNOR, J. M. \& DUNCAN, R. A. 1990. Evolution of the Walvis Ridge - Rio Grande Rise hot spot system: implications for African and South American plate motions over plumes. $J$. Geophys. Res., 95 (B11): 17475-17502.

OLIVEIRA, A.I. 1956. Brazil. In: JENKS, W.F. (ed.). Handbook of South American Geology. Baltimore: Geological Society of American, Memoir 65, 1-63.

OLSON, J. \& POLLARD, D.D. 1989. Inferring paleostresses from natural fracture patterns: a new method. Geology, 17: 345-348, apr.

PADILHA, A. L., TRIVERDI, N. B., VITORELLO, I. \& DA COSTA, J. M. 1991. Geophysical constraints on tectonic models of the Taubaté Basin, southeastern Brazil. Tectonophysics, 196: 157-172. 
PAULA COUTO, C. 1952. Fossil Mammals from the beginning of the Cenozoic in Brazil. Condylarthra, Litopterna, Xenungulata and Astrapotheria. Bull. Amer. Mus. Nat. Hist., 99(6): 335-394.

PAULA COUTO, C. 1953. A Bacia calcária de Itaboraí e a tectônica da costa sudeste do Brasil. DEGEO/DNPM, Notas preliminares. Estudos, Rio de Janeiro, 75, 12p.

PENHA, H. M.; FERRARI, A. L.; RIBEIRO, A.; AMADOR, E. S.; PACIULLO, F. V. P.; JUNHO, M. C. B. \& BRENNER, T. L. 1979. Projeto Folha Petrópolis, Relatório Final. Convênio IG/UFRJ - DRM.

PENHA, H. M.; FERRARI, A. L.; RIBEIRO, A.; AMADOR, E. S.; PACIULLO, F. V. P.; JUNHO, M. C. B. \& BRENNER, T. L. 1980. A geologia da Folha Petropólis. In: XXXI CONGRESSO BRASILEIRO DE GEOLOGIA, Camboriú, Anais, 5: 2965-2974.

PENHA, H. M.; FERRARI, A. L.; JUNHO, M. C. B.; SOUZA, S. L. A. \& BRENNER, T. L. 1982. Projeto Folha Itaipava, Relatório Final. Convênio IG/UFRJ - DRM (inédito).

PEREIRA, J.P. 1992. Considerações sobre a estratigrafia do Cenomaniano-Santoniano em algumas bacias marginais brasileiras e sua implicação na história tectônica e sedimentar da margem continental. Bol. Geoci. Petrobrás, 6 (3/4): 171 - 176.

PEREIRA, M. J.; BARBOSA, C. M.; AGRA, J.; GOMES, J. B.; ARANHA, L. G. F.; SATTO, M.; RAMOS, M.A.; CARVALHO, M.D.; STAMATO, M. \& BAGNI, O. 1986. Estratigrafia da Bacia de Santos: análise das seqüências, sistemas deposicionais e revisão litoestratigráfica. In: XXXIV CONGRESSO BRASILEIRO DE GEOLOGIA, SBG, Goiânia, Anais, 1: 65-79.

PETRI, S. et al. 1986. Guia de nomenclatura estratigráfica. Rev. Bras. Geoc., São Paulo, 16 (4): 376-415.

PETTIT, J. P. 1987. Criteria for sense of movement on fault surfaces in brittle rocks. J. Struct. Geol., 9 (516): 597-608.

PLINT, A.G. \& BROWNE, G.H. 1994. Tectonic event stratigraphy in a fluvio-lacustrine, strike-slip setting: The Boss Point Formation (Westphalian A), Cumberland basin, Maritime Canada. J. Sed. Res., B64 (3):341-364.

POLLARD, D.D. 1987. Elementary fracture mechanics applied to the structural interpretation of dykes. In: Halls, H.C. \& Fahrig, W.F. (eds). Mafic dyke swarms. Geol. Ass. Can. Spec. Paper, 34: 5- 24. 
PORTO JR., R. \& VALENTE, S.C. 1989. Ocorrência de traquito orbicular na região de Bangu, R.J. In: I SIMPÓSIO DE GEOLOGIA DO SUDESTE, Rio de Janeiro, Resumos, 180-181.

PRICE, L.I. \& CAMPOS, D. A. 1970. Fósseis pleistocênicos no Município de Itaboraí, Estado do Rio de Janeiro. In: XXIV CONGRESSO BRASILEIRO DE GEOLOGIA, Brasília, Anais, 355-358.

RAGAN, D.M. 1973. Strucutural Geology: an Introduction to Geometrical Techiques. 2 ed. New York: Wiley, $208 \mathrm{p}$.

RAMANE et al. 2000. Carta estratigráfica mundial. Comissão Internacional de Estratigrafia/UNESCO.

RAMOS, R. R. 1997. Estratigrafia da Sucessão Sedimentar Terciária da Bacia de Resende, entre Resende e Quatis (RJ), com ênfase na caracterização das litofácies, ciclicidade e paleocorrentes. Rio de Janeiro, 209 p. Dissertação de Mestrado, Departamento de Geologia, Instituto de Geociências, Universidade Federal do Rio de Janeiro.

RAMSAY, J. \& HUBER, M. I. The Techniques of Modern Structural Geology. London: Academic Press, 1987, 700 p. (Vol. 2, Folds and fractures).

RANGEL, H. D. 1987. A geologia do petróleo na bacia de Campos: concepções de Alberto Ribeiro Lamego em 1944. In: I SIMPÓSIO DE GEOLOGIA DO SUDESTE, SBG, regional RJ-ES, Rio de Janeiro, Anais, 1: 1-13.

RANGEL, H. D. \& BARROS, A. Z. N. 1993. Estratigrafia e evolução estrutural da área sul (adjacente ao Alto de Cabo Frio) na Bacia de Santos. In: III SIMPÓSIO DE GEOLOGIA DO SUDESTE, SBG, Rio de Janeiro, Anais, p. 57-70.

READING, H. G. 1980. Characteristics and recognition of strike-slip fault systems. In: BALLANCE, P.F. \& READING, H. G. (eds.). Sedimentation in oblique-slip mobile zones. Inter. Ass. Sed. Spec. Publ., 4: 7-26.

READING, H. G. 1996. (ed.) Sedimentary Environments: Processes, Facies and Stratigraphy. 3 ed. Blackwell Publishers, 688p.

RECHES, Z, 1999. Mechanisms of slip nucleation during earthquakes. Earth Plant. Sci. Lett., 170: 475-486.

REGELOUS, M. 1990. Geochemistry of dolerites from the Paraná flood basalt province, Southern Brazil. England, 200 p. $\mathrm{PhD}$ thesis, Open University. 
REINFELDS, I. \& NANSON, G. 1993. Formation of braided river floodplains, Waimakariri River, New Zealand. Sedimentology, 40:1113-1127.

REINECK, H. E. \& SINGH, I. B. 1980. Depositional Sedimentary Enviroments, 2 ed. Berlin: Springer Verlag, $551 \mathrm{p}$.

REITER, F. \& ACS, P. 1995. Programa demo para tratamento de dados estruturais - FpTectonics.

Disponível em http://www.uibk.ac.at/homepage/Franz.Reiter. Último acesso em 25/06/2001.

REIS, A.P. \& LICHT, O.A.B. 1977. Projeto Carta Geológica do Estado do Rio de Janeiro, Mapa

Geológico da Folha Barra de São João. Departamento de Recursos Minerais do Estado do Rio de Janeiro, Niterói, inédito.

REIS, A.P.; NUNES, H.H.R.; CHIVEGATTO, J.R.S.; LIMA, P.R.A. \& ROCHA, R.L.S. 1976. Geologia e Recursos minerais dsa folhas Cabo Frio e Farol do Cabo, DRM, Niterói (inédito). RENNE, P. R.; DECKART, K.; ERNESTO, M.; FÉRAUD, G. \& PICCIRILLO, E. M. 1996. Age of the Ponta Grossa dike swarm (Brazil), and implications to Paraná flood volcanism. Earth Plant. Sci. Lett., 144: 199-211.

RETALLACK, G. J. 1990. Soils of the past: na introduction to paleontology. Boston, Unwin Hyman, $520 \mathrm{p}$.

RICCOMINI, C. 1989. O Rift continental do sudeste do Brasil. São Paulo, 256 p. Tese de Doutorado, Instituto de Geociências, Universidade São Paulo.

RICCOMINI, C. 1995a. Tectonismo gerador e reformador dos depósitos sedimentares PósGondwânicos da porção centro-oriental do Estado de São Paulo e áreas vizinhas. São Paulo, 100 p. Tese de Livre Docência, Instituto de Geociências, Universidade de São Paulo.

RICCOMINI, C. 1995b. Padrão de fraturamentos do Maciço Alcalino de Cananéia, Estado de São

Paulo: relações com a tectônica mesozóico-cenozóica do sudeste do Brasil. Rev. Bras. Geoc., São Paulo, 25 (2): 79-84.

RICCOMINI, C. 1996. Tectônica da Bacia Baurú no Estado de São Paulo. In: XXIX CONGRESSO BRASILEIRO DE GEOLOGIA, SBG, Salvador, Anais, 5: 369-371.

RICCOMINI, C. 1997. Arcabouço estrutural e aspectos do tectonismo gerador e deformador da Bacia Bauru no Estado de São Paulo. Revista Brasileira de Geociências, São Paulo, 27 (2): 153-162, jun. 
RICCOMINI, C. \& COIMBRA, A.M. 1992. Geologia da bacia sedimentar. In: NEGRO JR., A; FERREIRA, A.A.; ALONZO, U.R. \& LUZ, P.C.A. (eds.). Solos da Cidade de São Paulo. São Paulo: USP/CNPq, 37-94.

RICCOMINI, C. \& RODRIGUES FRANCISCO, B. H. 1992. Idade potássio-argônio do derrame de ankaramito da Bacia de Itaboraí, Rio de Janeiro, Brasil: implicações tectônicas. In: XXXVII CONGRESSO BRASILEIRO DE GEOLOGIA, São Paulo, Bol. Res. Expandidos, p. 469-470. RICCOMINI, C.; MELO, M. S.; CARNEIRO, C.D.R.; ALMEIDA, F. F. M.; MIOTO, J. A. \& HASUI, Y. 1983. Sobre a ocorrência de um derrame de ankaramito na bacia de Volta Redonda (RJ) e sua importância na datação das bacias trafogênicas continentais do sudeste brasileiro. In: SIMPÓSIO REGIONAL DE GEOLOGIA, 4, São Paulo, Resumos, p. 23-24.

RICCOMINI, C.; MELO, M. S.; ALMEIDA, F. F. M. \& HASUI, Y. 1985. Geologia da Bacia de Volta Redonda, Rio de Janeiro, Brasil. An. Acad. Bras. Ci., Rio de Janeiro, 57: 518-519.

RICCOMINI, C., APPI, C.J., FREITAS, E.L., ARAI, M. 1987. Tectônica e sedimentação no Sistema de Rifts Continentais da Serra do Mar (bacias de Volta Redonda, Resende, Taubaté e São Paulo). In: I SIMPÓSIO DE GEOLOGIA RJ-ES, Rio de Janeiro, SBG, Atas, p. 253-298. RICCOMINI, C.; COUTINHO, J.M.C.; GUARANÁ, C.A.; COIMBRA, A.M.; HASHIRO, J.; ATENCIO,D,; \& YIOMASA,W.S. 1988. Evidências de hidrotermalismo em sedimentos da Bacia de São Paulo: considerações genéticas. An. Acad. Bras. Ci., Rio de Janeiro, 60: 105-106, Rio de Janeiro.

RICCOMINI, C.; PELLOGIA, A.U.G.; SALONI, J.C.L.; KOHENKE, M.W. \& FIGUEIRA, R.M. 1989. Neotectonic activity in the Serra do Mar rift system (Southeastern Brazil). J. South Am. Earth Sci., 2 (2): 191-197.

RICCOMINI, C.; SANT'ANNA, L.G.; COIMBRA, A.M. 1996. Argilominerais do paleolago Tremembé e sistemas deposicionais relacionados. Rev. Bras. Geoc., São Paulo, 26 (3): 169-82. RICHARDSON, R. M. 1992. Ridge forces, absolute plate motions, and the intraplate stress field. $J$. Geophys. Res., 97(B7): 11905 - 11913.

RICKWOOD, P.C. 1990. The anatomy of a dyke and the determination of propagation and magma flow directios. In: PARKER; RICKWOOD \& TURKER (eds.) Mafic dykes and emplacement mechanisms. Rotterdam: Balkema.

RIDEG, P., STEIN, J. \& TOTIS, E. 1989. A falha do morro de São João em Botafogo - Rio de Janeiro. In: I SIMPÓSIO DE GEOLOGIA DO SUDESTE, SBG, Rio de Janeiro, p. 130-131. 
RIEDEL, W. 1929. Zur Mechanik geologischer Brucherscheinungen: Centralbl. f. Mineral. Geol. u. Pal., v. 1929 B, p. 354-368.

ROBERTS, A. M. \& YIELDING, G. 1991. Deformation around basin-mrgin faults in the NorthSea/Mid-Norway Rift. In: ROBERTS, A. M., YIELDING, G. \& FREEMAN, B. (eds.) The Geometry of Normal Faults. Geol. Soc. Spec. Publ., 56: 61-78.

ROBERTS, A. M. \& YIELDING, G. 1994. Continental extensional tectonics. In: HANCOCK, P. L. (ed.) Continental Deformation, Pergamon-Press, p. 223-250.

RODRIGUES, C. R. V. \& HARALYI, N. L. E. 1984. Anomalias magnéticas lineares das folhas Itaboraí, Maricá, parte das folhas Saquarema e Rio Bonito, RJ. In: XXXIII CONGRESSO BRASILEIRO DE GEOLOGIA,Rio de Janeiro, Atas, p. 2004-2010.

RODRIGUES FRANCISCO, B. H. \& CUNHA, F. L. S. 1978. Geologia e estratigrafia da Bacia de São José, Município de Itaboraí, RJ. An. Acad. Bras. Ci., Rio de Janeiro, 50 (3): 381-416.

RODRIGUES FRANCISCO, B. H.; GONZALES, B.B.; PEROBA, C.E.N. \& GUEDES, S.C. 1986.

Estudo dos testemunhos de sondagem na Bacia de São José, Itaboraí, RJ. I. furo SJ-2T. Série Geologia, Seção de Paleontologia e Estratigrafia, DNPM, 27(2): 651-652.

ROSIER, G.F. 1965. Pesquisas geológicas na parte oriental do Estado do Rio de Janeiro e na parte vizinha do Estado de Minas Gerais. Bol. Div. Geol. Min., DNPM, Rio de Janeiro, 222, 40p.

ROSSETTI, D. F. 2000. Influence of low amplitude frequency relative sea-level changes in a wavedominated estuary (Miocene), São Luis Basin, northern Brazil. Sed. Geology, 133: 295-324.

RUELLAN, F. 1944. A evolução geomorfológica da baía de Guanabara e das regiões vizinhas. Rev. Bras. Geogr., ano IV, $\mathrm{n}^{\circ} 4$.

RUST, B. R. \& GIBLING, M. R. 1990. Braidplain evolution in the Pennsylvanian South Bar Formation, Sidney Basin, Nova Scotia, Canada. J. Sed. Petrol., 60: 59-72.

RUST, B. R. \& KOSTER, E.H. 1984. Coarse alluvial deposits. In: WALKER, R.G. (ed.). Facies Models. 2 ed. Geoscience Canada Reprint Series 1, p. 53-69.

SADOWSKI, G. R. 1976. Ativação de plataforma na América do Sul e as zonas de fratura do Atlântico Sul. In: XXIX CONGRESSO BRASILEIRO DE GEOLOGIA, Ouro Preto, Anais, 4: 13-23.

SADOWSKI, G. R. 1987. A possible relation between pulses of platform activation and plate kinematics. Tectonophysics, 143: 43-57. 
SADOWSKI, G. R. \& DIAS NETO, C. M. 1981. O lineamento sismo-tectônico de Cabo Frio. Rev. Bras. Geoc., São Paulo, 11 (4): 209-212.

SAN'KOV, V.A.; MIROSHNICHENKO, A.I.; LEVI, K.G., LUKHNEV, A.; MELNIKOV, A.I.; DELVAUX, D. 1997. Cenozoic stress field evolution in the Baikal rift zone. Bull. Centres. Res. Explor.-Prod. Elf Equitaine, 21: 435-455.

SALVADOR, E. D. 1994. Análise neotectônica da região do Vale do Rio Paraíba do Sul compreendida entre Cruzeiro (SP) e Itatiaia (RJ). São Paulo, 129 p. Dissertação de Mestrado, Instituto de Geociências, Universidade de São Paulo.

SALVADOR, E. D. \& RICCOMINI, C. 1995. Neotectônica do Alto Estrutural de Queluz (SP-RJ, Brasil). Rev. Bras. Geoc., São Paulo, 25 (3): 151-164.

SANT'ANNA, L.G. 1999. Geologia, Mineralogia e gênese das esmectitas dos depósitos paleogênicos do Rift Continental do Sudewste do Brasil. São Paulo, 239p. Tese de Doutorado, Instituto de Geociências, Universidade de São Paulo.

SANT'ANNA, L.G. \& RICCOMINI, C. 2001. Cimentação hidrotermal em depósitos sedimentares paleogênicos do Rift Continental do Sudeste do Brasil: mineralogia e relações tectônicas. Rev. Bras. Geoc., no prelo.

SANT'ANNA, L.G.; RICCOMINI, C.; CARVALHO, M.D.; SIAL, A.N.; RODRIGUES FRANCISCO, B.H. \& VALARELLI, J.V. 1998. Catodoluminescência e isótopos estáveis (C, O) calcário sinter da Bacia de Itaboraí, Rio de Janeiro, Brasil. In: XL CONGRESSO BRASILEIRO DE GEOLOGIA, Belo Horizonte, Resumos, p. 522.

SANT'ANNA, L.G.; RICCOMINI, C.; CARVALHO, M.D.; SIAL, A.N. \& RODRIGUES FRANCISCO, B.H. 2000. Paleocene/Eocene travertines in the Itaboraí basin (Rio de Janeiro State, southeastern Brazil). In: INTERNATIONAL GEOLOGY CONGRESS, 30, Rio de Janeiro, Brasil, Abstracts volume (CD-ROM).

SANTOS, R.P. 1994. Datation K/Ar e Rb/Sr d'argiles de mineralisation et de diagenése le long de la côte est de l'Amerique du Sud. Implications geodynamiques. France, 267p. Tese de Doutorado, Grenoble I.

SCHOBBENHAUS, C.; CAMPOS, D.A.; DERZE, G.R. \& ASMUS, H. E. 1984. Geologia do Brasil - texto explicativo do mapa geológico do Brasil e da área oceânica adjacente, incluindo depósitos minerais - escala 1:2500000. DNPM, MME, Brasília. 
SCHUMM, S. A. 1968. Speculations concerning paleohydrologic controls of terrestrial sedimentation. Geological Society of America Bulletin, 79: 1573-1588.

SEILACHER, A. 1982. General remarks about event deposits. In: EINSELE \& SEILACHER (eds.) Cyclic and Event Stratification. New York: Springer-Verlag, p. 161-174

SEILACHER, A. 1984. Sedimentary structures tentatively attributed to seismic events. Mar. Geol., 55: $1-12$.

SELBY, M.J. 1994. Hillslope sediment transport and deposition. In: PYE, K. (ed.). Sediment transport and depositional processes. Blackwell Scientific Publications, 397 p.

SICHEL; S.E.; CARLSOS, R.W.; ESPERANÇA, S.; ARAÚJO, A.L.N. \& VALENÇA, J.G. 1997. Preliminary isotopic study of the alcalic intrusive complexes along the Cabo Frio Lineament, RJ, Brazil. South-American Symposium on Isotope Geology, Brazil, p. 298- 300.

SILVA, M. A. M., FERRARI, A. L., PENHA, H. M., DAYAN, H., MORETTI, A. \& SILVA, T. M. 1996. Compartimentação tectônica da área emersa adjacente ao Alto de Cabo Frio e às bacias de Campos e Santos. In: Compartimentação tectônica entre as bacias de Campos e Santos: Papel da Zona de Fratura do Rio de Janeiro e magmatismo do Alto de Cabo Frio. Convênio GGO-UFF/PADCT, relatório parcial.

SILVA, T.M. \& FERRARI, A. L. 1997a. Controle tectônico da compartimentação geomorfológica no segmento nordeste do Rift Continental do Sudeste do Brasil. In: V SIMPÓSIO DE GEOLOGIA DO SUDESTE, SBG, Itatiaia - RJ, Resumos Expandidos, 48- 50.

SILVA, C.G. \& FERRARI, A.L. 1997b. Neotectônica no litoral nordeste do Estado do Rio de Janeiro. In: V SIMPÓSIO DE GEOLOGIA DO SUDESTE, SBG, Itatiaia - RJ, Resumos Expandidos, p. 80-82.

SRIVASTAVA, D.C. 2000. Geometric classification of conjugated vein arrays. J.S.G., 22: 713-722.

SLEEP, N.H. 1997. Lateral flow and ponding of starting plume material. J Geophys. Res., 102 (B5): 10001-10012.

SMITH, R.P. 1987. Dyke emplacement at Spanish Peaks, Colorado. In: HALLS, H.C. \& FAHRIG, W.F. (ed.) Mafic dyke swarms. Geol. Ass. Can. Spec. Paper, 34: 47-54.

SMITH, R. M. H., MASON, T.M. \& WARD, J.D. 1993. Flash-flood sediments and ichnofacies of the Late Pleistocene Homeb Silts, Kuiseb River, Namíbia. Sed. Geology, 85:579-599.

SMITH, J.V. 1995. True and apparent geométric variability of en-echelon vein arrays. J. Struct. Geol., 17: 1621- 1626. 
SOMMER, F.W. 1954. Sobre os frutos fósseis da bacia calcária de São José de Itaboraí. An. Acad. Bras. Ci., Rio de Janeiro, 16: 26p.

SONDER, L.J. 1990. Effects of density contrasts on the origem of stresses in the lithosphere: Relation to principal stress directions in the Transverse Ranges, Califórnia. Tectonics, 9: 761771.

SONOKI, I.K. \& GARDA, G.M. 1988. Idades K-Ar de rochas alcalinas do Brasil Meridional e

Paraguai Oriental: compilação e adaptação às novas constantes de decaimento. Bol. IG-USP, Série Científica, 19: 63- 85.

SOUZA, K. G. 1991. La marge continentale Bresilienne sud-orientale e les domaine oceanique adjacents: structure et evolution. France, 229p. Tese de Doutorado,Universidade Pierre e Marie Curie.

SPERLE, M.; BRAGA, L.F.S. \& KARNER, G.D. 1997. Aplicação de um modelo tectonofísico na porção marginal do sudeste do Brasil e suas implicações tectônicas. In: V CONGRESSO INTERNACIONAL DA SOCIEDADE BRASILEIRA DE GEOFÍSICA, São Paulo, Anais, 1:54- 55.

SQUIRES, R. L. \& ADVOCATE, D. M. 1984. Meniscate burrows from Miocene lacustrine-fluvial deposits, Diligencia Formation, Orocopia Mountains, Southern California. J. Paleon., 58: 593597.

STEFANIC, M. \& JURDY, D. M. 1992. Stress observations and driving force models for the south american plate. J. Geophys. Res., 97 (B8): 11905 - 11913.

STEWART, I. S. \& HANCOCK, P. L. 1994. Neotectonics. In: HANCOCK, P. L. (ed.) Continental Deformation, 370-409.

STEVENS, B. 1911. The laws of intrusion. Bulletin of American Institute of Mining Engenieers, p. $1-23$.

SUGUIO, K. 1969. Contribuição à geologia da Bacia de Taubaté, Vale do Paraíba - Estado de São Paulo. São Paulo, 106 p. Tese de Doutorado, Faculdade de Filosofia Ciências e Letras, Universidade de São Paulo.

SUGUIO, K.; MARTIN, L. \& FLEXOR, J.M. 1988. Quaternary sea levels of Brazilian cost: recent progress. Episodes, 11 (3): 203-208.

SUPPE, J. 1985. Principles of Structural Geology. New Jersey: Prentice Hall, Englewood Cliffs. 
SZATMARI, P. \& MOHRIAK, W. U. 1995. Plate model of post-breakup tectono-magmatic activity in the adjacent Atlantic. In: V SIMPÓSIO NACIONAL DE ESTUDOS TECTÔNICOS, SBG, Rio Grande do Sul, Anais, 1: 213- 214.

SYLVESTER, G.A. 1988. Strike-slip faults. Geol. Soc. Am. Bull., 100: 1666- 1703.

TCHALENKO, J. S. 1970. Similarities between shear zones of different magnitudes. Geol. Soc. Am. Bull., 81:1625-1640.

THOMPSON, R.N.; GIBSON, S.A.; MITCHELL, J.G.; DICKIN, A.P.; LEONARDOS, O.H.; BROD, J.A. \& GREENWOOD, J.C. 1998. Migrating Cretaceous-Eocene magmatism in the Serra do Mar alcaline province, SE Brazil: Melts from the deflected Trindade Mantle Plume? J. Petrol., 39 (8): 1493- 1526.

TIBANA, P; CASTRO, J. C. \& BARROCAS, S. L. C. 1984. Bacia de Itaborai. In: XXXIII CONGRESSO BRASILEIRO DE GEOLOGIA, SBG, Rio de Janeiro, Anais, 12: 5309-5316.

TOMMASI, A. \& VOUCHEZ, A. 2000. Mechanical anisotropy of the lithospheric mantle and continental rifting: observations and models. In: $31^{\circ}$ CONGRESSO INTERNACIONAL DE GEOLOGIA, Rio de Janeiro, Agosto 2000, Abstracts, CDROM.

TOMMASI, A. \& VOUCHEZ, A. 2001. Continental rifting parallel to ancient collisional belts: an effect of the mechanical anisotropy of the lithospheric mantle. Earth Planet. Sci. Lett., 185: 199-210.

TREAGUS, S.H. \& LISLE, R.J. 1997. Do principal surfaces of stress and strain always exist? $J$. Struct. Geol., 19 (7): 997- 1010.

TUPINAMBÁ, M., TEIXEIRA, W. \& HEILBRON, M. 1998. The Pan-African/Brasiliano Arcrelated magnatism at the costeiro domain of the Ribeira belt, southeastern Brazil: new geochronological and litogeochemical data. In: INTERNATIONAL CONFERENCE ON BASEMENT TECTONICS, 14, Ouro Preto. Abstracts, p. 12-14.

TURNER, S., REGELOUS, M., KELLEY, S., HAWKESWORTH, C. \& MANTOVANNI, M. 1994. Magmatism and continental break-up in the South Atlantic: high precision $\mathrm{Ar}^{40} / \mathrm{Ar}^{39}$ geochronology. Earth Planet. Sci. Lett., 121: 333-348.

ULBRICH, H.H.G.J. \& GOMES, C.B. 1981. Alkaline rocks from continental Brazil. Earth-Science Reviews, 17: 135-154.

VALENÇA, J.G. 1975. Rochas alcalinas do Estado do Rio de Janeiro - correlações geológicas. Rev. Min. Met., 336: 6-11. 
VALENÇA, J.G. 1980. Geology, Petrography and Petrogenesis of some alkaline igneous complexes of Rio de Janeiro state, Brazil. London, 248 p. Tese de Doutorado. University of Western Ontario.

VALENÇA, J.G. \& KLEIN, V.C. 1984. Complexos alcalinos situados a leste da Baía de Guanabara, Rio de Janeiro. In: XXXIII CONGRESSO BRASILEIRO DE GEOLOGIA, Rio de Janeiro, Anais, v. XII, p. 5317-5333.

VALENTE, S.C. 1997. Geochimal and isotopic on the petrogenesis of the Cretaceous dykes of Rio de Janeiro, Brazil. Belfast, 297 p. Tese de Doutorado, Departamento of Geology, School of Geociences, The Queen's University of Belfast..

VALENTE, S.C.; PORTO JR., R. \& DUARTE, B.P. 1991. Novas evidências de metassomatismo e propostas preliminares para a evolução magmática das intrusões de diabásio do Rio de Janeiro, RJ. In: II SIMPÓSIO DE GEOLOGIA DO SUDESTE, SBG/SP-RJ, São Paulo, Atas, p. 91-96.

VALENTE, S.C.; PORTO JR., R.; ALMEIDA, M.E.; PAIXÃO, M.A.P. \& MONTEIRO, M.A.S. 1992. Alteração deutérica e metassomatismo provocados por intrusão de alcali olivina basalto em granito no Maciço da Pedra Branca, Rio de Janeiro, RJ. In: XXXVII CONGRESSO BRASILEIRO DE GEOLOGIA, SBG/SP, São Paulo, Bol. Res. Expandidos: 63-64.

VALENTE, S.C.; MEIGHAN, I.G.; FALLICK, A.E.; ELLAM, R. L. \& SICHEL, S.E. 1994. Petrografia e geoquímica do enxame de diques do Rio de Janeiro, RJ. In: XXXVIII CONGRESSO BRASILEIRO DE GEOLOGIA, Camboriú, Anais, 167-169.

VALENTE, S.C.; MEIGHAN, I.G.; FALLICK, A.E.; ELLAM, R. L. 1995. Os diques de rochas alcalinas do Rio de Janeiro, RJ. V Cong. Bras. Geoquímica, Soc. Bras. Geoquímica, Rio de Janeiro (CD-ROM).

VANDECAR, J.C.; JAMES, D.E. \& ASSUMPÇÃO, M. 1995. Seismic evidence for a fossil mantle plume beneath South America and implications for plate driving forces. Nature, 378:25-31.

VAN DER BEEK, P.A.; ANDERSEN, P. \& CLOETHINGH, S. 1995. Morphotectonic evolution of rifted continental margins: Inferences from a tectonic-surface processes model and fission track thermochronology. Tectonics, 14 (2): 406-421.

VIEIRA, I.S. 1993. Geologia estrutural do Platô de São Paulo. Rio de Janeiro. Dissertação de Mestrado, Instituto de Geociências, Universidade Federal do Rio de Janeiro.

VOUCHEZ, A.; TOMMASI, A; BARRUOL, G.; MAUNAUS, J. 2000. Upper mantle deformation and seismic anisotropy in continental rifts. Phys. Chem. Earth (A), 25(2): 111-117. 
YIAMAMOTO, I.T. \& ARAI, M. 1996. Bacias cenozóicas do sudeste do Brasil e sua composição palinológica na caracterização dos paleoambientes. In: XLVII CONGRESSO NACIONAL DE BOTÂNICA, Nova Friburgo (RJ), Anais, p. 14.

YOUNES, A.I. \& ENGELDER, T. 1999. Key structures for the interpretation of the progressive Alleghanian deformation of the Appalachian plateau. GSA Bull., 11(2):219-239.

WALKER, R. G. \& CANT, D. J. 1984. Sandy fluvial systems. In: WALKER, R. G. (ed.) Facies models: Geocience Canada Reprint Ser. 1: 71-89.

WEISSEL, J.K. \& KARNER, G.D. 1989. Flexural uplift of rift flanks due to mechanical unloading of the lithosphere during extension. J. Geophys. Res., 94: 13919-13950.

WHITE, R. \& MCKENZIE, D. 1989. Magmatism at rift zones: The generation of volcanic continental margins and flood basalts. J. Geophys. Res., 94: 7685-7729.

WICKERT, W.Q. 1974. Contribuição ao estudo da paleontologia da Bacia de Taubaté, Estado de São Paulo. Rio de Janeiro. Dissertação de Mestrado, Instituto de Geociências, Universidade Federal do Rio de Janeiro.

WIEDEMANN, C.M. ; PENHA, H.M. \& SCHMIDT-THOME, R. 1987. Granitoides of Espírito Santo and Rio de Janeiro States. Rev. Bras. Geoc., São Paulo, 17(4): 674-689.

WILCOX, R.E.; HARDING,T.P. \& SEELY, D.R. 1973. Basic wrench tectonics. AAPG Bull., 57: 74- 96.

WOODCOCK, N.H. \& SCHUBERT, C. 1994. Continental strike-slip Tectonics. In: HANCOCK, P. L. (ed.) Continental Deformation, p. 251- 263.

ZALÀN, P.V. 1986. A tectônica transcorrente na exploração do petróleo: uma revisão. Rev. Bras. Geoc., São Paulo, $16(3): 245-257$.

ZALÀN, P.V. 1987. Identification of strike-slip faults is seismic sections. Soc. Expl. Geoph., 57th An. Mtg., p. 116-118.

ZALÀN, P.V.; WOLFF, S.; CONCEIÇÃO, C.J.; ASTOLFI, M.A.M.; VIEIRA, I.S.; APPI, V.T.; ZANOTTO, O.A. \& MARQUES, A. 1987. Tectonics and sedimentation of Paraná Basin. An. Simp. Gondwana, VII: 83-117.

ZARZA, A.M.A; CALVO, J.P \& GARCIA DEL CURA, M.A. 1993. Palaeogeomorphological controls and sedimentary styles of alluvial systems, Neogene of the NE of the Madrid Basin (central Spain). Spec. Publs. Int. Ass. Sediment., 17: 277-292. 
ZIMBRES, E. K.; KAWASHITA, K. \& VAN SCHMUS, W. R. 1990. Evidências de um núcleo transamazônico na região de Cabo Frio, RJ e sua conexão com o Cráton de Angola. In: XXXVI CONGRESSO BRASILEIRO DE GEOLOGIA, Natal, RN, SBG, Anais, 6, p.27352743.

ZOBACK, M. L. 1992. First-and Second-Order Patterns of Stress in the Lithosphere: The World Stress Map Project. J. Geophs. Res., 97(B8): 11703- 11728.

ZOBACK, M.L. \& RICHARDSON, R.M. 1996. Stress perturbations associated with the amazonas and other ancient continental rifts. J. Geophys. Res., 101: 5459- 5475.

ZOBACK, M. L. et al. 1989. Global patterns of tectonics stress. Nature, 341: 291-298.

ZOLNAI, G. 1991. Continental Wrench-Tectonics and Hydrocarbon Habitat. AAPG, Continuing Education Course Note Series, 30, second edition. 
ANEXO A - DATACÕES RADIOMÉTRICAS PELO MÉTODO $\mathrm{AR}^{40} / \mathrm{AR}^{39}$, REALIZADAS NO ACTLABS (CANADÁ) 
A.1. Preparação das amostras e separação mineral

As amostras foram britadas e secas a $105^{\circ} \mathrm{C}$ por 3 horas antes de moer. $\mathrm{O}$ britador e o moinho foram lavados duas vezes com acetona para eliminar uma potencial contaminação por amostras processadas previamente. As amostras foram peneiradas a $180-25010^{-6} \mathrm{~m}$.

Amostra E6a $\rightarrow 0.14 \mathrm{~g}$ de concentrado de flogopita foi separado, por líquido pesado, por separação ferromagnética e por FRICTION RUMP. O concentrado continha $60 \%$ de flogopita, $35 \%$ de augita e $5 \%$ de forsterita.

Amostra ICF3a $\rightarrow$ Foram separadas por líquido pesado $(255-257 \mathrm{SG}), 0.7 \mathrm{~g}$ de concentrado de feldspato alcalino, com aproximadamente $100 \%$ de sanidina.

Duas porções de cada amostra, ou fração separada, foram embaladas em folha de alumínio, para irradiação no reator nuclear.

\section{A.2. Irradiação das amostras no reator nuclear}

Foi utilizado para irradiação o Reator de Pesquisas da Universidade McMaster, em Hamilton, Ontário, Canada. As amostras e o mineral monitor do fluxo de neutron (J) foram irradiados na posição $5 \mathrm{C}$ do núcleo do reator. As amostras e o monitor foram escudados por cádmio. O grupo de monitores analisado para o grupo de amostras em questão, foi a sanidina de Fish Canyon, com idade de 27.95 Ma. Esse monitor foi colocado em diferentes posições no pacote de amostras a serem analisadas.

\section{A.3. Análises}

O mineral monitor foi completamente fundido de uma única vez, a $1800^{\circ} \mathrm{K}$, e o gás extraído foi então analisado. A sanidina monitora, de Fish Canyon, forneceu um valor de J igual a $0.00350+-0.000069$. 
As amostras foram aquecidas incrementalmente, em passos, em um forno de resistência. O gás extraído foi limpo e introduzido em um espectrômetro de massa e a intensidade de cada isótopo de Ar e as linhas de base foram medidas. Tal procedimento foi repetido quatro vezes. Após as correções das linhas de base, a intensidade de cada isótopo foi extrapolada para o momento de entrada da amostra no espectrômetro. Todos os isótopos foram corrigidos por fracionamento, vácuo e reação secundária de $\mathrm{K}, \mathrm{Ca} \mathrm{e}$ Cl. A razão de $\operatorname{Ar} 40 / \operatorname{Ar} 39$ foi usada para calcular a idade, com base no valor de $J$ calculado anteriormente, e referido acima. Todos os erros são dois sigmas da média.

\section{A.4. Resultados}

São apresentados a seguir os resultados referentes a cinco amostras: E6a; ME2b5; Ita5a; MI e ICF3a. 


\section{Amostra E6a}

Rocha: lamprófiro

Material analisado: flogopita

Local: dique 6da Pedreira Emasa (ver Figura 4.9), Bairro de Bangu, Rio de Janeiro.

Resultados: Nove incrementos foram analisados para essa amostra. Os incrementos 1 e 2 continham grandes quantidades de outros gases e forneceram resultados sem utilidade. Os seis incrementos seguintes deram bons resultados. O incremento 9 não forneceu uma quantidade de gás suficiente para análise. Cinco incrementos ( 3 a 7) resultaram em um bom platô, com uma idade de $77.1+/-1.0 \mathrm{Ma}$, com $94 \%$ do Ar39 observado. Incrementos 5 a 7 forneceram uma isócrona com idade de $77.0+/-1.7 \mathrm{Ma}$.

\section{Sample E6a}

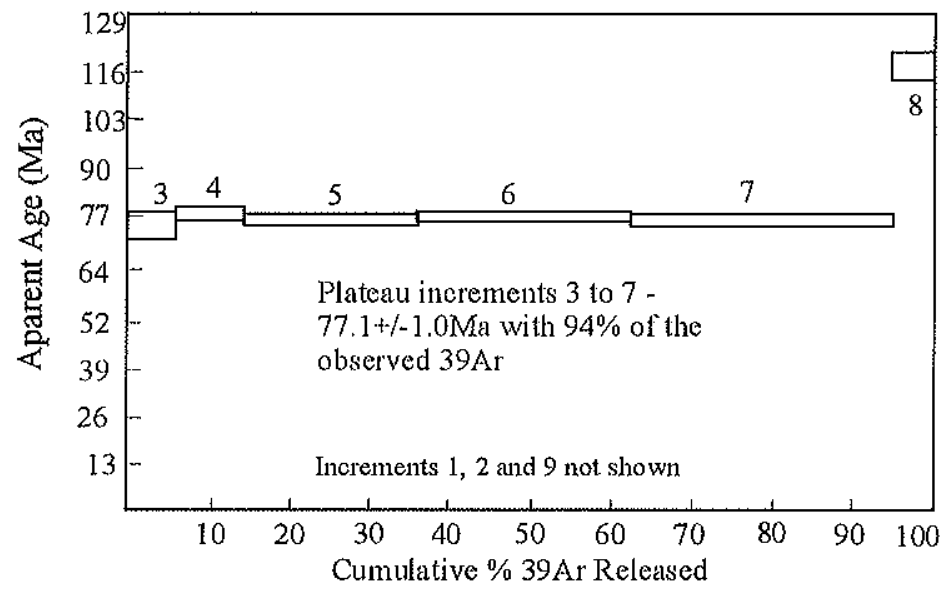

Sample E6a - Isochron

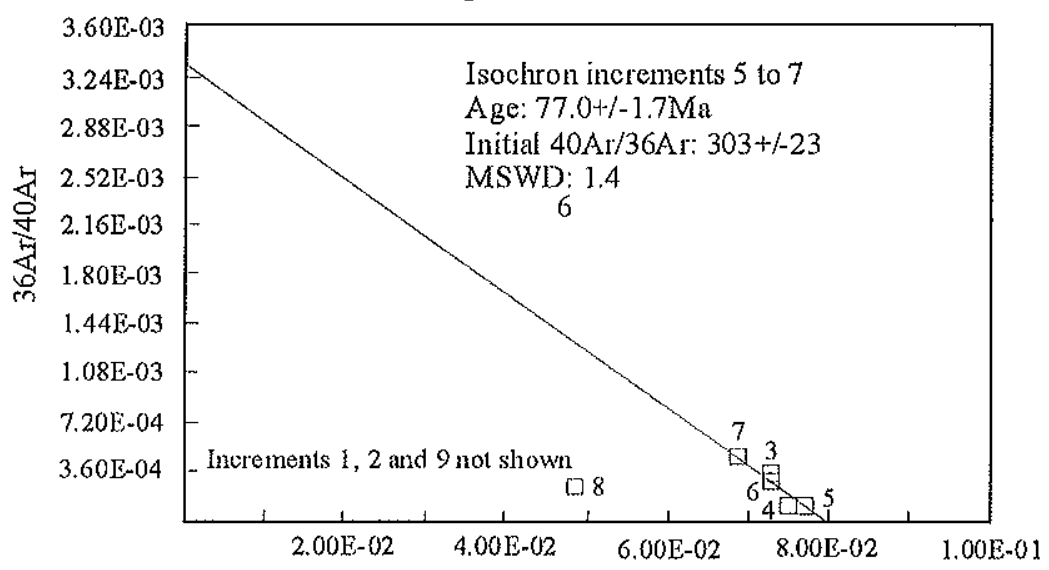




\section{Amostra ME2b5}

Rocha: fonolito

Material analisado: rocha total

Local: Mendanha, Pedreira Santo Antônio (dique 15 da Figura 4.5). Nova Iguaçu, RJ.

Resultados: Oito incrementos foram analisados para essa amostra. Não foi possível definir nenhum platô ou isócrona. Observa-se um claro aumento na idade, acompanhando o aumento da temperatura, característico de perda de argônio (ou da mistura de diferentes sistemas $\mathrm{K}-\mathrm{Ar}$ ). Os incrementos 2 a 5 resultaram em uma idade média ponderada de $54.2+/-2.8 \mathrm{Ma}$, com $76 \%$ do Ar39 observado. As idades relativas às temperaturas mais altas ficaram entre 65 e $70 \mathrm{Ma}$.

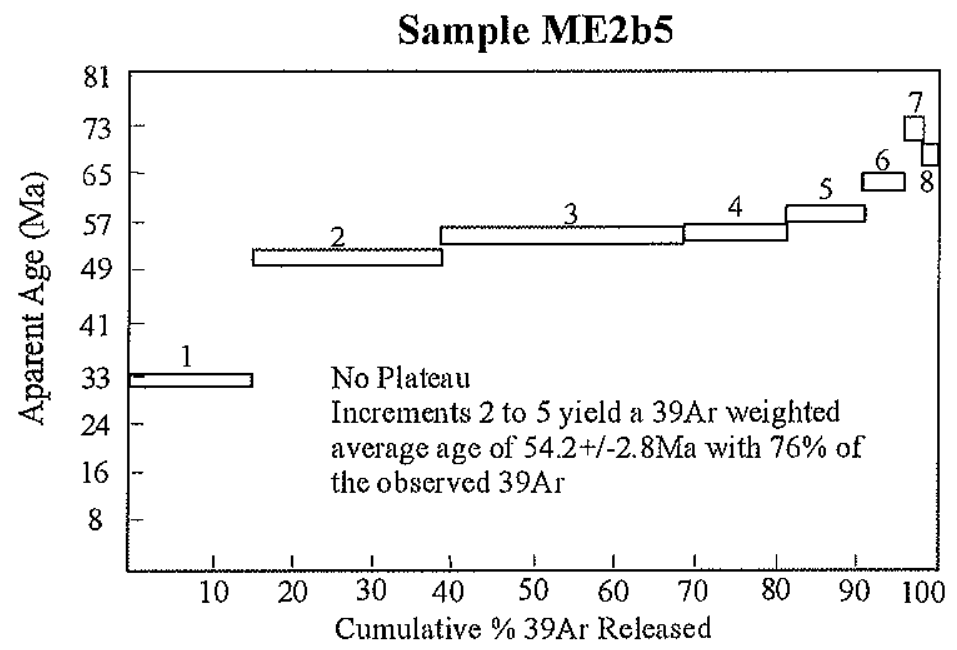




\section{Amostra Ita5a}

\section{Rocha: fonolito}

Material analisado: rocha total

Local: Complexo de Itaúna, Ponto 5 da Figura 4.35. Bairro do Salgueiro, São Gonçalo, RJ

Resultados: Oito incrementos foram analisados para essa amostra. Os incrementos 2 a 6 resultaram em um platô, com uma idade de $65.7+1-0.7 \mathrm{Ma}$, com $81 \%$ do $\operatorname{Ar} 39$ observado.

Sample Ita5a

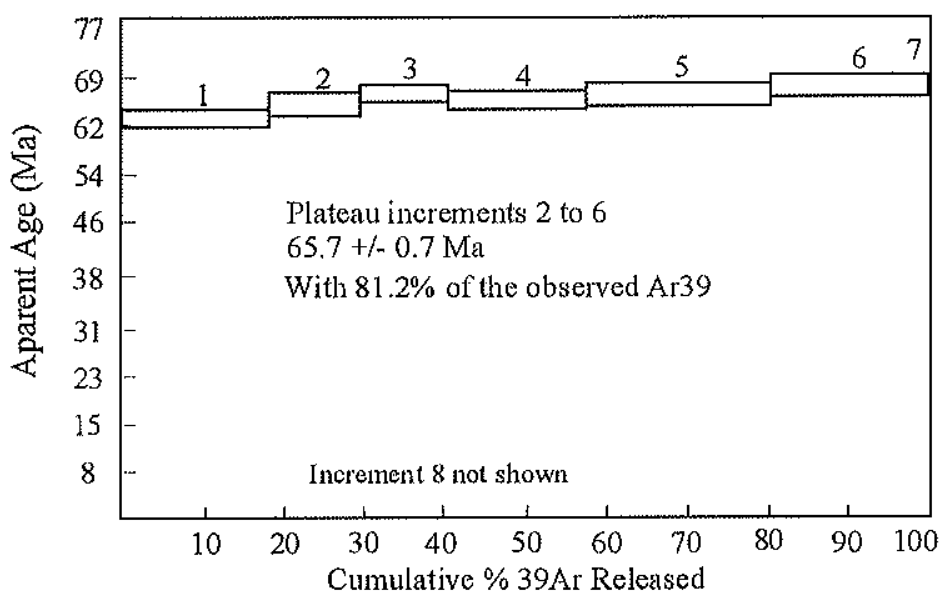




\section{Amostra M1}

Rocha: fonolito pórfiro

Material analisado: rocha total

Local: Plug de Monjolos (ver Figura 4.34). Distrito de Monjolos, Itaboraí, RJ.

Resultados: Seis incrementos foram analisados para essa amostra. Não foi possível definir nenhum platô ou isócrona para essa amostra. Os incrementos 2 a 6 resultaram em uma idade média ponderada de $56.6+/-1.2 \mathrm{Ma}$, com $62 \%$ do Ar39 observado.

Sample M1

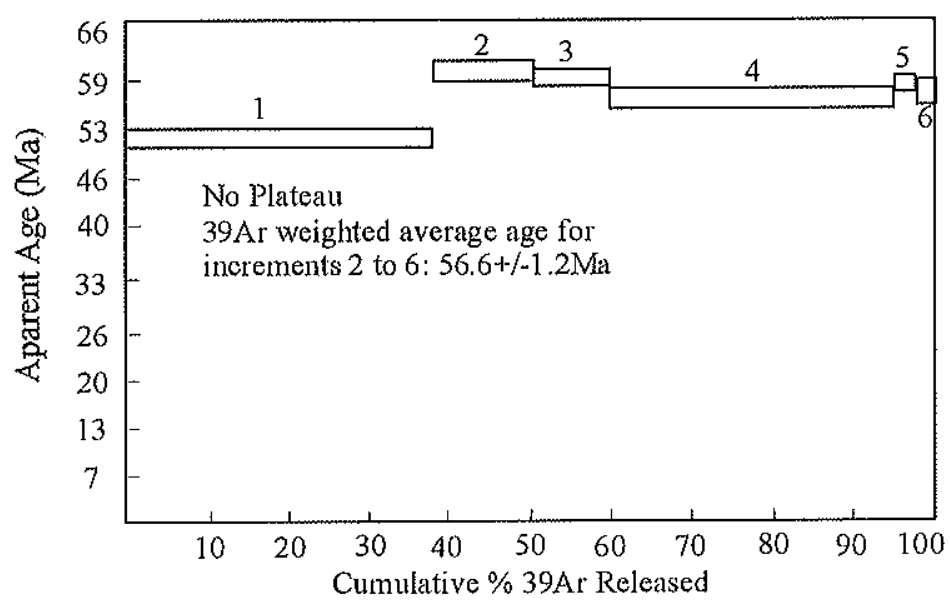




\section{Amostra ICF3a}

Rocha: fonolito pórfiro

Material analisado: sanidina

Local: Ponto 7 da Figura 4.75, Ponta do Boqueirão, Arraial do Cabo, RJ.

Resultados: Dez incrementos foram analisados para essa amostra. Os incrementos 2 a 4 forneceram um platô, com uma idade de $52.1+/ m 0.8 \mathrm{Ma}$, com $56 \%$ do Ar39 observado. Os incrementos 1 a 3 forneceram uma isócrona com uma idade de 50.8+/-1.0Ma. Os incrementos de mais al ta temperatura indicaram uma idade amis alta, de $55-56 \mathrm{Ma}$.

Sample ICF3a

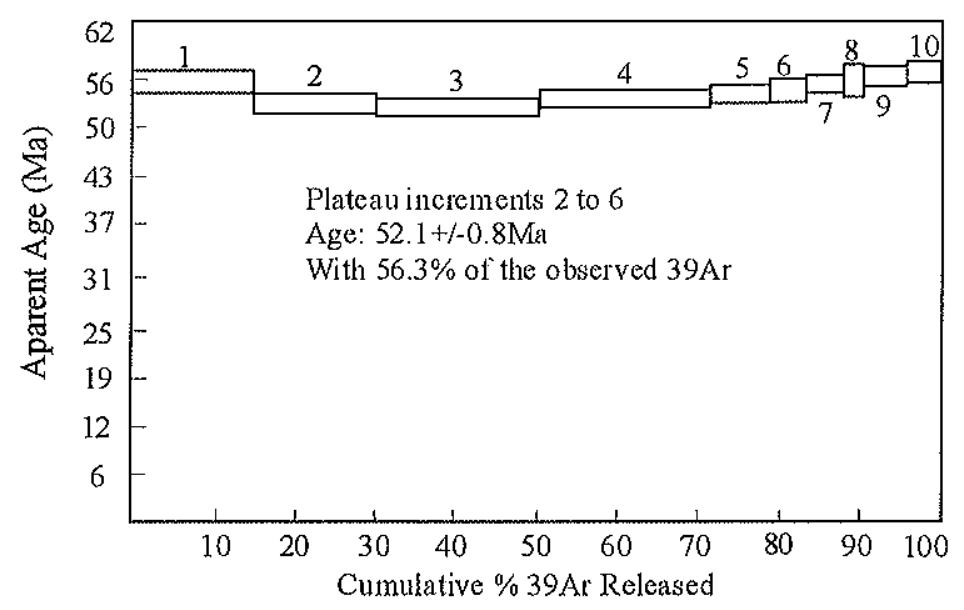

Sample ICF3a - Isochron

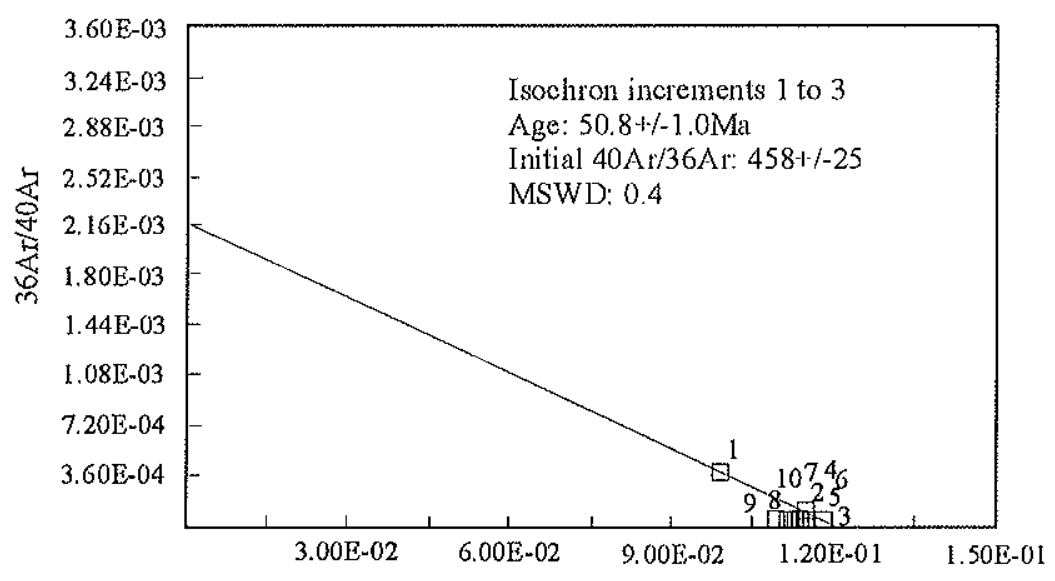


ANEXO B - DATAÇÕES RADIOMÉTRICAS PELO MÉTODO $\mathrm{AR}^{40} / \mathrm{AR}^{39}$, REALIZADAS NO IG/USP 
Foi realizada a datação radiométrica, pelo método $\operatorname{Ar} 40 / \operatorname{Ar} 39$, de uma amostra de brecha fonolítica do Plug do Country Club.

\section{B. 1. Preparação da Amostra}

A amostra foi fragmentada manualmente, com o auxílio de um martelo, envolta em um saco plástico. Os fragmentos foram lavados com álcool $\mathrm{e}$ bombardeados com ultra-som, para a retirada de sujeira e poeira. Os fragmentos a serem analisados foram selecionados com o auxílio de uma lupa binocular.

\section{B.2. Análises}

Foi utilizado como mineral padrão uma sanidina de Fish Canyon, que forneceu um $\mathrm{J}$ igual a $0.00475 \pm 1.79 \mathrm{E}-06$. As amostras foram aquecidas incrementalmente a laser.

\section{B.3. Resultados}

Os resultados mostrados a seguir referem-se a 3 fragmentos de uma mesma amostra de brecha fonolítica. São apresentados 3 platôs, uma isócrona e um ideograma. 


\section{3-01/PCC/Fonolito/Platô}

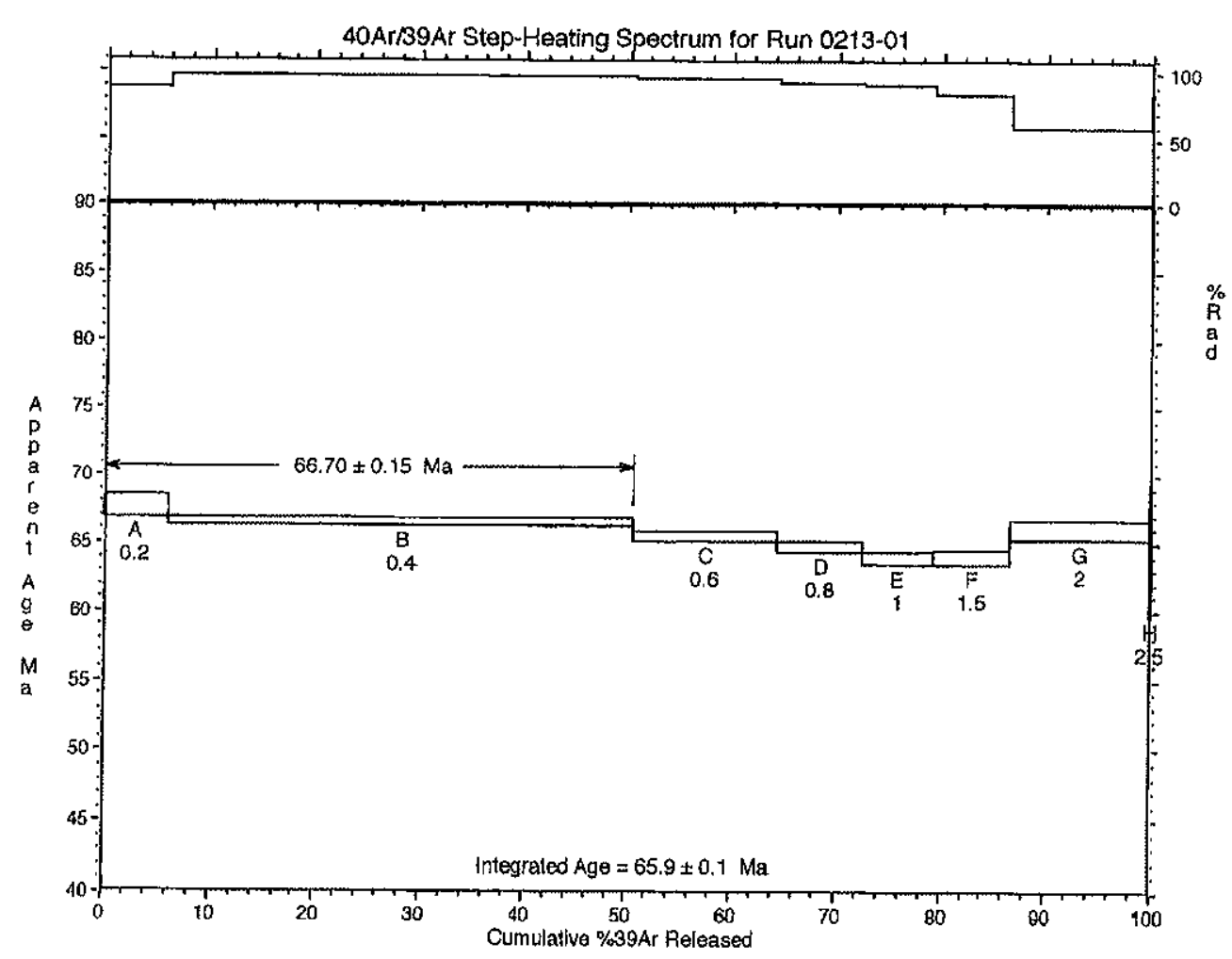

\section{3-02/PCC/Fonolito/Platô}

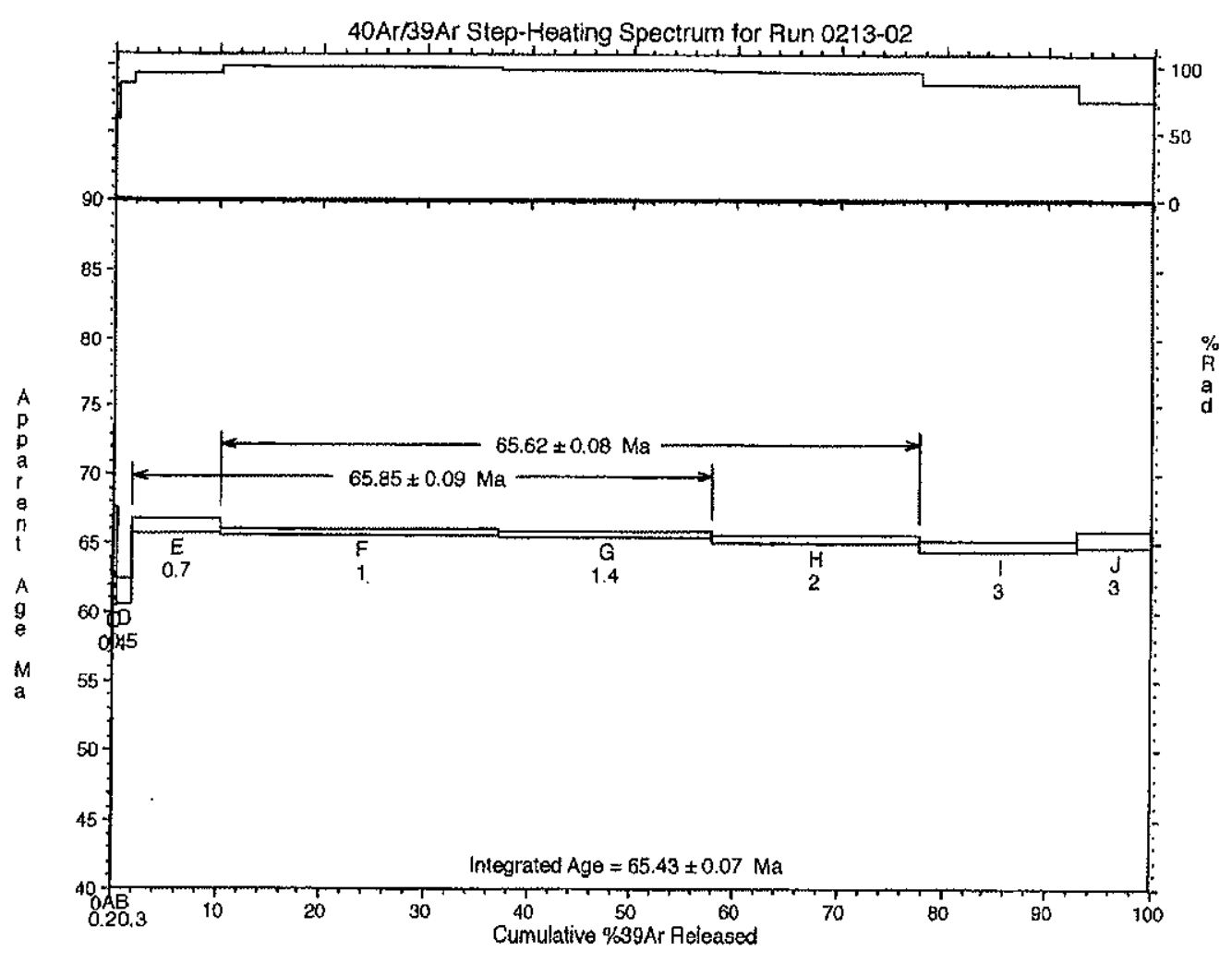


0213-03/PCC/Fonolito/Platô

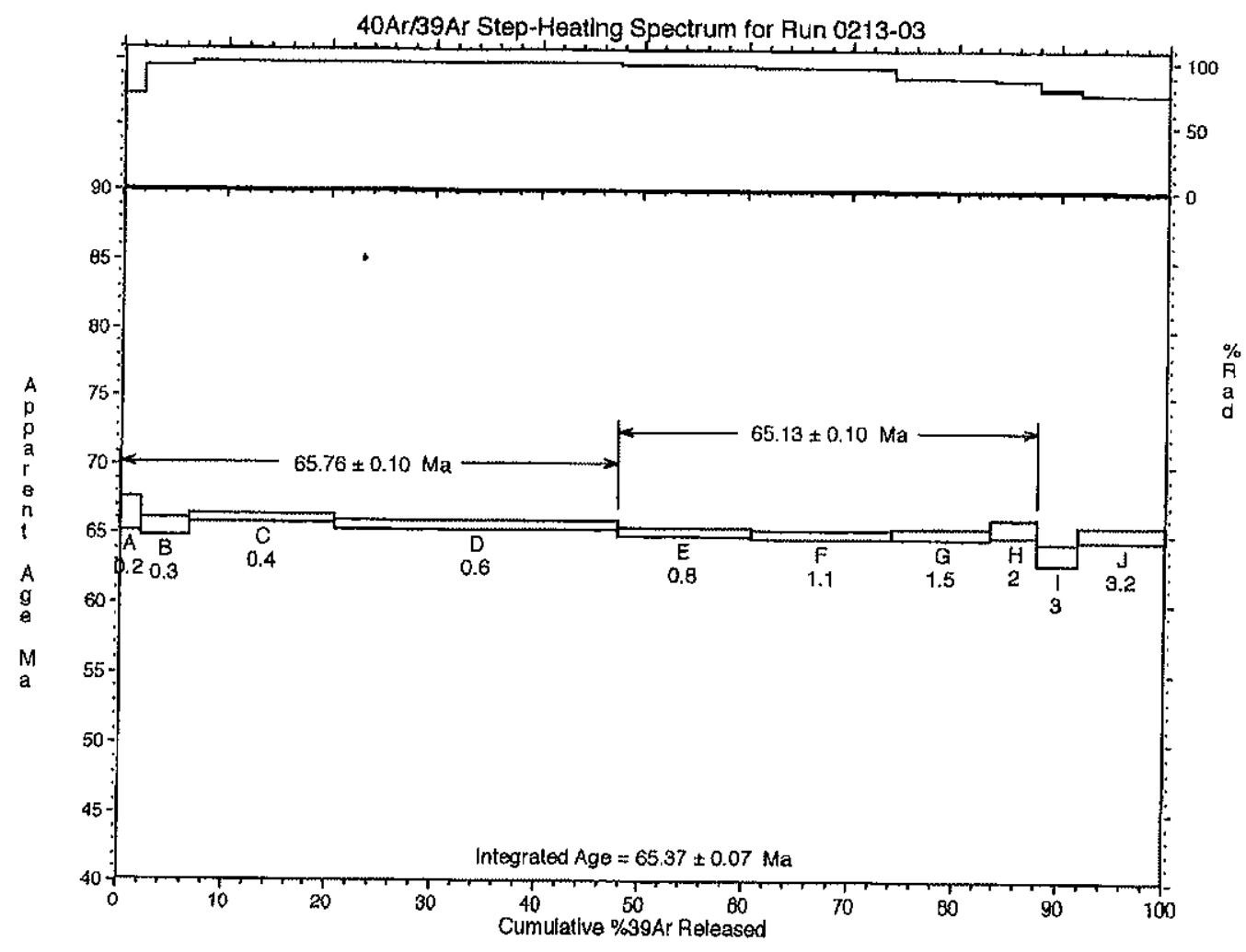




\section{3-01 a 03/PCC/Fonolito/Isócrona}

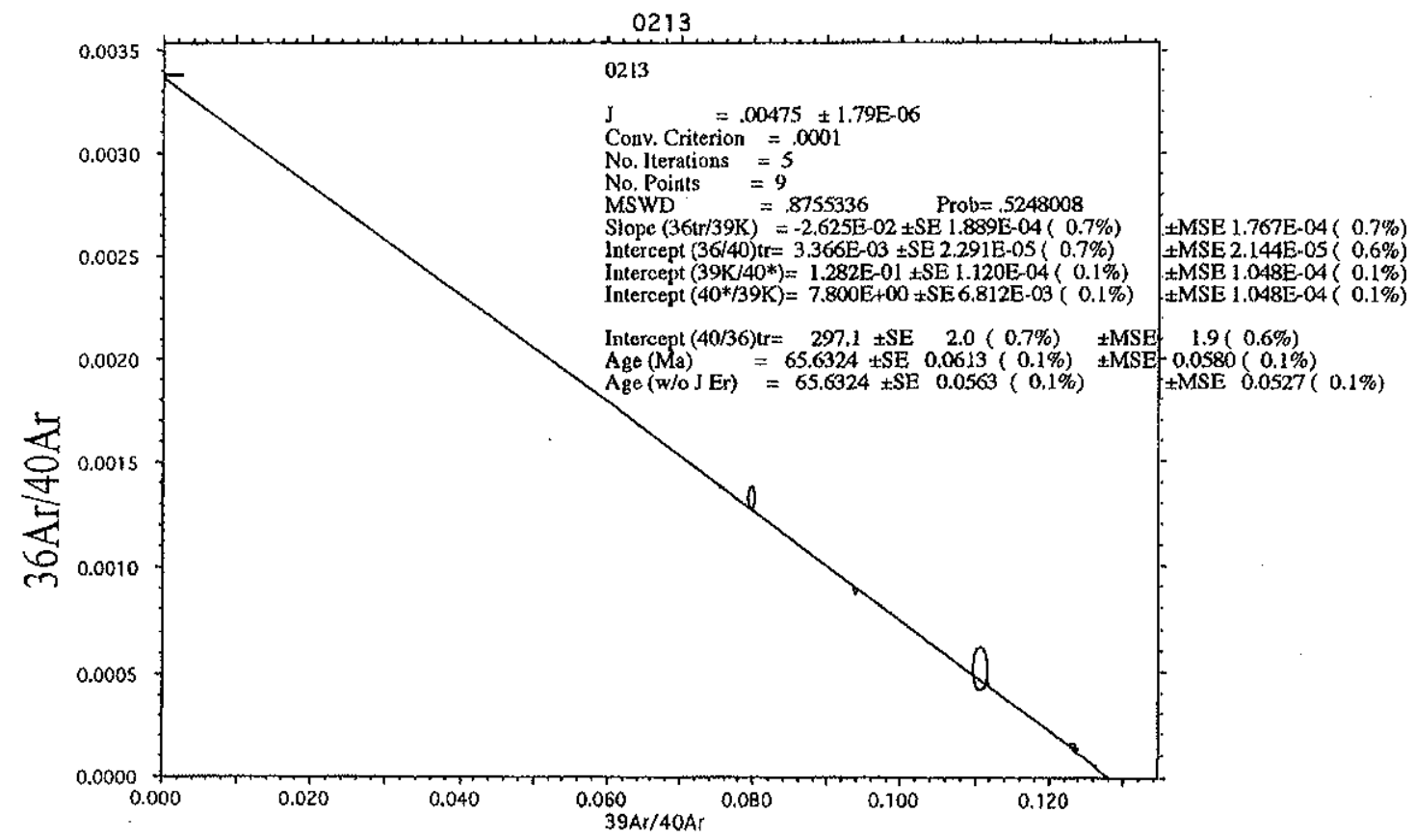

0213-01 a 03/PCC/Fonolito/Ideograma

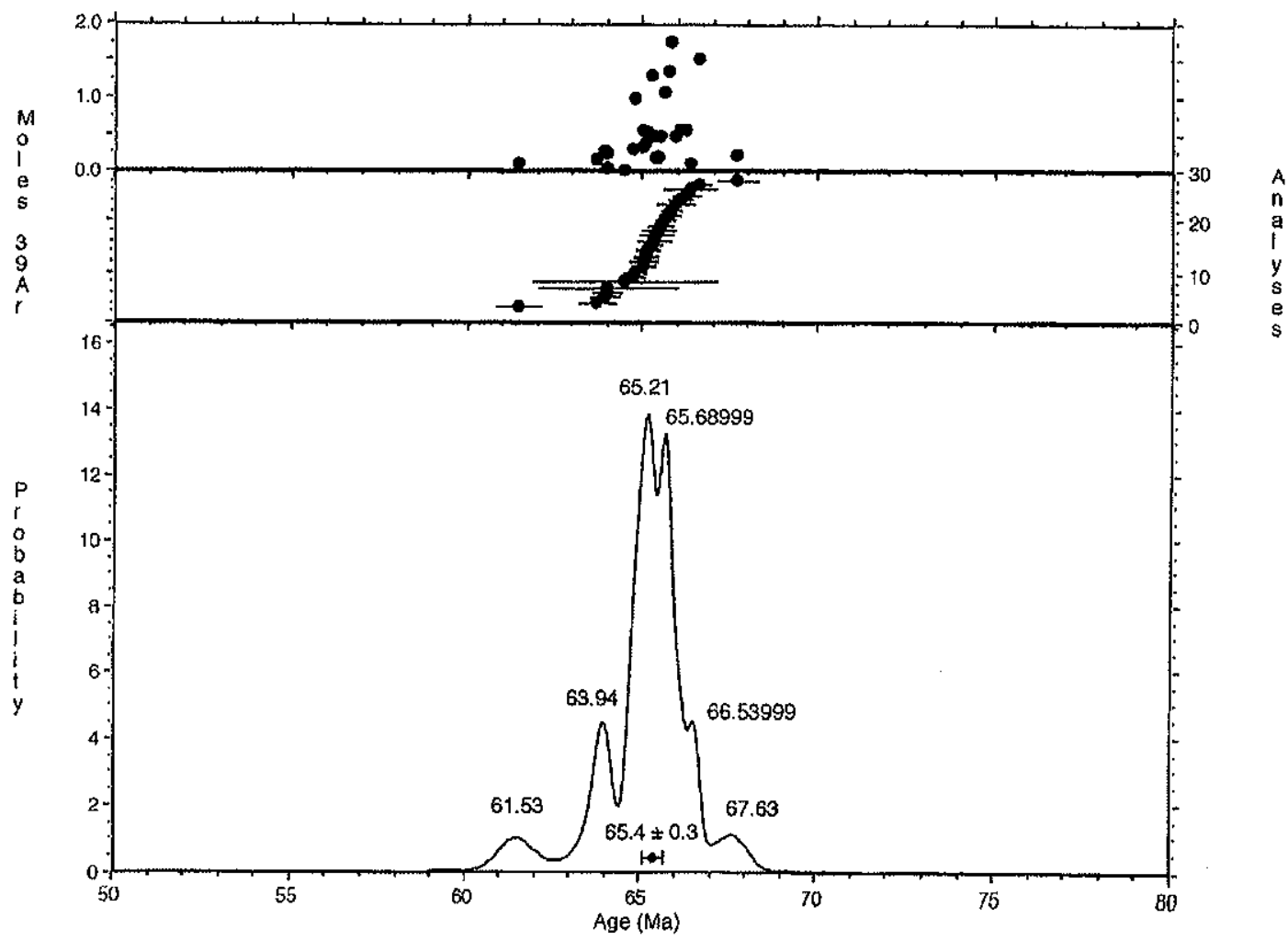


ANEXO C - DIFRATOGRAMAS DE RAIOS X. 


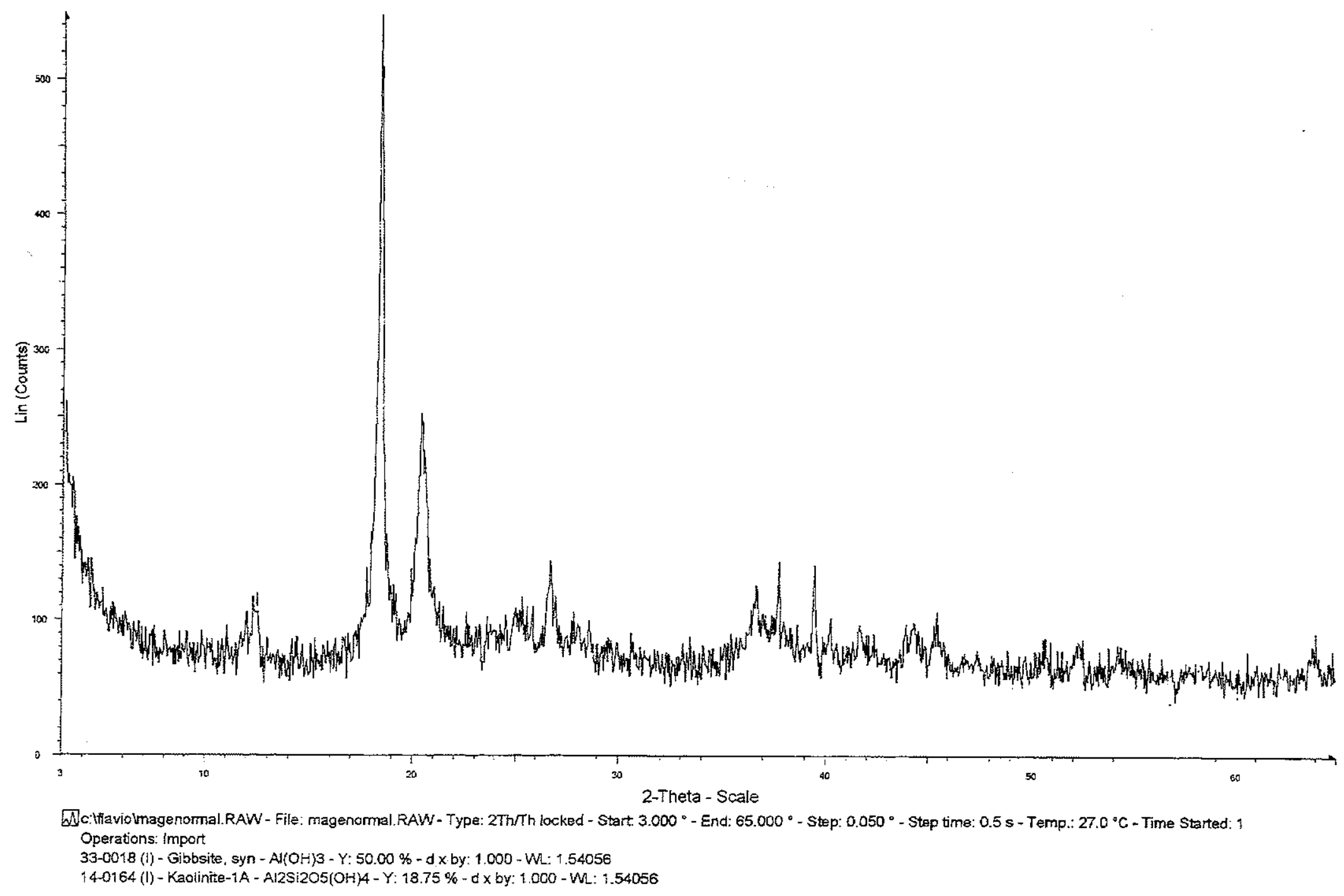

Figura C1 - Difratograma de raios x em amostra de gibsita da Formação Macacu. Ponto 26 da Figura 6.14, Magé, RJ. 